

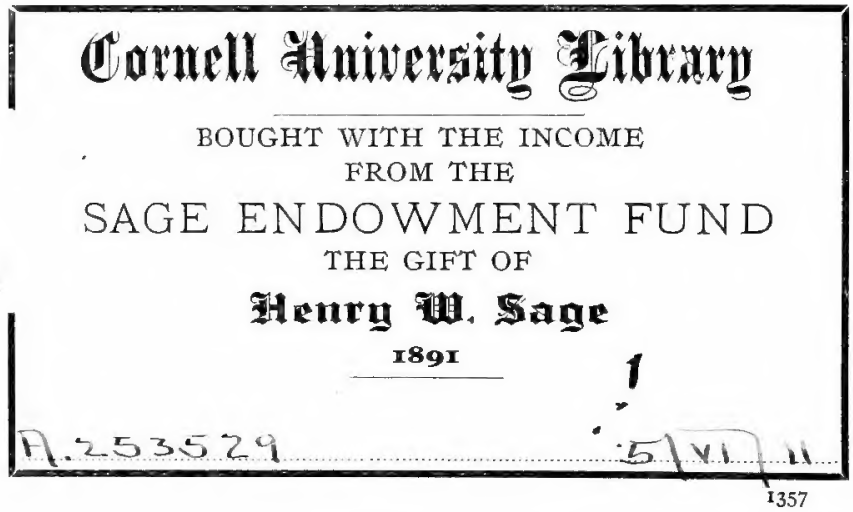




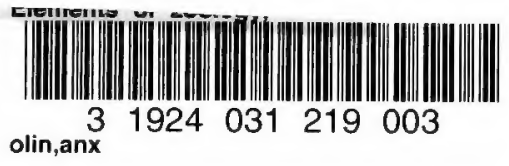




\section{Cornell University Library}

The original of this book is in
the Cornell University Library.

There are no known copyright restrictions in the United States on the use of the text. 


\section{ELEMENTS OF ZOOLOGY}




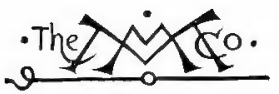

THE MACMILLAN COMPANY

NEW YORK - BOSTON - CHICAGO

SAN HRANCISCO

MACMILLAN \& CO, Limited

LONDON - BOMBAY - CALCUTTA

MELBOURNE

THE MACAILLAN CO. OF CANADA, Lto.

ToRonTo 



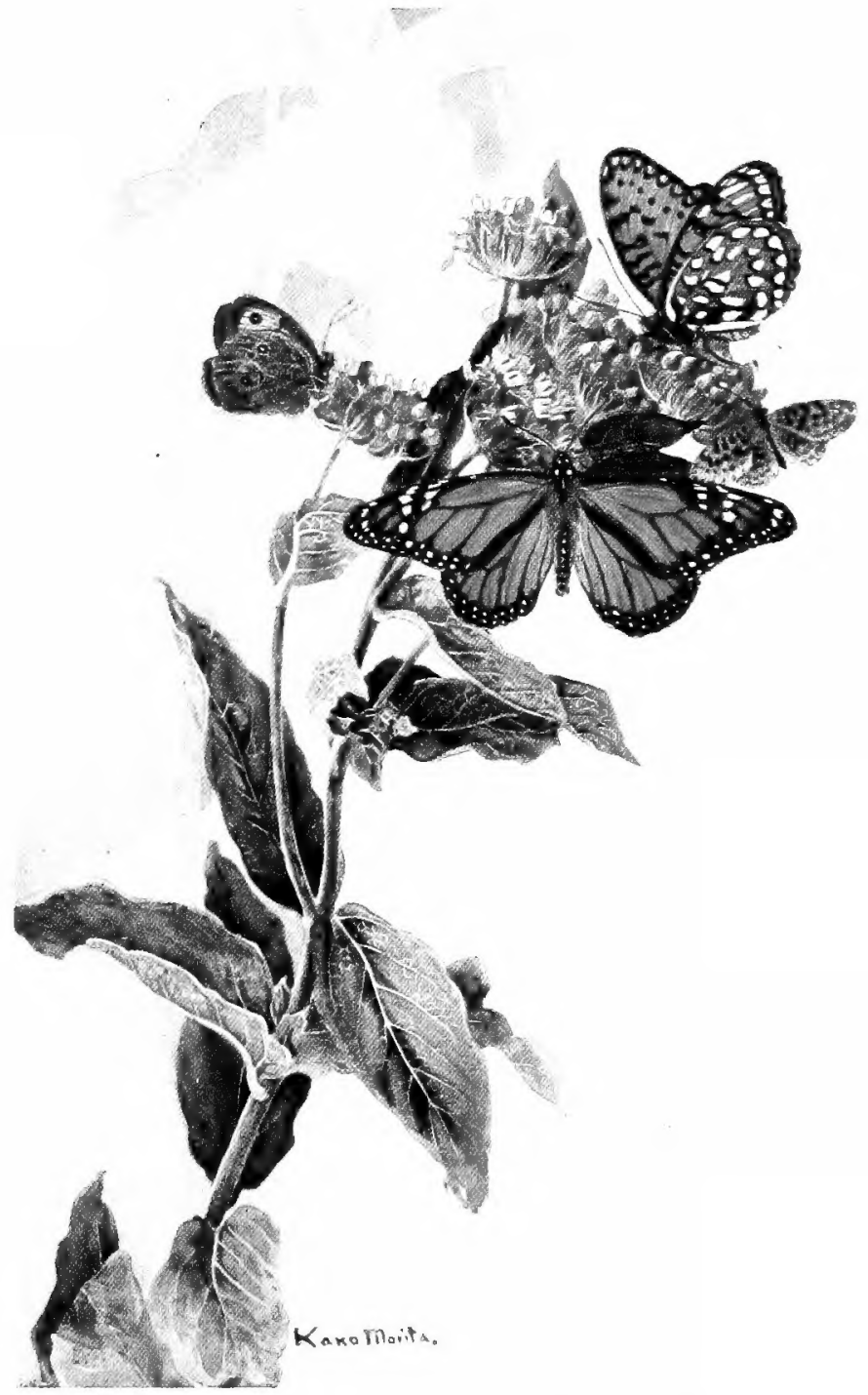

( ROOUP OF BUTTERFLIEW ON \&OLUEN-TROT, TO ILLOSTRATE DISPLAY OF COLOF ON WINGS. wonareh (Anosia plonimus); 10 tho lett, a mood nymph (Satyrus). 


\section{ELEMENTS OF ZOOLOGY}

\section{TO ACCOMPANY THE \\ FIELD AND LABORATORY STUDY OF ANIMALS}

$\mathrm{BY}$

CHARLES BENEDICT DAVENPORT, Ph.D.

DIRECTOR OF THE DEPARTMENT OF EXPERIMLNTAL EVOLUTION CARNEGIE INSTITUTION OF WASHINGTON, AND OF THE BIOLOGICAL LABORATORY OF THE BHOOKLY INSTITUTE OF ARTS AND SCIENCES, COLD SPRING HARBOR, LUNG ISLAND

AND

GERTRUDE CROTTY DAVENPORT, B.S. FORHERLY INSTRUCTOR IN ZOOLOGY AT THE UNIVERSITY OF KANSAS

WITH FOUR HUNDRED AND TWENTY-ONE ILLUSTRATIONS REVISED EDITION

X̃ew 通ork THE MACMILLAN COMPANY 1911 All rights reserved 
Coprrigit, 1900 and 1911, BY THE MACMILLAN OOMPANY.

Set up and electrotyped. Published February, I9r. 


\section{PREFACE}

This book has been rewritten to make certain additions that the experience of teachers has indicated would be useful and to introduce some of the newer topics of general bionomic or ecological importance whose study has marked the past decade. Zoology is a rapidly growing science, and text-books for secondary schools, no less than for colleges, must frequently be rewritten to give a proper view of the subject.

The additions relating to anatomy are intended to round out the student's knowledge as gained from a first-hand dissection of certain type-forms. What these forms should be is left to the teacher, but they are suggested in the treatment of each chapter dealing with "anatomy and physiology." Some work in dissection of types is indoubtedly beneficial, but the danger must be avoided of making the course primarily anatomical. There is this great importance of anatomical study - properly made by the student-that it gives him an understanding of the internal mechanism of organisms, including himself. In the modern development of medicine, which is undertaking more and more to educate the general public so that it may avoid disease, a knowledge on the part of every child of the organs and functions of the body will be of the greatest value. Indeed, it is hardly too much to predict that some day the importance of the dissection by every high-school child of a series of types leading to the mammal shall be regarded as essential for carrying out the 
programme of eliminating or at least diminishing the ravages of tuberculusis and venereal disease upon oux population.

On the other hand, an acquaintance with a variety of animals may well heighten an interest in nature and lift the mind away from the sordid and petty things of which our modern life in great cities is all too full. A love of nature is a moral tonic.

'The Laboratory Guicle has been omitted from this volume. This has been clone because the best teachers prefer each to use lis own laboratory guicle based upon animals and equipment at his command and his experience as to the work that is most successful with his own pupils. This is quite as it should be. With the modern methods of manifolding, a teacher can strike off in a short time directions to an indefinitely large class, and vary then as he thinks fit from year to year:

The book remains, not a treatise on the science of zoology, but an introduction to the study of animals. It contains an outline of what we conceive to be most inportant for the orlinary citizen to know concerning animals, and it will, we trust, stinulate a few to pursue the study of animals as a life work with the aim of adding to human knowledge and discovering important guiding principles.

The book is somewhat profusely illustrated. Many of the figures are from photographs. Many of the photographs of the late IV. H. C. Pyncheon and V. H. Lowe remain; those of the former being mostly of invertebrates at Cold Srring Harbor. In addition to those gifts of prints and cuts acknowledged in the Preface of the Finst Edition, we have to thank Mr. IV. S. Blatchley for permission to reproduce from his "Gleanings from Nature" our Figures 9.5 $a$ and 96. For permission to reproduce Figures 112 to 414,417 to 418 , and 420 , 
we are indehted to Messis. Henry Holt \& Co. For Figure 415 we have to thank the Cambriclge University Press, and for Figure 416 the Ray Society. For Fígures 317, 318, 319, and 348 we are indebted to the New York Zoological Society through its Director, Dr. W. T. Hormaday.

During the past ten years, we have received numerous photographs of animals and habitats. Some of these have been reprodnced for the most part withont naming the donors, but none the less with high appreciation of the gifts.

Finally, we have to thank those teachers who have marle useful suggestions as to how the book could be improved. We have had helpful criticisms from MIr. J. H. Emerton on the Spider Chapter, and Mr. W. L. W. Field of the Milton (Mass.) Academy has read the entire manuscript carefully and made many suggestions that we have carried out.

It seems improbable that with our increasing subwersion in scientific investigation we shall ever be able to offer another revision of this book; nevertheless, we shall prize a contimuation of that criticism and suggestion from teachers who use the book which in the past has brought us many friends.

\section{CHARLES B. DAVENPORT. GERTRUDE C. DAVENPORT.}

Cold SPRing Harbor, LONG Island, N.Y., November 28,1910 . 



\section{CONTENTS}

CHAPTER

PAGF

I. The Anatomy and Physiology of Insects: The Cricket 1

II. The Grasshopper: A Study of the Enemies of Vegetation. . . . . . . . . 11

III. The Butterfly: A Study in Animal Coloration . $\quad 29$

IV. The Beetle: A Study in Ecology . . . . . 60

V. The Fly: A Study of Disease-producing Animals 76

VI. Lithobius: A Study of Light-shunners • • $\quad 90$

VII. The Spider: A Study of Animal Architecture . . 102

VIII. The Anatomy and Physiology of Crustacea: The Lobster . . . . . . . . . 120

IX. The Crayfish: A Study in Geographical Distribution 128

X. Dalhnia: A Study of the Food of Fishes . . . 153

XI. The Anatomy and Physiology of Annelids . . . . 161

XII. The Earthworm: A Study in Subterrestrial Organisms . . . . . • • . . 168

XIII. Nereis: A Study of Life on the Seashore - . . 182

XIV. The Anatomy and Physiology of Mollusca, illustrated by the Snail . . . . . . 198

XV. The Slug: A Study in Animal Behavior . . . 208

XVI. The Fresh-water Clam: A Study of River Faunas . 22:3

XVII. The Anatomy and Physiology of Echinoderms, with Particular Reference to the Sea-urchins . . . 2988

XVIIL. The Starfish: A Study of Embryology . . . 246

XIX. Hydra: A Study of Attached Animals . . . 260 
CHAPTER PARE

XX. Paranceium: A Study of the Smallest Organisms . 280

XXI. The Ancestry of Tertebrates . . . . . . 289

XXII. The Sinelt: A study of Food Supply . . . 298

XXIII. The Frog: A Study of the Origin of Land Life . 3:5

XXIT. The Lizard: A Study of Dryness I overs . . . " \$49

SXV. The English Sparrow: A Study of Bixds and Migrations. . . . . . . . . 370

XXVI. The Mouse: A Study of the Evolution of Domestic Aniuals . . . . . . . . 120

XXVII. The Development of the Frog's Egg . . . . 4.1 XXVIII. A Brief IIistory of the science of Zoology . . 458 
ELEMENTS OF ZOOLOGY 



\section{ELEMENTS OF ZOOLOGY}

\section{CHAPTER I}

\section{THE CRICKET: A STUDY OF THE ANATOMY AND PHYSIOLOGY OF INSECTS}

THE cricket is a thing that can move of itself, can feed and grow and produce young like itself ; consequently it is living. It has numerous external parts and complex internal organs; hence it is an organism. It moves freely from place to place, and devours and digests solid food; and so it is an animal (Fig. 1).

An animal is a complex machine built up of a remarkable substance called protoplasm and of materials that it produces. Protoplasm looks like a jelly, but it is really itself highly organized, so that the animal machine differs from man-made machines in

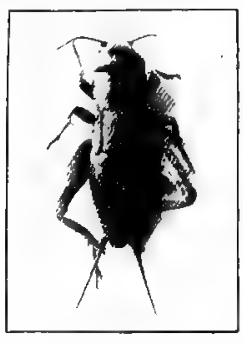

F I G, 1, - Cricket, immature. Nat. size. Photo. by W. H. C. P. having a mechanism inside the very substance of which its parts are made. Some idea of protoplasm may be got from Figure 2, which shows a bit of it existing as a free living animal with no other organs than those essential to all protoplasm. But in higher animals the body gains a great size; contains huge spaces that are filled with water or air; and is built up of membranes that cover the surface of the body (the skin) or line the food-canal and body-cavities, of masses that support the other parts (the skeleton) or are used for 
moving organs (the muscles), of threads that convey messages as telegraph wires do (the nerves), and of delicate tubes that convey air or food to the innermost parts of the body (the air-tubes and the bloor-vessels) or carry fluids and particles from the body to the exterior (the excretory and

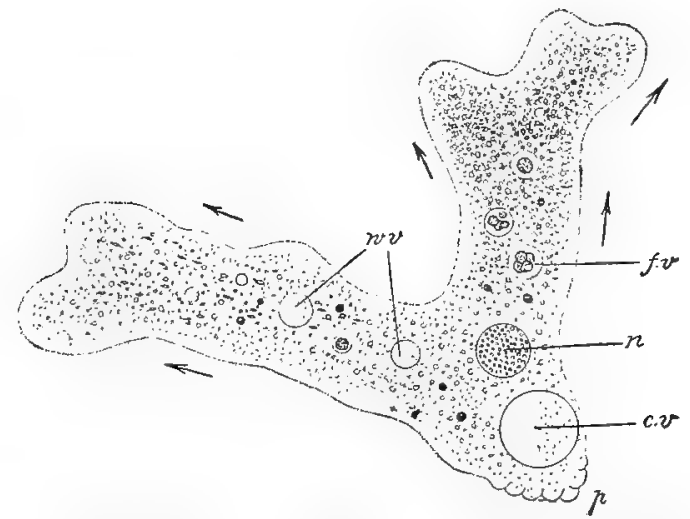

FIG. 2. - Amoba, the proteus animalcule. Greatly magnified. n., the nucleus ; $w . v_{\text {. }}$, water vacuoles ; $c . v_{\text {, }}$, coritractile vacuoles ; $f . v_{\text {. }}$, food vacuoles. E. B. Wilson, "The Cell"

reproductive ducts). These parts differ in form and arrangement in different kinds of animals. The study of the form and arrangement of the different organs of the body is called Anatomy; the study of the work the parts do is called Physiology.

General Form of the Cricket. - What general resemblance in form is there between a cricket and a cat? Which end moves forward in locomotion (anterior; the opposite end is called posterior)? Which surface is next to the earth (ventral), and which is normally turned up toward the sky (dorsal)? What different structures does each surface bear? 
Which side is right, which left, and why? Such are the questions which attention to a living cricket will readily answer. They are important because these surfaces and sides and ends are essentially similar even in such unrelated animals as the cricket and cat, which have this in common that they move over the ground.

The External Structure of the Cricket (Figs. 3 and 4). The cricket's exterior differs from ours in being covered with a thick varnish-like layer called the cuticula. This cuticula is the cricket's skeleton, for it supports the body and gives attachment to the muscles of the legs. The cuticula extends over the mouth parts and even into the mouth. It cannot

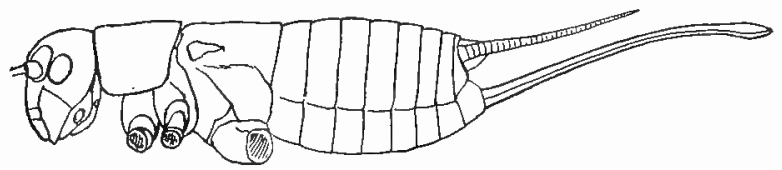

FIG. 3. - Side view of female ericket, with legs and wings removed.

stretch and so, in order to let the animal grow, the cuticula bursts from time to time and is shed. The cricket's body is made up of a trunk and appendages. The trunk consists of a series of rings, or somites (Fig. 4), which are grouped into three main regions known as head, thorax, and abdomen. The rings are most clearly seen on the abdomen, where each bears, on the two sides, a pair of small holes that are the entrance to the system of air-tubes of the cricket and are known as spiracles. The thorax is made up of three somites, each of which bears a pair of legs, and two of them each a pair of wings. On the head the somites are blended, but the original number can be made out by applying the rule that each somite carries a pair of appendages. There are one pair 
of feelers (antenna), a pair of jaws, a pair of under jaws (maxillce), and a paired under lip, (labium). In addition the eyes correspond to a somite and there is perhaps one other. The total number of somites to the body can, consequently, be computed.

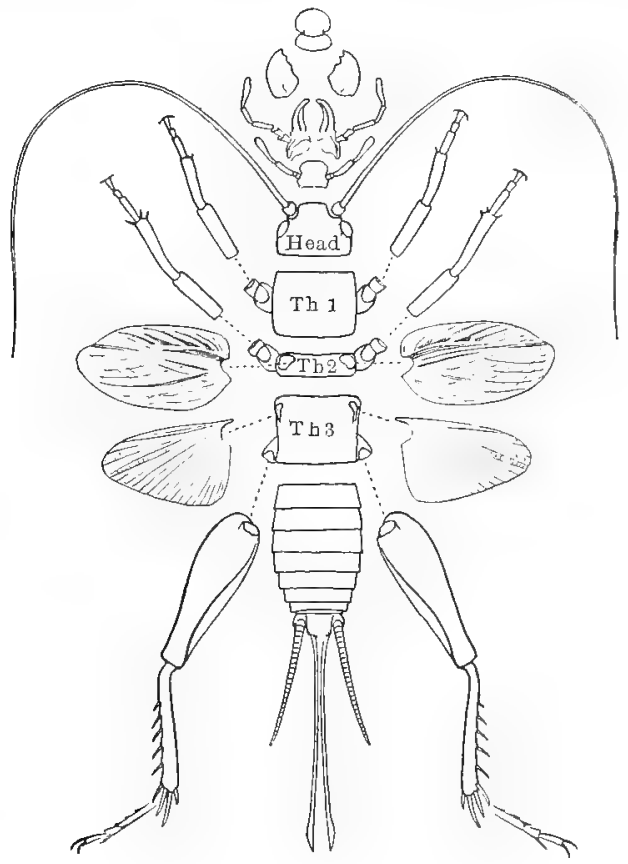

FIG. 4. - Dorsal view of cricket with appendages disarticulated.

The legs are covered with the cuticula, which is thick to give them strength to support the body, but divided by thin rings (joints) into segments to permit the legs to bend. The thick segment nearest the hody is called, on account of a resemblance in position to the upper bone of our legs, the 
femur; the next segment is the tibia; and then comes a threejointed tarsus. These three divisions are found among insects in general. With fewer, the insect could hardly walk.

The wings are broad, flat outgrowths of the body. wall and, like it, are covered by the cuticula. Between the two layers of the cuticula are remnants of a space in which run the air-tubes - these constitute the wing-veins, while the thin parts of the wing enclosed by the veins are called wing-cells. The arrangement of veins and cells in the different kinds of insects, though following one plan, shows many modifications in detail. In the cricket the upper wings are more leathery than the lower, which, when not in use, are folded like a fan under the protecting upper pair. The hind wings alone are used in flight. The mechanism of flight is as follows. The front edge of the wing is relatively stiff, while the hincler half is loose and flops up when the wing descends and down when it ascends. Consequently in both up and down stroke the wing meets a little resistance from behind and on the down stroke from below as well, and this resistance behind is what pushes the insect forward, while the resistance below keeps it up in the air. Each stroke counts a little, and by making many strokes a second even a heavy-bodied insect can propel itself in the air. The cricket, however, is very bad at flight and practically never uses its wings for this purpose.

Organs and Functions of Nutrition. - The mouth of the cricket lies between and at the base of its heavy jaws. This is the entrance to a digestive tube that runs through the middle or axis of the body and has its other opening in the last ring of the abdomen. As the food passes along this tube it is acted on mechanically and chemically in different ways, and the various parts of the tube show special regions each for its 
particular kind of work (cf. Fig. 5). The food of the cricket consists of various sorts of animal and vegetable débris, - old fragments of meat, pieces of cloth or paper, fallen fruit, etc. Bits of suitable size are torn off by the mandibles and carried to the gullet, where they are wet by the saliva. They then pass into the crop, an enlarged part of the tube, where the hard fool is held and worked over until it is softened hy various juices secreted by the glands. The food then passes

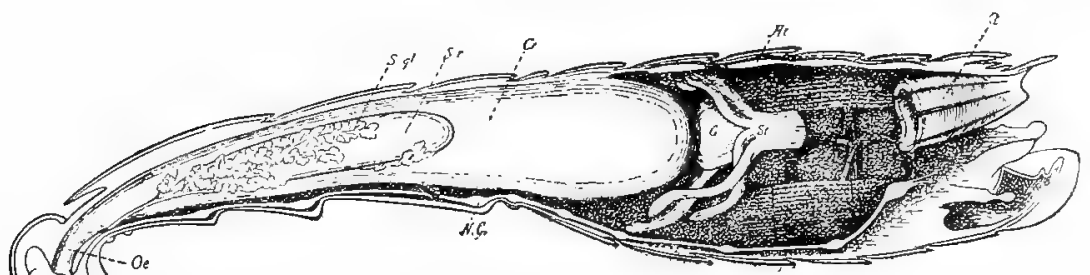

Frg. 5. - Longitudinal section of female cockroach to show position of principal organs, Oe., œesophagus; $S . g l$. salivary gland; $S . r$.,

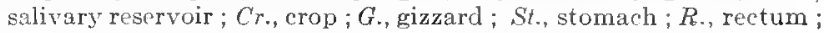
Hi., heart ; N.C., nerve cord. × 5 . After Miall and Denny.

to the third part of the tube, the stomach. Between crop and stomach a number of sacs open which secrete the digestive juices. From the stomach the digested food goes into a long plain tube - the intestine - through the walls of which the soluble portions pass and mix with the fluids of the body. Finally the indigestible portions collect in the hinder part of the tube to be from time to time expelled.

Respiration in the cricket is effected by a very clifferent mechanism from ours. From the spiracles on the rings of the abdomen and the thorax pairs of tubes called trachea enter the body and clivide again and again, going to the main muscles of the back, to the food-canal and reproductive organs, and to the 
ventral nerves and muscles (cf. Fig. 6). To all of these organs oxygen is carried by the air-tubes. The problem which has to be met is how to force the air in and out of these fine tubes. This seems to be done by bringing the sides of the body together, thus causing the fluids of the body to press on the air-tubes. When the spiracle is open, the air is forced out of it; when the spiracle is closed, the air is forced from the larger stems into the finer tubes lying in the tissues. There is a spiral spring (consisting of a thickening of the cuticula) in the inside of the main stems of the tracheæ that restores the cylindrical form of the tube after compression.

Circulation in the Cricket. - In the higher animals the food dissolved in the food-canal is carried by tubes, called hlood-vessels, to the heart, from which it is pumped to all parts of the body. The blood-vessels carry not only fluid food but also oxygen and bring away waste from the tissues. In insects, as we Fig. 6. - Alimentary canal of have seen, oxygen is carried by a special system of air-tubes. The

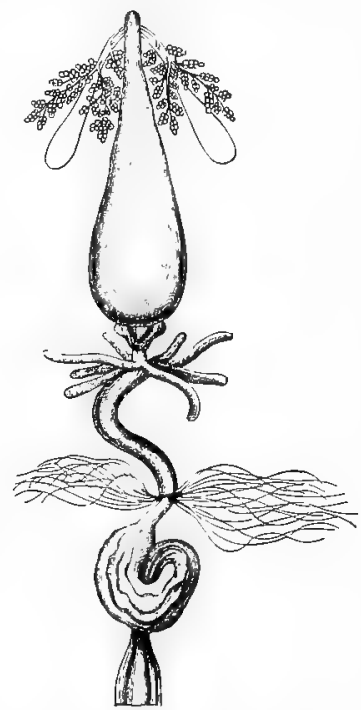
cockroach. $\times \frac{1}{3}$. Miall and Denny. digested food passes through the wall of the food-canal into the cavity of the body. In the hody-cavity it is kept in sluggish circulation by the heart, - a long dorsal tube full of holes, - the pulsations of which drive the body fluids forward.

Excretion in the Cricket. - In every chemical laboratory there are obtained, in addition to the useful things sought, 
certain useless or waste by-products, and these have to be carried away. So in the living body, which is a sort of chemical laboratory, there are many waste products, and these have to be taken from the tissues where they first appear and conveyed to the outside of the body. In insects these waste products are

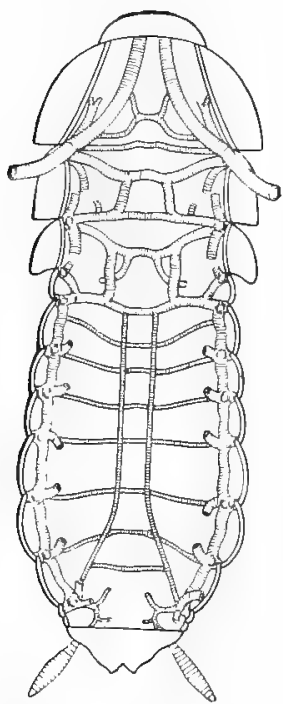

Fig. 7.-View of arrangement of tracheal or breathing tubes in the cockroach. After Miall and Denny. picked up from the body-fluids by means of tubes that empty into the intestine. From the intestine they pass with the undigestible food matter to the outer world.

Reproduction in the Cricket. - A variety of accidents - starvation, floods, severe cold, attack by other organisms - kill vast numbers of crickets each year. The normal number is maintained only by reproduction, or the production of new ones. While in some animals reproduction takes place by a division of the parental body into two nearly equal individuals, in the higher animals usually only a piece of the parent - called a germcell - is set free, and the offspring has to develop from this small bit. Also in most animals, but by no means all, two germcells (usually, hut not always, from different individuals) must meet and unite hefore develomment hegins. To provide food for the developing young, one of the two germ-cells is of large size and full of foodstuffs. It is called the egg, and the individual producing it is called a female. The other germcell is not stuffed with food, but is active and goes into the egg and through to its centre; it is called the sperm- 
cell and is produced by the male. The union of egg and sperm-cell is called fertitization. The young eggs are formed in the female cricket within several tubes that lie in the cavity of the abdomen and together make up the ovary. The ripe eggs reach the exterior through a tube or duct known as the oviduct, and in it they are fertilized. The chief business of the ovary is to produce food for the eggs. In the oviduct the egg becomes covered with a tough protecting shell. The tip of the body of the female cricket is drawn out into a long, firm "ovipositor" (Fig. 3), which can be prodded into the ground, so that the egg that is laid is placed several centimetres below the surface, where there is less danger of drying up, of being burned by the sun's rays, and of freezing and thawing during the winter.

The musculature of the cricket consists, in the abdomen, principally of dorsal and ventral muscles that bend and straighten the abdomen, telescope the segments, and aid respiration. In the thorax and the head are the powerful muscles that move the wings, legs, and mouth parts. The muscles are fastened to the outer cuticula, since there is no internal bony skeleton.

The nervous system of the cricket consists of a series of central masses of nerve-cells corresponding to our brain and spinal cord, and a system of nervous fibres running out from the central masses. The brain lies over the mouth as in man, but instead of connecting with a dorsal cord as in ourselves, it connects by means of a nervous ring surrounding the gullet with a pair of nerve-cords running along the ventral side of the body. These ventral nerve-cords are united by crossstrands at points where the cord is enlarged, forming little brains called ganglia, and from these ganglia nerve-fibres run out to the muscles and to the sense-organs. 
The sense-organs of the cricket are not so complex as our own. Organs of taste have been found in the mouth, and it is certain that insects can tell one kind of food from another. The sense of hearing is found among many insects, as the loud sounds made by some of them indicate. Indeed, in the grasshopper there is a membrane on the first segment of the abdomen which acts like the membrane of the drum of our ear. Finally, the organ of sight is well developed. The eyes of the cricket are a pair of large areas on the head made up of numerous little eyes, each of which sees a part of the field of view. Consequently the whole eye throws on the sensitive nerveendings a series of little pictures which together, like the blocks of a mosaic, make up the whole picture of what is before the insect. 


\section{CHAPTER II}

\section{THE GRASSHOPPER: A STUDY OF THE ENEMIES OF VEGETATION}

LiFe originated in the water and made its early development in the sea. But when, in the course of time, land suitahle for life appeared, vegetation became established there. By means

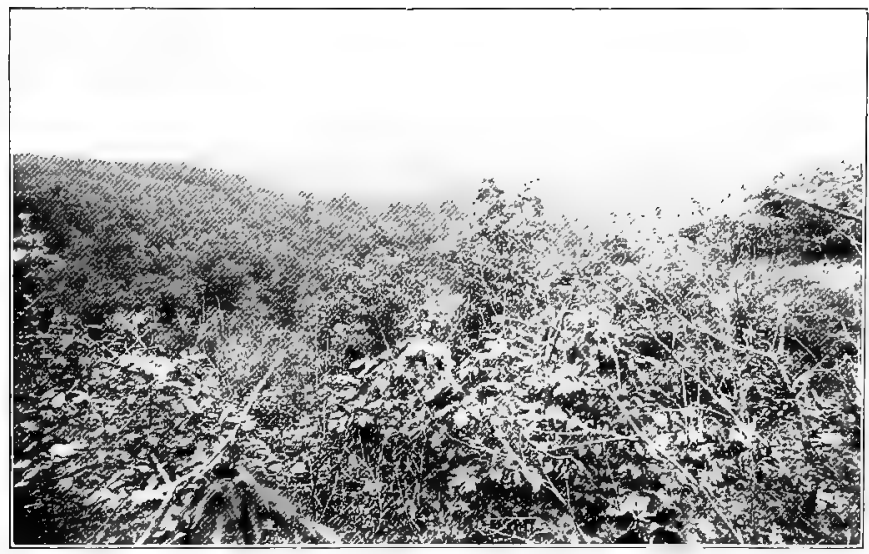

Frg. 8. - The vegetation-covered land.

of this vegetation the heat of the sunlight falling on the land became utilized by organisms (Fig. 8). When land vegetation had become established it offered a rich feeding ground for animals. Animals cannot, like plants, make use directly of 
the energy of the sun, but only indirectly by feeding on vegetation. Now the group of animals that ranks first among the feeders on terrestrial vegetation is that of insects.

Geology tells us that land plants first became prominent in what is called the Deronian age, or the age of fishes. At this time ferns and allied small plants and cone-bearing trees were already abundant. At this same time the first insects appeared, and some of them were like our crickets and grasshoppers. In the next age - - the Carboniferous - vegetation developed enormously, and it was at this time that most of our great coal-beds were laid down by the death of great forests. Insects appeared in great ahundance and variety and most of the lower groups of insects that we now know were there. So we see that the development of insect life on the land went on hand in hand with that of vegetation.

That insects have played well their part as devourers of vegetation there can he no doubt. We shall have occasion to see that this is so as we consider one by one the different groups of insects. One has only to consider the constant fight that the farmer wages against the insect enemies of crops to realize how fully able insects are to destroy vegetation. Everywhere the farmer uses poisonous sprays or powders, and even then his losses by hugs, cotton-boll beetles, potato-beetles, scale-insects, and the rest amount to many millions of dollars each year. As an example of destructive insects none is better than the grasshopper.

The grasshopper is, like the cricket, an animal belonging to a group known as insects (technically Hexapoda ${ }^{1}$ ). The group is given this terhnical name hecause nearly all insects have six legs. With few exceptions insects have also hoth

${ }^{1}$ From two Greek words meaning "six" and "legs." 
feelers, or antennce, and air-tubes, or trachece, by means of which they breathe or respire.

The grasshopper and its allies belong to a subdivision of the Hexapoda - the "order" Orthop'tera." In the memlers of this order the fore and hind wings are unequal, the jaws are used for biting, and the young, when they hatch out of the egg, look like their parents, excepting that they have no wings. While there is, then, during development something of a change in form, it is not a thoroughgoing or complete one. Insects which undergo only an incomplete change of form as they grow older are said to have an "incomplete metamorphosis."

The name "grasshopper" is applied to two "families" of Orthoptera, one of which has short horns or antennx; the other, long horns. Both of these families have long hind legs used in jumping, and an elongated body flattened from side to side. This shape enahles them to move in hetween closely packed blades of grass. The head is wedge-shaped and directed downwards.

Ecology. - The short-horned grasshoppers, which are the most destructive, live in all parts of the world, usually in rather dry situations, such as sandy slopes and uplands (Fig. 9), arid deserts, and rocky mountain sides. They all eat plants or herbs (hence are called herhivorous), and many species go in flocks or swarms. Such species are said to be social or gregarious, while kinds that live alone are called solitary.

Economics. - Grasshoppers are destructive to agriculture. In ordinary seasons the loss is relatively not great, but almost every autumn reports of great destruction caused by them come from different parts of the world. In our country great injury was formerly done by the Rocky Mountain locust. At

${ }_{1}^{1}$ Meaning "straight wings," i.e. lying straight out along the axis of the body. 


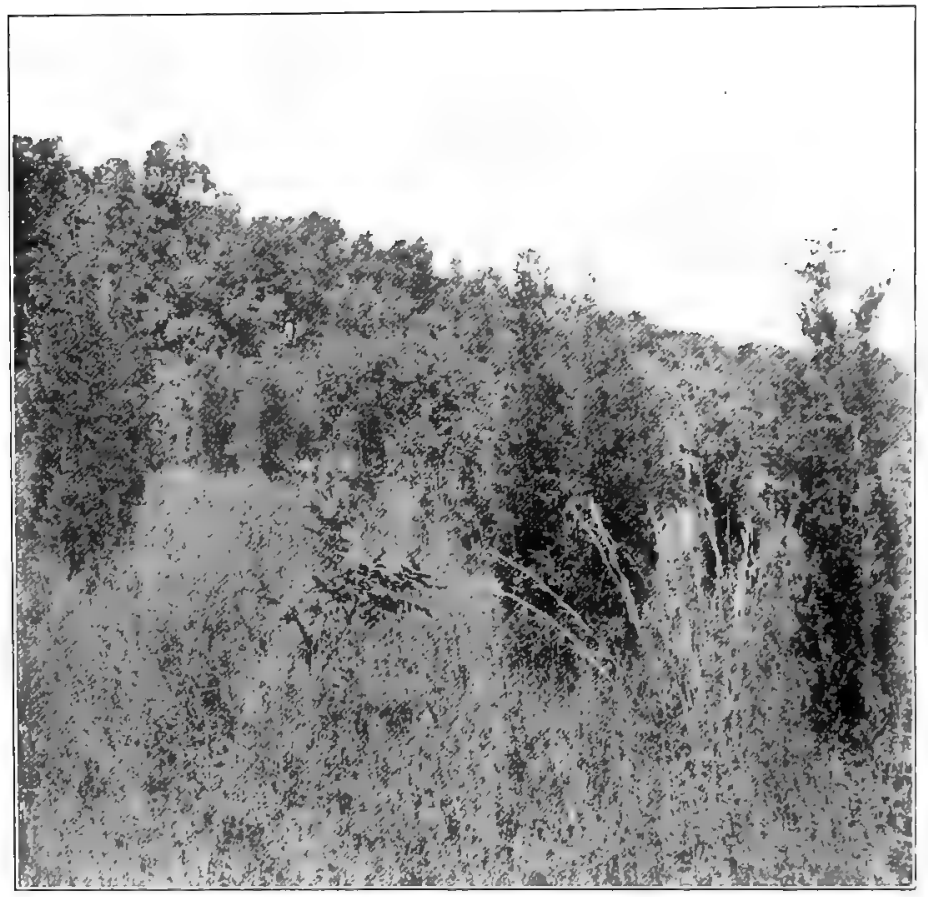

FIG. 9. - The home of the short-horned grasshoppers.

various times this species was impelled hy some cause, probably overcrowding, to fly eastward from its mountain home in countless numlees and to devastate the lowlands as far east as the Mississippi River. From 1873 to 1877 the Rorky Mountain locust was so destructive to vegetation in this region that ('ongress appointed a commission to investigate the species. In describing its effect the commission reports:-

"Falling upon a cornfivd, the insocts convert in a fow hours the green and promising acres into a desolate stretch of bare, spindling 
in two long, parallel strings of albumen, which lie coiled at the bottoms of ponds, hatch out in May, and metamorphose about a month later.

The frogs (Ranidix) are almost confined to the Northern Hemisphere and the East Indies. In the northern United

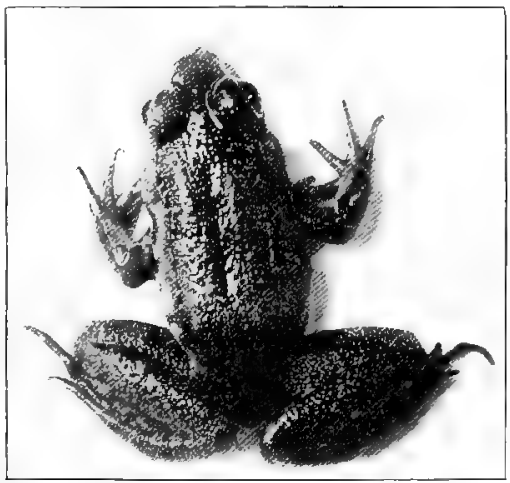

F'IG. 328. - Green frog, Rana clamitans. Nat. size. Photo. of living animal by W. H. C. P.

States there are some eight species, of which the commonest are: the leopard-frog, of green color, with irregular black blotches edged with whitish; the pickerel-frog, light brown, with two rows of oblong square brown blotches on the back; the wood-frog, living in damp woods, pale reddish brown, with a brown band on the side of the head; the green frog, of uniform bright green to brown color, with numerous small dark spots, and with glandular folds (Fg. 328); and the bullfrog, of great size, green, with small, faint spots on the back. 


\section{CHAPTER XXIV}

\section{THE LIZARD: A STUDY OF DRYNESS LOVERS}

In spreading over the land, animals have come into situations where rain falls only for a small part of the year. In such places not only is the ground usually dry, but vegetation is sparse. Nevertheless, certain animals have come permanently to occupy even such desert situations, and, indeed, entire genera or families prefer desert habitats. They are the lovers of dryness. The animals most common in our own deserts are certain hard-shelled, black beetles, lizards of many kinds, ${ }^{1}$ the little sphermophiles, looking like slender chipmunks, with now and then a rattlesnake. All of these animals and many others that live and feed on the ground burrow into the soil. There they remain during the heat of the day, coming forth at night to feed and seek their mates. These desert animals must go for weeks or even months without drinking water, such moisture as they can get being obtained from roots and green parts of succulent cacti. Alnost always the skin of such animals is hard, preventing the loss of internal waters by evaporation. Indeed the whole body of these animals seems to be very dry, and they need only a slight amount of water to live. Even in ordinarily moist climates there is a great deal of difference between animals in respect to their need and love of moisture. While many land animals are found in moist woods and under damp logs, or by the edges of lakes and 
stalks and stubs. . . Their flight may be likened to an immense snowstorm, extending from the ground to a height at which our visual organs perceive them only as minute, darting seintillations, leaving the imagination to picture them indefinite distances beyond. . . . In alighting, they circle in myriads about you, beating against. everything animate or inanimate - driving into open doors and windows; heaping about your feet and around your buildings, their jaws constantly at work, biting and testing all things in seeking what they can devour."

The locusts of the old World are likewise frequently very destructive. The species that lives in southern Europe, North Africa, Asia Minor, Syria, Java, and Japan is doubtless the locust of the Bible. The description given by the prophet Joel is very vivid and accurate:-

"A day of darkness and of gloominess, a day of clouds and of thick darkness, as the morning spread upon the mountains; a great people and a strong; there hath not been ever the like, neither shall be any more after it, even to the ycars of many generations. A fire devoureth before them, and behind them a flame burneth : the land is as the garden of Eden before them, and behind them a desolate wilderness; yea, and nothing shall escape then. The appearance of them is as the appearance of horses; and as horsemen, so shall they run. Like the noise of chariots on the tops of mountains shall they leap, like the noise of a flame of fire that devoureth the stubble, as a strong people set in battle array. Before their face the people shall be nuch pained; all faces shall gather blackness. They shall run like mighty men; they shall climb the wall like men of war; and they shall march every one on his ways, and they shall not break their ranks. . . . They shall run to and fro in the city; they shall run upon the wall; they shall climb up upon the houses; they shall enter in at the windows like a thief."

General Development of the Grasshopper. - The common red-legged grasshopper lays its eggs during autumn in holes in the ground two and three centimetres deep. The holes are 
drilled by the horny plates at the tip of the abdomen of the female. The eggs, 30 to 100 in number, are laid in a mass and covered with a sort of jelly. The eggs pass the winter in the ground and hatch in early summer into young grasshoppers. As the young grow larger they molt several times; that is, they cast off the cuticuld. After each molt the body is left soft and colorless and, heing freed of its hard, tight, varnish-like coat, it is in a condition to grow rapidly. After each molt the small wings or wing-pads also become larger, and the relative sizes of other parts of the body change. Just before the last molt the young grasshopper crawls up some vertical object, clutches it firmly with the hind feet, and remains motionless in this position for several hours. Then the cuticula splits along the middle of the back. The head and body inside the cuticula swell. The head protrudes through the split, and gradually the entire body works forward and out of the old cuticula, not easily indeed, hut with violent writhings and pullings. The legs and antennæe are especially hard to free. They can pass out through the joint s of the old skin only because they are soft and flabhy. But soon after they become exposed to the air the new cuticula, already formed beneath the old one, hardens into a firm covering. The wings, which developed in a roll, spread out, dry, and then fold up in the way we see them in the adult.

Allies of the Grasshopper. - The orler Orthoptera, to which the grasshopper belong's, inc]udes six principal families, which have certain resemblances to each other as well as points of difference from insects that belong to other orders. Typieally, they are rather soft-skinned, with long bodies and long legs. Most of them, except the praving mantises, feed on plants or on decaying matter. On account of their com- 
paratively soft skin they are a favorite food of hirds and other animals that eat insects.

The cockroaches (Blattidx) are by preference creatures of the tropics. Those that live in cold climates like dark and warm places. The few kinds found in our fields live chiefly under stones and logs, and some of them are wingless (Fig. 10). The two kinds that are our household pests were accidentally imported from Europe. One of these is the small, brown "Croton bug" which is found among water pipes in kitchens; and the other is the large black species common in sugar-rufineries, slaughter-houses, and bakeshops. All are omnivorous, eating such things as sugar, breadstuffs, clothing, bookbindings, bedhugs, and other insects. The eggs of cock-

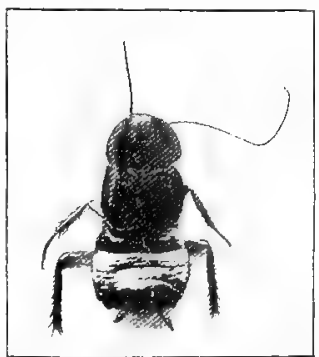

Fis. 10. - Wingless cockroach. Nat. size. Photo. by W. H. C. P. roaches are laid in a small lump, and all encloser in a single, brownish capsule through one end of which the young hatch.

The praying mantises (Manticlæ) have received their popular name hecause of the devotional attitude in which the greatly enlarged front legs are held. Unlike other Orthoptera they are carnivorous; that is, they feed upon live animals. They hunt and devour other insects, - some even that are larger than themselves, - and they prey upon each other. While most of the species are tropical, one (Fig. 11) is abundant in our Southern States and another occurs in the Missouri Valley.

The earwigs (Forficu'lidæ) resemble short-winged beetles (page 66), but differ from them in having large pincers or forceps at the hind end of the borly. The earwigs (Fig. 12) use the forceps in seizing prey or in grasping one another. Earwigs 
hide during the day under stones or débris of the seashore, or in flowers on which they feed. Those that hide in débris feed

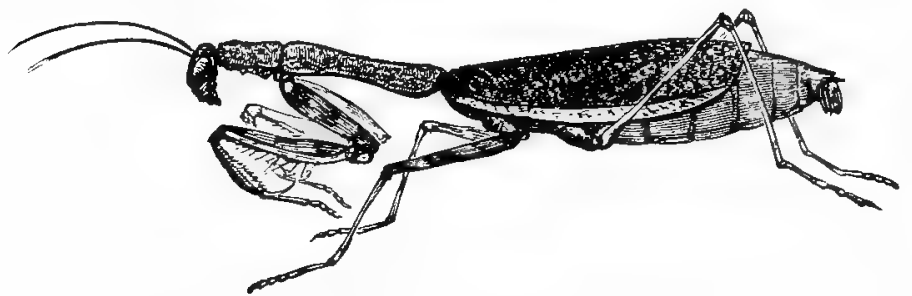

FIG. 11. - Phasmomantis carolina. Praying-mantis of southern United States. Nat. size. Copied from Packard.

on living and dead animals and plants found there. They either crawl about or fly during the night. The name "ear-
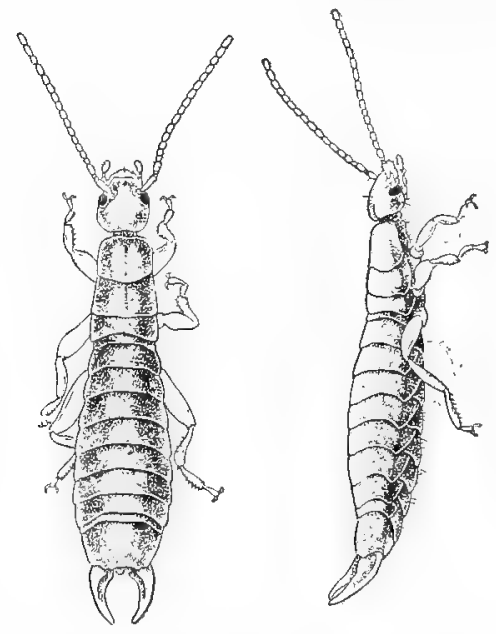

FIG. 12. - Dorsal and lateral views of an earwig, common along shores ( $A$ nisolabis maritima). wig" seems to have arisen from an unwarrantable belief that these insects penetrate into the ears of persons who are asleep. The walking-sticks and leaf-insects (Phasmidæ) show to a marvellous degree a likeness to the twigs and leaves among which they live. The most remarkable forms live in the tropics. Such have large wings which resemble in form, color, and venation either living or dry leaves. Upon those species that 
resemble dry leaves, blotches looking like mildew are found. Even the legs may be thin and expanded so as to resemble foliage. In our country occur only the twiglike, wingless forms known as walking-sticks (Fig. 13). These walkingsticks change color to correspond with the changes of twigs from season to season; for the young walking-sticks, which appear in the spring, are green like joung twigs, but in the autumn the adults are gray or brown. This likeness of animals to things outside of the animal kingdom has been called protective resemblance and has probably become established because of the freedom from attack which it gives to its possessors. Our common northern species feeds on leaves, especially those of the oak. Occasionally it does much damage to trees.

The long-horned grasshoppers and katydids (Locustidæ) are closely akin to the type studied. The family includes many grasshoppers

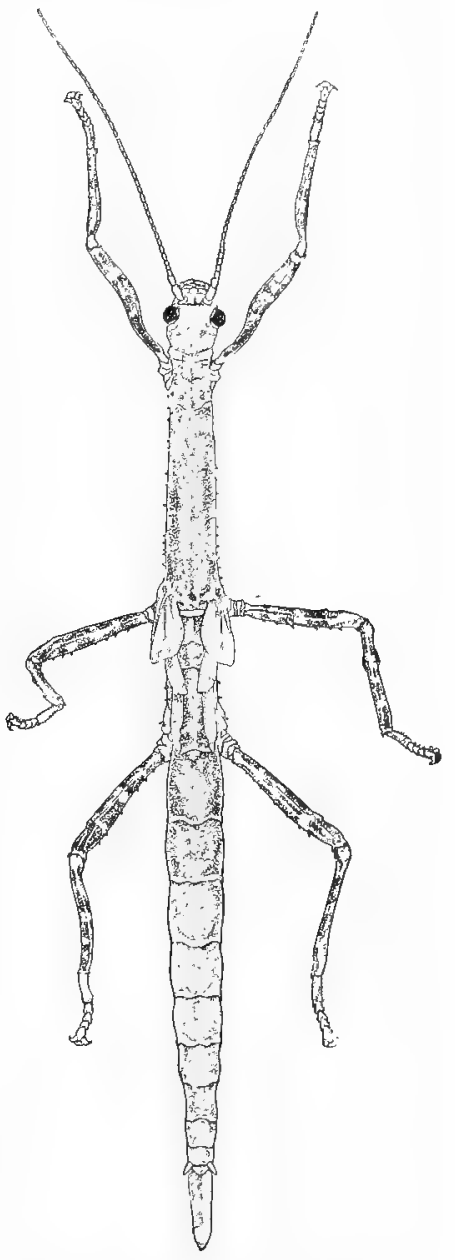

FIG. 13. - The northern "walkingstick" (Diapheromera Jemorata). 
found in meadows and marshes (Fig. 14). The Katydids have their whole trunk and wings green like the foliage they inhabit. When the large, upper wings are rubbed to-

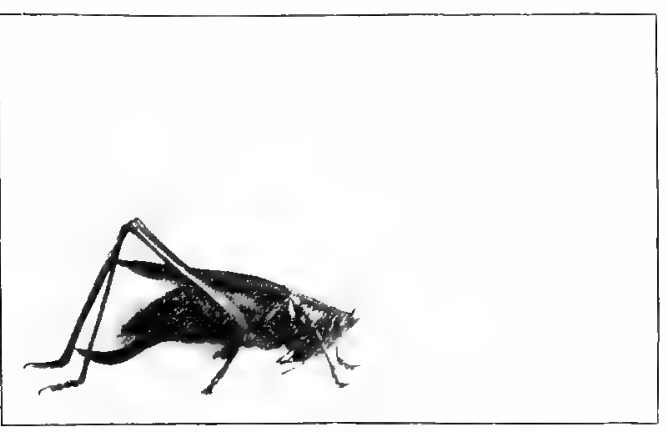

FIG. 14. - Orchclinum, meadow grasshopper. Nat. size. Photo. by W. H. C. P.

gether, they vibrate and cause the familiar note. Other members of this group are the Cricket Grasshoppers (Fig. 15), wingless forms of a brown color and arched profile, which live in cellars, under stones, and bark of trees, and the Cave Crickets, which live in constant darkness.

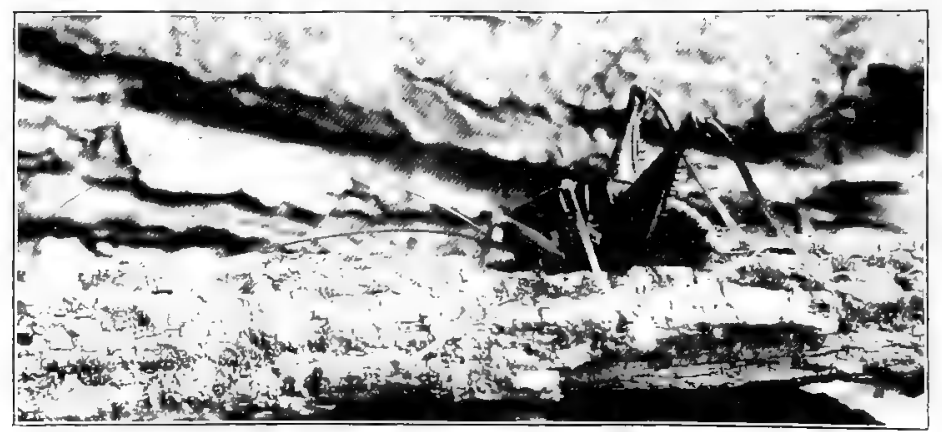

FIG. 15. - Ceuthophilus, cricket-grasshopper. Two-thirds nat. size. Photo. by W. H. C. P.

The crickets (Cryllidie) are found all over the world. They have short, cylindrical bodies and live chiefly in hidden 
places, such as beneath stones or in holes which they make in the ground. Their eggs are laid loosely in their retreats. They make a familiar chirping noise, the blended sounds of which, as heard on a summer evening, rise and fall in a distinct rhythm. The rate of chirp seems to be entircly cletermined by temperature, so that in the case of the "trec-cricket" one may compute the temperature by means of the formula $T=50+\frac{N-40}{4}$, in which $T$ stands for temperature in degrees Fahrenheit, and $N$ the number of chirps per minute. The mechanism by which the chirp is produced is as follows: Near the middle of each of the upper wings of the male cricket is a vein of such roughness as to form a sort of file, and near the edge of the wing is a thickened scraper. When the upper wings are brought in contact above the body, and the scraper of one is rubbed across the file of the other, the wings are set in vibration, producing the call.

A peculiar form of Gryllidx is the mole-cricket (Fig. 16), whose fore feet have become much modified for burrowing.

The Orthoptera constitute one of the lowest orders of insects. The orders described below in this chapter are also of simple organization:-

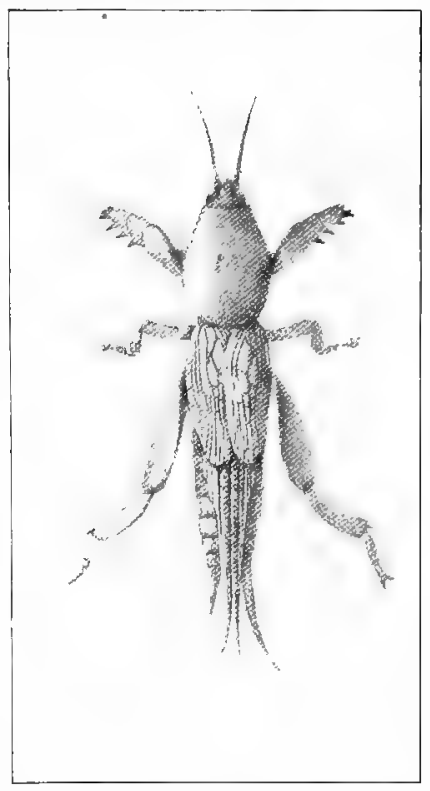

FIG. 16. - The mole cricket of the northern United States (Gryllotalpa borealis). 
The order Hemiptera includes certain insects which resemble the Urthoptera in undergoing an incomplete metamorphosis;

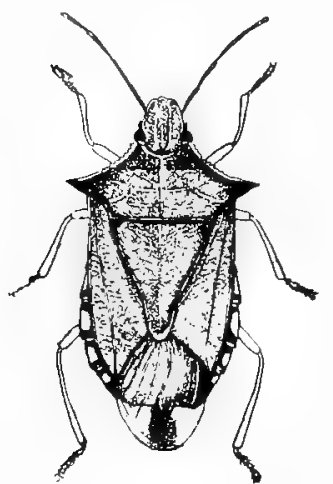

Ftg. 17. - The Spined Tree-

bug. After Lugger. so that the young, or larvæ, look much like the adults in form and develop without sudden transitions. They differ from the Orthoptera in having mouth parts adapted to piercing tissues and sucking the juices of animals and plants. There are two main groups; namely, the True Bugs, or Heteroptera, in which the first pair of wings are thick at the hase but have thin tips overlapping each other over the back (Fig. 16), and the clear-winged bugs, or Homoptera, in which the entire wings are thin and transparent and rest in contact over the back like the sides of a roof.

The suborder Heteroptera includes a vast number of insects usually of small size and of very varied habits. Some of them live under the water and are known as water-boatmen, back-swimmers, water-scorpions, and giant water-bugs. Others skip over the surface of the water and are known as water-striders (Fig. 18), while still others live only on land. Some of the latter, such as the chinch-bug, squash-

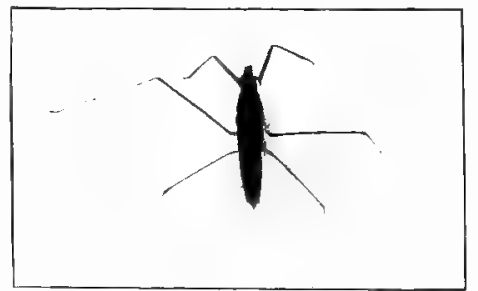

Fig. 18. - (Hygrotrechus.) The water-strider. Nat. size. Photo. by W. H. C. P. bugs, and stink-bugs, are very destructive to plants. Still others, such as the assassin-bugi (Fig. 19), kill injurious in- 
sects, and hence are useful to agriculture. To the Heteroptera also belongs the bedbug, a loathsome human parasite, most of whose near relatives live in flowers. Thus out of the Heteroptera, a prevailingly herbivorous group, there have arisen, through the acquisition of new habits, certain carnivorous forms, and finally certain parasitic ones. The extreme case of degeneration in this series is the family of lice, which have become

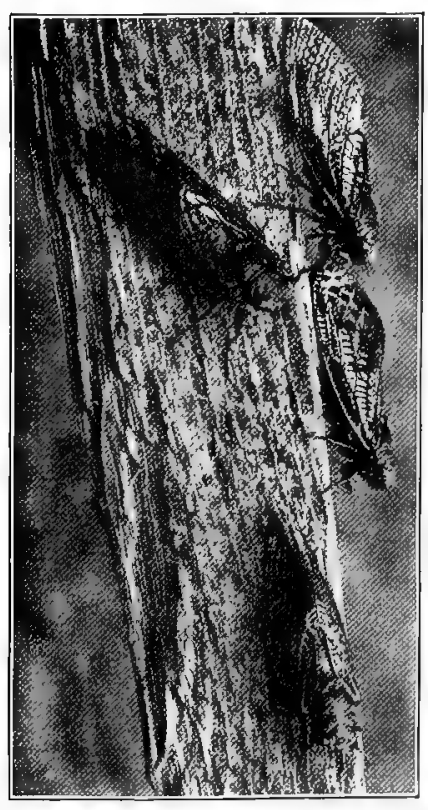

FIG. 20. - Cicada septemdecem, the seventeen-year locust. Reduced. Photo. by V. H. L. permanent

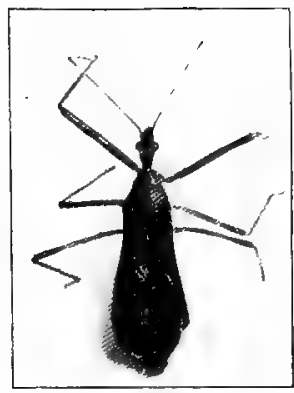

Fig. 19. - The assassin hug, Reduvius. Black. Nat. size. Photo. by W. H. C. P.

parasites, being unable to eat anything except the liquid or semiliquid food afforded by their "hosts."

The Homoptera include insects of very diverse size and form. The largest are the cicadas, or "locusts" (Fig. 20), some of which have the remarkable habit of requiring thirteen or seventeen years for their development. Consequently these cicadas appear only at intervals of thirteen or seventeen years. The eggs are laid in twigs, the young drop to the ground, bury themselves, and live by sucking juices from the roots of trees. Eventually they come to the surface, leave 
their larval skin (Fig. 21), and fly away as full-grown cicadas. In the case of our more familiar species of cicada there is a brood every year.

Besiles the cicalas the Homoptera include the little leafhoppers and tree-hoppers, the very destructive scale-bugs

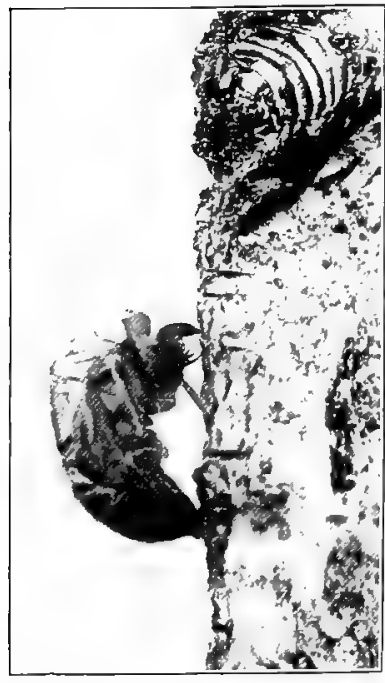

Fig. 21. - Pupal case of cicada. Two-thirds nat. size. Photo. by W.H. C. P. (Fig. 22), the mealy bugs, most of which attack fruit trees and their fruits, and the plant-lice, or aphids (Fig. 23).

The following groups, containing relatively few important species, are placed in this chapter with the Orthoptera although they are not closely related to that order.

The may flies (Ephemeridæ) are large winged insects which are seen in great numbers in early summer. Their fore wings are finely veined and much larger than the hind wings. The mouth parts are rudimentary, and there are two or three threadlike appendages at the tail end of the body (Fig. 24). As the systematic name implies, they have a very ephemeral existance in the winged or imago state. The imagos appear in swarms, eat nothing, and live only a few hours, to deposit their eggs upon or under stagnant water. The larva hatch in the water, feed upon small aquatic plants and insects, breathe by means of gills borne upon the back, and live in this immature condition for one, two, or even three years (Fig. 25). After many molts the winged form emerges from the water 
into the air, but, unlike all other insects, it undergoes an additional molt just before laying its eggs. As the insect is subjected to many accidents in its long and defenceless larval life and in its brief and precarious winged state, each species is preserved only by producing an enormous number of young.

The dragon-flies (Odona'ta) have four membranous, net-veined wings, of which the front pair are never larger than the hind ones. Their large heads carry relatively enormous eyes. Two groups of dragonflies may be distinguished according as the wings when at rest are extended (Fig. 26) or folded together over the back. Dragonflies live on the wing, hovering over water and preying upon other insects, especially mosquitoes. The eggs develop in the water into aquatic larvæ which are quite unlike

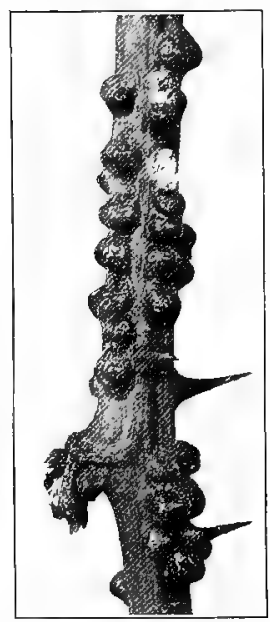

FIG. 22. - A scale insect (Lecanium). Remains of females after production of young; seen as swellings on the bark. Nat. size. Photo. by V.H. L.

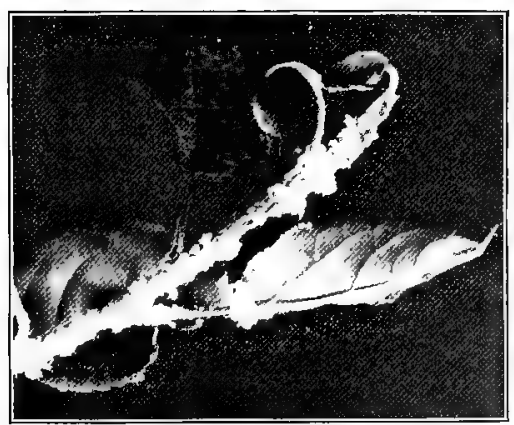

FIG. 23. - A woolly aphis (Schizoneura) on apple twig. Photo. by V. H. L. the adult. Especially the jaws are peculiar, heing jointed and capable of being suddenly thrust out, in order to catch the animals which serve as prey. These larvæ are easily reared over winter in an aquarium, where not only their ferocious habits, but also their peculiar method 
of lreathing by means of water taken in at the tail end of the food-canal, may be observed (Fig. 27).

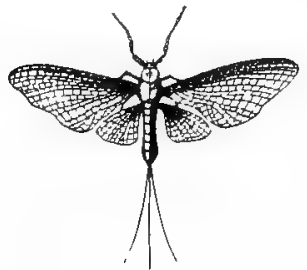

Fig. 24. - An adult May fly.

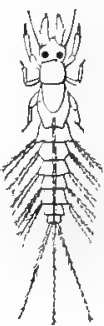

Fig. 25. - A larval May

fly. From Parker and Haswell.

White ants, or termites (Isoptera, Fig. 28), while not true ants, live a very similar social or communal life. They differ from ants in the venation of the net-veined wing (when present).

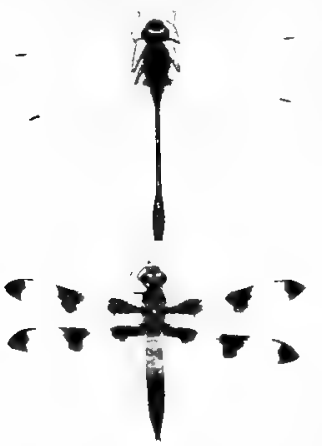

Fig. 26. - Two North American Odonata, belonging to the family Libellulidis. About onehalf nat. size. Photo. by V. H. L.
White ants are most abundant in the tropies, where they build great conical nests of sand cemented by their saliva; but they are found also in temperate countries. The common eastern termite (Termes favipes) ranges from Massachusetts southward, and lives

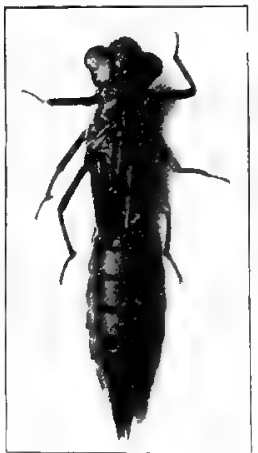

Fig. 27.--Old larva or pupa of Dragonfly (Eschna). Nat. size. Photo. by W. H. C. P.

in wood or under stones. Three kinds or castes of white ants occur in any community: (1) workers, with small, 
round heads and concealed mandibles; (2) soldiers, with large, square heads and long, powerful mandibles; and (3) the royal class of kings and queens, which have wings until after the

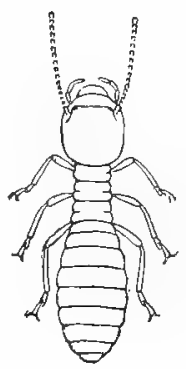
marriage flight. At a certain time in May the males and females from the various colonies fly forth to mate, and thus a breed-

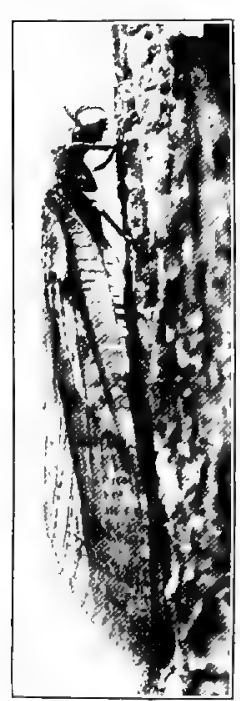

FIg. 29. - Corydalis, the dobson. Two-thirds nat. size. Photo. from life by W.H.C.P,

ing takes place between colonies. Only a few of the pairs, however,

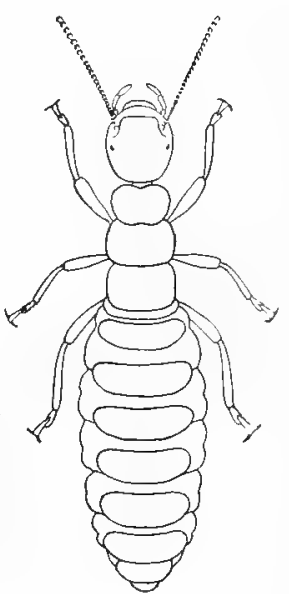

FIG. 28. - Worker and queen termite. find workers to aid them in establishing a new colony. The queen, after she is established in a new hive, merely produces young, the abdomen becoming immensely swollen and elongated to fifteen centimetres with the eggs which are about to be laid. In tropical countries the termites are troublesome to man by injuring trees and devouring the woodwork of houses.

The order Neuroptera includes certain insects which differ from the Orthoptera. in having larvæe very unlike the adult, and in having a resting pupal stage in which the metamorphosis into the adult is completed. There are four clear, net-veined wings, and the mouth parts are used for 
biting. The largest representative of this group is the Horned Coryclalis (Fig. 29), whose larva lives in streams and is callerl the dobson. The adult is found among fallen leaves or on tree-trunks.

The ant-lions are of interest because of the peculiar habits of the larvæ, which live in sheltered sandy places and make

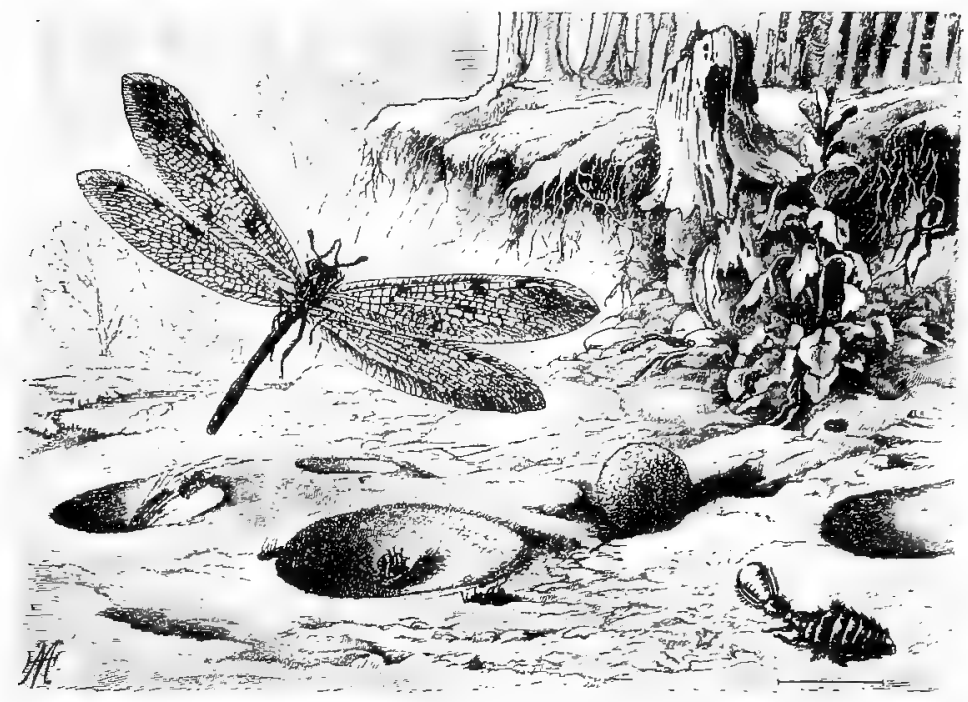

FIG. 30. - Life history of ant-lion. Larva in their pits; one on surface at right; hall containing pupa in centre; adult at left. Fron Bailey-Coleman, "Biology."

funnel-shaped pits a few centimetres in diameter. The sides of the pit are so steep that if an ant by accident falls into it and attempts to emerge, it will slide down to the bottom with the rolling sand. The larva lying in wait buried in the sand at the bottom, quickly protrudes its jaws and grasps its luckless prey (Fig. 30). 


\section{CHAPTER III}

\section{THE BUTTERFLY: A STUDY IN ANIMAL COLORATION}

Butterflies, together with Moths, belong to the order Lepidoptera, ${ }^{1}$ insects that when fully developed have long, coiled, sucking mouth parts forming, together, the proboscis, and large, membranous wings covered with colored scales. All Lepidoptera undergo a complete metamorphosis. Lepidoptera occur on all continents, but there are more species in the tropics of South America and Africa than elsewhere. The number of known species is over twenty-five thousand.

General Development. - The Lepidoptera in their development from the egg undergo fundamental changes in form. The eggs, of which the female may lay siveral hundred, consist of a germ enclosed in a tough coat or egg membrane. As the germ develops, the membrane

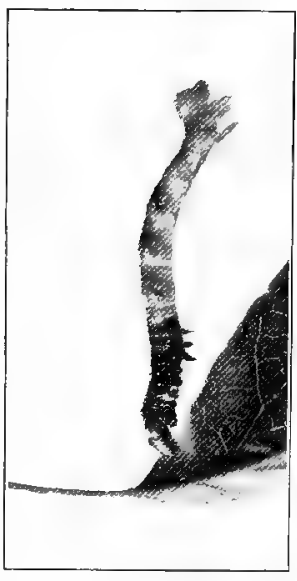

FIG. 31 . finally bursts and a little wormlike creature emerges. Its body is made up of a number of rings placed one behind the other. The first of the rings is the head and bears the biting jaws. Certain of the rings that follow hear legs which end in claws. 
Some of the hinder rings bear short, stubby feet. This is the larval stage of the butterfly, and is commonly known as the caterpillar (Fig. 31).

The raterpillar feeds ravenously and grows rapidly. Its body is enclosed in the cuticula. As the caterpillar grows, this skin is put under tension until fnally it bursts at the

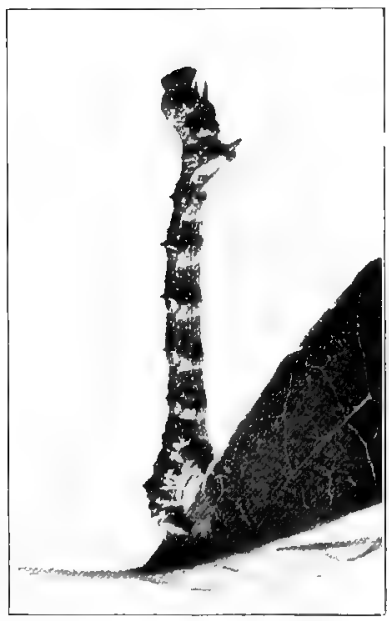

FIG. 32. - Molting caterpillar.

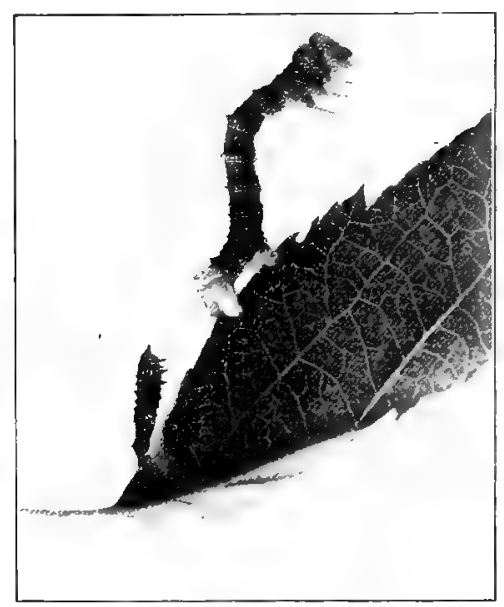

FIG. 33.-Period of stretching; old cuticula to left.

antcrior end (Fig. 32), and the caterpillar emerges, provided with a new cuticula formed beneath the old one. This new cuticula is, at first, elastic, and the caterpillar takes advantage of this fact to increase its length and diameter by as much as one-third (Fig. 33). The new skin rapidly hardens, and so confines the ever-developing caterpillar until it is again unable to withstand the internal pressures. Then another molt occurs. Thus the cuticula of the caterpillar makes it necessary that growth should not be continuous, but should proceed 
by jumps. From one molt until the next constitutes a stage in the eaterpillar's development, and most caterpillars pass through several of these stages. In the last stage the caterpillar ceases to feed and wanders about until, having reached a suitable locality, it molts for the last time. It is now shorter and stouter and is covered with a much thicker cuticula, and in this stage remains motionless for a long time. In this apparently quiescent stage the future butterfly is known as the pupa. Some caterpillars spin a web of silk about themselves known as the cocoon (Fjgs. 34, 35). The cocoon is attached to some object

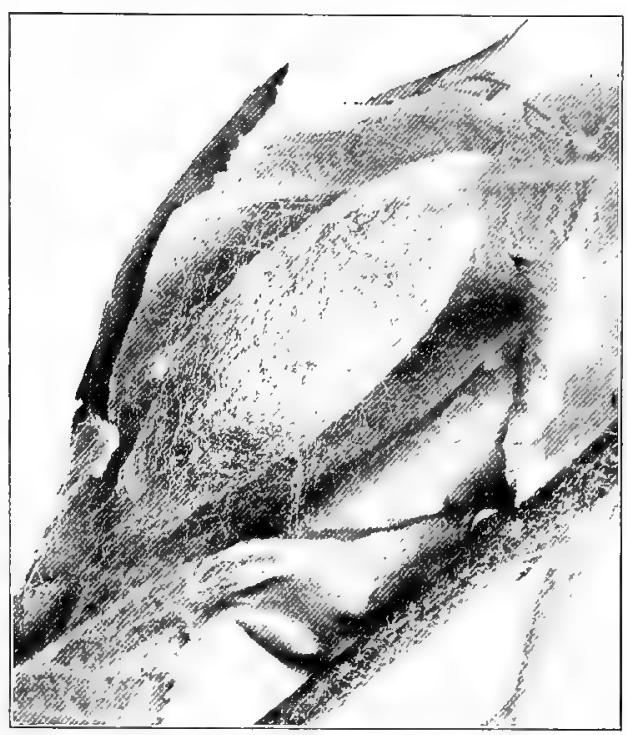

FIG. 34. - Cocoon.

above ground. Others pupate above ground, protected only by a thick cuticula, while still others pupate under ground in a sort of cell which in some species is lined with silk or silk mixed with the hairs of the caterpillar.

The inactivity of the pupa is only apparent. Inside the cuticula, development is proceeding rapidly, leacling to a very fundamental change of form. From the back of the animal there grow out wings, and from its head antennæ and 
the prohoscis, while from the uncler side grow three pair of feet. These may be seen pressing against the wall of the pupa. Finally, the cuticula of the pupa bursts, and there emerges the last stage of the butterfly, known as the imago. The wings, which are at first folded, are broadly expanded and

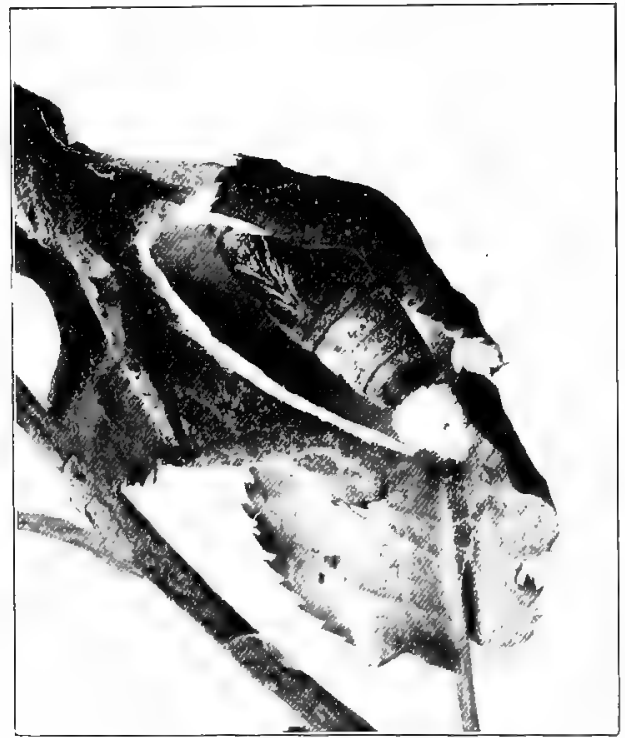

FIG. 35. - Cocoon, cut open to show pupa. dried, and then the butterfly is ready to take its flight (Frontispiece).

Ecology. - Butterflies feed mostly during the larval stage (Fig. 36); the pupa can take no food; the adults of many species touch no food, but in other cases suck the nectar of flowers, the sap of plants, and the juice of fruits. The larvæ feed, as a rule, on plants; but a few, such as the clothes-moth and cortain enemies of scaleinsects (page 24), feerl on animal matter. The plant feeders differ in the variety of food they use. At one extreme we have forms that starve unless they can reach their own particular food-plant; at the other extreme there are caterpillars which can live upon the foliage of many kinds of plants. Certain families of plants are especially preferred by cater- 
pillars as food. Thus of the hundred species of New England butterflies, eight feed upon oaks, eleven upon willows, thirteen upon the rose family, and twenty-eight upon the pea family. It follows from the restricted food of many caterpillars, that the range of the species must often be determined by that of its food-plant.

The imagos fly in the daytime, especially in the sunshine. Certain species are characteristic of the roadside, others of meadows, gardens, or woods, while still others are found flying everywhere. Owing to its ordinarily short life, the imago is usually found not far from its larval foodplant, upon which it lays its eggs.

The Wings of the Butterfly. The most conspicuous organs of the butterfly are, its wings, and of all insects the butterfly has the largest wings. The wings are conspicuous not only on account of their size, but also the brilliant colors which they usually wear. Our commonest butterflies are known to every

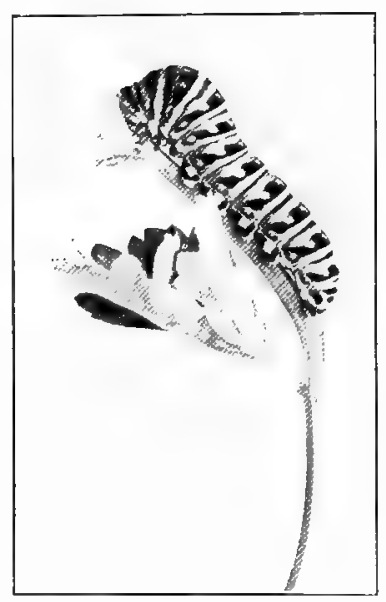

FIG. 36. - Feeding larva. lover of the fields owing to their striking white, yellow, red, and blue colors. While for most animals inconspicuousness seems to he arlvantageous, butterflies and a considerable numher of moths make no effort to hide their colors. The Lepidoptera stand in the insect world as a type that has developed organs for the display of color. Of the meaning of the color display of Lepidoptera we have only imperfect knowledge. Many of them are protected from the attack of their natural 
enemies - the birds - by a clisagreeable taste, and their bright colors serve to remind birds of their inedible nature and so afford them greater immunity from attack. But this can hardly be a complete explanation of the color of Lepicloptera, for many nocturnal species have strikingly beautiful color pattems. We shall consider directly some special uses to which the coloration of Jepidoptera has been put.

\section{The Broods of Butterflies and their Polymorphism. -} Butterflies winter over in various stages, some in the egg stage, some as larvæ, others as pupæ or as imagos. Some kinds pass the winter in either of two stages. In whatever stage they tarry, the life current runs very slow, and during this season few changes take place. In the spring, development goes on rapidly: the winter generation becomes mature and a summer gencration is started. Frequently there is more than one brood produced during the summer, even in the Northern States. Farther south two and even three summer broods are still commoner. Where two or three broods occur they may be quite dissimilar. This is very strikingly illustrated in the case of the Zehra Swallow-tail (Papilio ajax) of the southeastern United States, which has more than one brood each year. The early spring form ("marcellus" form) is the smallest, and has the tail tipped with white; the summer form ("ajax") is the largest, and has the tail two-thirds longer than the marcellus form. Other illustrations of this seasonal difference are given by the imported Cabbage Butterfy, the Gray-veined White, and the Spring Azure. This dissimilarity between the hroods of different seasons is known as "seasonal dimorphism" or "polymorphism." The cause of the difference between the different broods secms to be the dissimilar weather 
conditions, especially heat, under which they have developed. Mr. W. H. Edwards in this country, and Weismann and others in Europe, have shown that, when the summer brood is kept during development in a refrigerator, the butterfly has the color of the winter form.

Protective Resemblance and Mimicry. - Every one who has visited a natural history museum must have noticed that the polar mammals are apt to be more or less white, while those

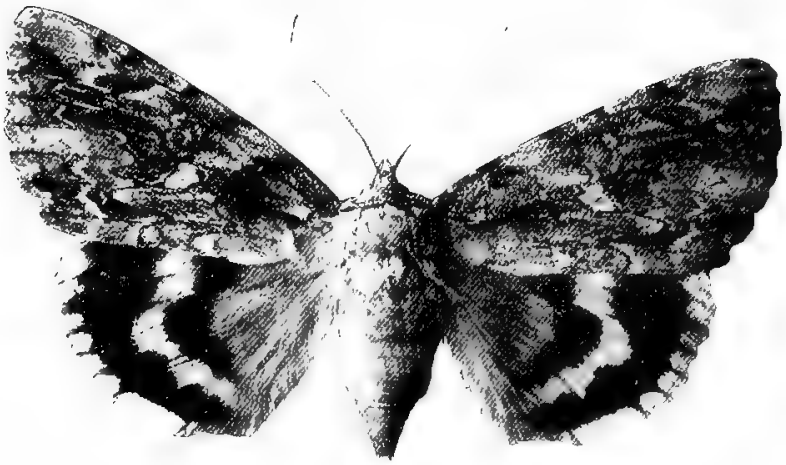

Fra. 37. - Catocala ilia, the underwing. Upper wings, bark color; lower wings, black with orange bands.

which live in tropical forests are dark. It is easy to understand that these colors in their proper surroundings make the animals which wear them hard to see. This may be of advantage in enabling them to escape the observation of their enemies, which are seeking for them, or to avoid being seen by their prey as they approach. This general resemblance to their hackground is seen even in some caterpillars, e.g. the tomato-worm, which is colored so exactly like the leaf on which it feeds that it is hard to find. Other eaterpillars, belonging to the family of "measuring worms," have the color of the 
twigs of the plant, on which they feed, and the resemblance is heightened by the way they have of stiffening and standing out like a branch from the stem. A common genus of moths

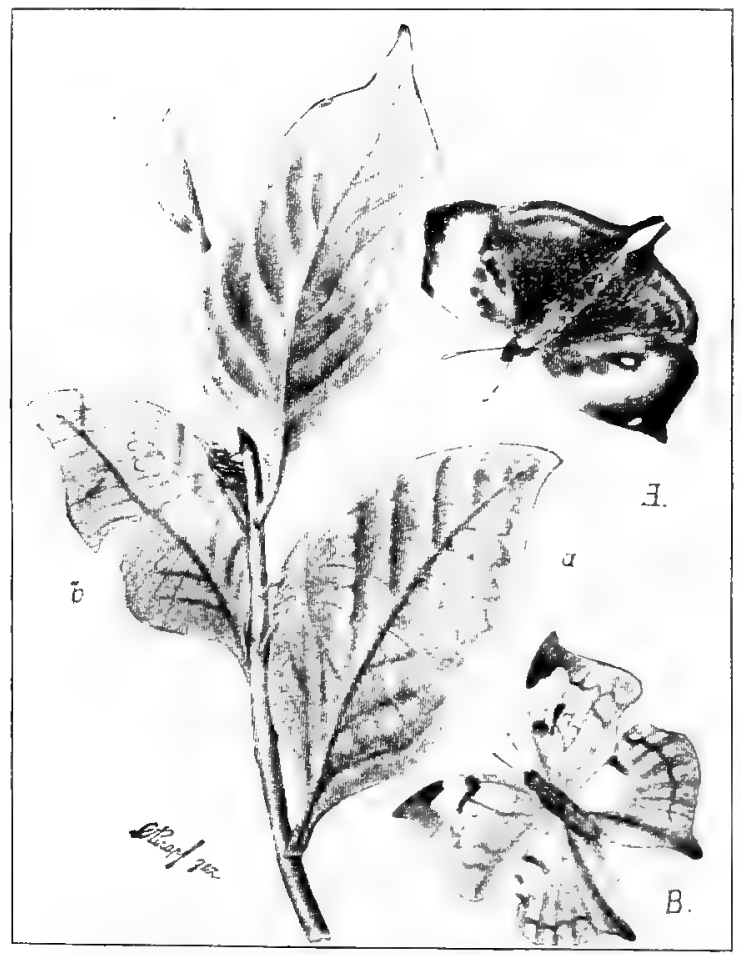

Fig. 38. - A, Kallima, the leaf-hutterfy of the East Indics, flying; $a$, at rest. $B$, Siderone, another leaf-butterfly, flying; $b$, at rest.

(Catoca'la, Fig. 37) which fly by night and have showy hind wings, rest hy day on trees, showing only their fore wings, which so closely resemble the lark as to be almost indistinguishal,le from it. Still more striking is the resemblance which 
we find between some adult hutterflies and dry leaves as seen, for example, in Kallima, a butterfly of the East Indies (Fig. 38). The resemblance of the butterfy to the leaf extends even to details, for the clear patches on the wing resemble hol's, while little circular markings resemble the patches made by particular kinds of fungi. This resemblance of an animal to inanimate objects in its environment is known as protective resemblance.

Examples of the species of butterflies which appear to be let alone by birds, owing to their disagreeable odor or acrid taste, are the Danaidx, to which family our "Monarch " belongs. ${ }^{1}$ Closely resembling the Monarch in this country is the "Viceroy" (Limenitis archippus). This resemblance of the edible Viceroy to the inedible, acrid Monarch is, it is believed, sufficient to deceive even the birds, and thus the Viceroy gains considerable immunity from attack. This resemblance of an edible to an immune species is known as mimicry. The origin of protective resemblance and mimicry are both explained hy the theory of Natural Selection, or Darwinism. Since either of them is of great utility to the organism, their possession, even to a slight degree, however accidentally gained, will give their possessor an advantage over its neighbors in the struggle for existence. Consequently it will be more apt to survive and transmit its peculiarity to its offspring. By this means an adapted race will arise and crowd out the unadapted.

Protective resemblance and mimicry in other animal groups. - Although Lepidoptera afford the best examples of protective coloration and mimicry, these phenomena are not confined to this group. Other insects besides the Lepidoptera 
show adaptation in color and form with reference to their environment. The case of leaf and stick insects has been referred to on page 18. Grasshoppers found on heaches and other sandy areas are much lighter than the same species in grassy mearlows. Some of the true bugs, which live on shrubs, resemble thorns. Some flies (page 82) mimic bees in shape and the humming sound that they make; and certain beetles almost exactly resemble the bark and lichens on which they occur. Among mammals and hirds the stripes with which their coat or plumage is marked serve to break the uniformity of coloration in the same way that the lights and shadows break the uniformity of a landscape. The striped animals blend into the landscape and so become inconspicuous. The spots on certain deer closely resemble the flecks of sunlight in the forest (Fig. 39). The light color of the under part of animals serves to reduce the effect of shade and so to do away with the sudden transition between the ground and the animal's body (Fig. 361). Many of the lower groups of animals, such as fishes and lizards, are able to change the color of their bodies so as to make them harmonize with their background. Thus the flatfishes or flounders are much lighter when they rest on clear sand than when they rest on mudrly bottoms, and crabs, by permitting the growth of seaweed on their backs, become hidden from their enemies. Other inhabitants of brilliantly colored coral reefs have the colors of coral. Thus arlaptations in color and form are wiclespread, and the general theory expressed in the precerling paragraph serves to account for them wherever found. But it would he rash to assert that every detail of form or color had been determined by the struggle for existence. 
Economics. - The Lepidoptera in general arre very destructive to vergetation. In the review of the different families that follow there will be found an account of some of the more important eronomic species. Infortunately we have in this country not only an abundance of injurious native species,

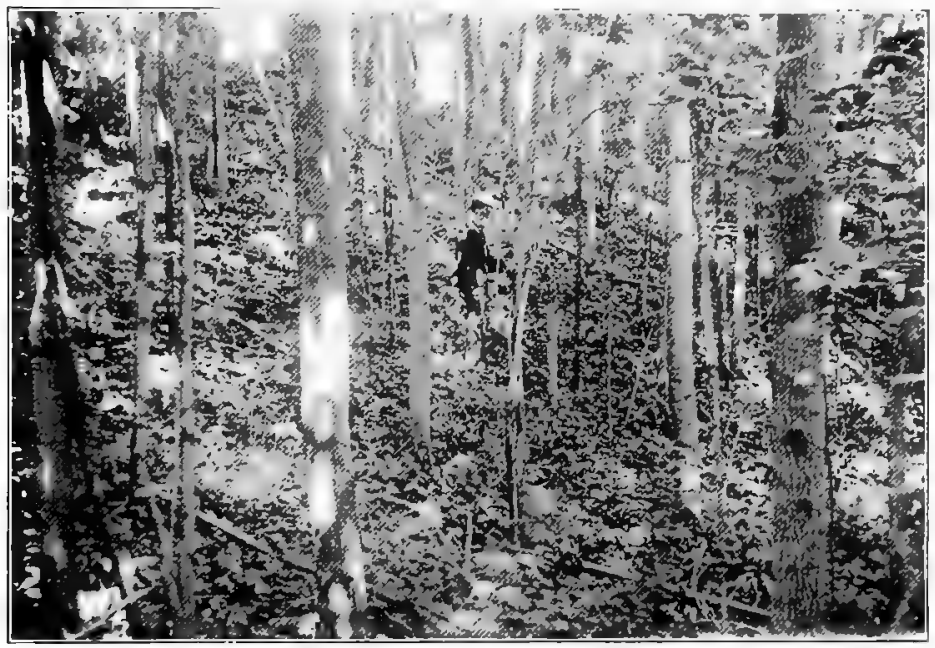

FIG. 39. - A " sylvan scene...

Where shadows dark and sunlight sheen,

Alternate come and go."

but many exotic forms that have been imported. When these forms were removed from their natural enemies thrir fecundity was left unchecked, and the result has been that they have brought great devastation on rast anricultural districts. The earnest attempt of a state to keep down for a while an introduced pest, even at great expense, is commentalile. Among the useful Jepicloptera are the silkworms, of which the most important belong to a single family (Bombycida) described below. 
Types of the Butterflies. - The Swallow-tails (Papilio) are our largest butterflies. Here helong the yellow Tiger Swallow-tail (turnus), with lolack stripes, which is found over nearly the whole United States; and the black Swallow-tail (asterias), whose wings are crossed by rows of yellow spots, and whose hind wing hears an orange, hlack-eyed spot. Its larvæ feed on will or cultivated composite plants, cspecially parsnip leaves.

The cabbage-butterflies (Pieris) have white or yellowish wings, tipped and spotted with black, or sometimes with orange. They hover over damp spots in roads or fly through garden patches. The larvæ are very destructive and feed on cabbage and related plants.

To the Nymphs belong the Angle-wings, whose fore wings are notched on their outer edgc. Here belongs the butterfly which we sometimes see on warm days in winter or early spring - the Mourning-rloak. This has purplish hrown wings with a broad yellow horder, and a row of pale blue spots. The Graptas belong here, too; they may be told by the silver spot on the hind wing. In the Admirals the wings are less deeply notched. The red Admiral is purplish black aloove, with an orange band and white spots running olliquely across the upper side of the fore wing. It occurs in England as well as in the U'nited States. Here helongs also the Viceroy, which is not closely relaterl, lout is quite similar to the Monarch because the former mimies the latter. They are both of a tawny orange color, with a white-spotted liack horder on the outer wing margin. The Monarch is the larger and, like the lirds, has the hahit of migrating southward in the fall and returning in the spring. The Fritillaries ${ }^{2}$ inchude some large butterflies, 
having numerous round and triangular silvery spots on the under side of the hind wing.

The Spring Azures (Lycænas ${ }^{1}$ ) include small satin or steelblue species which exhibit marked seasonable polymorphism; the Coppers, orange-red or hrown species; and the hair-streaks, or Theclas, ${ }^{2}$ small, brown butterflies usually with two tails to the hind wing.

The Hawk-moths (Sphingidæ ${ }^{3}$ ) fly swiftly and powerfully, and as they hover over flowers at dusk can harlly be distinguished from humming-birds. The larva have a

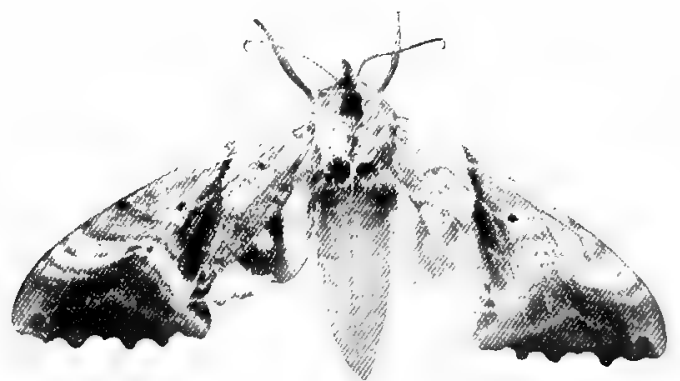

FIG.40. - Smerinthus geminatus, the twin-spotted sphinx. Nat. size. Photo. by W. H. C. P.

caudal horn or tubercle. The commonest of these are the tomato or potato "worm," green in color and banded. There are about one hundred species of the hawk-moths in the United States. The Twin-spotted Sphinx (Fig. 40), so called from the black spots of the bind wing, is destructive to fruit and shade trees. The Pandorus Sphinx (Fig. 41) is of a beautiful olive color; its larva feeds on vines.

${ }^{1}$ Lukaina, a poetic name of Venus.

${ }^{2}$ A Greek feminine name.

a From Sphinx, or sphinx, a fabled monster. The larva of this moth assumes an attitude like the sphinx. 
The wood-feeders (Xylotropids ${ }^{1}$ ) are chiefly medium to small, clear-rvinged species which fly at dusk or in daylight. Their larvæ live in stems of squash, cucumber, etc., and hore into shrubs and trees (Fig. 42).

The Tiger-moths (Arctiidæ ${ }^{2}$ ) are for the most part conspicuously striped or spotted. The larve are very hairy. The best known is the furry, brick-red and black Isabella

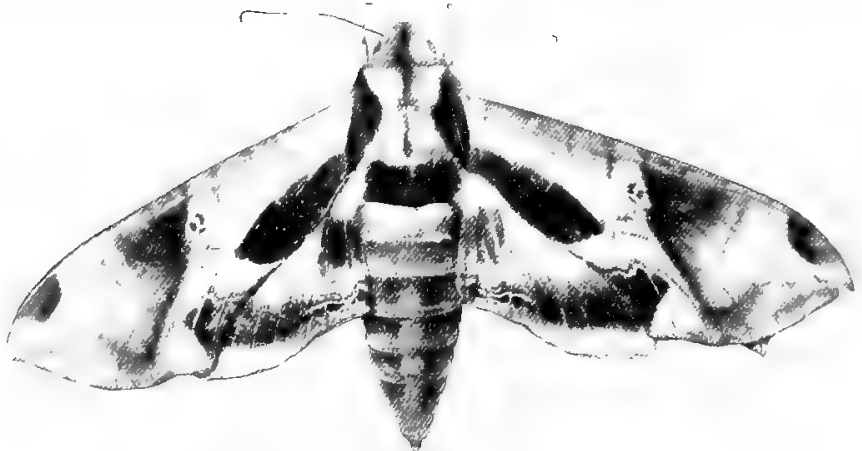

FIG. 41. - Phitampelus pandorus, the Pandorus sphinx. Nat. size. Photo. by W. II. C. P.

caterpillar, which can be seen during Octoher in New England, hurrying nervously in search of winter quarters.

The silkworms (Bombycidx ${ }^{3}$ ) include, as a rule, large and thick-borlied moths. Here belong the only moths of use to man. Of these, Bombyx mori ${ }^{4}$ is the most generally employed in the manufacture of silk. It originally came from ('hina, ferds on the leaves of the white mulherry, and is reared chiefly

1 xulon, wood; trepho, to feed; because the larve feed on wood.

2 From arktos, bear.

"Bombyx-like. Aristotle called the rustling silk bombox; hence the name Bonbyx for the silkworm.

${ }^{4}$ morus, a nulberry trec. 
in China, Japan, Italy, and France. The method of culture is as follows: The eggs ("grains") are laid in the autumn, kept over winter in a ciry, airy, and cool place, and hatched when the mulberry begins to send out its leaves. On these leaves the larvæ are put to feed, and after a month they begin to spin. For commercial purposes the larvæ are induced to spin the cocoons on prepared twigs or straw. A few days after the cocoon is completed its inhahitant is killed in hot water. The cocoon is made of a continuous thread about three thousand metres long, of which, however, only about six hundred metres make good silk. This long thread has to be unravelled. The outer end is loosened by soaking the cocoon in hot water; then several of

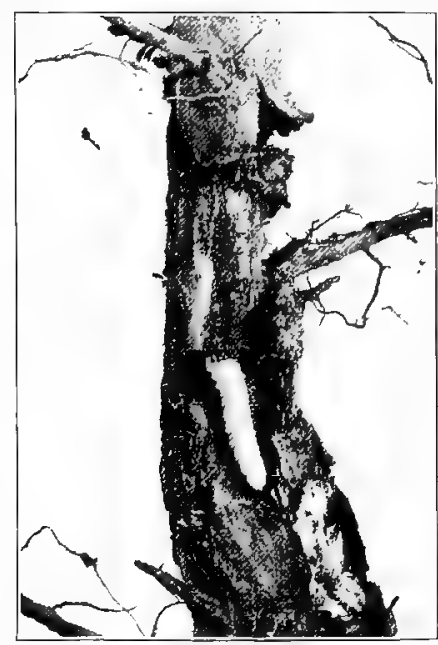

Frg. 42. - Larva of one of the Sesiid:e boring in stem. Nat. size. Photo. by V. H. L. these ends are brought together and united to form a single fibre of raw silk. Another imported silk-moth common in parts of the United States is the Cynthia ${ }^{1}$ moth, whose larva infests Ailanthus trees. True American forms are the brown Polyphemus ${ }^{2}$ moth, whose larva, is colored light green, with oblique yellow stripes; the Promethea ${ }^{3}$ moth, whose cocoon is formed in a folded leaf

${ }^{1}$ A poetic name of Diana, from the mountain Cynthus.

${ }^{2}$ The name of the fahled one-eyed giant blinded by Ulysses.

3 A name in Greek mythology. 
which is securely fastened by silk threads to its twig; the Cecropia moth, expanding six inches, whose coarse tegumentary cocoon is bound along its whole length to a twig; and the

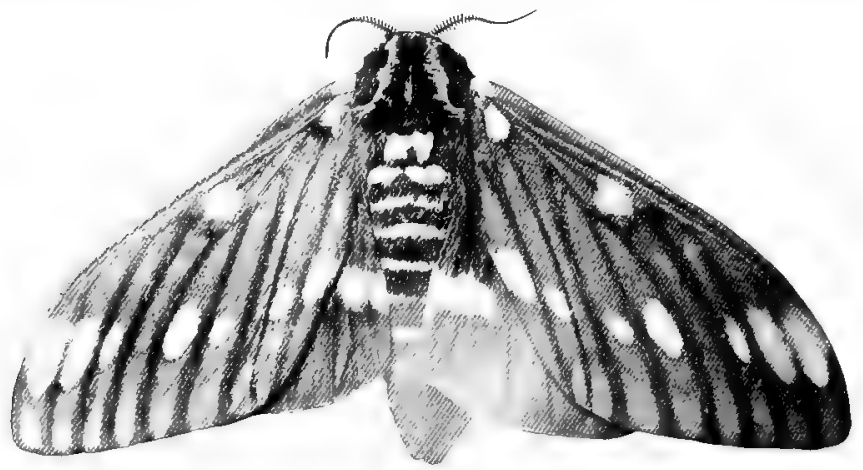

Fir. 43. - Citheronia regalis, the regal moth. Olive and red wings, yellow spots. Nat. size. Pboto. hy W. H. C. P.

nearly equally large Regal moth (Citheromia regalis, Fig. 43), whose larva is our largest caterpillar (Fig. 44). All of these species are casily reared from the larvæ or cocoons.

Closely allied to the Bombycids are the Tent-caterpillars,

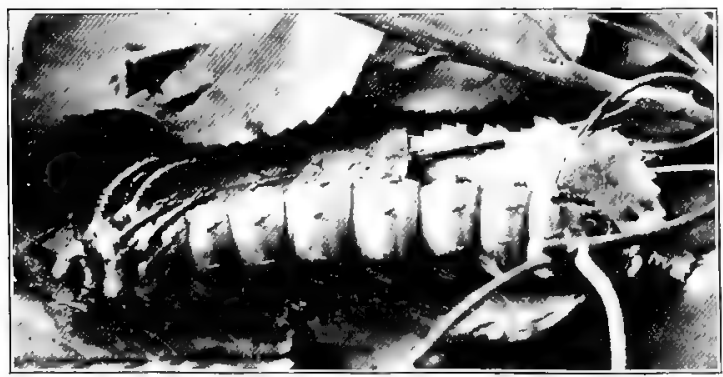

FIG. 44. - Larva of Citheronia regalis. Head to left. One-half nat. size. Photo. by W. H. C. P. 
which are never of great size. They are destructive species which infest apple trees and even forest trees (Figs. 45 and 46).

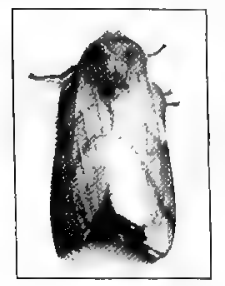

FIG. 45. - Adult female of $\mathrm{Cli}$ siocampa disstria. From life. Nat. size. Photo. by V. H. L.
Eggs are laid in a ring-like cluster around a twig (Fig. 47). Here they pass the winter and hatch out in the spring as young larvæ. The larvæ are gregarious and spin a tent-like web, on which they live when not feeding (Fig. 48). When ready to transform, they spin a cocoon made of a yellow powder mixed with silk.

The Owlet moths (Noctui-

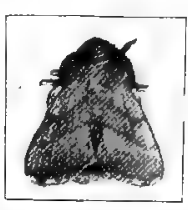

FIG. 46.-Adult male of Clisiocampa. From life. Nat. size. Photo. by $\mathrm{V}$. H. L.

dæ ${ }^{1}$ ) are night fliers and are attracted by our lamplights. They are the most numerous of all our moths, eighteen hundred species being known from our country. Among the largest memhers of this group are the Catocala ${ }^{2}$ moths already referred to. Here also are placed the boll-worm, which eats cotton-

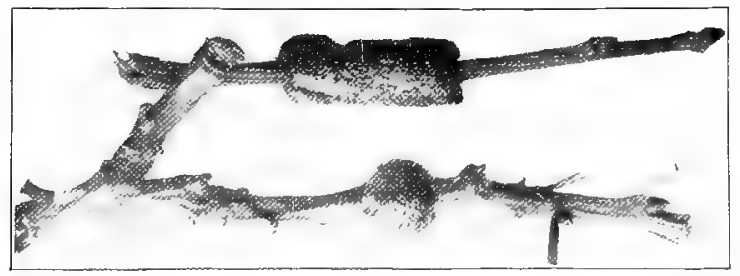

FIG. 47. - Egg-masses of forest tent-caterpillar, laid on branch. Photo. by V. H. L.

pods and green ears of maize; the cotton-worm, which destroys the foliage of cotton; the army-rworm, which devours grass

I From nox, night.

${ }^{2}$ kata, below; kalos, beautiful. 
and young grain; and the myriad cut-worms, of which some gnaw off young garden shoots at the level of the ground, while other kinds ascend trees and destroy buds.

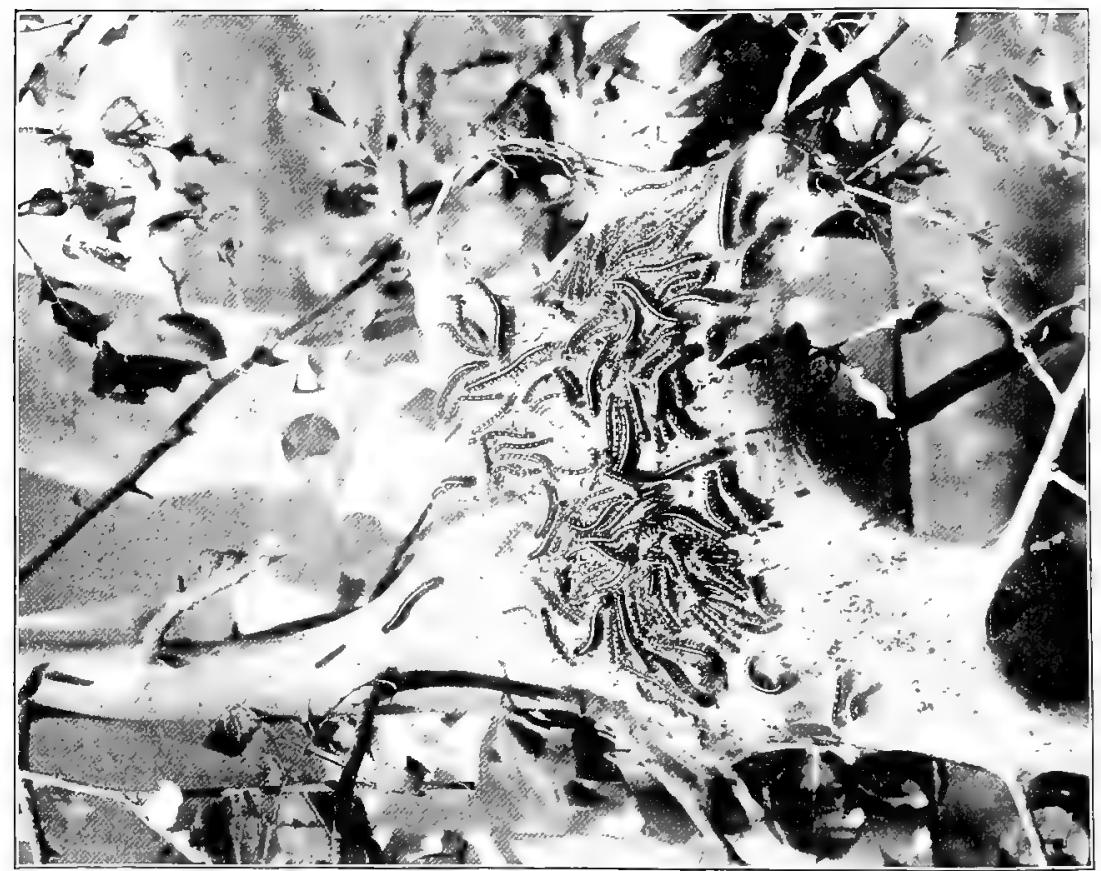

FIG. 48. - Nest of Clisiocampa disstria, the forest tent-caterpillar, showing the web and the way the larva crowd together on it. Photo. by V. H. L.

An allied family includes the Tussock moth (Fig. 49), whose variegated larva hears dense brush-like tufts of whitish hairs on the first four ahdominal segments, and is very destructive to shade trees in our cities; the Gypsy moth, imported some years ago into Massachusetts, where the state 
has attempted its annihilation; and the Brown-tail moth, also lately imported to Boston.

The measuring-worms (Geometridæ) are, like the Noctuids, very numerous and very destructive. They are so called because the larvæ have a way of proceeding, as it were, by inches in their locomotion (Fig. 50). One of the mast important subdivisions is that of the canker-worms, which often strip fruit and shade trees of their foliage.

The leaf-rollers (Tortricids ${ }^{1}$ ) comprise numerous small, inconspicuous moths whose larvæ are, notwithstanding, very destructive. They are so called because many species cause the leaf on which they feed to curl. One of the most destructive of these moths is the codling-moth, a great

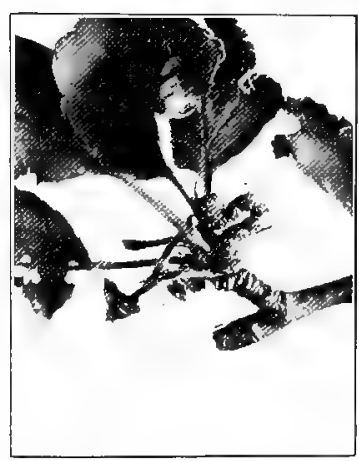

FIG. 50. - A "measuring worm." pest of the fruit- FIG.49--Notoluphus, grower, for the larva bores into the hearts of apples and pears, causing them to fall prematurely.

The tineids comprise the smallest of the Lepidoptera. Their wings frequently bear long fringes. The larvæ are so small that they often

${ }^{1}$ From torqueo, to roll or wind. 
live in the interior of leaves and form winding or blotch-like " mines" in them. The larvæ of some species make a case out of pieces of leaves united by silk and carry this about with them. They are known as "case-bearers" (Fig. 51). To this family belong the clothes-moth, of which we have three

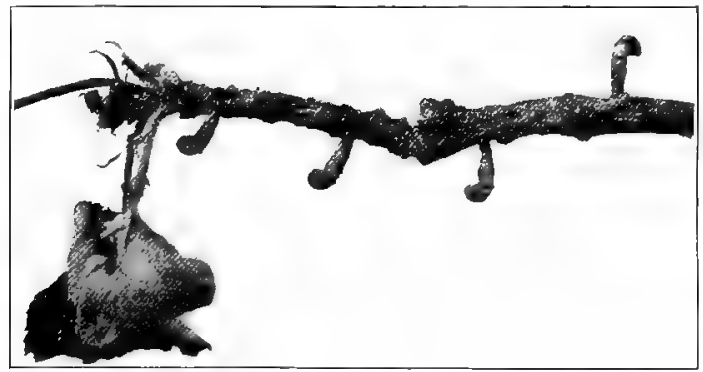

FIG. 51. - Case-bearing insects on a twig. Photo. from life by V. H. L.

species. They fly in the middle of spring and lay their eggs on woollen cloth, furs, or feathers, upon all of which the larvæ feed.

Another order of insects very different in appearance from the Iepidoptera but still related to them is the order Hymenoptera, ${ }^{1}$ which includes bees, wasps, ants, and certain less wellknown insects. They all have four similar membranous wings as the Lepicloptera do; but, unlike the Lepicloptera, their wings are not covered with scales, but are transparent. The mouth parts are formed for biting or for sucking, but the prohoscis is not so long that it rolls up as in Lepidoptera.

The Hymenoptera belong to one or the other of two groups the stinging Hymenoptera, in which the female is provided with a sting; and the horing Hymenoptera, which are provided 
with an ovipositor, or long tube, by which eggs can be placed at some distance below the surface. To the first division belong the bees, wasps, and hornets, certain digging or boring wasps, and the ants. To the second division belong certain species, - as, for example, the ichneumon-flies, - which are parasitic on other insects, the gall-flies or gall-wasps, and the plant-eating Hymenoptera.

The bees $\left(\right.$ Apidæ ${ }^{1}$ ) include both social species and those which lead solitary lives. Of the latter, some dig their nests in the ground, others are masons and build their nests of mud, others are carpenters and make tunnels through pithy plants or even solid wood, while still others are leaf-cutters. These leaf-cut-

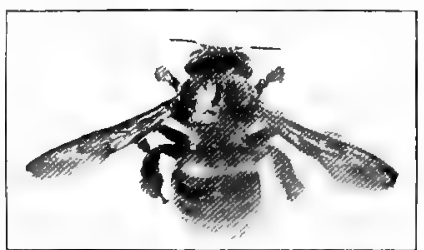

Fig. 53- Bombus, the bumblebee. Nat. size. Photo. by W.H.C.P. ting bees carve circular disks from rose leaves, out of which they make cells for their young.

Of the social bees, our native species belong to the genus Bombus, - the "bumble" bees (Fig. 53). The bumblebees build nests in the ground. The queens alone survive the winter. In the spring each queen chooses some mouse nest or other ready-formed cavity in a meadow, and places within it a ball of pollen. Upon this food she lays eggs, which develop into worker hees. As soon as the workers are fullgrown they begin the task of gathering food and the queen then devotes all her energy to egg-laying. Later in the season males and young queens also appear in the nest. The old and young queens dwell together in harmony until autumn, when all the members of the colony perish excepting ${ }^{1}$ From apis, bee. 
the young queens, which pass the winter in some sheltered spot and form new colonies in the spring.

The introduced, semi-domesticated honey-bees have quite a different social economy. In the first place, the nest is

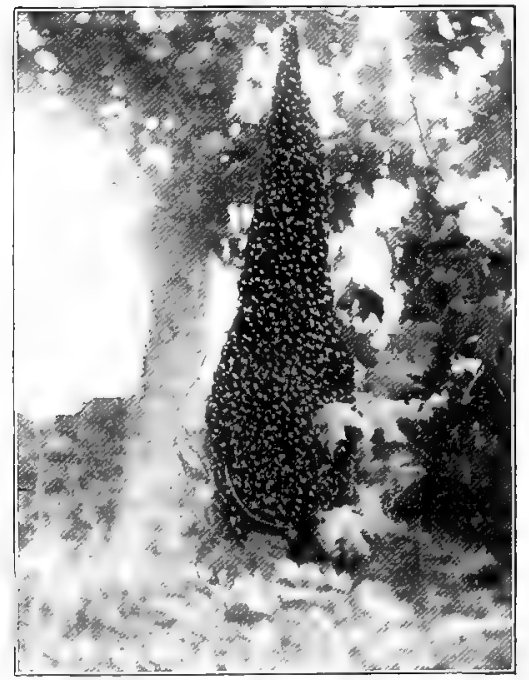

Fig. 54. - Swarm of bees. Photo. by D. and s.

perennial; consequently the young and old queens cannot remain in the same hive, else the nest would become overcrowded by the presence of too many families. As young queens mature, the old queen seeks to destroy them: but she is usually forced out of the hive by the workers, a number of which accompany her. This migration is what we call "swarming." 1 When several young queens mature at the same time, duels or repeated swarmjngs ensue until only one queen remains. When a new colony is starterl in a hive or hollow tree, a comb is formed of wax secreted ly the worker bees, and into this the queen deposits egger restined to develop into workers. Still later, eggs destined to form drones are laid in cells larger than those in which workers develop. The developing young workers and drones are fed with honey and hee-bread. Honey is derivel from the nectar of flowers which is lapped up ${ }^{1}$ Fig. 54. 
by the workers, is stored for a time in the crop, where it undergoes certain transformations, and is then regurgitated into the cells. The nature of the transformation of the nectar in the crop of the bee is not precisely known, but it is not great enough to prevent the characteristic flavors of the flowers of the buckwheat, orange, and so on, from being retained in the honey. The bee-bread is made from the pollen of the flowers, which is brought into the hive on the hind legs of the workers. When a new queen is needed for the colony, and the queen cells are empty, one may be produced by the workers in the following manner: The partitions between three worker cells are destroyed and two of the embryos are killed. The enlarged cell is filled with a special nutritive compound manufactured by the workers and known as royal jelly. The remaining embryo, fed upon this especially nutritious jelly, develops not into a worker but into a queen.

Of the true wasps (Vespid $x^{1}$ ), some are solitary; others, like certain of the bees, rear their families in the nests of other species (guest-wasps); while still others are social. The last group includes our best-known species. The colony of social wasps contains males, females, and workers. As in the case of bumblebees, only the females survive the winter; in the spring they build small nests and lay worker eggs. The workers, when grown, enlarge the nest and care for the numerous progeny of the queen. Our social wasps belong either to the genus Polistes, ${ }^{2}$ which includes the ordinary hlack, brown, or yellow bodied wasps, which build mushroom-shaped nests behind window blinds and under boards (Fig. 55) ; or to the genus Vespa, which includes the black and spotted hornets and yellowjackets, that build great masses of paper combs enclosed in a

${ }^{1}$ From vespa, wasp. 2 polistēs, founder of a city. 
nearly spherical gray paper envelope (Fig. 56). These are found attached to trees or parts of buildings. The paper is

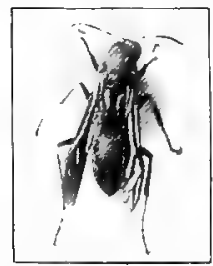

FIG. 55. - Polistes. slishtly reduced. Photo. by W. H. C.P. made of finely masticated wood-fibre cemented by a secretion. Certain yellow-jackets form nests in the ground. The hornets are well known as among the most vindictive of our northern insects, and their sting is capable of producing considerable pain. In all Hymenoptera the pain of the sting is due to the introrluction of a poison into the body of the victim through the stinging organ. This poison is secreted by a special gland of the insect.

The digger and mud wasps (Fossoria ${ }^{1}$ ) have the most varied habits. One of the most familiar species is Pclopoeus, ${ }^{2}$ which somewhat resembles a true wasp, but may be easily distinguished from it by the long, slender attachment of

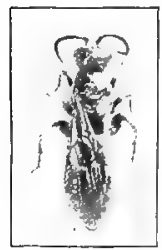

FIG. 57. - Digger wasp, showing pesition of wings. by W. H. C. P. Nat. size. Photo.

the abdomen to the thorax and by the fact that the wings when closed lie flat and horizontal (Fig. 57), while in the true wasps they are folded like a fan. Other species bore into the pith of plants or make burrows in the ground. Many are predaceous, feeding on spiders, cicarlas, etc. The ants (Formicidre ${ }^{3}$ ) constitute a well-known group having features so marked that other insects, excepting the termites, will hardly be confused with them. From the termites ants

${ }^{1}$ From fossor, digger. 2 pèlos, slime.

${ }^{3}$ From formica, ant. 
may be distinguished by the fact that the first segment of the abdomen forms a small knot or scale lying between the thorax and the remainder of the abdomen (Fig. 58).

The intelligence of ants is notorious. This intelligence has developed in connection with a highly organized social life. This social life is a communistic one. Homes are built, food is gathered, wars are made, and domains are defended bravely and loyally all for the sake of the entire community. The individual is little regarded, and each one is born to a caste from which escape is impossible. For, in addition to the dis-

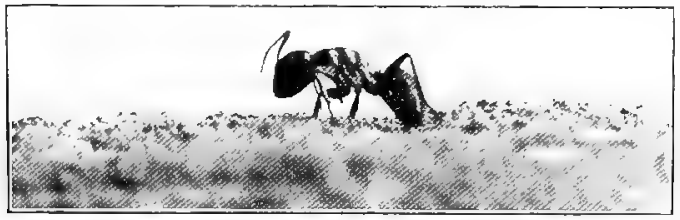

Fig. 58. - Camponotus, the carpenter ant. Uniformly black. Shows scale behind thorax. Nat. size. Photo. by W. H. C. P.

tinction of sex characteristic of other species, we have here workers, and these workers may be of different kinds. Thus certain workers get food and care for the young; others, which serve as soldiers and defend the colony or conduct war, are in some cases provided with powerful jaws. In some species there are three or more classes of workers, each having its characteristic form of hody.

Ant Colonies. - $\perp$ colony is founded by a female. On warm days the young males and females may leave the nests and take flight in great numbers. This is the marriage flight of the queens. Within a few hours after nightfall of the day of this flight the males perish, while the queens settle down to the ground, tear off their wings, and each of them seeks an 
appropriate place to begin the formation of a new colony. If by chance a queen is discovered by some of her workers, she is cared for by them; otherwise she must get on alone. She makes a small nest and lays eggs, which quickly develop into

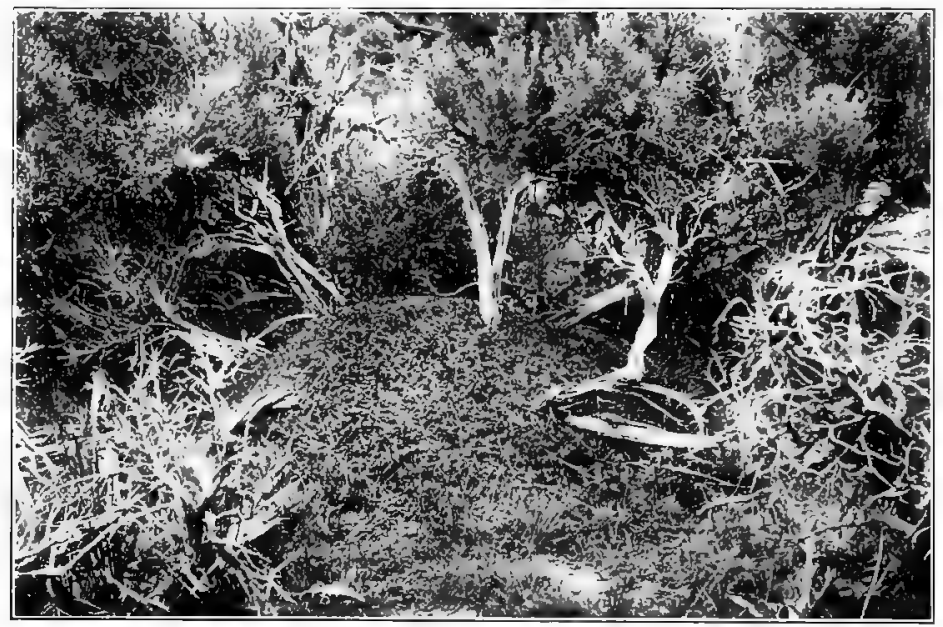

FIG. 59. - Mound over ants' nest, Nevada.

workers, which then assume the task of constructing the nest of the new colony. The nests of our ordinary species consist simply of tumncl-like passageways rlug in the ground and enlarged at intervals to form small chambers. Most species dig their nests preferably under protecting stones or the roots of trees; in other cases a hillock of earth and twigs, an "anthill," is construcotel. These mounds may attain a diameter of from six to ten feet. (Fig. 59).

Ant Language. - In commection with their commumal life ants have gained a power of communication. By the agency of their antennac, with which two comrades are constantly 
stroking each other, they can tell each other of the whereabouts of food, of the approach of an invading army, or of the need of aid. They distinguish members of their own community from those of other communities, and recognize one of their number, even after a long absence, and receive it back to the colony with demonstrations as of joy.

Social Life of Ants. - To illustrate the complex social life of ants, a more detailed account is here given of certain interesting species. Cortain ants, such for instance as our Formica ${ }^{1}$ sanguinea," a rust-red species often found living beneath large, flat stones, make slaves of another species of ant which (a curious coincidence) is a dark-colored species. In some slave-making species (the Amazons) the jaws have become so modified to aid in capturing slaves that they are absiolutely dependent upon their slaves for food, and would die surrounded by food were none of their slaves at hand to feed them.

The Harvester Ant. - One of our most interesting ants is the Agricultural Ant of Texas (Pogonomyrmex ${ }^{3}$ molefaciens ${ }^{4}$ ). This ant makes a circular clearing about its mound, upon which it allows only one species of grass to grow. The ripe seeds of the grass are carefully harvested by the ants and stored within the chambers of their mound. From time to time such seeds as have spoiled in the granaries are brought out and thrown away. During rainy seasons, some of these seeds germinate as though planted (Fig. 60).

The army ants, of which there are several species, oceur in great numbers in tropical South America. Like many other species which live by hunting, they migrate from a locality after having exhausted it of their food. While on the march, the young of the species are transported by some of the adults. When an army of these ants approaches a place, every living animal endeavors to escape. The breeding birds nust be on the alert to pick off the advance guard to prevent them from returning to the army with news of the presence of nestlings. Insects of all sorts, young and old, fall a ready prey to

1 Ant.

${ }^{3}$ pogon, beard ; myrmex, ant.

${ }^{2}$ Sanguis, blood, referring to color. $\quad{ }^{4}$ Mole or mound builder. 


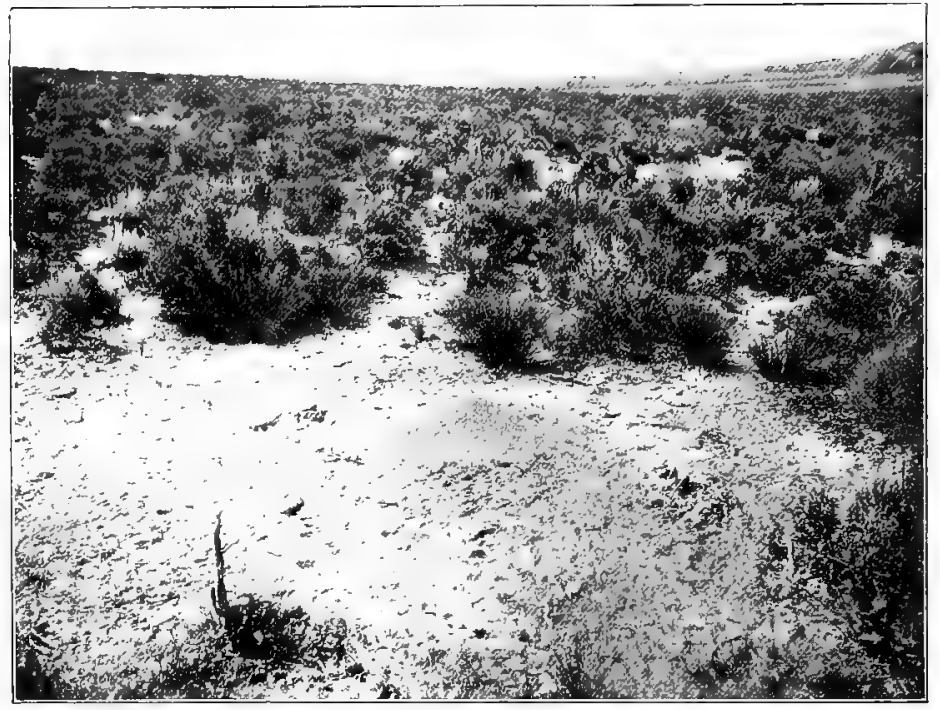

FIG. 60. - Mound and clearing of Harvester ant, near Great Salt Lake, Utah.

these swarms. Some spiders escape by suspending themselves by their threads, and insects which resemble leaves often find safety in keeping rigidly still. When an army of these ants enters a house, the

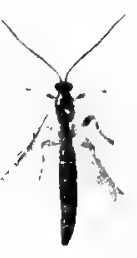

a.

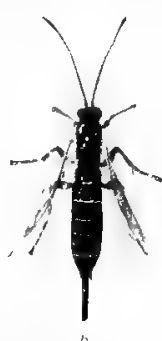

FIG. 61. - Pimpla pedalis, a parasite on the caterpillar of Clisiocampa. a. male, b. female. Photo. by V. H. L. inhabitants find it wisest to leave the invaders in possession, for in a few hours the house is cleared of every living thing - moths, cockroaches, rats, mice, all have fled or been devoured.

The leaf-custing ants are another tropical American species. The colony is very perfectly organized. The duties of the workers are divided among different gangs. Thus, when a tree has been selected, one gang ascends the trunk 
and cuts the leaves in picces of a definite shape. The pieces flutter to the ground, are picked up by another gang and carried to the entrance of the ant-hill, where they are deposited to be carried into the nest by a third relay. The bits of leaves are used to line certain of the passageways, and a fungus is grown upon them which serves the ants as food. The leaves are probably stored to provide this fungus food.

\section{The parasitic Hymenop-} tera have the habit either of laying eggs in the body of another insect, - one of the plant-lice, a caterpillar, or

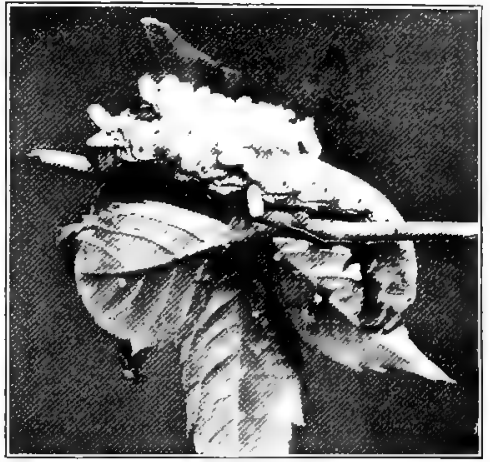

Fra. 62.-Cocoons of Mierogaster, a parasitic hymenopter, on a sphinx larva. Photo. from the living object by V.H. L. other species, - or else they lay their eggs in the nest of some species of insert so that the larva can make its own way into the host (Figs. 61-63). The long, tail-like ovipositors of the

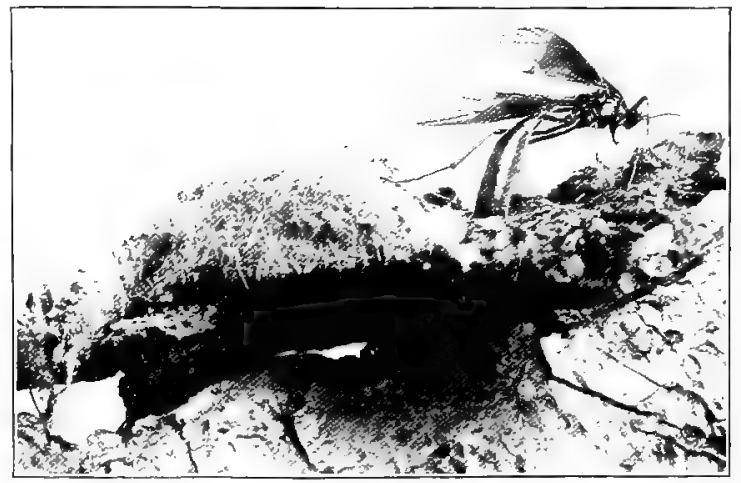

FIG, 63.- Ophion, an Ichneumon which infests caterpillars. Nat. size. Photo. by W. H. C. P. 
female ichneumon are, in some cases, used to drill holes into trees occupied by insect burrows, so that her eggs can he laid therein. These parasitie species are invaluable to agriculture in keeping down injurious insects.

The gall-wasps, popularly not distinguished from the strict gall-flies, are familiar to us from their works. They lay eggs

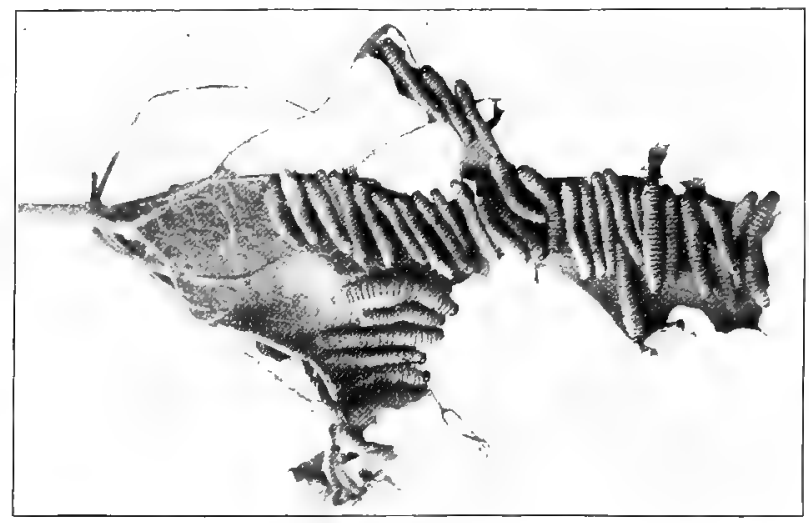

Fig. 64. - Larve of sawfly on grape leaf Photo. by V. H. L.

in various kinds of plants, especially in oaks and members of the rose family. An excessive growth of the plant tissue, called a gall, is caused either by a poison dropped into the plant with the egg. or lyy the irritation of the developing embryo. ${ }^{1}$ The galls of gall-wasps are often more or less spherical masses which are closed, in consequence of which the confined insect must bore its way out. The galls made by the same species of insect on one kind of tree are quite similar, but if the same insect stings another species of tree a different kind of gall is produced. Also when different species of gall-wasps sting one ${ }^{1}$ Cf. Fig. 93, p. 84. 
and the same leaf, the galls will be unlike. Hence the characteristic form of the gall is determined both by the species of plant and by the species of insect which lives in it. It is interesting to collect galls, watch for the emerging wasps, determine their species, and thus get their entire life history. The gall-wasps are, on the whole, injurious to agriculture.

The plant-eating Hymenoptera are extremely destructive pests. The young are known as "slugs," from their resemblance to the Fra. 65. - Eggs of Nematus, a sawfly on a true slugs, which are snail- gooseberry leaf. Photo. by V. H. L. like animals. They infest pear trees and rose bushes, leaving scorched, dried leaves behind them.' Here also belong the currant-worm and the sawflies (Figs. 64 and 65), which eat leaves like caterpillars, but differ from them in having twelve or sixteen prolegs instead of ten.

${ }^{1}$ See "The Pear Slug," in Circular No. 26, 2d Series, U. S. Department of Agriculture, Division of Entomology. 


\section{CHAPTER IV}

\section{THE BEETLE : A STUDY IN ECOLOGY}

Among all animals the beetles (Coleoptera ${ }^{1}$ ) are characterized hy having developed in the rlirection of passive resistance to their enemies through the acquisition of a hardened exterior. We know that seeds are preserved from the depredations of many preying animals and are protected from unfarorable climatic conditions by an outer covering which has a great variety of forms, but is always hard, angular, and unattractive. So, likewise, the beetles are distinguished, on the whole, by hardness, angularity, and unattractiveness as compared with the butterflies. Let us see how the insect type which has produced a body so gorgeous and frail as a butterfly can be so modified as to form a heetle. We notice first that the pair of front wings (called elytra) are greatly thickened and hardened so that they can no longer be used for flying but serve only to protect the membranous hind wings which are folded beneath them and on which flight depends. The cuticula of the head has become greatly thickened, feeding is accomplished by powerful biting jaws, the horny legs possess powerful spines and end in claws. These profound modifications of the body serve likemise to prevent the loss of the fluids of the body so that beetles can withstand the dryness of deserts as well as great extremes of heat and cold. In fact, the hard and rigid form of the beetle which makes it possible for it to live under very extreme conditions permits it to occupy every niche in nature. 
In consequence of this capacity for adaptation there are more species of beetles than of any other group of animals. Roughly speaking, one-half of all the insects and one-fourth of all the species of animals are beetles.

Some of the habitats occupied by beetles we shall now consider. Many beetles run on the surface of the ground even during the day. Such are the Running or Tiger bectles. Some live on the ground under stones during the day and go out at night on foraging expeditions. Others live a great deal of the time in the air, as, for example, the Fireflies. Another kind, of which the Potato-beetle is an example, lives on plants. Certain others, such as the meal-beetles and the household pest known as the Buffalo-bug, live buried in dry vegetable matter. In their larval state many beetles live in the trunks of trees. Still other forms live in carrion and decaying vegetable matter, and finally there are many kinds that spend their entire life in water.

In respect to their food beetles are equally adaptable. Some, like the Tiger and Ladybird beetles, live exclusively on live animals; others, like the Potato-beetle, feed on the foliage of plants. Many, like the Snout-beetles, suck the juices of fruits. Others feed on dry animal or vegetable matter. Still others devour carrion, and a very few are parasitic on other animals. In so far as certain beetles feed upon other carnivorous species of insects, as do certain Tiger and Carrion beetles, or upon small fish, as do some of the Dytiscidæ, or upon domestic hees, like certain allies of the weevils, they may be indirectly injuring man. Of all the families of beetles, probably the leaf-eaters cause greatest destruction; next to them come the weevils, followed by the "longhorns" and the others. Every part of the plant has its coleopterous enemy. As Le Conte and Horn 
have said: "The function of the Cerambycill is to hold the vegetable world in check by destroying woody fibre; the Bruchidæ (weevils) effect a similar result by attacking the seeds; and the Chrysomelidæ by destroying the leaves."

The geographical range of beetles is likewise great. They penetrate to the tops of the highest mountains. They are found on the most arid deserts, where they attain very great size and very great hardness. While they reach their greatest abundance in the heavily forested tropies, they are found in extreme northern lands.

During development beetles, like Lepidoptera and Hymenoptera, undergo great change in form. As an illustration we will consider the development of the Colorado Potato-beetle. In this species the orange-colored eggs are laid often in a very regular manner on the under side of the potato leaf. Here they develop for several days. In about a week, however, the young, reddish, black-spotted larva, or " grub," comes out. Like the aclult heetle, it has three pairs of thoracie legs. After feeding actively for two or three weelss, the larva descends into the ground, forms a naked yellow pupa, and emerges in about ten clays as an adult. From two to four broods are prorluced rluring the year. The adult beetles spend the winter in the ground, crawling forth and laying eggs the following spring (cf. Fig. 65a).

The habits of the larvæ of the different kinds of beetles are as varjerl as those of the adults. Some of the larve live in the ground with their jaws exposed in wait for prey. Many wander ahout to seek food either on land or under water. Others eat the wood in which they are embedded, while still others are nourished by the ball of carrion in which the mother has deposited her eggs. 
The form of the larva also varies much to adapt it to its surroundings. When the larva live under bark they become greatly flattened. Those that feed in wood or grain are mostly cylindrical. Those that live on the surface of leaves, like the Potato-heetle, are often oval or irregular in shape.

The number of species of beetles which have been described is probably over one hundred thousand. Of these, over ten thousand inhahit America north of Mexico. Fortunately

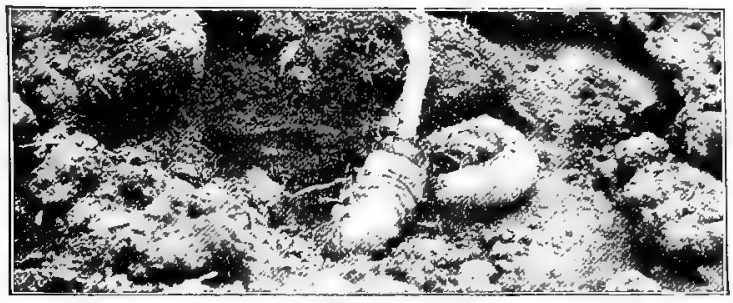

FIG. 65 a. - Larva of Lachnosterna, the June bug, at roots of aster. Photo. of living animals, nat. size, by V. H. L.

this vast number can be included within a relatively small number of families, of which the salient general characteristics will here be considered.

The running beetles are characterized by a more or less slender body, long, delicate legs, and quick movements. They are found chiefly on or near the ground. There are two principal families. The first includes the tiger-beetles ( $\mathrm{Cic}^{\prime \prime}$ indel'idæ ${ }^{1}$ ), which are colored bright brown or green (Fig. 66). They are light-lovers, heat and moisture lovers. Consequently they are found in sunny places, especially on paths or sandy shores which reflect the sun's rays, and almost always in the vicinity of water. In their flight they are among the swiftest of insects;

${ }^{1}$ Derived from candela, candle. 
a capacity of which they make use in the capture of living and especially of flying prey such as flies. Their powerful jaws are long and sharp, and so they are well adapted for seiz-
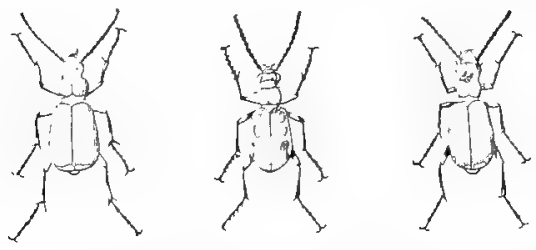

Fig. 66. - Three common species of Cicindela, the tiger-bectle. Left, red-copper bronze; middle, brown, with yellow markings; right, bright green, cream-colored markings. From Packard. ing and holding fast their victims. The larvæ are elongated, hunchbacked creatures, with a huge head armed with long jaws. They live in vertical burrows, generally in the vicinity of water. With their heads close to the entrances of their burrows they lie in wait for their prey.

The second family of the running beetles includes the groundbeetles (Carab'id ${ }^{1}$ ). This family is composed of about ten thousand species, of extremely varied form, size, and coloration. Most of them are of a shiny black color, usually with ridges or rows of points running along the elytra (Fig. $66 a$ ). They are, for the most part, darkness-lovers and contactlovers, and so occupy a very different place in nature from that of the tiger-beetles. During the daytime they are concealed underneath boards and stones, penetrat-

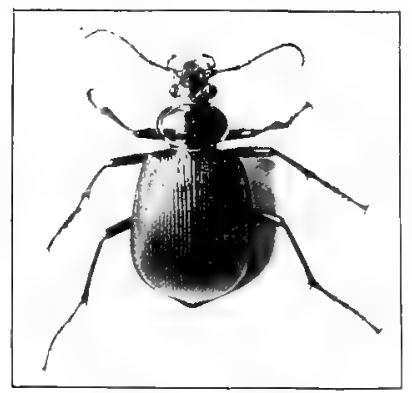

FIG. 66a. - Calusuma srrutator, the seareher, a ground-bectle. Nat. size. Photo. by W. H. C. P. ing into the narrowest crevices. But at night their instinct changes. They fly and climb trees and shrubs in search of 
other insects. Since most of them are moisture-lovers, they abound chiefly in the neighborhood of watercourses. Although the majority prey on living animals, some species are vegetablefeeders. The larve of one species are very destructive in the Southern States to young Indian corn. Certain forms cmit ill-smelling fluids, often with a popping sound. These fluids are believed to help clefend the bectles from their enemies.

The next two families, both water-beetles, the divers (Dytis'cid $x^{1}$ ) and the whirligig beetles (Gyrin'idæ ${ }^{2}$ ), include beetles which are quite as destructive to animal life of the water as the runners are to that of the land. As could be predicted from their habitat, they are moisture-lovers, contact-lovers, and cold-lovers. Their shape is peculiarly modified for life in or on the water. The legs are broad like oars and the body is pointed at the front and covered with fine hairs which entangle bubbles of air. The air-bublules help to buoy the animal in the water and to afford a supply of oxygen. The Dytiscidx are usually the larger species and have long, thread-like antennæ which they use in testing the character of the bottom. The Gyrinirla, which are small beetles, whirl around on the surface of the water, often in groups. They have short antennæ. Each eye is clivicled into an upper half, used for looking into the air, and a lower half, used for looking into the water. The larvæ of hoth of these families have a long and spindle-shaped or flattened borly and live in the water.

The water scavenger-beetles $\left(\mathrm{Hy}^{\prime \prime}\right.$ drophil'idlæ $\left.{ }^{3}\right)$ make up another family of aquatic beetles that are less strictly carnivorous

\footnotetext{
1 dytikos, fitted for diving.

2 gyros, circle; because this bectle swims in a circle.

${ }^{3}$ hydros, water; philos, loving. 
than those of the two preceding families, but they have other very similar instincts. On account of their living on decaying vegetation they do not move so rapidly through the water as the Dytiscirlæ. They have heavier and clumsier bodies. They carry a film of air on the lower surface of the body where the air-tulses open, and thus they are enatsled to spend a long time on the bottom without having to come to the surface.

The short-winged beetles (Ataph"ylin'idle $e^{1}$ ) are so called because the elytra cover only a short part of the abdomen (Fig.

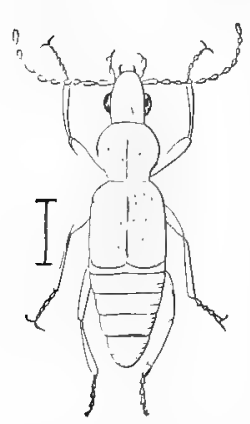

Fic. 67. - Astaphy-

linid Antluphtagus. From Packard. 67). Consequently they are not capable of long flight and are found chiefly on the ground. The family consists of a vast number of species varying greatly in their behavior, but for the most part they are lovers of darkness, contact, and moisture. In consequence of these instincts they are abundant under stones and in decaying woor and along shores of lakes and seas where débris is cast on the beach. They devour both animal and vegetable matter. Indeed, the family includes the great terrestrial scavengers among hectles. Their elongated body permits them to penetrate into woody fibre or into the earth for decaying vegetahle mold. Since their reactions are much like those of ants and of temites they are frequently found associater with these two groups, being even permanent and regular guests in the nest of such insects. Some species mimic ants and wasps not only in general form and color, but also in the movements of the tip of the abdomen, which, when the animal is irritated, is raised as though to sting (Fig. 68). The larve are not unlike the arlults and inhabit similar situations.

'Staphylinos, a kind of insect, from staphylc, bunch, of grapes. 


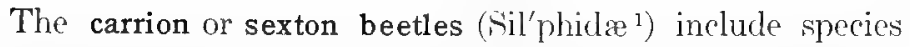
with a great range of size and form. Their reactions to light, moisture, ete., are much like those of the short-winged beetles, but they have taken a farther step away from the normal food

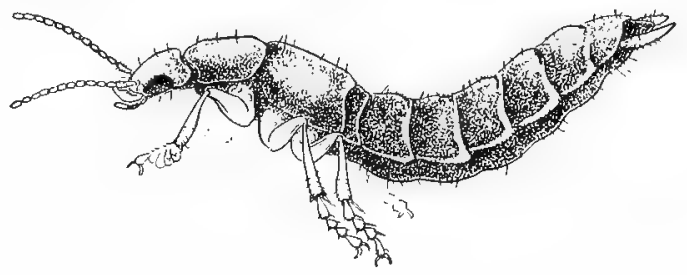

FIG. 68, - Side-view of a staphylinid, clevating its abdomen.

of beetles in that they have come to live exclusively upon carrion. Some of them are heavy-borlied, with powerful legs. When one or more pairs of these beetles cliscover a dearl hird or small mammal on the ground, they dig out the earth from underneath and pile it upon the animal until eventually the carcass is entirely buried. Then the female deposits her eggs upon the hody, so that a rich supply of food is provided for the young larvæ which hatch from the eggs.

Another division of the carrion-beetles are contact-lovers, and accordingly their

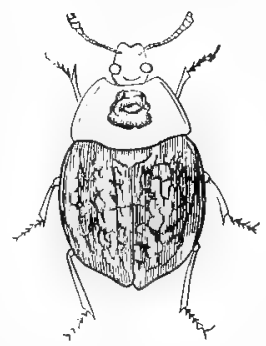
bodies are much flattened to enable them to FIG 69. - A rarrion penetrate into crevices (Fig. 69). They will often be found under the carcass of an animal lying on the ground. They lay beetle, Silpha americana. Fron "Standard Natural History."

their eggs and the young develop in these same restricted quarters.

' From silphe, the Greek name of an ill-smelling insect. 
The family of wool-beetles (Dermes'tid ${ }^{1}$ ) includes many small beetles that love contact and dryness. They feed upon the dryest sorts of animal matter, such as wool, leather, furs
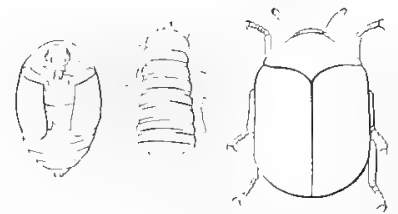

$\mathrm{FIC}_{\text {IG. 70. }} \mathrm{A}$ dermestid, or museum pest, Anthrenus. Left, larra; mirldle, pupa; right, adult. From Packard. of all sorts, and drier and salted meats. They can readily penetrate into the midst of such foodstuffs, on account of their small size. One of the memhers of this family is the familiar Buffalo-bug which devours clothing and carpets. Another species devours the dried specimens in collections of insects and plants such as are found in museums. Consequently such collections have to be subjected several times a year to the poisonous fumes of carbon disulphide. As in many other insects, it is the larvæ, which in this species are fuzzy, that cause the great destruction (Fig. 70).

The stag-beetles (Lucan'idx") have received their common name from the resemblance of their long, often branched mandibles to the antlers of a stag (Fig. 71). In the case of the giant stag-beetle of the Southern States, the mandibles are more than threefourths the length of the body. The larra are lovers of contact and moisture, and bore into the wood of the roots and trunks of trees. The adult beetle, as its antler-like mandihles suggest, is a lover of freedom, and roves ahout living on the sap of trees, which it procures by cutting through the thin bark.

The Lamellicorn beetles are distinguished by

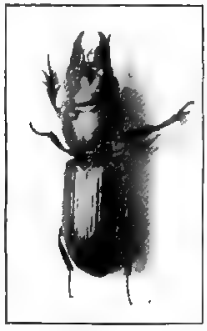

Fic. 71.-Dorcus, a stag - beetle. Nat. size. Photo. by W. H. C. P.

1 From derma, skin, and esthio, to gnaw. 2 From lucanus, surprise. 
the composition of the tip of the antennx out of a number of thin plates or lamellæ. The tumble-bugs or scavenger Lamellicorns (Scar"ab'ideæ ${ }^{1}$ ) are lovers of light and íreedom (Fig. 72). They form balls out of the dung of various animals which they sometimes roll long distances. The dung-rolling habit has long excited interest; indeed, among the Egyptians it was an object of superstition. So high was the veneration of this people for this their sacred beetle that they reproduced it in their paintings and sculpture. The ball of dung is really intended for the deposition of an egg,

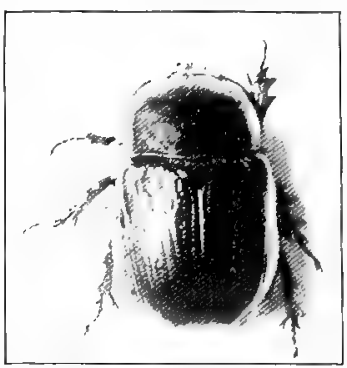

Fig. 72. - Copris, a tumblebug. Nat. size. Photo. by W. H. C.P. and it is rolled by both males and females to a hole in the ground which has been dug in a safe place for its reception.

The group of leaf-eating lamellicorns is represented by the June-bugs. The adults are attuned to a very

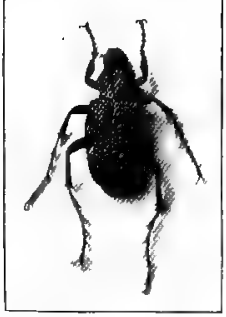

FIG. 73.- Macrodactylus, the rose-bug. Nat. size. Photo. by W. H. C. P. low intensity of light, so that they stay in hiding in the daytime, coming forth at night to feed upon the foliage of trees and shrubs. They are, however, attracted by lamplight, and enter through the open window with a busy humming sound, but soon come in violent contact with the wall or a piece of furniture, and fall heavily to the floor. The larvæ of June-bugs are lovers of contact and darkness. They pass the winter in the soil in burrows which they construct among the roots of garden vegetables and other plants (Fig. $65 a$ ). The ${ }^{1}$ Scarabeus, beetle. 
Rose-bug (Fig. 73), another species of this family, is active in the sunlight and is destructive to the blossoms or fruit of the rose, grape, cherry, and other plants.

The Metallic wood-borers (Bupres'ticlæ ${ }^{1}$ ) are destructive to trees. The larvæ love contact and darkness, and being pro-

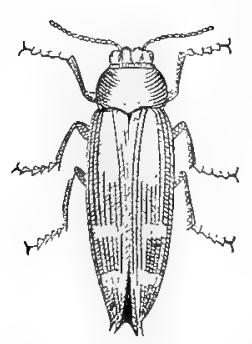

FIG. 74. - Buprestis rufipes, a metallic wood-borer. From "Standard Natural History." vided with large heads and powerful jaws, they gnaw their way through the bark and wood of trees. The adults have an entirely different behavior (Fig. 74). They love the sunlight and freedom; hence they are found upon flowers and the hark of trees. Here their metallic colors are conspicuous.

Closely allied to the foregoing is the family of click-beetles, or El"ater'idæ. ${ }^{2}$ These have the power, when placed on their backs, of leaping into the air by means of a special device on the under side of the animal (Fig. 75). The larvæ, called "wireworms" because of their round, hard bodies, live under the bark of trees and of rotten wood or upon vegetation in the ground. They are most destructive to sprouting grain, especially Indian corn. It requires several years for them to mature.

The fireflies (Lampyr'idæ ${ }^{3}$ ) make up another and a wellknown family. They have soft

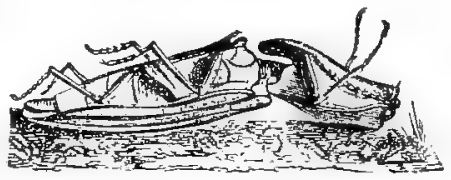

FIe. $75 .-$ Click-huetle. wing-like elytra, and on the thorax is a great shield, which partly or wholly covers the head. Certain species that do not

${ }^{1}$ From bouprestis, a Greek nanr for a beetle causing swelling in cattle (bous, ox).

2 elater, driver.

${ }^{3}$ lampo, to shine; oura, tail. 
give light live on flowers, especially the goldenrod; the luminous species are active at night. The light-giving organ lies in the abdomen. The larvæ also are luminous and are known as glowworms (Fig. 76).

In several of the foregoing families of beetles the adults live free, while the larvæ penetrate into wood. In the family of barkborers or engraver-beetles (Scolyt'idæ ${ }^{1}$ ), however, the adult also lives and feeds in the innermost layers of bark. In this case the adult beetle also is a lover

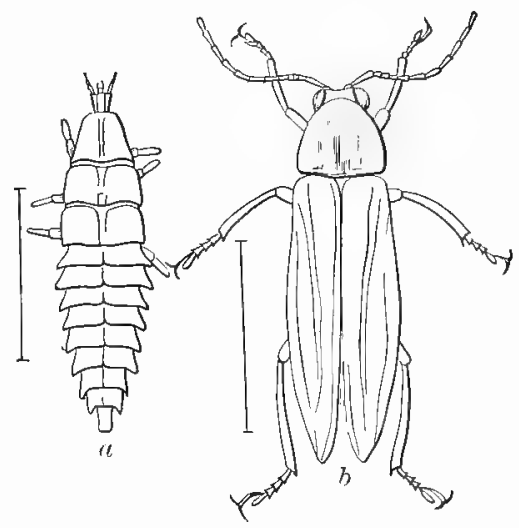

FIG. 76.--A firefly, Photuris. a. larva; $b$. adult. The lines to the left of figures represent actual lengths of animals. From Packard.

of contact and darkness. As they eat in lines, a pattern is formed which is characteristic for each species. Along these

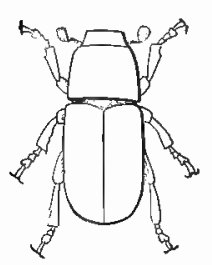

Fig. 77. - Den-

droctonus, an engraver beetle. Magnified 2.5 times. From "Standard Natural History." lines, niches are made in which eggs are laid and larvæ hatch. The borings are injurious to the trees, often causing their death. Herbaceous plants also are infested by certain species. An example is the destructive Pine-borer (Fig. 77), which is common throughout the United States and Canada.

One of the most injurious of all the families of beetles is that of the weevils (Curcu'lion'id $\left.æ^{2}\right)$. Most of our weevils are small, and their heads are drawn out into a long snout by

${ }^{1}$ From skolyptō, to mutilate. ${ }^{2}$ curculio, a grain-weevil. 
which they bore holes in plant tissue to receive their eggs (Fig. 78). The dull colors of the beetles render them incon-

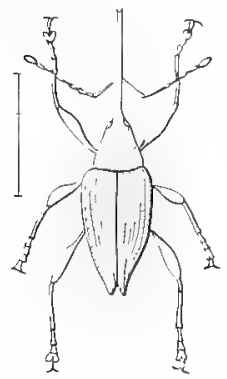

Fig. 78. - Balaninus, a weevil, of brown color. From Packard. spicuous to insect-feeding birds. The number of species is reckoned at over ten thousand, and the family is of world-wide distribution, its dispersion having been aided by commerce. Grain-weevils are great pests in stored wheat, rice, or maize. They also lay their eggs in planted seeds, buds, nuts, stone fruits, and fleshy fruits.

Extremely destructive also is the great family of long-horned beetles, "buckbeetles" (or Cer"ambyc'idæ ${ }^{1}$ ), of which about six hundred species are known in North America alone. The antennx and legs of these beetles are very long. 2 The larvæ bore into even the hardest woorls, and live there for two or three years. Timber and sharle trees are thus greatly damaged. A favorite collerting ground for "long-horns" is the goldenrod (Fig. 81).

Still another destructive family is that of the leafeating beetles (the Chrys"omel'idx $^{3}$ ), to which the Potato-beetle helongs. These heetles are thick and round in

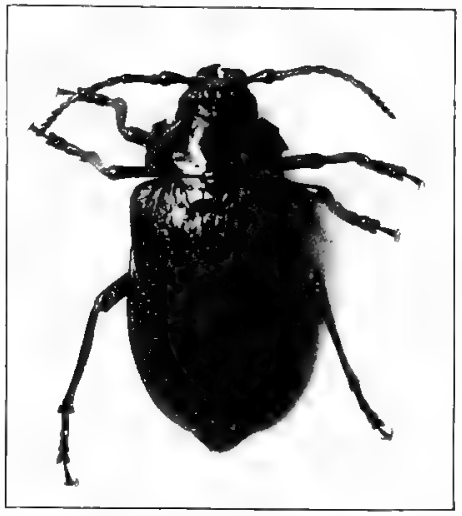

Fig. 79. - Prionus laticollis, a longhrorn. Black, Nat. size. Photo. by W. H. C. P.

${ }^{1}$ keramby $x$, a beetle with long horns.

${ }^{3}$ chrysamela, gold beetle.

${ }^{2}$ Figs. 79 and 80. 
shape. They lay their eggs upon the leares of plants. The larvæ feed on the leaves or burrow in the stem. Usually the larva is conspicuously colored and exposed, and relies for protection upon its disagreeahle odor and taste. The most destructive species to agriculture in the northern United States is the ten-lined Colorado potato-bectle. Until about 1859 this species fed upon the sand-bur, at the eastern base of the Rocky Mountains and south into Mexico. With the advent of settlers and the planting of the cultivated potato (a native of Mexico), this more thrifty, cultivated species was adopted as its foodplant, and the potatobeetle began its eastern migration. It spread slowly at first, but within fifteen years had reached

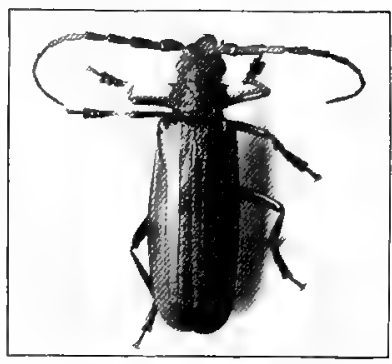

Fig. 80. - Orthosoma trunneum, the straight-bodied Prionid. Brown color. Nat. size. Photo. by W. H. C. P. the Atlantic coast. The little red, yellow, and hlack asparagus beetle; the yellow, hlack-striped cucumber and melon beetle, and the tortoise-beetle, whose broad, iridescent, translucent elytra are conspicuous on the leaves of the morning-glory, nettle, and other plants, all belong to this family.

So long has become our list of destructive beetles that it is with satisfaction that we turn at the end to a family which is almost wholly beneficial to the vegetable kingrom as well as to most vegetable-feerlers, including man. This is the ladybird family ( $\mathrm{Coc}^{\prime \prime}$ cinel'lirl $\left.\mathrm{x}^{1}\right)$. These beetles hunt their prey both in the larval and adult stages, feeding upon small insects and insect eggs (Figs. 82 and 83). They are especially active in freeing plants from scale-insects and plant-lice. So rapidly

1 From Greek kokkos, kerry. 
do the latter multiply that were it not for the voracious larvæ of the ladybird, most plants would be destroyed in a single season. The larvæ of the ladybirds are dark, spotted, and

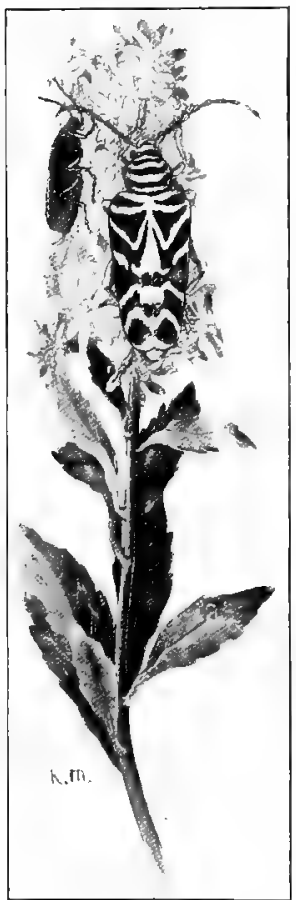

FIG. 81. - Cyllene robine, locust borer.

hairy. The elytra of the imago are in most species reddish in color.

The list of beetles directly or indirectly useful to man is small. The carrionbeetles, tumble-bugs, and rove-beetles, which feed upon decaying animal and vegetable matter, are useful as scavengers. Of those which serve us by killing other insects injurious to vegetation, the ladybird beetle stands first. The economic importance to us of this one family can hardly be estimated. Different kinds of ladybirds feed on different species of insects. At one time it seemed that the orange industry, if not that of fruits in general, was doomed in California on account of the destruction wrought by the introduction of a scale-insect. As the insect had been imported, we had no native beetle which attacked. Search was made abroad, and a ladybird beetle was found in Australia which feeds on this particular scale-insect. The Australian beetle was introduced into California, and now the scale-insect is subdued. The larvæ of some of the checkered beetles ${ }^{1}$ feed upon the larvæ of boring beetles, while the larvæ of tiger-heetles watch

1 A family of rather small beetles, living in flowers and on trees, and often with contrasting colors. 
at the mouth of their burrows for other insects upon which they feed. Carabid beetles are said to ascend trees in search of canker-worms. Larvæ of ground-heetles prey upon the pupating plum Curculios, and other beetles eat cutworms.

One beetle, the blister-bectle, known in the markets as the Spanish fly, has been for ages used as a drug. When disturbed, there exFIG. 82. - Pupa of Anatis ocellata on a leaf. Nat. size. Photo. by V. H. L. udes from the joints of this insect a liquid serving as a protection,

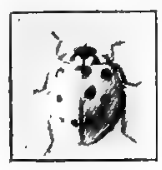

F IG. 83. Anatis acellata. Adult. Nat. size. Photo. by V. H. L. since it burns or blisters the disturber. This property is retained in the dried substance. The article sold in drug stores is obtained from crushing the dried beetle. The larvæ of various beetles have been prized as food by certain peoples from the Romans of Pliny's time down to the present, for they are eaten with relish by certain tribes of South American Indians. Fireflies sewn in lace are sometimes worn by the Spanish and Cuban women as adornments for evening dresses, while other beetles with particularly hard and beautifully colored and iridescent wing-covers are used as settings in hat ornaments and buckles, as well as in jewelry. 


\section{CHAPTER V}

\section{THE FLY: A STUDY OF DISEASE-PRODUCING ANIMALS}

Tue great majority of human diseases are due to the multiplication in man's body of other organisms. Such organisms are known as parasites. Parasites do not constitute a separate group of organisms by themselves, like the butterflies, but in almost every class certain species or even whole families have come to live upon other organisms. The usual history of the degradation of an animal to parasitism is as follows: The ancestors of the animal have come to live upon the waste products of other animals or even upon the outside of other animals. Later some of their descendants have come to penetrate into the interior of the host, as the parasitized animal is called, either through the skin or by way of the food-canal. It is advantageous for them to do so, because in the interior they find not only better food, but warmth and protection as well. The worst parasites are the smallest, because the small ones have almost unlinited power of multiplication and hecause most of them set free substances that act as poisons on the body of the host. One of the most dangerous groups of these microscopic parasites is that of the bacteria, which are usually classified as fungi; that is to say, plants without green coloringmatter. Not all, but nearly all, of the bacteria are parasites. Fully as dangerous, however, are the parasites belonging to the 
group protozoa, or primitive animals and it is especially with these that we have to deal in this chapter.

The greatest difficulty that a parasite has to encounter is how to find a way to pass from one individual to another. After it has wrought its fatal work upon the body of one individual, it must be able to reach a new host in order that it may not altogether perish with the host it has killed. There are two principal ways in which this transfer from one individual to another takes place. Either the parasites or their eggs are extruded from the body of the first host and are taken by a healthy individual with its ordinary food or water, or else the parasites are actually conveyed from one individual to another by means of so-called intermediary hosts. These intermediary hosts are sometimes animals that devour the carcass of an animal dead of a disease and are in turn eaten (with the disease germs) by a healthy individual belonging to the same species as that which dierl, or else they are animals that suck the blood of other animals, and in passing from individual to individual infect, of course unwittingly, the healthy with parasites from the diseased. This rôle of intermediary host is played by the group of flies (Dip'tera ${ }^{1}$ ) more than by any other. Consequently the Diptera are a great menace to man as conveyers of many of the most dreaded diseases to which he is subjected.

The Diptera are fitted to play the rôle in nature of diseasebearers because of their life history, instincts, and structure. For the most part they are lovers of heat, so that they are most abundant in the tropics. It is the Diptera and the diseases they bear, not the heat, that make the tropics such an unhealthy or even fatal abiding-place for man and for many of his

$$
1 \text { dis, twice; pteron, wing. }
$$


domesticated animals. In our climate the Diptera occur chiefly in houses, stables, and among animals, where the highest temperatures are to be found.

The larvæ of some Diptera live in the water, but others dwell in decaying matter. Indeed, some kinds feed exclusively upon horse manure and upon other kinds of filth, and others feed upon our foodstuffs. The larvæ that live in decaying matter are slender without even an enlargement for the head or with any especial organs around the mouth, since they have only to suck the fluids in which they develop. In accordance with their structure and habitat we find them loving moisture, darkness, a high temperature, and contact. The latter instinet leads them to penetrate into the material in which they loreed. Many egos are laid by each female parent, and their development is very rapirl; indeed, many generations are produced in a single summer.

The imagos, unlike the larvæ, live a free life and, for the most part, in the bright sunshine. They have only a single pair of wings, but they are powerful flyers and are thus weil fitted for their hicleous work in disseminating diseases. Their mouth parts are usually provided with a small, dagger-like organ with which they pierce the skin. Through the opening thus formed they suck the hlood of their victim. If the victim is diseased, the Diptera become thus inoculated with the disease, and when they pass to a healthy animal and puncture its skin, some of the clisease germs may he inserted into the body of the healthy individual. In this way mosquitoes cause malaria and yellow fever to spread.

The method of transportation of disease germs described in the ahove paragraph, although the commonest, is not the exclusive method. Wherever flies that have developed in 
filth or crawled over it to lay their eggs are permitted to walk over food, they may leave germs on the food. In this way germs of such intestinal diseases as diarrhœa, dysentery, typhoid, and cholera are disseminated, provided these cliseases are present in the neighborhood.

When people are crowded together, as in army camps, and insufficient care is exercised to keep flies from access to the foodstuffs, the transportation of intestinal diseases is appalling and the death rate enormous. This was sadly illustrated in some of the army camps of our Spanish-American War. The best way to prevent dysentery is to prevent the larvæ of flies from developing in the filth of the camps, and secondarily the adult, flies must be prevented from coming in contact with our bodies and our food.

The larvæ of Diptera may be exterminated by treating their breeding-places with insecticides, of which kerosene oil is one of the best. The adults may be kept away by screening the doors and windows.

Although so very numerous, flies would be still greater pests if it were not for the fact that they are preyed upon by various parasitic animals and plants. The larva of the house-fly is sometimes infested by minute parasites belonging to the insect group of Hymenoptera. A still more important foe is a minute fungus which infests house-fies in the autumn. The dead flies may often be seen on window-panes with fine white threads sticking out of the borly, and surrounded by a halo made up of the spores discharged from the fungus upon the glass. Finally, robber-flies and spiders kill great numbers.

The order Diptera is a large one and a difficult one to study, for it contains many species frequently composed of small individuals which are comparatively unknown. The members of 
the group can usually be distinguished by having only two wings, the posterior pair being rudimentary and transformed into "balancers" that end in knobs. An account of the principal families follows.

The short-horned Diptera (Brachycera ${ }^{1}$ ) is the division to which the house-fly, as well as various other common flies, belong. House-flies ${ }^{2}$ (Muscidæ) are of several species. In the commonest species the female lays one or two hundred eggs. These, in warm weather, hatch in a few hours into larva, commonly called "maggots." The larvæ are wholly footless, and even the hearl is only a slightly developed structure. The larvæ acquire full size in about a week; pupate and batch about a week later. The process of pupation is a complicated one, for all the larval organs, excepting certain patches of tissue, are destroyed. By the growth of these patches the individual is formed anew. These changes are all deep lying, and nothing seems more passive than the hrown pupal case. Finally the case breaks at one end, and the fully formed fly emerges. The metamorphosis which the fly has just undergone is a complete one.

The larvæ as well as the adult flies breathe, like other insects, by means of a system of air-tubes (trachex) which can be seen best in some aquatic larvæ with the aid of a strong magnifying-glass. The virtue of kerosene oil in killing larval flies is due to the fact that larvæ cannot breathe through the film of oil.

One of the most destructive members of the family Muscidæ is the tsetse-fly of tropical Africa (Fig. 84). The bite of this

I brachys, short; heras, a horn.

"It has been suggested that these should be called "typhoid flies" or "septic flies," to make familiar the danger that lurks in them. 
fly is so dangerous that horses and dogs cannot penetrate the region infested by it. Even herds of cattle may he killed by this fly. Consequently travellers have been hindered in penetrating into this country, and the opening up of tropical Africa to agriculture and commerce has been much interfered with. The injurious effect of the hite of this fly is due to a

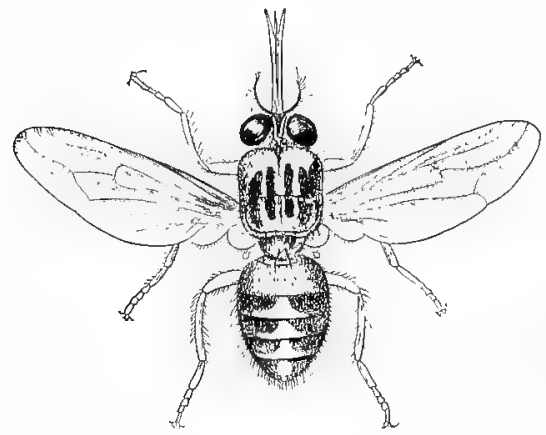

FIG. 84.-Glossina moristans, the tsetse-fly.

From the "Standard Natural History."

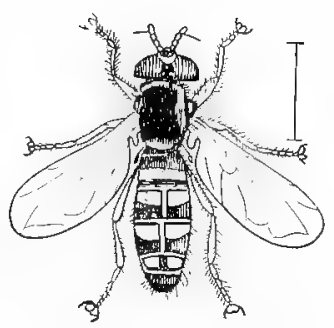

Fig. $84 a$. - Syrphus.

From Packard.

parasite introduced by it into the body of the victim, and causing the disease known as "sleeping sickness."

Another destructive family includes the bot-flies, which have a general resemblance to honey-bees or bumblebees. Their larvi are parasitic in mammals. Of this family the bot-fly of the horse is the most generally known. These flies hover about the legs of horses and lay their eggs upon the horse's hair. The larvæ, irritating the horse's skin, are licked by the horse into its mouth and swallowed. In the stomach or intestine of the horse they get abundant food, and there they develop. The larvæ of another species, "the ox-warble" or "grubs," are taken into the mouth of cattle, and live for a time in the gullet. Then they bore their way through the 
walls of this tube, and travel on until they make their way out through the skin to the surface. Another injurious species is the sheep bot-fly, whose larvæ cause "staggers" in sheep.

The flower-flies (Syrphiclæ ${ }^{1}$ ), like the bot-flies, mimic honeybees, bumblebees, and wasps. The adults feed on the pollen

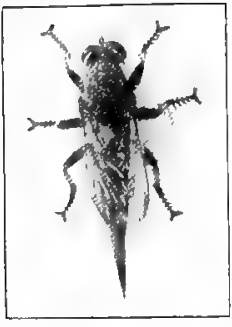

Fia. 85. - Robberfly. Nitt. size. Photo. by W. H. C. P. and nectar of flowers, and even imitate the humming of the bee. The larvæ of some forms feed upon plant-lice; others, upon decaying vegetable matter. They may occupy the nests of various stinging Hymenoptera. The larvæ of some species are known as rattailed maggots on account of their having a characteristic appendage. These are sometimes found floating in foul water or even in salt water (Fig. $84 a$ ).

The robber-flies are usually of large size, have a short head, prominent eyes, legs covered with stiff hairs, and abdomen either long and slender (Fig. 85) or stout. These flies attack and devour other flies and even insects much larger than themselves, such as bumblebees and dragon-flies.

The horse-flies include the largest flies, and those whose hite is the most painful (Figs. 86, 87). The female sucks the blood of various short-haired domestic animals, especially of horses and cattle. The male, however, feeds on flowers. The larve are carnivorous and live in the earth or water.

The long-horned flies (Nematocera) have generally slender bodies and long antennæ composed of six or more joints. The larva are frequently aquatic or infest plant tissues, but are not parasitic upon animals. To this suborder belong the black-flies, gall-gnats, mosquitoes, and crane-flies. 
The black-flies are familiar pests in the forests of our Northern country. The females, which alone suck blood, occur in such numbers and are so active that they render certain places

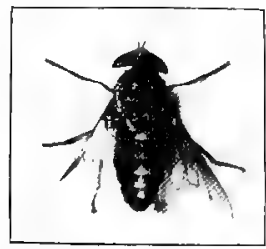

FIG. 86. - Tahanus lineola, whitelined horse-fly. $\times 1.2$. Photo. by W. H. C. P.

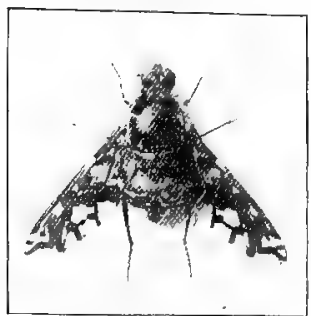

FIG. 87. - Chrysops, banded horsefly. × 1.5. Photo. by W. H.C.P.

almost uninhabitable to man. Their bite often produces widle-spreading and painful inflammation, accompanied by swelling (Fig. 88). The larvæ are aquatic. The Southern black-fly or "buffalo-gnat" sometimes causes the death of domestic animals.

The gall-gnats are minute flies which lay eggs on plants. The larvæ make their way into the plant tissue, and cause the further development of the tissue to he abnormal, so that excrescences or galls are produced. The galls are formed only in growing tissue such as the tips of hranches,

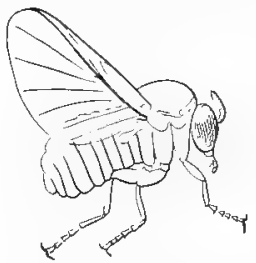

FIG. 88. - Simulium. the black-fly. Enlarged. From Packard. buds of flowers or growing leaves, and are less striking on the whole than the galls of Hemiptera (Fig. 89). A certain kind of gall-fly, called Hessian-fly (Fig. 90), is extremely injurious to wheat hecause it infests wheat seedlings and so weakens them that they produce no grain. Other minute gnats or midges are destructive to clover in the United States, either 
by binding the leaves together and sucking the sap of the plant or by destroying the young seed.

The mosquitoes, or Culicidre, ${ }^{1}$ are so well known that it is hardly necessary to describe them. The larvæ are aquatic.

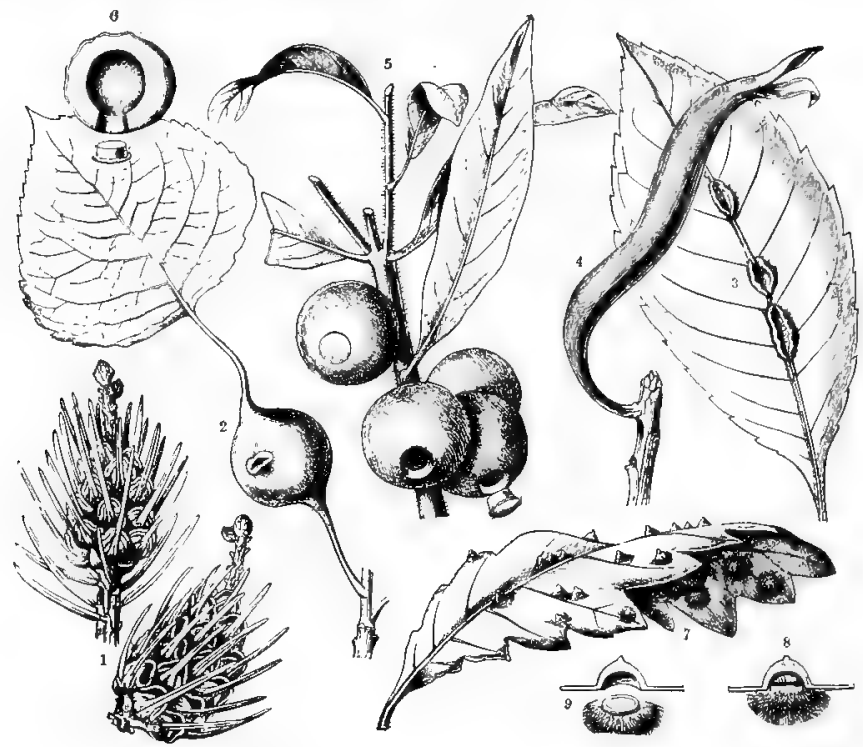

FiG. 89. - Plant galls produced by Hemiptera and Diptera. 1. Pinc-apple gall on twigs of the spruce fir produced by the spruce-gall A phis (Chermes abretis, one of the Hemiptera). 2. Covering gall on the petiole of the pyramidal poplar (Populus pyramidalis), produced by Pemphigus bursarius, one of the Hemiptera. 3. Covering galls on an ash leuf (Fraxinus excelsior), produced by Diplosis botularia (Diptera). 4. Covering gali nn Pistacia (Pistacia lentiscus), produced by Pemphigus cornicularius. 5. Solid galls on the cortex of Duvana longifolia, produced by Cecidoses eremite (Hemiptera). 6. Longitudinal section of one of these galls. 7. Capsule galls on the leaf of the turkey oak (Quercus cerris. Hemiptera), produced by Ceridomyia cerris. 8. One of these galls cut through, with the operculum still firmly attached. 9. The same, with the operculum falling away; 3 . The remaining figures natural size. From Kerner, "Pflanzen Leben."

${ }^{1}$ Culex was Pliny's name for fly. 
The eggs are laid in a boat-shaped mass, which floats on the surface of the water. The larvæ escape from the lower ends of the egg-cases, and are known as "wigglers." The larvæ of some species rest vertically near the surface of the water, head downward, with the tail end of the body at the surface of the water, since respiration takes place at that end (Fig. 91, A,c); other species lie horizontal at the surface of the water. Upon emerging from the water, the mosquito floats in its pupal skin until its

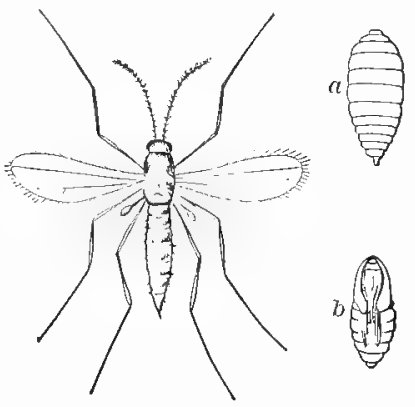

Frg. 90.-Cecidomyia, the Hessianfly. $a$, larva; $b$, pura. From the "Standard Natural History." legs and wings harden. Since a disturbance in the water at
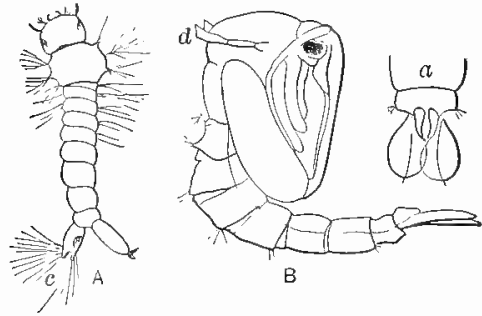

FIG. 91.-Culex, the mosquito. $A$, larva: $c$, its respiratory tube. $B$, pupa; $d$, the respiratory tubes; $a$, the end of the abdomen with the two oar-like swimming appendages, dorsal view. After drawing of E. Burgess. this time would jeopardize the life of the mosquito, this insect always breeds in quiet waters (Fig. 92). From the habits of the larva it follows that they can be easily killed while in the pond by pouring kerosene oil on the water, for this forms a film on the surface and prevents respiration. Minnows will free a pond from larvæ if the edges of the pond are kept free from grass so as to allow the fish to get to them.

Mosquitoes are not merely a nuisance, but are disseminators of some of the most dangerous of human diseases. Malaria 
is due to germs of microscopic organisms that live in the salivary glands of some kinds of mosquitoes (Anopheles) and are injected into the blood of its victim at the time of biting. The mosquito gets the malaria germs from the blood of infected persons. Another genus (Stegomyia) found in the tropics disseminates the germs of yellow fever. Still another species

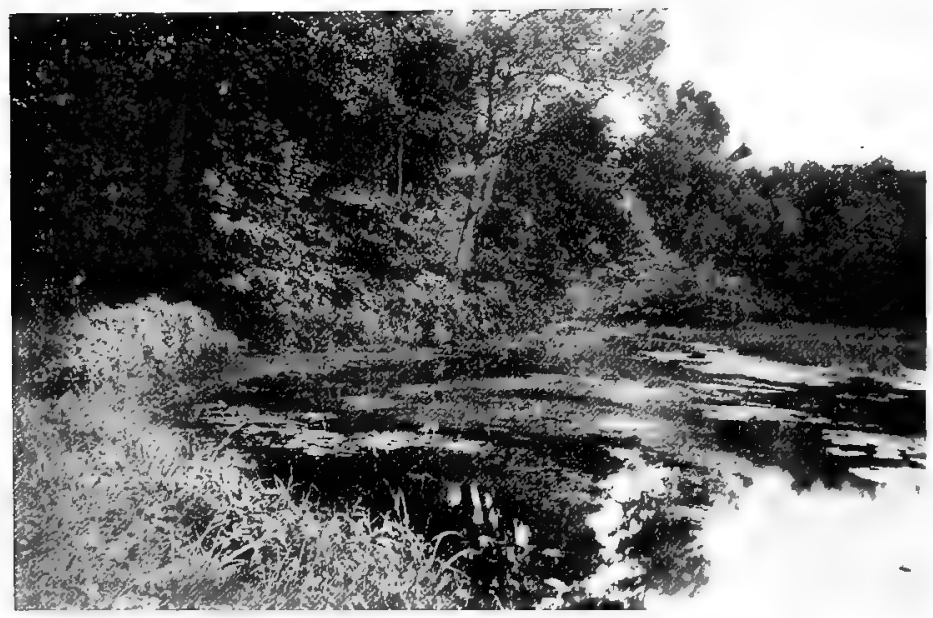

FIG. 92. - A quiet water where mosquitoes breed.

conveys about a minute round worm, Filaria ${ }^{1}$ hominis, ${ }^{2}$ allied to the vinegar eel, which thrives as a parasite in the blood-vessels of men living in the tropies, and causes a painful and usually fatal swelling of the arms and legs. The embryos are found in the surface circulation only at night, during which time man is most defenceless toward the mosquito. At this time they are sucked out of the blood by the mosquito and develop in its alimentary tract. Later they are deposited in stagnant

\footnotetext{
${ }_{1}^{1}$ fium, thread.
}

${ }^{2}$ of $\operatorname{man}$. 
water with the eggs of the mosquito, and reach man's borly again if the water be drunk by him.

The crane-flies (Tipulidæ, ${ }^{1}$ Fig. 93) look like mosquitoes, but can easily he distinguished from them by the fact that they have a $V$-shaped groove on the back of the thorax. They are larger, and have relatively longer legs than the mosquito. Their legs are easily broken, and seem to be so much in the

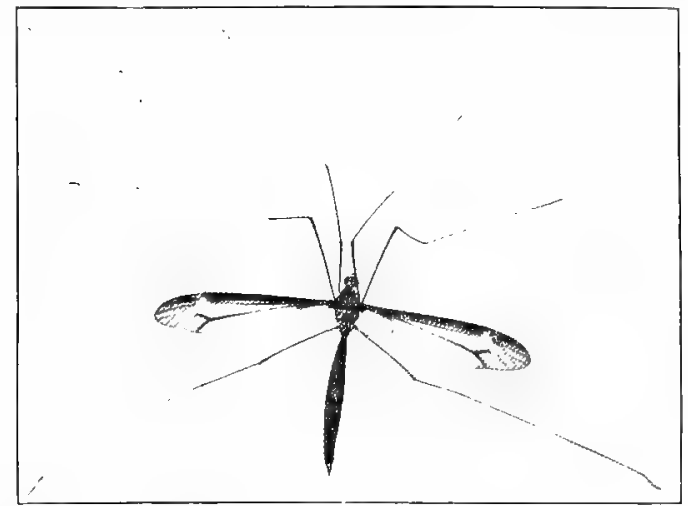

Fig. 93. - A crane-fly. Nat. size. Photo. by W, H. C. P.

way that flight is clumsy. The adults are quite harmless, but some of the larvæ work destruction by feerling upon tender plants and causing them to wither and die.

There remain to be considered a number of degenerate flies degenerate because parasitic in the adult state. The first family we may consider is that of the louse-flies. ${ }^{2}$ These small insects have a firm proboseis used for piercing, and stout legs. Only certain of the genera develop wings, and some of these lose them after they gain their hosts. They live, like lice, in the fur of mammals or the feathers of birds. They

${ }^{1}$ Latin, tipula, water-spider. 2 Suborder Pupipara. 
are viviparous, the larvæ being ready to pupate at the time of hirth. The sheep-tick is one of the best-known forms. Diptera allied to the foregoing live as parasites on the body of the honey-bee.

Fleas are likewise wingless, blood-sucking parasites. The body is compressed from side to side, so that it can move easily amongst the hairs of its host. The hindermost legs are strongest and are used in springing. Fleas develop in dust in the cracks of the floor and about the sleeping-places of domestic pets. One species prefers mankind and is believed to disseminate certain diseases such as the bubonic plague. They may be combated by means of cleanliness and Persian insect powder.

The foregoing study of the Diptera shows how great a menace they are to man's health. But indirectly they are injurious to man by attacking domestic animals and cultivated plants. Thus the tsetse-fly is a menace to the commerce of a large part of a continent. The horse-fly, the horn-fly, which worries cattle, the buffalo-gnat, which worries or even kills domestic animals, and the dangerous bot-fly are all causes of great loss to industry. Also the larvæ of some flies infest vegetables, such as cahluage, radish, cauliflower, onion, as well as various fruits, and cause great damage. The gall-gnats destroy clover and its seed; and, worst of all, the Hessian-fly infests wheat and Indian corn. This last-named scourge, so called because of a tradition that it was imported in the straw bedding of the troop-ships which brought over the Hessian mercenaries in 1775 , has spread, within a century, over the eastern half of the Uniter States, and has at various times injured the wheat crop to the value of millions of dollars. The larvæ of certain Muscidæ1 attack, in Europe, the stems, ${ }^{1}$ Of the genus Chlorops. 
leaves, and ears of wheat, rye, and barley, and cause in some years great destruction, especially in Scandinavia.

Over against the injury wrought by the Diptera may be placed certain benefits bestowed by them. In the first rank come certain species which prey upon injurious insects, either in the larval or adult stage. The robber-flies prey on the Diptera, Hymenoptera, and certain beetles, but they are not careful to choose alone injurious species. The larvæ of the Syrphidæ prey on the injurious plant-lice; those of horse-flies are carnivorous, and feed on insect larvæ. The larvæ of certain small flies are internal parasites of bugs, heetles, and other (mostly injurious) insects. Finally, the larvæ of some craneflies, robber-flies, and Syrphidæ, by boring into rotten wood, help in the work of forming forest mold. The Diptera, like almost every other insect group, has its economically injurious and beneficial species. However, the good that they do is so small in comparison with the destruction that they directly cause to animals and plants by worrying or feeding upon them or by bringing to them various noxious and fatal diseases that, on the whole, the world would be a better place to live in if there were no Diptera. 


\section{CHAPTER VI}

\section{LITHOBIUS}

\section{A STUDY OF LIGHT-SHUNNERS}

MAN is a diurnal animal, loving the sunlight. The animals that we know best are those that are active in the daytime since we ourselves are most active at that time. But many

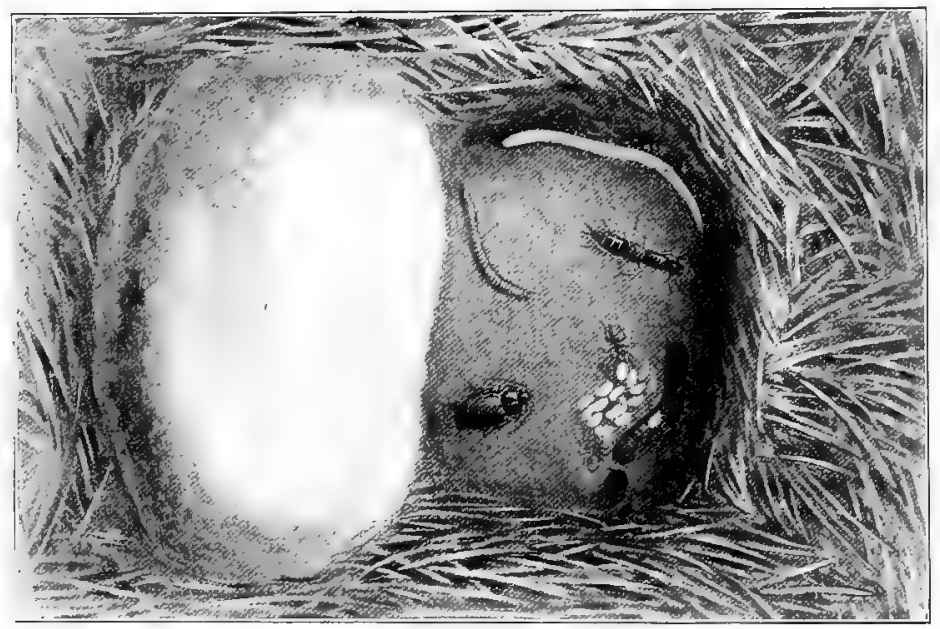

FIG. 94. - A colony of light-shunners under an upturned stone. From ahove downward in the figure, an earthworm, a short-winged beetle, a Julus, an ant with pupæ, and a carabid beetle.

classes of animals are entirely nocturnal. This is true because their organization is such that a strong light is disagreeable to them. They shum a strong intensity of light, and so in the daytime are found hidden under stones (Fig. 94) or the bark 
of trees (Fig. 94 a), in deep woods or in caves. If one of these light-shunners is placed on a table near a window, through which the sunlight is falling, it will turn tail to the sun and move away from the window. If one goes out at night with a lantern, however, one will find many animals running about on the surface of the ground seeking for food or for their mates. Many light-shunners, such as those that live in caves, remain

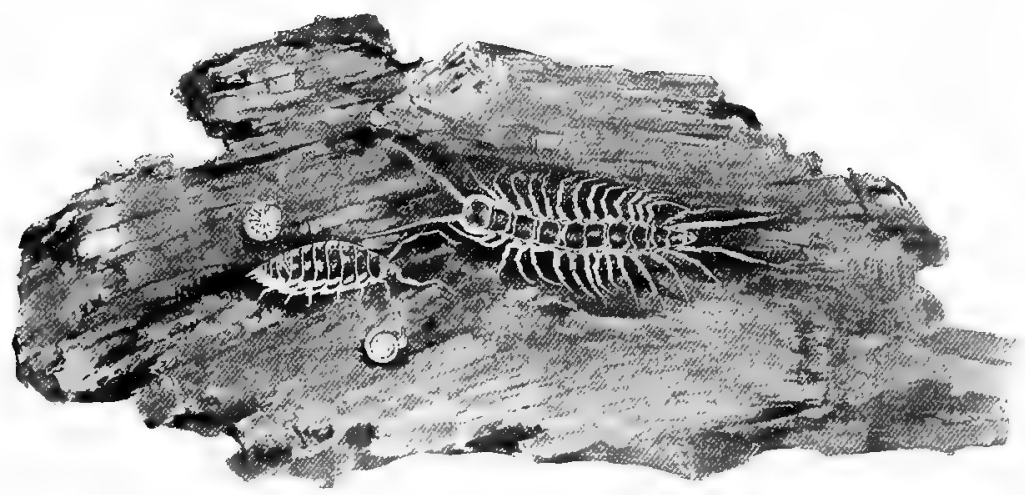

FIG. $94 a$. - A colony of light-shunners nn the under side of an upturned picce of wood. From left to right, Armidillidium, Oniscus, Helix, and Litholius.

there during their entire life, never experiencing rays of natural light. They get into the caves in the first place because they are light-shunners and because their organization fits them to live in the dark. Like most light-shunners, cave animals love not only darkness but contact and moisture as well ; all of these conditions they find in caves, particularly in damp crevices and corners. Very many close relatives of cave animals are to be found outside of caves in greenhouses, secreted under boards during the daytime, just because they find in greenhouses the conditions of equable temperature, moisture, and contact which their nature demands, 
The principal large cave animals are various bats, which are found clinging to the walls; a few salamanders, allied to our little red salamander of the woods (Fig. 95); and certain fishes, many of which are blind. A number of insects live in caves.

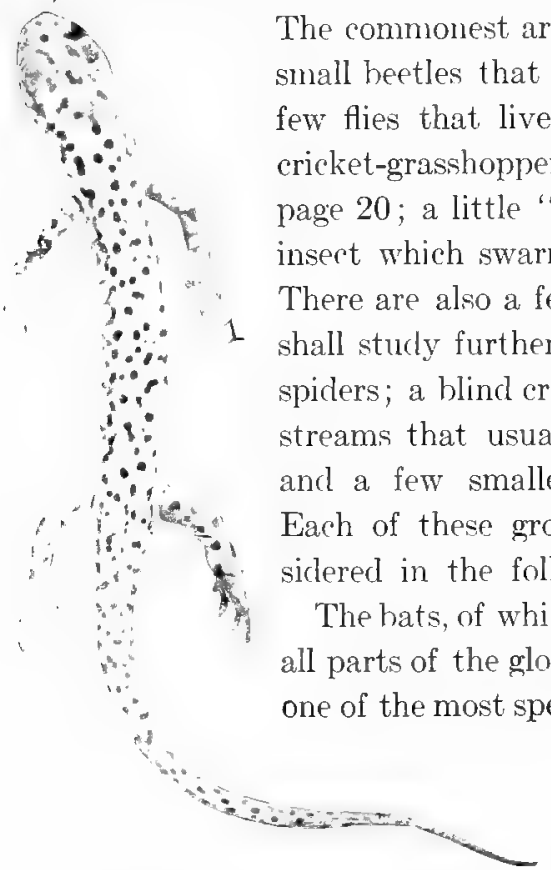

FIG. 95. - Adult of Spelerpes maculicaudus, the cave salamander. mals. They are able to fly, owing to the great elongation of their fingers and to a delicate membrane stretched hetween them. They fly almost exclusively at night or toward dusk; and they seem to be guided less by their eyes than by the vast number of clelicate organs of touch that are scattered over the wing membrane. Also the tip of the nose is crowded with touch organs, which are often borne on a fantastically folded membrane. The outer ears are usually very large, 
indicating an acute sense of hearing. These peculiarities are special adaptations to a nocturnal life in which other senses replace that of sight. During the daytime bats lie hidden in hollow trees, crevices of rocks, in caves, and behind window blinds of houses. Little explanation can be given for their peculiar relation to light; it does not seem to be an adaptation to feeding on nocturnal animals, for many bats are frugivorous. Doubtless they gain from their nocturnal habits a certain immunity from attack by hawks and other birds of prey. The most primitive of the living bats fly late in the day. As the group evolved the habit of flying at night was subsequently acquired, and this suggests that bats have heen getting more and more sensitive to light. In caves, bats fly back and forth but pass often into the free air to capture flying insects. Then, before dawn breaks, they return to the darkness of the cave.

The commonest salamander that inhabits our caves belongs to the species Spelerpes maculicaudus. This genus is widespread, being known from New England to Minnesota and into the Southern States. In New England, where there are no caves, it lives among the rocks and, like its relatives of the same genus, prefers moist crevices and lies concealed during the day. Wherever there are caves, as in Indiana and Kentucky, this salamander is found inhahiting them in great numbers, just because the caves offer the conditions to which they are adapted. The eyes of this salamander are functional, but there are other, less common, cave salamanders whose eyes are degenerating.

The cave fishes of the United States all belong to one family. ${ }^{1}$ Those members of the family that live in caves have a ${ }^{1}$ The Amblyop'sidæ (Fig. 95a). 
colorless body and eyes that are rudimentary or concealed beneath the skin. Their hehavior has been thus described: "If these Amblyopses be not alarmed, they come to the surface to feed, and swim in full sight, like white aquatic ghosts. They are then easily taken by the hand or net, if perfect silence is preserved, for they are unconscious of an enemy except through the medium of hearing; this sense, however, is evidently very acute, for at any noise they turn suddenly downwards, and hide beneath stones, etc., on the bottom" (Cope). There is, however, reason for thinking that their
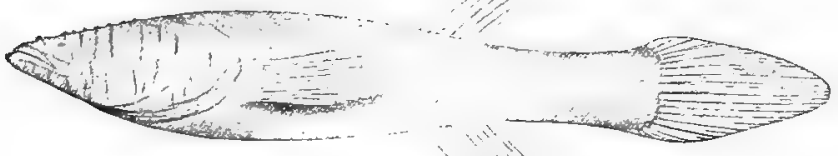

FIG. 95 a.-Amblyopsis, the cave blind-fish, from Blatchley: "Gleanings from Nature."

tactile sense is acute, for the head is provided with numerous tactile warts. These fishes spend their whole life in the caves, never seeing the light of day, and the question arises, whence did they come, how did they get into the caves, and why are they blind? As to the first question it is certain that they must have come from surface streams, because all their numerous close relatives still live ahove ground. To learn how the blind fishes got into caves we must study their relatives above ground, and we shall find that some inhabit dense swamps and others occur under stones in springs. The whole family of Amblyopsidæ are light-shunners and, being such, a cave has offered the best possible place for one of this family. As to why they are blind it appears that it is not due to their cave life, since some of the relatives above ground in regions where there are 
no caves have degenerating eyes. One may say that Amblyopsis came to inhabit caves because it was going blind rather than that it became blind because it got into a cave.

Of the cave beetles one belongs to the genus Quedius. It is found not so far within the cave but that a dim light reaches it. The adults are not wholly blind. It feeds on excrement or decaying remains of cave animals. Now Quedius is a large genus of the family of Staphylinidæ (page 66), most of the members of which are scavengers. As Quedius above ground is usually to be found under or embedded in decaying matter where it is in the dark, it involves no change of habits to be a scavenger of the caves. Another beetleAnophthalmus ${ }^{1}$ - has gone further ; it is found at the darkest part of the cave and is wholly blind. It belongs to the family of Carabidr (page 64) which are predaceous beetles that hunt chiefly at night. Anophthalmus may hunt all day and all night, for it lives in eternal darkness, and can get a supply, although all too

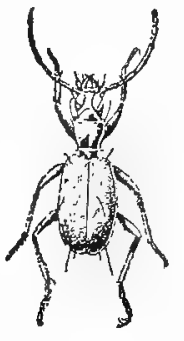

F I G. $\quad 96$. Anophthalmus, from Blatchley: "Gleanings from Nature." scanty, of living prey such as spiders, mites, and springtails.

The flies are among the most abundant of the inhabitants of caves. The commonest species are short-horns, which congregate in moist places on the walls and are exceedingly sluggish in their movements. Their larvæ live in the excrement of the larger animals or in carcasses. Outside of caves these flies are found under wood or stones.

The cave crickets belong to the genus Ceuthophilus (page 20). Their sight is defective, but they are sensitive to touch. Since the other members of the genus that live above ground 
hide during the day, it is easy to understand that the cave affords a favorable environment for such a light-shunning species.

The springtails, some of which live in caves, are among the smallest and simplest of insects, and perhaps the most numerous in individuals (Fig. 97). On a single bare beach one-fourth

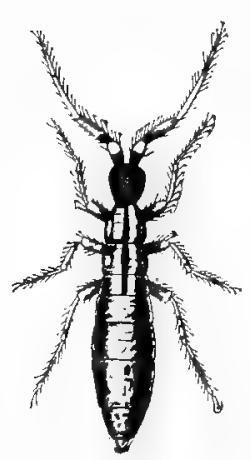

of a mile long the number of springtails living between high and low tide has been estimated at $100,000,000$. The group as a whole loves moisture. They also love contact, so one sees them burrowing into the sand. They are seen to be most numerous at night; they shun the light. Finally, they feed on any organic débris. This is evidently a group that is fitted to live in caves, and so the springtails are found in the caves of both Fra. 97.-A spring- America and Europe. Some of them in the tail. (From Parker caves are blind and colorless. But this conand $\mathrm{H}$ aswell's Text-book of dition is not to be attributed only to the Zoology.)

absence of light, for some of the allies of the cave springtails that live above ground are colorless and blind. Also some of the individuals of one species, at least, live above ground, while other individuals live in caves. Both sets shum the light of day; but it is only certain fortunate individuals that have got into caves.

Most of the spiclers that live in caves are related to those that build cobwebs in our cellars and barns. It is easy for such lovers of darkness and moisture to find a suitable home in caves. But the cave species live under stones and make only a few strands of web. They seem to feed on the larger springtails. 
Finally, the blind crayfish deserves a further word besides the brief reference in Chapter VIII. Most boys know that all crayfishes love the darker parts of streams, and when placed in strong light, they act as though it were painful to them. As they live in streams they would, in cavernous countries, often be brought to the point where a stream issues from a cave. The darkmess of the cave would be a lure to them. Consequently some of them in time would come to be permanent inhabitants of it. The loss of sight and pigment would follow.

Thus we see, in general, that the fauna of caves is not an accidental one, nor one made up of accidentally associated asimals. It is a society of light-shunners. They are lucky to have a cave to live in.

Lithobius belongs to the group Myriapoda, ${ }^{1}$ which is closely allied to insects, but is characterized by life in clark, moist places. The Myriapoda differ from most insects in being wingless and in having the body divided into two regions, head and trunk, and in having either one or two pairs of legs on each segment of the trunk, so that there are, all together, many pairs of legs instead of only three as in insects.

There are two principal groups of Myriapoda, the Centipedes and the Millipedes. The Centipedes (Chilop'oda ${ }^{2}$ ), to which group Litholius belongs, have only one pair of appendages to each body segment. They are active and ferocious animals. All are terrestrial and live chiefly under stones and bark, within or under decaying wood, among barn-yard refuse, in loose soil, and under fallen leaves. Chilopods feed upon living

I myrios, very many; pous, foot.

${ }^{2}$ More correctly Cheilopoda, from cheilos, lip, and pous, foot; because the mouth parts (modified feet) are partially united to form a sort of lip. 
insects, mollusks, and worms, and may be useful to agriculture through the destruction of injurious insects. Lithobius has been observed to spend hours in killing an earthworm, whose juices it sucked as food. Bluebottle flies also serve it as food while in confinement.

Litho'bius $^{1}$ is of world-wide distribution, and over one hundred species are recognized. Our common straw-colored,

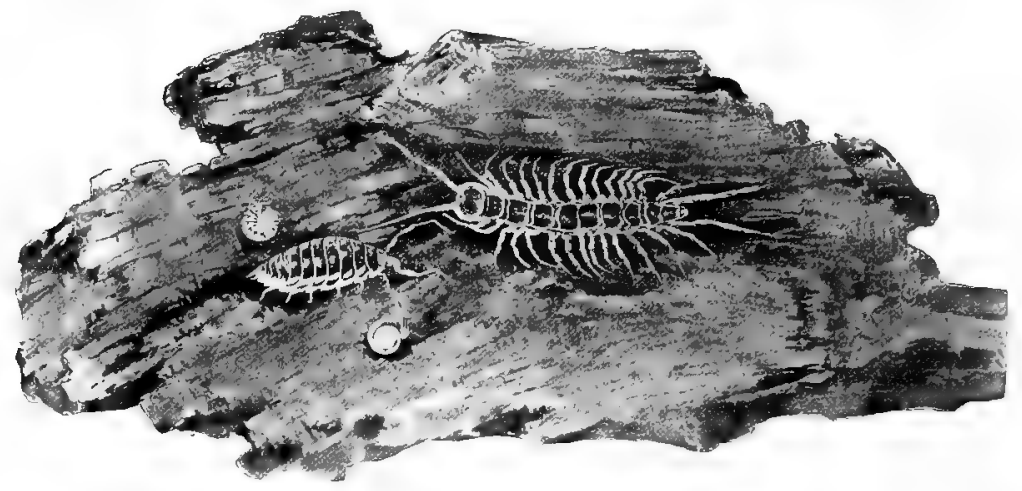

FIG. 95. - A piece of upturned bark with a colony of light-shunners, - Lithobius, a sow bug, a pill bug, and a small snail.

Eastern species, Lithobius forficatus ${ }^{2}$ (Fig. 98), is found also in South America, as well as over most of Europe. It seems to be replaced south of Virginia by another species, spinipes.

Scutig'era ${ }^{3}$ is easily distinguished by its long legs; its hind leg:, indeed, are longer than its trunk (Fig. 99). Our common Eastern species (rare north of New York City) is about 25 centimetres long, and is of a light brown color, with stripes on the back. It is very active, and feeds especially on spiders. It looks something like a spider itself when in rapid movement.

${ }^{1}$ lithos, stone; bios, to live. ${ }_{2}^{2}$ provided with shears, forfex.

'scutum, shield; gerrere, to bear. 


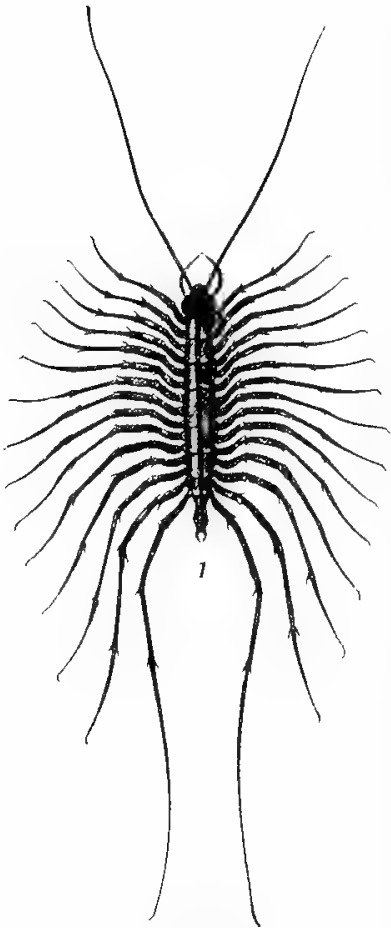

FIG. 99. - Scutigera. Nat. size. From Wood.

The Scutigeras are characteristic of the tropics, where they live preferably in cellars, crawling up horizontal walls.

Scol'opendra $^{1}$ includes longer and stouter myriapods than Iithobius (Fig. 100). To this genus belong the poisonous centipedes of tropical countries. Among these is the giant Scolopendra of our Southern States, South America, and the West Indies, which reaches a length of 25 centimetres or more. This animal has a poisonous bite, which is fatal to insects and other small animals, and causes painful and even dangerous wounds upon man. The biting apparatus is the first pair of feet, modified to form sharp hooks, and provided with poison-glands, which open near the apex of the claw. According to Humboldt, the Indian children of South America tear

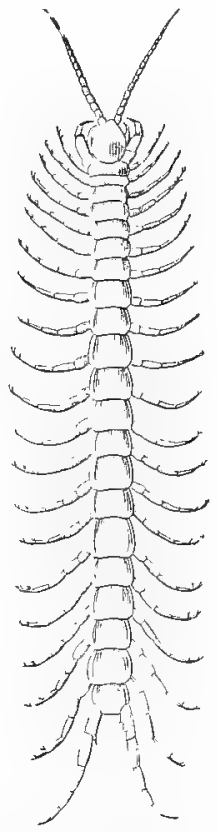

Frg. 100. - Scolopendra. Nat. size. From Leunis. off the heads of large centipedes and eat the remaining portions. 
Geoph'ilus ${ }^{1}$ includes relatively slow-moving species, often attaining great length, having up to two hundred segments to

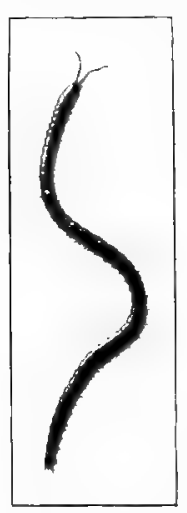

FIG, 101. - Geophilus mor$d a x$. Nat. size. Photo. by W.H.C.P. the trunk (Fig. 101). The species are common in Europe and America. They live mostly under stones. There is a European species, Geophilus electricus, which is phosphorescent and shines in the dark like a glow-fly.

The Millipedes, or Diplopoda, have, as the name implies, two pairs of legs to each segment of the trunk. They are usually more or less cylindrical animals. The antennæ are rather short, and the jaws, which are somewhat shorter than the centipede's, lack the poison-glands of that group. Accordingly we find the millipedes feeding not upon animal but upon regetable substances, for the chewing of which their mouth parts are well adapted. The following millipedes representing two families, can be found under boards in almost any greenhouse.

Julus is commonly known as the galley-worm (Fig. 102). The members of this genus crawl rather slowly, and when at rest coil the body. When disturbed, they give out a strong odor through lateral openings of the body. They feed on dead snails and earthrorms ; some species, on ears of Indian corn or strawberries. Their eggs are laid in holes

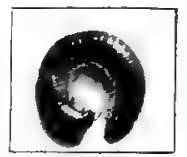

FIG. 102. - Julus canadensis. Nat. size. Photo. by W. H.C.P. in the ground in the spring; consequently they may be easily dug up at this season.

Pol'ydesmus $^{2}$ includes somewhat flattened species, which, ${ }^{1} g e$, the earth; phileo, to love. ${ }^{2}$ polys, much; desmos, band. 
when disturbed, roll up spirally. P. canadensis, of the northern United States, is deep brown, with hairy antennæ (Fig. 103). These myriapods are destructive to agriculture, especially to cabbage and strawberries.

Two genera of myriapods which stand somewhat isolated deserve a passing notice. Pau'ropus ${ }^{1}$ and allied genera include a few animals, about 1 millimetre long, found on the moist loam of woods. They are intermediate between chilopods and diplopods, inasmuch as they have only one pair of legs to a segment, but the segments tend to unite in pairs. Scol'opendrella ${ }^{2}$ is a small, white species, having very large antennæ and a pair of back-

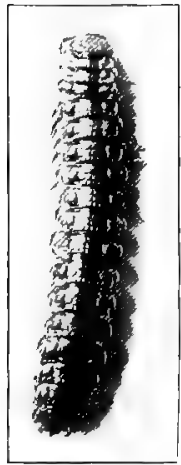

FIg. 103. - Polydesmus canadensis ( - P. serratus). 1.5. Photo. by W. H. C. P. ward-directed stylets. The mouth parts are very much like those of the lowest insects, so that Scolopendrella bridges the gap between myriapods and true insects. The presence of these connecting species indicates that the groups that are now separated are of common origin.

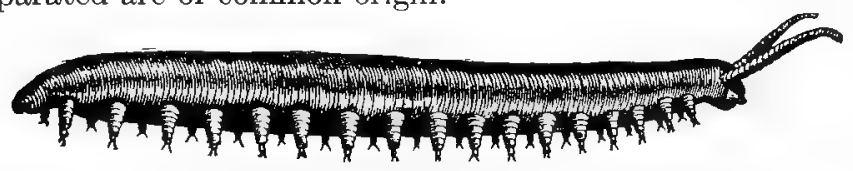

FIG. 104. - Peripatus, the air-breathing, wormlike animal that bridges the gap between Myriapods and worms.

Finally, the myriapods seem to be connected with the worms by a peculiar air-breathing tropical animal known as Perip'atus (Fig. 104). In many details of structure this resembles a polychaetous worm (Chapter XI).

${ }^{1}$ pauros, small; pous, foot.

${ }^{2}$ Diminutive of Scolopendra. 


\section{CHAPTER VII}

\section{THE SPIDER - A STUDY OF ANIMAL ARCHI- TECTURE}

Most plants are rooted to the soil, while most animals are free to move from place to place. Nevertheless many species of animals, particularly the higher ones, have some place to which they repeatedly return and which may be called their home. This home is usually the place which serves to rear the young and to shelter both them and their parents. The simplest sort of a house consists of a lot of agglutinated particles of sand enveloping the body of the animal. Within this sand-tube the eggs may be laid. Such a tube of sand is constructed by many worms (page 188). Certain mollusks, which are protected by hard shells, make burrows in rocks in which they pass a part of their lives. When these mollusks are very numerous (page 230), the rocks may be quite honeycombed by their hurrows. Many of the higher crustaceans form more or less permanent burrows in the sea bottom, where they may dwell and protect their eggs during the hreeding period. All of these sorts of homes, however, are very simple architecturally compared with those of some insects, spiders, and vertebrates.

Certain burrowing insects, like the termites (page 26) and ants (page 53), build complicated communal homes within the earth. Othere, like the wasps (page 51) and bees (page 49), construct nurseries of mud, paper, or wax. In the group of spiders complicated structures have been developed, less for 
the purpose of protecting the young or forming a communal home than for the purpose of entrapping prey. The forms of webs invented by spiders are very numerous and their study is full of interest. We shall consider them further on, after we have learned something of their structure (Fig. 105).

In the vertebrates the simplest homes are those made by

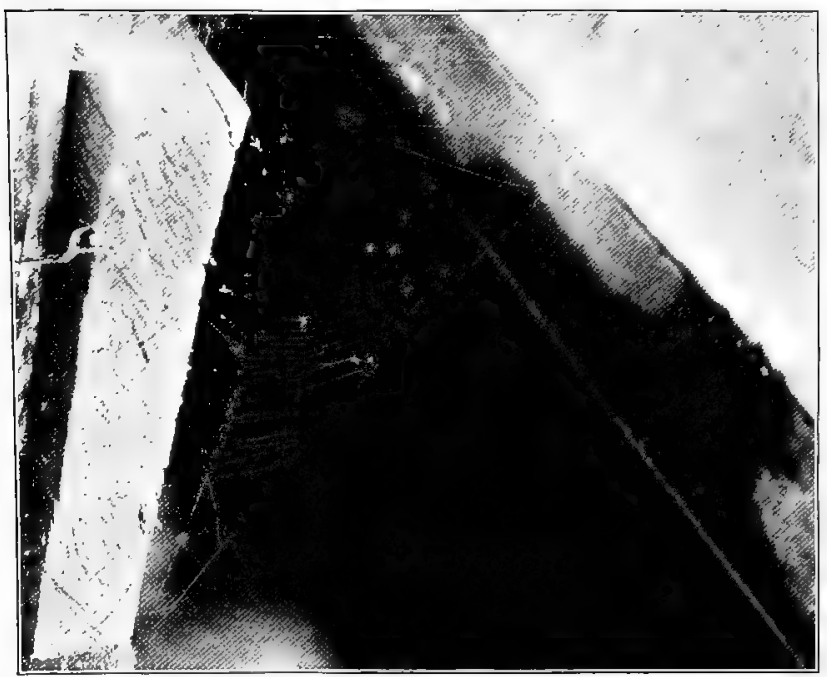

FIG. 105. - Web of Tetragnatha, placed horizontally over a fish-way. Photo. by W. H. C. P.

fishes. These may be merely piles of pebbles to cover the eggs or they may rise to the complexity of nests woven of plant fibre, as in the case of the sticklebacks (Fig. 315). The complicated nests built by birds, for the purpose of rearing their young, reach their highest expression in our Baltimore oriole and in the tailor bird of Australia. Finally among the mammals we find examples of animals that burrow like the wood rat of the Great Basin; that build houses 
of sticks, like the muskrat and beaver; that build nests in trees, like the squirrel; and that rear houses of skins, thatch, brick, stone, and wood, like man.

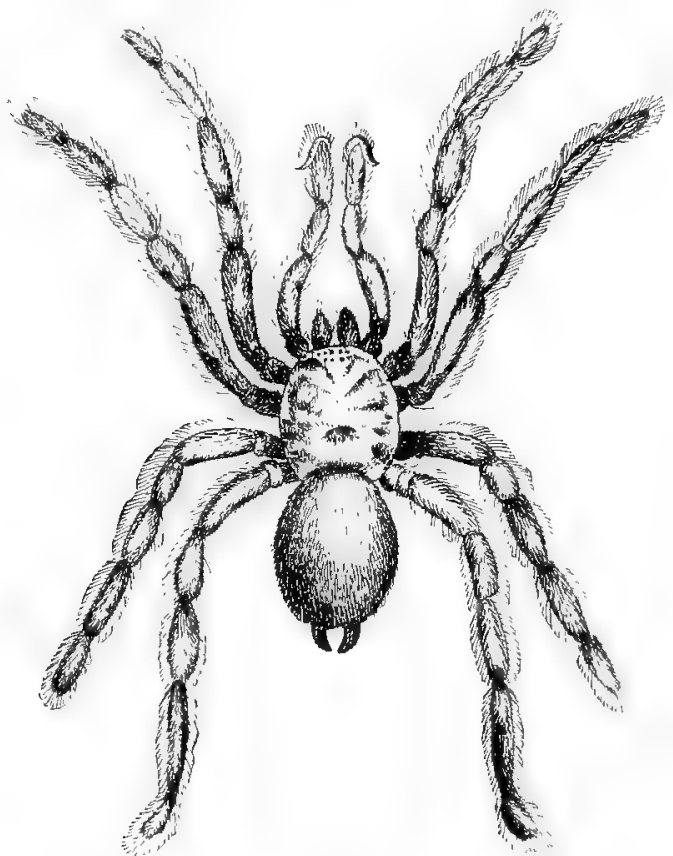

FIG. 106. - Mygale, a tunnel-weaver, allied to the "trap-door spider." Nat. size.

In the present chapter we shall consider a group of Arthropods, in which some sort of architecture is nearly universal. This is the group of Spiders (Araneina). They are characterized by the fact that the head and thorax are united in one piece, called the cephalo-thorax. The abdomen is connected with the cephalo-thorax by a stalk and bears the spinning organs (called spinnerets) at its hinder end (Fig. 106). 
Compound eyes and antennæ are absent, and so we see that spiders are very unlike insects. The first pair of mouth appendages are called cheli'cerce and end in claws, at whose apices the poison-glands open to the exterior. The second pair of mouth parts, called pedipalps, are long and seem to take the place of antennæ. Near the stalk of the abdomen on the ventral side is a pair of slits which open into two lung sacs. In a few spiders there is a second pair of slits; such spiders have four lung sacs.

All spiders spin a nest, but all do not spin webs. The large webs that attract our notice are the perfected product in the evolution of spinning. The most primitive spiders appear to be those that burrow in the earth and line their tubes with silk. Such spiders are

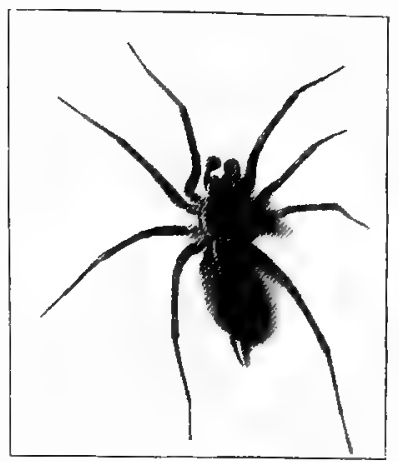

FIg. 107. - Agaiena, the common grass spider. Nat. size. Photo. by W.H. C. P. known as tunnel-weavers. They are found in our Southwestern States and are commonly known as trap-door spiders. The lid of the tube or tunnel is made of dry clay and is penetrated through and through by the spun silk. When the lid is closed, it looks exactly like the ground around it, so that the opening is easily overlooked. Some of these spiders acquire great size (Fig. 106). A step in advance is seen in the tube-weavers (Fig. 107). The tube-weavers spin in the grass their tubes of silk, at the bottom of which they live, while at the outer end they build over the grass a platform, which serves them mainly as a trap for jumping insects. Such are the webs that one sees in the grass on a dewy morning (Fig. 108). 
Next we have certain spiders which build irregular webs. Such are the line-weavers. To this group belong the common colsweb spiders of our cellars and outhouses. The web consists of a fine irregular mesh with strands running above and below it in various directions. The spider stands below the main part

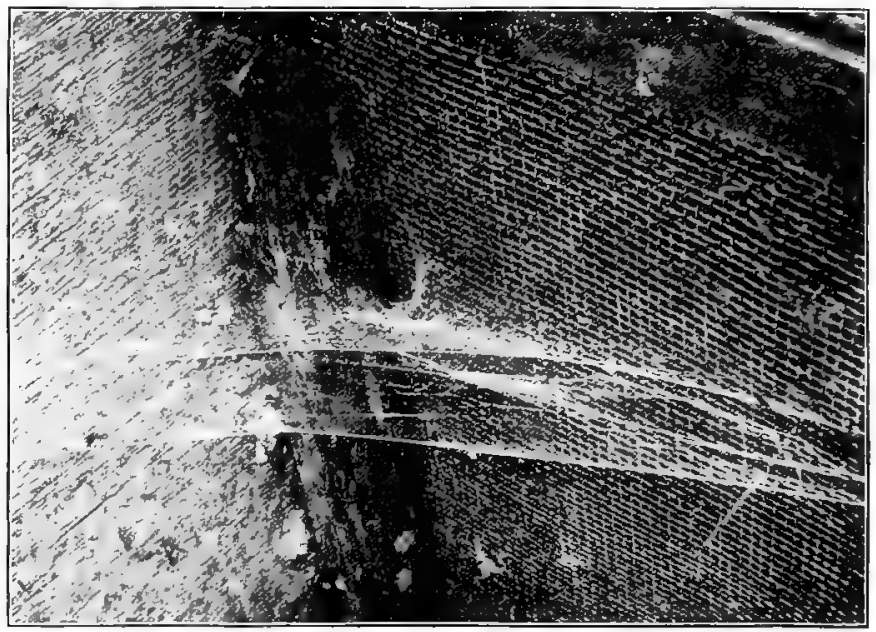

Frg. 108. - Web of a tube-weaver Tegenaria; looking down upon the web, which is in a corner between two vertical walls. The tube is in the angle. Photo. by W. H. C. P.

of the web, hanging back downward. Such a web serves to entangle and hold flying insects upon which the spider preys (Figs. 109, 109a).

Finally the orb-weavers (Orbitelariæ ${ }^{1}$ ) spin a web lying mostly in one plane and having a geometric form often of remarkable perfection and symmetry. Such extraordinary structures deserve careful attention. Foundation lines (Fig. 110) of unusual strength are first laid down to form the outer frame 1 orbis, circle; tela, web. 
of the web. Then radii are spun from a central little ball of floss to the frame. The radii are, often at least, laid down alternately on opposite sides of the centre. The number of radii formed by a species of spider is not perfectly constant, but

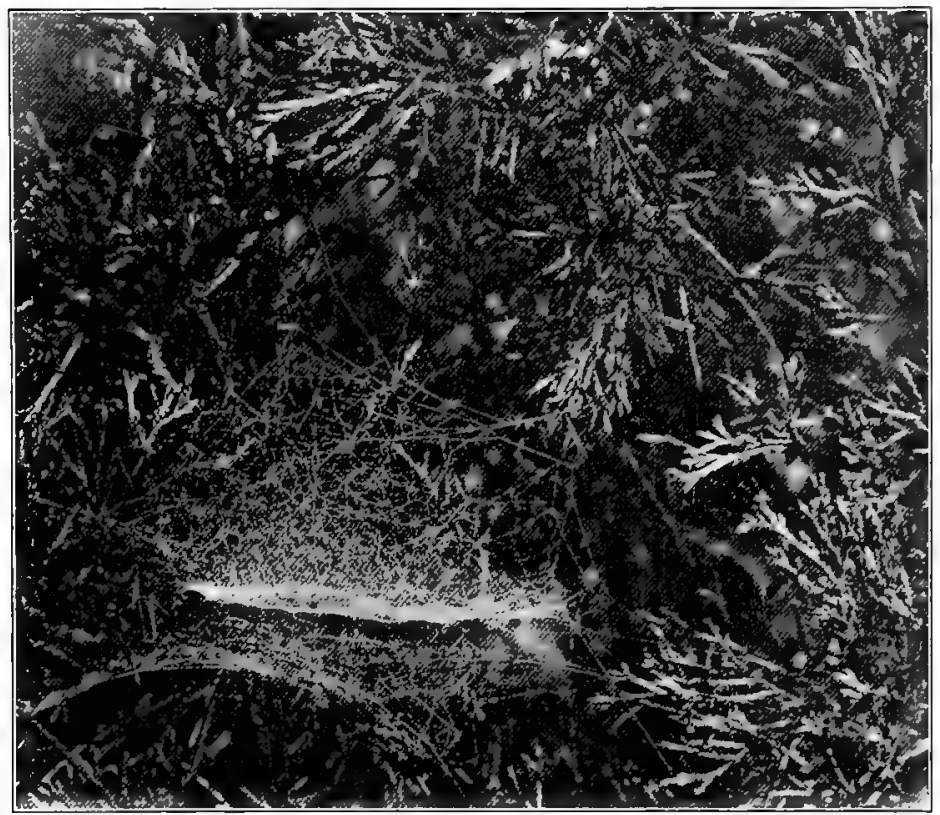

Fig. 109. - Web of a line-weaver. Photo. by Emerton.

varies within limits. It would be an interesting occupation to sketch a number of webs of Argiope, showing the variations in the number of radii and the other details of form. After the radii are placed, the spiral lines are laid down. In the completed web four regions are distinguishable, as follows, passing from the centre outward: (1) the inner spiral zone, consisting of four to eight turns at the centre; (2) the free zone in which 
no spiral is laid down; (3) the outer spiral, the main part of the spiral framework; (4) the foundation space, beyond the spiral lines, and at the outer margin of the web (Fig. 111). No study is more interesting than that of the details of

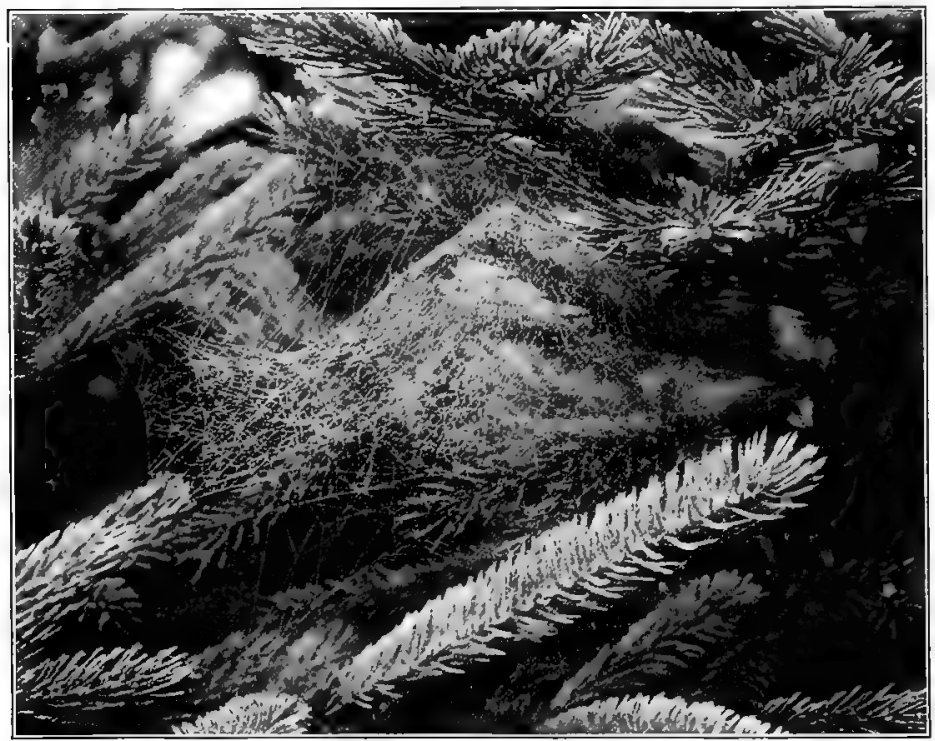

FIG. 109 a. - Web of Linyphia, one of the cobweb spinners, in a spruce tree. Photo. by Emerton.

construction of these parts of the spider-web, while they are being made out of doors or in large slass jars.

The web of the orb-weaver hasundergone, in different species, very striking morlifications. Thus, in some cases only fragments, as it were, of an orb are built (Fig. 112). In one case the spider lives in a recess behind the weh and keeps in touch with the web by means of a line running to its centre. By pulling upon this line the centre is drawn back towards the 
spider. If an insect should enter the weh, the spider releases its pull upon the central part, and the web springs outward, strikes the insect, and causes it to adhere to the threads.

While, on the one hand, some spiders have evolved in the direction of the construction of complicated webs, some, on the other hand, have never acquired the web-spinning habit. Such, for example, are the wandering spiders, which may be classified into three chief groups.

(1) Crab spiders are so called because they run sideways. They make nests by fastening together leaves by threads of silk. Their young are reared in these nests, and watched over by the mother (Fig. 113).

(2) Running Spiders. - These are for the most part large and powerful species which wander

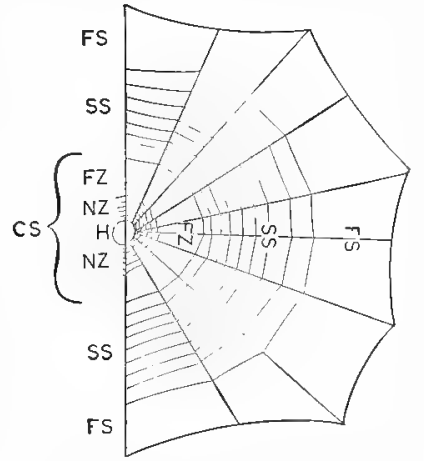

FIG. 110, - Diagram on nomenclature of parts of an orb-web. FS, foundation space; SS, spiral space; $C S$, central space; $F Z$, free zone ; $N Z$, notcherl zone; $H$, centre. From McCook. over fields or along watercourses in search of prey. Our Northern species are chiefly "wolf spiders" (Lycosidæ, ${ }^{1}$ Fig. 114). The female carries her eggs about in a special cocoon attached to the end of the abdomen. The young are borne on the back of the mother. The great size, black color, and hairiness of some of these spiders have given them an apparently unjustified reputation of being very poisonous. Naturalists who have allowed these spiders to bite the hand report that the bite is rarely more poisonous than that of the mosquito. Some of 
the Lycosidæ live on sandy wastes (Fig. 115), where they make holes in the ground lined with silk (Fig. 116).

(3) Jumping Spiders $\left(\right.$ At'tidæ $\left.^{1}\right)$. - This family includes many familiar, active species of high intelligence. Some of

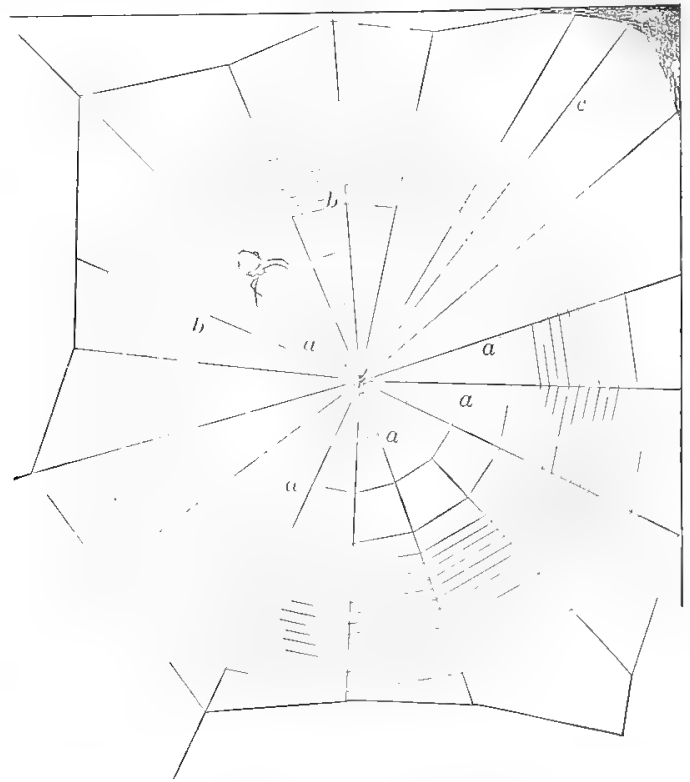

FIG. 111. - Orb-weh of Epeira. $a$, first spiral line; $b$, second spiral line; $c$, line to nest. From Enerton.

these of grayish color live in houses, and are recognized as members of this family by their half-running, half-jumping gait (Fig. 117). The cocoon is attached to some object and enclosed in a sort of tent, in which the mother also lives to guard the young.

Other Uses of the Spinning Instinct. - We have seen that

1 From Latin, Atta, club-footed man. 
spiders make webs of the silk that they spin and that many ground spiders line their nests with silk. Silk is, however, used for many other purposes, and it would be difficult to say which is the principal use. The mass of eggs that the female lays is always covered by a cocoon of silk. The silky threads may serve also to suspend the spider while it drops from a tree, or they may, by their friction with the air, serve to suspend sertain spiders in aerial migrations. ${ }^{1}$ This latter use is especially noteworthy. A small spider, when desirous of taking flight, climbs up some high object, such as a fence post, elevates the spinnerets, and spins loose silk into the

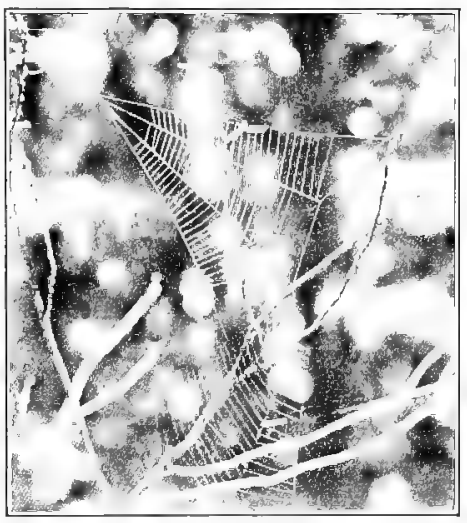

FIG. 112. - Web of Hyptiotes in a bush, one quarter of the real diameter. air (Fig. 118). After enough of it has been thus formed, the spider lets go, and is supported by the currents in the air while it is wafted great distances. Thus Darwin, on his voyage in the Beagle, saw cobwebs bearing up spiders floating: in the air over his vessel more than sixty miles from shore.

1 The ballooning habit of spiders has been noticed since early times, but it was formerly misinterpreted. Thus Pliny speaks of wool being rained. The poet Spenser wrote :-

" More subtle web Arachne cannot spin;

Nor the fine nets, which oft we woven see,

Of scorched dew, do not in th' ayre more lightly flee."

Thompson writes: -

"How still the breeze! save what the filmy threads

of dew evaporate brushes from the plain." 
The method of spinning deserves careful attention. The spinning-organs consist of a set of glands lying in the hinder part of the abdomen, and opening to the exterior through a number - often several hundred - of spinning "spools."

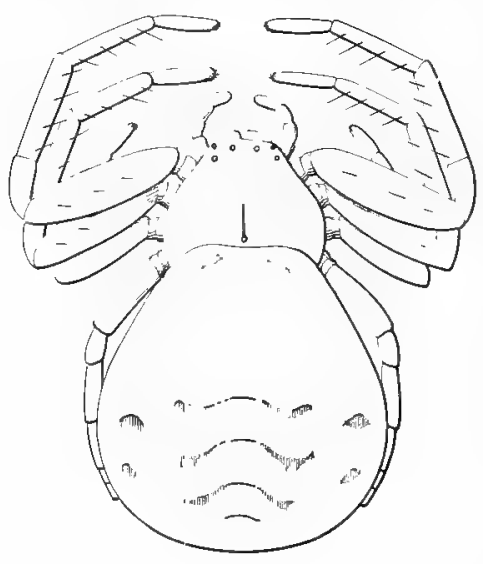

$\begin{array}{llll}0 & 0 & 0 & 0 \\ 0 & 0 & 0 & 0\end{array}$

FIG. 113. - Thomisus, a crab spider. Diagram showing arrangement of eyes at bottom of figure. From Emerton.

These spools are the modified mouths of glands, and are grouped upon and between tubercles called spinnerets. The secretions of the glands, as they are poured out into the air, fuse together and harden into a thread. The thickness of the thread is determined by the number of glands secreting together.

The economic importance of spider webs is considerable. First of all, they are of the greatest importance in capturing many destructive insects, such as flies, mosquitoes, and moths. Another use to which they have been put is in making silk cloth. The silk of the spider is smoother and glossier than that of the silkworm, but it is much harder to collect in quantity. A spool is passed against the spinnerets of an individual spider and slowly revolved, winding the silk upon it. The difficulty comes in rearing the spiders, for they are extremely voracious, and if the supply of flies is insufficient, they attack and devour one another. Consequently they must be kept isolated and fed individually, and yet yield in the end only an ounce or so (about 30 grammes) of silk. Other uses of spiders' 
silk are: in the construction of cross-hairs in telescopes and, in medicine, as a narcotic in case of fevers, - a temporary fad.

Poisonous Spiders. - Spiders are feared by many people from a belief that they are very poisonous, even fatally so. Spiders have, indeed, biting jaws provided with poison-glands, and their bite is often fatal to insects and even to small hirds and mammals. But most spiders cannot spread the jaws sufficiently to make a bite in the human skin, and even the largest forms seem to inflict but a slight wound, scarcely ever greater than that of a mosquito. The stories of the severe effects of the bite of the Tarantula, one of the Isycosidæ, are entirely fabulous.

Spiders show a marked sexual dimorphism. Particularly among

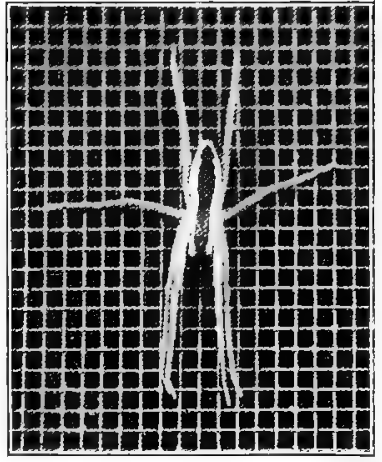

FIg. 114. - Ocyale (Pisaurina) undata. Half grown, natural size, resting on a screen door, using it as a sort of artificial web. Photo. by Emerton. the orb-weavers the males are much smaller than the females of the same species, but the legs of the male are relatively the longer and stronger. The male is usually shorter lived than the female, for the latter has often to watch the egg-cocoons, or carry them about with her until the young hatch out. The male also builds less perfect webs than the female. The relation existing hetween mated pairs is often peculiar. The male is frequently killed and eaten by the female; but if the male can overcome the female she may fall his victim. Among wandering spiders there is often a selection by the female from among several rivals, which engage in severe battles with each other. 
The Position of Spiders in the Zoological System. - Spiders clearly belong to the arthropods because, like the grasshopper, they have a thick cuticula (which is molted as the animal grows) and jointed legs. Spiders differ from insects, however, in several important respects. They possess four pairs of legs instead of three. The head and thorax are united. The

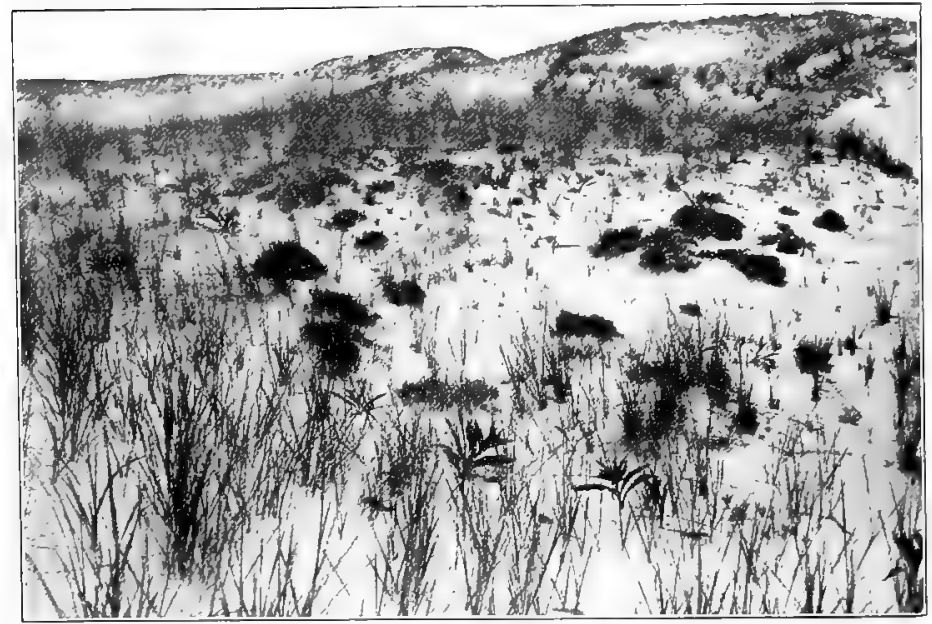

FIG. 115. - A sandy waste (dune region of Fire Island Beach, Long Island) where many spiders burrow in the sand.

antenna are absent. Consequently it is an error to speak of spiders as insects; rather they, together with several allied groups, belong to a distinct division of the arthropods, the Arachnida. The Arachnida, indeed, breathe air, but the air passes into a little pouch on the under side of the abdomen and in between numerous thin sheets, like the leares of a book, so that the whole hreathing apparatus is often called a lung book. They have also a system of air-tubes which is much 
less dereloped than that of insects. Although they belong to the air-breathing arthropods they are without wings, and are therefore confined to the surface of the ground, except in the case of the ballooning species just described. In conse-

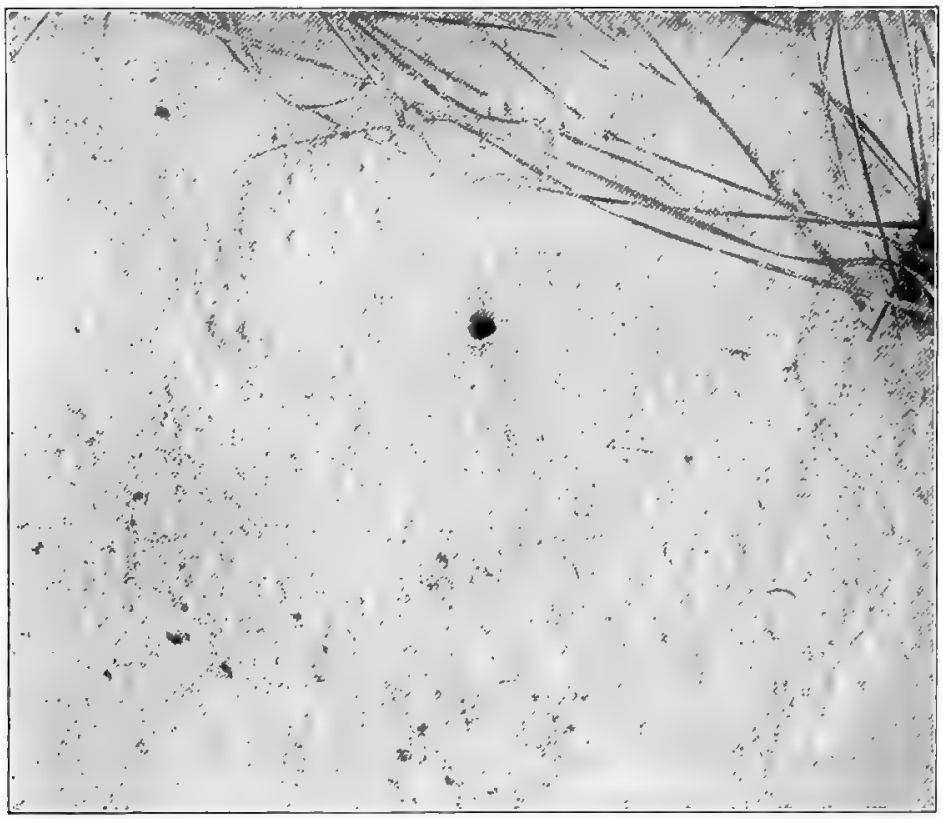

FIG. 116. - The entrance of the vertical tube to the sand-Lycosa.

quence, the thorax is not a distinct and prominent part of the body, as in insects, but is indistinguishably united with the head. The abdomen never carries legs as does that of the water arthropods. In this respect the Arachnicla agree with the insects rather than with the water-inhabiting crustaceans.

Although the spiders are the largest group of the Arachnida, there are several other kinds of animals included in this class. 
The scorpions (Fig. 119) and their allies are more primitive than the spiders, since their bodies are longer and more wormlike. The abdomen is divided into two regions: in front, a broader and, behind, a narrower called the post abdomen. The scorpions are animals of the tropics and of the deserts,

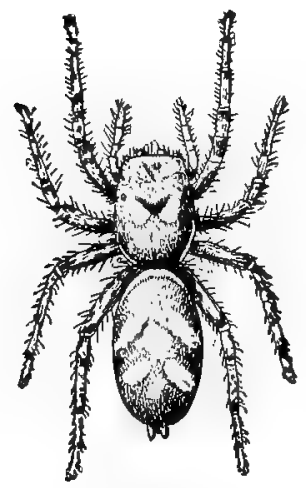

FIG. 117. - Attus, a jumping spider. From Emerton.

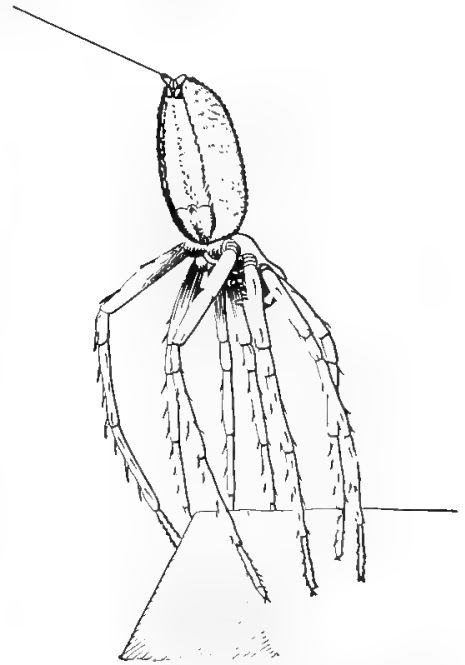

FIG. 118. - Young Lycosa about to fly. From Emerton.

and are found during the day under sticks and stones. Their thick skin enables them to resist the dry air of the desert which tends to wither all it touches. The tip of the tail bears a sting. Into this sting a poison sack empties. The wound of the large scorpions, such as are found in the tropics, is fatal to many animals upon which the scorpion preys. The wound is very painful to man and occasionally fatal. We have only one species of scorpion (Bu'thus) in our Southeastern States, but there are several species in the southwest. 
The harvestmen, or daddy-long-legs (Phal'angidea) are extremely common (Fig. 120). They are somewhat spider-like, but differ in having legs many times the length of the body. Their long legs enable them to walk over the foliage of trees and smaller plants by stepping from leaf to leaf. They wander over fields also and not uncommonly are seen on porches of houses. They are rapacious animals, feeding on small insects, and are highly beneficial to agriculture.

The mites and ticks (Acarina) have their abdomen united into one piece with the head and thorax, so that the body is round. They exhibit

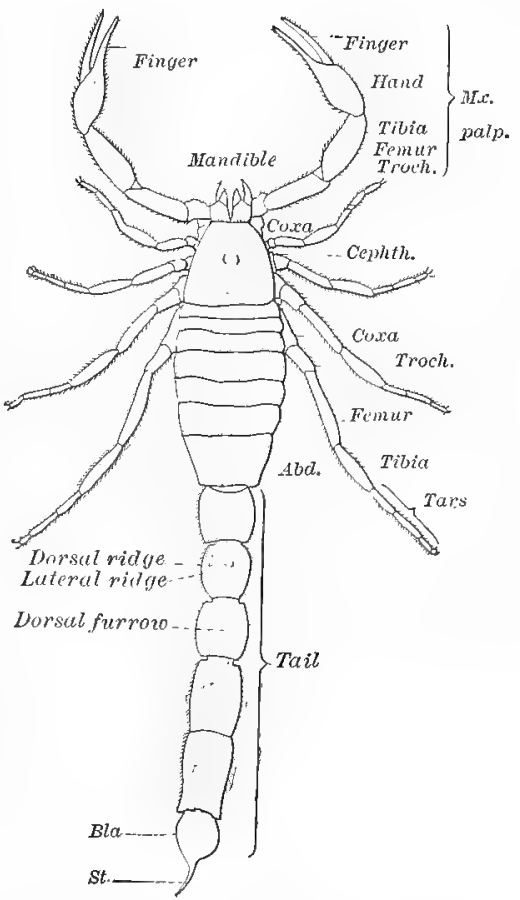

FIG. 119. - Buthus, a European scorpion. Dorsal view. $M x$., maxillary; Cephth., ceplalo-thorax ; Troch, trochanter ; Tars., tarsus; Abd., abdomen; Bla, poison bladder; St., sting. From Kraepelin in "Das Tierreich."

great diversity of form and habits, most being of very small size. All are terrestrial, excepting one group of aquatic mites (Hydrachnids). They are often of a bright red color. The free-living species prey on smaller animals as well as dead organic substances. Others are parasitic in animals or plants, living in fur or feathers (Fig. 121), and 


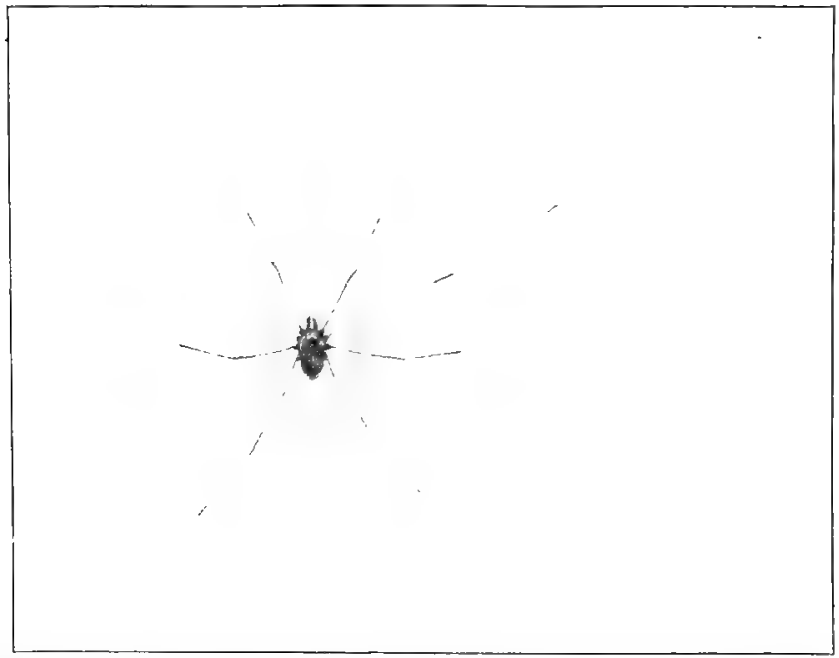

FIG. 120. - Liobunum dorsatum, one of the harvestmen. The long legs are apt to he thrown off in handling the living animal. The second left leg is accordingly absent in this specimen. Nat. size. Photo. by W. H. C. P.

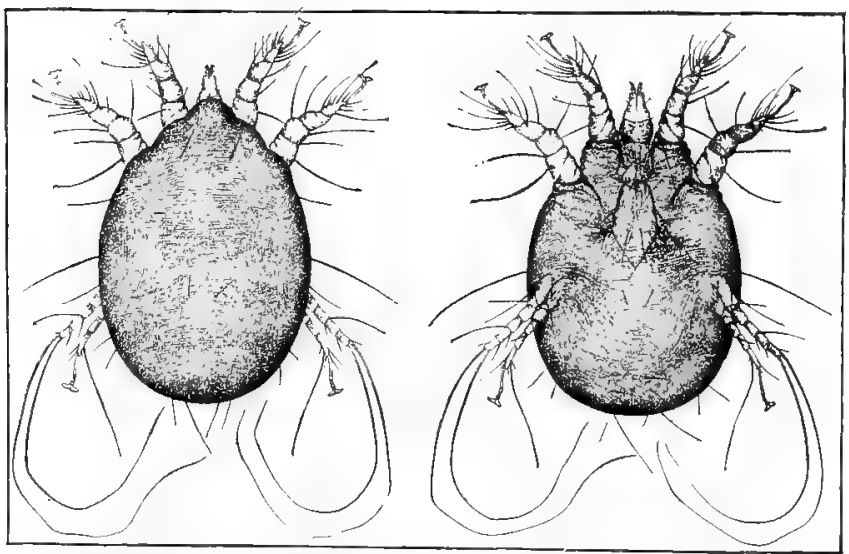

FIg. 121. - Psoroptes, the sheep scab, female. Right figure, dorsal view; left figure, ventral. Much enlarged. After Salmon, Bulletin 21, Bureau Animal Industry. 
even penetrating into the skin, as the small red "jigger" or " chigger" of our Southern States does.

Finally, there lives in the sea an aberrant family of spiders which crawl on the seabottom or over hydroids, and thus have forsaken a terrestrial life for a completely aquatic one (Fig. 122).

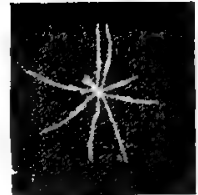

Fig. 122. - Pallene, a seaspider. $\times 1.5$. Photo. living by W.H.C.P. 


\section{CHAPTER VIII}

\section{THE ANATOMY AND PHYSIOLOGY OF CRUSTACEA: THE LOBSTER}

General Form of the Lobster. - The lobster closely resembles the crayfish (Fig. 123) except it is much larger. Like the cockroach it is approximately bilaterally symmetrical and is segmented. We may distinguish in the body the trunk and the appendages. The trunk is divided into two main regions : the abdomen and a united head and thorax (cephalothorax). The segments of the abdomen are distinct like those of the cricket, but unlike the latter each segment bears a pair of appendages. There are seven segments in the abdomen of the lobster. Since the segments of the cephalothorax are not distinct, they cannot be counted directly, but by assuming that each pair of appendages corresponds to a segment, as in the case of the abdomen, the number of cephalothoracic segments is estimated to be thirteen.

The appendages of the body show a diversity of form in accordance with the various kinds of work they have to do. At the front of the head are the two pairs of long organs of touch - antenns; then come the stout crushing jaws (mandibles); next are five pairs of appendages concerned in holding the food while it is being devoured. Then follow five pairs of walking

* appendages and, on the ahdomen, a number of pairs of flappers (swimmerets), the series terminating in the great tail flappers. As can he inferred from the structure of the appendages the lobster can both walk over the rocks at the edge of the sea or 


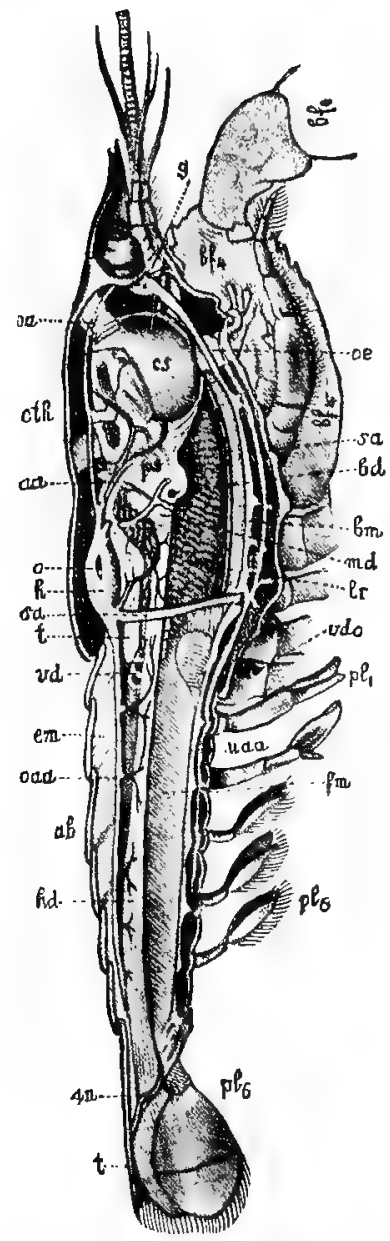

Fra. 123. - Median longitudinal section through the European crayfish showing parts of body appendages and internal organs. aa, artery to antenna; $a b$, abdomen; $a n$, anus; $b d$, bile duct ; $b f_{4}$, great claw ; $b m$, ventral nerve; $\mathrm{cs}$, stomach ; eth, eephalothorax; em, muscles of back; $\mathrm{fm}$, muscles of ventral side; $g$, brain; $h$, heart ; $h d$, large intestine ; $l r$, liver; $m d$, small intestine; $o$, opening in heart ; $o a$, artery to eye ; oaa, dorsal artery to ahdomen ; $o e$, gullet ; $p l, 1-5$, swimmerets ; $p l_{6}$, tail ; $p s$, hinder part of stomach ; $s a$, artery along sternum; $t$, testis (also tail) : $u a a$, artery to abdomen; $v d$, duct from testis ; vdo, outer opening of duct. 
in shallow water, or it can swim free in the water. By suddenly striking the tail fin forward the lobster can dart backward, trailing the great claws in the wake. The strokes of the powerful tail also tencls to roil the mud of the bottom and thus to hide the retreat of the animal. Although the body is encased in a cuticula of great thickness and firmness, yet the presence of thin-skinned joints makes not only the abdomen but also the largest of the appendages capable of complex movements.

Organs and Functions of Nutrition. - The lobster feeds principally upon fish, either dead or alive, upon various other crustacea and mollusks, and also upon marine plants. The food, held in place by the mouth-parts, is triturated by the jaws and passes by a short gullet into the stomach. ${ }^{1}$ The outer cuticula is turned in at the mouth and lines not only the gullet but also the stomach. In the tomach it is thickened and hardened in three points to form "teeth" which, in the muscular movements of the stomach, clash together in such a way as to crush any larger particles that have escaped the mincing of the jaws. Digestion takes place in the succeeding part of the foor canal which runs nearly straight to the last segment of the body. A great glanel (liver) secretes the digestive juices and empties them at the heginning of the intestine. Beyond the opening of the gland the absorption of the digested food takes place through the wall of the canal.

Organs and Functions of Respiration. - Oving to the fact that the lobster lives in the water from which it takes its oxygen, the respiratory organs are outgrowths of the body instead of internal tubes as in insects. Such outgrowths are called gills. Gills must have thin walls to allow of the passage of gases through them; they must he much branched to make 
as great a surface as possible for the passage of these gases, and they must be protected from injury, such as being bitten off by fishes. Consequently we find the gills of the lobster tufted and hidden under a fold of the skin - the carapace. From

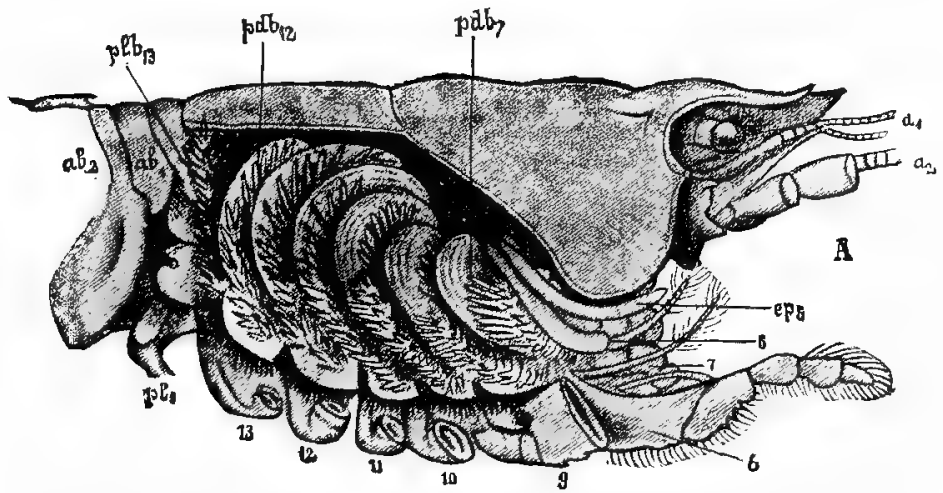

FIG. 124. - Respiratory organs of Astacus fluviatilis. The gill cover removed, and gills undisturbed. $a_{1}$, small antenua, $a_{2}$, large antenna ; $a b_{1}, a b_{2}$, first and second abdominal segment; $e p_{5}$, "scaphognathite"; $p l b$, "pleurobranch"; $p d b_{\bar{\tau}}, 12$, "podobranchs",; $p l_{1}$, first plropod ; 613 , thoracic appendages. From Lang, "Comparative Anatomy."

or near the base of each leg one to four gills arise and lie in the gill chamber. The water is pumped through this gill chamber by the motion of certain fanlike organs. Each gill contains a vessel carrying blood from the body to the gill (afferent) and one from the gills to the body (efferent). The total number of gills (Gk. branchia) varies with the species (Fig. 124). Usually one or two spring from the foot itself (podobranch); one or two from the joint (arthron) connecting foot to trunk (arthro-branch); and one from the side wall (pleuron) of the body (pleurobranch ${ }^{1}$ ).

1 Get a lobster or crayfish and see how many gills of each of these classes occur on each segment of the thorax (Fig. 125). 
Organs and Function of Circulation. - The circulatory organs of the lobster, as of the higher Crustacea in general, are

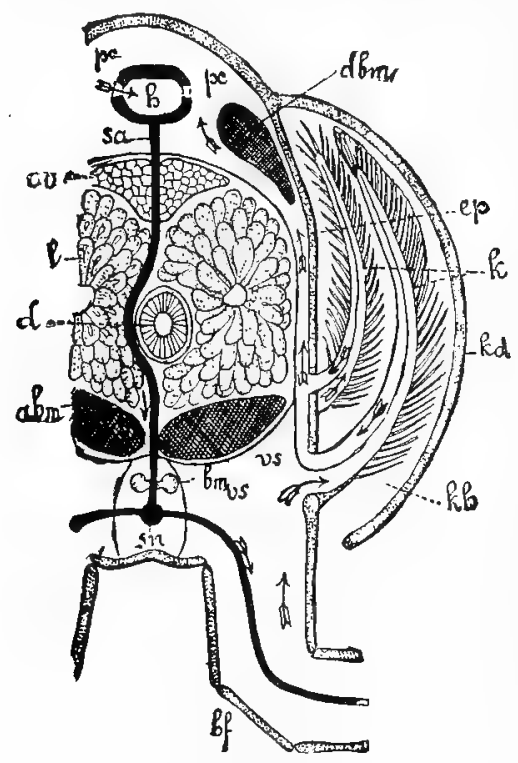

FIG. 125.-Cross section of thorax of Astacus fluviatilis of Europe, diagrammatic. $a b m$, ventral muscles of the abdomen; $b f$, leg; $b m$, main or ventral nerve cord; $d$, intestine; $d b m$, dorsal museles of abdomen; $e p$, wall of thorax; $o v$, ovary; $p c$, space around heart ; $s a$, $s n$, artery running along sternum; $v s$, ventral blood space. The arrows show the direction of blood flow. From Lang, "Comparative Anatomy." $h$, heart ; $k$, gills ; $k d$, gill cover ; $l$, liver ;

highly developed. The heart is a long, muscular tube lying in the dorsal part of the thorax. It is perforated by several pairs of lateral openings through which the body fluid passes from the surrounding body cavity into the heart. Thence it is forced downwards by a great artery to the ventral system, forward to the digestive glands, stomach, mouthparts, and eyes, and backwards to the muscles of the abdomen. The blood that enters these various organs oozes out into the general cavity of the body, streams into the gills, and is thence returned to the heart. Thus the heart and the tissues receive blood full of oxygen acquired in the gills. The blood of the lobster is not colored red like our "blood because it lacks the blood corpuscles that give our blood its color. Nevertheless the blood is able to absorb oxygen from the water and give it off again to the tissues. 
Excretion. - The elimination from the blood of the waste products of tissue changes takes place in a pair of organs lying at the base of the antennæ, and known as the green glands. Into these organs, which contain coiled tubules, the arteries enter and give up the waste products. These products accumulate in a bladder lying over the gland and from time to time pass out through a duct whose opening may be seen at the base of the great antennæ.

Reproductive Organs. - The sexes are separate in the lobster. The eggs are produced in a pair of great sacs which run along on top of the other viscera and are united by a connecting strand (Fig. 126). Each sac has its own duct to the exterior, and this opens at the base of the third pair of walking appendages. The sperm is formed in a pair of sacs resembling the ovary in general shape, but opening by a duct at the base of the last thoracic appendage.

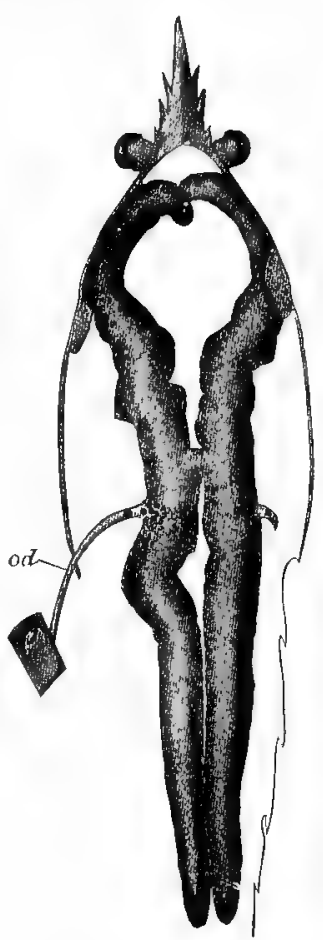

It will be noticed that excretory gland, FIa. 126. - View of ovaries oviduct, and sperm duct all open out at the base of appendages, and we shall see and oviduct $(o d)$ of American lobster, dorsal part of carapace removed. in studying the structure of ringed worms (" annelids") that nearly every segment has its duct. Consequently the three paired ducts of the lobster may be regarded as a rudiment of the condition found in ringed worms.

Musculature of the Lobster. - As the outer cuticula of the 


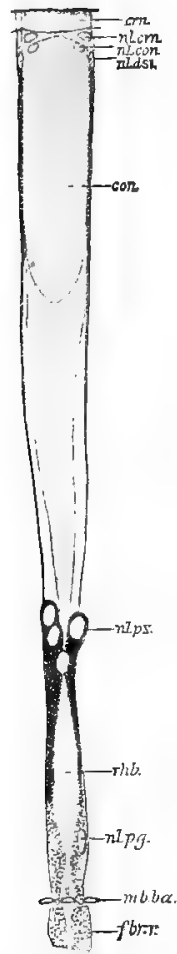

FIG. 127. - A single facet or elementary eye of the lobster. $c r n$, clear cuticula; nl.crn, nuclei of cuticula; con, cone cell ; nl.con, its nuclei ; $n l . d s t$, nuclei of outer pigment cells (retina) ; $n l p x$, nuclei of inner pigment cells; $r h b$, rod; $m b . b a$, membrane lying at base of rods; fbr.r, new fibre to pigment cells. G. H. Parker. lobster is very thick and strong it affords correspondingly powerful support for the well-developed musculature, for, as in the grasshopper so in the lobster, the muscles are attached to and pull upon the cuticula. The powerful muscles are able to make the strong strokes of the abdomen used in swimming. In the abdomen the dorsal muscles run longitudinally from the front edge of one segment to the front edge of the next. When they contract, the abdomen is straightened. The ventral muscles are very complicated. They run from one segment to the next and, as they are attached below the hinge of the segments, when they contract the abdomen is bent. The musculature of the appendages is well developed and complicated.

The nervous system is arranged essentially like that of the cricket. From the dorsal brain two nerves pass around the gullet forming the esophageal ring and then pass as a pair of nerves near to the ventral line as far as the hinder opening (anus) of the food canal. The two nerves are tied together by ganglia in most of the segments, and nerves are given off to the appendages, body muscles, viscera, and sense organs.

Of the sense organs touch seems to 
be located chiefly in the long antennæ which serve, like a blind man's cane, to inform the creature of what lies some distance in front of him. The location of the chemical sense seems to be in the smaller antennæ. The eyes are well developed and are placed on long stalks capable of a certain degree of rotation and of retraction out of danger. The
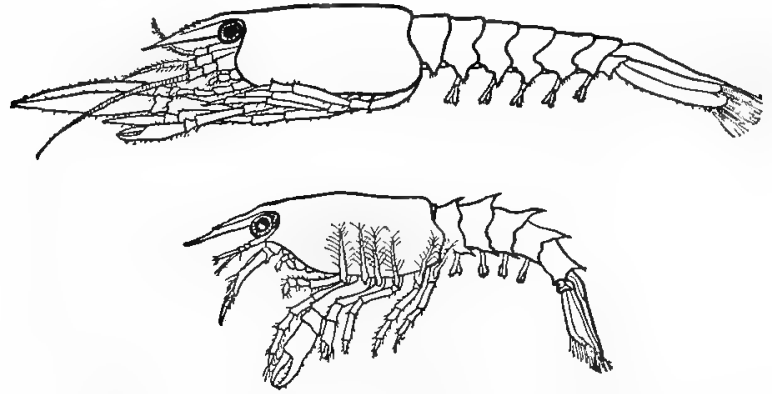

FIG. 128. - Upper figure, young Iobster with otocyst in place showing normal behavior. Lower figure, the same with otocyst removed; keeps upright with difficulty. From Loeb.

eye is compound like that of the cricket, and as many partial images are formed on the sensitive part of the eye — retina - as there are facets or elemental eyes (Fig. 127). There seems to be no true sense of hearing in the lobster; but it has a special organ of equilibrium and apparently a keen sense of position. This organ is the otocyst and is located in the basal joint of the smaller antennæ. The young of the lobster does not have an active otocyst (Fig. 128). The animal tends to roll from side to side except as the hanging appendages aid in keeping it stable. At a later stage its otocyst becomes active, and then the larva keeps its appendages stretched out in front and swims without rolling over. The otocyst is the chief organ that enables it to tell when it is right side up. 


\section{CHAPTER IX}

\section{THE CRAYFISH: A STUDY IN GEOGRAPHICAL DISTRIBUTION}

Every animal is adjusted to particular conditions of temperature, moisture, light, contact, food, and other factors of environment. These adjustments determine, as has been abundantly illustrated in the preceding chapters, the exact situation an animal shall occupy. The situation is known as its habitat. The number of different kinds of halitats is very great. They may, however, he grouped into certain large classes, so that we may distinguish marine animals, freshwater animals, terrestrial animals, subterrestrial animals, aerial animals, and so on. A particular species lives normally in one of these classes of habitats, and its distribution on the earth is limited by the bound s of its habitat. Thus the distribution of the brook trout follows branching lines on the map because the streams themselves do so. There are very few animals, either in the sea or on the land, whose distribution is ubiquitous, just because their suitable habitats are widely separated.

But not all of the similar habitats all over the whole world are occupied by a single species adapted to such a habitat. The trout of the brooks of one continent are not exactly the same as those of another continent. We find rather, in widely separated areas, different species which occupy precisely the same kinds of habitats. Consequently the traveller who journeys from his native land to a foreign country meets there 
a collection of strange animals. The American leaves behind him such wild animals of the woodland as the Virginia deer, the skunk, the woodchuck, porcupine, and opossum, and, if he goes to Europe, may see instead the roebuck, the polecat, and the hedgehog, but no representative of the group to which the opossum belongs. If he goes to Africa, his familiar forms will be replaced by still stranger oncs. Instead of the deer he will meet with antelopes and a lot of new groups represented by the elephant, rhinoceros, and hippopotamus. If he journeys to Australia, he will find that practically all the wild animals belong to the same group as does our opossum. The deer are there represented by kangaroos and the porcupine by the wombats. This dissimilarity even of the land quadrupeds in different parts of the globe has made it possible to divide the land into certain life-regions. Thus we have the North American; the Eurasian (i.e. Europe + northern and central Asia); the Oriental, south of the Himalayas; the Ethiopian, including that part of Africa south of the Sahara; the South American which stretches north into Mexico, and, finally, the Australian (Fig. 129).

These different life-regions are land areas more or less completely separated from each other by barriers of some kind, such as water, mountain chains, vast desert tracts, or sudden changes of temperature. In each of these isolated regions a peculiar and characteristic collection of animals, known as its fauna, has come to develop. The faunas of some of these regions are more closely interrelated than those of others, and this interrelation often gives an important clew to land connections in former geologic times. Thus the North American animals are much more closely related to those of Eurasia than are the African. This similarity of animal forms speaks for a former 
land connection between Europe and America by Behring's Strait or by the way of Greenland.

The comparison of the animals of a new country in which one may be journeying with those of one's native land gives

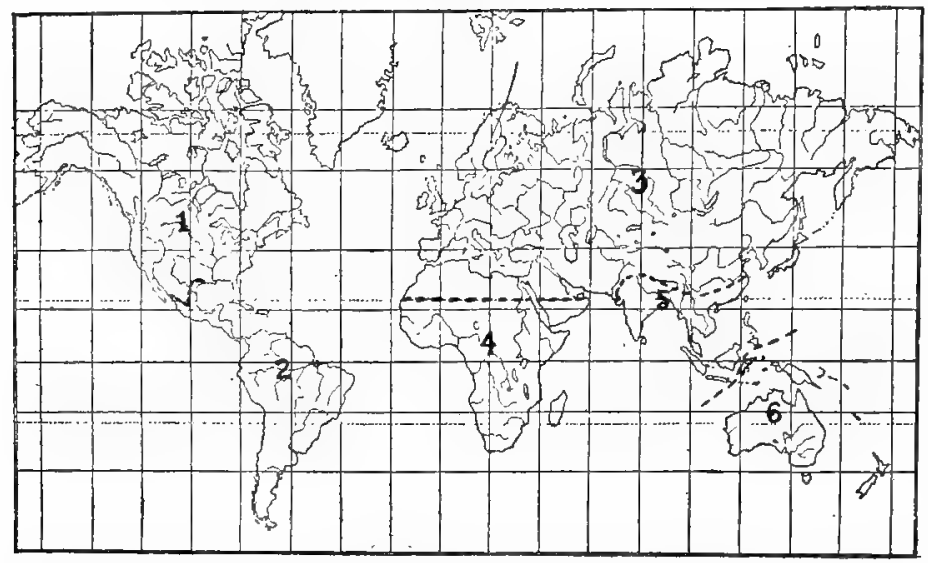

Fig. 129. - The zoological regions of the globe. 1, North American; 2, South American; 3, Eurasian; 4, Ethiopian; 5, Oriental ; 6, Australian.

the keenest zest to travel. We see, therefore, how important it is to be acquainted with the native fauna of our own country.

As a specific example of geographical distribution the crayfish ${ }^{\mathrm{I}}$ may be considered. This animal, which is closely related to the marine lohster, ${ }^{2}$ is an inhabitant of fresh-water lakes, rivers, and pools. It thrives in diverse surroundings; for

1 The old English spelling of this word was "crevis" or "crevice." The cre came to be spelled phonetically cray, while vis became changed to fish in accordance with the popular nomenclature of all aquatic animals.

${ }^{2}$ The English word "lobster" is from the old English lopystre, which is prohably mrrupted from the Latin locusta, by which term Pliny refers to the lobster. 
some species prefer cool mountain streams and others muddy pools, while certain species, both in Europe and America, are found in brackish as well as fresh water. Indeed, the European Astacus fluviatilus is said to be frequently caught off the Livonian coast, even some distance out at sea. Individuals of an American species have been taken from a mineral spring impregnated with sulphur and magnesia at a temperature of $70^{\circ} \mathrm{F}$. $\left(21^{\circ} \mathrm{C}\right.$.), while several kinds of the American "burrowing" or "chimney"-forming species have been found in meadows and clay bottoms, often at great distances from streams. Certain species that are blind inhahit caves only. In England, according to Huxley, "in granite districts, and others in which the soil yields little or no calcareous matters to the water which flows over it, crayfishes do not occur. They are intolerant of great heat or of much sunshine; hence they are most abundant in those parts of rivers which flow east and west, and thus yield the most shade from the midday sun."

There are two great groups of subfamilies of crayfishes. One, restricted to the Northern Hemisphere, is found in Europe, Asia, and North America. The other is found in the Southern Hemisphere, in Australia, Tasmania, New Zealand, Fiji Islands, Madagascar, and South America. No crayfishes have been found on the continent of Africa or in the rivers of northern Asia that flow into the Arctic Ocean, or in those of southern Asia. These Asiatic rivers are populated by fluviatile crabs, to which the crayfishes of the region have probably succumbed. All the islands now inhabited by crayfishes, such as England and Japan (excepting Cuba), were probably once connected with the mainland (Fig. 130).

The northern subfamily of crayfishes contains, according 
to Faxon, two genera - As'tacus and Cam'barus - of which the latter can be subdivided into the subgenera Cambarus and Cambaroicles. These groups occupy distinct geographical areas. The genus Astacus is found, in the Old World, in Europe anrl western Asia as far south as the Aral and Caspian seas, and in America in the region west of the Rocky Moun-

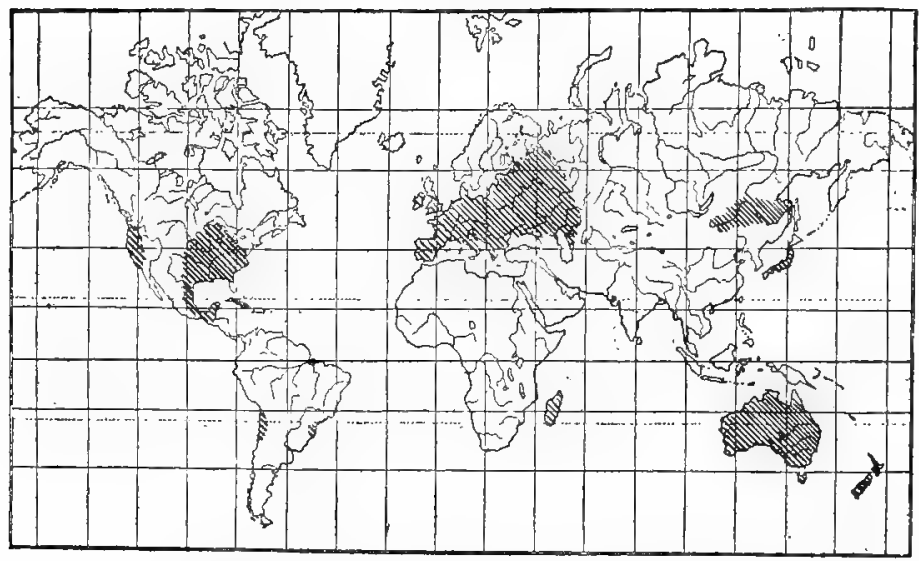

FIG. 130. - The distribution of crayfishes. The shaded areas are inhabited by various genera as described in the text.

tains, draining into the Great Salt Lake and the Pacific Ocean. It is thus seen to occupy the western sides of the two northern continents. Likerwise Cambarus and Cambaroides occupy the two eastern coasts of the northern continents; for Cambarus is found in North Ameriea east of the Rocky Mountains in the region bounded on the north by Lake Wimnipeg and New Brunswick and on the south by Cuatemala and Cuba, while Cambaroides is limited to the Amoor River basin in Asia, and to Japan.

We thus find among the crayfishes what is known as dis- 
continuous genera; that is, genera which now occupy widely separated areas, like Astacus in Europe and Pacific North America, but which once ranged over the intervening regions as well. From some cause, the struggle for existence became too severe in the intervening regions, so that Astacus and Cambarus were annihilated on the eastern and western sides of the continents respectively. In southern Asia we find that the struggle was doubtless with the successful river-crab. It is interesting to note that, probably on account of the preserving influence of climate, the other animals and the plants of the eastern sides of the two continents and those of the western sides are more alike than those from opposite sides of the same continent. One of the best pieces of evidence for the conclusion of a former hemispherical distribution of the two genera of crayfishes is that there occur in the caves of Carniola in southern Austria crayfishes ${ }^{1}$ belonging to the genus Cambarus; - the only known living representatives of this type in Europe. The mere fact that it lives in a cave is not sufficient to make the crayfish Carniola of a Cambarus, for in North America the genus has certainly not originated under the influence of subterranean life; it is more likely that the caves of Carniola have protected these crayfish from the widespread destruction which has overwhelmed their fellows outside.

Only one crayfish, Cambarus bartonii, is found in New England, and here only in the rivers of Maine, Vermont, and central and western Massachusetts. The conmon species of the Middle States is C. affinis. C. diogenes and C. immunis are common burrowing species of the Central States. C. pellucides is the blind species found in Mammoth and Wyandotte caves.

The food of the crayfish is very varied; it may be living or

${ }^{1}$ These crayfishes are blind, like the cave-inhahiting Camlarus of America. 
dead, animal or plant. On account of the need of calcareous matters in the food, crayfishes are especially fond of the stoneworts (Chara) and virious succulent roots, like the carrot. It is said that crayfishes sometimes make excursions inland in search of plant food. They likewise devour shells of snails, their own cast-off skins, and occasionally one another, shell and all.

The crayfish belongs to the class of Crustacea, since it breathes by means of gills, possesses two pairs of antemn, a pair of mandibles bearing palps, and a pair of appendages on all body segments excepting the last. The Crustacea are divided into two subclasses, -- Entomos'traca, of which Daphnia is an example, and Malacos'traca, to which the crayfish belongs. All the Malacostraca ${ }^{1}$ have nineteen pairs of appendages.

The lobster (Homa'rus) is, as we have alrearly scen, the nearest living salt-water relative of the crayfish. There are only two species of the genus Homarus. One, Homarus americanus, occurs on our Atlantic coast; the other, H. vulgaris, is the lohster of Europe. On our Pacific coast there is the "spiny lobster," but this is not closely related to the Eastern lohster (Fig. 131). The national government has transplanted the Atlantic lohster to several localities on the Pacific coast, but it is not yet known whether it will thrive there. The American lobster ranges from Labrador to Delaware Bay, and from near shore to a depth of 100 fathoms. It attains its greatest size on the rocky shores in the cooler waters from Maine to Labrador. It migrates but little along the coast; in the fall, however, it moves out into deep water, and in the

I From malakos, soft, ostration, shell; sine the shell is less hard than that of mollusks. 
spring back again into the shallower bays; the time of migration depending upon the length of the season. It is saicl to be a nocturnal animal, searching most actively for its food at

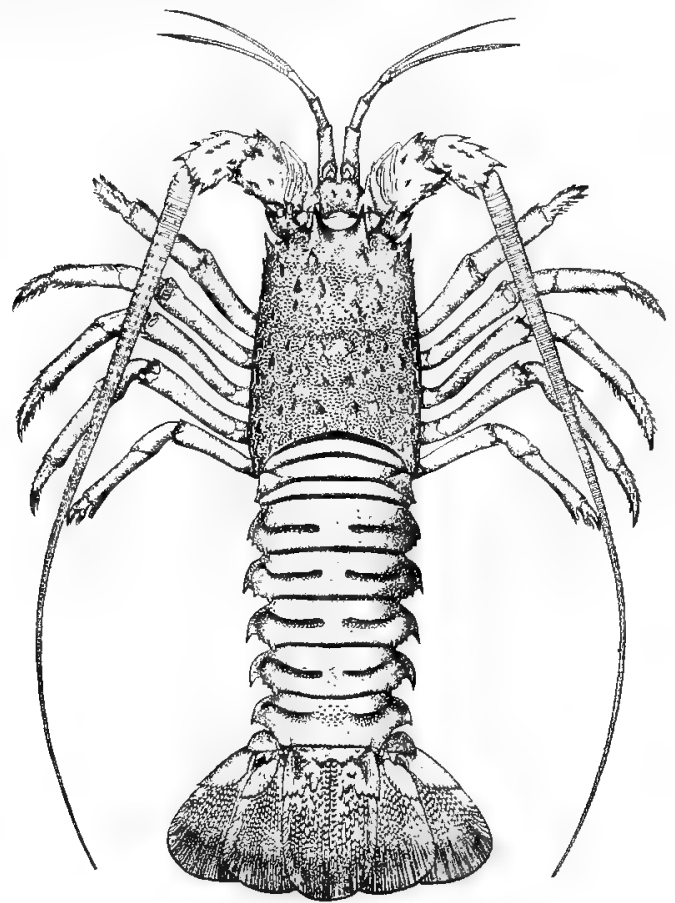

Fra. 131. - Palinurus, the spiny lobster. One-fourth nat. size. From Rathbun; drawn by $\mathrm{H}$. L. Todd.

night. The sense which probably aids it most in this search is the chemiral one, as the attraction of the bait in the traps the so-called lobster-pots - testifies. In respect to food it is, like the crayfish, omnivorous.

Protection of the Lobster. - There has been much difference of opinion in regard to the size at which a lobster 
becomes mature and before which, therefore, it cannot be caught without danger of extermination. The legislation on the matter has accordingly been very varied. In Connecticut the law makes the limit six inches, while in Massachusetts and New York it is placed at ten and one half inches. Herrick has carefully investigated the relation of length to maturity, and concludes that, on the Massachusetts coast at least, the lobster becomes mature between the limits of eight and twelve inches, and hence that all present legislative protection is insufficient. The rarity of large lobsters in our markets testifies to the correctness of this conclusion.

Enemies of the Lobster. - Besides its worst enemy, man, both the adult (particularly the egg-bearing female, called by fishermen the "berry lobster" or "berry hen") and young lobsters are attacked by many kinds of fish. Two or three internal parasites are known to infest the lobster, while sometimes it is greatly hampered in its movements by the number of messmates it carries about attached to its shell. Barnacles, mussels, tube-forming worms, and various sea weeds are all found at times attached to the shell of the lobster. Upon molting, however, the animal is enahled to rid itself of all these hangers-on; but this process is attencled with great dangers to the lobster, since the animal is, during molting, so soft hodied as to be able to offer little resistance to its enemies.

The molting process in the lobster and crayfish is accomplished in the following manner: previous to the throwing off of the old skin a new soft one is formed inside, the lime is absorbed from the old shell in a dorsal line along the carapace, reaching from the rostrum to its posterior margin. Absorption also takes place at the joints of the limbs. Such absorptions give a greater flexi- 
bility to the shell, which is useful in the act of molting. When the lobster has attained this st uge, it is dark in color, and known by fishermen as the "black lobster." The soft cuticula now breaks transversely immediately behind the carapace, the blood leaves the limbs, which are thus made flabbier, and by involuntary muscular movements they are drawn, large claw and all, through the joints of the old shell. The anterior portion of the body is first drawn out through the break behind the earapace and, lastly, the tail. Not only is the entire outer covering cast off, but the lining of the esophagus, stomach, and intestine as well, since these organs are formed by an infolding of the skin. By means of the return of the blood to the limbs and rapid absorption of water, the body of the lobster soon swells to a size far beyond that of the old shell. There remains in the stomach, after molting, a calcareous nodule which has long been known by the name of "crab's-eye." These "crab'seyes" were formerly much sought after as "charms " against ill health. Their function was for a long time rather obscure. It is now believed that during the time of absorption of lime from the shell, previous to molting, the blood becomes strongly impregnated with lime. If all the lime that must be removed were to remain in the blood, it would prohably be fatal to the animal; hence it is taken up by secreting cells located in the wall of the stomach, and there deposited. After the old skin is cast, the gastrolith is soon ahsorbed, probably to aid in strengthening the new shell. Bits of water-worn shells, entire gastropod shells, parts of lobster coverings, spines of sea-urchins, etc., have been found in the stomachs of lobsters and crayfish, which likewise would probably have been dissolved and used in hardening the shell. 
Shrimps and prawns ${ }^{1}$ belong to a thin-skinned, long-tailed family of Crustacea. ${ }^{2}$ They are extremely common in bays along our coast, and even penetrate into rivers. Two river shrimps ${ }^{3}$ are found in the United States east of the Mississippi River. These Crustacea are alble to maintain their enormous numbers only by virtue of their great reproductive capacity, which is the more necessary since they furnish almost the entire food supply for many kinds of fishes and other foes.

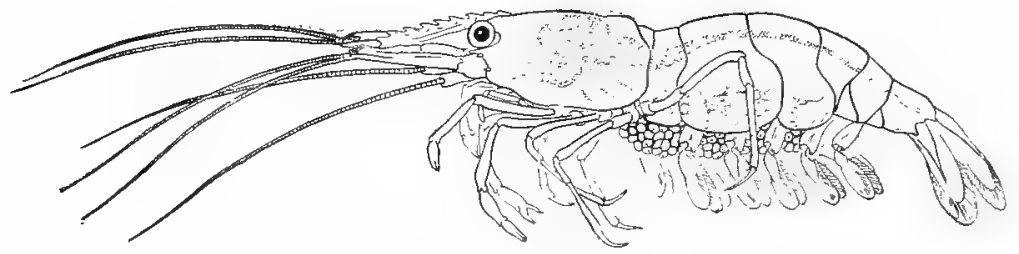

FIG. 132. - Palcemonetes vulgaris, a common shrimp.

Even in the principal shrimping grounds of the United States - such as San Francisco and New Orleans - there is said to be no diminution in the numbers of shrimps.

The burrowing shrimps (Thalassiniclix ${ }^{1}$ ) are crayfish-like species that hurrow in the mud flats of our coast. They remain concealed during the day. They are much smaller than crayfishes and are difficult to olstain, so they have no market value and are commonly little known.

The hermit-crabs (Pagurill $x^{5}$ ) occupy a position intermediate between the long and short tailed decapods in respect

${ }^{1}$ The term "shrimp" is applied to the smaller species, and "prawns" to the larger.

2 Fig. 132.

${ }^{3}$ Palcmon Ohionis and Paleomonetes exilipes.

${ }^{4}$ thalassinos, color of the sea.

${ }^{5}$ pagouros, a kind of cral). 
to the length of their abdomen. The abdomen is soft, and the young animal, which is at first free-living, protects it by inserting it within the coiled shell of some gastropod. The abdomen becomes unsymmetrical, heing coiled to one side to correspond with the shape of the borrowed house (Fig. 133). The abdominal feet become degenerate, with the exception of

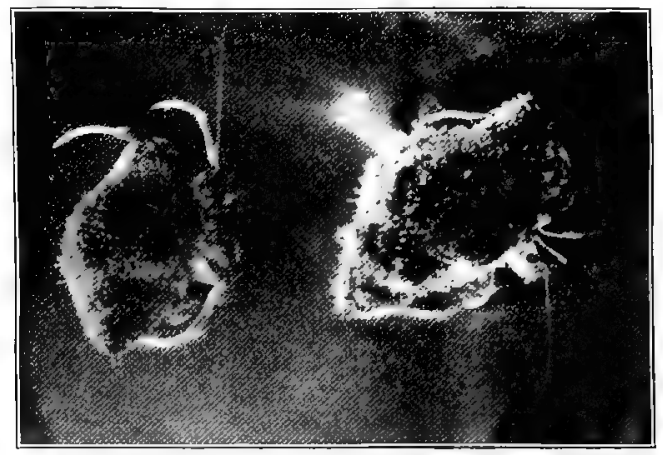

FIG. 133. - Eupagurus longicarpus. Two individuals in shells. Photo. while alive by W. H. C. P.

the posterior pair, which are each modified into a sort of hook, hy means of which the crab maintains itself securely in the shell. When one shell becomes too small, it is ahandoned for a larger one. Numerous species of hermit-crahs occur on our coast, ranging from the shore line to a depth of several hundred fathoms. Eupagurus longicarpus is the active little hermit found in almost any tide-pool from Massachusetts Bay to the Gulf of Mexico. Hydroids, polyps, sponges, often attach themselves to these borrowed shells (Fig. 133); indeed, one Chinese species always bears an anemone on its large claw, with which it plugs up the aperture when olliged to retreat within its shell. One of the East Indian hermit-crabs, the 
so-called palm-crab, feeds upon cocoanuts, which it opens by inserting its claws into the eyes and then breaking the shell upon the rocks.

The mole-crabs (Hippidæ ${ }^{1}$ ) include certain oval animals that burrow in sandy beaches, head first like a mole. The abdomen is partly turned under the body in a position some-

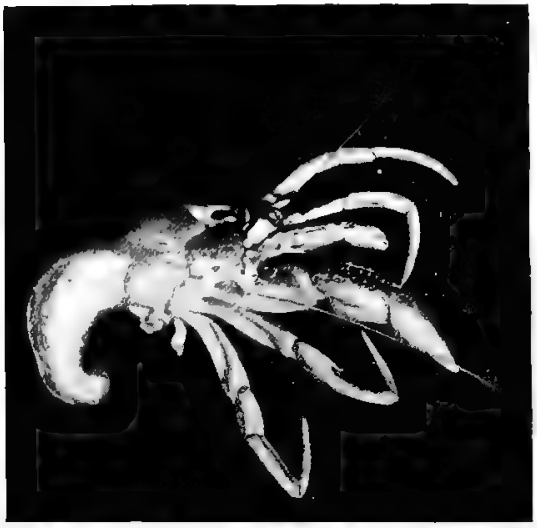

FIG. 134.-Eupagurus longicarpus removed from shell. $\quad \times 1 \frac{1}{2}$. Photo. by W. H. C. P.

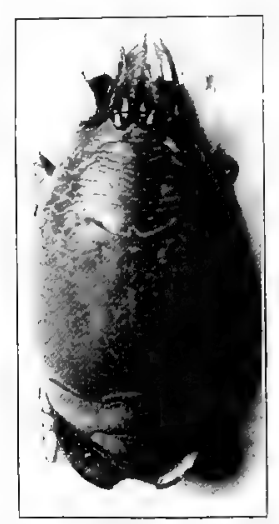

Fig. 135. - Hippa talpoides.

Nat. sizc. Photo. by W. H. C. P.

thing like that of the crabs. Therefore these animals make an interesting link between the long-tailed (Macrura) and shorttailed (Brachyura) crustaceans (Fig. 135).

The crabs (Brachyura) are represented on our shores by three principal families, which may be designated as triangular crabs, arched crabs, and square crabs.

The spider-crabs, or sea-spiders, as they are sometimes called, belong to the triangular crahs. As their name implies,

${ }^{1}$ From hippos, horse; used by Aristotle as the name of a kind of crab. 
their legs are very long and slender. ${ }^{1}$ These crabs frequent oyster-beds and sea-bottoms in general. When seen stalking over such uneven surfaces, the advantage of these stilt-like legs is at once evident. The surface of the body of some species of spider-crabs is hairy, entangling inorganic matter, while hydroids, barnacles, and algæ attach themselves to the shell, so that the crab, when quiet, is concealed by them, while

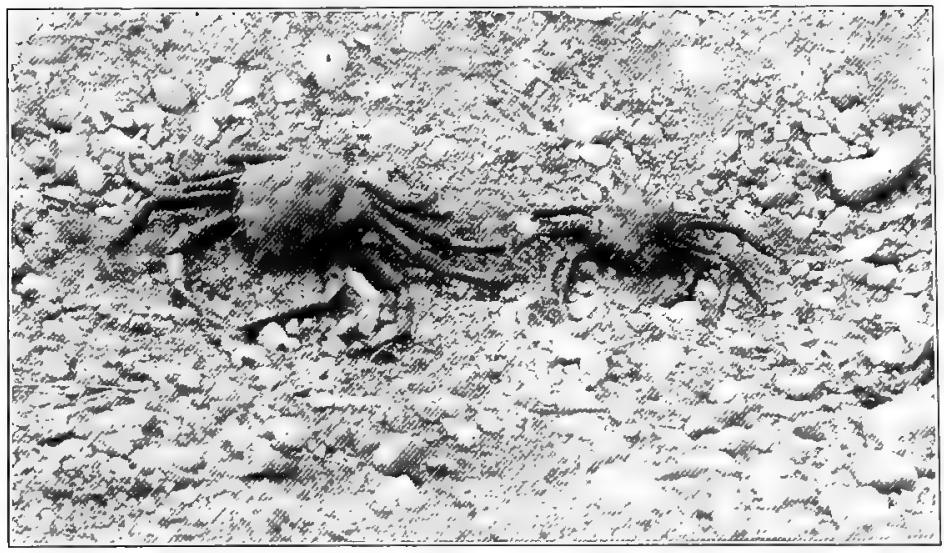

Frg. 136. - The smaller spider-crab, Libinia dubia. Two specimens lying on the beach.

these attached organisms, in turn, gain by their association with the crab most of the advantages of locomotion. Libin'ia du'bia (Fig. 136), which ranges from Cape Cod to the Gulf of Mexico, is the commonest of our species that undergo such concealment. The great Japanese spider-crab is said to be the largest of all the Crustacea, some individuals measuring, from tip to tip of the first pair of legs, 18 to 20 feet.

The edible crab is a typical arched crab. It is so called 
because the carapace is arched in front. The carapace is also broader than long, and narrower behind than in front. The

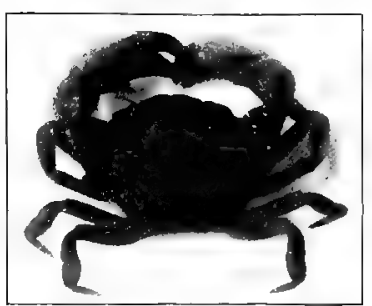

FIG. 137.-Panopeus sayi, allied to Cancer. The mudcrab. One-half nat. size. Photo. by W. H. C. P. legs of this family are short and broad, and in some species the posterior pair is especially broad - an adaptation for swimming. These crabs may be divided into two groups - the burrowing crabs and swimming crabs. To the burrowing crabs belongs the genus Cancer (Figs. 137, 138), which includes the edible crab of Europe, especially prized in England, together with several American species; while our common edible, soft-shelled or blue crab, Callinec'tes

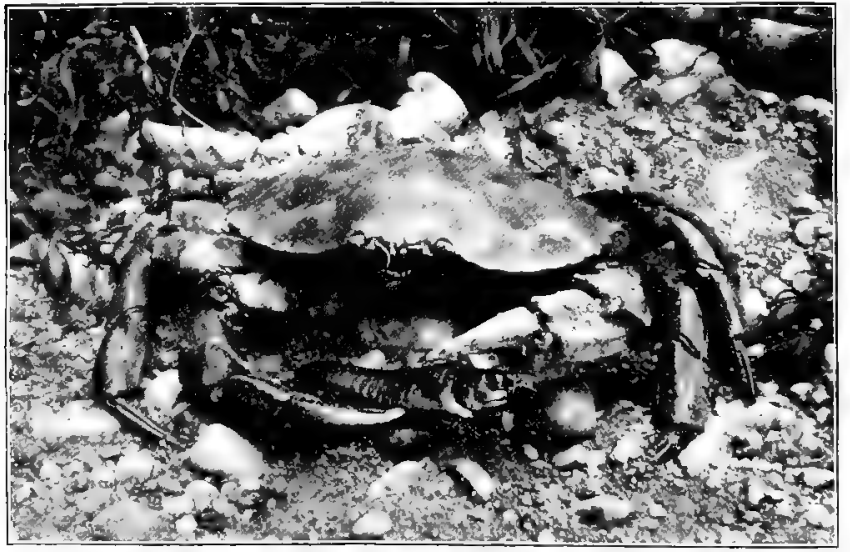

FIG. 138. - Cancer irroratus, the rock-crab. Reduced to one-third. Photo. by W. H. C. P.

hasta'tus of the East, and the beautiful "lady-crab" (Fig. 139), belong to the swimming group. Crabs of other families are, 
however, eaten in various localities and by various peoples. For example, our little oyster-crab (Fig. 140), found in the

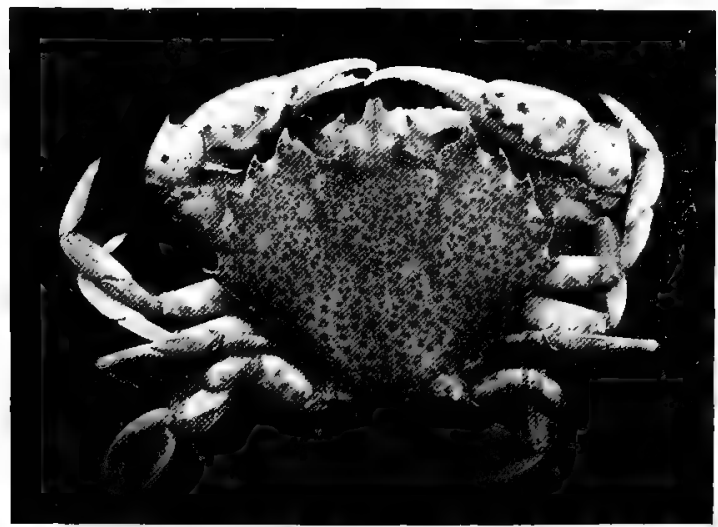

FIG. 139.-Platyonichus ocellatus, lady-erab. Reduced to one-third. Photo. by W. H. C. P.

mantle chamber of the oyster, is eaten by us together with the oyster or separately.

The fiddler-crabs are representative of the square crabs. These are the familiar animals which crowd salt-marshes and run sideways to and from their burrows (Fig. 141). One claw is much larger than the other. When the crab is disturbed, the large claw is brandished in a manner which has been likened to the movements of a fiddle

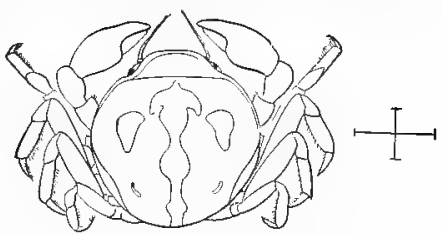

FIG. 140. - Pinnotheres ostreum. $\times 4$. From Rathbun.

as one plays upon it. Gelasi'mus pug'nax is the most abundant species, and ranges from Cape Cod to the Gulf of Mexico. Together with Cambarus it does much damage by burrowing in the levees of the Mississippi River (Fig. 142). 
There remain to be considered a number of orders of the higher crustacea (Mal'acostraca) other than decapods. The

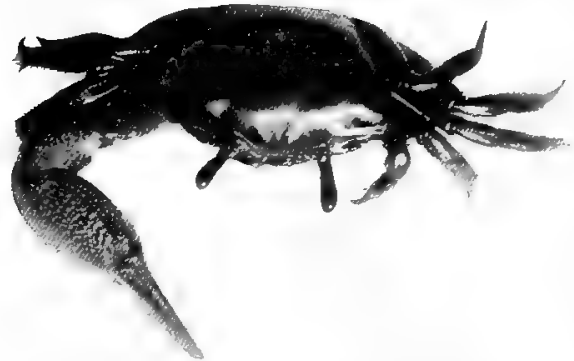

FIG. 141. - Gelasimus pugnax. Nat. size. Fronto-dorsal view. Photo. by W. H. C. P. is a little longer than a crayfish. Being hard to catch, it is not much used as

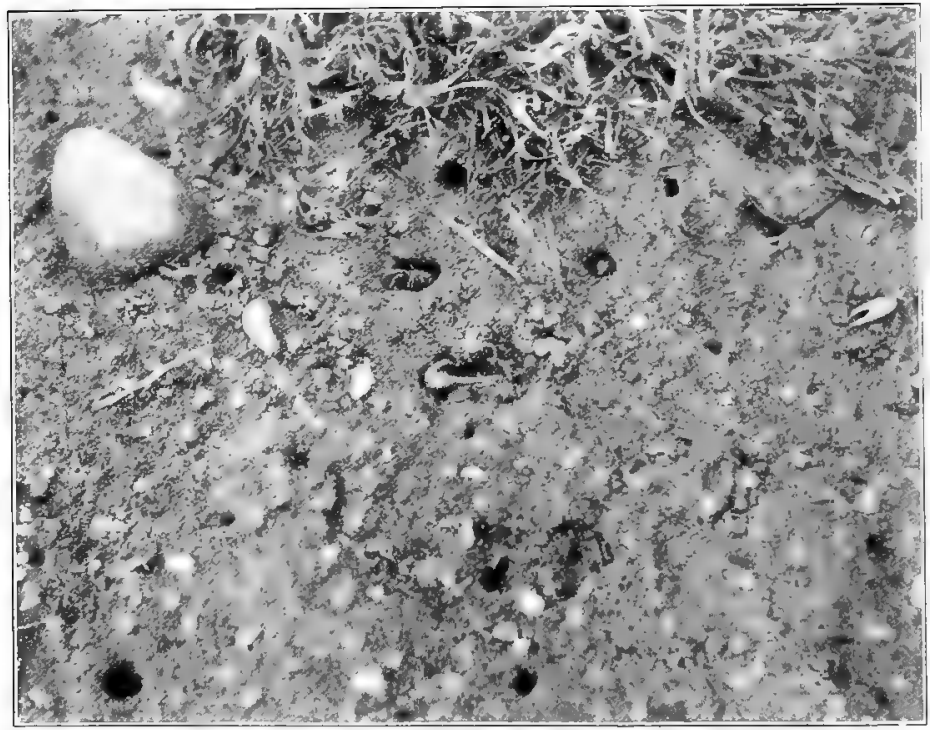

FIG. 142. - Fiddler-crabs and their burrows. The method of exposing the large claw at the opening of the burrow is shown. 
food. The Isopoda ${ }^{1}$ include certain marine and fresh-water groups, and the sow-bugs or wood-lice (Fig. 144), noteworthy as the largest group of land Crustacea. The Amphipoda ${ }^{2}$ are exclusively aquatic creatures, found under decaying vegetation on beaches of lakes or the sea (Fig. 145), and crawling amidst marine hydroids. Being laterally compressed, the Amphipods tend to lie on one side when at rest.

The economic importance of the decapods may be inferred from the fact that the receipts for the Atlantic lobsters taken and sold by United States fishermen was estimated for the year 1901 at $\$ 1,400,000$.

Formerly the American lobster

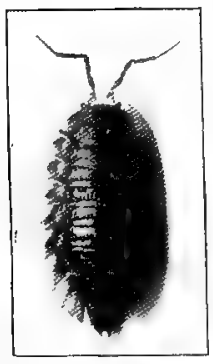

FIG. 144. Oniscus, the sowhug. Dorsal view. Nat. size. Photo. by W. H. C. P. was more numerous and attained greater size than now, but excessive fishing has so depleted the supply that the lolster

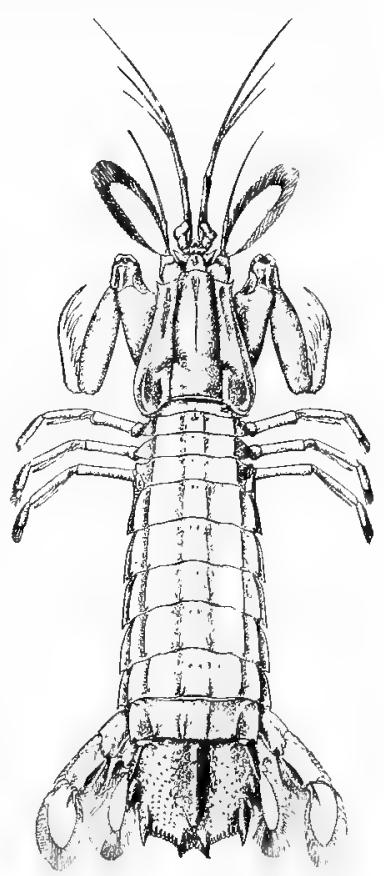

Fig. 143. - Squilla empusa, the mantis shrimp. Dorsal aspect. From Rathbun. is in danger of extermination. In Europe the so-called Norwegian lobster is much used as food, while on our Californian coast the so-called spiny lobster or sea-crayfish takes the place of our true Atlantic lobster and, like the latter, is said to be in danger of extermination on 1 isos, equal ; pous, foot. ${ }^{2}$ amphi, both; pous, foot. 
account of overfishing. The crayfish is not as much used for food in America as in Europe. In Paris it is so much esteemed that the enormous crayfish farms throughout France are uuable to supply that city; consequently crayfishes are

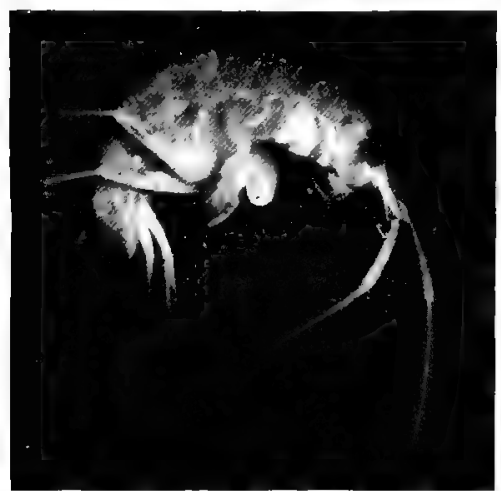

FIG. 145. - Talorchestia longicornis, the beach flea. Nat. size. Photo. by W. H. C. P. imported from Germany. In America, it is our French population mainly that makes a market for the crayfish.

Of the crabs which reach our market the most important is the blue crab. These crabs are kept moored in floating boxes until they have molted, and then they are sent to market as softshelled crabs. The value of the blue-crab fisheries on the Atlantic and Gulf coasts was almost half a million dollars. The shore-crabs (Cancer) are little eaten in the United States.' The shrimps and prawns have within recent years begun to appear in large numbers in the Eastern markets. For many years the Pacific species have been dried and shipped by the Chinese in large quantities to China.

Development of Lobsters. - Lobsters lay eggs in July and August. In the fall they migrate to deep water, and pass the

IVery unfortunate is the destruction of the "king-crah" (Limulus), which is only distantly related to the Decapoda. In Delaware Bay they are caught in great numbers and ground up as fertilizer. As they are taken only during the breeding season, they are bring rupidly exterminated. The American Limulus helongs to an order entirely unrepresented on the European coast (Fig. 146). 
winter there. In the spring they migrate back to the shore the female tarrying behind the male until the eggs of last summer, which she still carries attached to her swimmerets, shall be further grown. In June the young hatch out, molt,

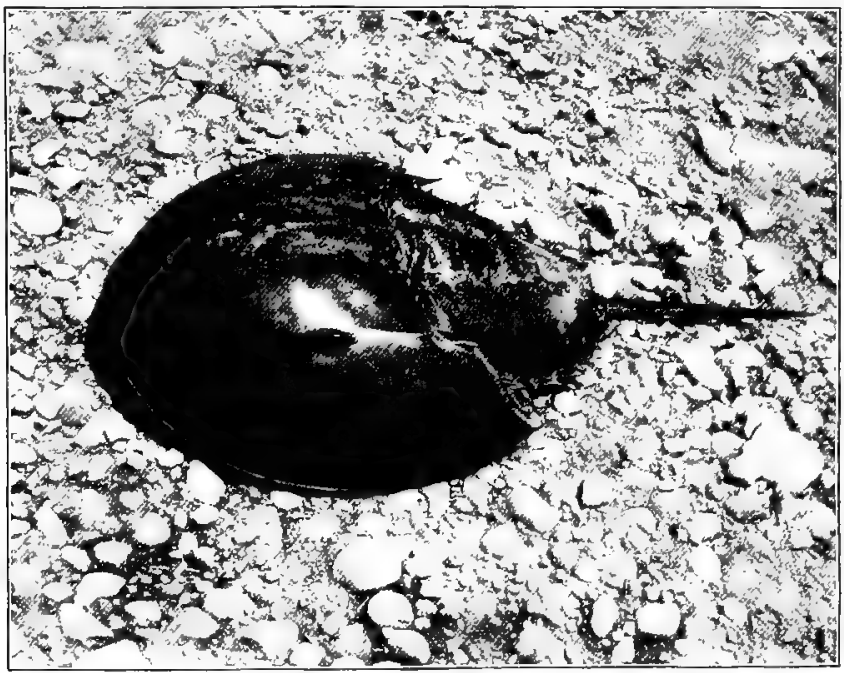

FIG. 146. - Limulus polyphemus, the king-crab or horseshoe-crab.

and swim to the surface. The female now molts, but does not spawn again for a whole year; that is, she spawns in alternate years. The number of eggs carried varies with the age of the female; middle-aged lobsters may carry up to one hundred thousand eggs, but the old or young ones as few as three thousand. The egg as freshly laid is about 1.5 millimetres in diameter and is stored with food material, called yolk, much as in the case of the hen's egg. As in the chick, the development takes place, as it were, on top of the egg (Figs. 147, 148). Eyes and mouth appendages early make 
their appearance; then the other appendages, and the tail (Fig. 149). For a long time the back of the thorax is greatly distended by the yolk stored there, and the eyes are huge (Fig. 150). During the early moltings (Fig. 151) the young lobsters undergo a terrible mortality, so that out of ten thousand embryos hardly two, on the average, survive. After the fifth

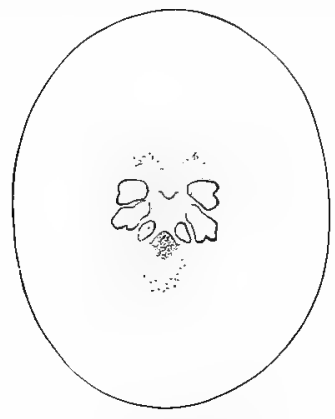

FIG. 147. - An early stage of development of egg of thelubster. Appendages hecoming bifid. Paired dotted areas above indicate eyes; these are followed by the first three paired appendages; antennules, antennæ, and mandibles. Below in the middle line is the forming tail ; above is the mouth. After Herrick.

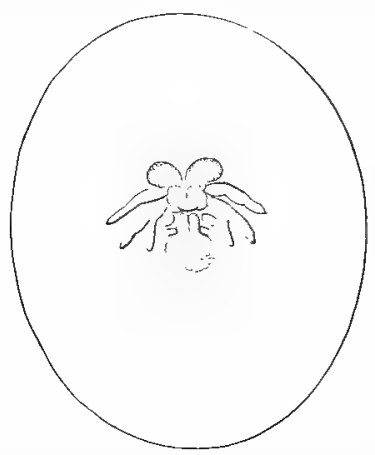

Fig. 148. - Surface view of egg nauphius. Antenuæ show beginning of segmentation; mandibles and maxilla seen on each side of the abdomen. Embryo 1618 days old. $\times 25$. From Herrick.

or sixth molt the little lobsters sink to the bottom, and then begin their journey shoreward. From this time until they are about four inches long, only very few individuals have ever been seen. This is due, it is said, to the fact that they hide deep down among the rocks, where they cannot be dredged. When they are four inches Iong or so, they become bolder, leave the rocks, and, like the adults, make burrows for themselves in the sand or uncler stones.

Development of Crayfish. - The crayfish develops simi- 
larly to the lobster, - from a large egg filled with yolk. The early stages are much like those of the lobster; but those changes which in the lohster take place cluring the first three stages of free life are in the crayfish passed in the egg. Consequently at the time the crayfish hatches it is almost, but not exactly, like an adult crayfish except in size. The tail-

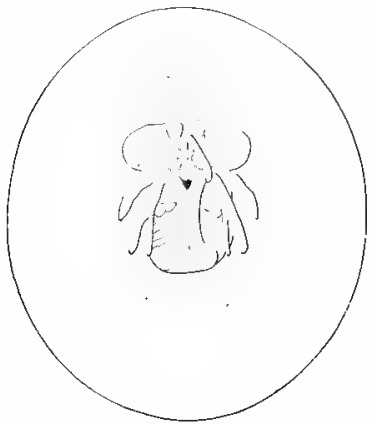

FIG. 149. - Surface view of embryo with all of thoracic appendages formed. The forked telson partly overlies the brain. Note the large eyes, which are yet without pigment. Embryo about 21 days old. $\times 25$. From Herrick.

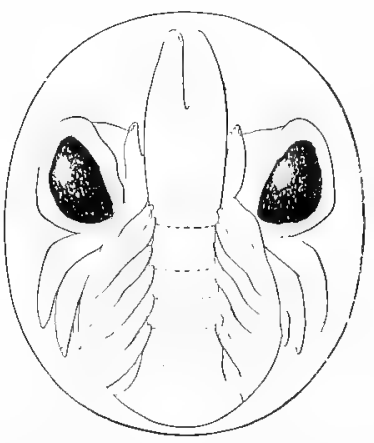

FIG. 150. - Lobster embryo. 61 days old ; eyes have developed pigment. $\times 15$. From Herrick.

fin of the just-hatched crayfish has, to be precise, a somewhat more oval form, and the first pair of swimmerets are undeveloped; but these differences soon disappear.

Regeneration of Lost Parts. - If you attempt to pick up a crab by one of its claws, you frequently find yourself in possession of a portion of the leg only, while the crustacean has made good its escape. Moreover, it will be seen that the leg always separates at a certain place; namely, between the second and third segments. This is the place where a fusion 
occurs between two segments which are free in the first larval stage. This power of protective mutilation occurs in those appendages which are most apt to be seized, - namely, the five thoracic legs, - and is wholly under the control of the reflex nervous system, for it may occur when the entire voluntary nervous system has been removed. The leg of a dead

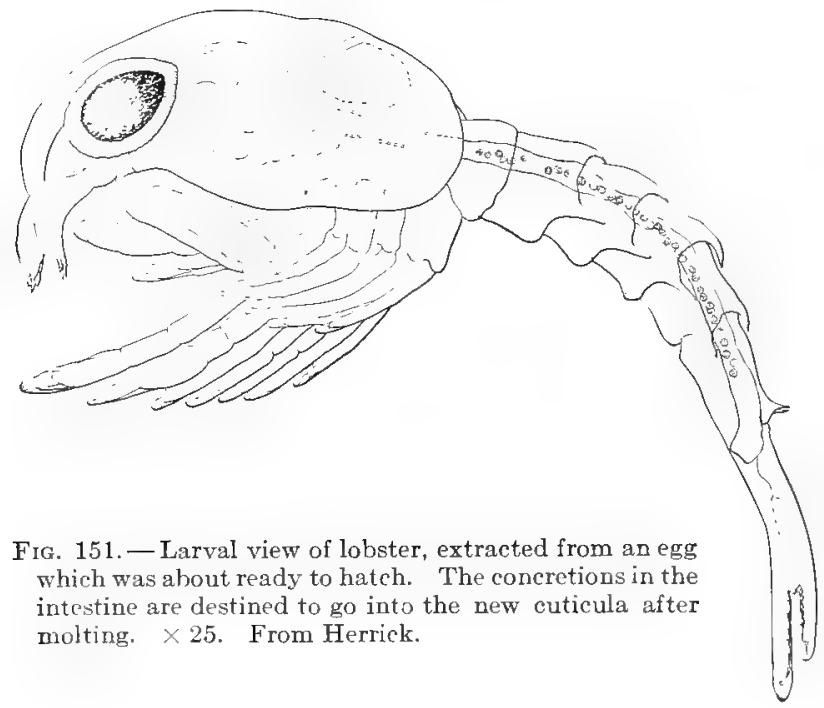

crustacean shows no such capacity. If the leg of a lobster is cut off at some point beyond that of normal rupture, the limb will later be found cast off up to this point. Here a sort of double membrane or diaphragm exists, with a central opening only large enough to admit the passage of nerves and bloodvessels. Upon rupture this passage is soon plugged up by coagulated blood - clearly a device to prevent excessive hemorrhages. Soon after a leg is cut off a papilla-like body 
grows out from the stump of the limb, develops into the shape of a small limb, and grows larger, with each successive molt, until the normal size is reached. The antennæ, too, are much exposed to injury, but with them autotomy is not practised. They begin to grow out at the place of injury, and at least one molt is necessary for their complete restoration.

Abnormalities in the claws of the lobster are not uncommon. The thumb-like protuberances of the next to the last of the joints of the great claw is sometimes bifid, or carries a large wart. The finger which opposes the thumb is also sometimes forked (Fig. 152). Many of these abnormalities are probably due to injury of the claw; but others cannot be explained in this way. For instance, cases have been observed of lobsters having crushing claws of equal size on the two sides of the body. Similar abnormalities are found in other arthropods. They are always instructive because, being natural phenomena,

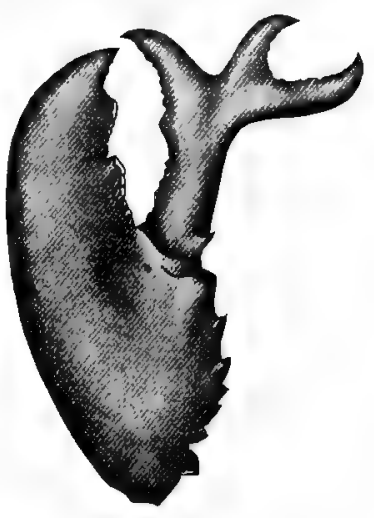

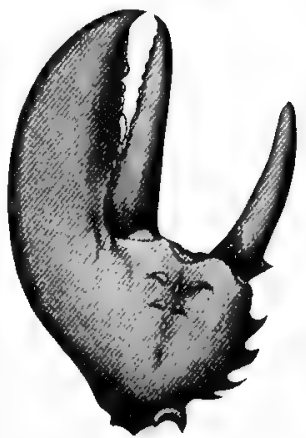

Frg. 152.-Two abnormal claws. Upper figure shows a double outgrowth to the finger. In lower figure there is an extra finger. From Herrick. they must have a cause, and this lies in the altered conditions of development.

Physiological Division of Labor. - The difference between a "highly developed" animal and a lowly organized one is not 
first of all a difference of size nor a difference in the number of parts, - just as a large population or numerous cities are not the primary characteristics of a highly civilized state. But just as a complex civilization is one in which each of the different citizens has his own special task to perform for the commonwealth, so a highly developed organism is one in which each different organ has its special rôle to play. The worm Nereis ${ }^{1}$ has more segments to the body than the crayfish, but these segments are very nearly alike - the fins especially are quite similar. In the crayfish, on the other hand, the appendages are dissimilar. Each pair has a special function to perform and is specially adapted, often complexly fashioned, to meet this need. What is true of the appendages is likewise true, to an equal degree, of the internal organs. The internal organs of Nereis are repeated in each segment; but in the crayfish the egg ducts lie in one segment, the heart in another part of the body, and so on. Some of the segments have given up one or more functions to perfect a single one in which it has specialized. There has been a division of lahor between the different parts of the hody, and in consequence a greater perfection in the performance of each function. More perfect fulfilment of function is the result of physiological division of labor, just as a higher civilization is the result of individual division of labor. 


\section{CHAPTER $\mathrm{X}$}

\section{DAPHNIA: A STUDY OF THE FOOD OF FISHES}

If one sweeps the long grass in a field with a stout, fine net, one will gather in a minute or two great numbers of insects. In this way one gets a notion of the vast abundance of insects that there must be on all the land. Little wonder then that vegetation suffers so from insect attacks or would suffer were the number of insects not kept down by birds, lizards, and toads which find their principal subsistence on them.

What insects are to the land the water-fleas or Entomostraca are to the water; they are ubiquitous there. And what insects are to the hirds Entomostraca are to fishes. How numerous they may become is shown when a fine silk net is drawn through the water and the small Entomostraca are strained out. By these means the volume of small organisms in one cubic centimetre of water has been determined for various localities. It appears, in general, that the organisms are more numerous in lakes than in streams (Fig. 153). Thus in studies made in the middle Illinois River and adjacent lakes the volume of organisms in $1 \mathrm{cu}$. metre of water was, for a small stream, 0.3 of a cubic centimetre; for a large river (the Illinois) $3 \mathrm{cu} . \mathrm{cm}$. ; for five lakes in Illinois, 2 to $23 \mathrm{cu} . \mathrm{cm}$. In one year the river (at Havana, Illinois) discharges 75,000 tons of mieroscopic organisms (Kofoid). In studies on the small lakes of Wisconsin, Birge has calculated the number of Entomostraca in a cubic metre at different levels and at different 
times of the year. The average for all localities and periods is about 40,000 individuals per cubic metre of water in the lakes. In the late spring the population of the lakes may rise to 250,000 per cubic metre near the surface; near the bottom

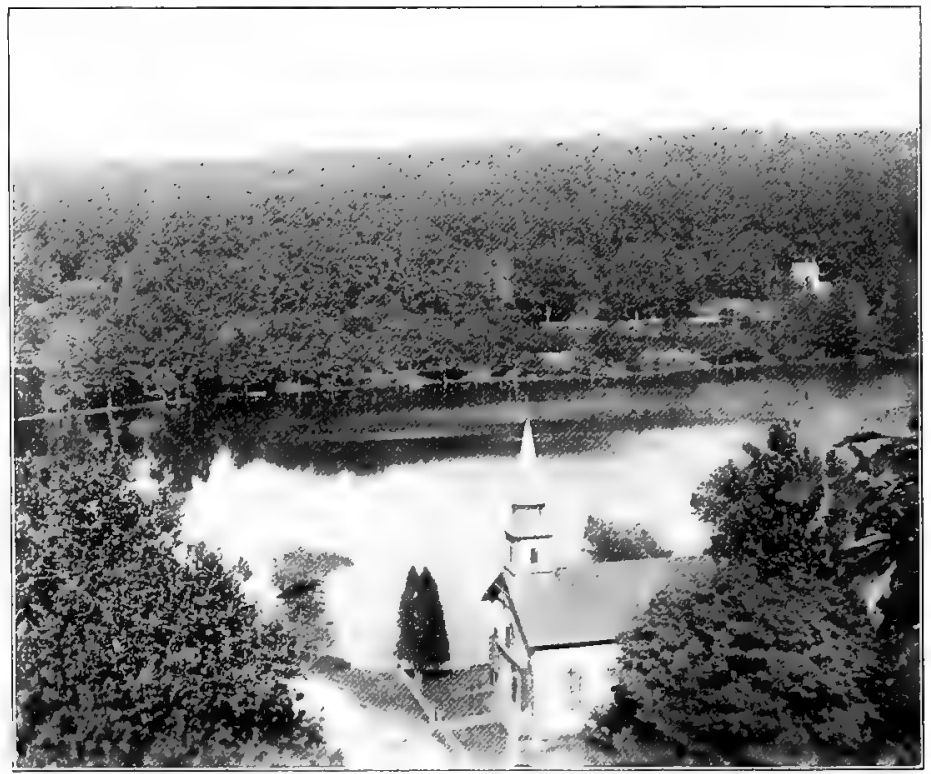

FIG. 153. - A typical lake, exposed to the sunlight and swarming with alge and Entomostraca.

it may fall to 500 or even less. In a lake of 80 square kilometres there may be 160 billion Entomostraca weighing all together about 20 tons, and this mass of organisms is renewed several times each summer.

The abundance of Entomostraca in a lake varies with the time of year. The numbers are relatively small during the winter, but with the melting of the ice at the end of March 
or in April they begin to increase, reaching a maximum in May. During the midsummer a marked decline occurs, to be followed by a rise at the end of September or in October; after that the numbers decline for the winter. The reason for these two maxima is that the spring and autumn are periods of rapid growth of the food of the Entomostraca, and this in turn is due to the mixing up of the waters at those periods, and consequently of the salts and organic stuff upon which, in last analysis, the Entomostraca depend. This mixing up of the waters depends on the variation of the density of water as its temperature changes. Water is heaviest at $4^{\circ} \mathrm{C}$. above the freezing-point and tends to settle below water that is warmer or colder than $4^{\circ} \mathrm{C}$. In the spring the bottom waters remain near the freezing-point $\left(0^{\circ} \mathrm{C}\right.$.), while the surface temperature rises. As it approaches $4^{\circ}$ the surface water grows heavier and falls to the bottom, forcing the colcler water up, and this goes on until the whole mass of the water has reached the temperature of $4^{\circ}$,- this constitutes the spring circulation of the water; after that, the surface water, becoming still warmer, remains on top. In the autumn the whole mass of water, even to the bottom, has at first a higher temperature than $4^{\circ} \mathrm{C}$., but as the frost comes the surface water gradually approaches $4^{\circ} \mathrm{C}$. and begins to fall, forcing the warmer, lighter water to the surface. Eventually the densest $\left(4^{\circ} \mathrm{C}\right.$.) water is at the bottom, while the surface water freezes (at $0^{\circ} \mathrm{C}$.) and floats on top. This is the autumnal movement of the waters. By means, then, of these remarkable vertical movements of the waters of lakes the bottom food is made available for the surface swarms of Entomostraca.

Entomostraca live not only in fresh water, but also in the sea - that greatest consumer of the sun's energy. Living 
in a rich soup of smaller green organisms upon which they can feed, they multiply enormously. As many as 20,000 of the adults of one species of Copepod have been counted in one culic meter of sea water, and of larval Entomostraca, nearly 200,000. And the total volunie of the Entomostraca of the ocean, if brought together, would make a conical hill about 12 kilometres in diameter and 300 metres high. The Entromostraca of the sea if driven into Iong Island Sound, which is 80 miles long and 10 miles wicle, would fill it full from the bottom to the present sea-level, leaving no room for water, and this rast bulk of organisms is frequently renewed.

This enormous mass of Entomostraca is made available for man, since it forms the principal food of many edible fishes. As the fish swims through the sea near the surface it opens its mouth and lets the water flow into it and out at the sirles through the gills. In passing out the small solid particles are strained from the water by the gill-rakers and are then swallowed. As the young fish feed they grow, and so the Entomostraca are transformed into food for man.

The group of Entomostraca includes a great varicty of organisms which are all of small size with a variable number of body segments and appendages. There are five orders which we will next consider.

The fairy shrimps or Branch'iopodia ${ }^{1}$ include long, mostly macroscopic organisms with 10 to 40 pairs of legs. The legs are leaf-like and serve both as pardlles and as hreathing organs. These animals are found in the spring in pools that dry up later in the year. They produce eggs which have such thick shells that they can withstand drying for a year or even several years; indeed they will not hatch until they have been dried.

${ }^{1}$ Latin, branchium, gill ; Greek, pous, foot. 
One genus (Artemia) loves water that is even denser than seawater. It lives in the Great Salt I Jake and in vats where salt is crystallizing out. To the genus Apus (Fig. 154) belongs the largest of our fairy shrimps, which is conspicuous because of its broad shell.

The water-fleas or Cladoc'era include Daphnia and numerous other very short Entomostraca that are much flattened from side to side (Fig. 155). They live in ponds and lakes all over the globe. During the autumn in northern latitudes certain species lay fertilized eggs that may lie dormant for a year or more. During the greater part of the year females alone occur, and unfertilized eggs (called also "parthenogenetic" or "summer" eggs) are alone produced.

The body of Daphnia is enclosed in a heavy shell. This makes the Daphnia so heavy that it tends to sink in the water and is only kept up by the vigorous swimming strokes of the

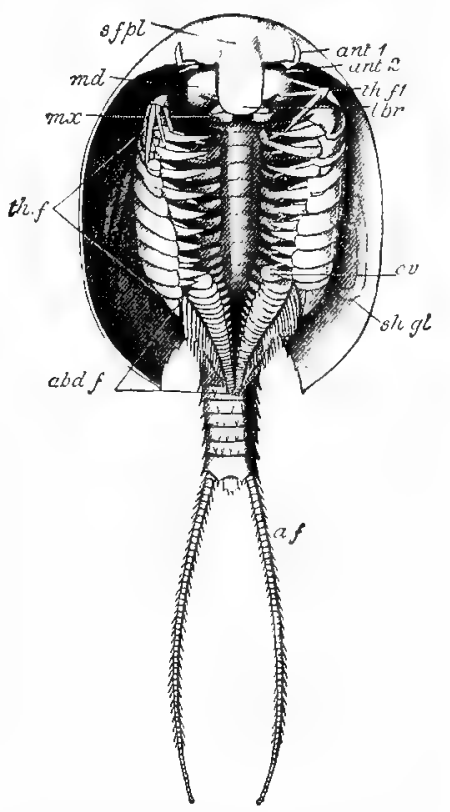

FrG. 154.-Apus glacialis, ventral aspect. $a b d . f$, abdominal feet; ant. 1 , antennule; ant. 2 , antenna; $l h r$, labrum; $m d$, mandible; $m x$, first maxilla; ov, aperture of oviduct; s.f.pl, sub-frontal plate; sh.gl, shell-giand; th.f, thoracic feet; th.f. 1, first thoracic foot. After Bcrnard.

legs and its great antennæ or feelers which increase the friction with the water, so that falling is less rapid.

The family of bivalve entomostraca or $\mathrm{Os}^{\prime} \operatorname{tracoda}^{1}$ comprise 1 ostrakon, shell of a testacean; eidos, like. 
some very abundant, minute, hean-shaped little crustaceans, which have to move their appendages very vigorously to support their heavy bodies in the water. The Ostracods are found in almost all pools and streams, especially in the early spring.

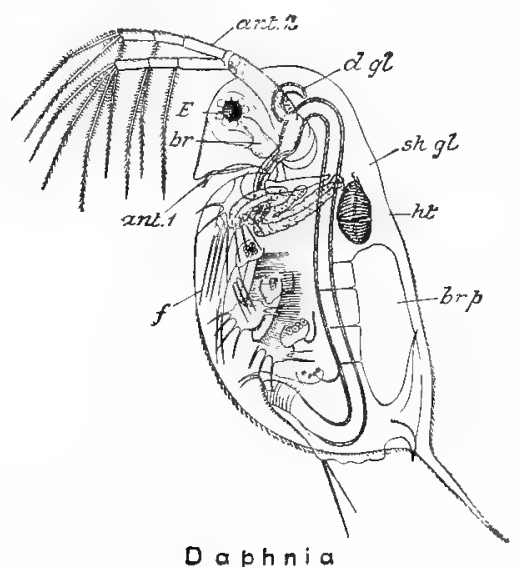

Daphnia

Many of them seem to be exclusively parthenogenetic.

Of the Copep'oda ${ }^{1}$ the commonest fresh-water genus is Cyclops, which occurs in a similar habitat with Daphnia and is sometimes found even in pure drinking water. The female carries a conspicuous egg-sac on each side of the abdomen, and reproduction occurs with such rapid-

FIG. 155. - Daphnia. ant, 1, 2, first and second antennæ; $b r$, brain; $b r . p$, broodpouch ; $d . g l$, gland $f$, spines on the fect ; $h t$, heart; sh.g, shell gland. After Claus. ity that one Cyclops might, under the most favorable conditions, have 5 billion descendants in one year. It is consequently easy to understand how Cyclops often becomes the most abundant entomostracan in our waters, and how in some lakes it has been found that there are over one million of them to each square metre of water surface. Large numbers of the Copepoda are marine. One of the most common is Acartia (Fig. 156), which swarms to such an extent on the surface of the water as to make great phosphorescent areas.

Barnacles are the only attached non-parasitic Crustacea. Certain species of them are found fastened to rocks on the ${ }^{1}$ kōpe, oar ; pous, foot. 


\section{DAPHNIA : A STLDY OF TIE FOOD OF FISLES 159}

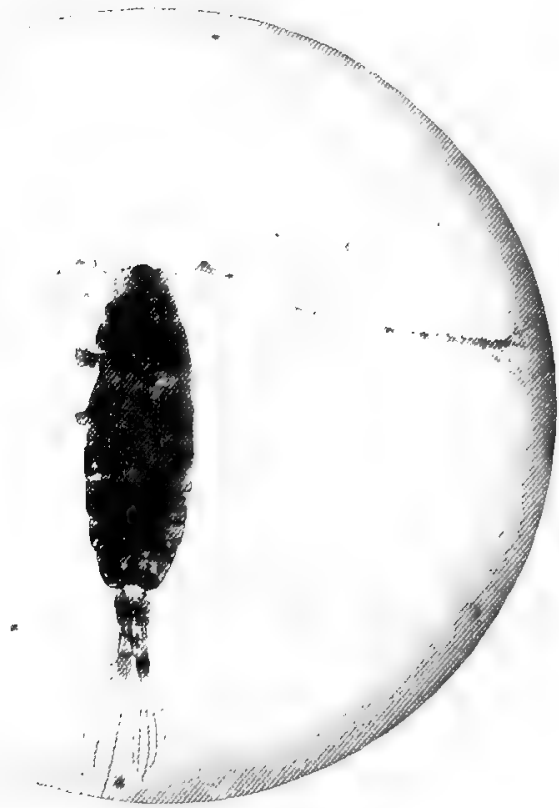

FIG. 156. - Acartia, a marine Copepod. Greatly magnified. Photo. by W. H. C. P.

seashore between tide-marks (Fig. 157). If you watch barnacles in rock pools, you can see them open the valves of their

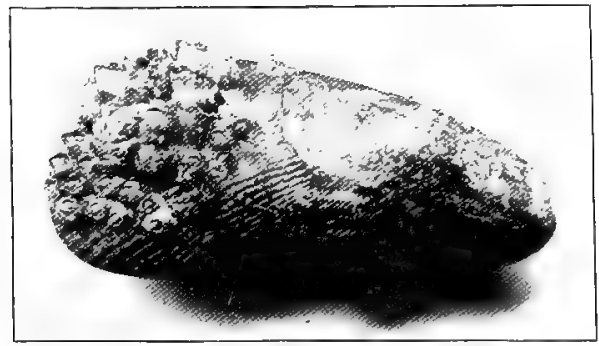

FIG. 157. - Mussel-shell bearing barnacles (Balanus). Photo. by W. H. C. P. 
shells, protrude their elongated appendages, which together form a sort of rake, and pull in particles which happen to be floating about them. Other species of harnacles attach themselves to floating seaweed, ship bottons, and whales; under these circumstances, despite their sessile hahit, they enjoy a constant change of locality. Barnacles doubtless gain great protection from the circumstance that they are sessile and enclosed in shells; but their peculiar hahits have given rise to certain peculiarities in reproduction. They are hermaphroditic; i.e. both male and female germ cells occur in the same indivirlual. Despite this fact, dwarf male individuals are occasionally found inside the shell of the barnacle; these are known as " complemental males." The general form of the

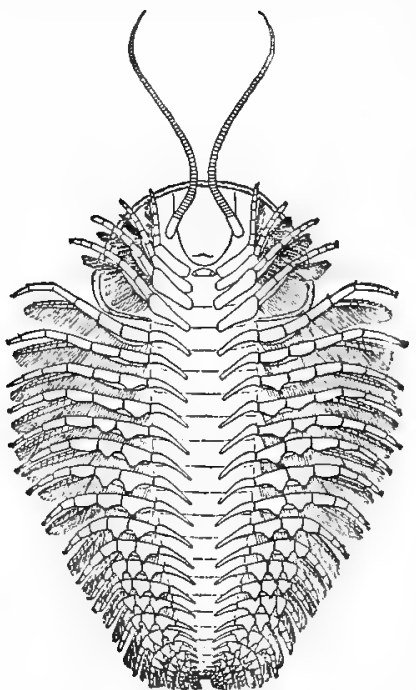

FIG. 15\%. - I rustration of the ventral aspect of a Trilobite. Note in particular the character of the appendiges. After Bexecher. barnacles has also become greatly modified by their sessile habit, so that they were long regarded as mollusks, until it was shown that the larvæ are almost exactly like those of other Entomostraca.

Trilobites ${ }^{1}$ are extinct giant Entomostraca, closely allied to Branchiopods. They were immensely abundant in early geologic times, and their remains form a large part of certain rocks. They had a segmented body, with bifid appendages and long antennæ, and their compound eyes were borne on the grent frontal shield. Some of them were nearly half a metre long (Fig. 158). 


\section{CHAPTER XI}

\section{THE ANATOMY AND PHYSIOLOGY OF ANNELIDS}

General Form of the Body. - The annelids or ringed worms (Fig. 159) are of especial interest because they seem to be the ancestors of all the higher animals having a hody composed of rings or segments. Such are all Crustacea, Tracheata (including insects), and Vertebrates. The origin of the ringed condition of the borly is uncertain; the lower worms do not have it, so it must have arisen from the unsegmented condition. We can help to understand how segmentation of the borly arase by inquiring as to its present meaning. The rings are more distinet when the worm contracts, less so when it expands in any part; consequently the rings are due to the muscles of the hody wall. Now in the most perfect annelids the cavity of the body is divided by partitions into a series of compartments, resembling the water-tight compartments of an ocean steamer (Fig. 161). The muscles of the body-wall run in each compartment from one partition to the next, so when they contract, swelling, like all muscles, chiefly in the midcle and little at the attached ends, they cause the wavy outline of the body that we see in the contracted worm. From one constriction (partition) to the next is one segment. The reason why the body muscles run in this way is to permit the worm to writhe - a morle of locomotion very useful in moving through mud or even water. The writhing, or S-shaped movement of the body (Fig. 182) necessitates, however, contract- 


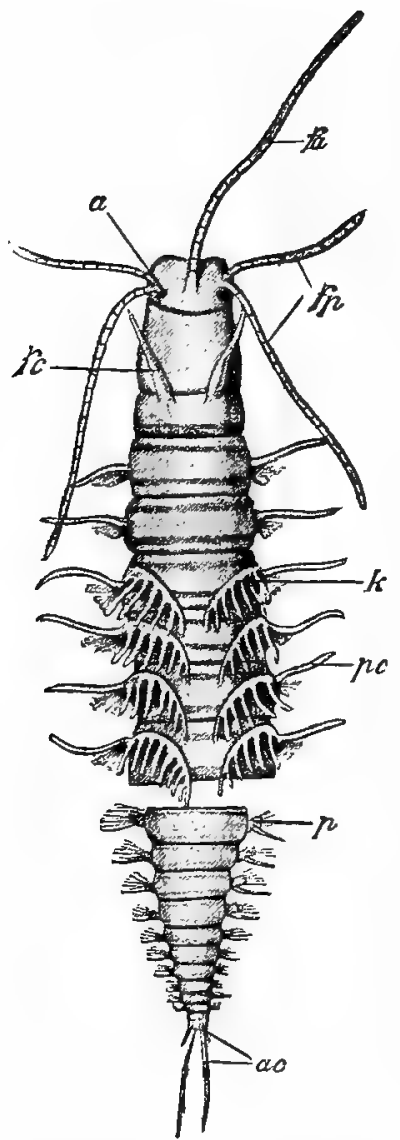

FIG, 159.-An annelid (Eunice). Anterior and posterior ends of the body only; dorsal view. $f a$, unpaired fecler; $f p$, paired feeler; $a$, eyes; $f c$, feeler-cirri ; $k$, gills ; $p c$, dorsal parapodia; $p$, parapodia; $a c$, anal cirri. After Lang. ing certain parts of the body-wall and expanding others on the same side of the body at the same time, and this is possible only with short muscles. When the muscles run continuously from head to tail, as in the "vinegar eel," the body flops from one side to the other as a whole.

The segmentation of the body has led to important consequences. Each segment contains not only its own muscles, but a pair of appendages that are moved by the muscles, nerves to control the muscles, blood-vessels to supply them with food, and a pair of excretory organs to carry off waste products. Each segment is, indeed, a nearly complete organism, and, consequently, even small parts of an annelid cut out from the rest of the body may live a long time and even regenerate the lost head and tail.

The head of the annelid is simple in the earthworm and the other herbivorous forms; but in Nereis and the other carnivorous species (Fig. 160) it gains a great size and is provided with various sense 
organs - tactile organs known as dorsal tentacles and ventral "palps" and eyes and taste organs. The tail segment, which contains the anus, frequently bears a pair of tentacles which are useful when the worm moves, as it often does, backward.

The lateral appendages of the more perfect annelids are stout, fleshy, paired protuberances on each segment of the trunk. These are covered with a thin skin to permit of exchange of gases with the water, and so they would be without support were it not for great dark bristles, one of which lies
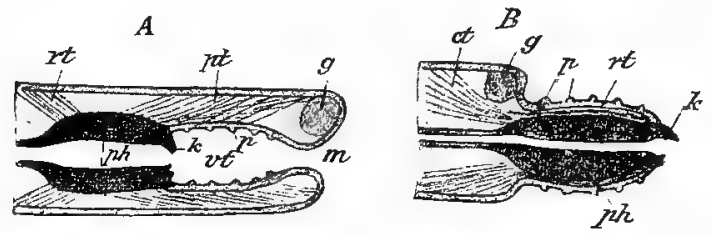

FIG. 160. - Diagrammatic representation of pharynx of a carnivorous Annelid. 0 , brain; $k$. jaw ; $p h$, pharynx; $m$, mouth; $r$, retractors; $p t$, protruders; vt, extrusible part of pharynx; $p$, its papilla. $A$, pharynx retracted. $B$, pharynx protruded. In $B$, ct, retractors; $p t$, flexible part of pharynx. After Lang.

in the axis of each of the two main lobes of the appendage and serves for the direct attachment of the muscles that move the appendages. In addition, the appendage carries many finer bristles (chætæ, whence the name "chætopod," applied to the group to which Nereis belongs), and these are exceedingly diverse in form in the different families of chrtopods. In certain species the bristles cover and protect the body (Fig. 179).

The organs of nutrition consist of a food-canal and its glands. The food-canal usually begins in a mouth cavity at the hinder end of which is a thick muscular pharynx, the entrance to which is guarded by a pair of jaws made of the same substance as the 
cuticula. The remarkable thing about this front end of the food-canal is that it can be rolled out, carrying the jaws to some distance in front of the head, where they can seize their prey and drag it back into the mouth (Fig. 160). Behind the pharynx comes a short gullet into which glands pour digestive fluids, and then comes the long intestine, extending through the middle of the trunk to the last segment. The food-canal of the polychætes hehind the pharynx is characterized by great simplicity (Fig. 161).

Respiration in polychætes is effected through the skin, particularly that of the swimning appendages. It is important to notice that this is the primitive condition out of which the respiratory organs of ('rustacea have arisen, but in the latter group, owing to the thick cuticula of the legs and the larger size of the anmal, sperial outgrowths of the appendages (gills) have heen evolved. We see the beginnings of such gills in certain polychetes (Fig. 159). In sessile polychieta (page 188) respiration is confined to certain appendages which have hecome greatly enlarged so as to extend beyond the mouth of the tubes in which they live.

The circulatory system of polychietes is highly developed. A contracting vessel extends along the whole of the mid-dorsal line and a smaller tube runs along the midventral line (Fig. 161). These are connected in each segment (Nereis) by a pair of vessels which (in Polychætes) break up into capillaries in the swimming appendages or gills to facilitate respiration. Blood-vessels also run to the intectine to absorb the digested food. The heart pulsates rhythmically, forcing hlood toward the head. The blood contains a few corpuseles, but the fluid is itself red and capable of uniting chemically with oxygen at the skin and yielding it to the tissues. 


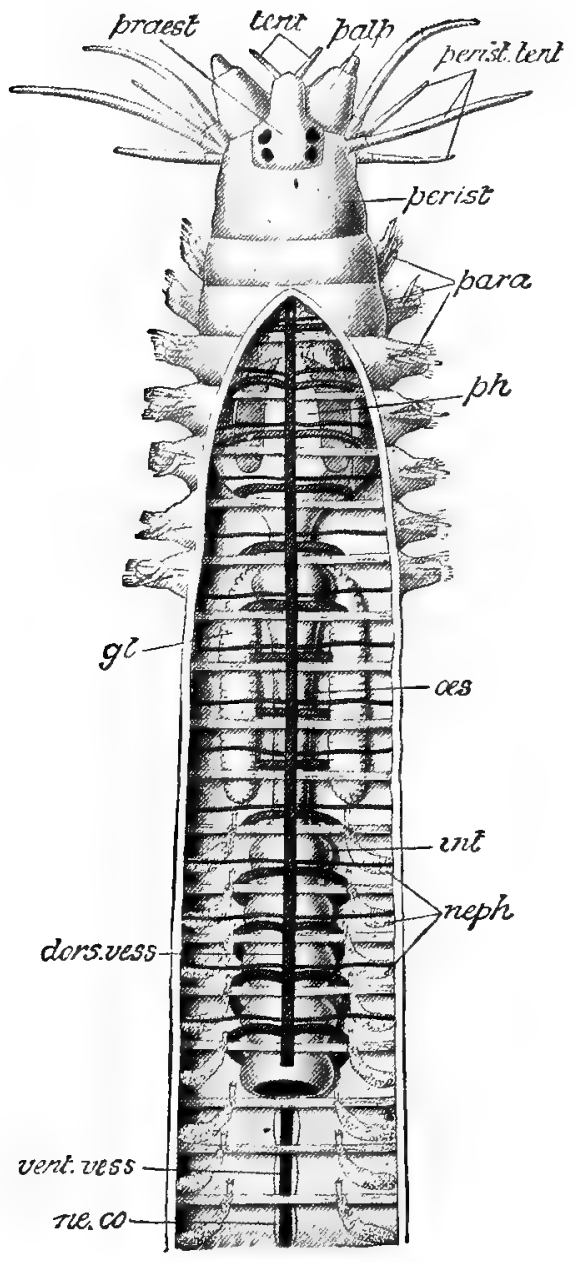

FIG. 161. - Semi-diagrammatic view of anterior part of body of Nereis with dorsal wall removed so as to show alimentary canal, oes, int; the septa; blood-vessels (dors. vess, vent. vess.); and the nephridia (neph). Behind, intestine removed to show ventral hlood-vessel and nerve cord (ne.co); gl, glands of esophagus; para, swimming feet; perist, peristome; perist. tent, tentacles of the peristome; $p h$, pharynx and its jaws; praest, part of head lying above mouth. From Parker and Haswell. 
The execretory organs are little coiled tubes of which typically a pair lies in each segment (Fig. 161). The inner mouth of the tube opens into the body-cavity, where it sucks in particles floating in the body-cayity. The wall of the tube, which is richly supplied with blood-vessels, extracts from the blood the waste products, thus purifying it. The inner end and ravity of the tube is lined by little beating hairs (cilia) which maintain a movement of fluids toward the outer end of the tube. It is to be noted that the excretory tubes are repeated in nearly every segment, for we have seen that in the higher animals - Crustacea - tubes are found in various segments but performing diverse functions. This is a law of evolution of organs - at first a repetition of similar ones with a common function and then a reduction of the total number with a specialization of function and structure to each.

The reproductive organs of annelids are relatively simple. Although the sexes are separate in Polychætes and in the earthworm and its allies (Oligochetes) both eggs and sperm are formed in the same individual; nevertheless any egg of an individual is not fertilized by a sperm-cell of the same individual. The egg and sperm-cells develop in the lining of the body-cavity and when ripe, fall into the borly fluid. They are sometimes picked up by the excretory tubes and cast into the sea, where fertilization occurs; but sometimes the ripe individuals break in two in order to allow the sexual products to escape. In certain annelids the escape of the egg and sperm occurs in thousands of individuals at the same hour, so that the sea swarms with eggs and sperm; thus the chances of their getting together are increased. The special case of Autolytus is referred to on page 187. From the fertilized eggs embryos covered with cilia arise, which swim free in the sea as they 
develop. There is abundant food for them here, but the danger is great, for the surface is constantly being swept by fishes that live on the pelagic fauna.

The musculature of annelids has been treated of in the introduction to this chapter. The nervous system is of the same type as that we have studied in the lobster-a dorsal brain and a double ventral nerve chain connected by a nervous ring around the pharynx. From the ventral nerve-cord in each segment branches go off to the two lobes of the parldles.

The sense-organs of annelids vary greatly in the different orders. In the earthworm they are few and simple. The whole surface of the body bears sensory hairs, and as these are the only sense-organs known in the earthworm they are probably (in different regions of the body) capable of being irritated by mechanical, chemical, thermal, or luminous stimuli. Nereis, on the other hand, has special sense-organs. Four eyes rest on the brain. Each is a cuplike depression of the skin. At the bottom of each are the special sensitive cells connected with a prominent nerve going to the brain. The tentacles of Nereis are doubtless tactile, and the palps probahly have also a taste sense. Thus we see that a carnivorous form like Nereis has well-developed sense-organs, enabling it to find its prey; while herbivorous species, like the earthworm, lack such special sense-organs, Each species has organs agreeing with its needs. 


\section{CHAPTER XII}

\section{THE EARTHWORM: A STUDY IN SUBTERRESTRIAL ORGANISMS}

THERE is every reason for believing that the primitive organisms lived in water, for we find the simpler organisms living in water to-dlay. Indeed, the small ancestral organisms would dry up if exposed to air. Whether the very earliest organisms developed in fresh water or in salt water is uncertain and immaterial, but it is quite certain that the principal branches of the animal kingdom originated in the sea, on or near the shore. From the shallow seas their descendants passed on the one hand into the depths of the sea and on the other either up the estuaries and into the rivers or, in a few cases, directly upon the land. Of the forms that thus came to inhahit fresh water many have succeeded in reaching the shallow pools and small streams which dry up during a part of the year. Such animals have been forced, in order to protect themselves from desiccation, to penetrate into the muddy bottoms. This habit of living in the ground is now common to many kinds of animals. The elementary instincts with which the burrowing habit is associated are, first of all, a love of contact and of darkness and, usually, of moisture also. The food of burrowing animals is usually any sort of organic débris and roots, but the higher types, like the moles, feed on lower subterrestrial organisms.

Even at the seashore many kinds of marine animals have acquired burrowing habits. Thus, many of the simplest organisms, such as sponges, burrow into solid objects at the 
bottom of the sea. Perhaps the commonest hurrowers, however, are those elongated animals - elongated in association with the burrowing capacity - that we call sea-worms. A fuller account of many of them is given in another chapter. Many of the Crustacea burrow and feed upon the burrowing worms.

The burrowers of the land are the best known to us. They have been derived from organisms that lived in fresh water.

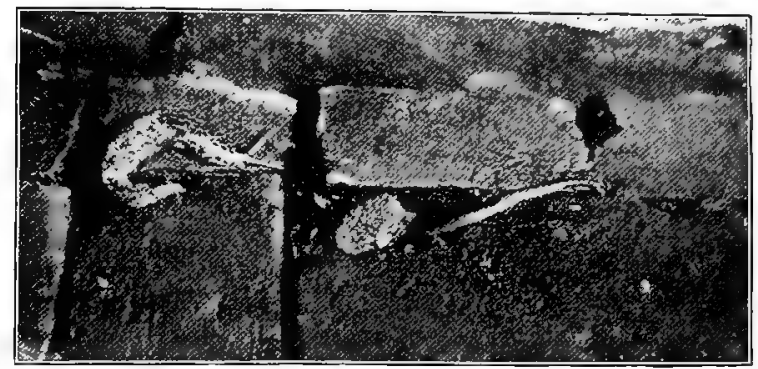

Fig. 162. - Flash-light photograph of earthworm and slug crawling on a pavement at night. Photo. by D. and S.

Among the land burrowers are the earthworms; certain Crustacea, like the crayfish; many insect larvæ; and a few mollusks and vertebrates. In the present chapter we have especially to consider the earthworm (Oliogochæta ${ }^{1}$ ).

Earthworms, as the name implies, are inhabitants of the ground, through which they burrow and in which they gain their food. They sometimes come to the surface at night in search of companions and food (Fig. 162). Even during the day in rainy weather they extend the anterior end of the body out of their burrows. Earthworms, found on the surface at other times, have, for the most part, been parasitized by a 
fly, and are in consequence weak or dying. During the daytime, if the surface moisture permits, they lie near the mouth of their burrows, probably for the sake of the sun's warmth. In this position they can be seen by looking down into the holes. At such times they are often caught by hircls. In dry weather, or when the ground is freezing, earthworms burrow decp to a moist stratum, or to below the frost-line, and hibernate there.

Food. - Earthworms are omnivorous. As they burrow through the ground, the earth is taken into the food tract, and the digestible particles are dissolved out and absorbed as food. Earthworms can, however, he fed upon green and dead leaves, decaying wood, seedlings, hits of flesh, and even filter paper. Earthworms have the habit of dragging into their burrows leaves which they intend to devour. There the leaves are moistened with a fluid excreted by the worm. This fluid partially digests the food. After being taken into the alimentary tract, the food reaches an organ of the canal known as the gizzard. This part has thick muscular walls, and contains in its cavity small stones; by the action of both the muscular gizzard and the small stones, the food is ground up in much the same way as are the grains of corn by the aid of stones in the gizzard of a hen.

Resistance and Regeneration. - Earthworms have a remarkable power of resisting certain untoward conditions. Thus they may be kept for months in a moist vessel without food, or with only filter paper, without starving. On the other hand, they die in a dry atmosphere in a few hours, whereas they may be submerged in water for several days without injury. Very remarkable is their power of healing after injury. If an earthworm be cut in two near the middle, and the halves 
he kept under favorable conditions, each half may develop its missing organs, so that two complete worms will result. The anterior half of one worm may be attached to the hincler end of a second worm by the cut edges, owing to the fact that the cut edges grow together. This operation is called grafting.

Economics. - Earthworms are, to a certain extent, injurious to vegetation, since they eat tender seedlings and roots; but, on the other hand, they are almost indispensable to agriculture. Their burrows permit rain to percolate deep into the ground, instead of running off on the surface. They keep the soil loose, facilitating the penetration of the roots of plants. The earth that passes through their bodies is ejected on the surface of the ground near the openings of their burrows, and is called a "casting." By means of castings the deeper-lying earth is brought to the surface, and the surface layer of rich earth, called "vegetable mold," is in this way increased in thickness by ardditions to its upper surface. The thickness of the layer of mold which the castings of one year, if uniformly spread out, would make has been estimated by Darwin to be in England about two-tenths of an inch. Most of these castings are merely taken from the deeper-lying mold, but they are enriched by the intestinal secretions in passing through the body of the worm. These intestinal secretions are said to have the power of slowly dissolving sand and thus of turning it into soil. Darwin says: "It is a marvellous reflection that the whole of the superficial mold over any smooth expanse has passed, and will again pass, every few years, through the bodies of worms. The plow is one of the most ancient and most valuable of man's inventions, but long before he existed the land was, in fact, regularly plowed, and still continues to be thus plowed, by earthworms." 
Earthworms are also a source of disease. They burrow into the carcasses of huried animals that have died of infection and bring the disease germs to the surface, where they may infect healthy animals. They are believed to carry the germs of gapes - a worm parasitic in chicks.

Earthworms belong to the sub-kingdom of ringed worms (Annelids ${ }^{1}$ ). The annelids are divided into two orders, one of which lives chiefly in the sea and is called Pol'ychæta, ${ }^{2}$ while the other lives chiefly in fresh water or in the ground and is known as Ol'igochata. Earthworms belong to the latter order. This order is distinguished, in addition to its nonmarine life, by the ahsence of foot-pads and parapodia, by having few bristles, and by the absence both of tactile appendages at the head end and of gills.

The Oligochata are either aquatic or terrestrial. The aquatic Oligochata are among the commonest inhabitants of ponds and ditches, living sometimes in the mud and sometimes at the surface of the water.

Tubifex ${ }^{3}$ is common in slow-running hrooks, and lives in the mud of the bottom, forming tubes in it. The threarl-like bodies of the worm are stretched up beyond the surface of the mud and wave in the water in graceful undulations. Often the worms are so numerous that their reddish color gives a decided tinge to the bottom. They thrive well in fresh-water aquaria.

Dero ${ }^{4}$ is very common on the surface of ponds, particularly in the midst of duckweed (Lemna), the leaves of which it cements together to form a floating tube in which it lives, and by which it is accompanied in all its migrations. Dero can

${ }^{1}$ annulus, a little ring.

${ }^{2}$ poly, many ; chata, hair,
${ }^{3}$ tubus, tube; facere, to make.

4 dero, to skin or flay. 
also be told by the sort of funnel at the hinder end of the transparent body, from the margins of which finger-like filaments arise which aid in respiration (Fig. 163).

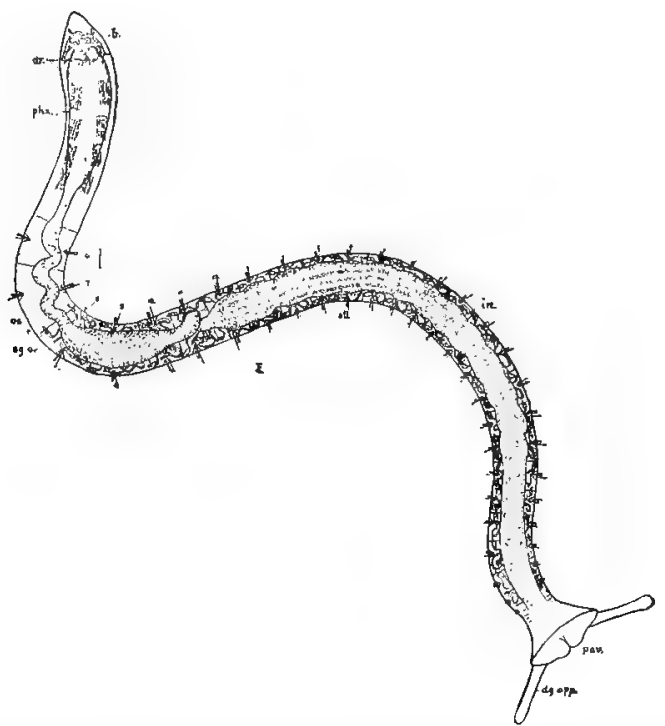

FIG. 163. - Dero, the duck-weed worm. Enlarged. After Reighard. The lettering is as follows: or., mouth; phx., pharynx; oe., esophagus; sg.o., segmental organ ; in., intestine ; pav., pavilion or tunnel ; dg.app., fingerlike appendages. From Reighard.

Nais ${ }^{1}$ does not construct tubes, and it has no respiratory filaments at the hinder end of the body (Fig. 164). It also has eyes; while Dero has none. Both Dero and Nais have the interesting habit of reproducing by dividing the body transversely. In the middle of the body tentacles hegin to arise, a new mouth is formed, and the worm constricts into two. Indeed, sometimes several new heads may be forming in the ${ }^{1}$ nais, a water-nymph. 
midst of a single worm. This habit is of advantage not only in multiplying the number of individuals of the species, but also as a means of protection. For if, by chance, the larva of the water-beetle (Dytiscus) seizes a Nais and hites it in

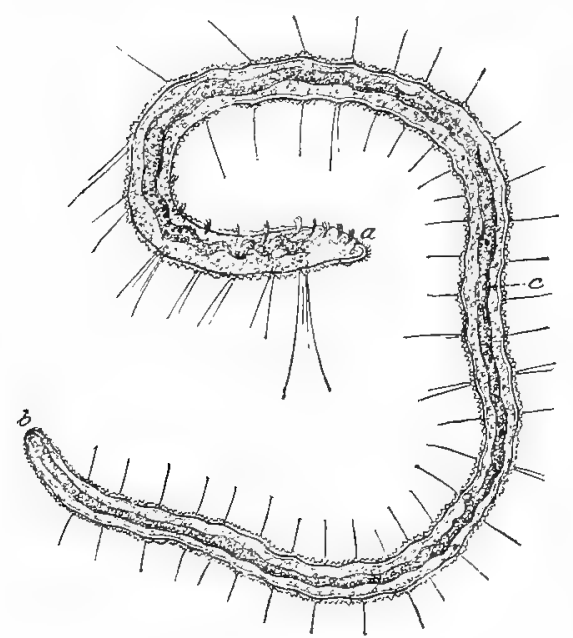

FIG. 164. - Nais. $a$, mouth; $b$, anus; $c$, intestine. From Leunis. two, the part which escapes can go on developing new individuals.

The terrestrial Oligochætæ include the common earthworm and, in addition, worms that live on the seashore between the tides and even in places which are rich in vapors of ammonia arising from decaying stuff.

There is another group of fresh-water worms which is closely related to the Oligochæta but which has a very different appearance. The leeches, or "bloodsuckers," are flattened worms, which, like the earthworm, show metamerism; that is, there is a repetition of the internal organs. They are also segmented; that is, the body has external rings, although they may he olscure. One segment does not, however, as in the earthworm, correspond with one set of internal organs (metamere), but there are three, four, or five segments to a metamere. Leches have no appendages and no bristles; but they have a sucking disk at the posterior end of the body for the purpose of sticking to things (Fig. 165). They usually 
have a smaller, anterior sucking disk around the mouth, which may or may not be provided with teeth, for the purpose of cutting through the skin. When there are no teeth, the pharynx can be thrust out, forming a proboscis. With a few exceptions, all leeches live in water; but in Ceylon there is a land-leech which lives in foliage and attacks man and other animals. Other leeches may live in clamp places at a considerable distance from water. Such a leech has been described in this country that was dug up in a garden at a point about 60 metres from the nearest rivulet, where it was feeding on earthworms. Leeches suck the blood of fishes and other aquatic animals. Certain kinds devour worms, insects, and other small creatures. Rarely do they feed on plants.

The commonest of the larger bloodsuckers of our waters is Nephelis, ${ }^{1}$ which is not distinctly segmented.

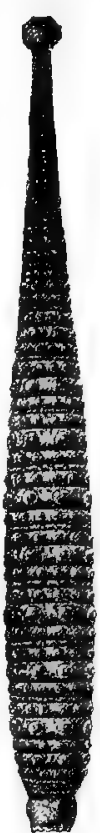

\section{Pontobdella}

FIG. 165.- Two leeches, Clepsine, found in ponds, often parasitic on frogs; and Pontobdella, a marine species living on fish. From Parker and Haswell.

It varies from black to slate color, and is sometimes striped or spotted. It lives in running water, ditches, and ponds.

Clepsine ${ }^{2}$ is a very flat and broad leech, which is common under floating wood. It feeds on snails and creeps like the inch-worm. The female carries its young attached to its under-surface (Fig. 165). 
In conclusion brief mention must be made of certain wormlike animals still more distantly related to the earthworm. The first of these is marine, but has the same slow-moving, burrowing habits as the earthworm. These animals have become more modified in connection with their burrowing habits than the earthworm, for they have lost not only their

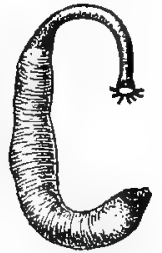

FIG. 166. - Phascolosoma, a Gephyrean. One-fourth nat. size. From Leunis. appendages, but in the adult stage even the segmentation of the body. This is the class Gephyrea. ${ }^{1}$

This group contains several rather rare animals, some of which are edible, and are held in esteem by the Chinese. One of the commonest is Phascolosoma, ${ }^{2}$ which is a tough but smooth-skinned, cigar-shaped worm, which one can dig up on our sandy seabeaches (Fig. 166). One end is pointed; from the other a great proboscis ending in tentacles surrounding a mouth can be extruded. Another species found on our beaches after a storm, something like a small cucumber in shape and size, has a row of bristles at each end, indicating its relationship with the bristlebearing worms. This striking species,

${ }_{1}$ gephyra, bridge; because they were once considered to bridge the gap between holothurians and worms.

${ }^{2}$ phaskolos, sac; soma, body.

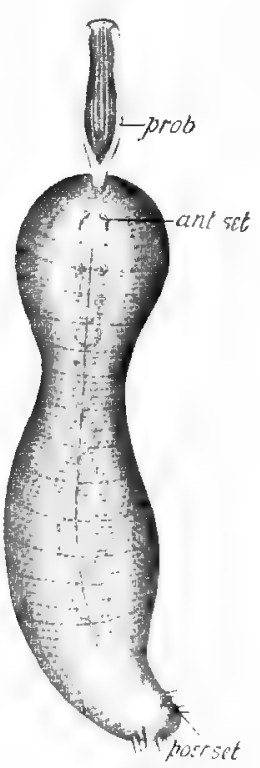

FIg. 167.-- Echiurus. About one-half nat. size. prob, proboscis; ant. set, anterior setæ; post. set, posterior seta. After Greef, from Parker and Haswell's Textbook. 
Echiurus, ${ }^{1}$ is segmented when young like Nereis, but eventually it loses its segmentation (Fig. 167).

Possibly allied to the Gephyrea is the group of Bryoz'oa, ${ }^{2}$ or moss-animals. These are noteworthy from the fact that

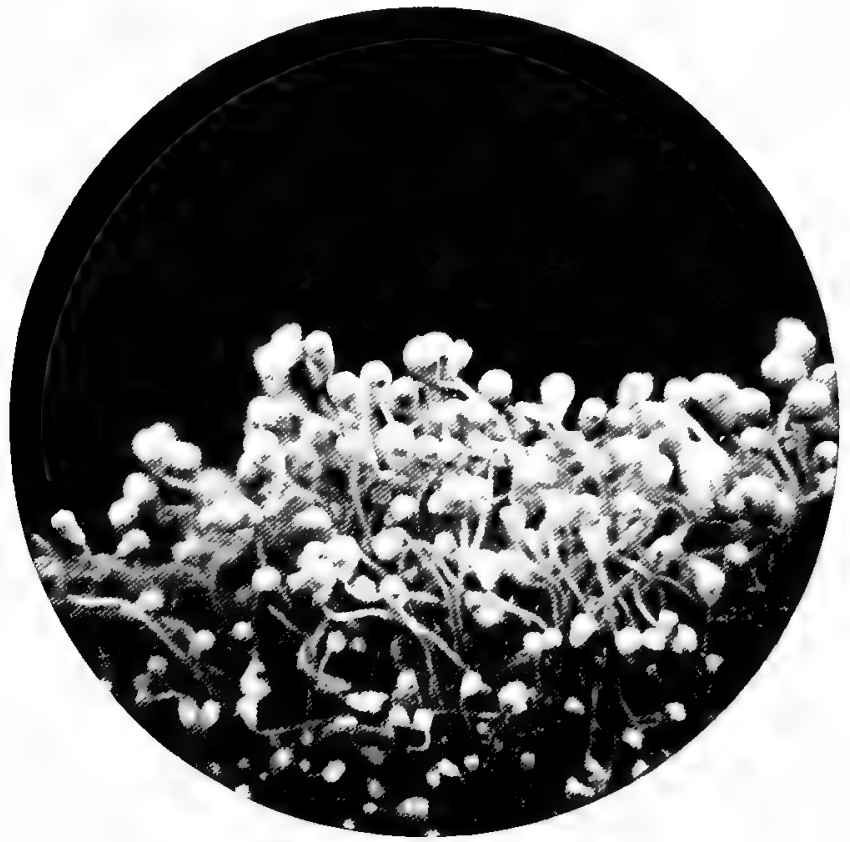

FIG. 168. - Pedicellina americana, an endoproctous bryozoan. A colony, magnified 15 diams. Photo. of living animals hy W. H. C. P.

they are compound, many individials budding off from one another, as in plants. They are found abundantly both in the sea and in fresh water. There are two main groups, the End'oprocta (Fig. 168), in which the individual consists of a

${ }^{1}$ echis, adder; oura, tail.

2 bruon, moss ; zoon, animal. 


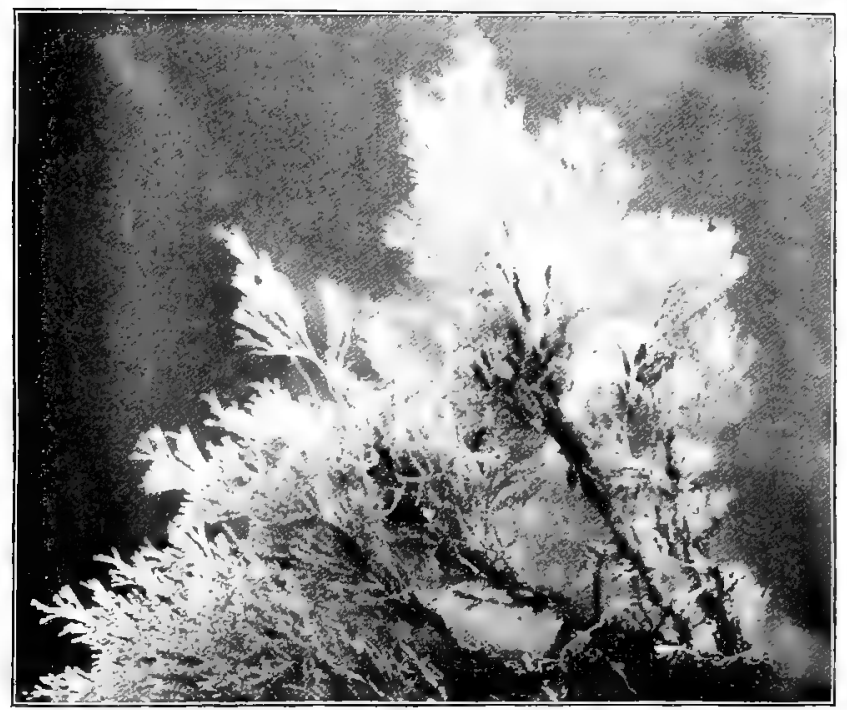

FIG. 169. - Bugula turrita, a marine ectoproct. A colony, magnified 1.5 diams. Photo. of living animals by W. H. C. P.

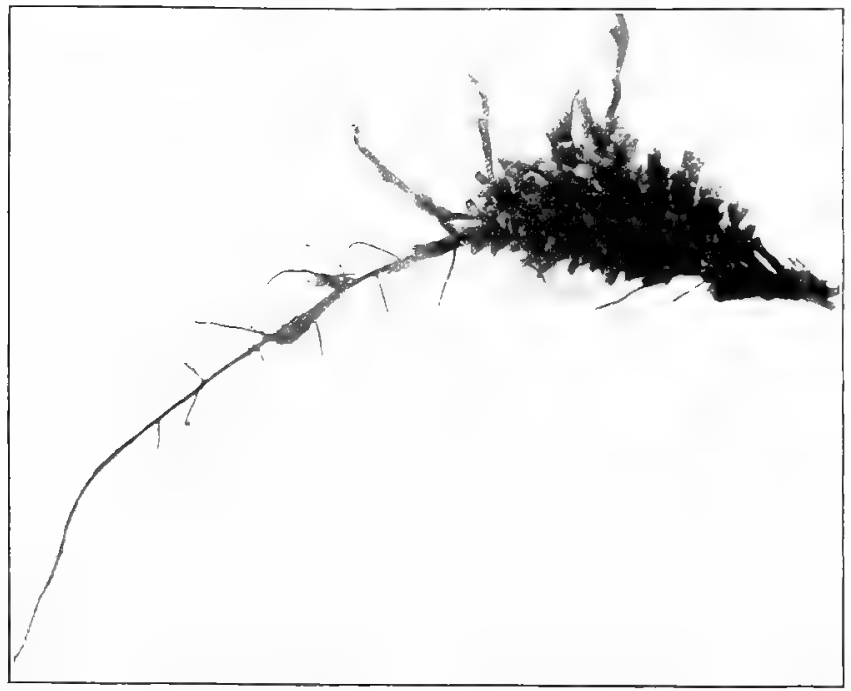

Fig. 170. - Plumatella polymorpha, a fresh-water ectoproct, magnified 1.5 diams. Photo of living animals by W. H. C. P. 
long stalk and a "head" or body proper; and the Ect'oprocta (Figs. 169, 170), usually without such a stalk. The
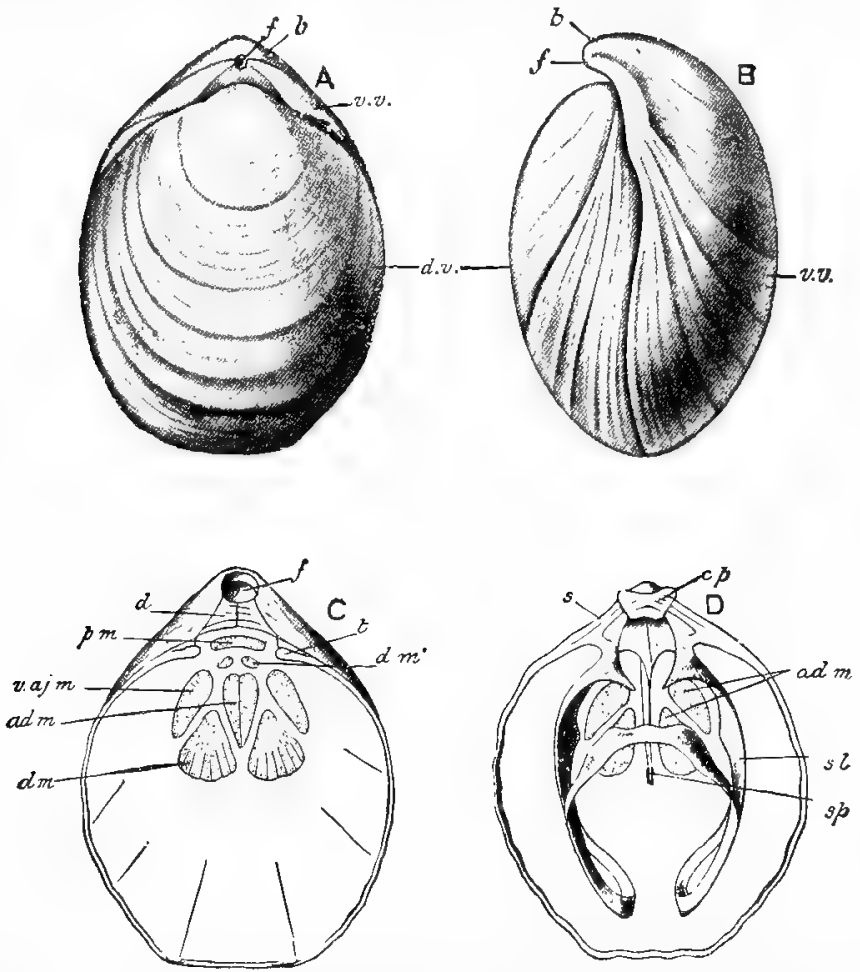

FIG. 171. - A, entire shell of the brachiopod Magellania from dorsal aspect; $B$, from left side; $C$, interinr of ventral valve; $D$, of dorsal valve ad.m, impressions of closing muscle; $b$, beak of shell ; c.p, "cardinal" process of shell ; $d$, plate closing the ventral shell ; $d . m$, impression of muscles that open the valves; $d . v$, dorsal valve; $f$, hole through which stalk passes to attach shell to the rock; $p . m$, impression made by muscle that protrudes the stalk; $s$, socket for tooth $(t)$ of ventral valve; s.l, loop to hold tentacles; $s p$, partitiou or septum; v.v, ventral valve. From Parkcr and Haswell.

Ectoprocta are the commoner. The marine species form lacelike mats on seaweed, or stand up as branching, bushy colonies 
(Fig. 169). Some of the fresh-water forms make loose, antlerlike colonies (Fig. 170), while others lie on the surface of a more or less spherical mass of jelly which they have themselves secreted.

The lamp-shells (Brachiopoda) are a vanishing class. Their fossil remains crowd the rocks almost from the first appearance

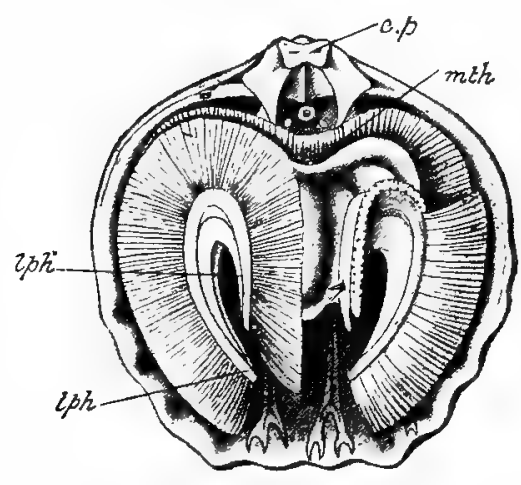

FIG. 172. - The brachiojod Magellania, with the ventral valve removed. c.p, the "cardinal" projection of shell; $l p h$, the bearer of the tentacles "lophophore"; $l p h$, its coiled arm, the tentacles removed from right side; mth, mouth. From Parker and Haswell. of organic remains. While thousands of fossil species have been described, only about 125 living species are known, - all marine. Although the individuals are usually numerous in localities where they occur, the localities are few. In our country they are found on the coast of Maine and near Cape Hatteras. The Brachiopoda have a twovalved shell like a clam, but the valves are not right and left, but dorsal and ventral (Fig. 171), and consequently have nothing to do with the shells of mollusks. The body somewhat resembles that of a single individual of a Bryozoan colony - two arms stand up on the right and left of the mouth and these are crowded with tentacles whose cilia create a vortex in the water, bringing small particles to the mouth (Fig. 172). The food canal is hent like a $U$, the loop of the $U$ heing at the hinge of the valves, half buried in the sand, while mouth and arms are elevated into the surrounding water. On account of the fact 
that Brachiopoda originated so long ago their affinities are hard to decipher. They seem to be more closely related to the Annelida and Bryozoa than to the Mollusks, but they lie near to the ancestral stem whence all of these branches have arisen. 


\section{CHAPTER XIII}

\section{NEREIS: A STUDY OF LIFE ON THE SEASHORE}

More than any other part of the earth the seashore has been the place of origin of the diverse types of animal life. The reason for this is not far to seek if it be granted that a diver-

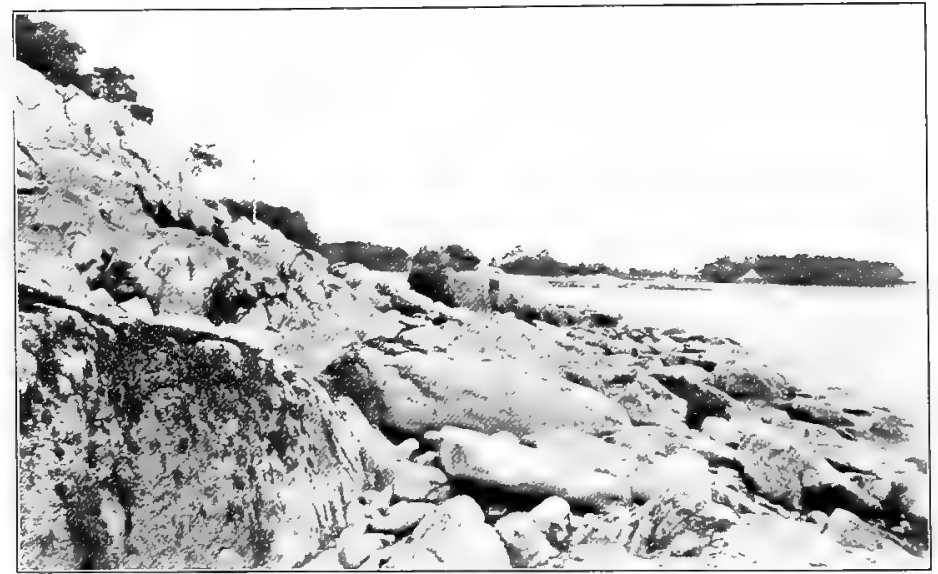

FIG. 173. - The rocky shore, worn smooth by the beating of the sea.

sity of environment favors the origin of a great variety of forms of life. When we realize fully how admirably each organism is fitted to some particular niche in nature, we cannot doubt that the more varied the environment, the more varied the life. Some of the niches which the seashore offers may be 
recognized by any one who travels along the coust. ITe may see alorupt rocky promontoriess whose hises stamb in many fathoms of water. Against such a wall of rock the restless sea

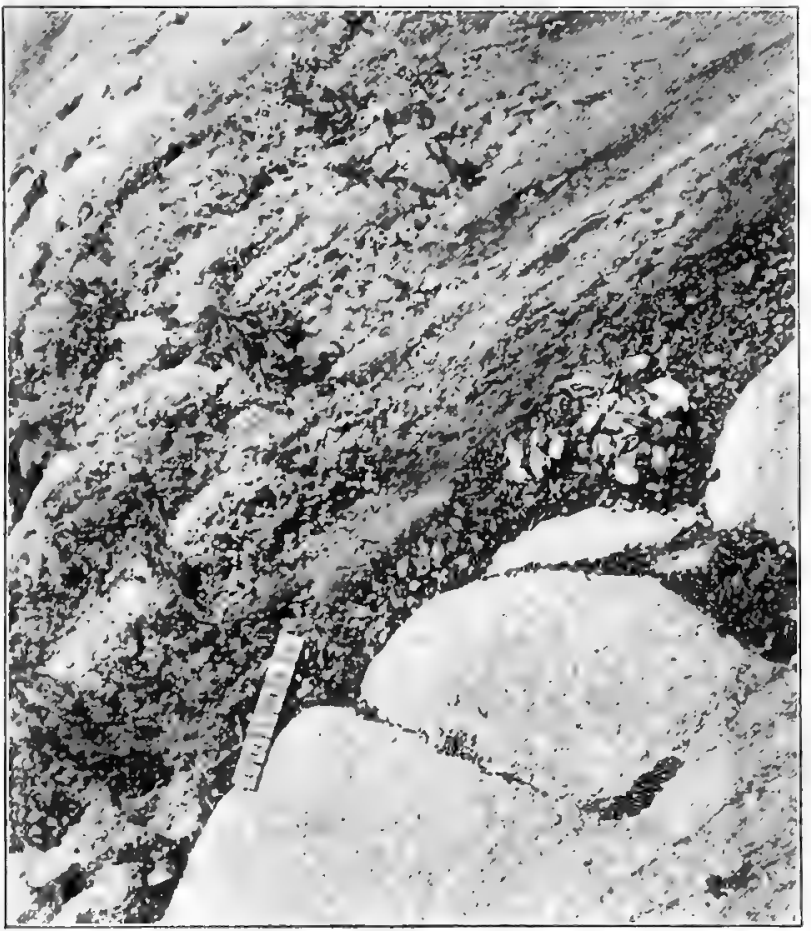

Fig. 174. - I hit of the recky shore, and its arlhering organisms. It the left some brown staweed, at the right bunches of nussels lying in crevices of the rock, in the centre and above barnacles adhering to the rock.

is ever hurling itself, wearing the rocks smooth by its repeated beatings, and yet the crevices of these same rocks are occupied by many kinds of animals. These aro alse to maintain their place either by being rooted to the rocks, like the 
hydroirls, the sponges, ${ }^{1}$ the mussels, and the barnacles (Fig. 174), or else they have some device for clinging fast, as in the case of the starfish, and many snails and crabs. At the opposite physiographic extreme we find the sea penetrating as a harbor deep into the mainland.2 The boundary between the sea and the land is in these cases often very uncertain

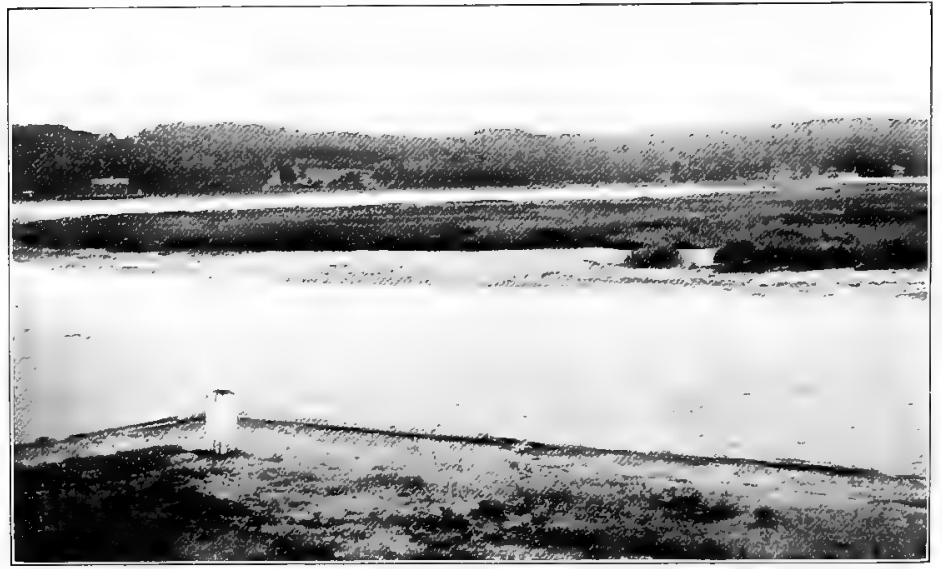

FIG. 175. - An enclosed harbor or arm of the sea penetrating deep into the mainland.

hecallse the semiaquatic plants grow far out into the water, forming the edge of a salt-marsh. Here twice a day the sea bottom is exposerl to the air by the retreating tide, and terrestrial animals wander out upon it to feed. In this situation the permanent animals are those that burrow in the mud or penetrate hetween the roots of marsh-grass or swim ahout on the surface of the water (Fig. 176). These animals feed on the débris thut floats on the surface of the water or else crawl about on the hottom to browse on the algx which flourish 
there. These animals of the quiet harbor are mostly weak and defenceless; they seek chiefly to avoid their enemies by retreating from thern. Between the rocky promontories and the salt-marsh exist all possible gradations, and in each different habitat one will find a totally different fauna.

In this chapter we shall consider an animal living in the bottoms of harbors, known as the sandworm (Ne'reis). It

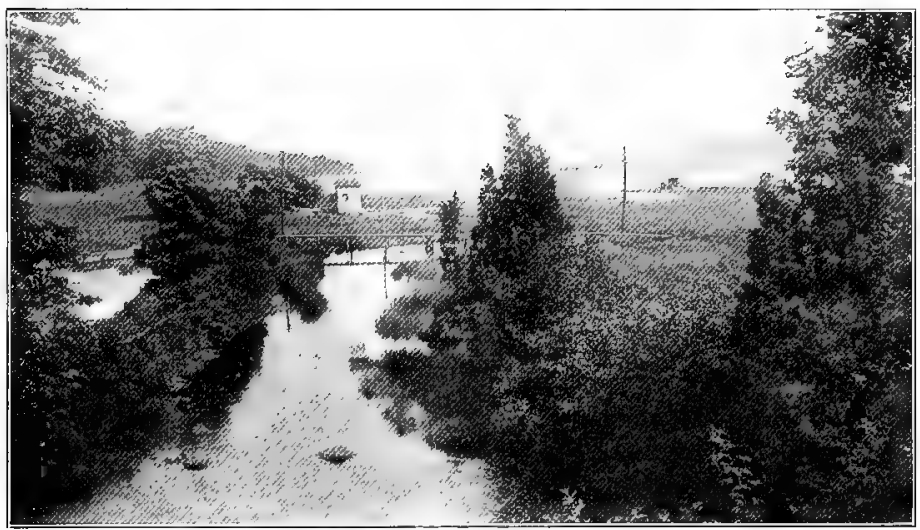

FIG. 176. An estuary with a salt-marsh in the distance where semiaquatic plants grow far out into the sea.

abounds in sandy or muddy beaches at or below low-water mark and is especially ahundant where tidal currents flow swiftly, thus constantly renewing the water, oxygen, and food particles. Nereis is, for the most part, a lover of darkness and contact. Hence it inhabits burrows which it. lines with a secretion of mucilaginous consistency that hinds together the particles of sand or mud. For a week or two in summer, however, during the breeding season, Nereis gains a new set of instincts. It leaves its burrows and swims about near the surface of the sea. 
Nereis lives on both plant and animal food. To capture its prey it thrusts out a long proboscis, provided with two power-

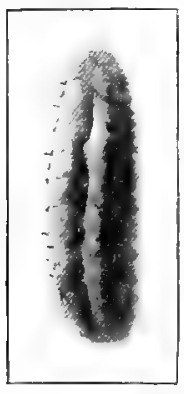
ful jaws. The thrusting-out consists essentially of a rolling inside out, - just as the finger of a glove may be rolled inside out. When the proboscis is rolled in again, the jaws, retaining their grip on the food, carry it into the food canal. ${ }^{1}$ While many kinds of small animals serve Nereis as food, it is itsclf devoured by varions fishes which dig it out of the sand or capture it when it swims free at night FIG. 177. - Lep-
idonotus, the during the breedscaled worm. ing season. Such a Nat. size. favorite with fishes
Photo. hy $W$. favation H. C.P. naturally makes excellent bait, and is well known to fishermen under the name "clamworm " or "sandworm."

We have seen that Nereis lives for a short period each year a free life, swimming in the sea. Accordingly its body is divided into rings of muscle enabling it to writhe. Locomotion by writhing is further facilitated by the existence of a pair of appendages (parapodia) on each segment. The appendages are nearly alike on all the segments of the body. They diminish in size, FIG. 178.-Aphrodite, a sea-mouse. however, toward the tail. Cor- Nat. size. From Johnston.

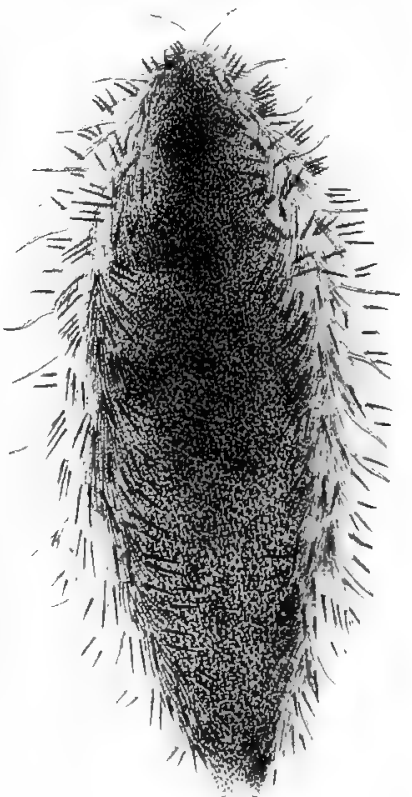


related with its carnivorous life are its powerful jaws and welldeveloped sense organs on the head. These consist of eyes, feelers, and tasting organs.

From such forms as Nereis there has developed a long series of worms inhabiting the sand or constructing special tubes in which to live. At the end of the series there are included worms that live permanently in thin limy tubes and have lost the locomotor and sense organs of Nereis. We shall examine in order some of these different worms and shall observe certain modifications in structure which they undergo in relation to their modified life.

But first we should know that not all free-living, marine annelids are like Nereis. On the one hand we have forms that do not burrow at all in the sea bottom, but which lie so close to stones and shells that they seem to form a part of them. Their flat body is covered with scales, and they are known as scaled-worms (Fig. 177). In a few members of this group, known as " seamice" (Fig. 178), the scales are hidden from view by long bristles. These bristles are merely greatly enlarged represen-

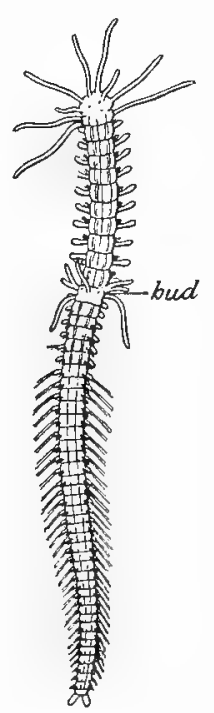

FIG. 179. - Autolytus, a representative of a family of Polycheta in which the animal buds off male or female individuals from it: hinder end. bud, head of the budded individual. After A. Agassiz. tatives of the bristles found on the swimming pads of Nereis.

A second form (Autolytus ${ }^{1}$, Fig. 179) lives in little tubes attached to seaweeds and hydroids. Its method of repro-

1 autos, self ; luo, to separate; hence, self-separating. 
duction is remarkahle. The same method, however, occurs in different guises in many other free-living annelicls. In this form the parldles or parapodia at the anterior half of the animal are different from those at the posterior half, for the

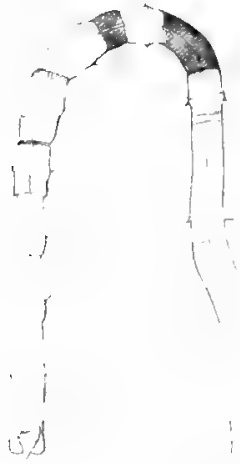

Fig. 1>0. - Clymenella, straw-worm. The anterior segments only are shown. After M. Lewis. latter are large and fitted for swimming. Eventually one of the middle segments of the horly becomes transformed into a head, bearing eyes and tentacles; then the whole of the hinder half breaks off "of itself." The newly formed head is now the head end of the new individual. This individual leads a different kind of life from the half which remains in the tube, for it swims freely in the water. The separated individuals are either male or female, whereas the part which lives in the tube never produces eggs, but merely forms a new tail every time the old tail is cut off to form a sexual individual.

We have now to consider the non-locomotor or sedentary Polychrta. The first of these is not greatly changed from the frec-living type. This is Clymenella (Fig. 180), which looks like a redclish, jointed straw. It builds tuhes of agglutinated sand in which it spends much of its life. Parapodia occur on each segment, but they are very small. Amphitrite (Fig. 181) builds firm tuhes of sand. Its parapodia are rudimentary behind. The function of respiration is carried on by three pairs of paraporia which are borne on the hearl. These are immensely enlarged, forming blood-red gill tufts. Amphitrite has many close allies that show different stages of degeneration. Thus the 
worm known as the "blood-spot" (Polycirrus, Fig. 182) is reduced in size, and instead of gill tufts it has a large number of

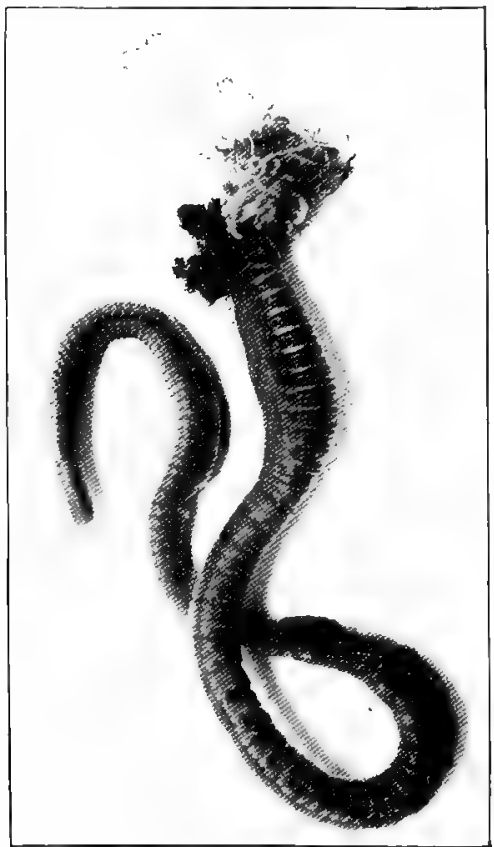

FIG. 181. - Amphitrite, removed from its FIG. 182. - Polycirrus, the blood tube. Nat. size. Photo. by W. H. C. P.

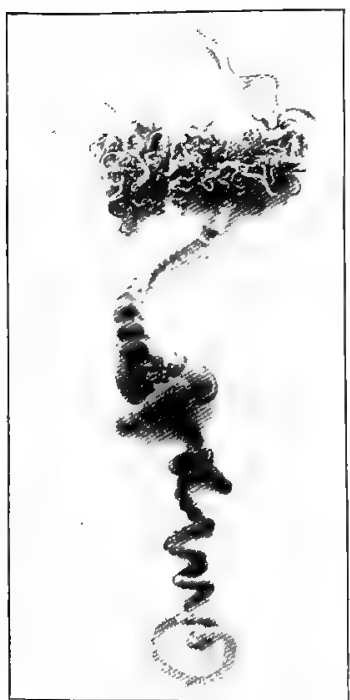

spot. Nat. size. Photo.

thread-like organs, the cirri, at the head end. Certain species, such as Cistenides (Fig. 183), form complicated tubes out of grains of sand cemented together in a regular arrangement so as to form a firm wall.

Finally, Serpula ${ }^{1}$ secretes crooked, round, calcareous tubes, which may be found adhering to stones near low water 
(Fig. 184). From the mouth of the tube the head, with its tentacles, may be protruderl, but it quickly retracts from danger

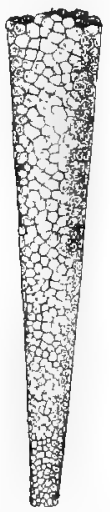

FIG. 183. - Tube of

Cistenides slightly enlarged. and closes the opening of the tube, as a marine snail does its shell, by means of an operculum or lid.

We have now to consicler some groups of worms which differ from the annelicls in not having the trunk composed of a series of rings. The first of these is the group of nemerteans (Nemertini, Fig. 185). It includes chiefly marine animals, of somewhat flattened form and great length, even as great as thirty metres. They protrude a long, slender proboscis. The body readily breaks up into a great many pieces when the worms are handled roughly, but since each of the pieces may regenerate into an entire worm, this behavior is not self-destruction, but self-preservation. These worms are especially abundant in the sand of the seashore, although land nemerteans occur. The other two groups of unringed worms have gained a parasitic habit, and in consequence have become much modified in form

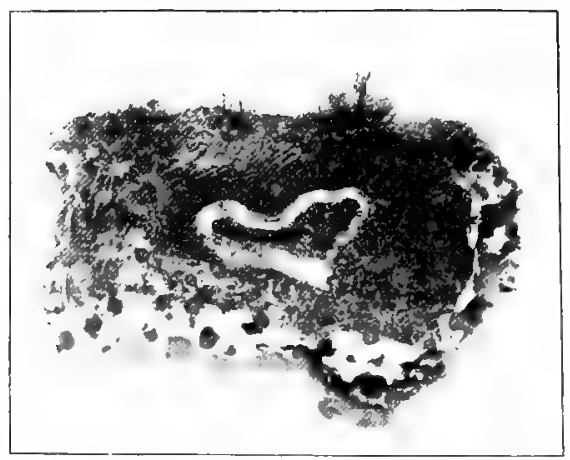

FIG. 184. - Serpula tube on a bit of oyster shell that is perforated by the boring sponge. The tube lies in the centre of the figure. Nat. size. Photo, by W. H, C. P. 
and structure. Such is the case with some of the roundworms. Some of these are thread-like, live in springs or pools, and are regarded by the uninitiated as animated horsehairs. Others are spindle-shaped, as, for example, the "vinegar eel" and the roundworms that are common in stagnant water. Others live in the food canal, as, for example, the stomach-worm (As'caris) of the horse and the pinworm of man. Others still penetrate into the muscles, and cause great pain and often death. Such is the porkworm (Trichi'na ${ }^{1}$ ), which gets into man by means of uncooked pork, multiplies in the food canal, migrates in great numbers into the muscles and encysts itself there (Fig. 186).

The second group that is partly parasitic is that of the

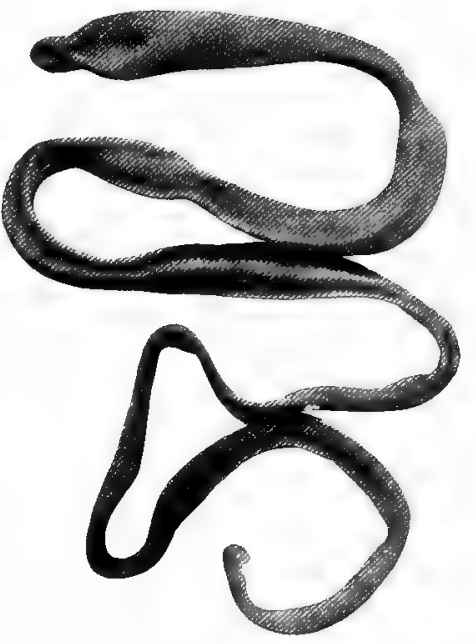

FIG. 185. - Cerebratulus, a cream-colored nemertean. Head end at upper part of figure; mouth turned toward observer, proboscis retracted. Instantaneous photograph of living worm by W. H. C. P.

flatworms. Some flatworms live free in ponds. They will be found abundantly among plants taken from small ponds in the summer and autumn, and are commonly known as Plana'ria ${ }^{1}$ (Fig. 187). They may he recognized not only by their flattened form, but also by a curious proboscis which protrudes from the middle of the under side of the body and hears a mouth at its tip. These creatures have a marvellous power

$$
1 \text { thrix, hair. }
$$

${ }^{2}$ planus, flat. 


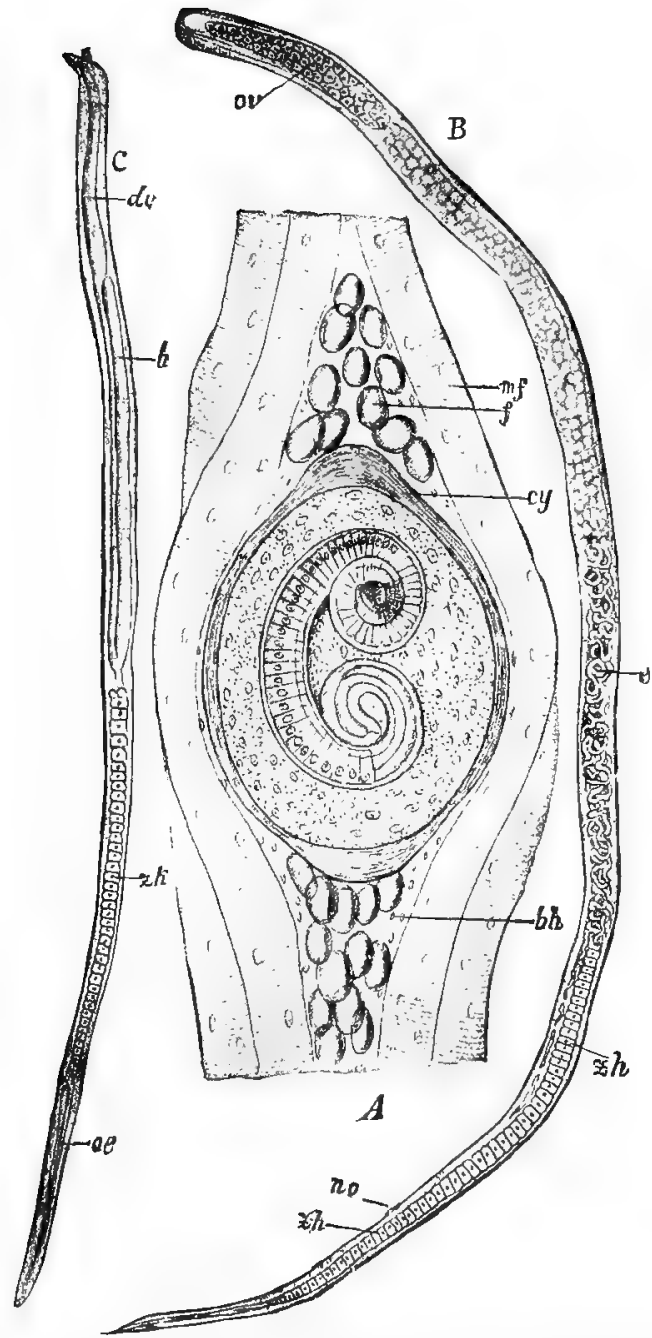

FIg. 186. - Trichina. $A$, encysted form in muscle of pork ; $B$, female ; $C$, male; $b h$, envelope of cyst; cy, cyst; $d e$, male duct; $e$, embryos; $f$, fat globules; $h$, testis; $m f$, musele fibre ; oe, pharynx ; ov, ovary ; no, opening to egg duct; $z h$, cell masses in intestines. After Claus. 
of regeneration, so that every piece into which a worm is cut will reproduce an entire one (Fig. 188).

Other flatworms are parasitic, such as the liver-fluke of the sheep (Fig. 189). This destructive parasite has a complicated series of stages to go through before it becomes adult. Thus the flukes in the liver of the sheep produce eggs which develop into embryos. These embryos get out of the liver into the food canal, and thence to the exterior. If they are deposited near a pool of water, they may develop further; otherwise they must die. In the water a ciliated larva ${ }^{1}$ hatches from each egg, swims about for a time until it finds a fresh-water snail, hores into it, and encysts itself there. In this encysted stage the worm is known as a "sporocyst," because it is full of germs (spores) of a new generation. $^{2}$ The spores develop in the snail into curious organisms, a sort of secondary larvæ known as redia. The redix may produce, by a lind of internal budding, new rediæ, and so on repeatedly, until at last, on the
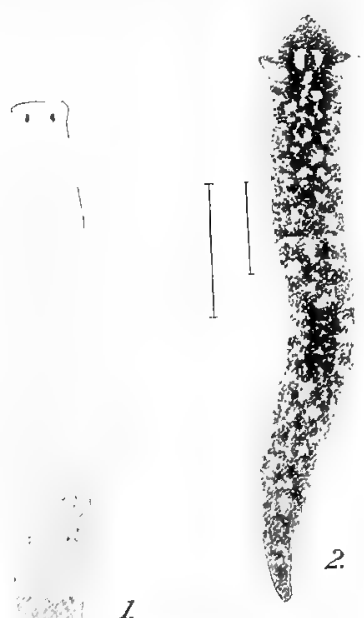
I.
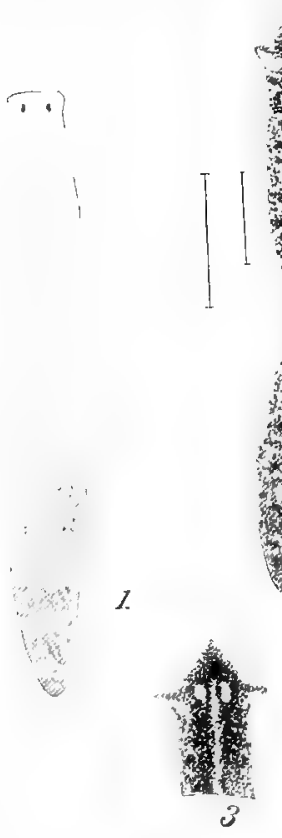

FIg. 187. - Species of fresh-water Planaria. 1, Dendrocolum lacteum, crean color; $2, \mathrm{Pla}-$ naria maculata; 3 , head end of same to show light streak. After Woodworth.

death of the snail, or from some other cause, the last generation of rediæ produces liver-flukes. ${ }^{4}$ The young liver-flukes wriggle

1 Fig. 190, A.

${ }^{2}$ Fig. 190, B.

${ }^{3}$ Fig. 190, C.

4 These, while young, have tails, and are called "cercaria," Fig. 190, D. 
out of the snail, attach themselves to damp grass, lose their tails, and encyst themselves. If these cysts be eaten by a sheep, they develop in the sheep's body into an adult liver-fluke

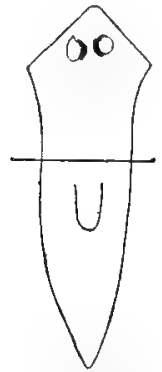

Dec.10.
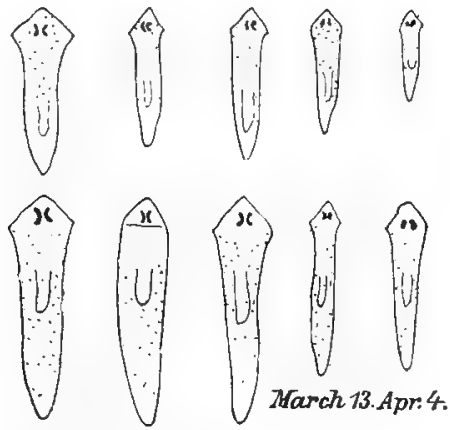

Jan.25. Feb5. Feb.17

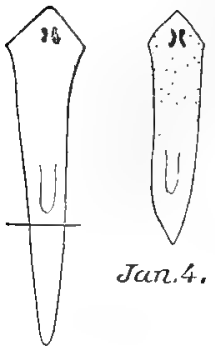

Dec. 10.
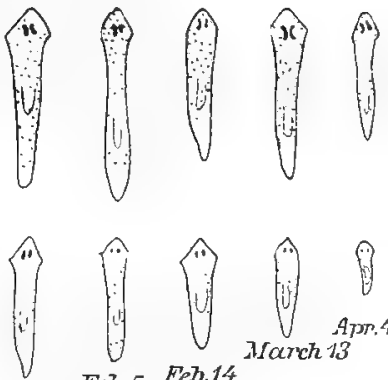

Jan. 25 .

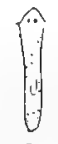

Feb.5.

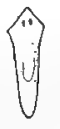

Feb. 14

FIG. 188. - Showing results of cutting Planarians into two pieces; the pieces develop into entire animals. After Morgan.

(Fig. 189). Thus the stages which we can recognize in the liverfluke are :

First generation : egg from liver-fluke, larva, and adult sporocyst.

Second generation: redia (this may be several times repeated).

Third generation: "cercaria" larva, encysted larva, and adult liver-fluke. 
Another flatworm is such an ahject parasite that it has lost most of the organs usually possessed by worms. This is the tapeworm (Fig. 191). When the eggs of the tapeworm are taken into the body of an herbivorous animal, the embryos develop there for a while and then stop. When flesh containing these embryos is eaten by a carnivorous animal, the emhryos attach themselves to the food canal of their host by means of hooks and sometimes also by means of four suckers. The head thus constituted (called scolex) produces, by rapid growth, a long chain of segments, each of which is full of germs. The chain, or "tape," absorbs fluid food, which soaks through its body-wall. As the segments at the older end of the animal mature, they are set free and pass out of the alimentary tract to be picked up,

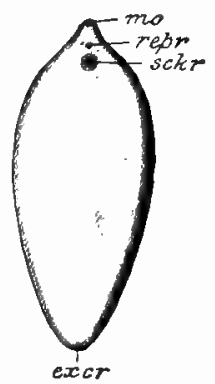

FIG. 189. - Distomum, the liver-fluke. Nat. size. Excr, excretory pore; mo, mouth; repr, reproductive aperture ; sckr, posterior sucker. From Parker and Haswell. perchance, in the food of an herbivorous animal or else to perish.

The tapeworms are remarkable because they show to what extremes of degeneration a parasite may go. They have lost so fundamental an organ as the food canal. All complex sense-organs and organs of locomotion are lacking, and the worms have become mere sacs of reproductive cells. This is the usual tendency of internal parasites, - to multiply enormously their means of reproduction so as to increase the chance of infecting another host. On the other hand, the sense-organs, hrain and nervous system, and muscles tend to degenerate because the parasite has little use for them. 
The economic importance of parasitic worms is very great. Thus, although no great epidemics of the flukes have occurred in this country, a million sheep are annually lost by this parasite in Great Britain; and in 1879 and 1880 it was estimated that three million sheep died annually in England alone of
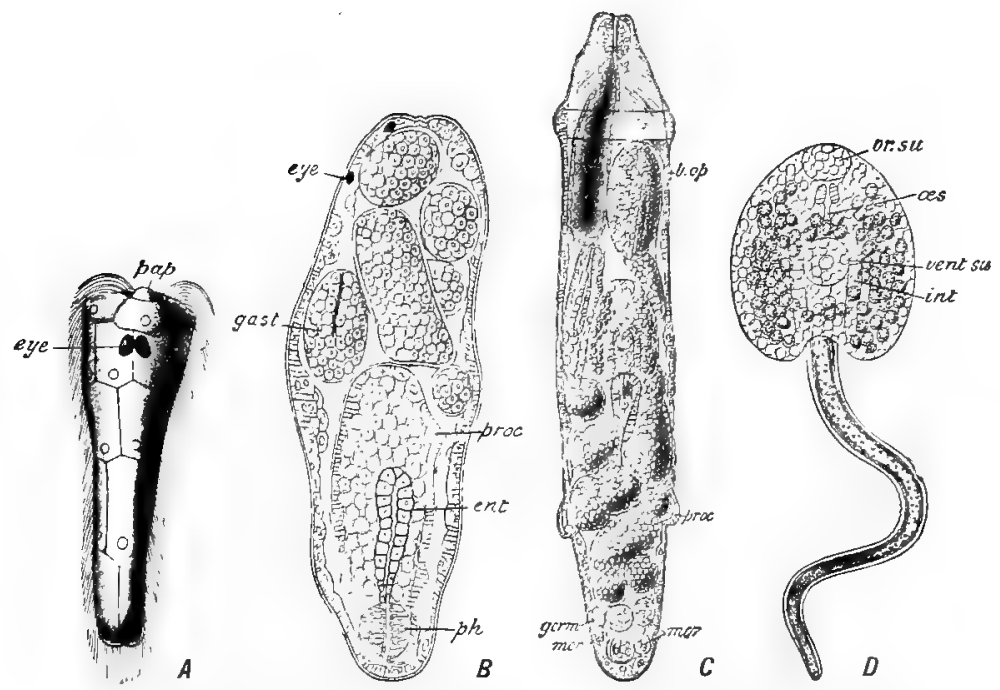

FIG. 190. - Development of Distomum. A, ciliated larva; $B$, sporocyst containing developing redixe; $C$, redise, containing a daughter rediæ and embryo liver-flukes; $D$, free-swimning, tailed larva of liver-fluke; $b$. op, birth opening; ent, food canal of redia; eye, eyespots; gast, young redia; germ, mor, early stages in formation of the embryn liver-fluke; int, intestine of larval liver-fluke; res, oesophagus ; or. su, oral sucker; pap, head papilla of ciliated larva, $A$; $p h$, pharnyx; proc, processes of redia; vent. su, ventral sucker. After Thomas.

this parasite. In Buenos Ayres, luring 1882, a million sheep died of fluke disease. By great care in preventing infection, especially during damp seasons, we may be able to prevent any such disaster in this country. 


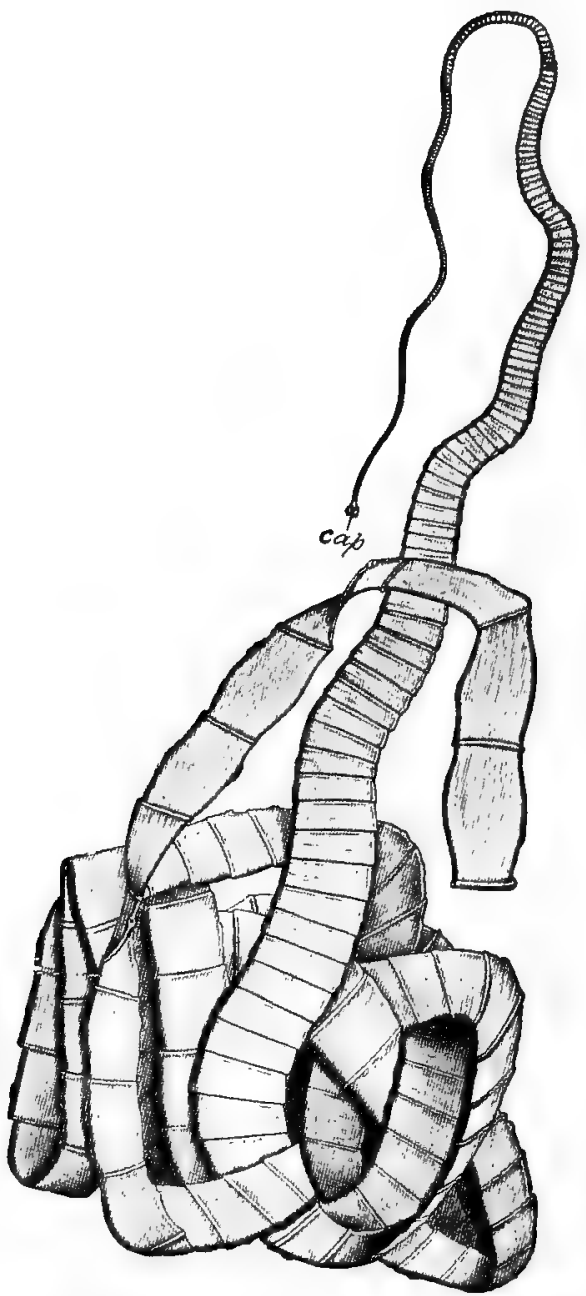

FIG. 191. - Tania solium, the human tapeworm. Entire specimen, about natural size. Cap, head. After Leuckart. 


\section{CHAPTER XIV}

\section{THE ANATOMY AND PHYSIOLOGY OF MOLLUSCA: ILLUSTRATED BY THE SNAIL}

General Form of the Body. - Mollusks are non-segmented animals; Cuvier spoke of them as "massive" animals, since their form is usually short and stout in strong contrast with that of the elongated worms. They have a right and a left side and a dorsal and ventral surface, but in many mollusks, as in the snail, the body is coiled into a close spiral, so that the primitive bilateral symmetry is obscured. In view of the fact that of the three main groups of the mollusks - lamellibranchs, gasteropods, and cephalopods - two are almost exclusively symmetrical and the third (gasteropods) contains a great number of synmetrical forms, we may conclude that bilateral symmetry is the prinitive condition for mollusks and that the spiral of most gasteropods is a special and recent modification. Such a spiral shell was probably originally a conical cap over the body. As this cap was built up at the edge to accommodate the increasing bulk of the growing young, it elongated until finally it formed a long, unwieldy cone. The most convenient and compact form for storing such a body is a spiral or helix. This is the conclition of the shell of most gasteropods; it is well illustrated by the common snail.

The soft body of the mollusk is usually supported and protected by a shell (Fig. 192). This is formed from the skin, here called "mantle," whose glands pour out a secretion that 
hardens in contact with the air or water. Increase of the shell takes place chiefly at the margin. Here the three layers of which the shell is composed are secreted - the prismatic layer (Fig. 192, prs) made up of prisms whose axes are perpendicular to the surface, the thin outer varnish which serves to protect the shell from chemical action and bears most of the characteristic coloration of the shell ( $p r c$ ), and, inside the prismatic layer, thin sheets of lime $(n)$ which are secreted not only at the margin, but farther back on the mantle. The shell of a bivalve has essentially the same structure.

The skin of mollusks

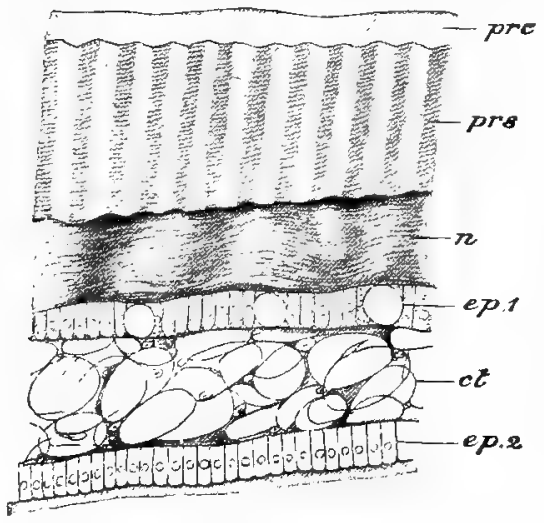

FIG, 192.-Cross-section of the shell and mantle of Anodonta. ct, connective tissue layer of the mantle; $e p .1$, its outer cell-laycr ; cp. . , it sinner cell-laser ; $n$, "mother of pearl" layer of shell; prs, prismatic layer; pre, "periostracum" or outer varnish, also called "epidermis." From Parker and Haswell.

is relatively soft, but in land species like the garden snails it gains a considerable thickness and is, moreover, abundantly provided with glands which pour out a mucus over the skin when it becomes too dry, thus preventing further loss of water. The outer wall of the body has always an organ characteristic of mollusks; namely, the mantle. In lamellibranchs this is a great pair of folds arising from near the mid-dorsal line of the body and reaching down on each side to the mid-ventral line. This is the organ that secretes the two valves of lamellibranchs. In gasteropods (Fig. 193) the 
mantle fold is less conspicuous because it is hidden deep in the spire, but the edge of it may be seen protruding from the margin of the aperture. In the naked mollusks - e.g. the slugs - the mantle appears as a reduced cap on the back of the animal.

Appendages are not present in most mollusks; locomotion is effected in the snail by the whole ventral part of the body

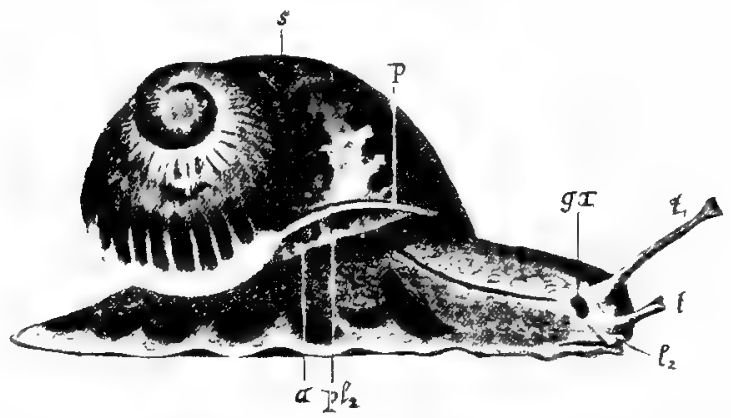

Fig. 193. - The snail Helix aspersa, fully extended from the right. After

Howes. $a$, anus at edge of mantle; $p l_{2}$, the breathing pore; $s$, shell; $p$, edge of "aperture" of shell ; ga, the genital aperture; $t_{1}$, one of the two tentacles carrying the eyes; $t$, anterior tentacles; $l_{2}$, upper lip. From Lang.

- the foot. In these animals a great mucus gland lies just above the skin of the foot and pours out, from near the anterior part of the body, a stream of mucus over which the animal glides. The different modifications that the foot shows in different mollusks are considered in the following chapters. In contrast to the foot the head bears very characteristic appendages - the tentacles, which can be rolled out of harm's way or be stretched to an extraordinary distance.

Organs of Nutrition. - The different species of mollusks feed on almost every kind of organic stuff, from the fine organic débris suspended in water to the succulent green leaves of 
gardens, and even on live animals, including those of their own species. In snails the mouth lies in a large head bearing various sense-organs. Just inside the mouth a short gullet leads to a tough pad upon which is a file-like rasping organ called the radula (Fig. 194). The teeth in one cross-row are not all alike as in a file, but vary in a complex way that differs in

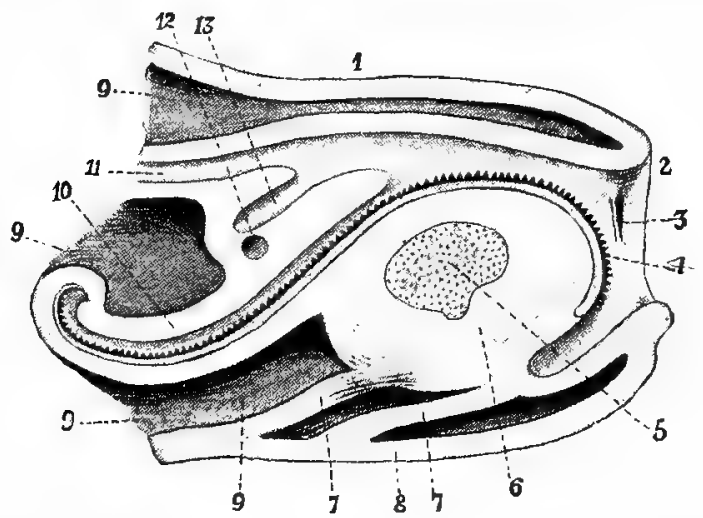

FIG. 194. - The snout of a snail cut vertically and lengthwise to show the mouth and rasping organ. 1, Dorsal wall of head; 2 , mouth; 3 , jaw ; 4, radula ; 5, eartilage of tongue ; 6 , muscular wall of pharynx ; 7, museles running from pharynx to ventral wall of head ; 8 , space in head for withdrawal of tongue; 9 , pocket for radula; 10 , œsophagus; 11 , opening to salivary gland ; 12 , fold behind radular pocket. From Lang.

different species; the successive cross-rows are, however, very similar. The teeth are composed of a tough, hard substance (chitin), but the front rows, which are those that are in action at any time, eventually wear off and are replaced by new teeth that push forward. During feeding, the hard edges of the mouth or " jaws" are protruded, and the food is dragged into the mouth and cut into small pieces which then pass on to the fleshy pad, where they are rasped or grated by the radula. Thence the food passes through an œsophagus to an enlarged 
part of the foor-canal called the crop. On the crop lie the salivary glands (Fig. 195, 10), and the first stages of digestion occur here. Beyond the crop is the stomach (14) into which opens the great digestive gland (11). Here is done the main work of rendering fluid the usable parts of the food; the digested portion enters into the blood, the unusahle portion passes through the intestine to the anus (18) which by a loop is brought not far from the head, so that it may be exposed outside of the shell when the animal is expanded (Fig. 193). Thus we see that the striking peculiarities of the food-canal are its radula, its huge digestive gland, and its $U$-shape.

The digestive organs of the lamellibranchs lack the radula and crop, but there is an enormous liver in the midst of which the food-canal seems to lie. The anus is situated at the opposite end of the animal from the mouth. In the case of cephalopods there are jaws and a radula; also the large digestive gland occurs and the anus lies well forward. In their digestive apparatus the cephalopods closely approach the gasteropods.

Organ of Respiration. - In most aquatic gasteropods there is at least one gill (occasionally two) lying close to the inner wall of the mantle cavity (Fig. 196). The gills consist of numerous finger-like processes in which the blood-vessels run. Water that is brought into the mantle cavity bathes the gills which extract oxygen from it. In cephalopods are one to two pairs of plume-like gills lying in the mantle cavity. In common snails on the other hand, owing to their terrestrial life, the gill is wholly wanting and the whole mantle cavity becomes a lung richly provided with blood-vessels. As stated elsewhere, air-breathing mollusks can respire through the whole surface of the body. 
Organs of Circulation. - In mollusks there is a dorsal heart usually consisting of two chambers: one, the auricle (Fig. 196, aur), receives the blood from the respiratory organs; the other,
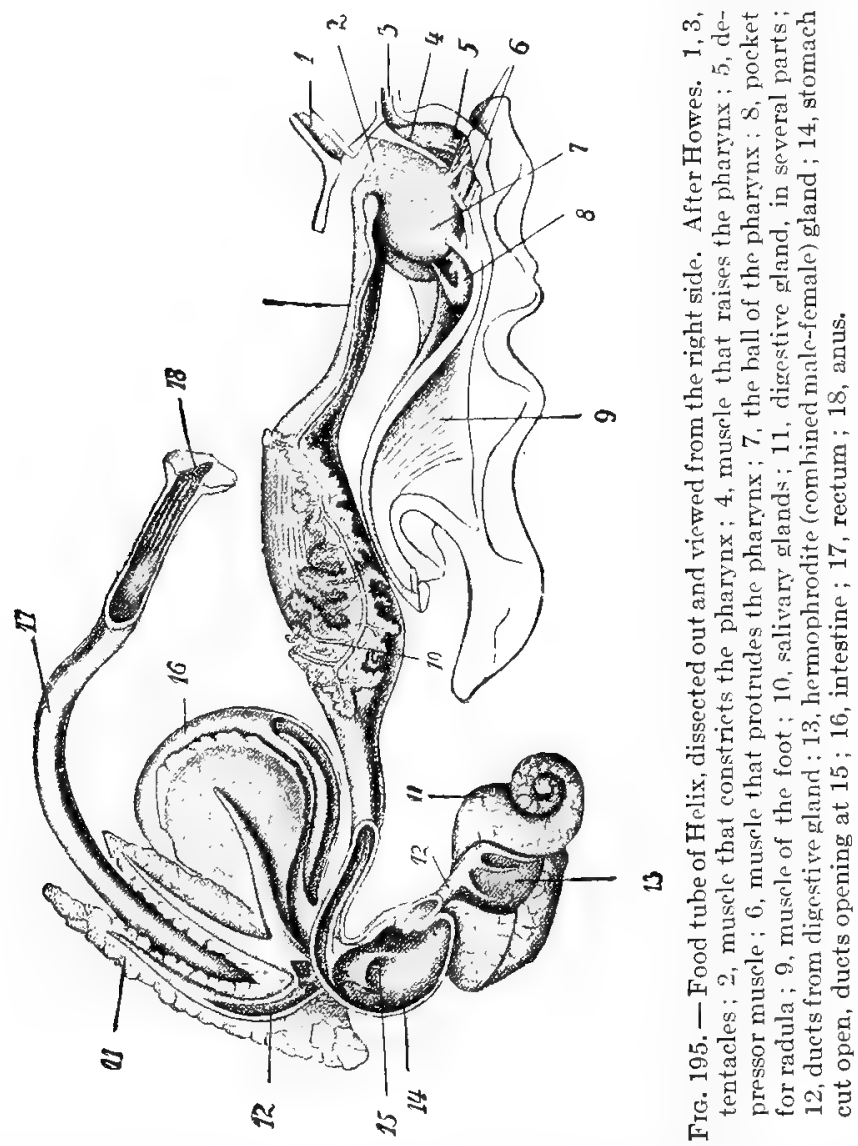

the ventricle (vent), pumps it onward to the different parts of the body. In the snail the circulation is as follows: The 
blood that is forced out of the ventricle finds almost immediately two paths open to it; one large vessel (post. aort) goes to the digestive gland, the intestine, and part of the reproductive organs, while the other vessel (ant. aort) leads to the main muscles of the head and foot, the stomach and crop, and to such of the reproductive organs as are not supplied by the first artery. Over each organ the artery breaks up into the finest capillaries so as to come into most intimate contact with the tissues, where it does its work of receiving or conveying fluid food and oxygen. Beyond, these capillaries flow together into veins by which the blood is carried to the mantle chamber or lung. Here is another capillary system in which the blood is aerated and out of which it is collected into a large vein that leads directly to the auricle of the heart.

The blood of the snail, as of most other mollusks, is colorless. However, on exposure to the air, so that it can absorb oxygen, it turns slightly bluish. This change of color is due to the oxidation of a substance that carries oxygen from the respiratory surface to the tissues, just as the red coloring matter (hem'oglobin) of our blood does. The oxygen carrier of mollusks is called hem'ocyanin. A few mollusks have also hemoglobin in the blood.

FIG. 196. - Dissection of a large marine snail, Triton. The mantle cut along dorsal line leaving gill on left flap and rectum on right, pharynx, crop, and kidney cut into to show structure. an, anus; ant. aort, artery going to head; aur, auricle (receiving ehamber) of heart; buc, cavity of pharynx; cer. buc.con, nerve connecting pharynx to brain (cer.g); cten, gill; int, intestine; $l$. buc. $g$, left pharyngeal ganglia; $l$. sal. $g l$, left salivary gland; neph, kidney and its opening (neph. ap) ; od, odontophore ; oes, cesophagus, cut at oes' ; osph, "osphradium," a taste organ ; ovid, oviduct ; pluer. o, ganglion supplying the viscera; post. aort, artery to viscera; post. oes, part of osophagus behind crop; rad. $s$, radula sack; rect, rectum; sal. du, salivary duct; siph, siphon; supr. $\theta$, ganglia above viscera; tent, tentacle and its nerve, tent. $n$; vent, ventricle of heart. 


\section{ANATOMY AND PIIYSIOLOGY OF MOLLLSCA 205}

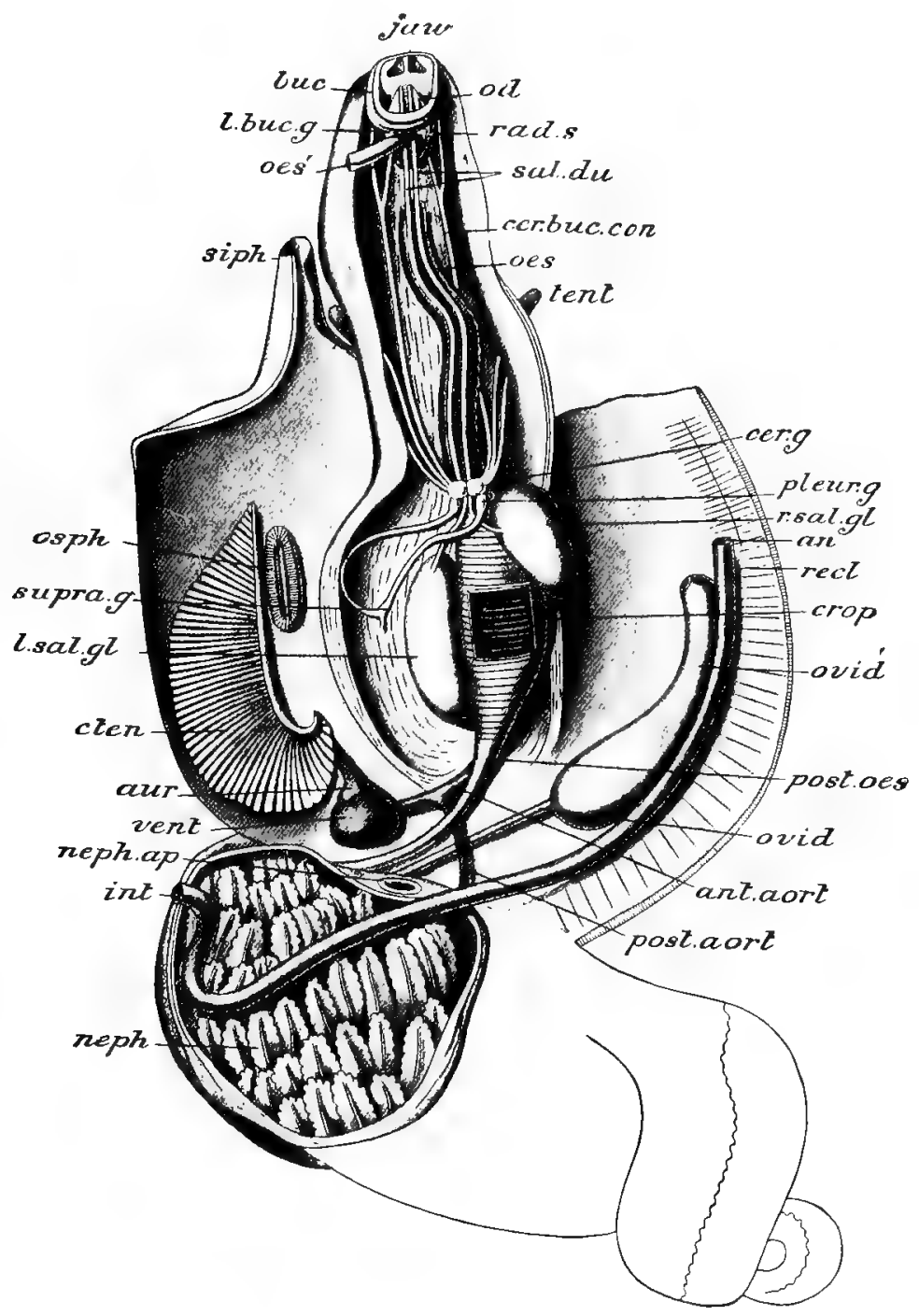


Organs of Excretion. - Mollusks have well-developed kidneys which are paired in most symmetrical species; but in unsymmetrical species, like most gasteropods, only one is present. In the snail the kidney lies close to the heart. It opens on the one hand into the body-cavity surrounding the heart and, on the other, into the mantle-cavity near the anal opening behind the right eye-stalk.

Organs of Reproduction. - The sexes in mollusks are usually separate, but in land-snails the eggs and sperm-cells are produced in different parts of one and the same gland. The eggs on their way out receive a large amount of albumen from a gland, and further down in the oviduct an egg membrane is secreted. The eggs of land-snails are laid at various times of the year in bunches in moss or under hoards and leaves, and are clear, translucent little spheres about two millimetres in diameter.

Musculature. -- The whole skin in the snail is highly muscular, but the muscles gain their greatest importance in the foot, where they assist in locomotion. Important muscles run to the head from the visceral region, and it is by them that the head is retracted into the shell (Fig. 195, 5-7).

Nervous System.-- The nervous system of mollusks is very different from that of annelids and Crustacea. There are a few pairs of knots of nerrous matter or ganglia. The tro menbers of a pair are united by nerves, and each ganglion is connected with the brain. The hrain is a pair of ganglia (Fig.196, cer.g) lying over the cesophagus. It sends out nerves forward to the various sense-organs of the hear and backward to a pair of ganglia lying just below the oesophagus and to a second pair lying in the foot. These lower ganglia receive nerves from the skin and its muscles, and from the various viscera. Thus 
the whole nervous system is characterized by the compactness of its central ganglia.

Sense-organs. - The sense of touch seems to reside in all parts of the skin, but is best developed in the tentacles. Snails have a delicate chemical sense. Those that live in water will direct themselves toward a bit of food when a current from the food bathes their bodies. A land-snail will apparently smell food several centimetres away. The chemical sense seems to be located either near the opening of the mouth, or, as in some marine snails, in a special organ located on the mantle wall and known as the osphradium (Fig. 196, osph). Eyes are placed in the garden-snail at the tip of the upper tentacles. The eye, which can be retracted into the tentacle, consists of a nearly globular cup containing a central lens and a retina. It is doubtful whether, despite the long-stalked eye, snails can see far; indeed, they are nocturnal animals and live in dark places during the day, so that they could not make use of a very delicate and perfect optical apparatus. Eyes occur also in lamellibranchs and cephalopods. They are numerous on the mantle of the scallop, and the squid has a pair of very perfect eyes. As for hearing, there is little evidence that snails have this sense. The "otocysts" that are found in most gasteropors are probably (like the otocysts of higher crustacea) organs of equilibrium. 


\section{CHAPTER XV}

\section{THE SLUG: A STUDY IN ANIMAL BEHAVIOR}

EVERY movement that an animal makes is a response to some stimulus applied to its contractile substance. This stimulus may be applied directly to the contractile substance; as, for example, when a muscle is pinched. Thus if we pinch the muscle of a frog's leg after the leg has been removed from the body, the muscle that has been irritated will contract. The stimulus may, however, be applied indirectly, as when we dodge a ball moving near us. In this case the sight of the ball stimulates the eye, a message is sent to the brain and from the brain to the muscles which produce the dodging. In either case it is clear the movement results from some stimulus. With the exception of a possible origination of a stimulus in the brain itself all movements are reactions to some external stimulus. Now the stimuli which affect us are those changes in the external world for the appreciation of which our body is provided with certain parts called sense-organs. We have a sense-organ for receiving the stimulus of light, the eye. We have sense-organs for appreciating the contact quality of bodies including vibration, the organs of touch and of hearing. We have organs for testing the chemical qualities of substances, the organs of taste and smell. We have organs for detecting changes of temperature. These lie scattered in the skin over the whole surface of the body. We have organs for appreciating pressure, both its direction and its amount, and especially we can appreciate gravity when we move up or down. By 
means of all these senses then, and of certain others, we not only become aware of the world about us and of what changes are taking place in it, but our behavior in this world is determined.

What is true of ourselves in respect to the determination of our behavior by environment is true of all other animals, for man is, indeed, in respect to his senses, merely one of the animals. When we turn over a stone (Fig. 94), and see a number of insects under it, hastening away until finally all have become hidden again, we may be sure that this rapid movement is in response to the stimulus of light, which suddenly falls upon them, and to the withdrawal of the comfortable contact with the stone above. The movement to which the animals have been stimulated will he found to be, for the most part, away from the light. This tends to bring them into a darker region, and if in the neighborhood they find a crevice or hole, they will come to rest there. So, too, if we look at a stream full of trout, we shall find that they all stand with their heads directed up-stream. They are responding to the moving current which would tend to carry them away.

When we see a ladybird beetle in the autumn climbing up the side of a house, or a potato beetle climbing up a potato plant, we may be sure that they are reacting to the guiding stimulus of gravity; and when we see flies coming toward a bit of carrion, flying against the wind, we may be sure that they are directed in their movements by the chemical particles conveyed by the wind from the carrion to their sense-organs.

No group of animals better illustrates the principles of animal behavior than the slowly moving snails and slugs. They are not only sensitive to a great variety of stimuli, but the great deliberateness of their movements enables us to 
study their reactions to different stimuli, taken one at a time. In this chapter we shall consider the different sorts of animals related to the slugs and snails, with special reference to their behavior.

The slug belongs to the group of Mollus'ca $^{1}$ clefined as animals which possess two distinctive organs - the foot, hy means of which locomotion is effected, and the mantle, a fold of skin covering over or enclosing a greater or less part of the borly. The mantle usually secretes on its outer surface a calcareous shell. Exceptionally, both shell and mantle may be entirely absent in the adult. Among the Mollusca the slug is placel in the class Gasteropoda. The front part of the body, called the head, hears the sensc-organs which are in nervous connection with a brain situated just over the mouth. The foot is an unpaired organ situated upon the ventral side of the borly and is used to crawl upon. It is rather remarkable that, despite the slowness of its locomotion and the ease with which the movements associated with locomotion can be stuclied, the exact mechanism of locomotion in the slug is unknown. The slug exudes a constant stream of mucus from the mouth of a sack situated just over the sole of the foot, and this stream of mucus seems to be the apparatus of propulsion. The stream of new mucus impinges upon that already thrown out and the reaction drives the animal forward. Crasteropods " usually have an external shell, but some species are without it, as is the case with the slug. When the shell is present, it is made of one piece; that is, it is univalve.

Slugs belong to the group of air-breathing, land-inhabiting gasteroporls, or Pulmonata. ${ }^{3}$ They may be found in the spring,

$$
1 \text { mollis, soft. } \quad{ }^{2} \text { gaster, helly, stomach; pous, foot. }
$$

${ }^{3}$ Provided with lungs; from pulmo, lung. 
summer, and autumn under wet decaying pieces of wood, under stones or fruit, in the grass, on the shady side of fences; in a word, in moist, dark situations. They especially shun sand, ashes, and sawdust, because these substances tend to dry up the mucus which they secrete over their body to retain its internal fluids. Slugs are nocturnal (Fig. 162), hence they have the reputation of being rather rare. During the winter they live in the ground, encased in their own slime, but some species frequent greenhouses in cold weather and in consequence of this habit may remain active all the year round.

The food of slugs consists chiefly of the green leaves of succulent plants, and also of ripe fruit, such as apples. Our largest slug, Limax maximus, ${ }^{1}$ is easily maintained in captivity by keeping in a dark box and feeding on the blanched leaves of cabbage.
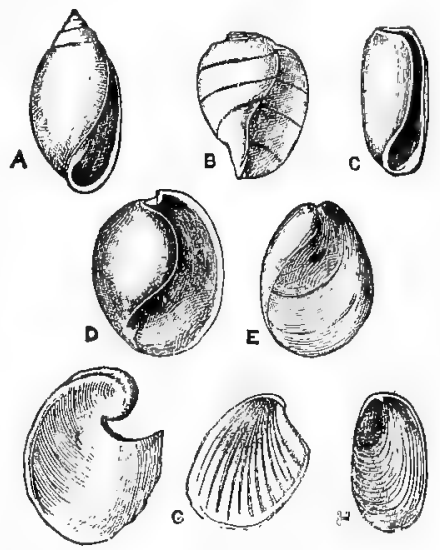

FIG. 197.-Illustrating the transition of form in the shell of certain Opisthobranchs, from the pointed spiral to the almost flat plate. The genera figured are: $A$, Actæon; $B$, Aplustrum; $C$, Cylichna; $D$, Atys ; $E$, Philine; $F$, Dolabella; $G$, Aplysia; $H$, Pleurobranchus. Drawn to various scales. From Cooke, "Mollusca."

In captivity one individual will sometimes devour another.

Economically, slugs are of importance because at times in some localities they cause much destruction in gardens and greenhouses. Particularly in Europe, a species of Limax has often devastated fields of young shoots and devoured many bulbous plants.

In the apparent absence of a shell the slug seems to be an 
aberrant gasteropod. Other land gasteropods - the snails have an evident shell. In Limax the shell is reduced to a thin, horny plate, embedded in the mantle. Between the condition

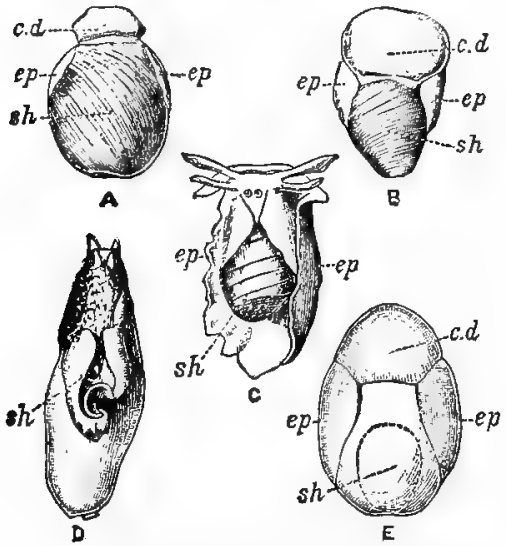

FIG. 198. - Illustrating the gradual covering of the shell $(s h)$ in certajn Opisthobranchs by the epipodia (ep) and mantle; c.d, cephalic disc. Drawn to various seales. $A$, Haminea; $B$, Seaphander ; $C$, Aplustrun ; $D$, Aplysia; $E$, Philine. From Cooke, "Mollusca." seen in the snail and that in Limax there are intermediate conditions, some in which the large shell is partly covered by the mantle, and others in which the shell has become reduced in size. In allies of Limax in a genus called Arion the shell is reduced to a few calcareous grains. An exactly similar series in the degeneration of the shell is found in certain marine snails, illustrated in Figure 197. The beginnings of this process of covering the shell are seen in many gasteropods in which the mantle edges may protrude beyond the lips of the aperture, and are folded back over the outer surface of the shell. A mere developed condition is seen in species like Aplysia, in which the mantle is permanently turned over the back. ${ }^{1}$ In Limax the turned-up edges of the mantle have permanently grown together. The turning back of the mantle scems to afford additional protection to the visceral mass. But after the complete overgrowth of the mantle the shell is useless, and consequently degenerates.

\footnotetext{
1 Fig. $198 D$.
} 
The lung-snails (Pulmonates) are either terrestrial, like the slug, or aquatic. Of the terrestrial pulmonates other than the slug the most important are the snails of the genus Helix. ${ }^{1}$ Helix ${ }^{2}$ is noteworthy, because it is richer in species than any other molluscan genus, containing over three thousand of them. The distribution of the genus is world-wide. In North America the snails are most abundant in limestone regions, hence they are

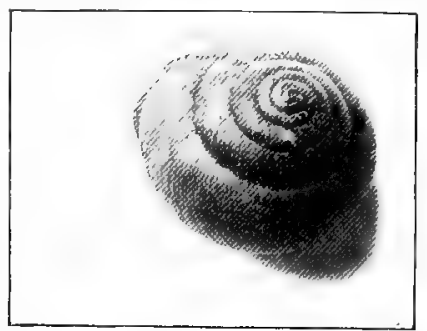

FIG. 199. - Shell of Helix albolabris, a common forest snail. Nat. size. Photo. by W. H. C. P.

less common in New England than in many other parts of the United States.

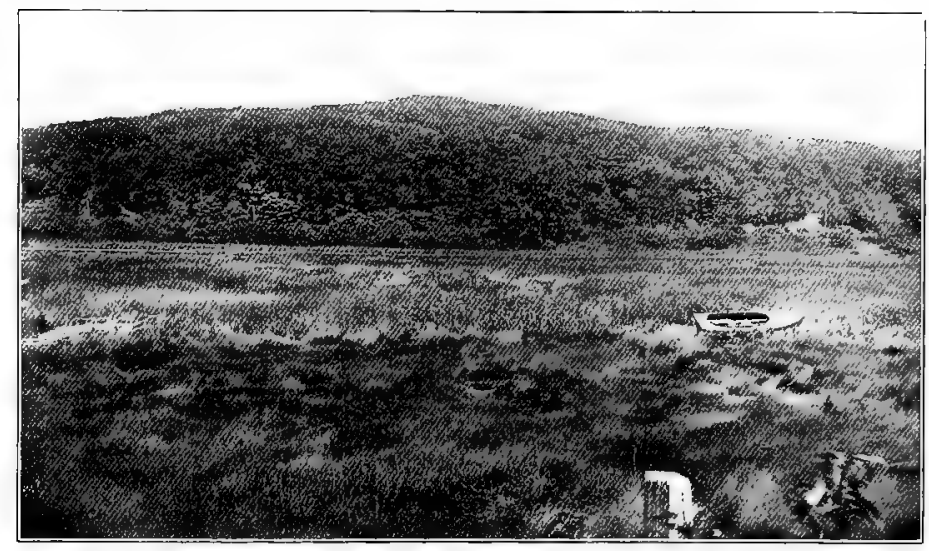

Fig. 200. - A salt marsh by the edge of the sea, where Melampus lives.

The reason why Helix contains so many species is because it is undergoing a rapid evolution to-day. That this is so is

${ }^{1}$ helix, a turning round, as in the spire of a snail-shell. $\quad{ }^{2}$ Fig. 199. 
shown by the enormous variability of individual species. Thus in our own country a species, Helix nemoralis, introduced from Europe, has produced at Lexington, Virginia, 385 varieties in an area not over one-half mile in extent. These variations

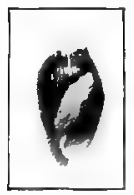

FIG. 201.- Melanlus, the salt-niarsh snail. Nat. size. Photo. by W. H. C. P. consist of different combinations of ground color and of stripes on the shell. But the animal itself is equally variable, for any species of Helix, collected in large numbers, will show individıals having abnormalities both in regard to the number of tentacles and of eyes upon each tentacle. Besides Helix, a very abundant cosmopolitan land pulmonate is Pupa. ${ }^{1}$ The shell is many times whorled, and has a blunt apex. Being of small size, it is, however, less commonly known. It is found in woods under leaves or in old stumps and decaying logs, where it feeds. It is a lover of darkness, moisture, and contact.

Intermediate between the terrestrial and aquatic pulmonates is the family Auriculidx, the members of which live on the seashore, in salt marshes (Fig. 200 ), or on rocks where they may even be immersed in brackish water at high tides. One of the commonest forms is Melampus (Fig. 201), found among the roots of marsh-grass.

Of the aquatic pulmonates three genera are common and easily distinguishable. Limnæa, ${ }^{2}$ the "pond snail," is common in

${ }^{1}$ A little girl or doll.

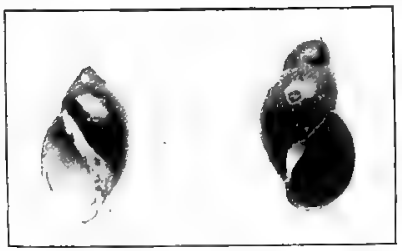

FIG. 202.-Left Physa, heterostropha, the left-handed pond snail. Right, Limnæa, the righthanded pond snail, with the apex croded off as is usually the case in adult shells. Nat. size. Photo. by W. II. C. P.

2 From limne, a marsh. 
ditches and muddy or stagnant ponds. Its shell runs up into a sharp spire, and is right-handed, i.e. holding the shell so that its aperture is next the observer and below, the aperture is at the right (Fig. 202). Limnæa crawls over the bottom, up the stalks of aquatic plants, and on the surface film of water. It comes to the surface, indeed, with great regularity, thrusts its lung-opening out into the air and breathes, and then it rapidly retreats into the water. It is a remarkable fact that an air-breathing organism, whose ancestors were aquatic and gill-breathing, should, after having once become emancipated from the water and having acquired lungs, have returned again to the water. Indeed, some Limnæas have become so adjusted to an aquatic life that they can live at the bottom of deep lakes and never come to the surface to breathe. In the case of such snails the lung is permanently filled with water; the oxygen dissolved in the water being used in respiration. The Limnæas that live in shallow ponds are deprived of water in times of drought. They then burrow deep in the mud and close the aperture of their shell. By this means the loss of the water of the body is prevented and the existence of the animal is prolonged until the return of the rainy season.

Physa ${ }^{1}$ has a smaller, relatively stouter shell than Limnæa, and one whose coil is left-handed (Fig. 202). It lives in even the smaller ponds and brooks, and may be easily reared in aquaria. It feeds freely upon any kind of vegetable matter. Physa heterostropha is the common species of the United States (Fig. 202, left).

Planorbis ${ }^{2}$ is coiled in one plane like a watchspring. ${ }^{3}$ It

${ }^{1}$ physa, bellows.

${ }^{2}$ planus, flat; orbis, circle.

${ }^{3}$ Fig. 203. 
lives in a similar habitat with Physa. A great many species are known, and they vary much in size. Snails of this genus

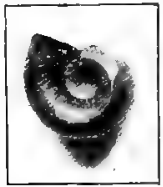

FIG. 203. - Planorbis, the flat-coiled pond snail. Nat. size Photo. by W. H. C. P. likewise are easily kept in the aquarium, and lay numerous eggs encased in gelatinous envelopes adhering to the glass.

Of the shells of marine gasteropods, which are favorite objects in collections because of their beauty and permanence, only a few types can be mentioned.

Lit'torina $^{1}$ is an example of the entiremouthed marine snails. The commonest form at most parts of the shore-line north of New York at the present time is Littorina littorea. ${ }^{2}$ This is known in England as the periwinkle, and is there used as food. As its systematic name implies, it occurs on the seashore, which it often crowds so as to force all other species from it. It occurs north to Greenland, and on the northwestern European coast. It has not always occupied our shores, but has been migrating southward.

In 1855 Littorina was found in the Gulf of Saint Lawrence; in 1869 it was stated to occur in Halifax; in 1870 a few individuals were found on the Maine coast; during 1871 the species occurred on the New Hampshire

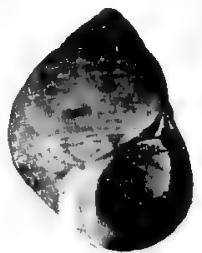

FIG. 204. - Littorina littorea, the shore snail. Nat. size. Photo. by W. H. C.P. coast; in 1872 one specimen was found at Nalem, Massachusetts; in 1875 the first two specimons were taken at Woods Hole, Massachusetts, south of Cape Cod; in 1880 the first specimen was taken at Now Haven; in 1891 it occurred as far south as Delaware Bay. In 1899 it was not very abundant at 1 Fig. 204. ${ }^{2}$ From littus, the seashore. 
Cold Spring Harbor, near the western end of Long Island Sound, but has since become so. Persons who live on the coast south of New York City would do well to note carefully the abundance of the species on their part of the shore-line. Besides littorea there are two species of Littorina which were on our coast when records first began to be made. The species may be distinguished by the circumstances that $L$. littorea has a black head and a heavy shell of brown or olive color. L. rudis ${ }^{1}$ is smaller, its shell has an angle at the apex of $60^{\circ}$ to $70^{\circ}$, and varies in color from white to red. L. palliata ${ }^{2}$ has a shell with an apical angle of $95^{\circ}$, and varying from white to orange, slate, or brown.

Nat'ica is another common species with an entire aperture to the shell. It can be at once distinguished from Littorina by the "umbilicus," or de-

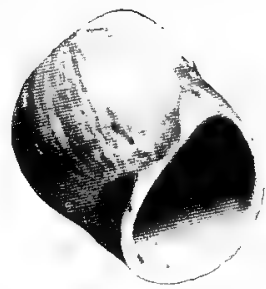

Frg. 205. - Natica (Lunatia) heros. Two-thirds nat. size. Photo. by W. H. C. P. pression situated at the left of the mouth and in the axis of the shell (Fig. 205). In the living animal the shell is often quite enveloped by the large fleshy foot. The members of this genus lay their eggs in spiral "collars" made of agglutinated sand. These are common objects of the seashore.

Ful'gur $^{3}$ is a good example of a prosobranch having a canal at the mouth of the shell. The canal exists for the purpose of containing the siphon by which water is brought to the animal as it lies buried in the sand. Fulgur is our largest common gasteropod.

Its shell is about 150 millimetres long, and pear-shaped. In one species the margins of whorls are grooved (Fig. 206); in the
'Rough, rude.
${ }^{2}$ A cloak.
${ }^{3}$ Lightning. 
other they are carried out into thorns. The egg-cases are tough and membranaceous and resemble rows of coin strung on a string,

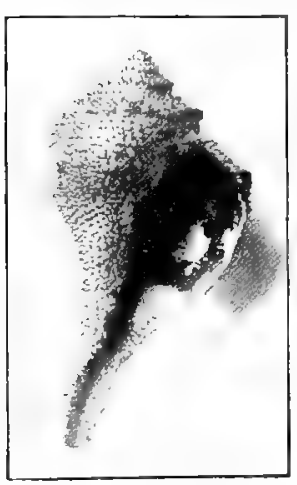

Fic. 206. - Shell of Fulgur (Sycotypus) caniculatus, one of the Fasiolaridse. Onefourth nat. size. Photo. by W. H. C. P. the whole being slightly coiled.

In $U^{\prime}$ rosalpinx ${ }^{1}$ the canal is short (Fig. 207). This typical representative of the murexes is everywhere abundant on our Eastern coast. It is much hated by oystermen, by whom it is known as the "oyster drill." It bores through the shell of this and other bivalves by means of its radula and sucks out the contents through the hole.

The muddy bottoms of protected marine harbors are occupied by the mudsnail (Nassa), whose canal is a mere notch through which the very long siphon can be extended. The long siphon enables it to draw in pure water while its body is embedded in the mud. This burrowing serves either as a protection from predaceous species or prevents desiccation when the flats are left uncovered by the retreating of the tide. One may often see Nassas grouped in solid masses around the body of some dead mollusk. They are attracted toward the food by a marked chemical sense, and they move toward the source of any current that conveys particles that stimulate this sense.

Crepid'ula, the boat shell or "decker,"

${ }^{1}$ oura, tail ; salpinx, a trumpet.

2 A small sandal (crepida).

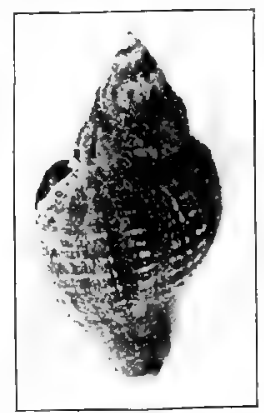

FIG. 207. - Urosalpinx, the oyster drill. Nat size. Photo. by W. H. C. $P$. 
belongs to a type in which the spire has become almost obsolete. It is still represented, however, in a rudimentary way at the left of the aperture (Fig. 208). The modified shape is associated with the habit the mollusk has of lying, aperture downward, close to the rock or another shell. By this means the animal is better protected. The " deck" is a plate which has been developed internally

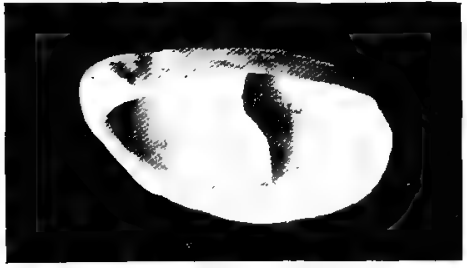

FIG. 208. - Crepidula, the boat shell. Two-thirds nat. size. Photo. by W. H. C. P. to help hold the animal in the shell.

The limpets are modified sea-snails. They are bilaterally

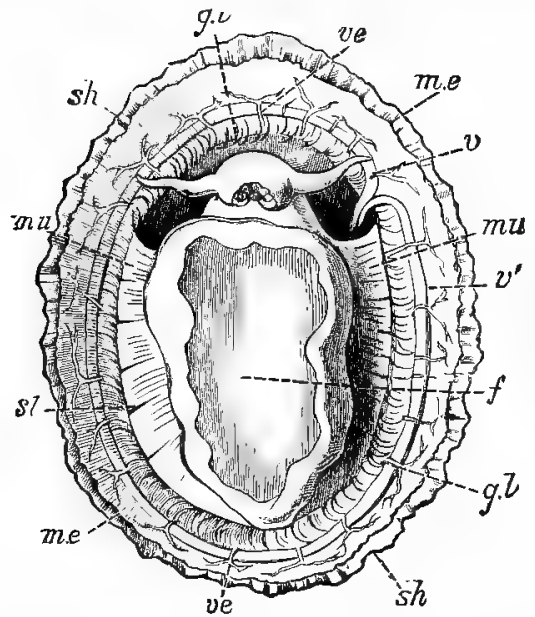

FIG. 209. - Patella vulgata, seen from the ventral side. $f$, foot; $g . l$, circlet of gill lamellx; m.e, edge of the mantle; $m u$, attachment muscle; $s l$, slits in the attachment muscle; sh, shell; $v$, efferent branchial vessel; $v^{\prime}$, aorta; ve, smaller vessels. From the "Cambridge Natural History." symmetrical and are covered by a flat, conical shell which is applied closely to the rock all around the base in such a way as to protect the animal within. In some species (genus Fissurella ${ }^{1}$ ) there is an opening at the apex of the shell through which the water is expelled that has passed over the gills.

Our common Eastern rock limpet is not perforated ; it is known as Acmcea. ${ }^{2}$ In

${ }^{1}$ A little slit or fissure.

2 akmaios, in full bloom, maturity. 
Europe, limpets (Patella, Fig. 209) are used as food; but on our Eastern coast they are too rare for this.

The hinder-gilled mollusks (Opisthobranchs) include a large proportion of symmetrical shell-less species. The most

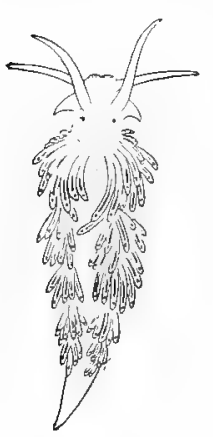
familiar of these are the sea-slugs. They may be found among hydroids hanging from rocks, or in tide-pools. Our species are usually less than twenty millimetres long. They are often covered with numerous gills, which give them a velvety aspect. When placed in an aquarium, they lay eggs in gelatinous coils on the hydroid stems. Eolis ${ }^{1}$ is a common genus (Fig. 210). Besides the gasteropods, two groups of mollusks may be briefly mentioned here. In one FIa. 210.-Eolis. group the body is very symmetrical, not only externally, but also internally, which is not true of most symmetrical gasteropods. A common representative is Chiton ${ }^{2}$ (Fig. 211). This animal has a sort of coat of mail, since its shell is made up of eight pieces, lying one behind the other, along its back. When removed from the rock or shell on which it rests, it coils up like a pill-bug or armadillo.

Coördinate with the Gasteropoda is the group of squids and cuttlefishes (C'eph'alopoda $\left.{ }^{3}\right)$. They have a large, distinct head, a circle of arms about the mouth, a funnel-

FIG. 211.-Chiton (Trachydermon) apiculatus, the armadillo snail. Nat. size. Photo. by W. H. C. P. shaped foot, and huge eyes on each side of the head (Fig. 212). The squids are the best-known cephalopods, since they travel

1 Eolis, daughter of Eolus, the god of the winds.

${ }^{2}$ Coat, case, covering.

${ }^{3}$ kephale, head; pous, foot; because the arms or foot are placed around the mouth. 
in schools in our harbors and are often cast upon the shore after a storm. They can also be obtained in the markets of our coastwise cities, since their flesh is used to a certain extent as food. Cuttlefishes, best known from their " bones" or rudimentary shells lying deep in the mantle, are inhabitants of deeper waters. They have shorter bodies than the squids, and their arms are eight in number, instead of ten as in the case of the squids. In both groups locomotion is effected by the reaction to a stream of water which is taken into the mantle chamber at the edges of the mantle and is forced out through the "funnel," which lies between the eyes (Fig. 212).

The shell is rudimentary in both the squids and the cuttlefishes, and like that of the slug is embedded in the mantle. There are two living genera of Cephalopoda which have an external shell. One is an ally of the cuttlefishes - the paper nautilus or Argonauta, ${ }^{1}$ which is found in all tropical seas.

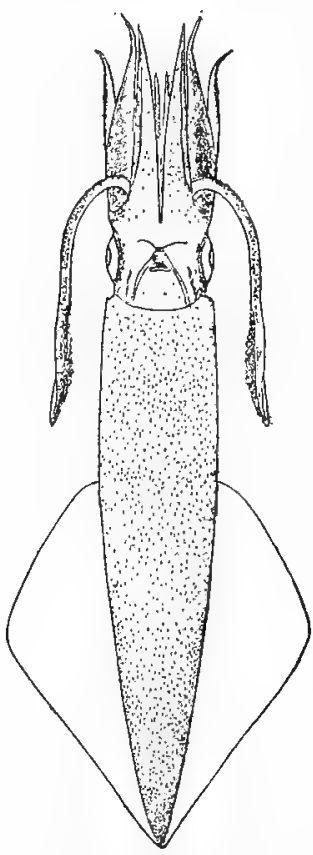

FIG. 212-Loligo Pealii, Eastern squid. One-third nat. size. From Rathbun.

The other is the sole survivor of a once abundant group. This is the Pearly Nautilus of the Indian and Pacific oceans. Its shell is divided into water-tight compartments, in the last formed of which the animal lies. It keeps its attachment to the shell by means of a central strand of tissue - the siphon (Fig. 213, s). Allied to the Nautilus is the huge family of 1 A sailor in the Argo. 
Ammonites, of which two thousand fossil (extinct) species are known, ranging through many geological ages.

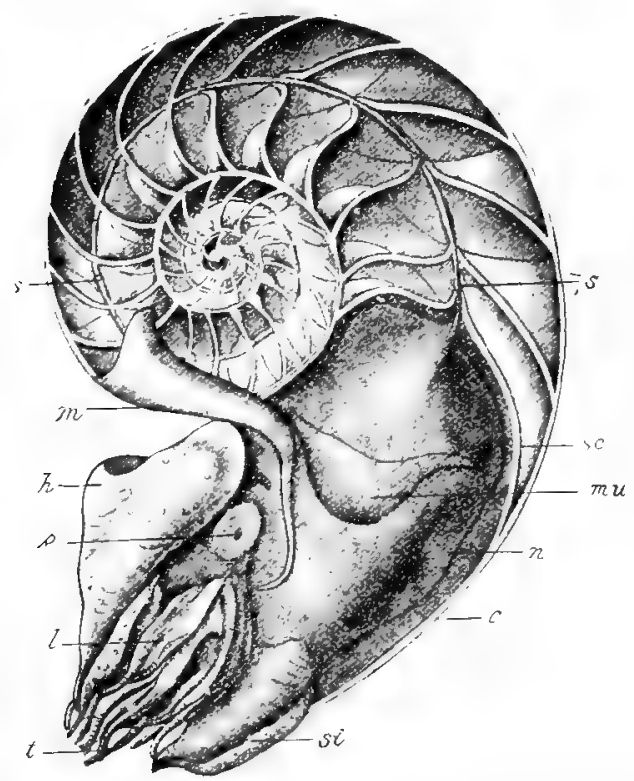

FIg. 213. - Nautilus pompilius, the Pearly Nautilus. Median section. $c$, outermost chamber whose bottom is formed by the septum, se; s, siphon travers-

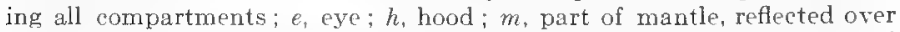
the shell ; $l$, lobes enclosing tentacles $(t) ; s i$, incomplete funnel; $m u$, shell muscle; $n$, gland secreting the capsules for eggs. After Owen. 


\section{CHAPTER XVI}

\section{THE FRESH-WATER CLAM: A STUDY OF RIVER FAUNAS}

Tне main divisions of the animal kingdom originated along the seashore. From the seashore animals have passed to the bottom of the deep sea, over the surface of the seas, and into the estuaries that open into the seas. Certain forms have penetrated farther and farther up the estuaries and have become, eventually, permanent inhabitants of fresh water.

The habitats offered by fresh water are of several sorts. First there are the fowing streams (Figs. 214, 215). Near the mouths of streams the current is slow, while in the upper courses it is rapid. Then there are the permanent bodies of fresh water, such as ponds and lakes. Finally there are the intermittent streams and ponds in which animals are subjected alternately to water and drought. In the present chapter we have to consider the animals that live in rivers and some of the adaptations they show to a fluviatile life. In the first place the number of different kinds of animals and the alsundance of individuals is less in swiftly flowing rivers than in lakes, for the swiftly flowing river is a difficult habitat in which to live. Free-swimming organisms tend to be swept away unless they are powerful enough swimmers to stem the current. The minute organisms that swarm at home on the surface of lakes are found in rivers merely as victims of floods, and are being swept away to their destruction. The animals 


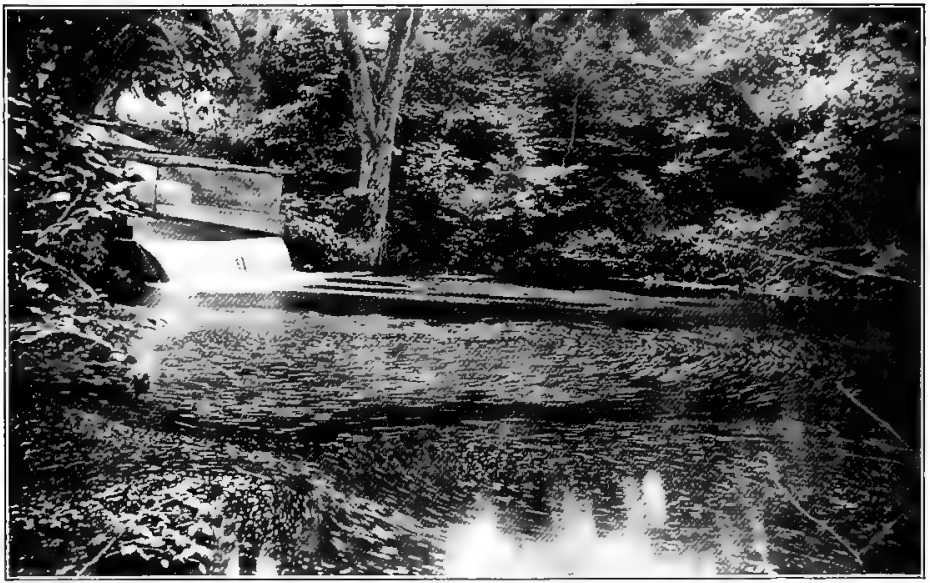

FIG. 214. - A pool where a waterfall flows into a relatively quiet sheet of water. The home of hydra, fresh-water clams, planarians, and leeches.

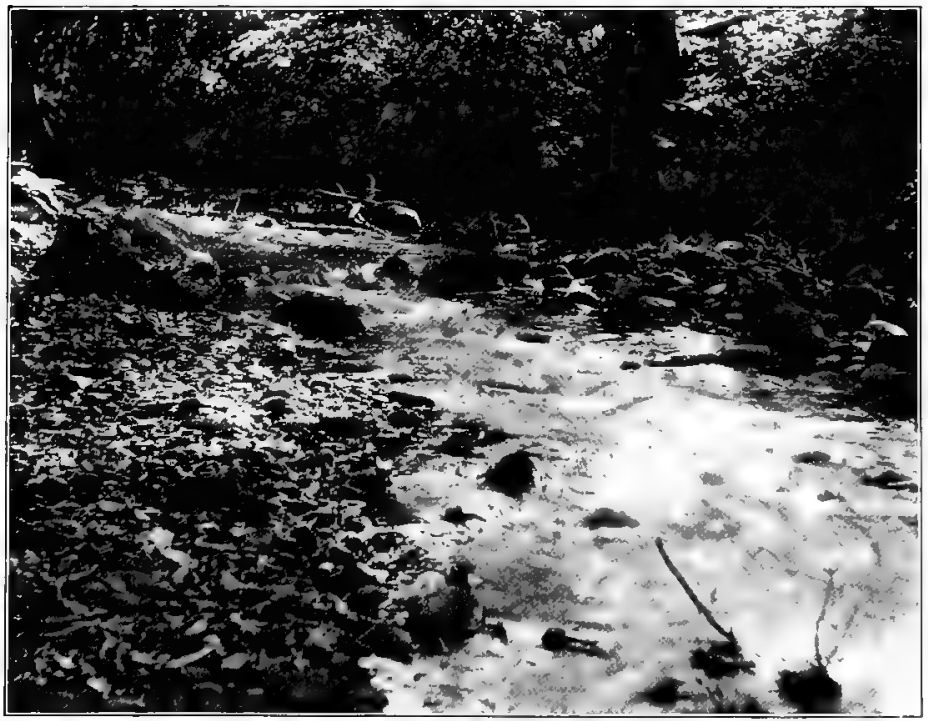

FIG. 215. - A rapidly flowing stream with a fauna like that shown in Fig. 216. 
that permanently reside in and are best fitted for the river habitat have either clinging organs or a high specific gravity and live on the bottom, or else they burrow into the bottom mud. Consequently, we find in rivers many attached animals (Fig. 216). Thus there are sponges, the little hydra which is referred to in Chapter XIX, Bryozoa, and, in certain parts of the world, even barnacles. Among the animals that can cling by means of an adhesive surface are a great variety of snails, whose powerful foot enables its possessor to adhere to the rocky bed of rivers. Here too one finds flatworms and leeches and the larvæ of certain insects which live in nets cemented to the stones. Among animals that are provided with other means of prehension are crayfish, which live under stones and in pools. In the mud or sand at the bottom are found numerous worms and, especially in limestone countries, fresh-water clams.

All these different kinds of fluviatile animals have been derived directly or indirectly from the ocean and have found themselves well adapted to live in a rushing current. It will be worth while to see how they have reached their present home.

The fresh-water sponges belong to one small group, whereas their marine allies are vastly more varied. The origin of freshwater sponges is, however, obscure. Of the Hydra-like animals there are a few that are found chiefly in estuaries; and in such locations they show us that representatives of the group are still emigrating from the sea. So, too, in the case of the Bryozoa there are several species allied to marine families of that class that are found in the lower courses of streams and are evidently just beginning to become emancipated from the sea. The river mollusks belong to several different groups which have migrated independently into the streams. Thus in the South- 


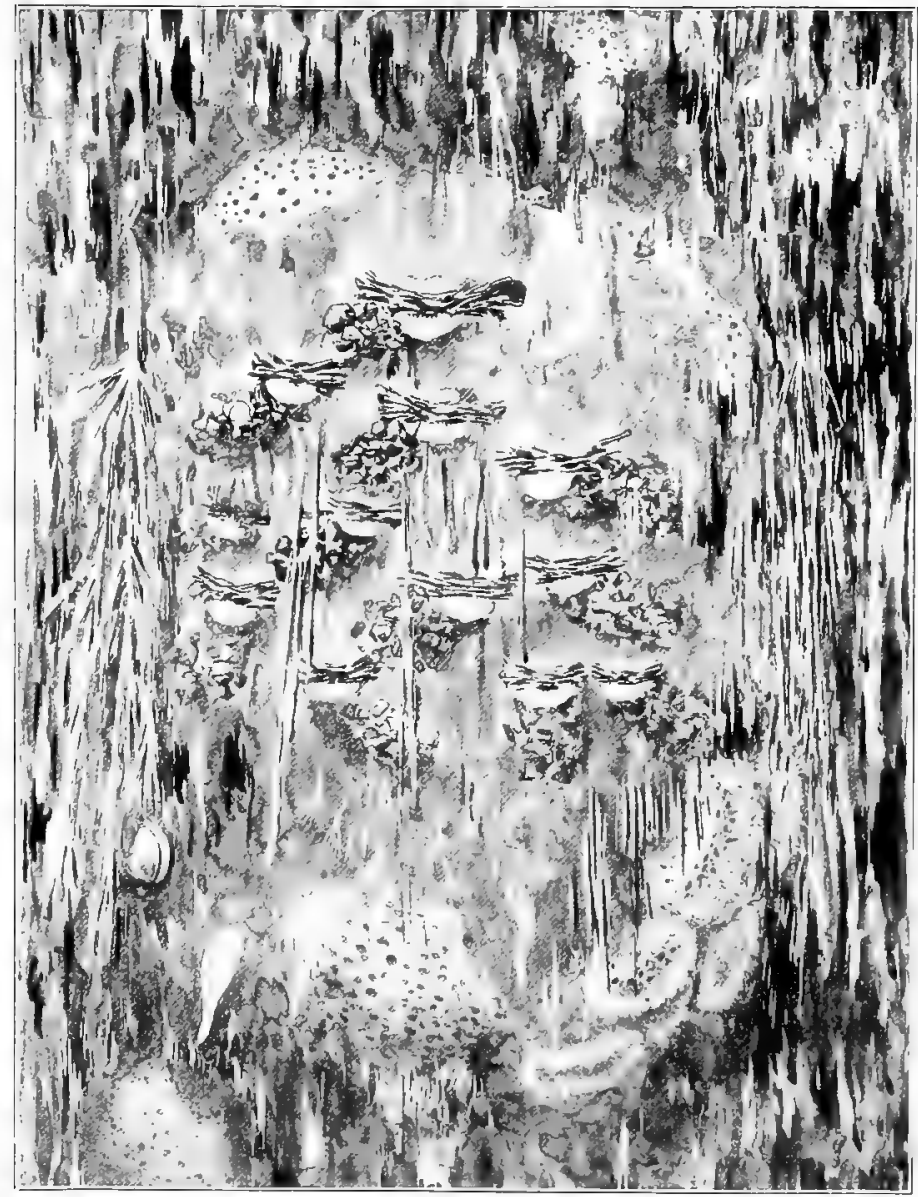

FIG. 216. - The fauna of a rapidly flowing stream. In the centre, nets of the caddis-fly ; below, some hydras; still farther down, a sponge with a leech and a clam (Psidium) left, and a bryozoan (Pectinatella) to the right. J. H. Emerton. 
ern states we have certain large water snails which are allied to species found on the coast of the Gulf of Mexico. The Unios find their nearest marine allies among the mussels of the sea. In fact in the group of mussels the attempt to acquire a fluviatile life has been made several times independently. In Europe a mussel, very similar to that of the seacoast, has entered the rivers of Russia and, by the aid of connecting canals, those of Germany (Dreisenia). Among the fishes there are those that pass from the sea to rivers regularly once a year during the spawning season. Others live in estuaries, but travel up and down to a limited extent. In view of the migration of fishes to-day it is not difficult to see how some of them, although of marine ancestry, came to live permanently in the rivers.

Of all the varied animals of fresh water perhaps the most conspicuous, in our Central states, are the clams. These we may now consider in detail. The fresh-water clams belong to the group of lamellibranch mollusks, characterized by the absence of a distinct head, by the possession of leaf-like gills on the sides of the body, and by the presence of a limy shell composed of a right and a left valve. Economically this group is the most important to man of all Mollusea. It includes both marine and fresh-water species. About six thousand species of living lamellibranchs and over ten thousand fossil species are recognized. They all fall into two principal subdivisions. The first (Siphonata) includes species which possess a siphon and have the mantle edges grown together, while the second (Asiphonata) has no siphon and has the mantle lobes for the most part wholly separated. Consequently the first group can live in the mud, drawing pure water from the surface, whereas the second cannot do so. 
The fresh-water mussels (Anodonta and Unio) are extremely common in the ponds, lakes, and rivers of North America. Anodonta is more apt to be found in still waters and Unio in running waters. They lie partly buried in the mud of the bottom, with the valves of the shell gaping open and the partly united edges of the mantle protruding. They do not lead wholly sedentary lives, but may burrow or plow along the bottom.
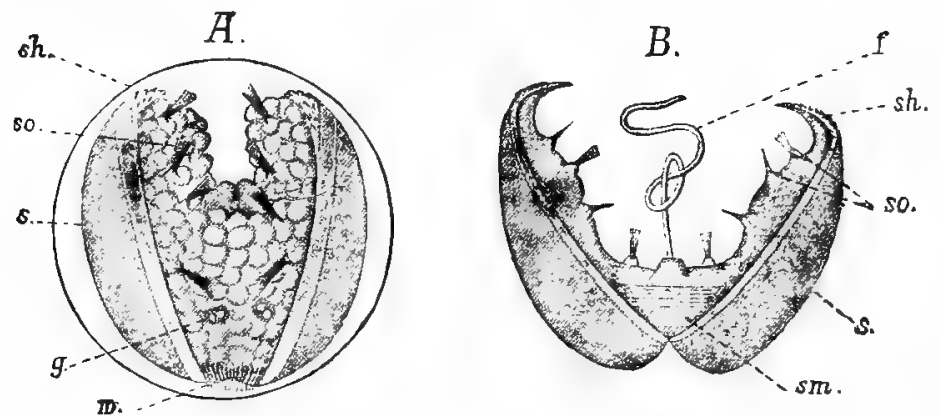

FIG. 217. - $A$, advanced embryo Anodonta ; $B$, free Glochidium ; $f$, provisional byssus ; $s$, shell ; $s h$, hooks ; $s m$, adductor muscle ; so, sense organs ; $w$, cilia. From Korschelt and Heider's " Embryology."

Their food is gained from organic particles borne along in the current of the water. A part of this current is carried through the mantle chamber and forced out again, deprived of usable food and of the oxygen used in respiration. By devouring organic matter these clams act as useful scavengers of the water. On account of the sessile habits of Unios they can hardly go in search of their food, and so it is necessary that they should live in a current of water which will bring them food.

The family of Unionidæ, to which Unio and Anodontia belong, is of world-wide distribution, but nowhere else are 
Unionidæ so numerous as in the United States. They show in our country a most marvellous variability also, so that hundreds of kinds have been described from our waters. The abundance of Unios in North America is due to the fact that nowhere else is there such a large area of soluble limestone as in our Mississippi Valley. The clams take from the water the lime which they use in making their shells, change it into an insoluble form, and thereby reduce the amount of the inorganic matter in solution, and so render it more fit to drink and to sustain other animal and plant life.

Although numerous and of large size, Unios do not seem to be much used as human food. The aborigines, however, made use of them, as the great shell-heaps on the banks of rivers of the Ohio Valley testify. They yield also pearls, which occasionally, especially in the Ohio Valley, are of precious quality. Even the small, imperfect pearls are of value, since they are ground up to make the powder used in polishing the more valuable pearls.

The spawning season of our Unios is short. The eggs pass, during the latter part of Octoher, into the gills of the parent, where they undergo their early development, protected by the parent shell and supplied richly with oxygen. The cleavage of the egg is into unequal spheres because of the larger amount of yolk in some of the cells than in the others. Eventually a shell is formed, which divides into two valves united by a straight hinge. A spine is formed on the free edge of each valve, and a thread ("byssus") is secreted from the body. The young (Glochidium, Fig. 217), in the spring, become free from the mother and attach themselves to the gills or fins of a fish by means of the spines on the shells. Here they become transformed. The single adductor muscle disappears, and 
becomes replaced by the two found in the adult; the gills

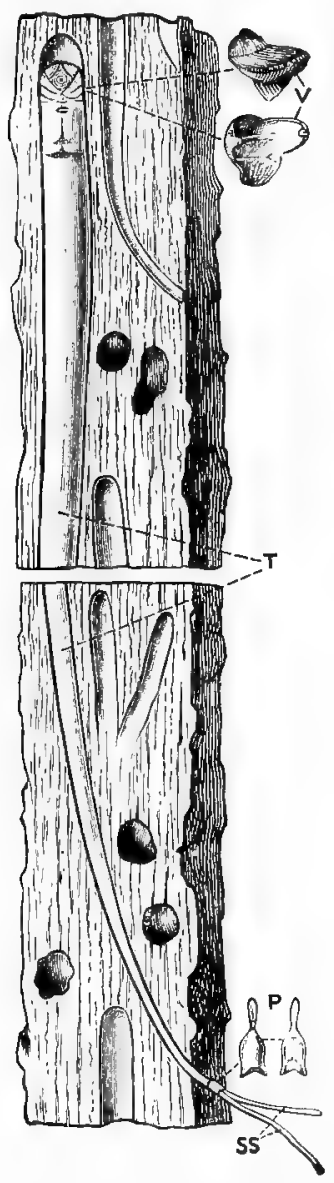
FIG. 218. - Teredo navalis, clude certain wood and rock boring in a piece of timber. $P$, species, which do great damage by bortuhe; $V$, valves of shell. From the "Cambridge Natural History." arise, the shell gains its adult character, and becomes free from the fish on which it has lived temporarily as a parasite.

There are other species of fresh-water lamellibranchs besides the Unionidæ. They have much the shape of our common hard-shell clam of the sea, but are much smaller in size, rarely exceeding fifteen millimetres. Cyclas is of worldwide distribution, but it is especially common in North America. It occurs in ditches, ponds, and rivers of New England, as well as in the South and West. Some species of the genus inhabit brackish water.

The remaining families which we shall consider come from the sea, and all occur on our Eastern coast. Three grand divisions may be recognized : (1) the burrowers (Pholadidæ, Teredidæ, Solenidæ, Myidæ); (2) the heavyshelled bottom feeders (Mactridæ, Veneridæ, and Arcidæ) ; (3) the byssus spinners (Mytilidæ, Aviculidæ, Pectinidæ, Ledidæ, and Ostreidæ).

The Teredidæ ${ }^{1}$ and Pholadidæ ${ }^{2}$ in1 tereo, to bore.

${ }^{2}$ pholas, Greek name for a boring mussel. 
ing into wooden vessels and pilings (Fig. 218). In such locations they are commonly called ship-worms. The boring is done by the movements of the shell, combined with the action of the muscles and foot. The only thing which seems effectively to stop these mollusks from boring into wood is iron rust, so that piles driven full of nails are apt not to be attacked.

In the razor-shells (Solenidæ, ${ }^{1}$ Fig. 219), the animal, like the shell, is elongated and subcylindrical. By means of its

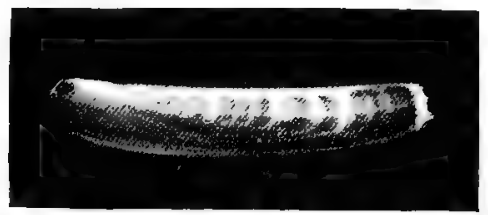

FIG. 219. - Ensis directus. Young. Nat. size. Photo, by W. H. C. P.

foot, which can be protruded between the valves, it excavates with great rapidity a hole in the sand or mud into which it draws itself. These mollusks are sometimes used for food, but it is not easy to get them in quantity.

The hen-clams (Mactrid ${ }^{2}$ ) include species that are more elliptical and larger than the common hard-shelled clam or "quohog," and have a proportionately lighter shell (Fig. 220). They are not often used as food because they become very tough when cooked.

The soft-shelled clams (Myidæ ${ }^{3}$ ) include the common clam of New England, Mya arenaria, abundant along our whole Eastern coast and much used as food. These clams occur in great numbers in every mud-flat. Their great siphon is extended at high tide to the surface of the ground, so as to

1 solèn, a channel or tube.

2 maktra, a baking-trough.

${ }^{3}$ mya, Greek name for a kind of mussel. 
take in and throw out water (Fig. 221); but at low tide it is retracted, and the clam lies invisible in its burrow. This

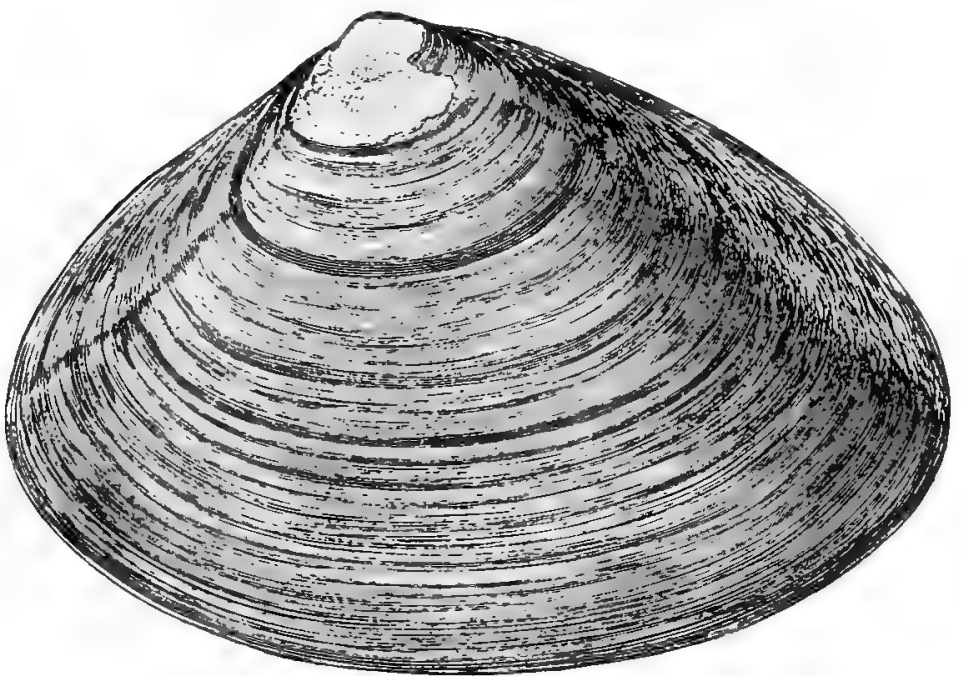

Fig. 220. - Mactra solidissima, the Eastern hen clam. Nat. size. From Gould-Binney.

clam was much prized by the Indians, as the great, ancient shell-heaps along the coast testify. In 1892 the clam com-

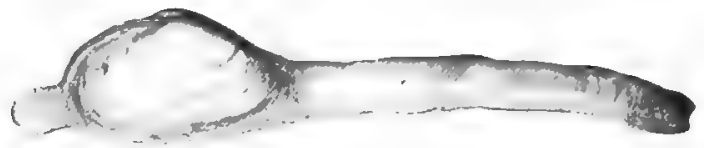

Fig. 221. - The "soft-sholled" clam (Mya arenaria), with its siphon extruded to the right and its foot projecting to the left.

merce for New England was estimated to be worth nearly half a million dollars (Fig. 222).

The hard-shelled clams (Venerida ${ }^{1}$ ) include Tenus merce-

${ }^{1}$ Venus, the goddess of love. 


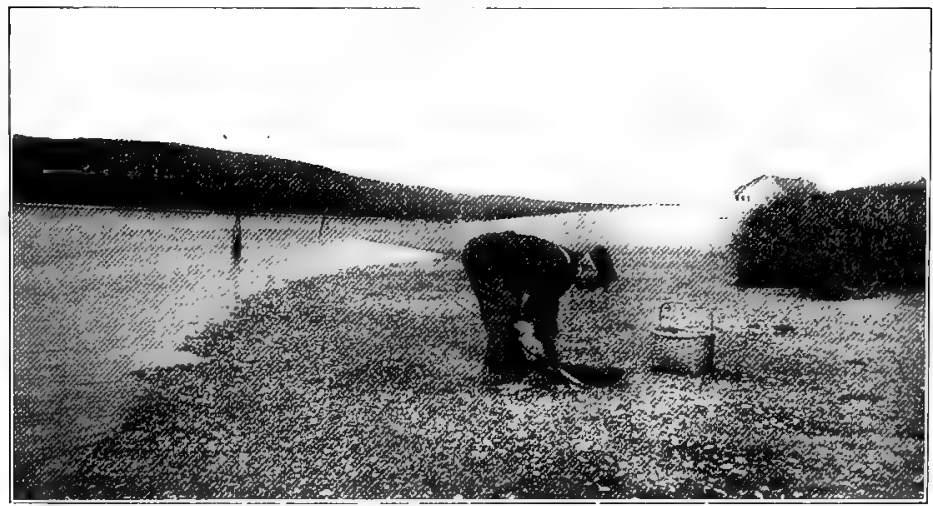

Fig. 222, - On the mud-flat, digging the soft-shell clam.

naria, which is the commonest species, and is most abundant south of Cape Cod. It owes its name "mercenaria" to the fact that the purple-colored patch seen on the margin of the

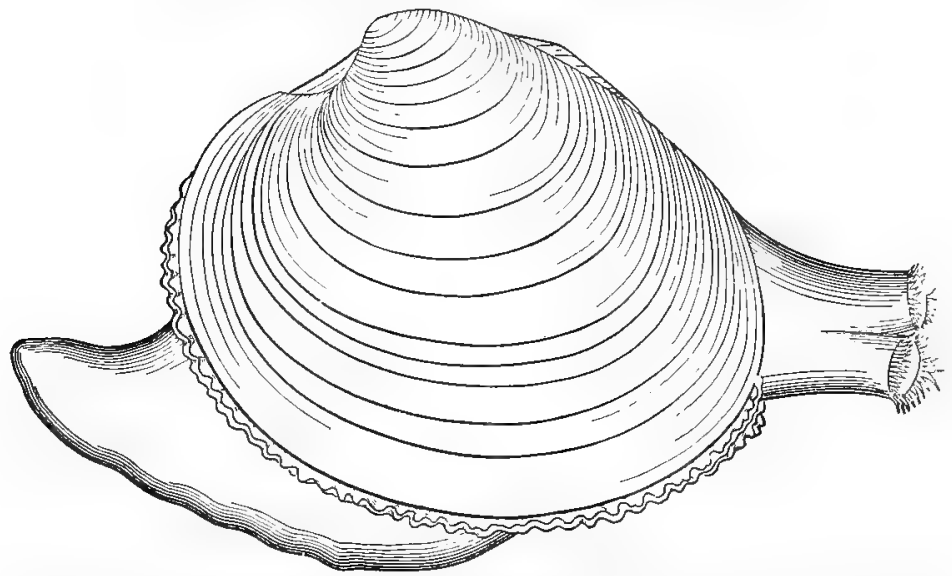

Fig. 223. - Tenus mercenaria, the hard-shelled clam. At the left the foot protrudes from the shell; at the right the siphons. Nat. size. From Verrill, "Invertebrates of Vineyard Sound." 
shell was used as money ("wampum") by the Indians. The

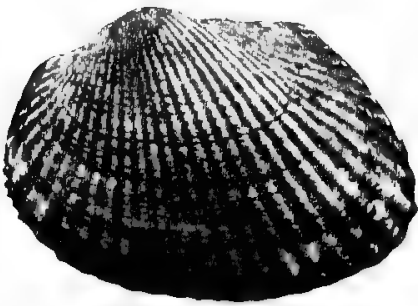

FIG. 224. - Arca pexata, the bloody clam. Nat. size. Photo. by W. H. C. P.

shell is extremely heavy, and usually nearly circular in outline (Fig. 223).

The arks (Arcidæ ${ }^{\mathrm{I}}$ ) and their allies include several species having a more or less elongated hinge-joint crowded with many small teeth. Our common Eastern species (Arca pexata, Fig. 224) has bright red blood and is commonly known as the "bloody clam."

The mussels (Mytilid ${ }^{2}$ ) are the familiar blue black, wedge-

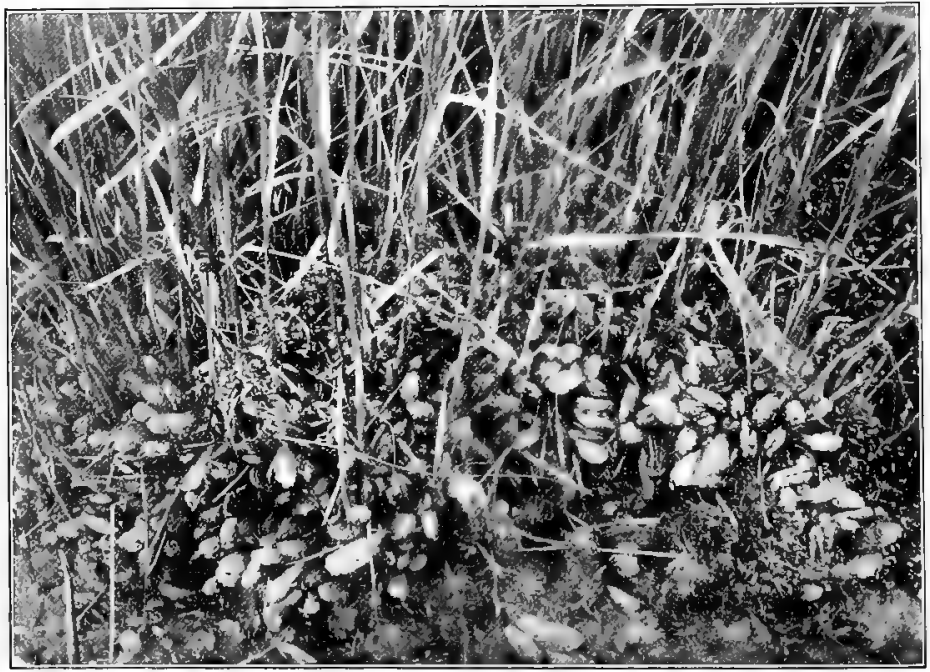

FIG, 225. - Bit of bed of musals lving at hase of the marsh-grass (Spartina), exposed at low tide. At rising tide a swift current flows over this bed.

1 arca, an ark.

${ }^{2}$ mytilos, an edible mussel of the Greeks. 
shaped shells attach in clusters or beds to rocks near low tide. In the absence of rocks they may attach themselves to the roots of the marsh-grass. They form so solid a wall here as to protect the mud and the marsh-grass that is growing in it from being washed away. Thus the relations of marsh-grass and mussels are reciprocally advantageous (Fig. 225). Mussels are edible and in Europe they are reared for the market on woven nets, which are submerged at each tide.

The pearl mussels (Aviculidæ ${ }^{1}$ ) are a group closely allied to the last, but not

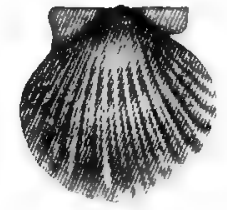

Fig. 226. - Thescallop (Pecten irradians). Right or lower valve. Onehalf nat. size. represented on shores. They are important because they produce the best pearls. Pearl-fishing has been carried on since the earliest preserved historic records. The pearl banks of Ceylon are known to have been fished for two

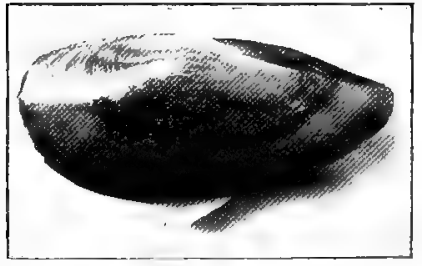

FIG. 227. - One of the Ledidæ. Yoldia, foot protruding below. Nat. size. Photo. by W.H.C.P. thousand years. The finest pearls, however, come from the Persian Gulf. They are gathered there by native divers, who, after taking several deep breaths, either dive down unaided or descend upon weighted ropes. When they can no longer remain under water, they either ascend again unaided or are rapidly drawn up to the boats above. The pearl oysters brought up to the surface are then examined for pearls. The pearl is the secretion of the oyster about a small foreign body, such as a grain of sand or a parasitic worm. This secretion prevents the irritant from injuring the tissues. It is of the ${ }^{1}$ A small bird (avis). 
same nature as the substance lining the shell. The latter is the mother-of-pearl of commerce, and is used for knifehandles, buttons, and the like. The iridescence is not due to the chemical composition of the secreted substance, but to the fact that it is deposited so as to leave fine lines on the surface which diffract the light.

The scallop-shells (Pectinidæ ${ }^{1}$ ) occur along our whole coast. They live in shallow water, and are capable of rapid movement in the water by clapping the valves. The adductor muscle

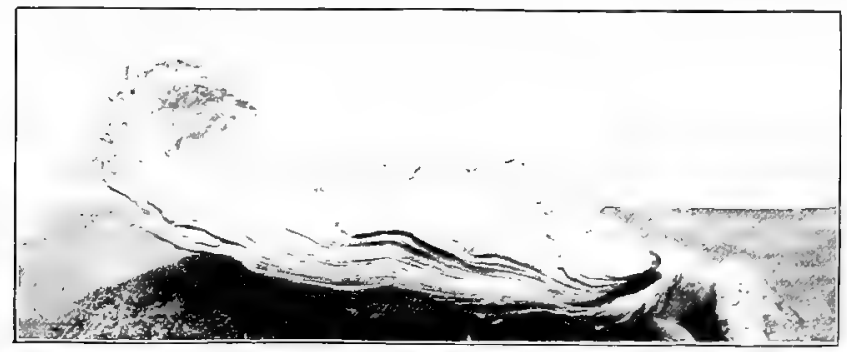

FIg. 228. - The Eastern oyster (Ostrea virginiana). One-third nat. size. Photo. by W. H. C. P.

of the valves alone is eaten by man. The common species is Pecten irradians, which has a ribbed shell of varying color (Fig. 226).

The lidas (Ledidæ) include certain elongated shells with a shiny epidermis, and a large number of teeth on the hinge, which are found chiefly in mud in rather deep water. The animal has a large foot (Fig. 227) with which it burrows rapidly. It can also move rapidly through the water as the scallops do.

The oysters (Ostreidæ ${ }^{2}$ ) include the most important invertebrate food fishery, being valued at twenty to thirty million dollars per year for our Atlantic seaboard. Oysters are found 
on all coasts. Our Ostrea virginiana ${ }^{1}$ extends from the Gulf of St. Lawrence to the Gulf of Mexico. The oysters of our Western coast are not so important as the Atlantic species. In Japan, however, there is a species occasionally gaining a length of three feet. The principal European species is Ostrea edulis. The oyster was formerly commoner and larger north of Cape Cod than it is now, for the great aboriginal shell-heaps ("Kitchen-middens") of the New England coast contain shells of enormous size. The cause of this gradual extinction of the oyster is uncertain, but is believed to be due partly to general climatic and geographic changes and partly to overfishing.

${ }^{1}$ Fig. 228. 


\section{CHAPTER XVII}

\section{THE ANATOMY AND PHYSIOLOGY OF ECHINO- DERMS WITH PARTICULAR REFERENCE TO THE SEA-URCHINS}

General Form of the Body. - In the echinoderms the body has a radial arrangenent of parts; i.e. there are more than two similar parts arranged around the chief axis of the body, whereas in hilaterally symmetrical animals, like ourselves, there are only two such parts. In echinoderms the number of such parts is nearly constant; namely, five (Fig. 229). Now a radial arrangement of parts is a characteristic of an attached organism - a hydroid sea-anemone, sunflower, or tree - as a bilateral arrangement is of a locomotor organism. Consequently it is tolcrably certain that the ancestors of echinoderms were attached animals. Among modern echinoderms such attached animals are, indeed, found in the groups of Crinoids or Sea-lilies, a group that was formerly more abundant than it is now (Fig. 252). Also in earlier geologic times echinoderms were represented by two or three other classes now totally extinct, of which some were stalked. It is possible that from such sessile organisms the free-living echinoderms of to-day sprang.

In the body of any echinoderm we recognize a main axis with two quite different poles, i.e. at the two ends of the axis the body is quite different. That pole where the mouth usually lies is called oral; the opposite pole aboral. Typically there are five equal parts arranged about this main axis. In 
those sea-urchins, however, that have assumed the hah,it of free locomotion on the oral surface (Fig. 230), the mouth has moved from the centre toward one edge and the anus, which is typically at the centre of the aboral pole, has moved toward the opposite edge, so that, in these cases, the body has become bilaterally symmetrical and the alimentary tract tends to run horizontally instead of vertically. This result shows the effect of a locomotor habit on the radial form.

The body-wall of echinoderms contains limy plates (Fig. 230). These are best developed in the sea-urchins and sea-lilies, where they encase the entire body. Ten bands run along meridians from one pole to the other; in alternating bands the plates are perforated for passage of

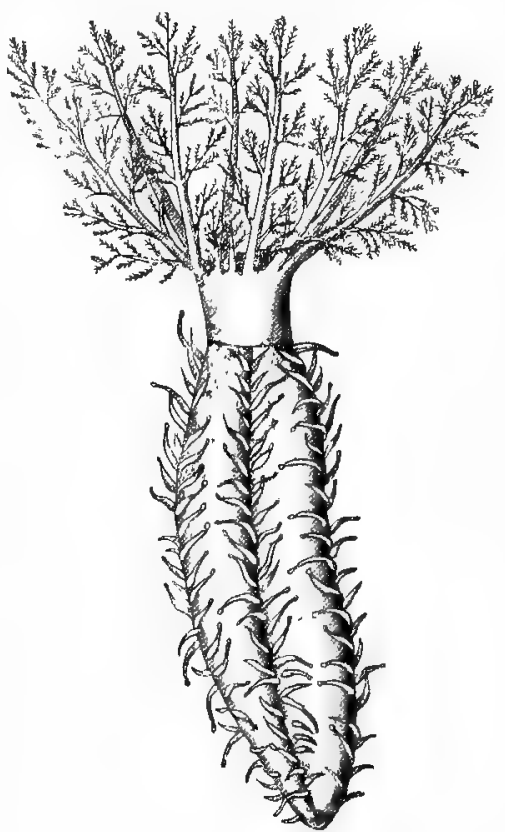

FIG. 229. - A sea-cucumber (Cucumaria), showing the radial, tree-like, arrangement of parts in an echinoderm. Parts are seen to be arranged on a hasis of five. Three rows of tubular feet show; two rows aro hidden. There are ten tentacles at the upper end of the body of which two (front middle) are small. From Parker and Haswell. the tube-feet - such are called the radial bands or radii; the others are called interradii. In starfishes the interradii are small and unimportant, forming the part of the body-wall lying between the arms. The liny plates lie embedded 
in the skin where they have been formed; from them often arise other structures - spines, which gain a great

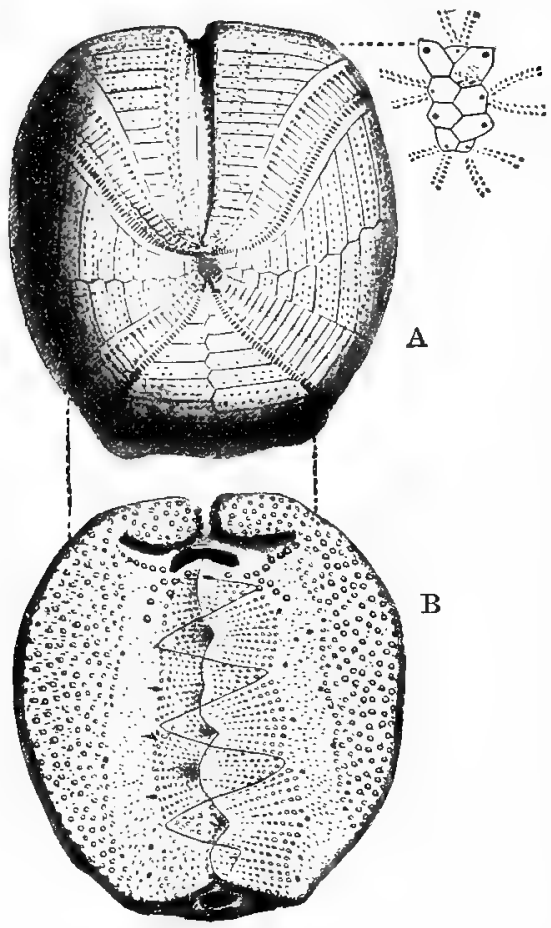

FIG. 230. - A sea-urchin that has gained a bilateral shape. The mouth is shown at the upper (anterior) end; the anus at the posterior end. $A$, dorsal or aboral view; $B$, ventral or oral view. From Parker and Haswell. size in certain sea-urchins and are moved by muscles at their base. Certain spines are modified and have special uses; such are the little forceps that abound about the mouth and are believed to help keep the other spines clean. In the sea-cucumbers (Holothurians), alone, is the skeleton insignificant, being made up of small spicules that take on a variety of forms, such as rods, anchors, wheels, etc. (Fig. 231). Since these bodies are relatively small, the skin of holothurians is flexible and often transparent.

The Water-vascular System. - The most characteristic feature of echinoderms is a system of water-tubes which serve for locomotion. This system opens to the exterior by means of a sieve-like body placed at the aboral pole called the madreporite. Thence a canal runs to a circular canal sur- 
rounding the œsophagus, and from this canal a tube runs out and along each of the radii. From this radial canal in turn a series of tube-feet are given off on the right and left; these are the locomotor organs (Fig, 232). Thus the locomotor organs are tubes closed at the outer end and full of water. At its inner end each tube-foot is swollen into a large bladder. The way a tube-foot acts is as follows: The circular muscles in the wall of the bladder and of the foot itself contract, thus forcing water out into the tube-foot, which in consequence elongates enormously and may reach out beyond the tip of the spines. Upon touching a solid object the sucker on the end of the tube catches hold. Then the muscles that run lengthwise of the foot contract and shorten the foot, its fluid flowing into the bladder. If the solid object is immovable, then the

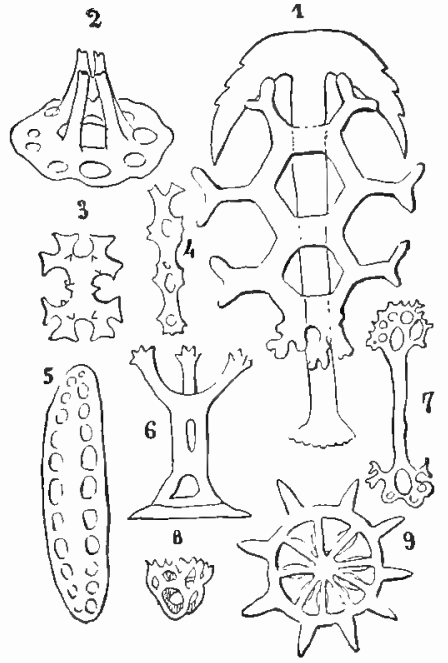

FIG. 231. - Spiculæ from the skin of sea-curumbers. 1, anchor and anchor plate; 2, "stool" of Cucumaria; (Fig. 229) 3, "cross" from a Cucumaria; 4 , rod from tube-feet; 5 , supporting plate from tube-feet; 6 , another form of "stool" ; 7 , rod from tube-feet; 8 , latticed hemisphere; 9, "wheel." All much magnified. From Lang. starfish or sea-urchin moves toward it; but if the object is easily moved, it may be brought toward the echinoderm.

Organs of Nutrition. - A complete foot-canal, beginning with a mouth and ending at an anus, is found in echinoderms in general, excepting the serpent-star and a few other starfish. The mouth is guarded by hard parts which in sea-urchins 
become five large, bony jaws-constituting together the "lantern of Aristotle" (Fig. 233). These jaws are worked by powerful muscles, and each carries a chisel-shaped tooth

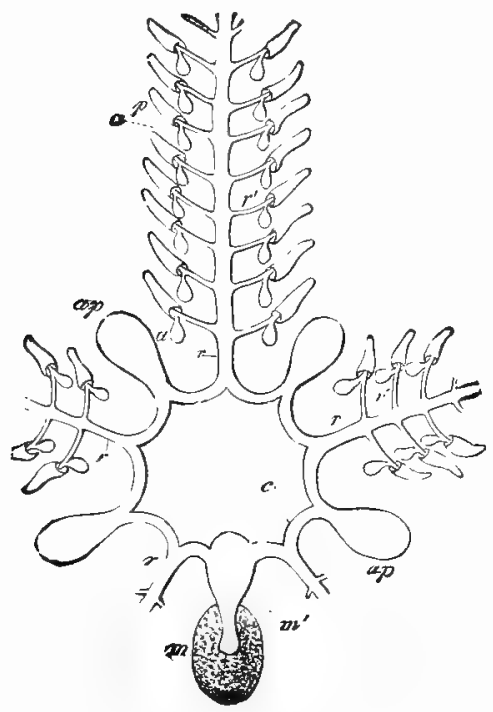

Frc. 232. - The water-vascular system of a starfish $m$, madreporite, connecting by a canai, $\left(m^{\prime}\right)$, with the circular canal $(c)$, from which the rarlial vessels $(r)$, run to each arm and on which lie the vesicles $(a p)$ that serve as reservoirs. From the radial vessels (r) tubes $\left(r^{\prime}\right)$, are given off to the tube-feet and their bladders $(a)$. From Parker and Haswell. that is capable of continuous growth. It would be difficult to find in nature adaptations more complete than the transformation of twentyfive incipient plates into five powerful and effective jaws.

The food, torn up by the jaws, passes into the digestive tube which, instead of extending straight to the ahoral pole, forms a large loop in the body. No distinction between stomach and intestine is to be made out, and there are usually no large glands; but in most echinoids there is a long tube lying alongside the intestine (siph, Fig. 234), opening from it near the mouth and emptying into it again at the middle third of its course.

It is possible that this tube serves to supply oxygen to the blood vessels that go to the intestine primarily for liquid food.

Organs of Respiration. - These are very varied in the different classes of the echinoderms, and probably in each 
individual several different organs aid in breathing. In sea-urchins, as in starfishes, there are hollow outgrowths of the skin which are so thin that oxygen can be absorbed by them from the surrounding water. In starfishes such outgrowths are very numerous and small ; in echinoids there are a few large ones near the mouth. Respiration probably also takes place through the walls of the ambulacral feet and in the extra intestine, as just described. The class of holothurians have an extensive, muchbranched sac which lies in the cavity of the body and is filled with water that is periodically

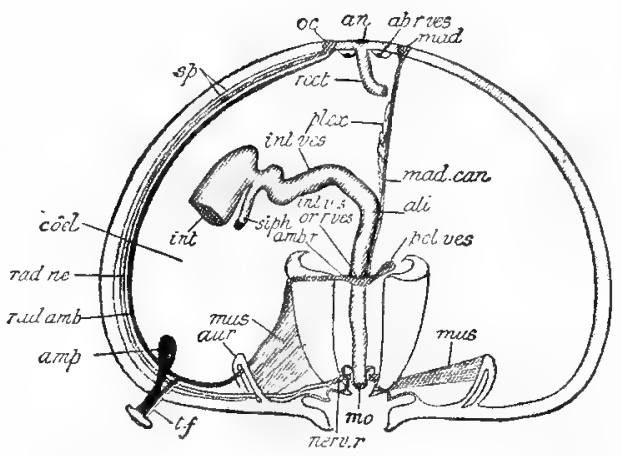

FIG. 233. - A section through a typical sea-urchin, showing the mouth (mo.) and the jaws with the muscles (mus.) that move them. The food canal (ali.) has been cut at the beginning of the intestine (int.) and the great loop (cf. Fig. 234) of the latter removed for simplicity. The rectum (rect.) and anus (an.) lie at the upper pole. Other parts that are referred to are: $a b . r$. ves, circular vessel around anus; amp, bladders at base of tube-feet ( $t . f$.$) ;$ aur, calcareous loops for attachment of muscles; coel, the body cavity; int. nes, intestinal blood vessel; mad., madreporite and its canal (mad. can.) ; nerv. $r$, nerve-ring about mouth; oc, eyebearing plate; or. $r, v$, circular vessel around mouth; plex, gland on madreporic canal; pol. ves, reservoir to water system; rad. $a m b$, radial ambulacral vessel; rad. ne, radial nerve; siph, a tube on the intestine (cf. Fig. 234). From Parker and Haswell.

renewed. This sac is called a "water-lung " or "respiratory tree."

Organs of circulation are ill defined. Great spaces or cavities occur in the body which frequently surround the other organs. These spaces contain sea-water plus a certain 
amount of nutritive matter. Traces of thin-walled vessels occur; one set accompanies the water-vascular system and a complicated set of capillaries lies in the intestines. No "pulsating" heart is known; hence the fluid must pass only

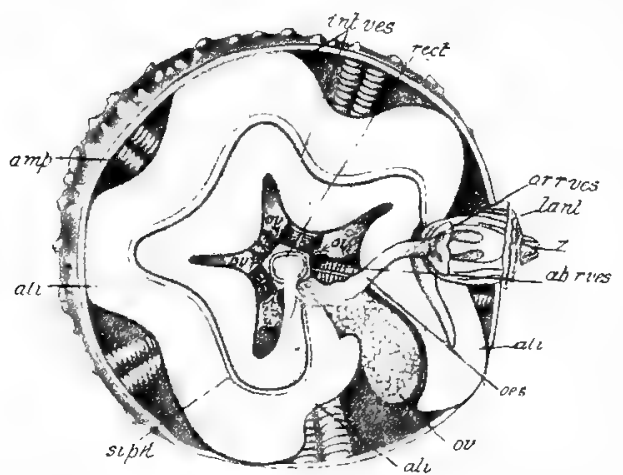
after removal of the oral half of the body wall. The food canal (ali.) is shown entire, beginning at the lantern (lant.) and passing along the oesophagus ( $\alpha s$.$) and intestine (ali. ali.) to the rectum (rect.).$ Parts of five ovaries (ov.) are seen arranged around the anus. The blood vessels are represented by a circular vessel around the mouth (or. $r$. ves.), one around the anus ( $a b . r$. ves.), and a vessel on the intestine (int. ves.). The siphon is shown at siph. From Parker and Haswell.
FIG. 234. - View of internal organs of a sea-urchin

very slowly through these spaces.

Organs of excretion are not present, probably because the dissolved products of decomposition readily pass out through the tubefeet and the skin, which are bathed by constantly renewed sea-water.

Reproductive Organs.-The sexes are usually separate in echinoderms. The eggs or sperm-cells are usually formed in the walls of pouches opening interradially; in typical seaurchins, at apertures in five plates lying around the anus. Eggs are poured out and stream down among the spines and often develop there under their protection.

Musculature. - Owing to the rigid outer skeleton, a general body musculature is nearly wanting except in holothurians. Muscles move the jaws and the spines of sea-urchins, and these are frequently very powerful. 
The nervous system is mainly on the surface of the skin. There is a ring of nervous tissue (Fig. 233, nerv. $r$ ) surrounding the mouth and scnding a branch along each radius ( $\mathrm{rad} . \mathrm{ne}$.). Each branch controls the movement of the tube-feet of its radius. In sea-urchins a special set of nerves go to the musculature of the jaws.

Sense-organs. - The tube-feet are certainly delicately sensitive to touch in all echinoderms, and in starfishes the terminal tentacles seem to be specialized organs of sense. Red "eye-spots" are found at the ends of the arms of starfishes. These spots are covered with little pits or depressions that are full of pigment and no doubt absorb light, but can hardly form a picture on a retina. Over the oral surface of the radii of seaurchins are scattered modified spines consisting of small spheres resting on a tubercle (Fig. 235). These normally hang straight down; and if a sea-urchin be turned wrong side up, they press on

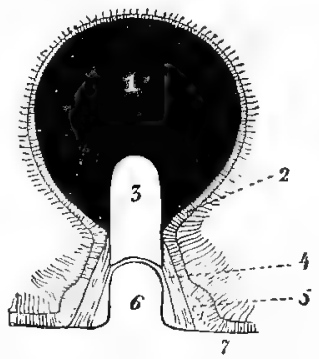

FIG. 235. - One of the little spheres of sea-urchins, diagrammatic and much magnified; cut lengthwise. (1), the calcareous mass covered with skin (2), borne on a limy stem (3), which in turn is worked by muscles at (4), over a knol) (6) of the limy plates (7). The muscles are under the control of a nerve-centre at (5). From Lang.

the skin and perhaps thus make the animal aware of its abnormal position. They are thus thought to be organs of " orientation," - informing the animal of its position in the world. 


\section{CHAPTER XVIII}

\section{THE STARFISH: A STUDY OF EMBRYOLOGY}

Since fatal accidents are all the time happening to individuals of any species, in the course of time a species would become entirely extinct were there not some way of continuing it. All animals as well as plants have a single method of making good the losses due to death, and this method is the division of the individual, so that two or even a hundred or more take the place of one. This process of multiplication of individuals through the division of a single individual is called reproduction.

Although all forms of reproduction are fundamentally one, several sorts may be distinguished, owing to certain minor differences between them. Thus there is the method of fission, as seen in the lowest organisms, in which the body of the reproducing individual divides into two equivalent parts. Then there is reproduction by budding, as seen in certain aquatic animals and nearly all plants, where an outgrowth or bud arises on the side of the parent individual. This bud gradually develops into the form of the adult and may then, under certain circumstances, be cut off from the body of the parent individual. Also there is the method of sporulation, in which the body of a single organism breaks up at once into a large number of equivalent parts called spores. The method that has become commonest among both animals and plants, however, is that of reproduction by germ-cells. By this process 
only a small part of the body is divided off to form the next generation. In this case the living thing thus separated from the parent is not only very small but, apparently, very simple. It undergoes a series of changes by which it becomes more and more complex until finally the adult form is achieved. The study which traces the changes that the egg passes through in its development into the adult is known as embryology. As an example of the embryological history of an organism we may consider the development of the starfish egg.

Development. - Starfishes have the sexes distinct; and the sex can sometimes be told by the color. In the common Eastern species ${ }^{1}$ the female has a bluish tint, while the males are of a reddish brown color. Both the eggs and sperm are extruded into the water through small openings on the aboral surface at the interspace between two adjacent arms. The egg is hardly visible to the naked eye and is enclosed in a delicate membrane through which one of the sperms penetrates into the egg. This is called fertilization. The entrance of the sperm seems to start the development of the egg. First, the egg undergoes cleavage; that is to say, the single sphere breaks up into two, four, eight, sixteen spheres, and so on (Fig. 236). Finally a hollow ball, made up of these spheres or cells, is formed, called the "blastula." Next the wall of this hollow sphere is pushed in at one side, forming a sort of cup with two walls. This is the so-called "gastrula." The cavity of this cup is the digestive cavity. At first it is a sac with only one opening, but later a second opening, the true mouth, breaks through and the former opening persists as the anus. Pairs of arms, edged with cilia, now bud out on each side of the body. At this stage the organism is alike 

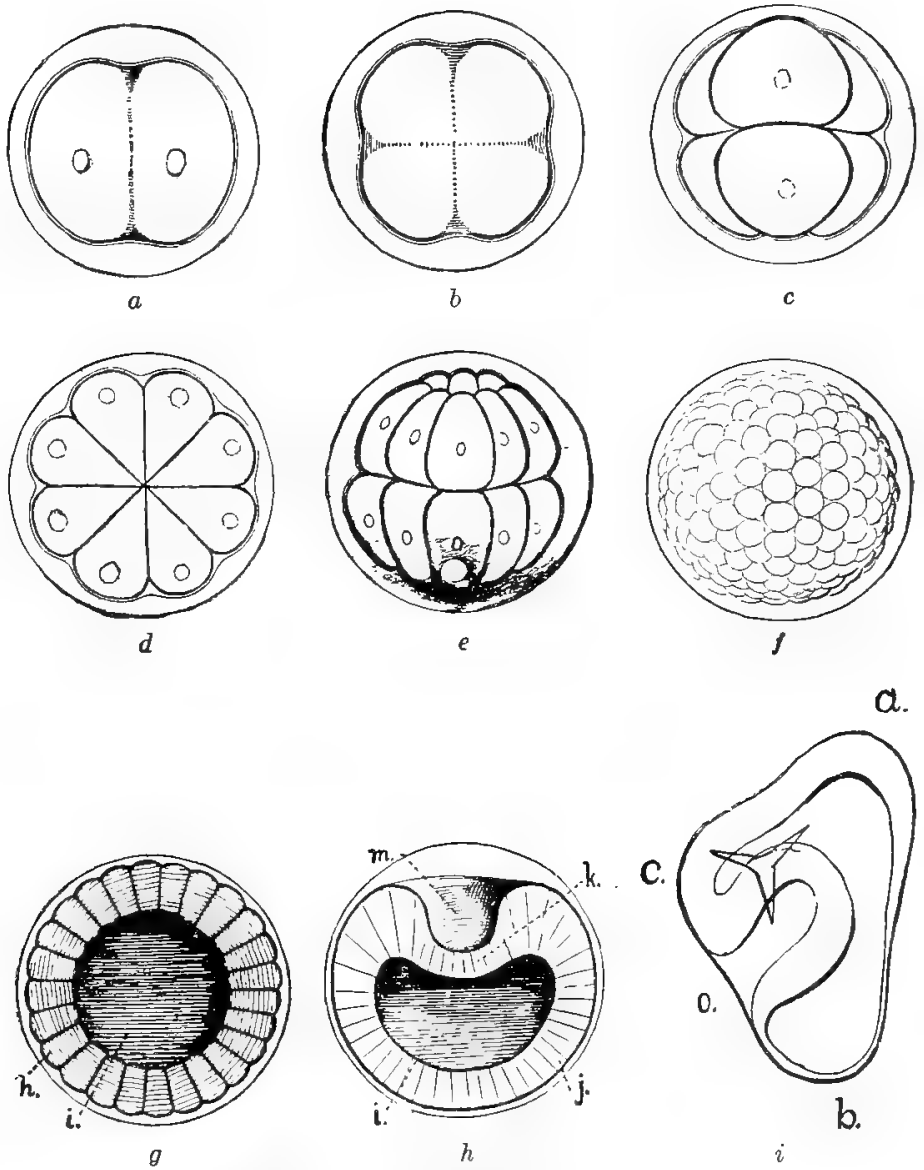

FIG. 236. - Illustrating the transformations from the egg to the young Iarva of an echinoderm (the sea-urchin, Arbacia). From W. K. Brooks. $a$, first cleavage plane formed, 2-cell stage; $b$, second clcavage plane formed, 4-cell stage; $c$, third cleavage plane formed, 8-cell stage; $d$, view from one pole of the 16-cell stage; e, same stage from the side; $f$, a later stage with numerous cells; $g$, sane stage seen in section, the "blastula" ; $h$, the transition to the gastrula stage; $i$, side view of young larva. 
on the two sides or bilaterally symmetrical. ${ }^{1}$ It swims freely in the water and is known as a larva. The larva has, it will be observed, very little relation in form to the adult starfish. The change from the larval to the adult starfish is known as a metamorphosis. Even in the bilateral stage the system of water-tubes of the adult starfish has begun to form and, finally, over the stomach on the left side five pockets, radially arranged, make their appearance; these are the five radial water-tubes, one of which runs down each future arm. On the right side of the stomach, calcareous plates are laid down to form the aboral wall of the starfish. ${ }^{2}$ The young star is now found as a parasite at the hinder end of the larva. Soon all the front end of the larva, together with the long arms, becomes absorbed.

The larva now ceases to swim and settles to the bottom. There the process of resorption is completed, the upper and lower surfaces of the star approach each other, the limy skeleton and sucking-feet rapidly develop. At this stage the disk is so large and the arms so short that the young starfish looks more like a sea-urchin than an adult starfish. The elongated arms are acquired at a later stage.

${ }^{1}$ FIGs. 237, 238.

2 FIGS. 239, 240, $a b, a b^{\prime}$.

Figs. 237-240. - Larval stages and metamorphosis of starfish. After drawings of E. B. Wilson, from Brooks, "Invertebrate Zoology."

Fig. 237. - Dorsal view of starfish larva with beginnings of ciliated arms.

Fig. 238. - Ventral view of same larva.

FIG. 239. - Side view of an older larva in which young star is beginning to arise.

FIG. 240. - Ventral view of same larva, $a$, anterior end; $b$, posterior end; 1-4, ciliated projections; $a^{\prime}$, preoral arms; am, oral surface of young star with beginning water-tubes, $a m-a m^{5} ; a b, a b^{\prime}, a b^{5}$, ahoral surface of star; $c$, postoral arm; $i$, intestine; $m$, mouth; $n$, lateral arm; $o$, anus ; $\infty$, œsophagus; $q, q^{1}$, dorsal lateral arms; $s$, stomach; $w w^{\prime}$, water tubes; $a m$, Fig. 238, region from which water-tubes arise. 

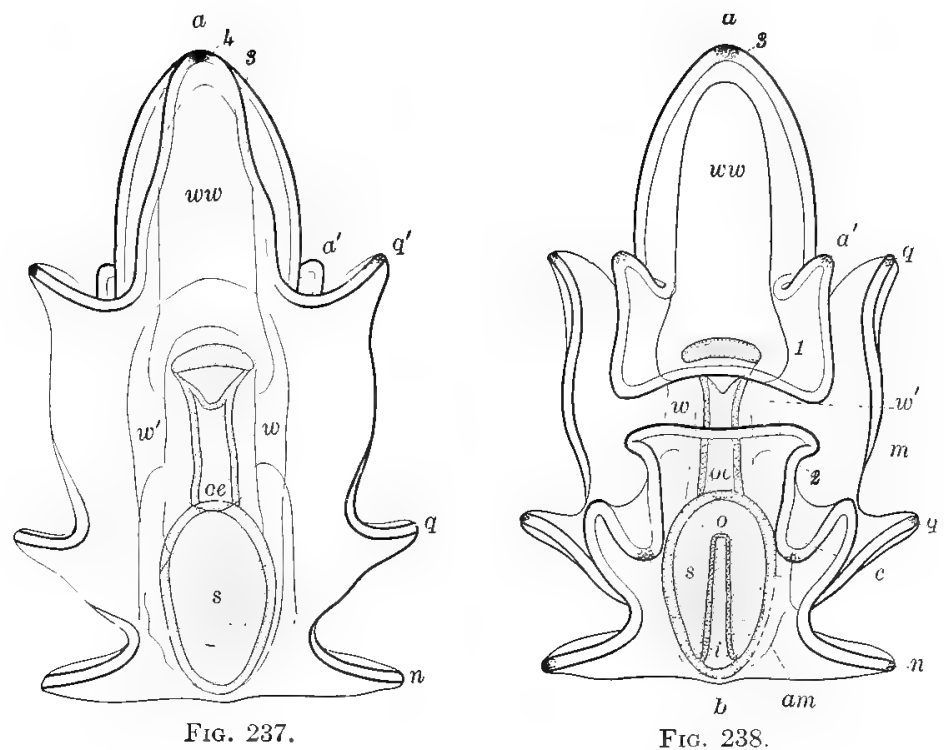

FIG. 238.
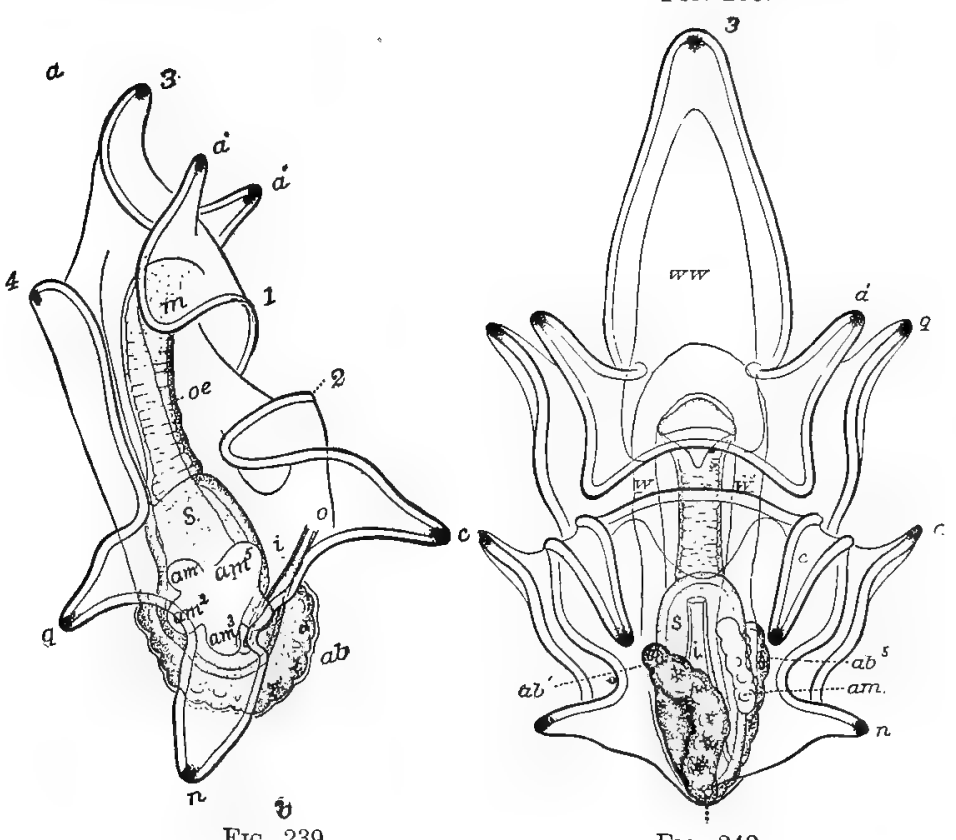

FIG. 240. 
Systematic Position. - The starfishes belong to the group of Echinodermata, ${ }^{1}$ as is proved by their five-rayed structure; the well-developed system of limy plates in the skin; a system of water-tubes, used for locomotion; and the separation of the intestine from the body-cavity.

Distribution and Habitat. - The common pink starfish of the eastern United States (Asterias ${ }^{2}$ vulgaris ${ }^{3}$ ) ranges from Labrador to northern Florida. ${ }^{4}$ It lives near the shore, extending out into fairly deep water, but is not abundant at greater depths than sixty fathoms.

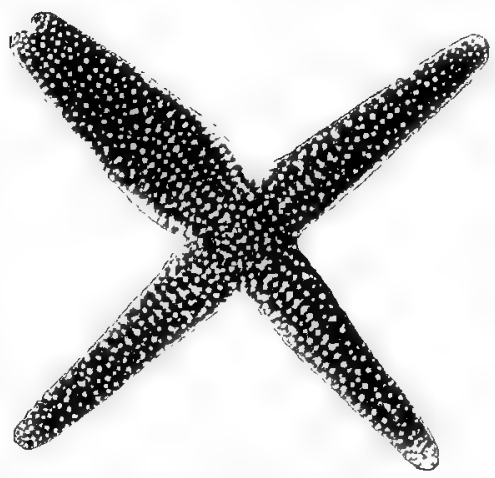

FIG. 241. - Abnormal starfish (Asterias), apparently produced by fusion of two rays. One-half nat, size. Photo. by W. H. C. P.

It is found especially on the oyster-heds, where it is very destructive. On rocky coasts starfishes will be found in crevices of the rock or in tide-pools. They love cool waters, and are often found hanging on vertical walls or ledges. Upon reaching the surface of quiet water, they may extend one or more of their arms out upon the under side of the surface film and seem to hang in part from it.

Abnormalities are frequently found among starfishes, partly on account of their capacity for regeneration, even from

${ }^{1}$ echinos, hedgehog, sea-urchin ; derma, skin.

2 From aster, star.

${ }^{3}$ Common.

${ }^{4}$ A dark brown form, sometimes called Asterias Forbesii, is recognized by some authors as a separate species inhabiting the coast from Massachusetts Bay southward. 
the risk and a single arm. Thus one may find a starfish with three or four rays, or with a small ray between normal-sized ones. Not all abnormalities seem to be the result of mutilation, however; for example, sometimes two arms seem to be fused (Fig. 241).

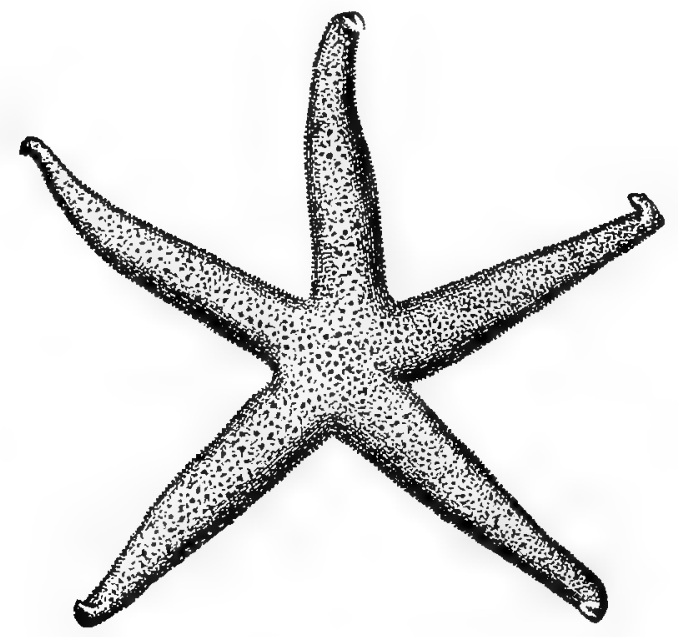

FIG. 242. - Cribella sanguinolenta. Nat. size. From Leunis.

Other Starfishes. - Besides Asterias vulgaris there are over five hundred species of starfishes. In some of these - as in Asterias - the skeletal plates of the skin make a network; in others they form a solid calcareous covering. ${ }^{1}$

1 To the first class belong, besides Asterias vulgaris, Asterias ochracea, which occurs commonly on the Pacific coast from Sitka, Alaska, to San Diego, California. This has a much thicker, more solid skin than the Atlantie species. A. giganter attains a diameter of over two feet. As an example of the second class may be cited Cribella sanouinolenta (Fig. 181), a smooth, leathery, blood-red starfish, about ten centimetres in diameter, which, next to $A$. vulgaris, is our commonest Eastern species. 
Certain starfishes have many arms instead of only fivr. ${ }^{1}$ In still other starfishes the rays are partially connected by a membrane like the web of a duck's foot, so that the whole outline is nearly pentagonal (Fig. 244). In extreme cases the outline becomes strictly pentagonal or even approximately circular in plan, like a sea-urchin. The last species shows a transition between starfish and urchin.

The Serpent-stars. - In the serpent-stars (Ophiu- Fig. 243. - Solaster, a multi-rayed starfish. oridea $^{2}$ ) the organs are

Reduced. From Leunis.

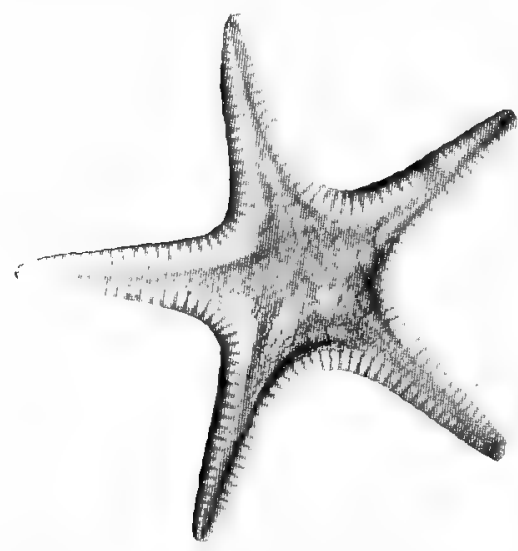

FIG. 244. - Archiaster, a webbed starfish. Slightly reduced. Photo. by W. H. C.P. not prolonged from the disk into the arms, consequently the arms may be thrown off without injury to the animal; hence the name "brittle-star." The brittlestars fall into two groups, in one of which, the serpentstars, the arms are unbranched, ${ }^{3}$ while in the

${ }^{1}$ It is so in the case of solaster endeca of the northern Atlantic (Fig. 243).

${ }^{2}$ ophis, serpent; oura, tail.

${ }^{3}$ Fig. 245. 
other, the "basket-fish," the arms are branched." The serpent-stars " live in crevices of the rock and, being of rather small size, are not commonly seen. At the base of the arms, on the right and left, are a pair of slits, which form the exits from pouches into which the reproductive glands open (Fig. 246). In certain species the pouches are used for brooding the young.

The hasket-fish occur in Northeastern waters, from low tide to one hundred fathoms, and are often brought up by fisher-

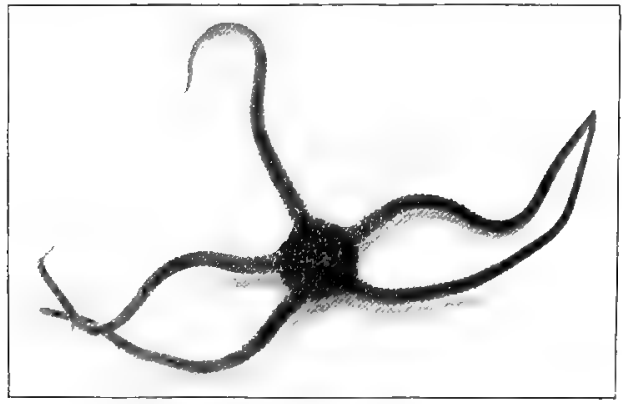

Fig. 245. - Amphiura squamata. One of the Ophiuridx. Nat, size. Photo. by W. H. C. P.

men, to whose lines they are led by their instincts to cling. The branching of the arms enables the animal to hold its prey, which consists of shrimp and fish.

The sea-urchins, or echinoids, may be regarded as starfishes in which the arms have shortened and the disk enlarged so as to fill up the interspaces, and make a solid, nearly spherical form. The sea-urchins eat various small animals and get food

1 Fig. 246.

Of the serpent-stars there are two common forms on the New England coast, - a white spceies, with long, slender arms, Amphiura squamata (Fig. 245), and the spotted Ophiopholis, which has shorter, stonter arms. 
also from small bits of organic matter in the mud which they swallow. They live more concealed than the starfish, for some burrow in the mud and others - such as our green sea-

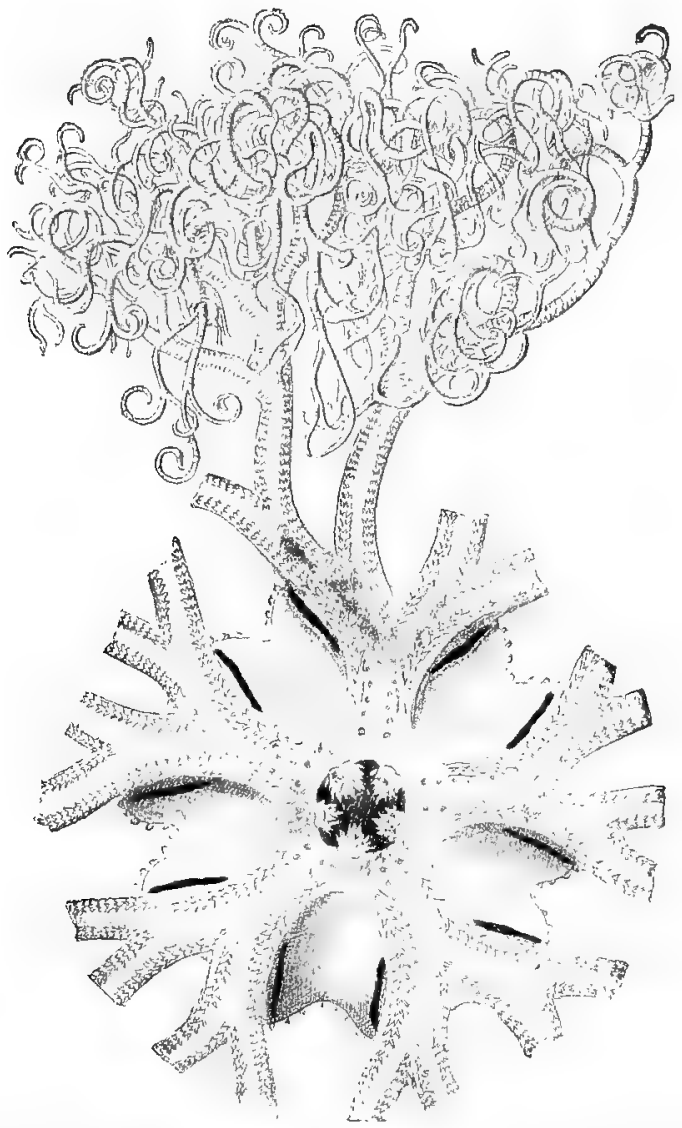

Fig. 246. - Part of basket fish (only a portion of one arm showing) viewed from oral pole. In each inter-radius a pair of slits leading to the brood pouches. From Lang. 
urchin of the Maine coast (Fig. 247)- grind out pockets in the rocks by means of their spines. ()thers cover themselves with seaweed, and thus become inconspicuous. Besides the green seamurchin, which is found north of Cape Cod, we have a black sea-urchin (Arbacia), which extends south as far as

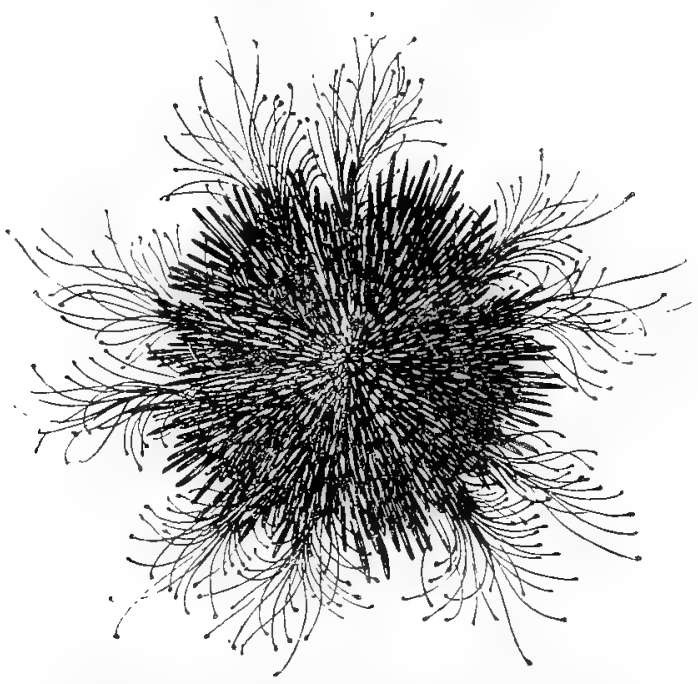

FIG. 247, - Strongylocentrotus, the Eastern green sea-urchin, with tube feet extended. From "Standard Natural History."

North Carolina. We have on the east coast also two kinds of flat sea-urchins (sand-clollars), which live in the sand from low water to one hundred fathons. Their spines are small and silky (Fig. 248).

The sea-cucumbers, or Holothurians, ${ }^{1}$ may be likened to softskinned sea-urchins, with the body drawn out to the form of a cucumber, or even of a worm. The limy skeleton is reduced 
to small plates lying in the skin. The mouth is surrounded by a circle of tentacles (Fig. 249). The ambulacral feet are sometimes absent. The Holothurians live in sand and mud, often deeply buried, and feed on small marine animals or the decay-

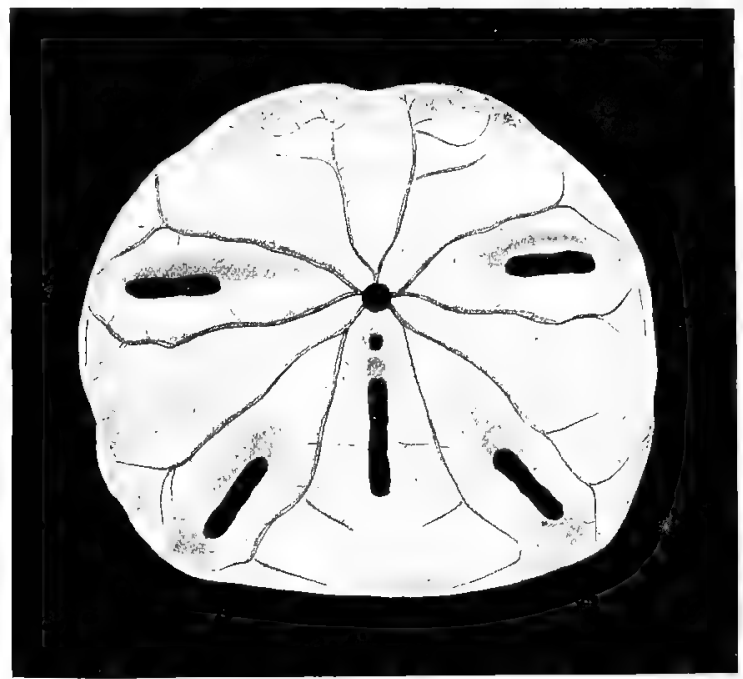

FIa. 248. - View from mouth side of a sand-dollar (Mellita). From Lang. ing particles mingled with the mud which they devour. They are of considerable economic importance. The members of one genus (Holothuria) are taken in great numbers on the coral reefs of the Pacific Ocean and the China Sea, where they are commonly known as "trepangs." They are cut open, washed, boiled, dried, and sometimes smoked. They are sold in Chinese ports and some species are considered by Chinese epicureans as great delicacies, being cut up into small lumps which are boiled to make a soup. 
Several species of Holothurians occur on the Maine coast. A barrel-shaped form with a sort of tail (Caudina, ${ }^{1}$ Fig. 250) occurs on

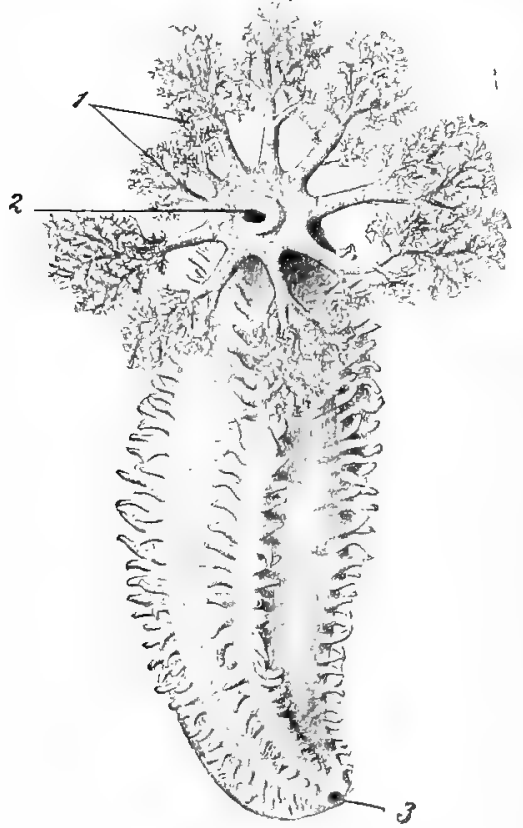
the Massachusetts coast. A worm-like form, but with a beautifully transparent skin (Synapta, ${ }^{2}$ Fig. 251), is found in sandy beaches from Massachusetts to New Jersey.

The sea-lilies, or Crinoids, ${ }^{3}$ are familiar as fossils to residents of New York State and the Ohio and Mississippi valleys. The living animals are less often seen, for they are inhabitants of the deep sea. They have a cup-like body, with the mouth at its centre directed upward, and surrounded by tentacles (Fig. 252). The cup is either

FIG. 249. - One of the sea-curumbers borne on the end of a long (Cucumaria) showing mouth (2), surrounding tentacles (1), and anus (3). Ahout nat. size. From Lang. stalk or is unstalked. The former condition is more usual among the fossil species; the latter becomes more and more common as the geological ages follow one another.

${ }^{1}$ cauda, tail.

2 sunaptos, fastened together ; from sun, with, and apto, to fasten.

${ }^{3}$ krinon, lily ; eidos, form. 


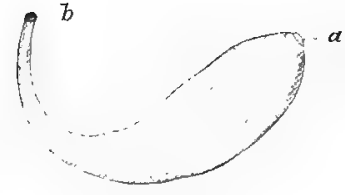

Frg. 250. - Caudina, the tailed Holothurian. $a$, mouth; $b$, anus. After Sclenka.

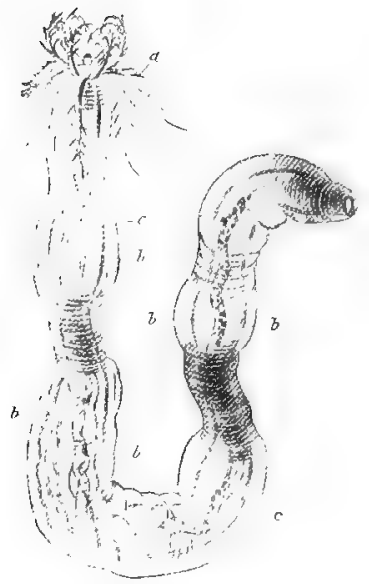

FIG. 251. - Synapta inherens. $a$, tentacles: $b$, longitudinal muscles; $c$, alimentary tract. After Quatrefages.

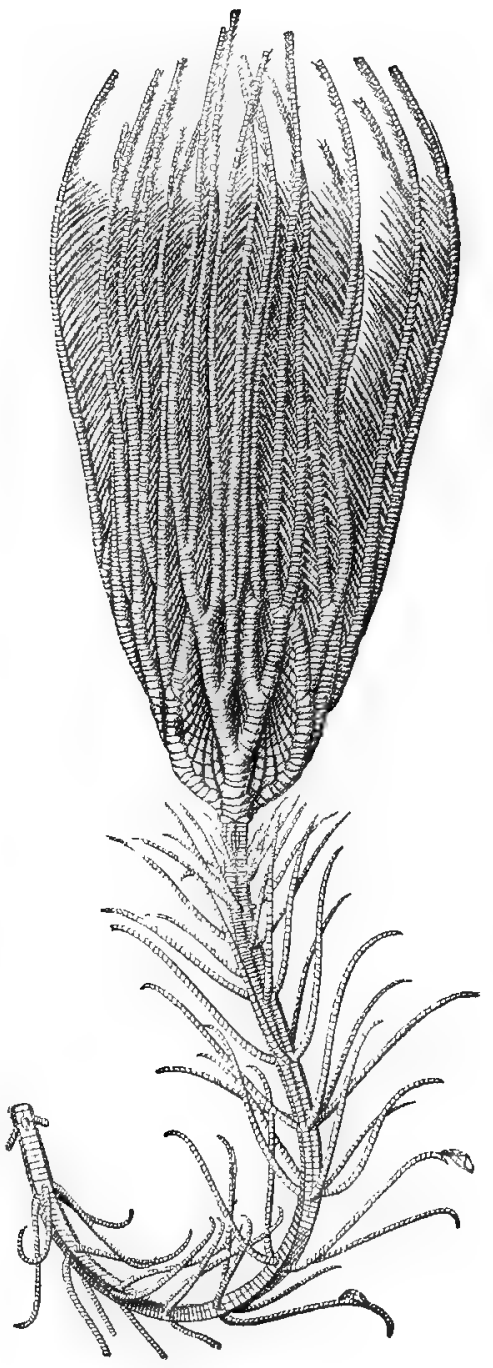

FIG. 252. - A sea lily, Melacrinus interruptus. After P. H. Carpenter. 


\section{CHAPTER XIX}

\section{HYDRA: A STUDY OF ATTACHED ANIMALS}

A common distinction between plants and animals is that plants are attached and rooted to the soil, whereas animals are able to move from place to place. Although this distinction holds in the rase of most animals and plants it is not without numerous exceptions. Thus there are many lowly organisms which are assigued to the plant kingdom that have never lost the power of swimming about. This is true of the small, green organisms that live on the surface of the sea or in the waters of ponds. It is also true of the whole group of bacteria that play so important a part in disease. On the other hand, there are a few animals that have lost the capacity for locomotion in their adult stage and are rooted to the suhstratum like plants. There are four different types of attuched or sessile animals: (1) the Sponges and (2) the group of Coclenterata, both of which we shall consider in the present chapter; (3) the Mossanimals or Bryozoa considered in Chapter XII; and (4) the Mantle-animals or Tunicates considered in Chapter XXI. In their young stages all of these animals are free-swimming, but throughout their adult life are attached to the solid objects of the bottom. We are hound to conelude that all attached animals have been derived from free-swimming ancestors, and we have therefore two questions to answer: Why should any free-swimming form evolve into an attached one, and What changes have attached animals undergone in abandoning their free life? 
In regard to the first question we can only say that in the attached condition animals are no less able to live and multiply than in the free-living state. The sponges and the corals that help to build oceanic islands, and the Bryozoa that are found on every sea-coast and in nearly every lake and pond are eminently successful groups.

In regard to the changes in form which aecompany sessile life more may he said. First, the attached or sessile animals tend to grow, like the trees, by buds. The new individuals, budded from the old, may in some cases separate from the parent individual and swim away to become attached again at a distance, or they may remain as permanent branches. By repetition of the budding process a tree-like form may be produced, as in the corals. Secondly, attached animals, since they do not move from place to place, have less need of senseorgans with which to find the way. Consequently, we often find attached animals devoid of organs of hearing and even of sight, although the touch reaction is always present. As a result of the reduction of sense-organs on the head, the brain has become greatly reduced. Of course all locomotor organs have become rudimentary and the muscular system has correspondingly become very rudimentary. These reductions in turn have affected the nervous system so that it has become greatly simplified. Thirdly, since attached animals are not able to hunt for their prey, they must take what is wafted to them by currents in the water. Furthermore, they are supplied with a mechanism for making whirlpools the apex of which leads to their mouths. This mechanism often consists of tentacles covered with cilia, the beating of which creates the vortex whereby small particles of food are drawn into the mouth. Finally, the methods of reproduction have been 
multiplied. In addition to reproduction by means of eggs and the buds already referred to, there are special kinds of buds formed to tide the species over some difficult period such as winter or periodic drought.

The Hydra, which is the type of attached animal we propose to study, belongs to the phylum of C'œlenterata, - a phylum that includes buth sponges and certain organisms with nettle organs. The Colenterata are, for the most part, sessile animals. Consequently they have a more or less radial or tree-like form, since animals attached to the earth tend to form a cylindrical stem with branches springing out on all sides of it. They have also a system of internal cavities serving for the digestion of food as well as for a body-carity. The hody-wall (which is also the wall of the food-eavity) is made up of two layers, - an outer skin, or ectoderm, which is protective and contains sense-organs, and an inner skin, or entoderm, which has a digestive and absorbing function.

The sponges are sessile; have no nettling organs, and have the body-wall perforated by many fine incurrent openings and a large exhalent opening (Fig. 253). Most sponges produce buds and give rise to colonies; they also frequently produce little round bodies which survive when the rest of the species is killed in the winter and hatch out the following spring. A few sponges are simple individuals, having the form of a cask. The delicate hody-wall is supported by a network of spieules made up, in the different groups, of different materials. In some cases the spicules are limy, as in all the common fresh-water species; in other cases they are silicious, as in the glass sponges; while still others are homy, like the bath-sponges. Generally the sponge is not a simple individual, but is a colony made up of a number of individuals (zooids) that have budded 
from a central one. This is the case, for example, in the bathsponges. A small bath-sponge is eomposed of the skeleton of only a single individual, whereas the larger sponges may be com-

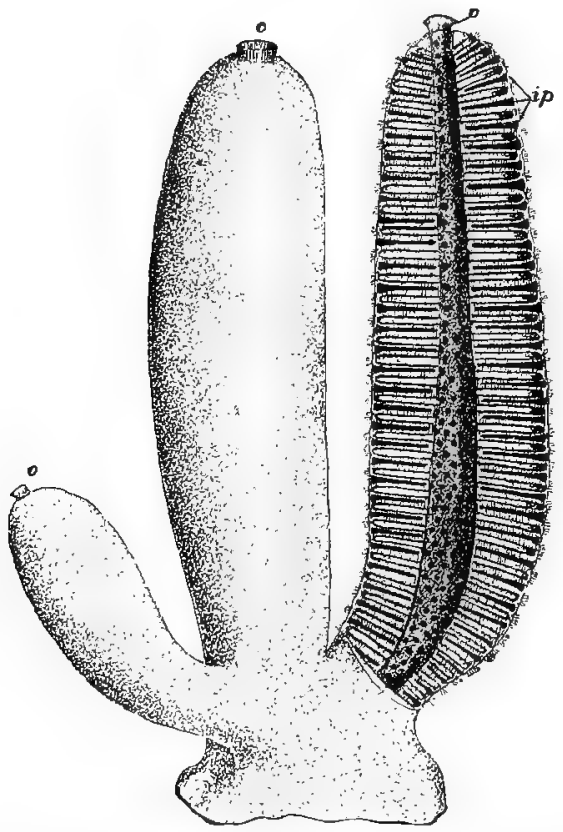

Fig. 253. - Sycon gelatinosum. A portion slightly magnified: one cylinder (that to the right) bisected longitudinally to show the central stomachcavity opening on the exterior by the osculum, and the position of the incurrent and radial canals; the former indicated by the black bands, the latter dotted. ip. marks the position of three of the groups of inhalant pores at the outer ends of the incurrent canals; o, osculum.

posed of half a dozen or more zooids, the number of which may be determined by counting the number of large openings in the sponge. The soft living matter may easily be removed from the skeleton, and this is regularly done in preparing the sponges used in commerce. Our common bath-sponges come from 
tropical waters and are torn, either by divers or, as in Florida, by hooks of special form, from the rocks at the bottom of the sea near the coast. Ahout 2250 persons are engaged in the sponge fisheries of Florida, and the annual catch is sold for about half a million dollars. The principal centre of the industry is Key West.

The group of nettle animals is characterized first of all by little organs which, in many species, are capable of irritating even the skin of man; these organs consist of a little bladiler which secretes a poisonous fluid and a long tube by which it passes out of the bladder. The nettle animals also have a true mouth surrounded by tentacles. The Hydra belong to this group.

There are two common species of Hydra: the one is of a green color (Hydra ${ }^{1}$ viridis ${ }^{2}$ ), and the other is flesh-colored ( $H$. fusca ${ }^{3}$ ). They are found in standing or slow-running water, attached to submerged plants, sticks, and stones. Throughout the winter they live at the bottom of ponds, below the ice. The body of Hydra is soft and highly contractile, so that, when first drawn from the water, it appears like a speck of jelly. Left undisturbed, the animal expands, and its five to eight tentacles wave slowly about in search of food. The tentacles are richly supplied with nettling cells, each of which contains a fluid-filled capsule, in which is coiled a threar-like tube. When stimulated by contact with some foreign borly, the tentacle closes around it, while from each capsule the lasso-thread rolls out as the finger of a glove is rolled inside out, and an irritating poison is discharged. If a small animal has been the irritant, it is instantly caught in the thread, paralyzed by the

1 hydra, a mythological monster, capable of regenerating its head.

2 Green.

3 Brown. 
poison, and soon conveyed to the Hydra's mouth. The principal food of Hydra consists of small worms and the smaller Crustacea, such as Daphnia and Cyclops.

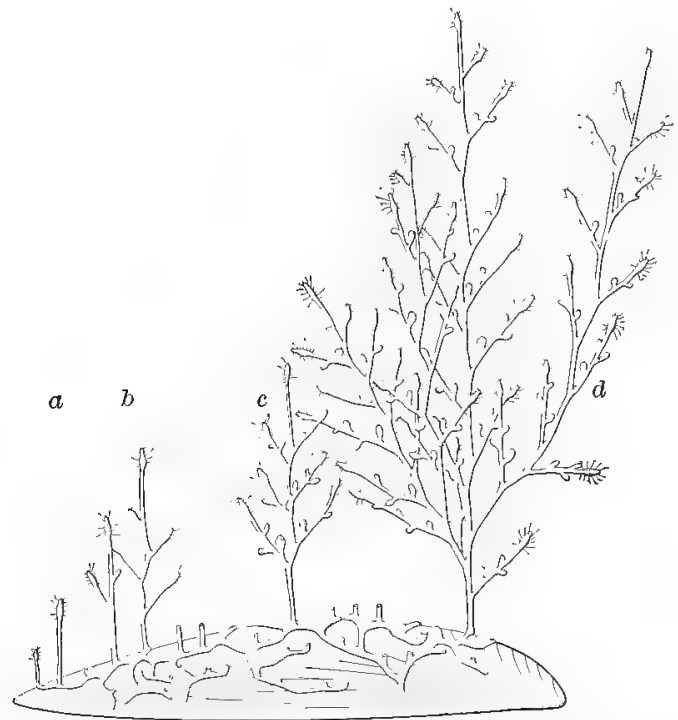

Fig. 254. - A colony of Cordylophora lacustris, on a shell of Mytilus. For clearness, a number of the erect branches are cut off at the stolon. $a$, very young shoot without lateral hranches; $b$, young stock with lateral branches but no gonophores; $c$, a stock with gonophores on lateral branches; $d$, fully grown stock with lateral stems. After Schulze.

Fresh-water Hydroids are of extremely few kinds. Hydra was once regarded as the only instance, but others are now known. One of these, called Cordyloph'ora (Fig. 254), is found chiefly in brackish water or in fresh water near the coast. Like many of the marine hydroids, Cordylophora produces its young in special capsules, called gonophores, which are rudimentary jellyfishes (Fig. 254,c). The young become free when 
they have gained an elongated, cylindrical form. There are other fresh-water species which have free jellyfishes. In this

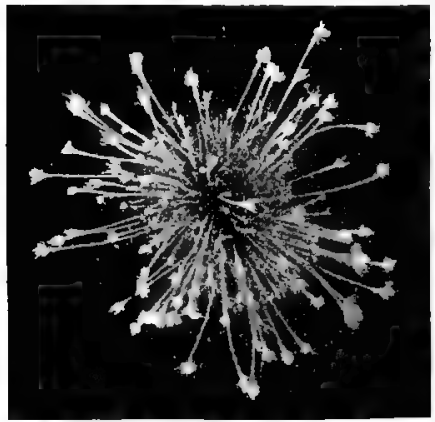

FIG. 255.- Stylactis, a tubularian hydroid, growing on a snail. Nat. size. Photo. of living animal by W. H. C..P. country we have a species, ${ }^{1}$ hitherto known only about Philadelphia, whose hydroid stage is extremely small and bears no tentacles. The jellyfishes are set free during July. Freshwater jellyfishes have also been described from Lake Tanganyika, Africa, and from a tank at Regent's Park, London, to which they had doubtless been imported on plants. It is very probable that all freshwater hydroids which produce

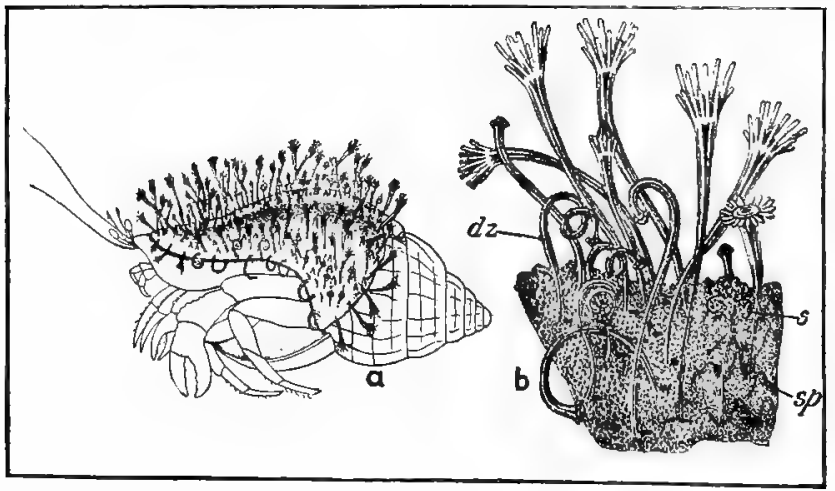

FIG. 256. - Hydractinia, a tubularian hydroid. a, colony growing on gastropod shell inhabited by a hermit-crab; bit of colony enlarged; $d z$, modified, tactile individuals; s, reproductive individuals; $s p$, spines. From Parker and Haswell. 
jellyfish have, geologically speaking, recently come from the sea. Hydra is, however, probably a genus that has been established in fresh water for a long time.

The marine hydroids are, in contrast to the fresh-water ones, very numerous. The organ-pipe corals (Hydrocorallidæ ${ }^{1}$ ) are peculiar in that they secrete a great amount of calcareous substance, so that they were formerly regarded as belonging to the typical corals (Scyphozoa, see page 275). They may be easily distinguished by the absence of radial septæ in the cups occupied by the hydroid. Here belong the millepore corals of Florida.

The tubulurian hydroids (Tubularidæ ${ }^{2}$ ) include some $\mathrm{Hy}-$ droids of large size, since single individuals of Tubularia may become six inches long. Other species grow on gasteropod shells which are occupied by hermit-crabs (Figs. 255 and 256). So thickly do they grow that they make a plush-like covering on the upper part of the shell, and they have the curious habit of building out the lip of the shell so as to enlarge the aperture. Because they do this the hermit-crab, as it grows larger, is not forced to exchange the shell for a larger one, and so does not leave the hydroids on the cast-off shell to roll about on the beach and perish.

Of the bell-hydroids, Campanularid ${ }^{3}{ }^{3}$ one of the common representatives is Ohelia, ${ }^{4}$ which may be found at low tide hanging from rocks beneath seaweed, and looking like delicate white threads (Fig. 257). Observed under the microscope each stem appears as a series of heads called hydranths placed in zigzag fashion, one beyond the other. Another

1 Combining the qualities of Hydra and the corals.

${ }^{2}$ From tubulus, a little tube.

${ }^{3}$ campanula, a little bell.

${ }^{4}$ obelos, a spit. 
common kind is Sertularia, ${ }^{1}$ which forms rusty brown threads (Fig. 258). All the hydranths of one stem occur in one plane and oppositely.

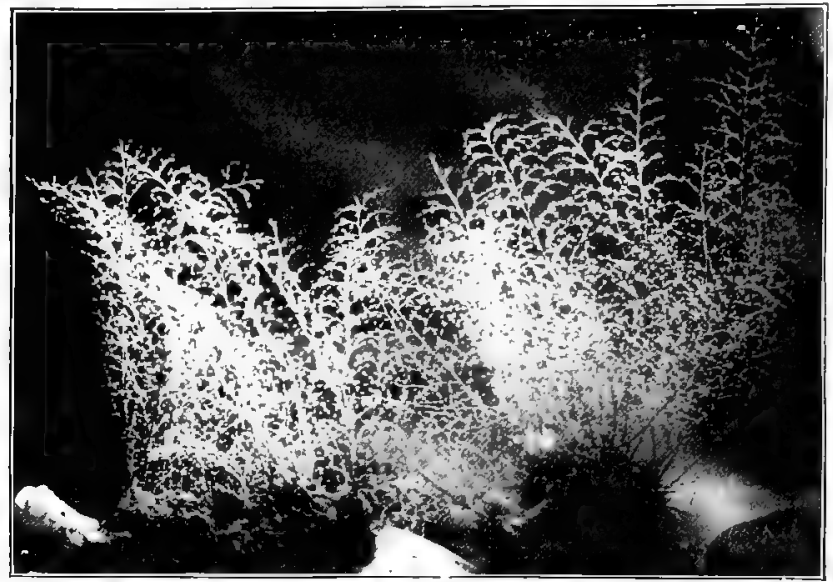

FIG. 257. - Obelia, a group of campanularian hydroid colonies. Nat. size. Photo. by W. H. C. P.

Both tubularian and campanularian hydroids may give rise to jellyfishes. These jellyfishes are formed as buds on the

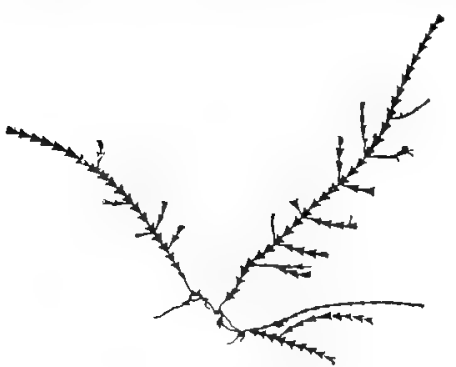

Fig. 258. - Sertularia, a small colony. 1.5 nat. size.

${ }^{1}$ Derived from serta, garland. hydranth, and after they become able to move of themselves they are cut off from the parent and swim away. ${ }^{2}$ The jellyfishes then give rise to the sexual products and discharge them into the water (Fig. 260). As in this case the life-history of the animal consists of an attached individual alternating ${ }^{2}$ Fig. 259 . 
with a free-swimming one, we have here an alternation of generations. In other cases the jellyfish is formed but never separated from the parent, and the eggs develop in the bud. In still

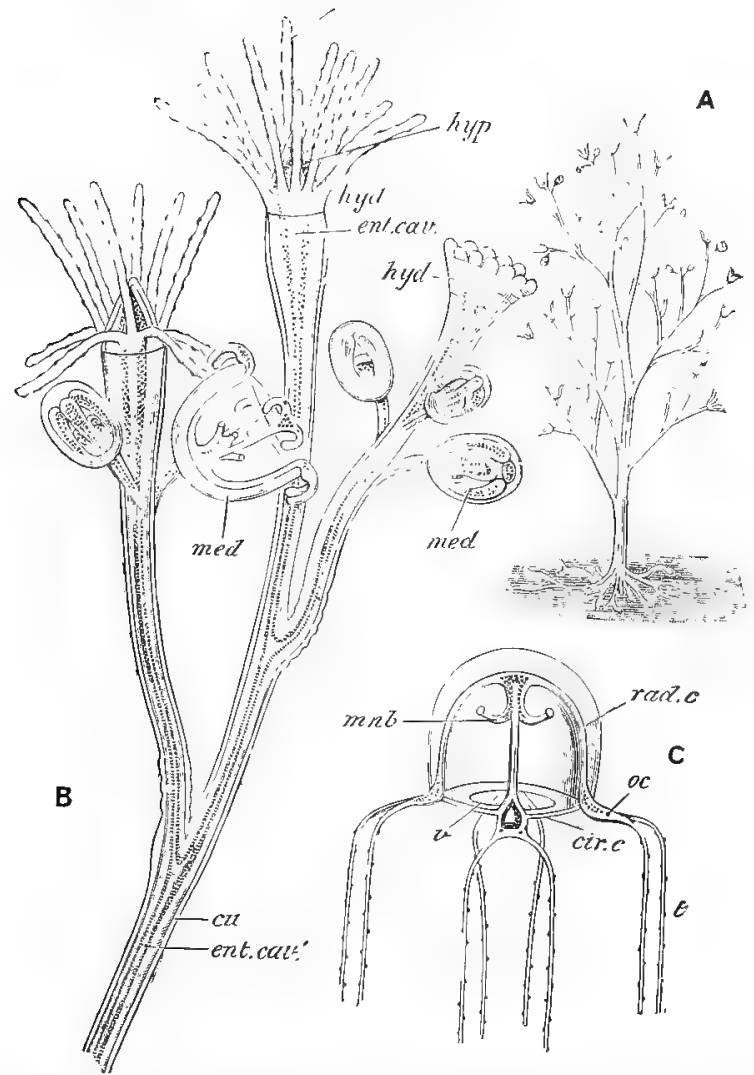

FIG. 259. - Bougainvillea ramosa. $A$, entire colony, natural size; $B$, portion of the same magnified; $C$, inmature medusa; cir.c, circular canal; $c u$, cuticle or perisare; ent.cav., enteric cavity; hyd, polyp 'or hydranth; hyp, hypostome or manubrium; med, medusa; mnb, manubrium; rad.c, radial canal; $t$, tentacle; $v$, velum. From Parker's "Biology," after Allman. This is closely allied to the New England B. supercitians. 
other cases a mere bud is formed which hecomes full of sexual products without ever acquiring resemblance to a jellyfish. ${ }^{1}$ The jellyfish is the primitive type which has undergone a reduction in some cases to a gonophore. It is an interesting fact that in certain species sometimes jellyfishes and some-

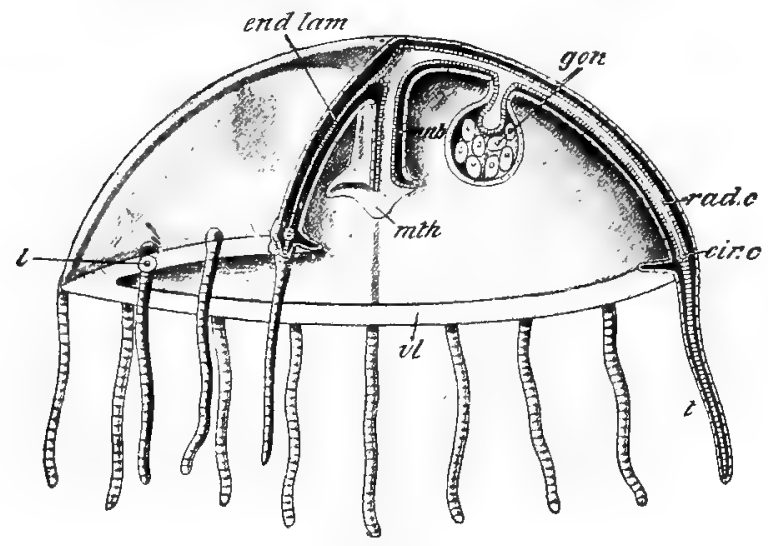

FTG. 260. - Dissection of a medusa with rather more than one-quarter of the umbrella and manubrium cut away (diagrammatic). The ectoderm is dotted, the entoderm (end. lam.), striated; the black is a nembrane between them; l, eyst containing a little sensory body ; $v l$, "velum," a shelf to diminish the opening of the bell. Food system: $m$ th, mouth; $m n b$, manubriun, or gullet; rad.c. cir.c, radial and circular canals, parts of the digestive eavity. Reproductive system: gon, germ-cells.

times gonophores will he produced. In the hell-hydroids the gonophores are encased in a cuticular capsule, but in the tubularian hydroids they are quite naked.

There are certain hydromedusæ in which the hydroid stage is unknown or known to he lacking. Here belong some jellyfishes of our Eastern coast, which may become twenty to thirty centimetres in diameter (Fig. 261). Besides these the sea 
contains many small species, which are easily captured in the net, and which are of extreme beauty and delicacy.

Besides the Hydromedus:e, the group of Hydrozoa includes the siphonophores. ${ }^{2}$ These animals are always colonial and free-swimming, and are among the most beautiful inhabitants of the sea. Those who have crossed the Atlantic are ar'quainted with the "Portuguese man-of-war" (Physalia," Fig. 262), which often swarms in the Gulf stream. The huge

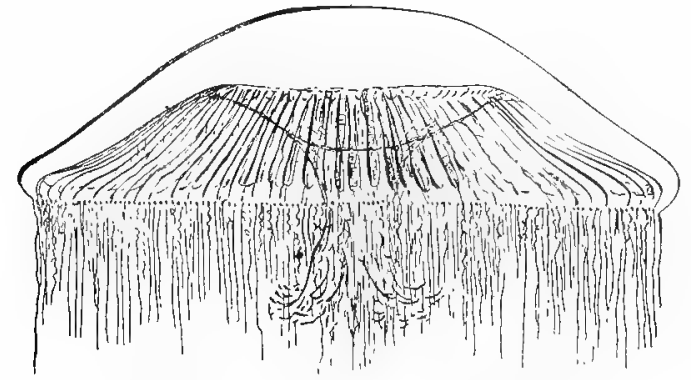

FIG. 261. -- A large jellyfish that has no hydroid staga (Zygodactyla). Rcduced. From a drawing hy A. Agassiz.

float which lies on the surface of the water serves also as a sail by which the animal is transported by the wind. There are other smaller, more graceful species of more typical form (Fig. 262 a). The structure of a siphonophore is very complex. From the float hangs a central stem. Upon this stem are budded feeding zooids (hydranth-like forms provided with mouth and tentacles) and reproductive zooids (forms which produce the germ-cells). There are leaf-like (xpansions, alio, which are rudimentary jellyfishes. All the many forms budded on the stem are modifications of the hydroid type.

Contrasted with the Hydrozoa are the beaker animals 1 siphon, a siphon; phorus, bearing. 2 bladder. 


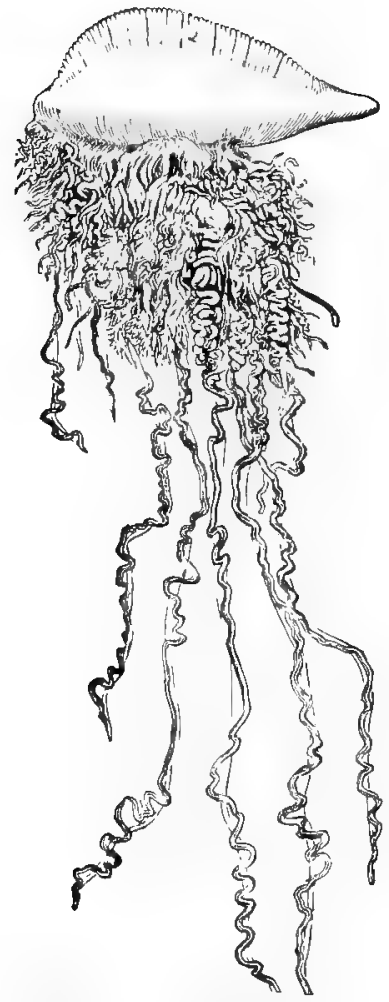

FIg. 202. - Physalia arthusa. Nat. size. After Agassiz.

FIG. 262 a. - Halistemma tergestinum. The entire colony. ca, conosare; $d z$, dactylozooid; hph, hydrophyllium or bract; net, nectocalyx or swinming-bell; nte, battery of nematocysts; $p$, polyp; pn, pneumatophore or float; $t$, tentacle. After Claus. 
(Scyphozoa 1), which are, on the whole, larger. These, too, occur both in the sessile, polyp form, and in the jellyfish form. The sea-anemones are common examples of the polyp. They are, for the most part, solitary, fleshy creatures, often brilliantly colored, and therefore appropriately called by the Germans

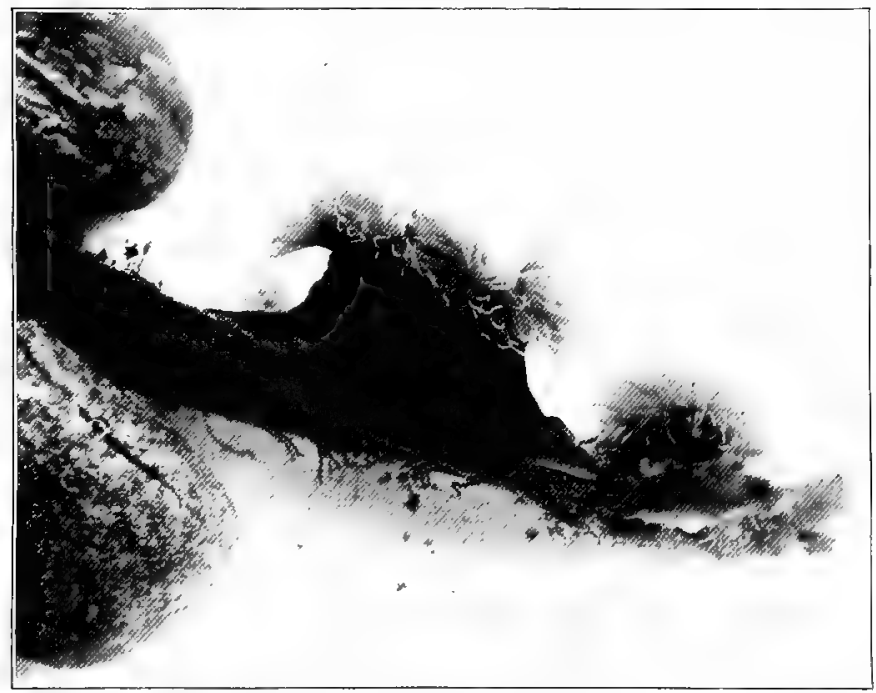

FIG. 263. - Metridium, one of our sea-anemones. Two individuals shown expanded. Photo. of the living animals in the water, by W. H. C. P.

"sea-roses," and in this country and in England "sea-anemones." They are of cylindrical form, bear a circle of tentacles around the mouth at the upper end, 'and have a muscular base by which they attach themselves. They vary in diameter from one-sixth of an inch to two feet. Some species live in the sand, out of which they get some organic food, and at least one species is free-swimming. 
Our commonest Northern sea-anemone is Metridium marginatum (Fig. 2633), which occurs on rocky shores south to New Jersey, but reaches its centre of development along the coast of Maine. It varies greatly in color, some individuals being

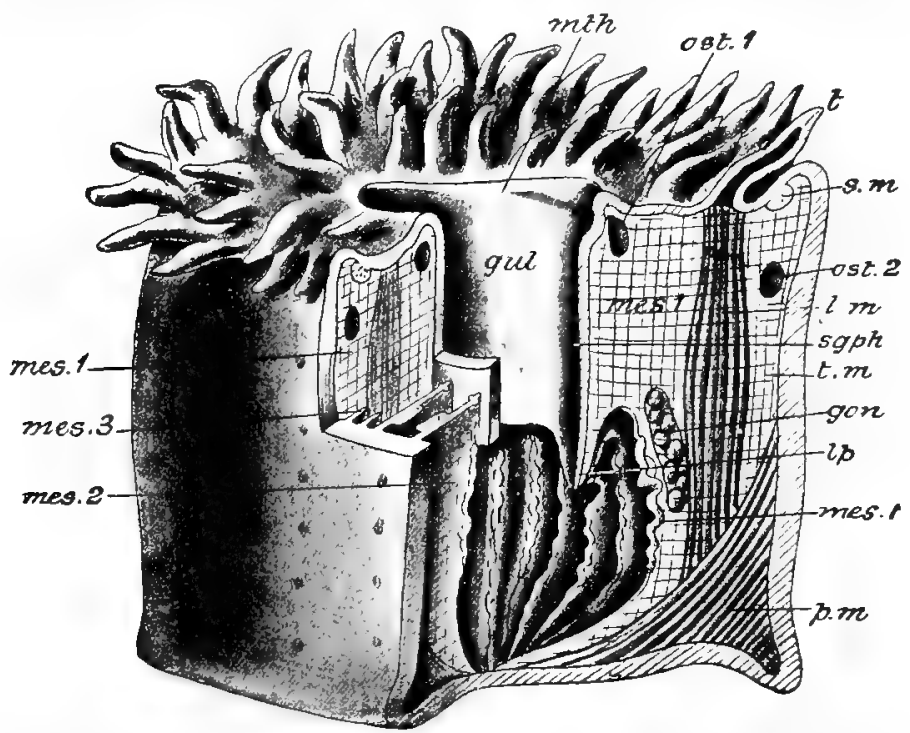

FIG. 264. - Sea-anemons witl wall partly cut away. t, tentacles. Muscular system: l.m, longitudinai muscle; $p . m$, parictal muscles, or those of the body-wall; s.m, sphincter, or circular closing, muscles; $t . m$, transverse muscles. Food system: mth, mouth; gul, gullet; sgph, siphonoglyph; mes, 1,2,3, "mesenteries" of first, second, and third order of size ; lp, lappets; ost. 1,2, openings in mesenteries; mes. $f$, mesenterial filaments.

white, others salmon-colored or olive. The flat upper surface bears the slit-like opening to the internal sac. Either one or both angles of this slit have thickened edges. and corresponding to this difference is a difference in the internal structure. Inside, the central cavity is separated into compartments by radial partitions (Fig. 264). 
The coral polyp does not differ essentially from Metridium. But it has the habit of secreting lime at its base, so that, in course of time, a high cup is built up. The top of the cup bears radial septa, ${ }^{1}$ which are laid down in the interspaces between the fleshy partitions such as are found in Metridium. Since most corals, like hydroids, bud freely, and since every bud secretes coral at its base, an extensive and complicated limy mass may be produced. This is the way in which the brain corals and branching corals are formed.

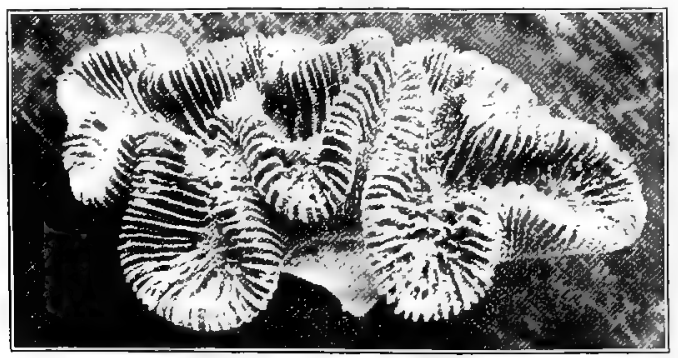

Fig. 265. - Coral cup of Manicina. Nat. size. Photo. hy W. H. C. P.

The only coral of the northeastern United States is Astrangia dance, which occurs north to Cape Cod. It is a beautifully transparent species, and forms thin encrustations of limy matter (Fig. 266).

The Sea Walnuts or Ctenophora are a small group of exclusively marine organisms that are usually placed in the group Cnidaria, but differ very widely either from the Hyrlra or the Scyphozoa. The mouth lies centrally at the lower pole of the barrel-shaped animal, and is usually guarded by one or two tentacles. The food-cavity runs through the axis of the body, enlarging near the upper pole. From this enlargement a 
certain number of canals run out along the surface of the jellylike body. The surface of the body is clad with special hairlike bodies or cilia, which are arranged after the manner of the teeth on a comb. A large number of combs is placed in each of the rows running from the upper to the lower pole, and by their incessant beating the animal is driven forward.

The body of the ctenophore is very transparent, a result of its composition; for it is made up chiefly of water with a small

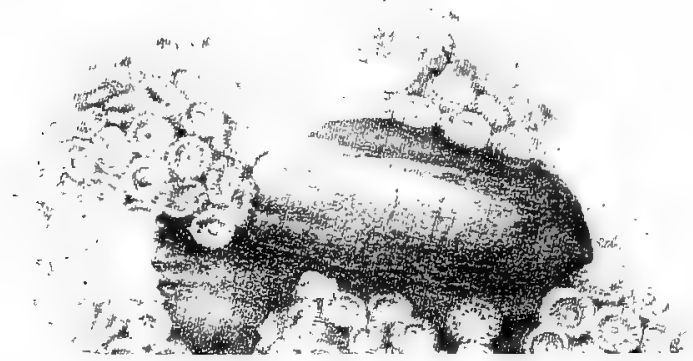

Fig. 266. - Astrangia dance, a cluster of our Northern coral-polyps, resting on limy bases of their own secretion. The animals are extremely delicate and transparent. From a lithograph by Louis Agassiz's artist Sonrel.

amount of pure jelly. Consequently the organism is as clear as the sea itself, so that the animal is hard to distinguish. Many marine animals are as transparent as the water, and there is reason for thinking that they enjoy, in consequence, a certain immunity from attack by their enemies. It is curious, however, that these same animals are phosphorescent, so that they glow brilliantly in the water at night, especially after irritation (Fig. 267).

Coral reefs are almost exclusively the product of coral polyps modified by the environmental conditions. The reefbuilding corals live in shallow water from low-water mark to a depth of one hundred feet only. Their distribution along 
the coast-line depends upon the winter temperature of the sea, since they cannot live at a temperature below $20^{\circ} \mathrm{C}$. Consequently reef-building corals are confined to warm latitudes. However, tropical shores which are washed by arctic currents, such as the west coasts of Africa and South America, are destitute of coral formations. On the other hand, shores in the temperate zone that are washed by tropical currents, such as our Florida coast which is washed by the Gulf Stream, may be rich in coral reefs. Corals demand undiluted sea-water, hence they do not thrive in harbors which receive the waters of great rivers - a circumstance of great importance for the commerce of tropical countries. Moreover, corals require a rock bottom on which to build, and they cannot gain a foothold on shores where the cliffs descend precipitously to great depths. Coral reefs receive different names ac-

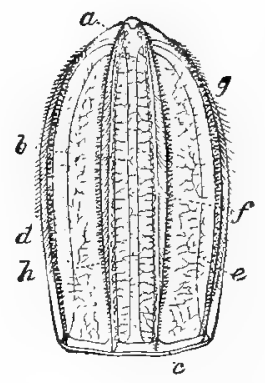

FIG. 267. - A sea-walnut, seen from the broad side (Idylia). Half nat. size. $a$, anal opening; $b$, lateral tube; $c_{1}$ circular tube ; $d, e, f, c, h$, rows of paddles. After Agassiz. cording to their varying relations to the shore. Fringing reefs are found close to the shore-line. Barrier reefs lie at some distance from land, with a body of quiet water between them and the shore. An Atoll is a further step, in which a small island, formerly surrounded by a barrier reef, has disappeared, leaving a circular reef surrounding a body of water (Fig. 268). Exactly how the central land disappears, whether by subsidence of the sea floor as the reef grows up or by being washed away, is still a matter of dispute.

Budding and the formation of colonies. - The nettle animals, as we have seen, are one of the groups of animals that 
have the habit of forming colonies by budding. In all cases the buds arise from a definite part of the parent body and develop into a definite form, often exactly like that produced from the egg. When the buds remain attached to the parent, a compound individual or colony is produced. These colonies differ greatly in form. Thus among hydroids we have colonies which produce runners, from which alone, and not from other hydranths, new hydranths arise. In another case (Obelia),

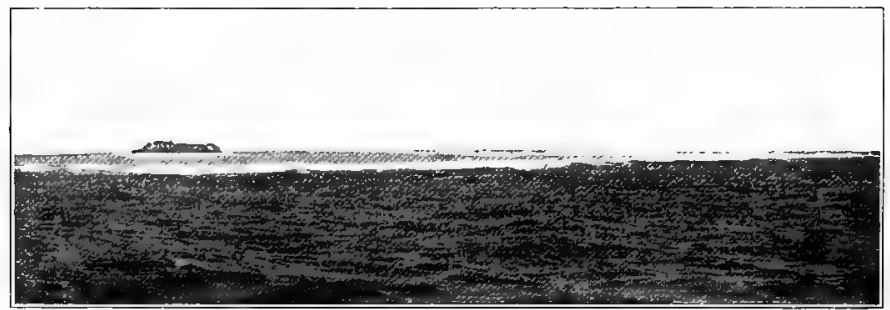

HIG. 269. - Atoll in Fiji Islands (Nanuku Levu). The large circle of white made by breakers indicates the position of the coral reef. A small bit of land still remains in the interior lagoon. Photo. by Dr. W. MeM. Woodworth. From A. Agassiz, "Coral Reefs of Fiji."

one hydroid buds from the side of another and rises beyond it, continuing the main stem of the colony. Since its descendants do the same, the stalk is made up of successive generations of hydranths. Sometimes the hydranths are placed close together and opposite, like the leaves of arbor vitæ (Sertularia, Fig. 258). Again, there may be a main stalk composed of one hydranth and a series of lateral branches in one plane, making a fan-like arrangement of the colony. Or the lateral branches may rise in any plane, producing a bushy colony. The variety in the form of colony possessed even by a single species adds to the diversity of hydroids.

In any colony a division of labor may occur among the con- 
stituent individuals, or zooids. Thus in the simplest cases among the nettle animals we have crawling zooids, or stolons, and feeding zooids. In other species we have, in addition, reproductive zooids, nettling zooids, and passive, thorn-like zooids. These zooids are, in their earliest stages, equivalent, and seem to have the power of developing into the same thing. Nevertheless some of them develop into very imperfect individuals incapable of exercising any active function. These organized colonies are interesting from a sociological standpoint because they illustrate the complete subserviency of the individual to the good of the community. This subserviency is found in all successful colonies of animals.

Regeneration. - Closely allied to the power of budding is that of reproducing a lost organ. Supposing the "head" (mouth and tentacles) of a Hydra to be cut off, the base will reproduce the lost head. Suppose the base to be removed, the head will reproduce a new base. When a Hydra is cut in two transversely, two Hydras result where formerly there was only one. Even three or more Hydras may arise when a Hydra has been cut into so many pieces. Where other conditions are favorable to life, you can hardly kill a Hydra by mutilation. A trace of this capacity for regeneration, as it is called, is seen also in man when a wound heals and a diseased organ, even when partly destroyed, is made whole again. 


\section{CHAPTER XX}

\section{PARAMGCIUM: A STUDY OF THE SMALLEST ORGANISMS}

THE smallest organisms have an especial interest hecause they show the simplest structure and because they must have been the earliest produced. Thus they are the nearest living representatives of the ancestors of both the animal and plant kingdoms. What the first organism that evolved was will doubtless never be known, but if it were found it probably would be invisible to the naked eye. The process of evolution has led to an increase in the complexity of the individual and also, in the long run, to an increase in its size. These simplest organisms are placed in the group Protozoa, a group that is characterized by the fact that the body contains no specialized tissues and organs, but is marle up of a single cell, and is usually microscopic. Protozoa live in water or in moist situations. The lowest plants are known as Protophyta. As it is impossible to clraw a sharp line separating the Protozoa and Protophyta, they are sometimes placed in one group named Protista.

Although so minute, the Protista play a rôle of great importance in the world and are of especial interest to man. Indeed their work is of a sort that can best be done by an organism of small size. In the first place many of the Protista, both animals and plants, contain leaf green or chlorophyl. This enables them to make use of the energy of sunlight to build up 
their bodies out of inorganic materials. As they grow they divide, and this capacity for multiplication seems unlimited. The Protista swarm upon the surface of ponds and of the sea. They are devoured by myriads of Crustacea (Entomostraca), whose capacity for reproduction seems, in turn, limited only by the number of Protista. These Entomostraca, however, constitute, as shown in more detail in Chapter $\mathrm{X}$, the main food supply of many of our most important food fishes. Thus the chain of relations is complete between the Protista and man.

The Protista that are without pigment occupy a very different niche in nature. They live on organic matter. Many of them devour the decaying materials that are found on the bottom of ponds. Some live on the surface of other organisms, feeding upon the waste matters eliminated. But many others have gone farther and live as parasites in the interior of the body of other organisms. In the highly nutritious medium in which they now find themselves they multiply tremendously. As a result of this accelerated growth they eliminate large quantities of substances into the body which are often highly injurious, even bringing about the death of the higher infested animal. Until a few years ago it was supposed that the most dangerous of these parasitic Protista were plants, but to-day we recognize that almost any group of Protista may give rise to dangerous human parasites. "Malaria," yellow fever, cholera, and many other tropical diseases of man and domesticated animals are due to Protozoa. Many of these parasitic Protozoa are conveyed from one individual to another by means of insects that bite persons already parasitized. The parasites imbibed with the blood of the victim usually develop further within the insect and, when the 
insect bites a healthy person, the latter becomes inoculated with the disease. Thus biting insects are disseminators of disease.

Protozoa were unknown to man until the latter half of the seventeenth century, when a Dutch naturalist named Leeuwenhoek, by means of the newly invented compound microscope, studied and described several kinds which he had found in standing water and called animalcula or water insects. Later, these creatures were called Infusoria because they develop in infusions of organic matter in water. As the microscope hecame perfected, progress was made in the study of these organisms, but less than a century ago several eminent zoologists maintained that the Infusoria possessed digestive, nervous, circulatory, and reproductive organs. The proper s.tructure of Protozoa has been generally recognized only within the last sixty years.

The ideas formerly entertained concerning the origin of Protozoa were as erroneous as those relating to their internal structure. These erroneous ideas were a tradition from a time when even scientific men held that many of the larger animals, such as eels, bees, and flies, were generated without parents. This was the theory of "spontaneous generation." In time this theory became much more restricted. It was found that the maggots in putrid meat are not generated "spontaneously" out of the meat, but are derived from flies' eggs, and, in their turn, develop into fertile flies. But the idea that "Infusoria" are formed out of the organic material of infusions continued to be held until much more recently, - until Pasteur, ${ }^{1}$ Tyndall, and others proved that fluids heated to a sufficiently high temperature for a long enough time, and then, while hot, sealed

I Fig. 269. 
from contact with the dust of the air, do not develop Infusoria, no matter how long they may be kept. This method of excluding Infusoria and other minute organisms, especially bacteria, is employed to-day in canning meat, vegetables, and fruit. The experiments referred to gave a death-lolow to the theory of spontaneous generation, and led to the conclusion that all Protozoa are derived from living germs.

Whence the living germs come which enter the water it is not difficult to determine. Many Protozoa can pass into a quiescent " spore " stage in which they may be dried and blown about without loss of life. Dry grass, straw, and other substances contain some of the germs, and others float in the air and fall as dust into the water. Even drinking water may contain here and there an infusorian or its germ. When, therefore, one fills a clean vessel with pure water, and puts hay or

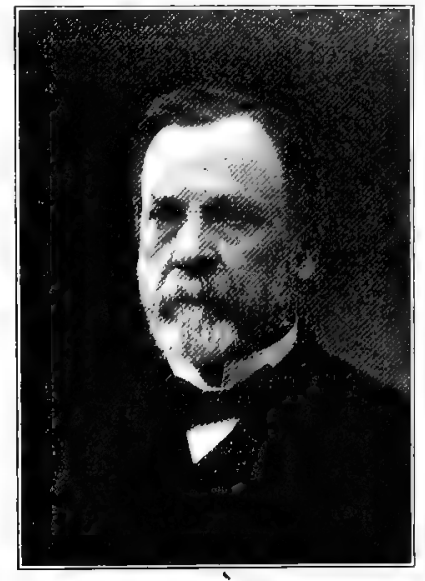

FIG. 269. - Louis Pasteur, discoverer of the importance of bacteria in the air for disease and fermentation. dry leaves in it, and lets it stand open to the air in a warm place, it is pretty certain that there will be germs in the mixture. The heat and the organic infusion merely facilitate their development.

The reproductive capacity of Protozoa is so great that their importance in the world, despite their small size, is not astonishing. One of the early students of Protozoa, Ehrenberg, computed that from one individual of Paramocium 
$268,000,000$ might be developed in one month by the process of division. Apparently the division does not ordinarily go on indefinitely, but from time to time the Paramœcia unite temporarily in pairs and undergo an exchange of some of their nuclear matter. This is cloubtless the beginning of what is known in the higher animals as sexual reproduction.

The Protozoa ${ }^{1}$ are divided into four principal classes arranged according to the character of the locomotion. In the simplest forms, called Rhizop'oda, the entire body changes

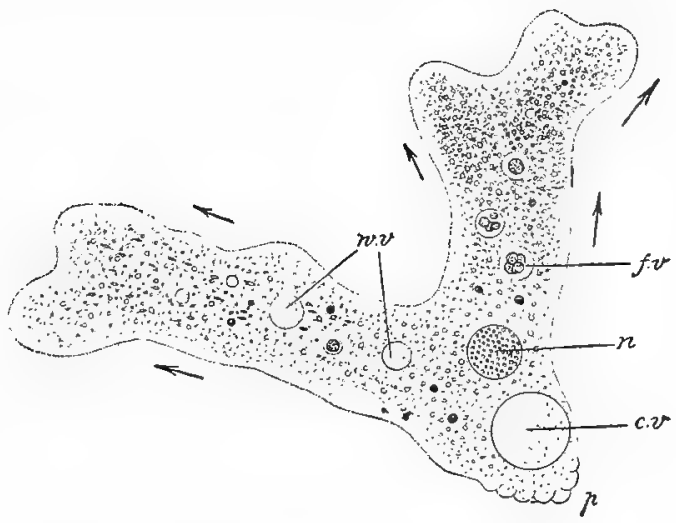

FIG. 270. - Amcha, the proteus animalcule. Greatly magnified. $n$, the nucleus; $w . v$, water vacuoles; $c . v$, contractile vacuoles: $f . v$, food vacuoles. E. B. Wilson, "The Cell."

shape and the appendages can be retracted so that the whole body assumes a spherical mass. The simplest of the Rhizopods is the Amœba. ${ }^{2}$ This type varies greatly in size, from $0.02 \mathrm{~mm}$. to about $0.3 \mathrm{~mm}$. It appears as a clear, glistening body of changing outline. The body, when viewed with a high power, shows a complicated structure. It contains various 
granules derived from ingested food, vacuoles of water, and a dense though transparent, spherical or ellipsoidal body, the nucleus, which it is often difficult to make out on the living animal. ${ }^{1}$ The whole substance of the Amœba is mobile, so that the internal organs have no fixed relation to one another. Quantities of Amœba can usually be obtained for study by gathering the mud from the edges of stagnant pools, or by

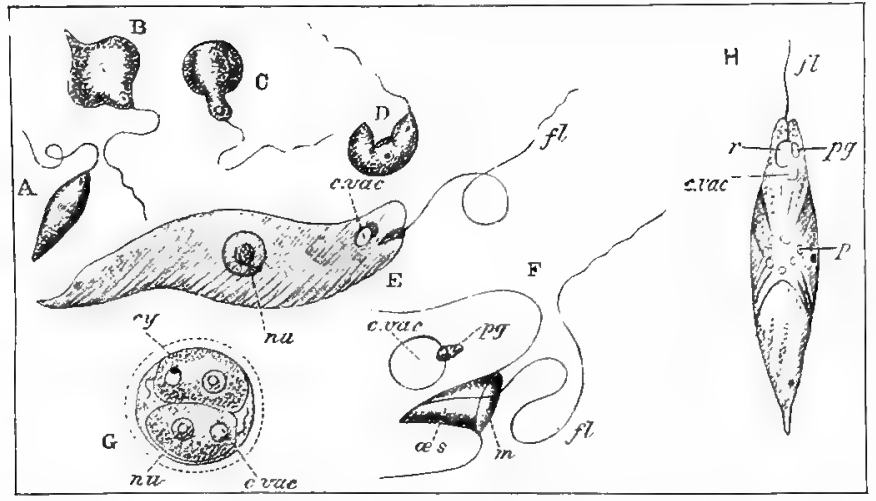

FIG. 271, - Euglena viridis, a lash-animalcule, $A-D$, four views illustrating the characteristic movements; $E$ and $H$, enlarged views of adult; $F$, outline of anterior end further enlarged; $G$, resting stage ; cy, cyst ; $f$, flagellum; $m$, mouth; $n u$, nucleus; $a$, gullet; $p g$, pigment spot; $r$, reservoir. After Kent and Klebs.

scraping the green growth from flower-pots and letting these gatherings, covered with a little water, stand in a fairly warm place for two or three weeks.

The second class is that of the spore animalcules, or Spo'rozoa. This class includes some of the worst parasites among the Protozoa. Here belong the germs of "malaria" and a host of related diseases occurring almost exclusively in the tropics. The Sporozoa are minute, rod-like organisms. They 
increase by transverse division; but periodically they roll up into a sphere, form a tough shell, and divide into numerous "spores," which, uncler favorable conditions, are set free in great numbers.

The third class, known as lash-animalcules, or Flagellata, is well represented by a common form, Euglena (Fig. 271). It is of microscopic size, but occurs in such numbers as often to give a decided green color to the pools of water it inhabits. It

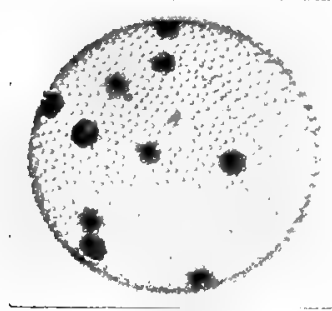

FIG. 272. - Volvox globator. Much magnified. Photo. of the living animal. is spindle-shaped, and bears a lash at its anterior end. At the base of the lash is a red "eyespot."

Allied to Euglena is Volvox, ${ }^{1}$ a spherical, multicellular organism, half aninal and half plant, and forming a sort of connecting link between the Protozoa (or one-celled animals) and the multicellular higher organisms. Volvox occurs abundantly in our ponds, and gets its name from its manner of revolving in the water (Fig. 272).

To the fourth or highest class of Protozoa has been restricted the name Infusoria formerly applied to all Protozoa. In the Infusoria the body has a definite and more or less permanent form. The hair-like appendages (cilia), by which they move about or seize their prey, cannot be retracted.

Of all the Infusoria, none is more abundant than Paramocium. It occurs everywhere, principally in stagnant fresh water, but also in salt water. It lives entirely on vegetable food, and is sure to abound wherever plant matter is undergoing decay. When a culture is once started from a hay in- 
fusion, which takes one or two weeks, it will be found to thrive well on corn-meal.

Since the cilia of Paramoecium are of nearly uniform size and occur all over the body, it has been assigned to the order Holotricha. In another order of Infusoria the cilia are greatly

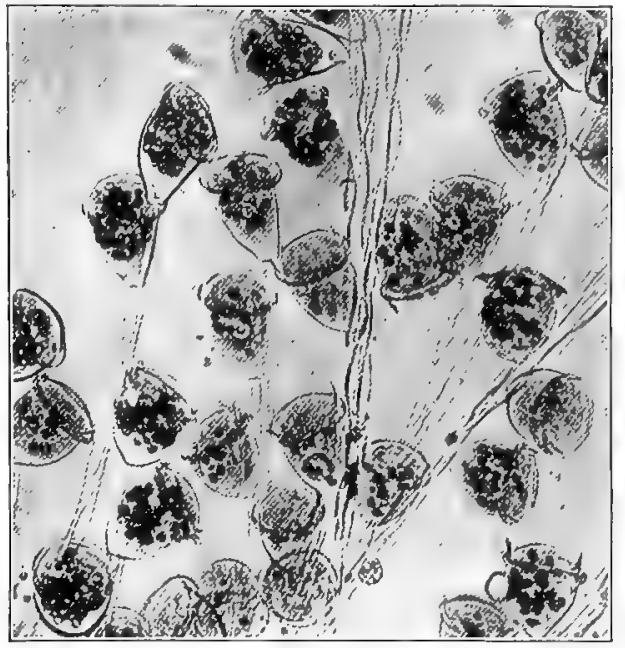

FrG. 273. - A stalked Vorticella, Carchesium. Greatly magnified. From a photograph of the living animals.

enlarged around the mouth, and on account of this difference in size the order is named Heterotricha. As an example of the Heterotricha, the trumpet-animalcule (Stentor ${ }^{1}$ ) may be mentioned. This is found attached to vegetalble débris sticks, stones, water-weeds, and other objects-occurring in pools, ponds, lakes, and sluggish streams. These things should be gathered and placed in an aquarium, when the Stentors, if present, will attach themselves to the glass sides of the vessel.

1 Stentor, a Greek at Troy, known for his loud voice. 
The attachment of Stentor to objects is not permanent, for it may loose its hold and swim free. When the animal is stained in hæmatoxylin, the characteristic nucleus, looking like a chain of beads, becomes evident.

The bell-animalcule (Vorticella) is found in pools or infusions, permanently attached by a long stalk. When the animal is irritated, it contracts its stalk, which twists into a close spiral. In other species, colonies are formed, so that a number of heads is attached to a central stalk (Fig. 273). A colony, when fully expanded, appears like a fine, white mould attached to a sulmerged object. In both of these types the food consists of small organic particles, which are swept into the gullet by the circlet of cilia placed around the upper end of the body.

The Suctoria are sessile Infusoria, from whose upper surface numerous remarkahle sucking tentacles arise. By means of these tentacles the animal can hold on to Paramocia and other free-swimming Infusoria, from which it extracts the body fluids. Some Suctoria are stalked, while others are unstalked. They are found most abundantly in standing water, either fresh or salt, and are often attached to other animals, Bryozoa, entomostracans, and pulmonate mollusks. 


\section{CHAPTER XXI}

\section{THE ANCESTRY OF VERTEBRATES}

SOMEWHERE out of the great variety of phyla of invertebrates the vertebrate stem arose. The origin of this branch of the animal kingdom has a special interest for us because to it belong not only man but also the most of our favorite fellowcreatures, our domestic animals, the birds, and the fishes. We have now to consider what is known of the ancestry of vertebrates.

In seeking the origin of any phylum we must first separate out what is essential and miniversal in it from what is secondary and special. And first of all, the phylum of vertebrates is distinguished by the possession of an internal skeleton whose simplest forerunner is a rod of tissue lying in the axis of the body and running from the head to the end of the tail. This rod is called the chorda. It is found in some simple animals which have no other internal skeleton, and so they and vertebrates are often classed together as Chordates. The essential feature of Chordates are four: (1) the chorda just referred to; (2) gill-slits passing through the wall of the throat so that water taken into the mouth passes out through the neck, as is seen in fishes; (3) a nervous cord that lies wholly on the dorsal side of the animal ; and (4) a heart which lies on the ventral side. Any animal which can show this combination of characters, or any of them, thereby reveals its affinity to the vertebrates, no matter how lowly it may be. 
Not less important are the points in which chordates resemble other animals. First of all they are bilaterally symmetrical animals, at least in their young stages; secondly, they are segmented animals, and they have ventral organs repeated as in other externally ringed animals. Consequently they show their affinities to the great groups to which annelids and arthropods also helong. A diagram showing the relationship of chorlates to the invertebrate groups already studied would be something like this:

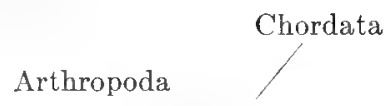

Annelida

Echinodermata Mollusea

Scolecida ${ }^{1}$

Coelenterata

Porifera

Protozoa

Applying now the four criteria of chordates enumerated above, we find that they discover strange associates for the vertebrates. Of these the most romarkable is a group long known as Tunicates, animals which in some cases are attached and in others float on the surface of the sea. Tunicates show a great variety of external forms (Fig. 274), but they all reveal their chordate nature in their youthful forms. Thus in the tadpole stage (Fig. 275) we see the chorda (noto) in the axis of the body, the nerve-cord (med) above it; and one of the throat slits (stig) already formed. When the animal attaches itself, it loses its tail and chorda, but the number of gill-slits

1 Includes flatworms, roundworms, rotifers, bryozoans, and brachiopods. 
greatly increases. The body now shows (Fig. 276) two openings; one inhalent $(o)$, and one exhalent $(a t)$. Some species,

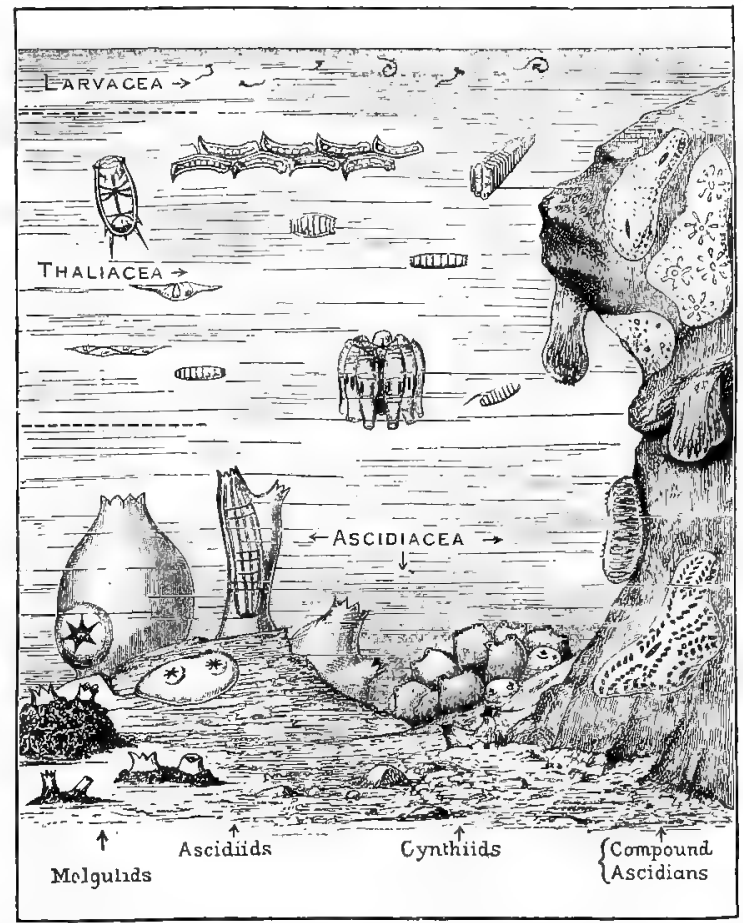

Frg. 274. - A group of Tunicates showing the attached forms (Ascidiacea) both simple (left-hand side of picture) and compound (at right); the oceanic forms (Thaliacea) that swim near the surface; and the small tailed forms (Larvacea) that look like the larval stages of higher Tunicata. From Cambridge Natural History.

after becoming attached, form colonies by budding new zooids upon the side of their body. The whole colony may have a common exhalent opening (Fig. 277, $\mathrm{cl}$ ).

Below the tunicates is a small group of worm-like animals 

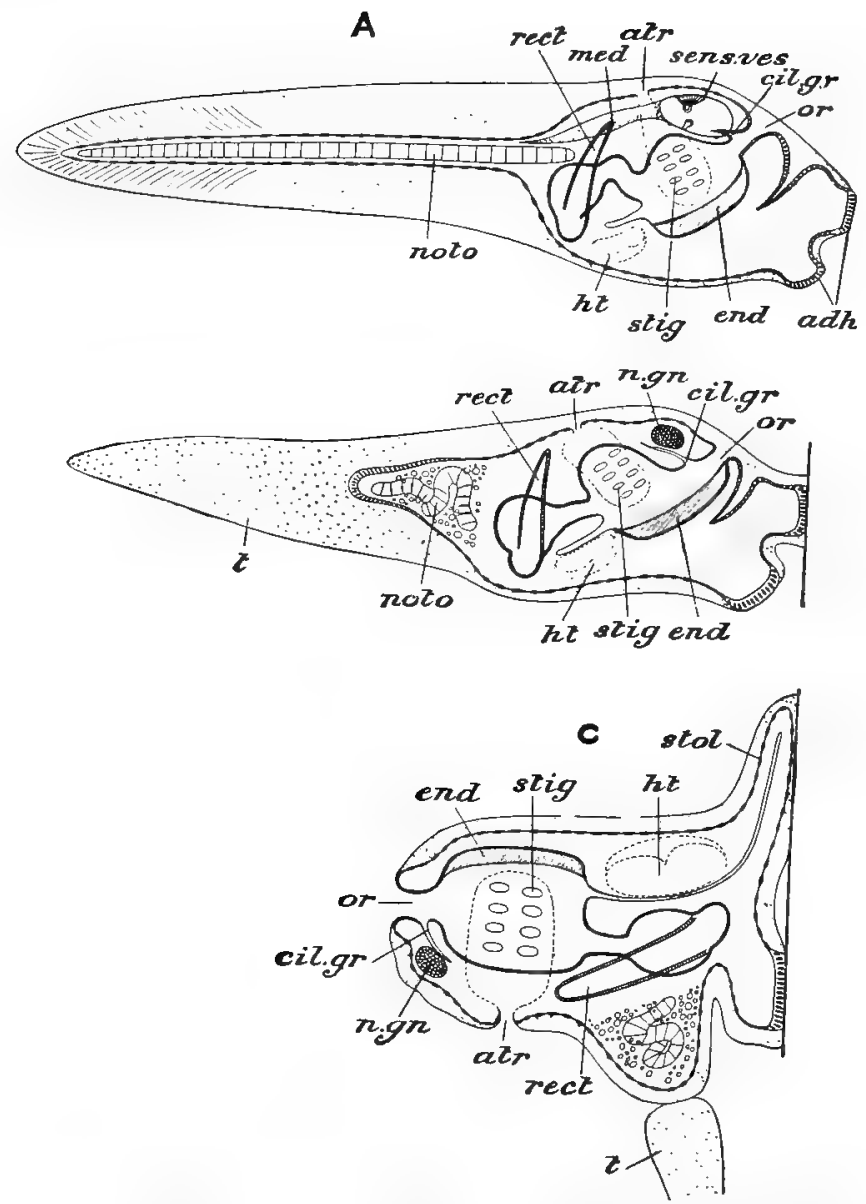

FIG. 275. - Diagram of the metamorphosis of the free, tailed larva into the fixed Tunicate. $A$, stage of free-swimming larva; $B$, recently fixed larva : $C$, older fixed stage; $a d h$, papillse for adhesion to the rock; atr, "atrial" cavity; cil.or, ciliated groove on wall of pharynx; end, glandular groove in pharynx; $h t$, heart; med, ganglion of heart; n.gn, brain; noto, notochord; or, mouth; rect, rectum; sens.ves, sense space; stig, throat (gill) slits; stol, shoot from which buds arise; $t$, tail. From Korschelt and Heider. 
whose affinity with chordates is a little less certain. These animals belong to the genus Balanoglossus (Fig. 278); they

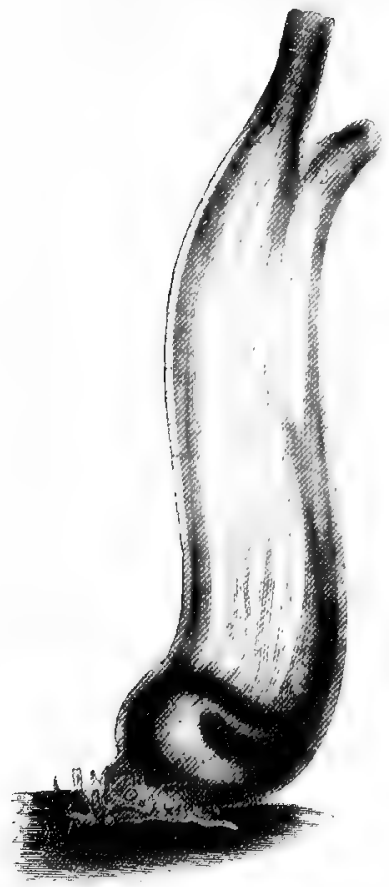

FIG. 276. - Ciona, a simple Tunicate. $o$, mouth; at, opening of atrium, or exhalent opening; st, stolon. After Leuckart and Nitsche's diagram. live in the mud of the seashore and have doubtless lost many organs as a result of their burrowing habit. The elon-

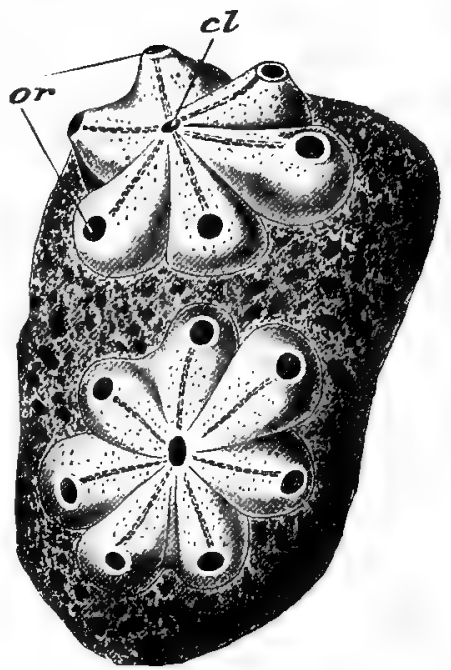

FIG. 277, - Two small colonies of compound Tunicates (Botryllus). The "zooids" are grouped about a center, have a common cloacal opening $(c l)$, but separate mouths (or). After Milne-Edwards.

gated body is divisible into three parts: the proboscis at the anterior end; the collar; and the trunk. In the trunk an anterior region containing gill-slits ( $b r$, Fig. 279), and a posterior region that is without gills can be distinguished. The mouth lies between the proboscis and collar and leads into a nearly 
straight food-canal, in the anterior part of which there are numerous openings to the exterior - - the gill-slits. There is

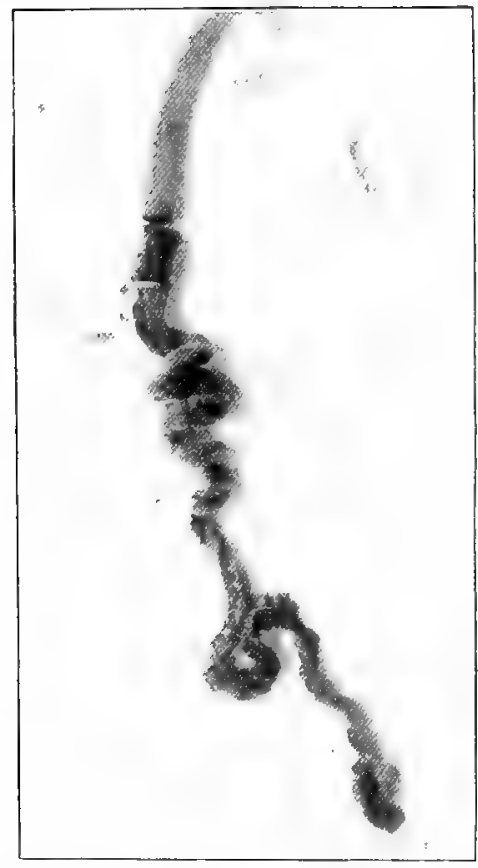

FIG. 27s. - Talanoglossus, the acorntongued worm. The proboseis at the anterior end is at the top of the figure (partly rutside); lehind it is an orange-colored collar; then follows the long, brown-red trunk. Nat. size. Photo. of living aninal by W. H. C. P. a small sac, lying dorsal to the pharynx, which is regarded as a chorda. The brain is dorsal, and there are both dorsal and ventral nerves. If Balanoglossus is indeed a chordate, it is a degenerate descendant of a primitive form.

Above the tunicates, and showing the clearest possible affinities to the fishes, is a remarkahle animal about 5 centimetres long. It lives almost buried in the sand of the seashore in various parts of the world, and is known as Amphioxus (Fig. 280). It is bilaterally symmetrical, or nearly so, and has a distinctly segmented body. The foodcanal runs nearly straight through the body and is perforated in the pharynx by 90 or more pairs of gillslits. These do not, however, open directly to the exterior, but into a large chamber that has a single posterior connection with the outer world. Through the axis of the body, from the tip of the snout to the end of the tail, runs the chorda, which, in this animal, is a sort of jelly-like rod 
(Fig. 281, nch). The nervous system (br and $s p . c d$ ) lies above the chorda; it begins in a slight enlargement whose cavity communicates with the exterior by a nasal pit and carries a large pigmented "eyespot" (e. sp). The blood system consists of a ventral vessel carrying blood forward and a dorsal one carrying it backward. The ventral vessel connects with the dorsal vessel by a pair of vessels running along each gillarch (br.sep, between the gillslits), and from the pharynx the blood runs toward the tail. The direction of the dorsal current in the trunk of Amphioxus is thus exactly opposite to that of worms. There is a series of kidney tubules $(n p h)$ much resembling those of annelids, and the reproductive cells are formed in glands that are repeated in many segments of the body. In Amphioxus, as in invertebrates, the outer skin consists of a single layer of cells, below which lie cells of a connecting nature. Finally, on the exterior a pair of folds, like fins, runs continuously from near the mouth to the outer pore of the gill-chamber.

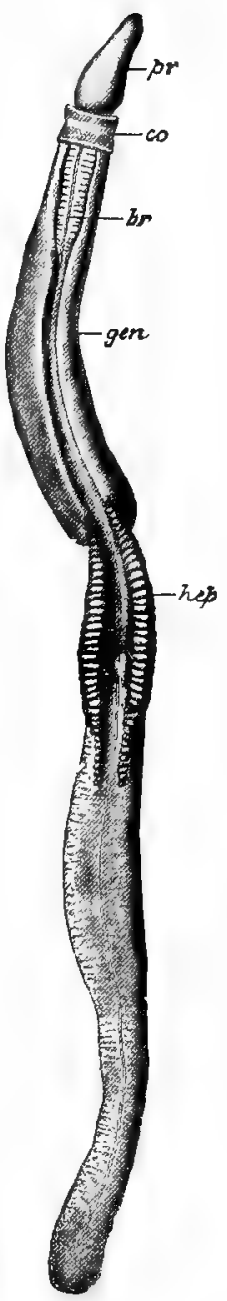

FIG. 279. - Drawing of entire Balanoglnssus. br, gills; $c o$, collar; gen, genital ridges; hep, ridges lying over liver: pr, proloscis. From Parker and $\mathrm{Haswell}$; after Spengel. 
This is believed to be the forerunner of the appendages of vertebrates.

This review of the most primitive chordates indicates that the ancestors of vertebrates were elongated, worm-like, seg-
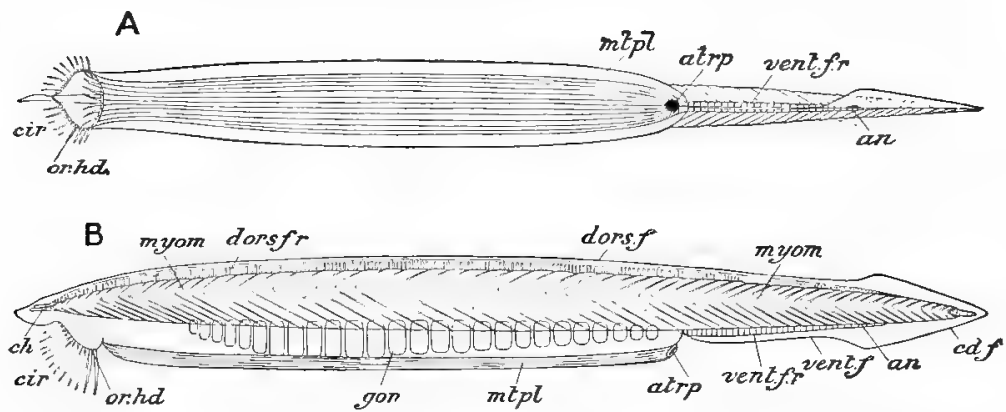

FIG. 280. - Amphioxus lanceolatus. $A$, ventral ; $B$, side view of the entire animal. an, anus; atrp, atriopore; $c d . f$, caudal fin; cir, cirri; dors.f, dorsal fin; dors.f.r, dorsal fin-rays; gon, gonads; $m t p l$, metapleure; myom, myomeres; nch, notochord; or.hd, oral hood; vent.f, ventral fin; vent.f.r, ventral fin-rays. After Kirkaldy.

mented animals. In this respect they resembled annelids, but in certain respects the internal organs of vertebrates are inverted as compared with those of invertebrates thus:-

Main nerve-cord

Heart . . .

Direction of flow in ventral vessel in trunk

Direction of flow in dorsal vessel in trunk

INVERTEBRATES

ventral

dorsal

toward head

toward tail
VERTEBRATES

dorsal

ventral

toward tail

toward head

It will be seen that the relations of the above parts in vertebrates become the same as in Invertebrates if we think of the former as turned on their backs. It seems, at first sight, 
improbable that such a change in position could have occurred; but when we recall that the ancestors of vertebrates, like modern prechordates, probably assumed a vertical position, it is not so difficult to understand how the transition may have occurred. The mouth must have changed from the neural side (on which the nerve cord lies) to the hæmal side (that of the heart), and we find that in the larva of Amphioxus it lies on neither the neural nor hæmal side, but halfway between; a significant position if it indicates a stage in the ances-

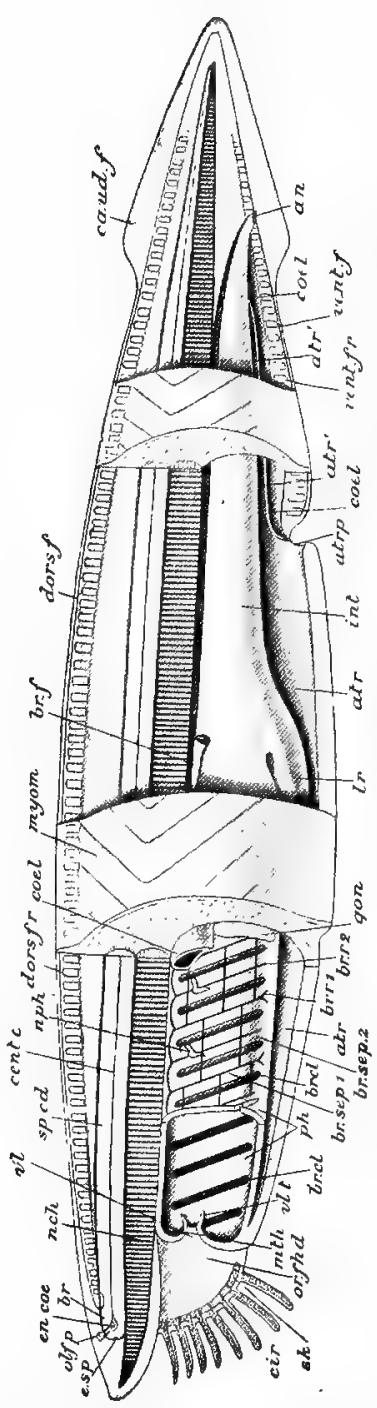

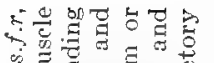
o 올

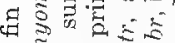

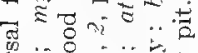

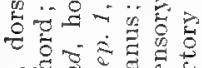

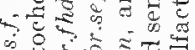

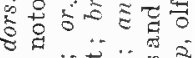

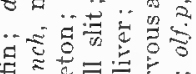
4 들

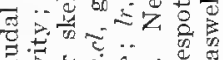
ฮู $-y=0$ कृ

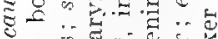

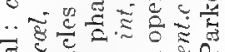
Tू

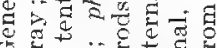

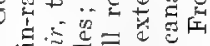

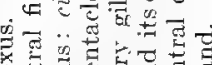

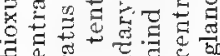

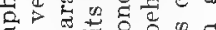

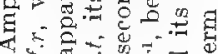

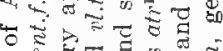
政实 E... 효을 和

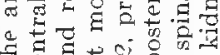
ह

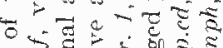

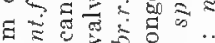
क्ष

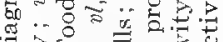
A

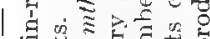

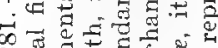

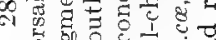

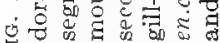
昰

tral movement of the mouth from the neural to the hæmal side. 


\section{CHAPTER XXII}

\section{THE SMELT: A STUDY OF FOOD SUPPLY}

GREEN plants only can transform inorganic substances into living matter with the aid of the energy of the sun. Yet it is upon such inorganic substances that all living matter eventually depends for its increase, and it is from solar energy that all vital energy sooner or later comes. Accordingly, animals, including man, must get their energy either from plants or from plant-devouring animals.

The total amount of energy derived from the sun is enormous. On the land this energy is absorbed by forests, by the grasses of prairies and mearlows, and by growing crops; and is by them transformed into new, living material. Man is constantly working to increase the proportion of solar energy that becomes fixed in the crops, but only a very small proportion of the surface of the land is yet under cultivation. There are great tracts, such as deserts and rocky places, where the falling energy seems to be quite wasted, and the same seems to be true of the water surface of the earth, which amounts to three-fifths of the whole (Fig. 282). It is, however, very far from the truth that the solar energy falling on the sea is lost, for the entire surface of the sea swarms with microscopic green organisms which are to the sea what the grass of the fields is to the land. The green plants of the ocean are the food of the small Crustacea called Entomostraca (p. 156), and these, as we saw in Chapter $\mathrm{X}$, in turn are the food of fishes. In 
employing fish as food man is utilizing the energy that falls on the sunlit ocean (Fig. $282 a$ ).

So great is the expanse of the ocean that the amount of surface alga and of the fishes is practically unlimited. No nation has utilized to the utmost the possibility of fish food from the sea, yet some derive their main sustenance from fish-

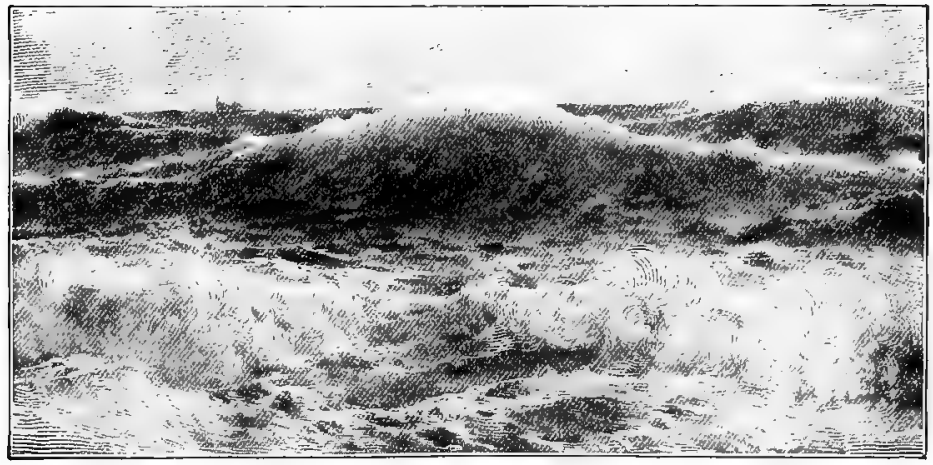

FIG. 282. - The Open Sea.

eries. This is particularly true of Holland, and it is an old proverb in that country "that the foundation of Amsterdam was laid on herring bones."

The principal fisheries in the United States are those of cod, herring, mackerel, and salmon. Boston and Gloucester fishing fleets alone in the year 1902 supplied about 33,000 tons of codfish to our markets, and probably twice as much was taken by other nations combined. The herring fishery, which reaches its greatest importance on the northwestern coast of Europe, has engaged annually 100,000 men and over 300 larger vessels during the past quarter of a century. As many as 22 million herring have been caught in two days by fishermen of a single English town. One of the greatest fisheries of the United 
States is that of the salmon; over three million cases containing thirteen to fifteen million fish are packed annually on our Pacific coast. Over 43 million salmon were caught in Alaska in one year (1908). These figures, which are so large

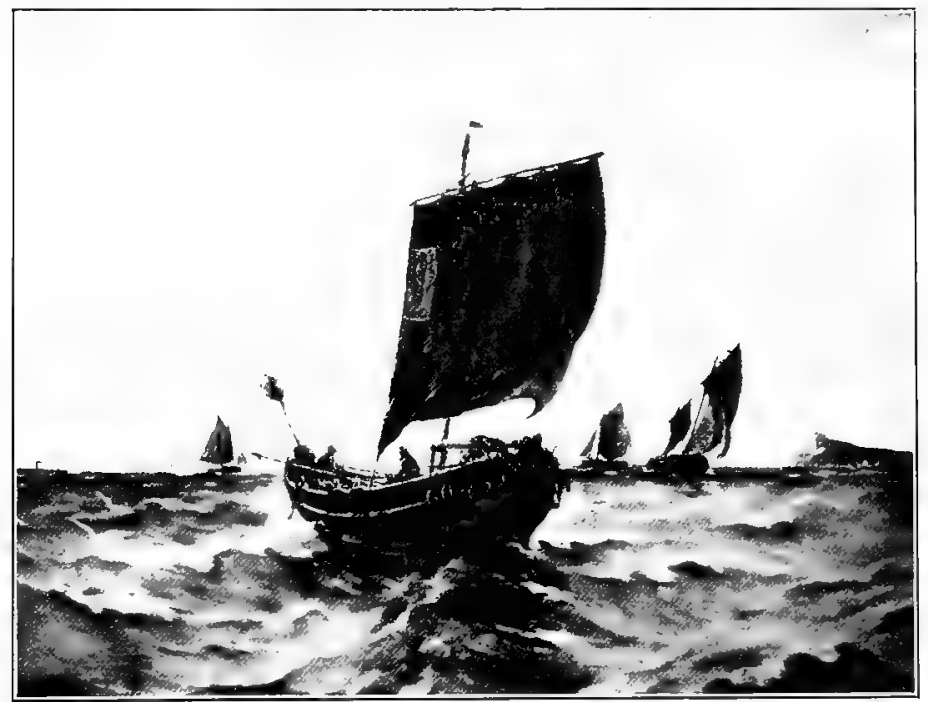

FIG. $282 a .-$ The Return of the Fishermen. From a painting by Bertheleny.

as to be difficult to grasp, give us a faint idea of the vastness of the process by which the energy absorbed by the microscopic organisms of the sea is utilized as food by man.

Fish are employed hy man, not only as food, but, heing sometimes obtained in greater numbers than the market requires, they have been used to fertilize the land. Most coastal states have declared it illegal to use fish as fertilizers of land, and there is now little excuse for doing so. Modern canning methods make it now possible to utilize even the largest 
catches; the excess is immediately preserved to be used in periods of scarcity. The bones and scraps from canning factories may well be used in the manufacture of fertilizers, for they are rich in phosphorus and other important foods for plants.

Fish culture. - Excessive fishing has depleted many rivers in which fish were formerly abundant. An attempt has been made, with more or less success, to restock such streams. Fish are artificially hatched, and the young (or fry) are shipped to the streams needing to be restocked. The United States maintains 49 such fish hatcheries, which in 1904 distributed $1,250,000,000$ fish. In addition, many states maintain independent hatcheries, so that the total number of young annually hatched and set free by all our hatcheries must approach two billion. Of course a large proportion of these young fish are de-

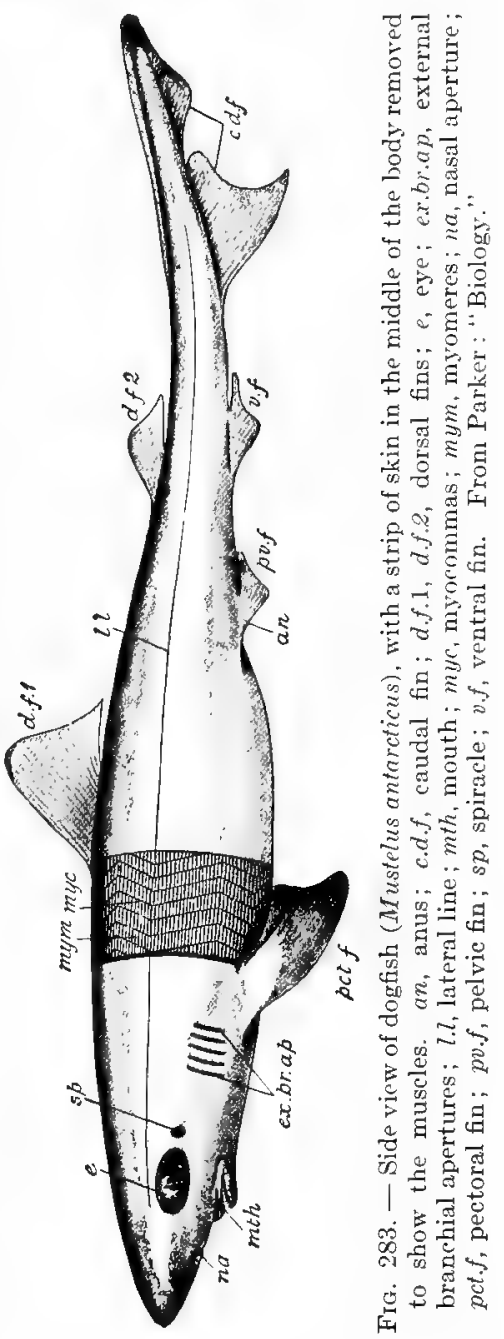


stroyed before they reach maturity, but there can be little doubt that vast numbers survive to breed.

Fishes are one group of the vertebrates, or back-boned animals. Vertebrates are characterized by the possession of an internal skeleton that supports the soft parts of the body, by the possession of two pairs of limbs, and by paired openings leading from the throat to the outside, which last are found in the higher forms in the embryonic stage only. In the fishes

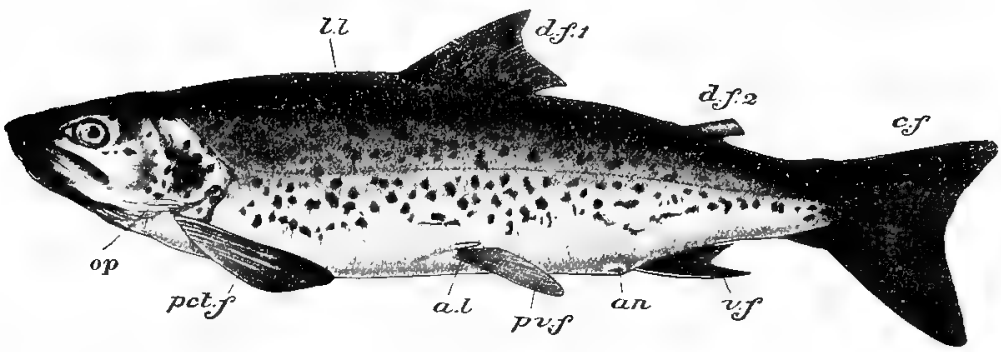

FIG. 284. - Salmo fario. a.l, adipose lobe of pelvic fin; an, anus; c.f, caudal fin; d.f.1, first dorsal ; d.f.2, second dorsal or adipose fin; l.l, lateral line ; $o p$, operculum; pct.f, pectoral fin; pv.f, pelvic fin; $v . f$, ventral fin. After Jardine.

these openings are lined by finger-like processes into which the blood flows. These are known as gills and it is in them that the blood takes oxygen from the water. The appendages of fishes are used as padrlles in the water and are known as fins. The tail is well developed and, by its powerful side-blows in the water, propels the fish rapidly forward.

Classification. - Fishes are classified into five groups, the lowest of which contains the lamprey eels. The next higher in organization (cartilagenous fishes) includes the sharks, skates, and rays." The third group (the bony fishes) includes the vast majority of our common fishes. A fourth group - 
(armored fishes) Ganoids - was in former geological times much more abundant than now, but still populates the waters of our Central States. The fifth group is that of the Lungfishes (Dipnoans), which includes a few rare fishes that live in the mud. As the bony fishes are the best known and most widespread we may take one of them, the brown trout (Fig. 284), for an anatomical study.

The general form of body.- Three regions may be distinguished; viz. head, trunk, and tail. The hear bears the mouth and many organs of special sense. Its conical form facilitates passage through the water. The head is encased in large, bony plates; the trunk is covered by scales; and the tail carries a thin membrane. The trunk bears two pairs of appendages and three median appendages in addition to the tail. The plates and scales constitute the external skeleton, which is developed in the skin. The internal skeleton consists of an axial portion replacing the chorla. This is made up of dice-box (or hour-glass) shaped bodies,

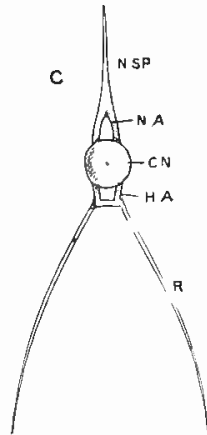

FIG. 285. - One of the anterior vertebræ of the tail of the trout. $C N$, the centrum ; $\quad$ N.A, neural areh: $N$. $S P$, neural spine; H.A, hamal arch (because toward heart); $R$, ribs. From Parker and Haswell. each of which bears ahove a bony arch, which protects the main or dorsal nerve and supports the median fin (Fig. 285). Below, each hears a pair of slender bones, the ribs in front of the anus and the ventral arches behind. The brain-case consists of numerous bones, some of which arise in the skin and others belong to the axial skeleton (Fig. 286). Here on the head skeletal parts of widely different origin come together into one cranium, and even form parts of one and the same bone. In our own skull 
the parts of the bones that carry teeth are of skin origin, and the same is true of the thin bones that make the sicles and roof

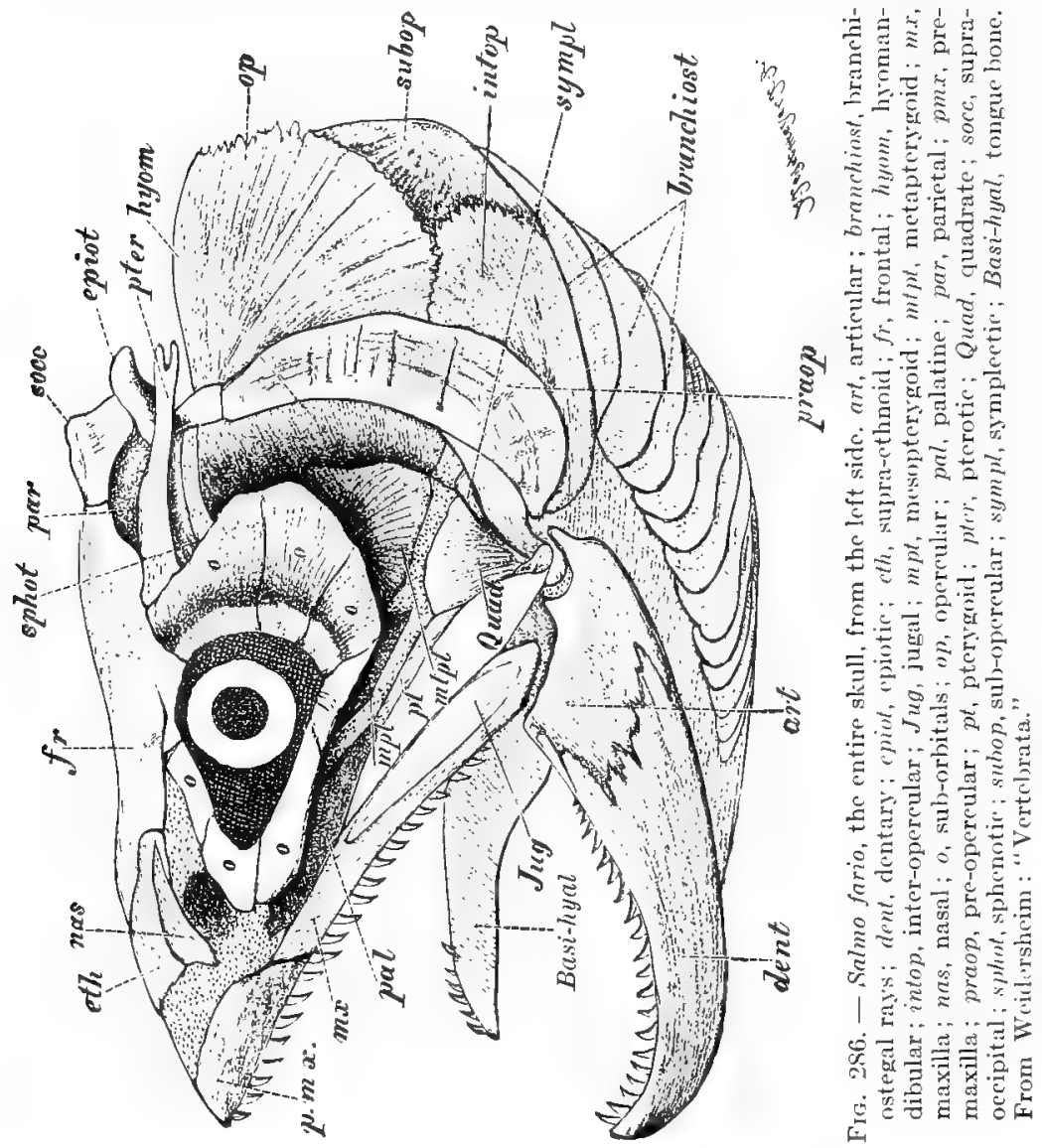

of our skull. The thick base of the skull is a forward continuation of the vertebræ of the axial skeleton. 
In addition to the axial skeleton there is the skeleton of the anterior and posterior appendages. The skeleton of each pair of appendages is borne upon a bony ring which nearly encircles the body. These are called respectively the shoulder and pelvic girdles. The skeleton of the fin consists of a row of cylindrical bones which bear at their outer extremities the horny rays that support the fins.

Organs and function of nutrition (Fig. 287). - The large mouth bears teeth not only on its jaws but also on its roof $(v o)$. The whole of the interior of the mouth was, in the ancestors of fishes, covered with scales of the same sort as those that covered the body just outside the mouth. All teeth have their origin in such fish-scales. In early fishes the number of teeth was large and the position undefined, but in the higher animals the number has become limited to a single row on each jaw. At the hinder part of the mouth are four vertical gill-slits $(p h)$, fringed by a bony straining apparatus, the gill-rakers. The water that has been taken in through the mouth is forced out through the gills by closing the mouth in front and raising its roof so as to expel the water. The remainder of the foodcanal consists of a stomach that is twisted on itself and of an intestine which usually forms either no convolutions or only the simplest. The liver $(r)$ communicates by a tube with the anterior part of the intestine, and is provided with a large gall-bladder $(g . b l)$. Immediately below the liver opening is a bunch of hollow tubes called the cæca (py.c). These are also digestive in function. An air-bladder ( $a . b l)$ lies just over the intestine, and in front it opens into the pharynx $(p n . d)$. The air-bladder of fishes functions so as to enable the fish to vary the volume of gases in the body and thus to vary its specific gravity. It is often spoken of as an organ of 


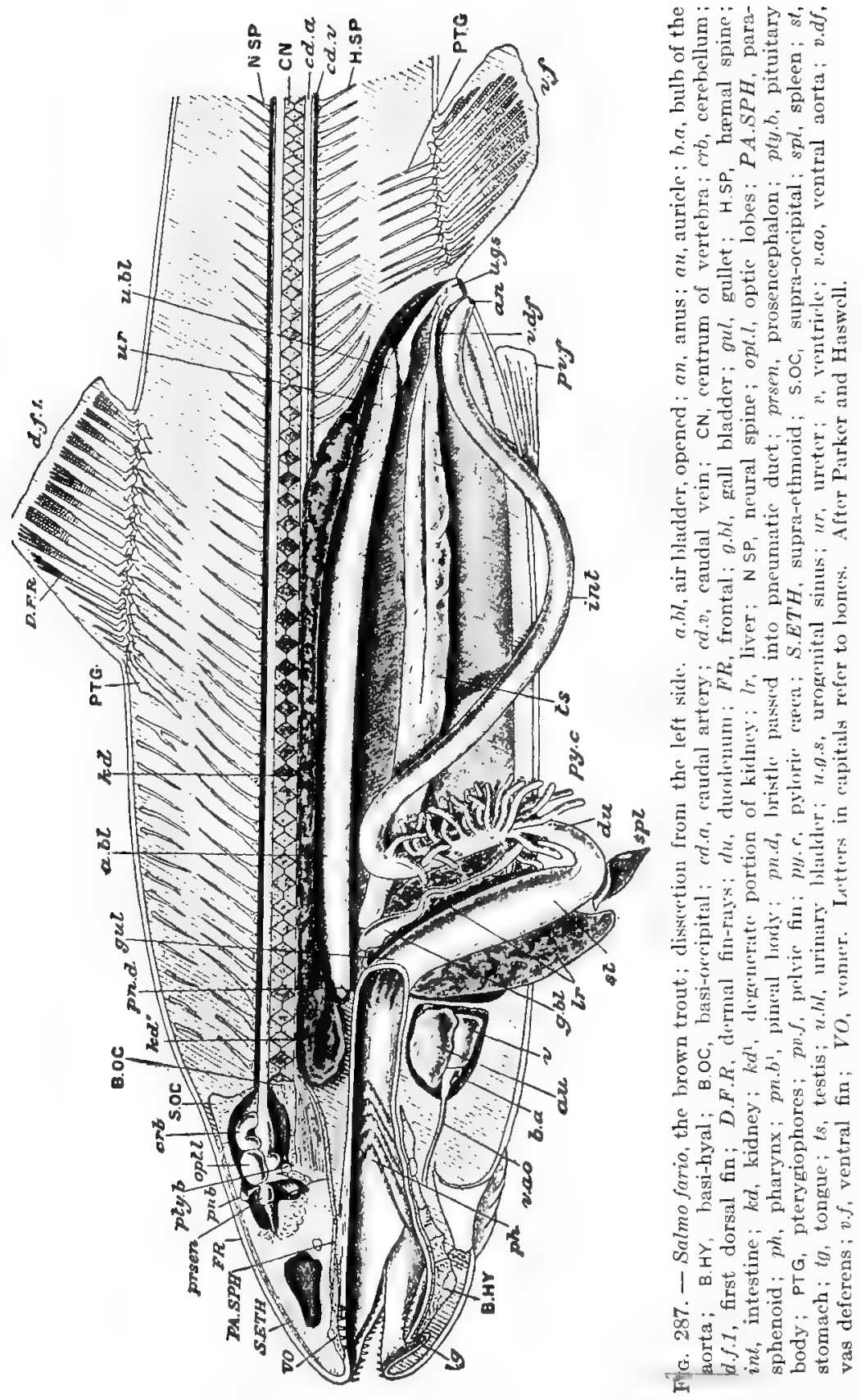


flotation, and in it the lungs of land vertebrates seem to be foreshadowed.

Respiration. - The first stage in respiration is carried out in the gills, where the oxygen in the water is picked up by the blood which circulates in them. The second stage of the respiratory process occurs in the tissues to which the blood gives up its oxygen.

Organs of circulation. - Beneath the pharynx of the trout there is a heart, consisting of two chambers, an auricle and a ventricle. The auricle receives the venous blood from the trunk directly and that from the intestine after it has passed through the liver, where it relinquishes most of its foor. The ventricle is more muscular and passes into the aorta, as the main vessel leading out from it is called. Together they force the blood through the gills, where it is purified and from which it passes to the head, trunk, trunk-walls, and viscera. The blood, as in other vertebrates, contains red blood corpuscles.

The organs of excretion are a pair of kidneys $(k d)$, lying all along the dorsal wall of the abdomen above the air-bladder. In early development each kidney consists of a series of tubules, one for each segment of the hody, as in annelids. These tubules collect fluids from the hody-cavity as well as from the blood-vessels and convey it to the outside.

Organs of reproduction. - The number of eggs laid by most fishes is very great, and so fishes have correspondingly large ovaries. The germ-glands both of the female and male lie along the sides of the body-cavity, and both open to the exterior at a point immediately behind the vent (u.g.s). The eggs and sperm are both thrown out into the water. There fertilization of the eggs (i.e. union with a sperm) takes place and development begins. 
Musculature. - The muscles may be classified, like the general parts of the body, into muscles of the trunk (Fig. 283) and tail and muscles of the head, including those of the jaws, tongue-bones, operculum, and gill-arches.

The nervous system consists of the brain and spinal cord and of the nerves supplying the skin, sense-organs, viscera, and limbs. The brain (Fig. 287, crb, etc.) is by far the largest mass of the nervous system because it receives nerves of general sense and probably has a general control over the behavior of the animal. It is divided into three parts, sometimes called fore, mid, and hind brain. In the higher vertebrate classes these parts develop in different proportions.

Sense-organs. - The organs of chemical sense reside in the olfactory sac on the snout. The lips of the sac have closed near the middle, leaving a front and rear opening through which the water rushes. Other organs of chemical sense are the organs of the lateral line, which at its anterior end divides into many branches running over the head. Originally the sense-organs of this line were distributed along the bottom of a sort of trench. Now, however, the trench is covered over by the skin and scales forming a canal. The scales are perforated at intervals to connect the outside with the interior of the canal. There is good reason for thinking that the ear is only a specialized part of the lateral line organ, and that is where it got its semicircular canals. There is also an otolith in each ear which probably assists in the equilibrium of the fish. The eye of the fish has to be used under the water. Our eyes are not fitted for seeing under water as our lens is too flat. In the case of the trout the lens is nearly spherical and is forced back towards the retina. Rays from the water will not be bent on entering the lens, which 
has about the same specific gravity as water, but will be severely bent as they leave it. This accounts for the small distance between the lens and the retina.

The smelts belong to the bony fishes and are related to the trout. They are preëminently inhabitants of the northern temperate zone, since all but one of the ten genera occur only there. They are small marine fishes, and although a few are inhabitants of the deep sea, most live near the shore, and in the spring ascend rivers to spawn. Some of them have become cut off from descending to the sea, and live permanently, as "landlocked". forms, in fresh water. Such "land-locked" individuals are of smaller size than the marine ones. The food of smelts, like that of other salmons, is chiefly animal, consisting of smaller fishes or insects, small crustaceans, and mollusks.

Smelt are of considerable economic importance, since they share with other members of the salmon family a delicately flavored flesh. Our Atlantic form (Osmerus ${ }^{1}$ mordax $^{2}$ ), which ranges from Delaware Bay northward, is caught most abundantly in Maine. The total Atlantic smelt fishery is valued at $\$ 125,000$. Smelt eggs are artificially hatched and planted in rivers previously uninhabited by them. Smelt are said to return to these rivers after spending the winter in the sea.

The family Salmonidæ, which in its widest sense includes the smelts, ${ }^{3}$ comprises some of our most important food fishes. It is distinguished from other families of spineless finned fishes by having both ventral ( $v . f$, in Fig. 284) and adipose fins (d.f, Fig. 284) present. The head is naked, but the body is scaly and rounded.

1 osmerus, odorous ; the Greek name is the equivalent of the English "smelt."

${ }^{2}$ Biting.

${ }^{3}$ By recent authors the smelts are assigned to a distinct family, the Argentinida. 
Besides the smelt there are, in this family, numerous important species. The salmon proper ${ }^{1}$ are restricted to the north temperate and arctic regions, and live either in the sea, migrating to fresh water to spawn, or exclusively in brooks and lakes. The migrations of salmon from the sea up the rivers are remarkable. Hundreds of miles are sometimes journeyed, rapids swum, and falls leaped, for the purpose of laying eggs in some remote lake. At the end of their journey the eggs are laid and male and female parents clie. On the Atlantic coast the Penobscot River has the most important run of salmon. The Pacific salmon pass up the Sacramento and Columbia rivers, and up many rivers of British Columbia and Alaska. In these rivers the fish are caught as they ascend to breed. Such is the greediness and lack of foresight of the canning fisheries on the Columbia River that very few salmon are permitted to pass the nets of the canning factories, and consequently the apparently inexhaustible supply of this fish has been immensely reduced and threatened with destruction, but it will probally he preserved by the assistance of artificial hatching.

The trout, of which there is a number of kinds on both continents, is commercially much less important than the salmon proper. As a result of overfishing, and the pollution of streams by factories and sewage, this fish is disappearing from Eastern waters.

The whitefish, of which we possess many species, is exclusively an inhahitant of fresh water ${ }^{2}$ and is derived chiefly from the Great Lakes. Its tecth are almost rompletely absent, or very small ; it feerls almost exclusively upon small arthropods and mollusks. It is of very great commercial importance, 
its fisheries being valued at nearly three million dollars a year.

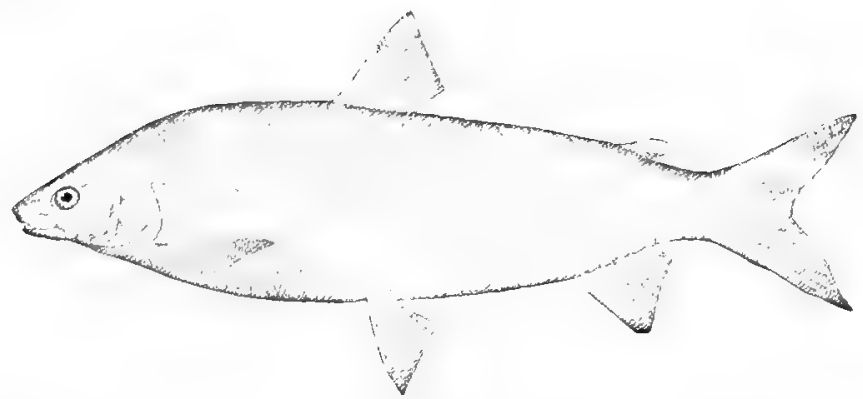

Fig. 288, - Coregonus, the lake whitefish. Much reduced. From Goode.

Leaving now the salmon, we may briefly consider some of the other more important families of bony fishes.

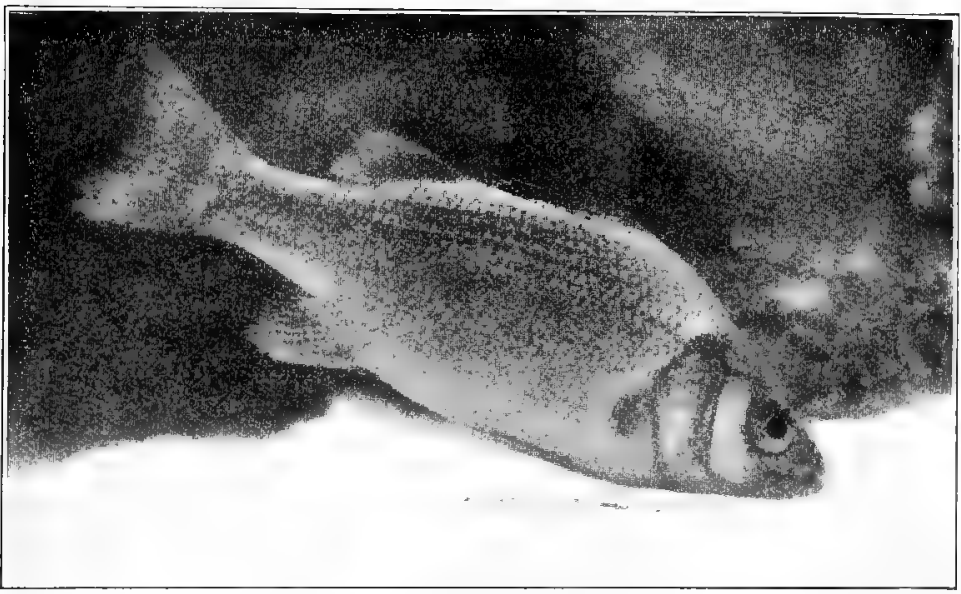

FIG. 289. - Morone americana, the white perch. The fish is searching for food along the bottom of the aquarium, an instinct which it shows in nature also. About one-third nat. size. Photo. of living animal by Dr. R. W. Shufeldt, from "Bull. U. S. Fish Com.," 1899. 
The darters are spiny-rayed fishes of small size, from four to seventeen centimetres long, brightly colored, and with welldeveloped pectoral fins. They live in clear streams, half concealed under stones, and are most abundant in the Mississippi drainage basin.

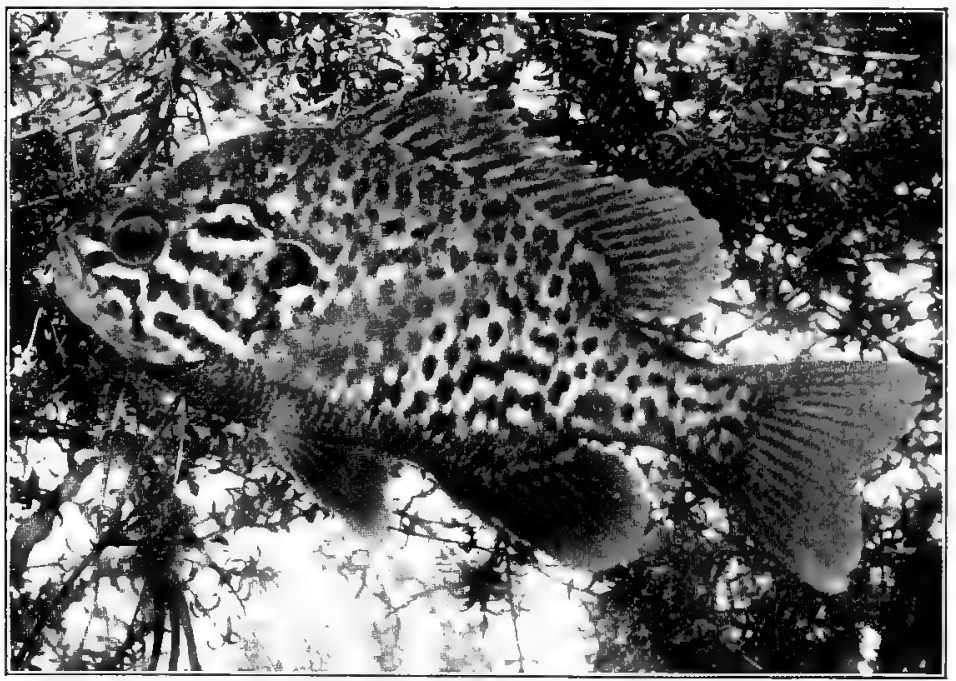

FIG. 290, - Eupomatis gibbosus, the common sunfish. Two-thirds nat. size. Photo. of living animal by Dr. R. W. Shufeldt, "Bull. U. S. Fish Com.," 1899.

The perches are a widespread family, represented in this country chiefly by the common yellow perch of the East, the "wall-eyed pike" of the Great Lake region, and the white perch of the Atlantic coast (Fig. 289). These fish have an oblong, compressed body covered with small scales; they are highly rapacious, and are believed to be destructive to the young of other species of fish. They are esteemed as food, although not to the extent of annihilation. 
The sunfishes ${ }^{1}$ have a perch-like form, but have only one dorsal fin instead of two. They live in fresh water, have rapacious habits, are brilliantly colored, and build nests in the sand, which the male watches over and defends with courage. Some species living in the Great Lakes are known as black bass, or rock bass. The small species, with the brilliant red edge to the operculum, is called pumpkinseed.

The toadfishes (Fig. 291) are represented in our faunas by a common species which lives under stones in harbors and attaches its eggs to the under side of stones. It is a vigorous fighter.

The sculpin (Fig. 292) is closely related to the toadfish. Like the latter, FIG. 291.-Batrachus tau, it has a broad head and nearly scaleless body. The pectoral fins are large, and the two dorsal fins extend along the

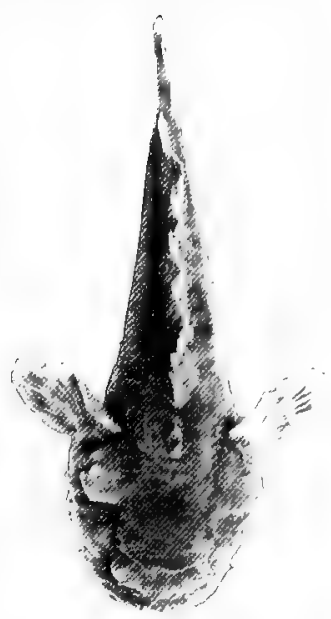
the toadfish. Dorsal view. Two-thirds nat. size. Photo. by W. H. C. P.

greater part of the back. Allied to the foregoing is the rock eel (Fig. 293), which is sometimes brought up in the seine from a depth of 8 to 10 fathoms.

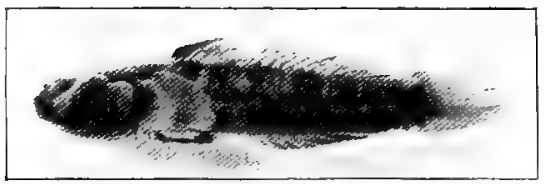

FIG. 292. - The little sculpin, Acanthocottus. Two-thirds nat. size. Photo. by W. H. C. P.

${ }^{1}$ Fig. 290. 
The silversides are especially abundant along our Atlantic coast. They have an elongated, somewhat compressed body,

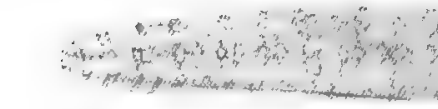

FIG. 293. - Pholis, the rock cel. Right side. Nat. size. Photo.

and a broad, bright silvery band on the sides, against a greenish general body color. The clors:al spines are slender. The

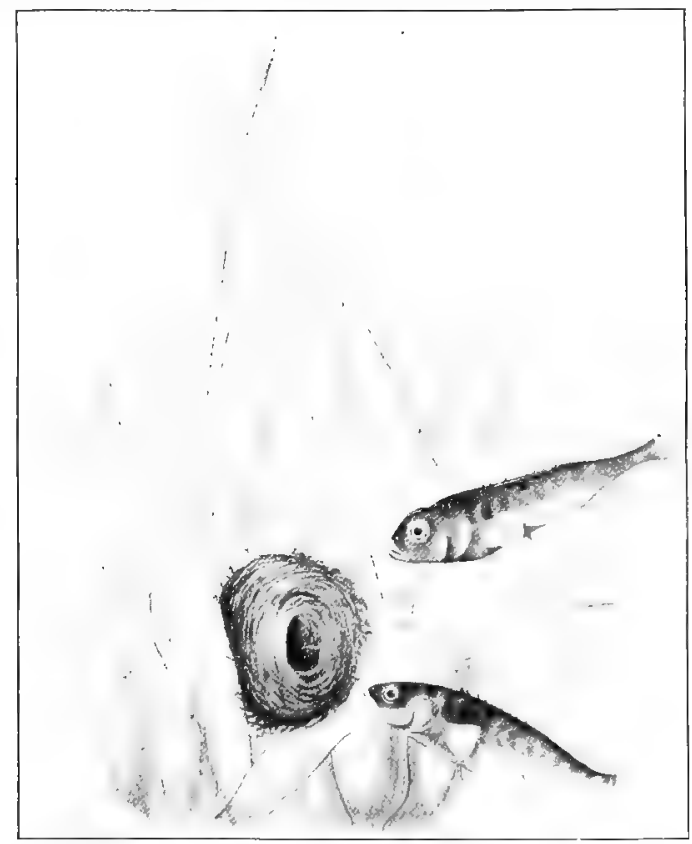

FIG. 294. - Gasterosteus pungitius, the nine-spined stickleback; male (above) and female near the nest in rushes. The female is about to deposit its eggs in the nest. 
fish swim near shore, in dense schools. One species on the California coast is known as a "smelt," and is a good food fish. The sticklebacks are small, elongated fishes, having an extremely slender tail and a large mouth. The dorsal fin

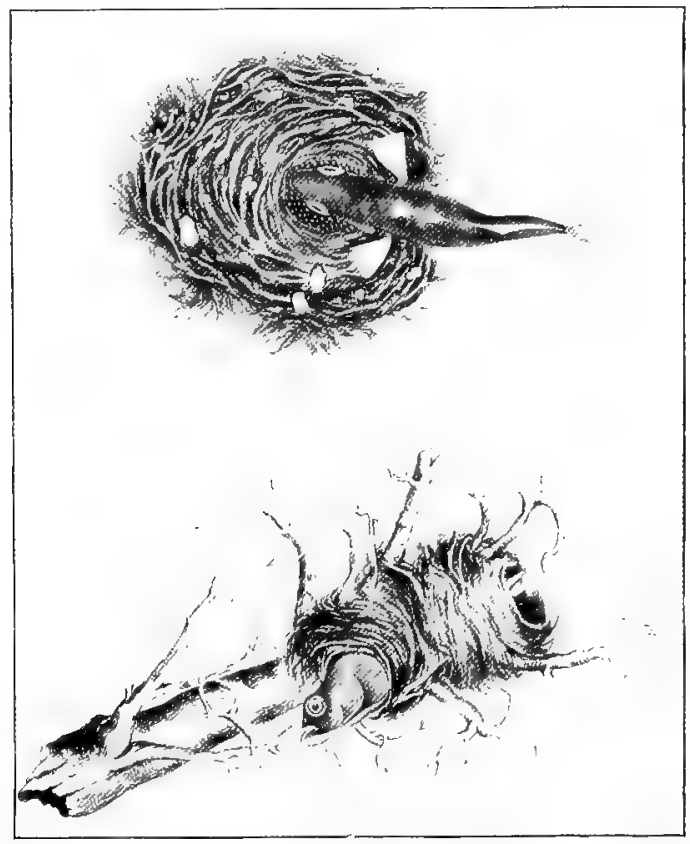

FIG. 295. - Gasterosteus bispinosus, the two-spined stickleback. Above, nest with eggs, and male entering. Below, male depositing its milt on the eggs.

Figs. 294 and 295 are reproductions of water-color paintings in the $\mathrm{Mu}-$ seum of Comparative Zoology at Harvard College.

is preceded by two or more large, isolated spines. The fishes live in either fresh or brackish water. In some of the species the male builds an elaborate nest from bits of aquatic plants, firmly united by a special sticky secretion. The nest, which 
is built among the plants of the stream, consists of a short cylinder, through the horizontal cavity of which the fish can lie while it deposits its eggs. The male guards the single nest,

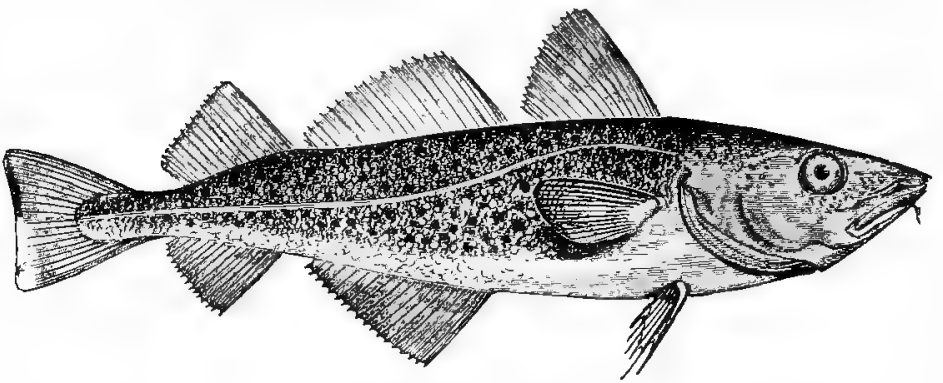

FIG. 296. - Gadus morrhua, the codfish. About onc-seventh nat. size. After Storer.

and is polygamous, i.e. fertilizes in the one nest the eggs from various females (Figs. 294, 295).

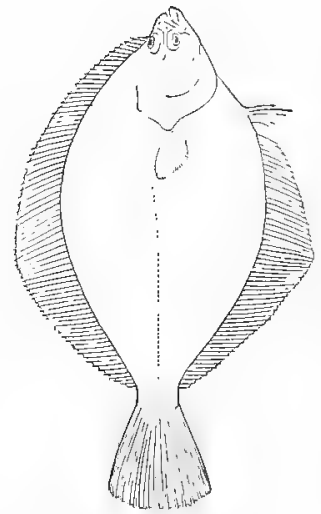

Fig. 297.- Outline of one of the flatfishes, seen from the upper side, reduced. From "Cambridge Nat. Hist."

The codfishes, among the most important of food fish, have ventral fins, without spines, and jointed fin-rays, well-developed tail fin, and barbel on chin. Our common codfish (Fig. 296) occurs over the whole of the North Atlantic; but the most important fishing localities are the banks near Newfoundland, especially Grand Bank.

The flatfishes are peculiar among fishes in that they have the habit in the adult stage of lying on one side. In consequence the under eye migrates to the upper side, so that both eyes come to lie on the same side of the body. The mouth also tends to become unsym- 
metrical. The flatfish, consequently, illustrates well the principles of self-adjustment to a peculiar environment (Fig. 297).

The catfishes have four to eight long barbels around the mouth, and have no scales on the hody (Fig. 298). They are most common in South America, but there are a large number of species in the U'nited States, mostly found in the Mississippi Valley and the Great Lakes, inhabiting deep or sluggish waters, and living in the mud. The common New

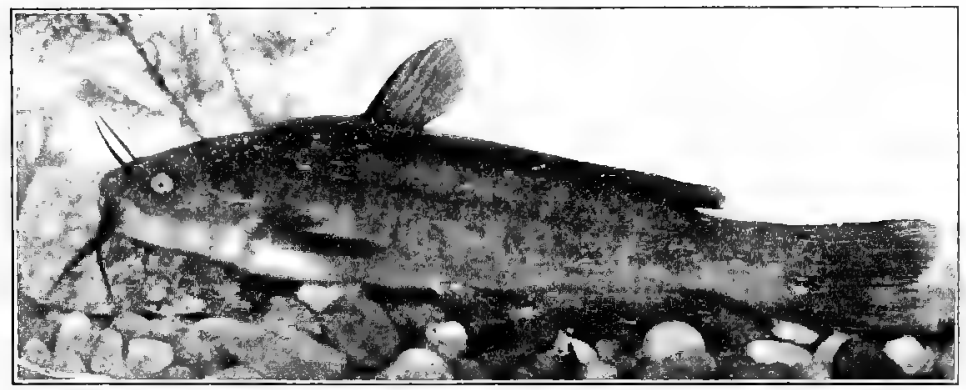

Fig. 298. - Ameiurus nebulosus, the catfish. About one-half nat. size. Photo. of living animal by Dr. R. W. Shufeldt, "Bull. U. S. Fish Com.," 1899.

England species is Ameiurus catus. It was with reference to our common New England species, the bullhead or horn-pout, ${ }^{1}$ that Thoreau wrote that they are "a bloodthirsty and bullying race of rangers, inhabiting the river-bottoms, with ever a lance at rest and ready to do battle with their nearest neighbor." The stiff, jagged rays of the pectoral fins can make severe wounds. The great catfish of the Mississippi River may weigh up to ninety kilograms, and, like most other species of catfish, is much prized as food.

The suckers are characteristic North American fish abundant in every creek, and consequently known to every 
lover of woods and brooks. The lips are thick, and drawn down at the corners. ${ }^{1}$ They are rather sluggish fishes, feed on small aquatic insects, and suck up mud. They are not generally esteemed as food, inasmuch as their flesh is coarse

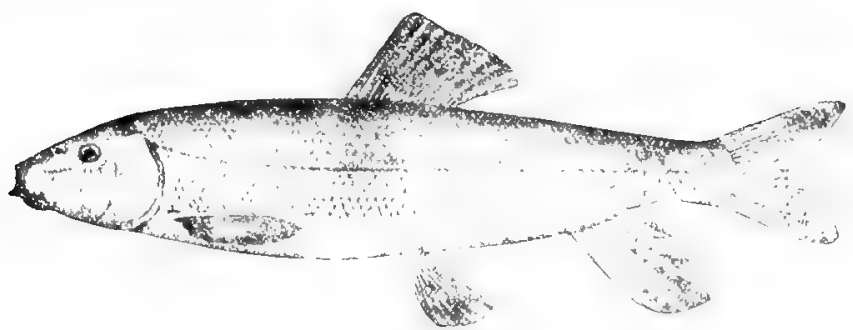

Frg. 299. - The brook sucker. After Goode.

and very full of bones. In the Mississippi Valley, however, they are so aluundant and large that they are of some commercial importance.

The term "minnow" is applied to two distinct families of

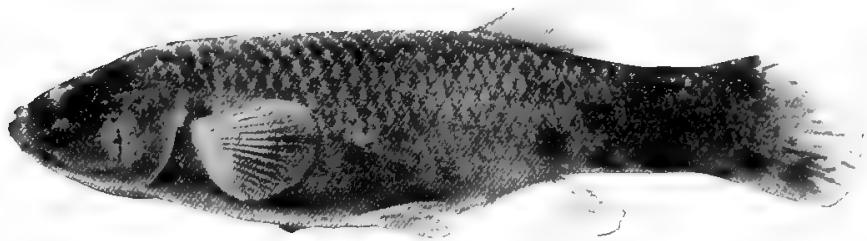

FIG. 300. - Fundulus heteroclitus, a killifish or shore minnow. Nat. size.

small fish. One of these is also known as "killifish." The killifish have a broad head covered with scales, and have welldeveloped teeth in the mouth. They occur in schools in shallow water along the shore, and ascend streams to their source. They are carnivorous, and feed at the surface. In one species from the Southern coast, the male is only about

s Fig. 299. 
two centimetres long, and is the smallest known vertebrate. Our commonest species on the shore or in brackish water is Fundulus ${ }^{1}$ (Fig. 300). The minnows of the other family have a narrow head without scales, and with few teeth in the mouth. They occur exclusively in fresh water, and are known as " shiners." The "goldfish" is related to this group.

The pike and pickerel $\left(\right.$ Esox $\left.^{2}\right)$ are roughly cylindrical fishes, with large mouth, elongated, depressed jaws, and strong,

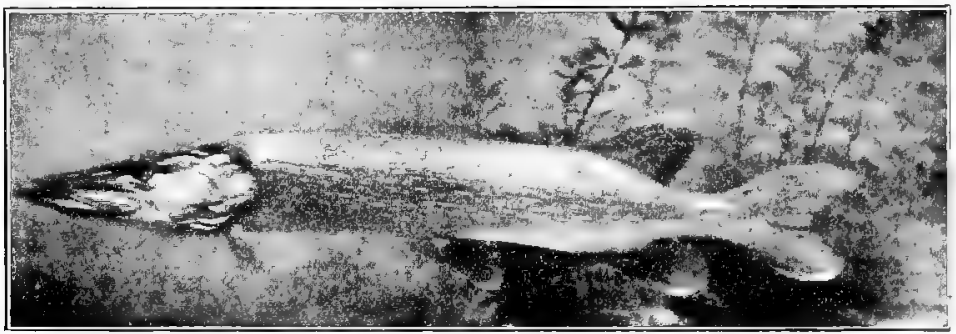

Fig. 301. - Lucius lucius, the pike. About one-fifth nat. size. Photo. of living animal by Dr. R. W. Shufeldt, "Bull. U. S. Fish Com.," 1899.

hooked teeth. They are large and voracious fresh-water fishes, confined, with the exception of a single species, to the United States. The "muskallunge" of the Great Lakes reaches a length of two metres. It is, fortunately, somewhat rare, otherwise there would be few other inhabitants of our large streams.

The shad is a representative of a family the herring family - which has played an important part in the civilization of Europe. The Emperor Charles $V$. said that the herring brought greater wealth to the Netherlands than did America

1 fundus, hottom.

2 isox, a fish living in the Rhine, mentioned by Pliny. 
to Spain. Our common shad $^{1}$ ranges from Newfoundland to Florida. ${ }^{2}$ With the Pacific salmon and cod it is commercially one of our most important fishes, for the catch of Atlantic shad for 1902 was valued at nearly one million dollars. The Pacific coast has been successfully stocked with shad from the Atlantic. The Atlantic shad, like the salmon, migrate up streams to deposit their eggs. The alewives have the same habit. The herring, on the contrary, spawn in the sea. As the common name, allied to the German Heer, an

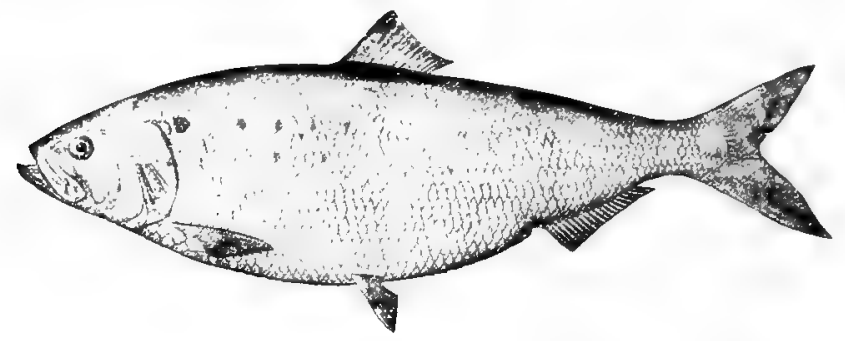

FIG. 302. - Alosa sapidissima, the shad. After Goode.

army, implies, they travel in great schools. The menhaden, which also occur in great schools, have of late years been destroyed in vast numbers to make fertilizers.

The eels are easily distinguished by their serpent-like form, the absence of ventral fins, the long dorsal fin, and the rudimentary or absent scales. These fish occur all along our coast, and ascend streams. During the day they lie hidden in mud, and at night they feed, their principal prey being small aquatic animals, the young of other fish, and shrimps and crayfishes during the molting period. On account of the narrowness of

${ }^{1}$ Alosa sapidissima; Alosa, from Saxon allis, old name of the European shad; sapidissima, most delicious.

2 Fig. 302. 
the gill-opening, they may live for some time out of water in a moist place. The reproduction of the eel was long a mystery. All sorts of creatures have in past times been supposed to produce them, ranging from the gods to water beetles. They have even been thought to be generated from slime. We now know, however, that there are both male and female individuals; that the males live chiefly, but not exclusively, in the

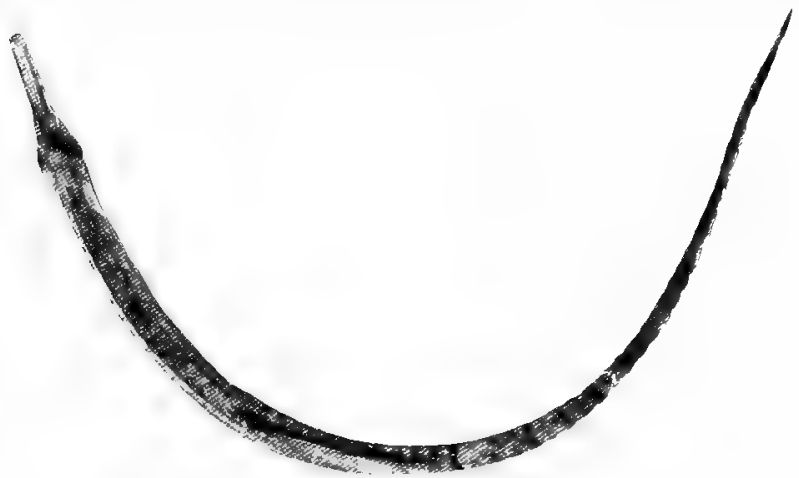

FIG. 303. - Siphostoma fuscum, the pipe-fish. Nat. sizc. Photo.

sea; that reproduction occurs chiefly in the sea; and that the young females come from the sea and pass up the rivers during the spring.

The pipe-fishes and their allies ${ }^{1}$ include a number of aberrant forms. Some of these are greatly elongated, like the pipefish proper (Fig. 303) ; others are shorter and stouter, like the "sea-horse." All have a prolonged snout, and usually a long, slender tail. The body is encased in bony plates, and the male is often provided with a brood-pouch, in which the developing young are carried.

${ }^{1}$ Lophobranchii. 
Having considered the bony fishes in detail, we may take up the other classes of fishes.

The lamprey eels, or Cyclostomi, are the only parasitic vertebrates. In the adult stage they either live attached to

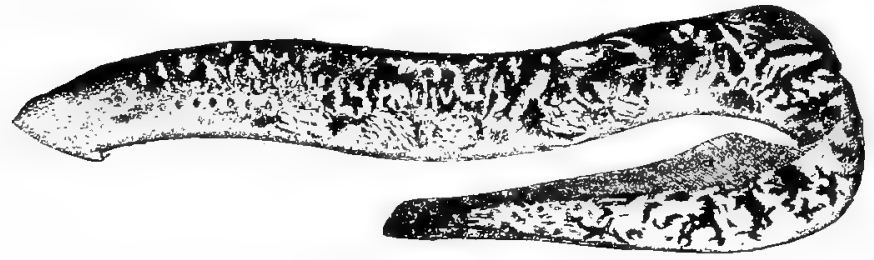

FIG. 304. - Petromyzon, the lamprey. One-fourth nat. size. After Goode.

the outside of other fishes, sucking their blood, or else they may penetrate into the body cavity. They do not bite, hecause they have no lower jaw, and are known as "roundmouthed" eels." Lampreys are found in the seas and in the rivers of the temperate zones. They occur on our Eastern coast and ascend rivers; others live in the lakes of New York,

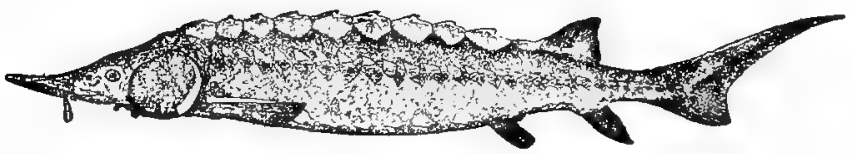

FIG. 305. - Acipenser, the sturgeon. One-sixteenth nat. size. After Goode.

in the Great Lakes, and in the Misisisippi Valley. In Europe they are much esteemed as food.

The sharks and rays (Selachians) include all inhabitants of the sea. They may be distinguished from the bony fishes by the rough skin, beset with spines, and by a skeleton that is made not of bone, but of cartilage. We have a number 1 Fig. 304. 
of sharks on our Northeastern coast, of which the dog-fishes and the sand-shark are the commonest (Fig. 283). They are all carnivorous animals and powerful swimmers. They feed on the larger crustaceans and fish.

The living Ganoidei are a remnant of a very extensive group which existed in geological times. North America is especially

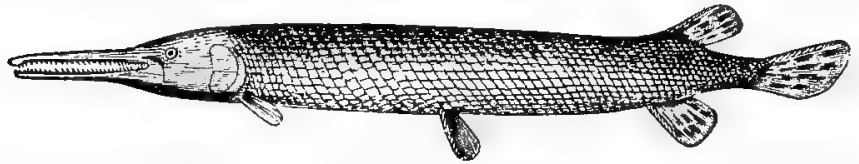

FrG. 306. - Lepidosteus, the garpike. One-eighth nat. size. After Tenney. rich in existing representatives of this group, as of several other old groups, such as the turtles, tailed amphibians, and the king-crab. Of the five families of ganoids, four are represented in this country. In the following four paragraphs a type of each of the native families is considered.

The sturgeons have five rows of hony scales on the trunk and four barbels on the head. ${ }^{1}$ They occur both in the sea

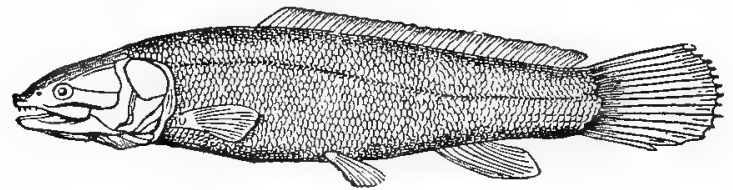

Fig. 307. - Amia calva, the bowfin. One-sixth nat. size. From Leunis.

and in the Great Lakes and the rivers of the Central States. Although of large size, they feed for the most part on small aquatic animals, such as worms, insect larvæ, and small fish. The flesh of some species is much used as food ; the eggs taken from the ovaries (roe) are pressed into a delicacy known as "caviar."

${ }^{1}$ Fig. 305. 


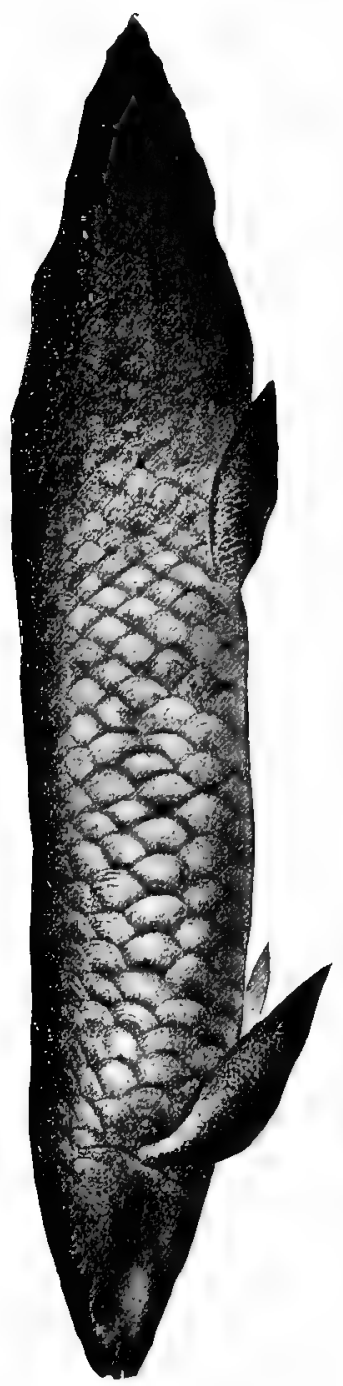

The spoonbill, which has an elongated, flattened snout and is almost without scales, is a large fish found in the Mississippi River. It is also called "paddle-fish" or " duck-bill catfish." It becomes two metres I long, and seeks small animals in the mud, which it stirs up with its snout. The garpikes are known by their long snout (Fig. 306). They are completely clad in an enamel coat

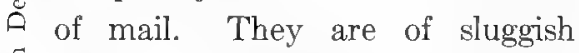
I habits, but voracious, and their flesh is valueless as food. One species is found in China, the others in the rivers of North America.

The bowfin (Amia ${ }^{1}$ ) occurs in the rivers and lakes of the United States. It has a short body, a blunt head, and a long dorsal fin (Fig. है 307). It is the sole survivor of a formerly large family.

The Dipnoi ${ }^{2}$ include only three rare foreign forms, which seem to form a transition between fishes and the higher groups, for some of them have lungs in addition to gills. From some such lunged fishes must the amphibia have arisen (Fig. 308).

${ }^{1}$ Ancient name of a fish.

2 dis, twice; pnoe, breath. 


\section{CHAPTER XXIII}

\section{THE FROG :- A STUDY OF THE ORIGIN OF LAND LIFE}

IT is certain that the primitive animals lived in water because all the lowest forms that we know to-day are aquatic and dry up at once if left in the air. Only some of the higher and more specialized forms have been able to live on dry land. Such are the insects, spiders, certain parasitic forms, and the higher vertebrates. There are a few scattered, terrestrial representatives of other groups, such as the earthworms, certain Crustacea (the wood-lice), and land snails. Animals that are fitted to live in water find that they are not well adapted to the land because of the great differences in the two habitats. In the first place, water animals usually have only a thin skin. This would not protect the body from loss of water in the air. Consequently, only the thicker skinned aquatic animals can become terrestrial. Second, such thick-skinned aquatic animals must have gills for breathing. These thin-walled structures cannot exist in dry air. Breathing organs of land animals must be placed deep in the body so that the air is moistened by the body before it reaches them. Again the weight of the body is supported in the water by its buoyancy, so that the appendages are placed laterally and function as oars. But on the land the body must be supported by the appendages on the solid substratum, consequently the appendages are placed below the body. Finally, since all those 
animals that depend upon currents of water to bring them food have a mode of feeding that is incompatible with living in the air, they have given rise to no terrestrial species.

The newt well illustrates the changes of form and structure that an aquatic animal must undergo in adapting itself to the land. The young newts, as they hatch from the eggs lying in the water, are thin-skinned animals with delicate, bushy gills

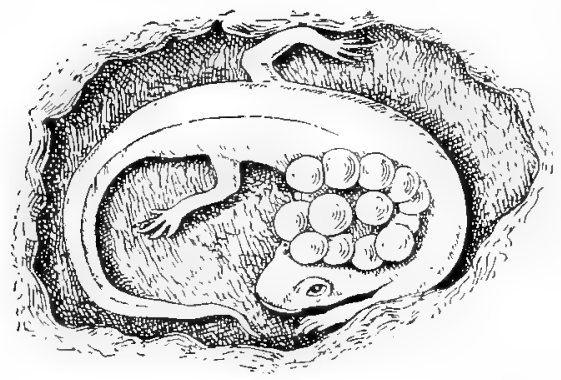

FIG. 309. - A female newt (Desmognathus fuscus) guarding its eggs in a hole by the side of water. Nat. size. After Wilder. extending out from the side of the head. The legs are very small, or absent, and locomotion is by a large fin on the tail. By the movement of this fin the animal is propelled through the water very much as a fisherman sculls a boat. By the time the newt has left the water and has become adjusted to the moist air of the damp ground on which it lives, the outer layers of its skin have become somewhat horny and the bushy gills have become lost (Fig. 309). Respiration now takes place in the throat, or in other cases in pockets formed from the throat and known as the lungs. Four legs directed downward support the body above the ground, and the tail-fin withers away, so that only a rounded tail remains.

The transformation that the individual newt undergoes in its lifetime is an epitome of the evolution of many terrestrial forms. Thus, in the tropies, certain shore crabs have come to live in the upper part of the beach and eventually in the forests 
and even on the trees. Their gills have withered away, and the gill cavities now function as lungs. The hard shell, which served as a coat of mail to ward off attacks of enemies in the sea, serves the land crabs to prevent the loss of water. Again, the ancestors of the wood-lice are common in streams, and even in this situation are already provided over the whole body with a thick skin called the cuticula. The possession of this cuticula has permitted the development of land life in this group. The gills, which are thin-walled plates in the aquatic forms, become hollowed out to form lungs. In the case of snails the thick skin, which is useful in secreting the shell of the aquatic forms, has permitted some of its possessors to live on land. Certain representatives of the group, namely, the slugs, have lost the shell without suffering any disadvantage, because they have a very thick skin. Even with the thick skin, however, slugs do not risk a very dry situation, and if forced to remain long in dry air they varnish themselves over with a water-tight layer of mucus. In the slugs, as we have already seen, the gill-chamber has been transformed into a lung-chamber by the degeneration of the gills and the diminution of the gill-opening so that the influx of air may be reduced or increased as it is dry or moist.

Why have any aquatic organisms given rise to terrestrial descendants, in spite of the fact that there is room in the sea for all, and food is almost inexhaustible? The probable answer to this question is that some species whose structure permitted land life found it advantageous to leave the water from time to time to escape from enemies. In the new field they obtained an abundance of oxygen and food, so they prolonged their stay there until, finally, they became better adapted to the land than to the sea. 
The first animals to come to the land were probably the earthworms, many of whose aquatic allies live in ponds that are apt to dry up during the summer. The aquatic worms are preserved from annihilation only by burying themselves in the muddy, damp bottom. One of the next groups to give rise to terrestrial forms was that of the Arthropods, some of the representatives of which still retain in their bodies evidences of their aquatic ancestry. Thus in the terrestrial Peripatus

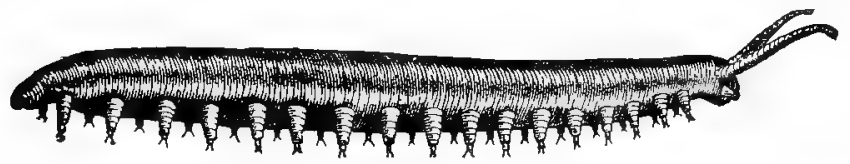

FiG. 310. - Peripatus, the air-breathing wormlike animal that bridges the gap between Myriapods and worms.

(Fig. 310) the air-breathing organs have not yet developed, and the appendages are placed laterally instead of ventrally. From some such primitive form the plant-eating insects arose, and on account of the almost limitless supply of vegetation developed mightily. Then came the carnivorous forms, like the spiders and their allies, to prey on their herbivorous forerunners.

Among the vertebrates the primitive forms lived in the water, but in the group Amphibia, which includes the newts, salamanders, frogs, and toads, there are forms that show the transition from aquatic to terrestrial life. Most of them begin life as aquatic animals and end it as terrestrial.

The Amphibia comprise about a thousand species which are distributed in three great groups. Those forms that retain their tails permanently, even when they come to land, are known as Urode'la. They are confined in their distribution to the Northern Hemisphere, excepting two or three species 
that extend their range along the Andes south of the Equator. North America is especially rich both in species and individuals of Urodela. Those which lose the tail in the adult stage, like the frogs, are called the Amu'ra. These are found in all parts of the world, especially in South America and Australia. A third group (Gym'nophiona), which is found only in the tropies, contains animals that have a worm-like body, live in the ground, and have more or less rudimentary eyes. It will be seen that the Amphibia are found chiefly in tropical and subtropical countries, although a large number thrive in colder parts of the temperate zone.

As an example to illustrate the structure of Amphibia we may take the frog.

General Form of the Body. - The frog is not a typical amphibian, since it has lost its tail, so that only head and trunk remain, and the anal opening lies at the very hind end of the body. The appendages have become long and slender as compared with those of the fish, and five distinct toes are present on each foot. The whole body is covered with a delicate skin devoid of scales such as fishes have, or other outgrowths and coverings of the skin such as are found in birds and mammals. The skin contains abundant glands, however, the secretions of which may be poured over the skin to protect it from drying up.

The Skeleton of the frog consists of an axial and an appendicular part (Fig. 311). The vertebral column consists of a few simple vertebræ, to each of which a pair of short ribs is fused. The skeleton of the rudimentary tail is represented by a long, bony rod. ${ }^{1}$ The skull is simple as compared with that of the fish, partly because of the absence of gills and partly because ${ }^{1}$ Urostyle, UST., Fig. 311. 


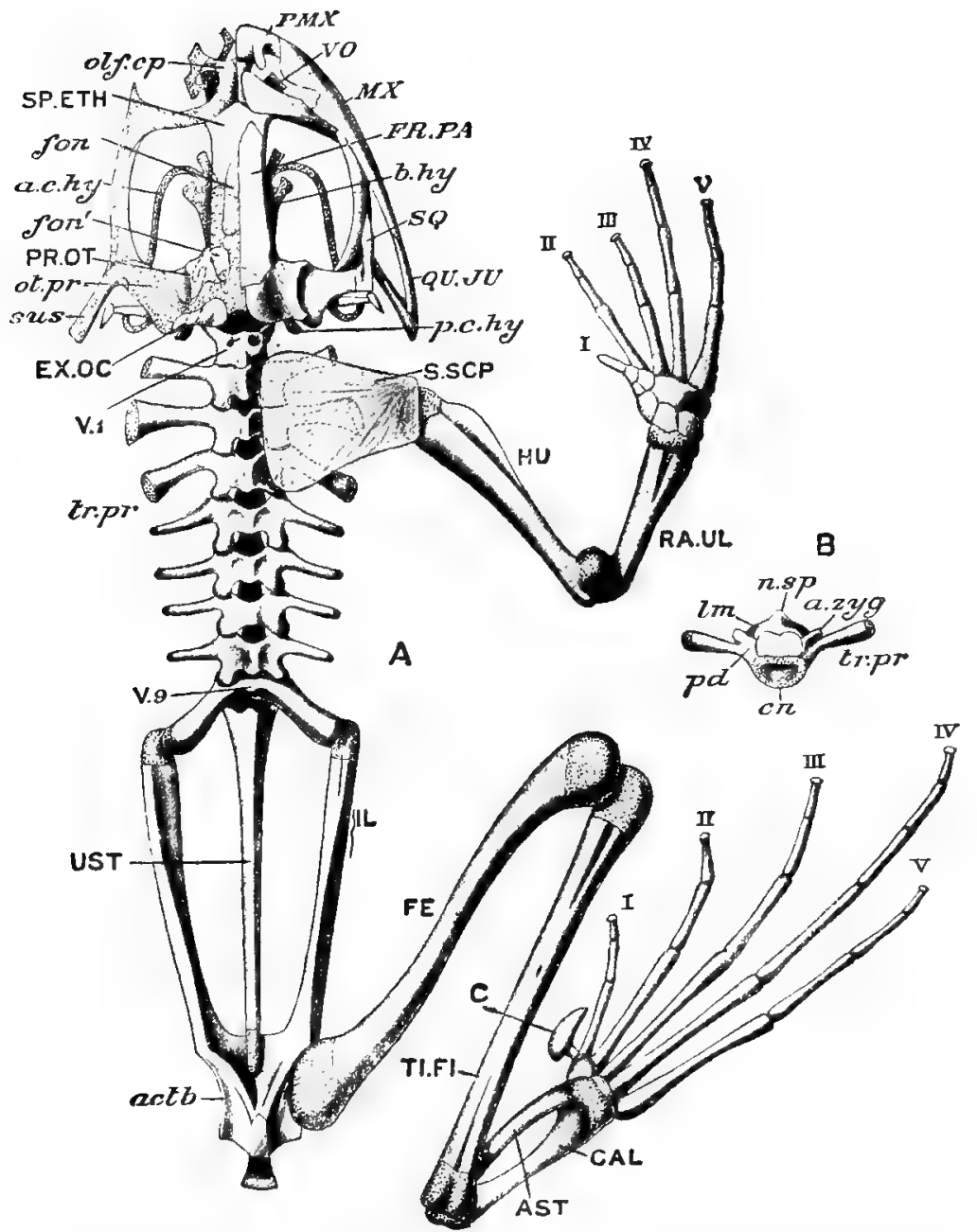

FIG. 311. - The skeleton of the frog (Rana temporaria). A. Skeleton seen from above. The left half of the shoulder girdle and the loft fore and hind legs are removed, also the membrane bones on the left side of the skull. Cartilagenous parts are dotted. Names of bones that are first forned in cartilage are in GOTHIC capitals, those formed directly in the skin are in $I T A L I C$ capitals. a.c.hy, anterior horn of hyoid bone; $a c t$, depression to receive femur (fe.); AST, "astragalus" ; b.hy, base of hyoid; $C_{0}$ "calcan," bone of a spur; CAL, "calcaneum" of the ankle; 
of a reduction and fusion of parts. The teeth, instearl of being scattered over the mouth, are found chiefly on the jaws, but there are also a few small patches of teeth on the roof of the mouth.

The shoulder girclle forms a complete ring extending from the shoulder blade (S.SCP), which lies on the ribs, to the hreastbone below. To this are attached the upper armbones (HU) of the relatively short fore legs. The lower arm is supported by a united radius and ulna. The pelvic girdle is so long as to give great elasticity to the attachment of the skeleton of the long and powerful hind legs, which are used in jumping (FE and $\mathrm{TI} . \mathrm{FI}$ ).

Organs of Nutrition. - The food of frogs is very varied, consisting of worms, mollusks, insects, small fishes, tadpoles, etc. These are caught in the roomy mouth, often with the aid of the tongue, which is attached in front and
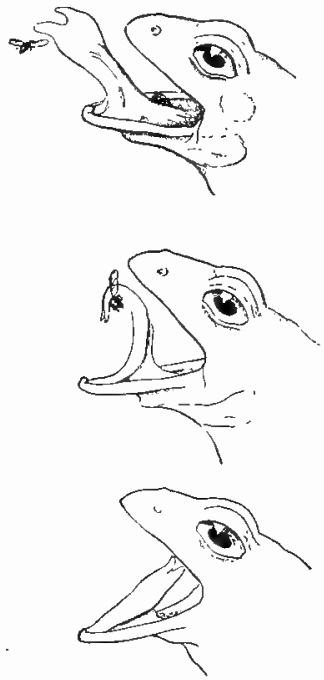

FIG. 312. - Three stages (from above downward) in the moverment of the tongue of a frog in eatching an insert. From "Cambridge Nat. Hist." free behind, so that the hind end may be flopped out some distance in front of the mouth to strike an insect (Fig. 312).

EXOC, exoccipital, connecting with vertebral column; FE, femur; fon, openings in skull; FR.PA, fronto-parietal; HU, humerus; $I L$, ileum; $M X$, maxilla; olf.cp, olfactory capsule; ot.pr, otic process; p.c.hy, posterior horn of hyoid; $P M Y$, premaxilla; PR.OT, pro-otic bone (ear); RA.UL, radio-ulna; SP.ETH, sphenethmoid; SQ, squamosal; S.SCP, suprascapula; sus, bone suspending lower jaw from skull; TI.FI, tibiofibula; tr.pr, transverse process; UST, urostyle. V.1, cervical vertebra; v.9, sacrol vertebra; $V O$, vomer; $I-V$, digits. B. The fourth vertebra, anterior face; a.zyg, anterior linking process; $c n$, centrum; $l m$, lamina; n.sp, neural spine; $p d$, pedicel; tr.pr, transverse process. After Howes, from Parker and Haswell. 
Beyond the mouth a short gullet leads to the large stomach. Next, the food passes into the upper digestive portion of the

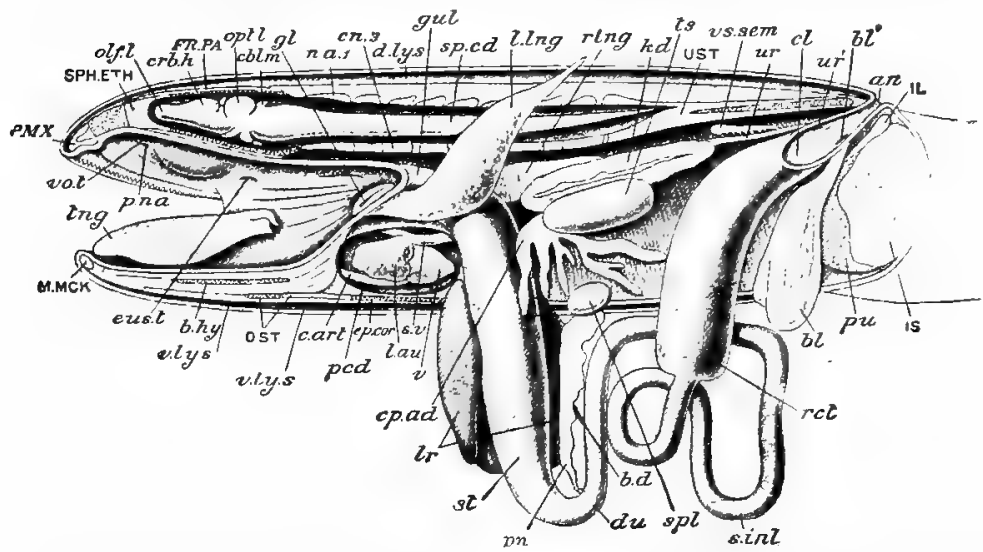

FIG. 313. - Diagram of viscera of a male frog, Rana temporaria, seen from the left side. Skeletal System: Skull: FR.PA, fronto-parietal of cranium; $P M T^{-}$ premaxilla; SPH.ETH, sphenethmoid; M.MCK, cartilage base of lower jaw; b.hy, tongue-bone (hyoid); vo.t, teeth on vomer bone. Vertebral Column: cn.3, centrum of third vertebra; n.a.1, neural arch of first vertebra; UST, urostyle. Girdles and Appendages: ep.cor, epicoracoid; IL, ileum; 1S, ischium; O.ST, omo- and epi-sternum; pu, pubis. Almentary Srstem: tho, tongue; eus.t, Eustachian tube (remnant of gill-slit); $u l$, glottis; gul, gullet; st, stomach; $d u$, duodenum; $l r$, liver; b.d, bile duct; $p n$, pancreas; $s . i n t$, small intestine; rct, rectum; $c l$, cloaca; an, anus. Circulatory Srstem: c.art, conus arteriosus l.au, left auricle; $p c d$, pericardium; s.v, sinus venosus; v, ventricle; cp.ad, fat body; d.ly.s, dorsal lymph sinus; $s p l$, spleen; v.ly.s, ventral lymph sinus. Respiratory System: l.lng, left lung; r.lng, right lung; $p . n a$, posterior'naros. Urogentral Srstem: $k d$, kidney*; $u r$, ureter opening into the cloaca, $c l$, at $u r^{\prime} ; b l$, urinary bladder opening at $b l^{\prime}$ into the cloaca ; ts, testis; vs.sem, semins: 1 vesicle. Nervous System: crb.h, cerebral hemisphere; $c b l m$, cerebellum; sp.r spinal cord; olf.l, olfactory lobe of brain; opt.l, optic lobe of brain. From Parts: and Haswell.

intestine, known as the duodenum, where the secretions of the liver and the pancreas are poured (Fig. 313). This is followed by a long, absorbing portion, and this, in turn, by the rectum, which receives also the excretory and reproductive products, and consequently functions as a "cloaca." 
Organs of Respiration. - Although the young frog (tadpole) uses gills for absorbing the oxygen dissolved in water, the adult breathes also air. Even the adult doubtless absorbs the oxygen of the water through the thin skin, and perhaps also through the lining of the pharynx; but the main organ of respiration is the pair of lungs ( $r . \operatorname{lng}$ and l.lng). The lungs are sacs whose inner surface is divided by partitions into aircells which greatly increase the respiratory surface. Through the thin walls of the air-cells there flows a constant stream of blood, gaining oxygen from the air in the lungs.

Organs of Circulation. - The impure blood from the body collects in a single vessel, and then enters a chamber of the heart called the right auricle. Thence it passes through an opening, guarded by valves, to a chamber that has thick muscular walls, and is called the ventricle. When the ventricle contracts, the blood is prevented by the valves from returning to the auricles, and passes out of the ventricle into a great arterial trunk, or "conus" (Fig. 314). Alongside of the right auricle, but completely separated from it by a partition, is the left auricle. This contains richly oxygenated blood freshly received from the lungs. The left auricle contracts at the same time with the right, and pours its blood into the same ventricle. It would seem inevitable that the pure and impure blood should completely mingle, but this is prevented by the prompt contraction of the ventricle, assisted by a rather complicated mechanism. The conus lies on the right side of the ventricle, so that it is nearer to the stream of impure blood emerging from the right auricle, and is first filled by it. The first outlets from the conus that this impure blood meets are the arteries that go to the lungs, and so, with the assistance of certain valves in the conus, the impure blood flows to the lungs. As the ventricle continues to empty itself, a mixed 
blood emerges, and, slipping over the entrance to the now filled pulmonary arteries, goes on to the dorsal aorta and the organs

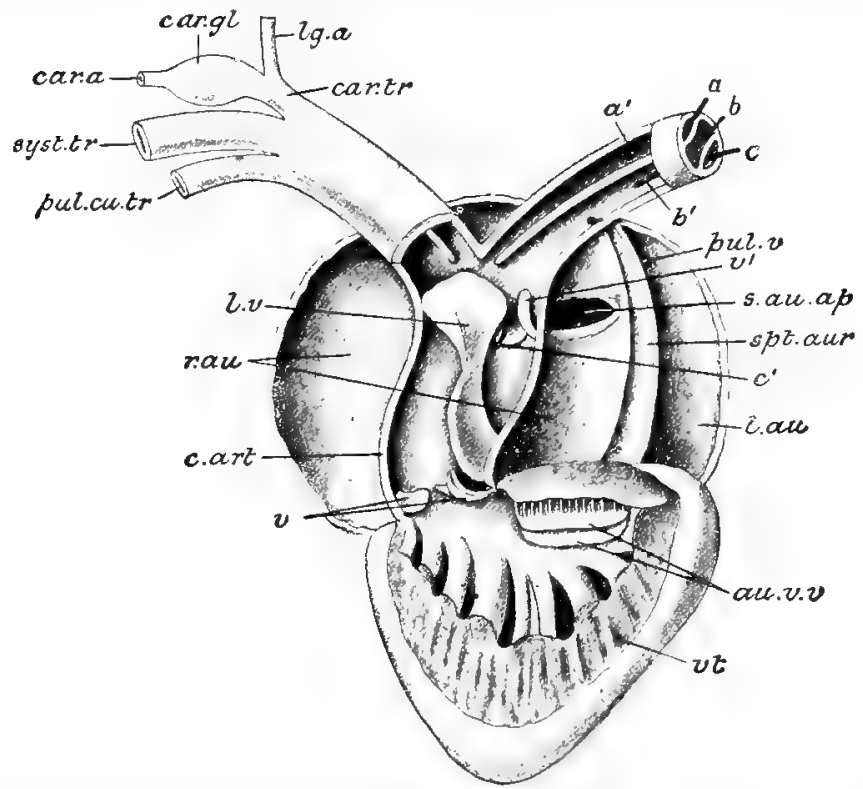

FIG. 314. - The heart of the frog with the carities lairl open. Blood enters from the venous sinus into the right auricle, r.au, at s.au.ap. The right auricle is completely separated from the left (l.au) by a partition (spt.aur). Both auricles open by the same aperture, guarded by two valves $(a u, v . v)$ into the ventricle, $v t$. The left auricle receires the pulmonary veins at pul.w. The exit of blood from the ventricle is guarded by valves at $v$, and its further path directed by a valye at $l . v$, into the right and left pulmonary arteries, pul.cu.tr, and $c, c, c^{\prime}$, into the arteries going to the general trunk, syst.tr and $b, b^{\prime}$, and into the arteries going to the head, cartr, with its carotid artery (car.a) and so-called gland $(c a r . g l)$; and with its tongue branch (lg.a).

of the trunk; finally the purest blood, which is the last to leave the ventricle, passes on to the last pair of vessels, which go to the brain, where it is most needed. The fact that the trunk 
receives mixed blood results first in a relatively low body temperature and, second, in slow chemical changes in the bodya sluggish life.

Organs of Excretion and Reproduction. - The two kidneys (Fig. $313, k d$ ) lie in the dorsal part of the body cavity. They

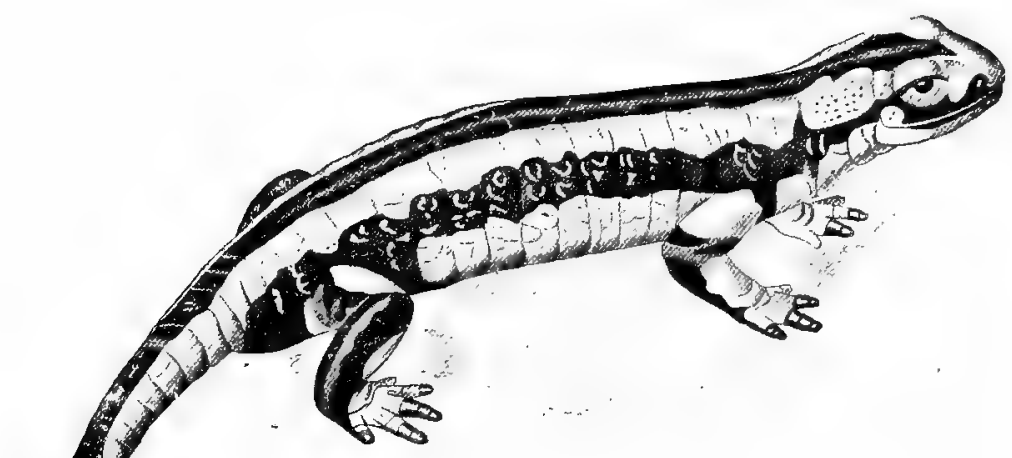

FIG. 315. - A urode, Salamandra maculosa, of Europe, showing external ringed condition of the body. After Cuvier.

consist of a mass of tuluules closely intertwined with blood-vessels that yield their waste products to the tubules from which they pass by the ureters to the cloaca.

The male germ glands ( $t . s$ ) lie at the anterior end of the kidneys and their products pass through certain tubules of the kidney and so, by way of the ureters, to the cloaca. Thus certain of the excretory tubules serve in the frog, as in annelids, to carry the germ cells to the exterior.

The ovaries of the frog are large sacs covering the kidneys. The ripe eggs fall from the ovary into the body cavity, are picked up by the oviducts which open into the body cavity, 
and are carried through them to the cloaca, receiving on their journey the jelly, which swells up enormously when the eggs enter the water at the time they are laid and while the sperm is making its way to the eggs.

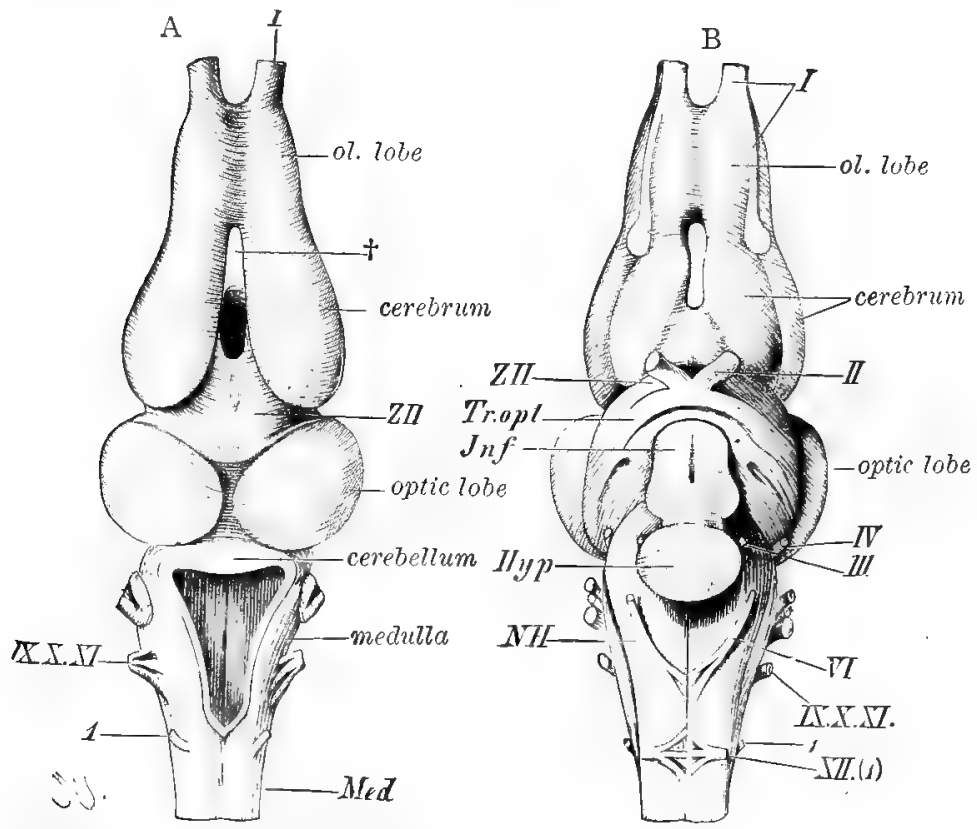

Fra. 316. - The hrain of the frog viewed from ahove (A) and below (B).

$I$, olfactory nerve going to olfactory lobe $(o l . l o b e)$. II, optie nerve going to Tr.opt, the optic tract of the brain. III, IV,VI, IX, X, XI, XII (1), other nerves to brain. $Z, H$, mid brain; $J n f$, infundibulum. Med, the medulla with its first nerve at 1. From Wiedersheim, "Comp. Anat."

The muscular system of the frog is reduced on account of its shortened body. In the tailed amphilians the ringed condition of the hody musculature is still evident (Fig. 315), but in the frog this appears only in the straight abdominal muscles. 


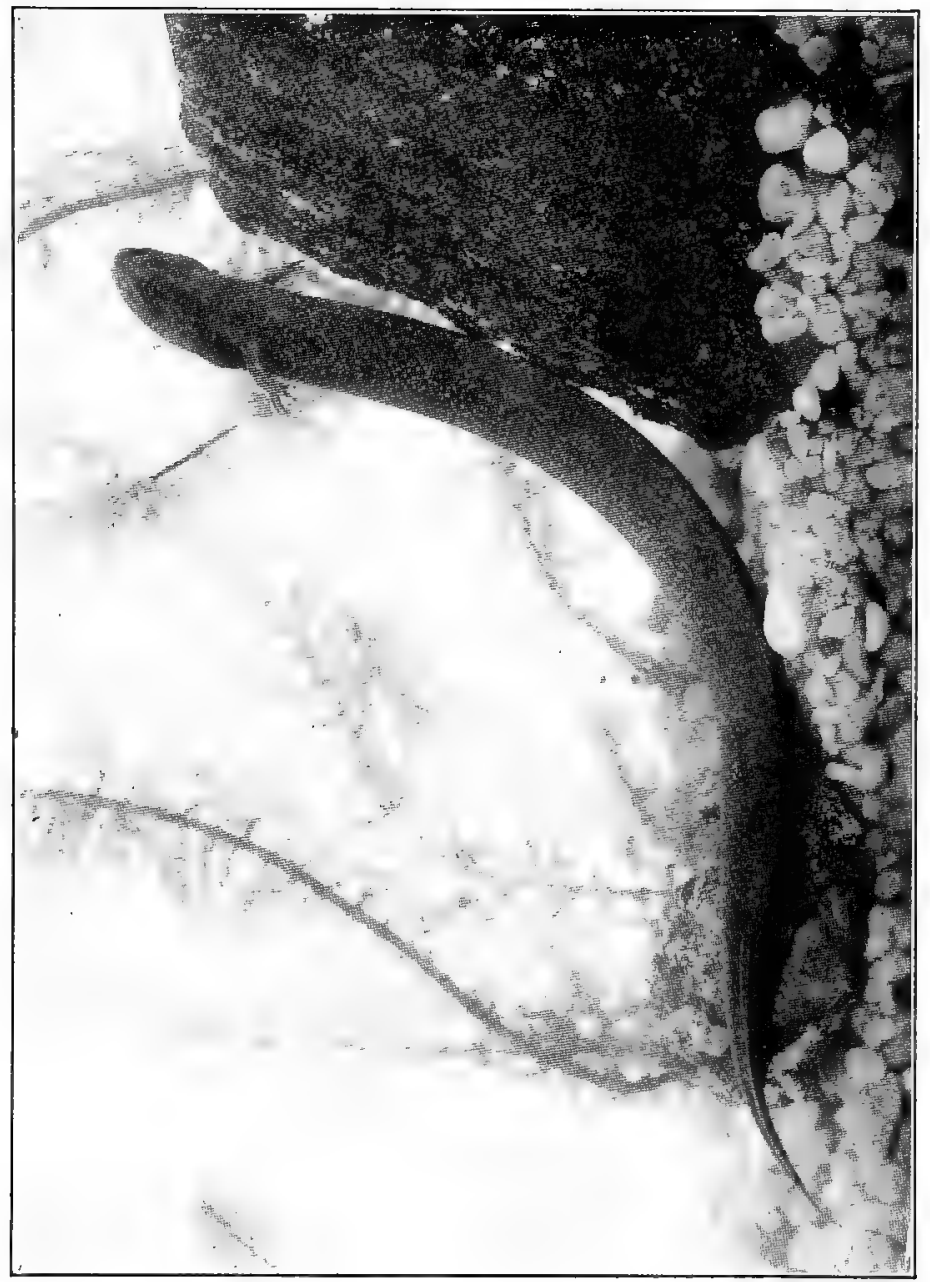

势 
The muscles of the breast and appendages offer special complications.

The nervous system shows an advance over that of fishes. The brain has two large lobes in front (olfactory lobes, ol.lobe), but the front part of the brain proper (cerebrum) and

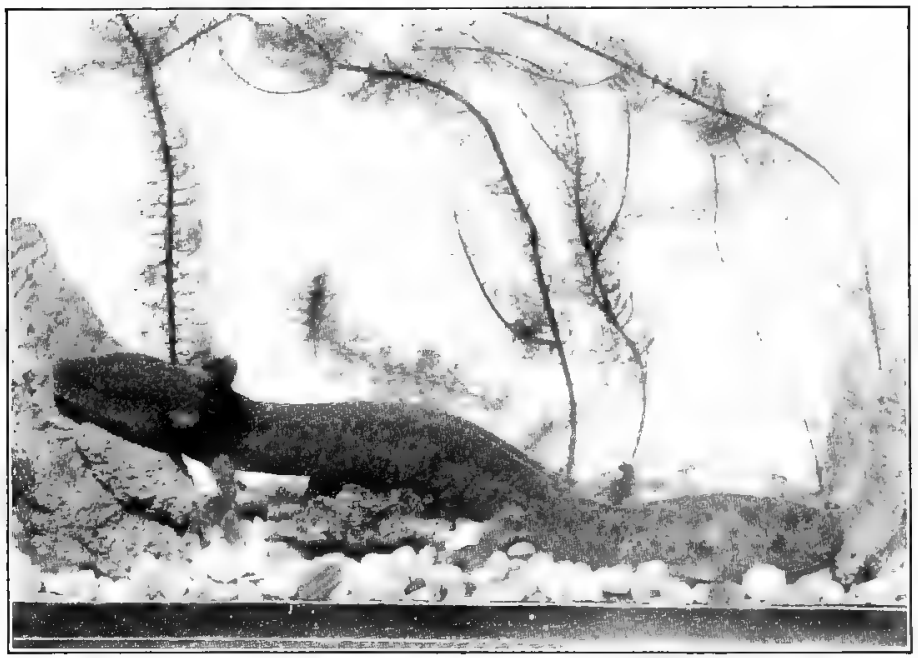

FIG. 318. - Mud-puppy (Necturus), photographed while living in an aquarium. From Report N. Y. Zoological Society.

the cerebellum are poorly developed. The spinal cord is shortened and modified on account of the shortening of the trunk.

Sense-organs. - The sense of smell is chiefly located in the nasal sacs, which open anteriorly to the exterior and posteriorly into the mouth. The eye is essentially like that of other vertebrates. The ear also consists of a central chamber and three semicircular canals. There is a large external membrane, and 
its vibrations are conveyed to the inner ear by a single rod instead of the flexible chain present in man.

Families of Urodela. - Of the American Urodela, ${ }^{1}$ the mud-eel, or Siren, of the Southern States has external gills and persistent gill-slits. This species becomes sixty centimetres long and snake-like, has lost its hind legs, and is of a dark lead color (Fig. 317). It is needlessly feared by the negro rice cultivators, who slaughter it in great numbers.

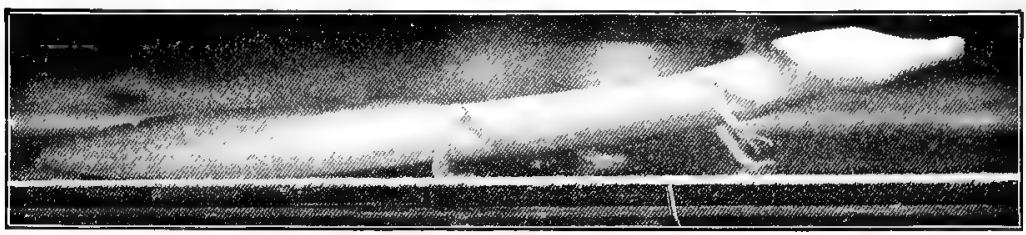

FIg. 318 a. - Typhlomolge, a blind, necturus-like salamander from the caves of Texas. Photo. from life. After W. W. Norman, from "The American Nituralist."

The mud-puppy (Necturus), frequently known also as waterdog, is found from the Hudson River to the Mississippi Valley, and is very abundant in the Great Lakes. Its external gills are very large, and red with the blood flowing in them. It feeds on small water animals. In April or May it lays eggs about the size of a pea. A curiously modified form of Necturus occurs in caves of North America (Fig. 318). Another member of this family is the cave "olm" of western Austria.

The Congo snake (Amphiumidx) is found in the Carolinas and Gulf States. This black, snake-like urodele is about a metre long, and lives in bayous and muddy ditches (Fig. 319). It has the entirely undeserved reputation of being injurious. 
The hellbender (Cryptobranchidæ ${ }^{1}$ ) inhahits the Ohio Valley and the South. ${ }^{2}$ It loses its gills before it becomes adult and the gills-slits close. It is a very voracious scavenger of the water, bites the hook fiercely, and is noted for its great tenacity of life under unfavorable conditions. The only other

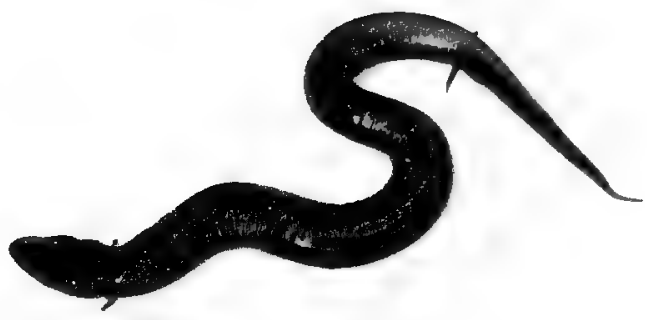

FIG. 319. - The "Congo snake" (Amphiuma means). From the Report N. Y. Zoological Society.

living representative of this family is the Japanese giant salamander, which becomes three metres long.

The salamanders (Amblystomidse ${ }^{3}$ ) include some twenty-five species belonging to five genera, four of which occur in northern and eastern Asia, and the fifth, Amblystoma, is confined to the United States and Mexico, except for one species that occurs in Siam. In this family the external gills are absorbed

1 kryptos, hidden; branchion, gill.

${ }^{2}$ Fig. 320 .

${ }^{3}$ From amblys, blunt; stoma, mouth. 
in early life. The common species of New England and the Central States is known as the Spotted Salamander. It is

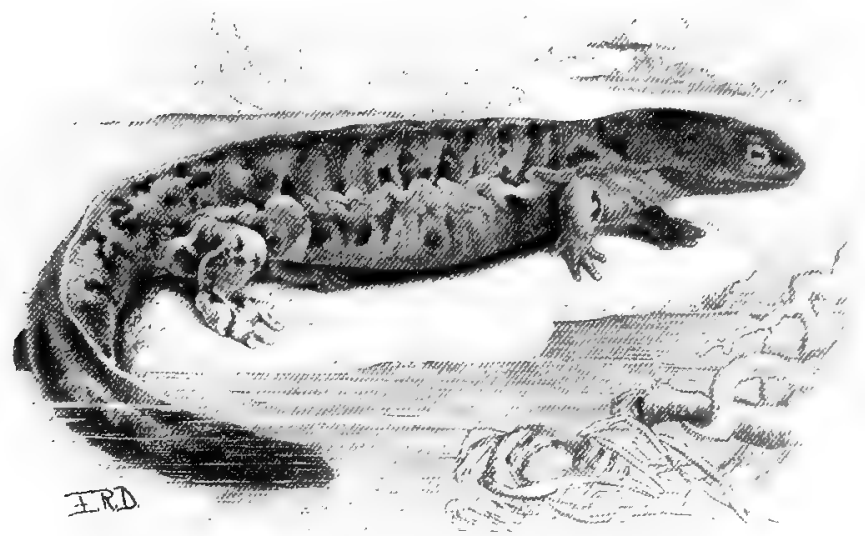

FIG. 320. - Cryptobranchus, the "hellbender." Reduced. From "Standard Natural History."

about 15 centimetres long, and black, with a series of yellow spots on each side of the back. It lays eggs in springs or ponds during April ; the dark gray eggs are contained in great masses of jelly which are attached to sticks at or near the surface of the

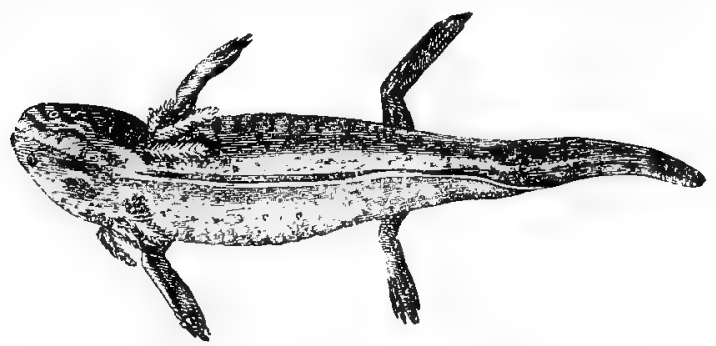

FIG. 321. - The larva of Amblystoma tigrinum. the Axolotl stage of the tiger salamander. From Mivart. 
water. The larvæ of the more southern species often reach a size considerably larger than the adult, and breed before the gills are absorbed. In a Mexican species the larval state is never passed. The larva of Amblystoma (Fig. 321) was formerly described, indeed, as a distinct species under the name of Axolotl.
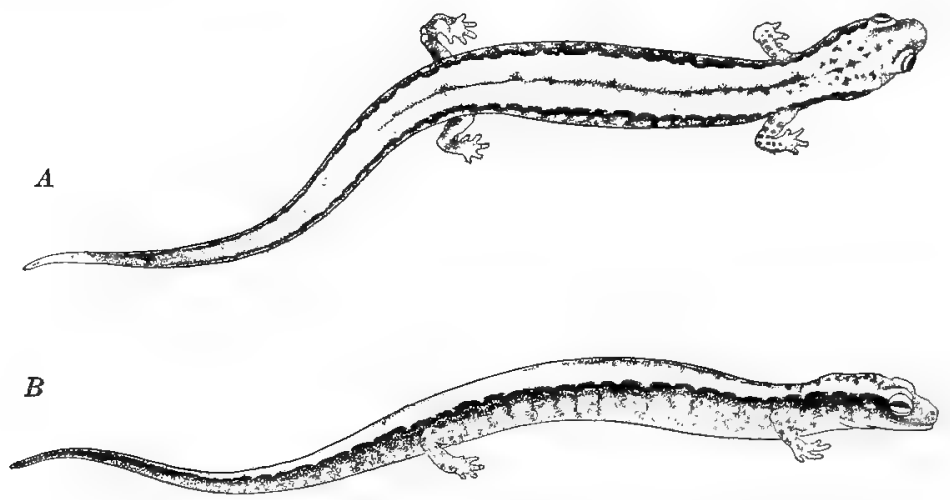

FIG. 322. - The red-backed salamander (Plethodon) : $A$, dorsal view ; $B$, lateral view. Nat. sizc, From life.

The newts ${ }^{1}$ (Plethodontidæ ${ }^{2}$ and Desmognathidæ ${ }^{3}$ ) include a number of small I'rodeles, having a close general resemblance and similar habits.

Plethodon, of the eastern Lnited States, is lead-colored above, very often with a broad, red dorsal band (Fig. 322). It is found under logs, and is very active. Spelerpes is lemon-yellow and white below, and Desmognathus is brown above, with gray or

1 Newts may be captured by sweeping with a net the muddy bottoms of small, spring-fed pools. They ean be kept for months in an aquarium, where they should be fed thrice a week with earthworms or freshly chopped beef.

${ }^{2}$ plethos, abundance; odontos, tooth.

3 desmos, bond; gnathos, jaw. 
purplish spots on the sides. Both Spelerpes and Desmognathus live in and about rumning brooks, under stones and fallen logs. Their eggs are attached to the under surface of submerged stones. The adults are easy to keep in confinement in a moist fernery. They may be obtained out of doors all the year round, excepting during the time of deep snow.

Metamorphosis. - As we have seen, all Amphibia have gills while young, but some lose them before maturity while others retain them permanently. Those species which retain the gills pass their whole life in water; the others may live on the land. The loss of gills is associated with the assumption of a land life. In the Amblystoma we have species which are curiously intermediate between the two classes in that they may retain their gills, tail-fins, and other structures adapted to aquatic life, ${ }^{1}$ even to the time of reproduction; or they may lose their gills and tail-fins. The first result follows if they are prevented from coming on land; the second, if they are forced to leave the water. The capacity of the Mexican Axolotl for either becoming an ardult or remaining a larva was first shown by some experiments of the German naturalist Weismann and a pupil of his. It will be seen that, when forced to live in the water, Axolotl retains permanently a larval condition; and one would never know that in this larval condition the animal is not adult were it not for the accident of its sometimes becoming adult. It is quite possible that all of the Urodela which retain their gills throughout life may formerly have had a gill-less adult stage which is now lost.

Early Development of Urodela. - The eggs of Urodela are deposited in a gelatinous mass in water, and are attached to submerged plants, or to other objects in the water, either singly 
or in masses, according to the species. The eggs contain much yolk; consequently the clearage is partial, and the embryo seems to develop on a small part only of the yolk, and for

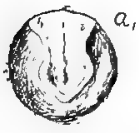

FIG. I.

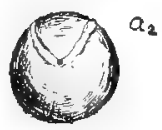

FIG.2.

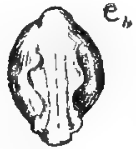

FIG. то.

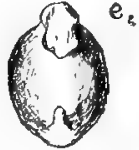

FIG. II,

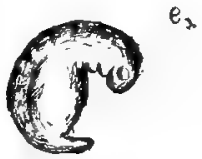

FIG, I2.

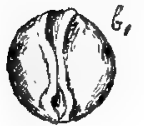

FIG. 3 .

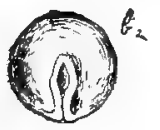

FIG. 4.

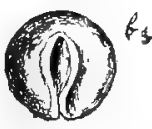

FIG. 5 .

FIG. 8.

FiG. 9.

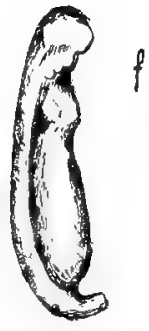

FIG. I3.
FIC. I4.

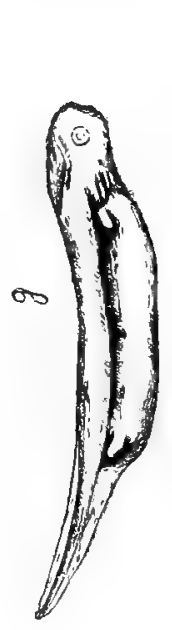

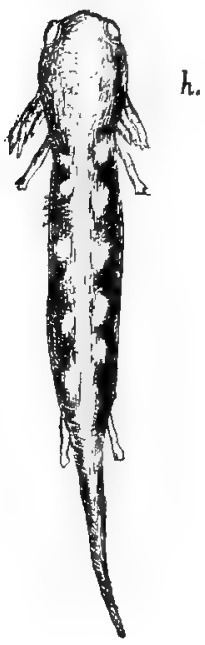

FIG. I5.

FIg. 323. - Developmental stages of Sprlerpes hitineatus. Figs. 1-5, neural
groove beginning to form; Figs. 0 , 7, neural groove closed; Figs. 8, 9, head l,eginning to form; Figs. 10-12, tail formed, yolk absorbing; Fig. 13, embryo capahle of moving in cgg membrane; Fig. 14, embryo just able to swim: Fig. 15, three day's after hatching. The letters indieate the successive stages. After H. H. Wilder, from "The American Naturalist."

some time after hatching the yolk mass hangs as a lump on the under side of the cmbryo. Very carly a rleep groove, bounded by a pair of folds, arises on the edge. This groove is large in 
front (Fig. $323 \mathrm{~b}$ ). It forms the beginning of the brain and spinal cord. The feathery gills and the beginnings of the appendages next sprout out, while the trunk continues to elongate and assume the form of a young salamander (Fig. $323 h$ ).

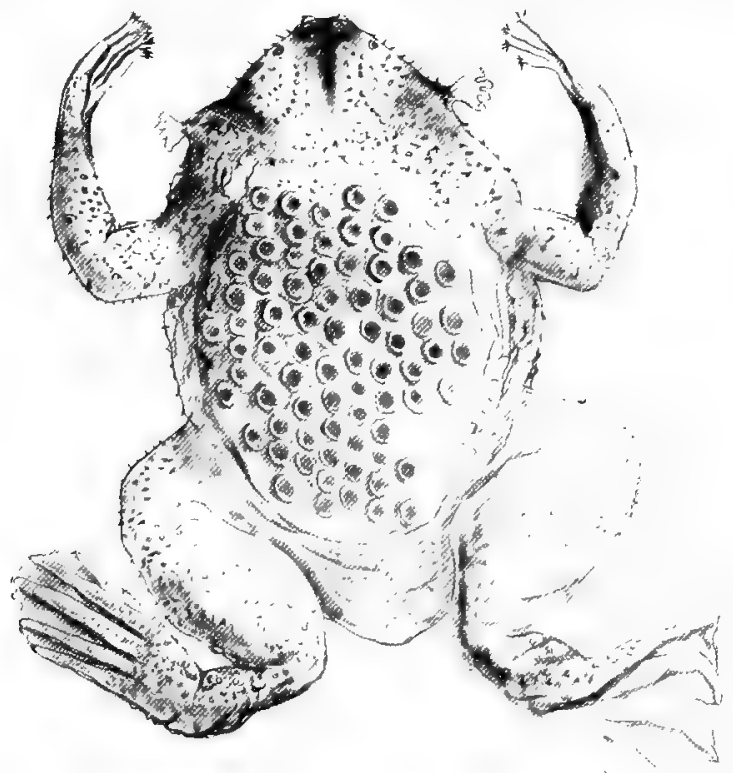

FIG. 324. - Pipa americana. Female with young in pits on its back.

Families of Anura. - - Of the Anura there are eight or ten times as many species as there are of the Urodela. They are distributed into nearly a score of families. Of these a few of the more interesting deserve to be mentioned.

The South American Pipa (Pipidæ) is noteworthy because of the habit which the female has of brooding its young in pits of the skin on its back (Figs. 324, 325). 
in two long, paralleI strings of albumen, which lie coiled at the bottoms of ponds, hatch out in May, and metamorphose ahout a month later.

The frogs (Ranidie) are almost confined to the Northern Hemisphere and the East Indies. In the northern United

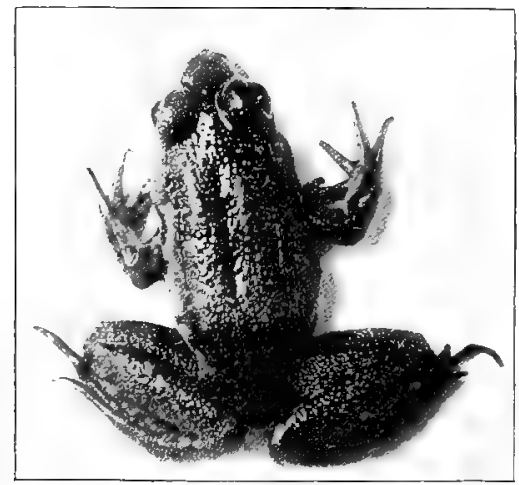

FIG. 328, - Green frog, Rana clamitans. Nat, size. Photo, of living animal by W. H. C.P.

States there are some eight species, of which the commonest are: the leopard-frog, of green color, with irregular black blotches edged with whitish; the pickerel-frog, light brown, with two rows of ollong square brown blotches on the back; the wood-frog, living in damp woods, pale reddlish brown, with a brown band on the side of the head; the green frog, of uniform bright green to hrown color, with numerous small dark spots, and with glandular folds (Fg. 328); and the bullfrog, of great size, green, with small, faint spots on the back. 


\section{CHAPTER XXIV}

\section{THE LIZARD: A STUDY OF DRYNESS LOVERS}

In spreading over the land, animals have come into situations where rain falls only for a small part of the year. In such places not only is the ground usually dry, but vegetation is sparse. Nevertheless, certain animals have come permanently to occupy even such desert situations, and, indeed, entire genera or families prefer desert habitats. They are the lovers of dryness. The animals most common in our own deserts are certain hard-shelled, black beetles, lizards of many kinds, ${ }^{\mathrm{I}}$ the little sphermophiles, looking like slender chipmunks, with now and then a rattlesnake. All of these animals and many others that live and feed on the ground burrow into the soil. There they remain during the heat of the day, coming forth at night to feed and seek their mates. These desert animals must go for weeks or even months without drinking water, such moisture as they can get being obtained from roots and green parts of succulent cacti. Almost always the skin of such animals is hard, preventing the loss of internal waters by evaporation. Indeed the whole hody of these animals seems to be very clry, and they need only a slight amount of water to live. Even in ordinarily moist climates there is a great deal of difference between animals in respect to their need and love of moisture. While many land animals are found in moist woods and under damp logs, or by the edges of lakes and 
swamps, others frequent dry country roads, sandy beaches, and the driest hilltops. Certain land-snails live by preference in sandy places and even in deserts. The tiger-beetles and some flies are characteristic of dry situations. One or two species of sowbugs are capable of living away from moisture, although their ancestors so recently left the water. Cer-

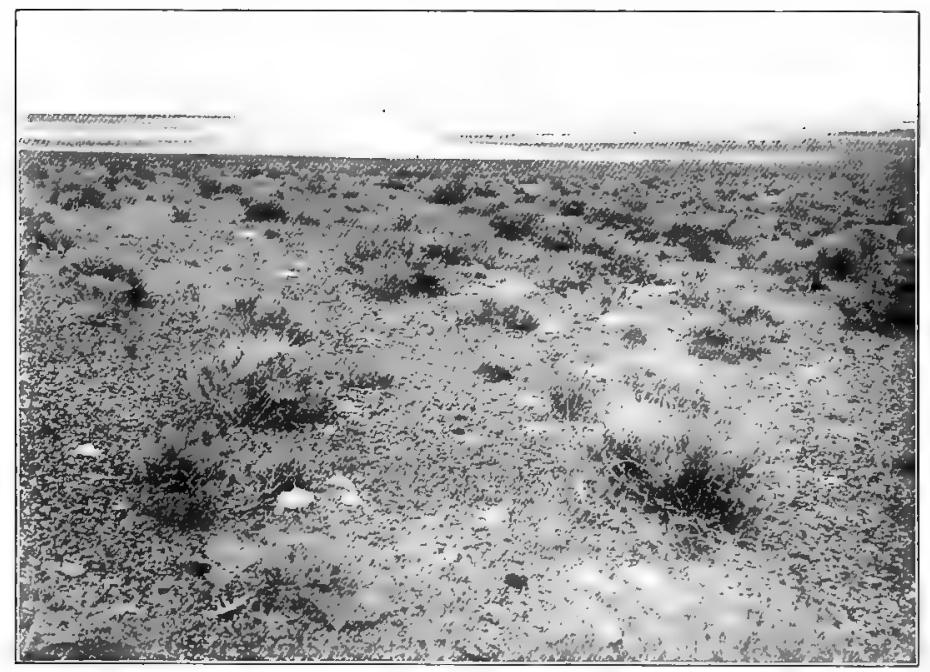

FIG. 329, - Home of lizards (scene in the Nevada desert). They rest on the stones, dart like streaks of light across the desert floor and into the "bunch grass."

tain birds shun the marshy places which their allies prefer. Field plovers and the Eskimo curlew belong to the waterfowl, but they live in the dry uplands. Animals that thus inhabit dry situations are there by preference because of their nature. They would find life in marshes not only distasteful, but probably incompatible with existence.

The reptiles, which are on the whole best represented in the 
desert, are vertebrates in whose skin horny or bony patches are formed. They constantly breathe by means of lungs, and lay large eggs provided with a tough, leathery, or calcareous

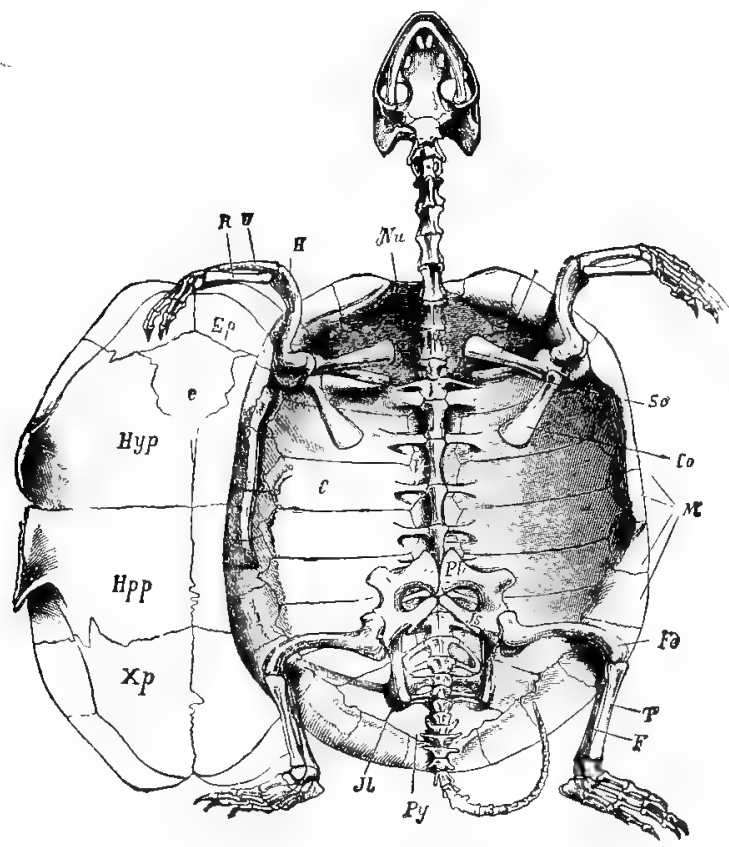

FIG. 330. - Skeleton of a turtle (Cistudo, of Europe), seen from below, the plaștron having been removed and placed at one side. $C$, rib-plate: $C o$, corocoid, a part of the shoulder girdle; $F$, fibula; $F e$, femur; $H$, humerus; $J l$, ilium; $I s$, ischium; $P u$, pubis; Pro, pro-coracoid; $R$, radius; $S c$, scapula; $T$, tibia; $U$, ulna; $e$, "entoplastron" or inner plate of plastron; $E p$, epiplastron or upper plate; $M$, marginal plates; $N u$, nuchal plate; $P y$, pygal plates. From Zittel.

shell. There are about thirty-five hundred species of living reptiles, which are grouped into four principal orders as follows :(1) Turtles, or Chelonia, (2) Lizards, or Sauria, (3) Serpents, or Ophidia, (4) Alligators, or Crocodilina. 
As an example of the structure of a reptile, we may consider the anatomy of the turtle.

General form of body. - The turtle is depressed and rounded, and the trunk carries an upper and a lower plate, affording protection to the entire body.

Skeleton. The vertebræ are few, in correspondence with the shortened body, and are immovalble upon each other (Fig. 330). The spines of the vertebræ are flattened out to form

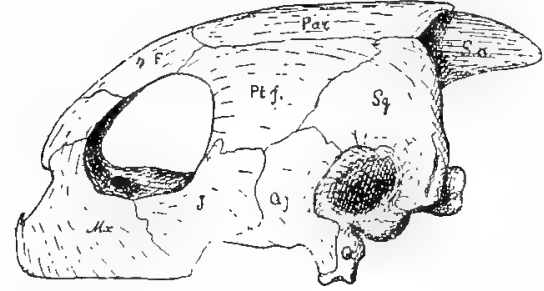

FIG. 331. - Skull of a turtle (Chelone) viewed from the left side. The bones shown are named from in front backward: $M x$, maxillary ; $F$, frontal; $J$, jugal ; $P t . f$, postfrontal; $Q j$, quadrato-jugal; $Q$, quadrate: Sq. squamosal ; Par, parietal; S.o, supraoccipital. Fron "Cambridge Nat. Hist." the median row of bony plates, and the ribs are flattened to form the "costal" plates. These, with certain plates at the margin, form the "carapace" of the turtle. The bony carapace is covered by horny plates which are derived from the skin, and only roughly agree with the bony plates lying below them. The breast-bone and ventral ribs are replaced by the "plastron," which is marle up of four paired and one median plate. The skull is massive, and the bones of the side of the head form a broad arch, enveloping and protecting, but separated by a space from, the lrain-case proper (Fig. 331). The shoulder and pelvie girdles are fused with the shell, but the skeleton of the appendages is typical, though often showing special adaptations for swimming.

The organs of nutrition. - The food of turtles is extremely varied, according to their habitats. Land tortoises eat toad- 
stools, fruits, and other vegetable matter. Water turtles eat worms, insects, frogs, and fishes. Some sea-turtles, like our green turtle, eat various algæ; others, like the tortoise-shell turtle, are carnivorous, living on fish and mollusks. The jaws are toothless, but are provided with a sharp cutting edge. The stomach and intestines are simple. The cloaca is large.

Organs of circulation. - The general features of the circulation are similar to those for birds described in the next chapter. But the heart, while showing an advance over amphibians, is far from showing the perfection of development found in birds and mammals. Venous blood from the body is received by the right auricle and poured into the ventricle. The ventricle is incompletely divided into a right and a left chamber by a perforated partition (Fig. 332, a). When the auricles contract, the blood

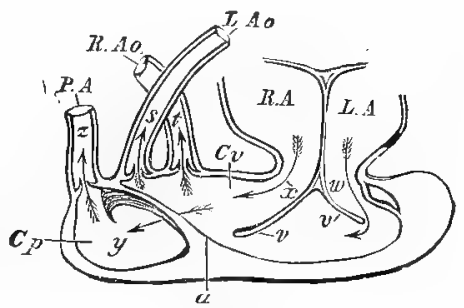

FIfr. 332, - Diagram of the heart of a turtle. Systemic hlood from the right auricle (R.A), passes by the course, $x$, through the opening at $y$ in the incomplete septum, $a$, into the chamber, $C D$; thence, on contraction of the ventricle to the pulmonary -artery $(P . A)$ by the path $z$. Blood from the lungs passes from the left auricle (L.A) through the passage $w$ (guarded hy the valve, $w$ ), into the larger chamber of the ventricle. On contraction, the opening $y$ being automatically closed, the blood goes by $s$ and $t$ to the left and right aortas, respectively, and so on to the body. After Huxley.

from the right auricle passes to the right side of the ventricle, called the pulmonary space $(C p)$, and the blood from the left auricle (pure and bright hecause having just come from the lungs) fills the rest of the ventricle. When the ventricle contracts, the imperfect partition $(a)$, cutting off the pulmonary space, becomes drawn tight across the ventricle. The blood in the pulmonary space goes to the lungs to become 
purified, and the pure blood in the ventricle, mingled with some venous blood, goes to the aortas $(R A o, L A o)$, and so on to the trunk and head. Thus, in the turtles, the body receives a little impure blood, and this fact results in keeping down the temperature of the body.

The organs of respiration are a pair of large lungs. These show a great advance over thase of the frog, since they are not mere sacs, but contain many lobules.

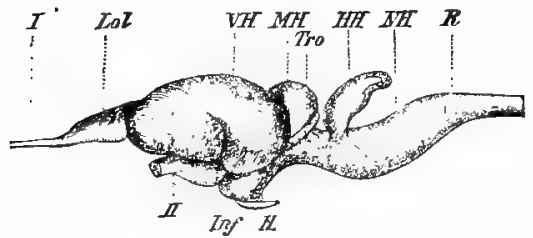

FIG. 333. - Side view of the brain of a turtle (Emys). I, olfactory nerve; $I I$, optic nerve; Lol, lobe of smell; $V H$, cerehral hemispheres; $M H$, optic lobes; Tro, "optic tract"; $H H$, cerchellum; $N H$, medulla; $R$, spinal cord; Inf, "infundibulum "terminating in the "hypophysis." From Wiedersheim, "Comp. Anat."

As the body is encased in an inflexible shell, the lungs cannot be filled by raising the ribs, as is the case with us, and so the turtle seems to depend largely upon the movements of its capacious throat to force air into or from the lungs. Certain water tortoises have great sacs opening from the cloaca, whose walls are filled with hlood-vessels, and which may be alternately filled with and emptied of water through the cloacal opening. The oxygen of the fresh water is absorbed by the blood-vessels in the wall of the sac. Thus these sacs are like gill chambers in some lower animals, and enable the turtles to breathe even while submerged. However, this device is only a temporary expedient and cannot long replace respiration by the lungs.

The organs of excretion and reproduction. - The kidneys are small and round, in marked contrast to those of amphibians, of which, indeed, they represent only the posterior portion. They are, on the other hand, like the kidneys of the 
higher vertebrates. The testes and ovaries lie dorsal, near the kidneys, and discharge their products by special tubes (not through the excretory tubules) into the cloaca. The eggs are provided with a hard egg-shell and, in most pond and river species, are laid in the spring in sandy soil at a depth of 30 to 80 centimetres.

The muscular system of turtles is (in correspondence with the round, bone-encased body) much reduced, except in the neck and appendages, which are capalble of varied and extraordinarily rapid movements.

The nervous system shows, at least so far as the brain goes, a decided advance over amphibians. The lobes of smell are reduced in size, and the cerebral hemispheres are well developed (Fig. 333). Also the cerebellum attains a fair size, indicating increasing power of correlated movements.

The sense-organs are well developed. Turtles are very sensitive to touch, even on the shell. They discriminate between various sorts of closely related plants, showing a welldeveloped sense of taste and smell. The ear shows no great advance over that of Amphibia. The eye is protected by a ring of bony plates in the sclerotic coat. In addition to two eyelids there is a membrane - the nictating membrane - that can be rapidly drawn across the front of the eyeball; this we shall see also in birds. It probably serves to cleanse the front of the eye and perhaps to regulate the amount of light entering the eye. Although not present in turtles, mention must be here made of a third eye looking out from the middle of the skull, and called the pineal eye. This eye is functional in some lizards (Fig. 334). In our own brains there is a rudimentary organ having the same relative position, and which has long been known as the pineal gland. This organ 
was once regarded by a philosopher as the seat of the soul, on the ground that the soul is a unit and that the pineal gland

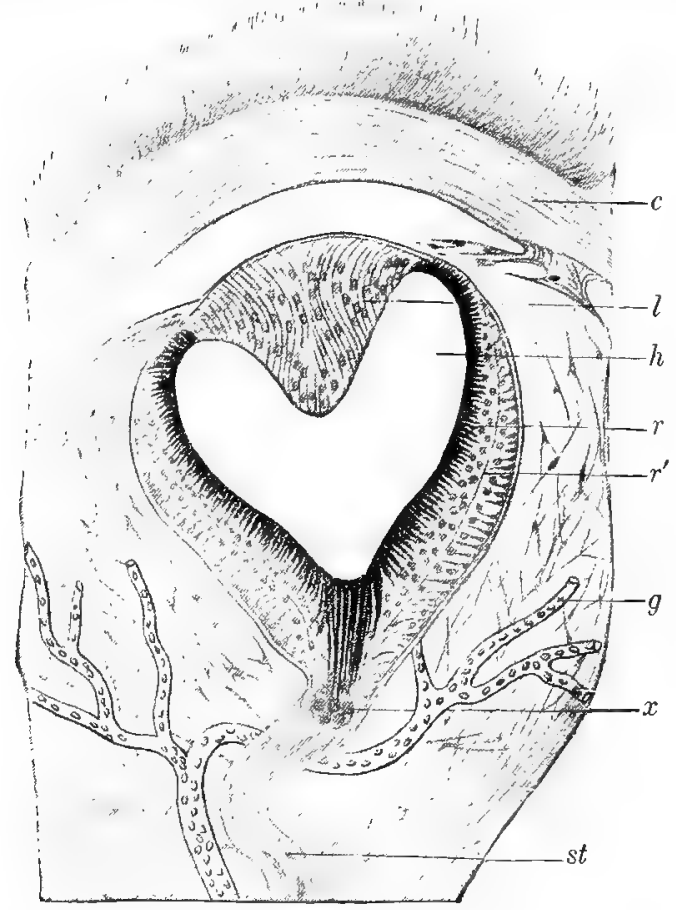

FIG. 334. - Section of the pineal eye of a lizard (Hatteria) : $c$, cornea;

$l$, lens; $h$, carity of eyeball; $r, r^{\prime}$, retina; $x$, cells in stalk; st, stalk; $g$, blond-vessels. After Spencer.

is unpaired. We now know that it is the rudiment of a once functional eye.

The lizards (Sauria) constitute a large order characteristic of the tropical and subtropical countries, and reaching the maximum of its development in South America, while in the 
northern continents it is relatively poorly represented. Most lizards have an elongated body, four legs, eyelids, and a breastbone or sternum. Lizards are, as a rule, carnivorous, and since they destroy insects injurious to vegetation they may be considered as beneficial to man.

Most of our lizards belong to the family Iguan'idæ, ${ }^{1}$ a family that is most abundant in the Westem Hemisphere. They are known by the thick tongue, by a large scale in the

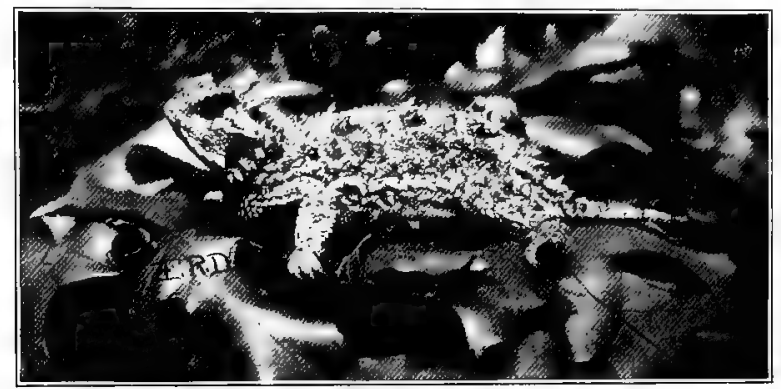

FIG. 335. - Phrynosoma, the horned toad. Photo. hy E. R. D.

middle of the head in front of the eyes, and by the fact that all four legs are well developed. The genus Anolis, known as the American chameleon, contains eighty tropical species. Our species lives in pine woods from the latitude of Tennessee south to the Gulf and the island of Cuba. Its graceful form and bright colors make it one of the most beautiful of lizards. It lives on trees, eats insects, is not timid, can live well in confinement, and, like the chameleon of Europe, has the power of changing its colors from bright green to dirty brown. Besides Anolis, we have various other lizards of the family Iguanidæ. The horned toad of the Southwest, which has a broad, flattened

${ }^{1}$ Native name. 
body and long spines on the head, and lives in dry, sandy places, is a familiar object. ${ }^{1}$ In the South Central and Southern States lives the elongated "swift," of varying color, often with black, irregular cross hands above, with iridescent colors on the throat of the male, and with large, strongly keeled scales

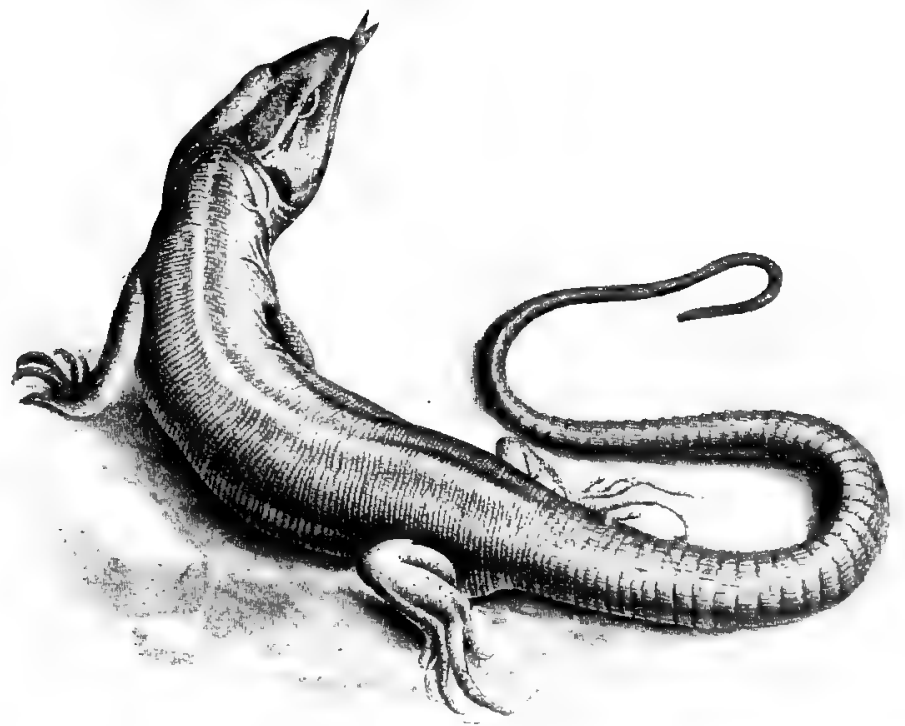

FIG. 336. - Lacerta viridis, the green lizard of Europe. After Brehm.

and a slender tail. The largest of the Iguanidx is the "leguan" of the West Indies and South America, which gains a length of 1.75 metres, or over five feet.

The family of water-lizards, or Varan'idæ, ${ }^{2}$ contains the largest known lizards. The Nile varanus attains a length of nearly two metres. It lives in the rivers of Africa, feeds on small crustaceans, birds, birds' eggs, frogs, fish, and occasion-

${ }^{1}$ Fig. 335. $\quad{ }^{2}$ Latinized from the Arabic word waran, lizard. 
ally also on young crocodiles and crocodile eggs. The ancient Egyptians regarded these crocodile-like lizards as the greatest enemies of the crocodile.

The common lizards (Lacertidæ ${ }^{1}$ ) of middle and southern Europe are agile, harmless creatures, often of bright colors, and are commonly and favorably known. The more abun-

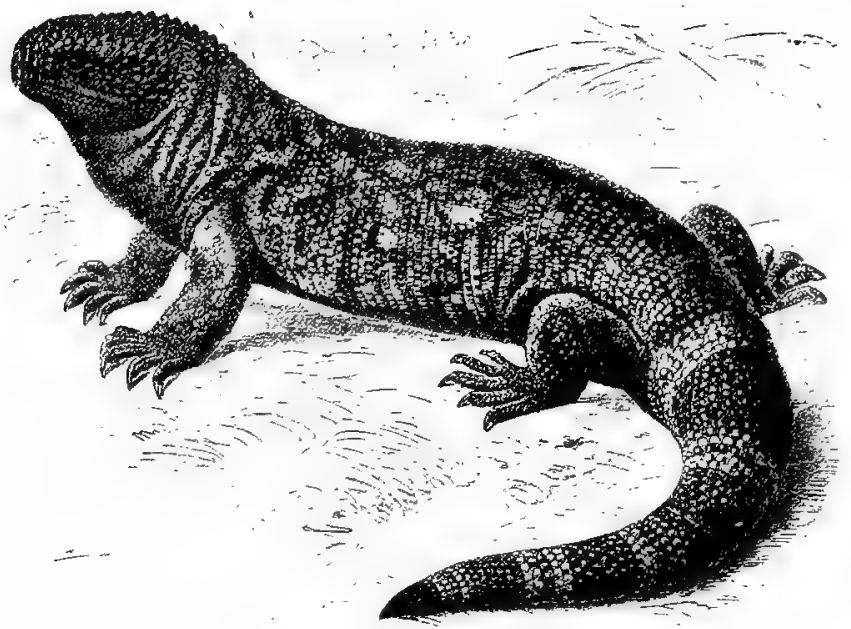

FIG. 337, - Heloderma, the Gila monster. About two-fifths nat. size. From Brehm.

dant are the "green lizard" (Fig. 336), the "sand-lizard," and the "wall-lizard" of the Latin countries.

The Gila monster (Helodermidæ) is the largest lizard of the United States. It inhabits New Mexico, Arizona, and the country southward. The lizard is colored brown, with reddish spots and numerous yellowish punctations (Fig. 337). It is nocturnal in its habits, and its bite is very poisonous, although rarely fatal to man.

1 From lacerta, lizard. 
The family of slow-worms includes the famous glass-snake, or joint-snake, of the South. This snake-like lizard has no legs, or only rudiments of the hinder pair. It is noted for the ease with which it breaks in two when struck or lifted by the tail. This result is due to the fact that, as in certain other lizards, the vertebræ of the tail are unossified along the middle plane, so that they separate at this point upon the slightest blow. The muscles of this species seem also to be arranged

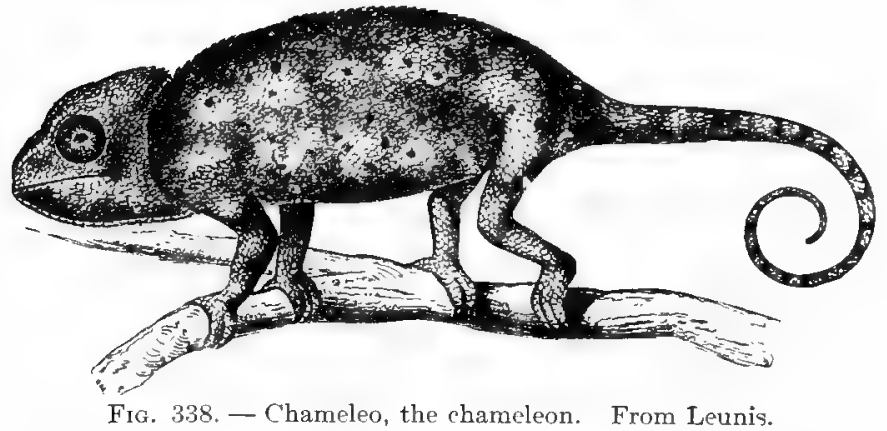

so as to facilitate separation. In Europe there is a lizard of this family, the so-called "blindworm" (having, however, well-developed eyes), which is found in retired localities, from which it comes out, especially in the evening, to capture earthworms and slugs.

The Chameleon, famed in literature, comes from Africa. Its change of color depends upon the possession of several layers of different color in the skin, which can be separately expanded or contracted as required, in consequence of which sometimes one, sometimes another, color comes to predominate. It captures insects, a habit which is facilitated by its power of protruding the tongue to over half the length of its 
body and bringing the sticky end in contact with its prey. The protrusions and retractions of the tongue take place with marvellous rapidity (Fig. 338).

While in point of size the lizards of geologically recent times are inconsiderable, those of former epochs were huge. These

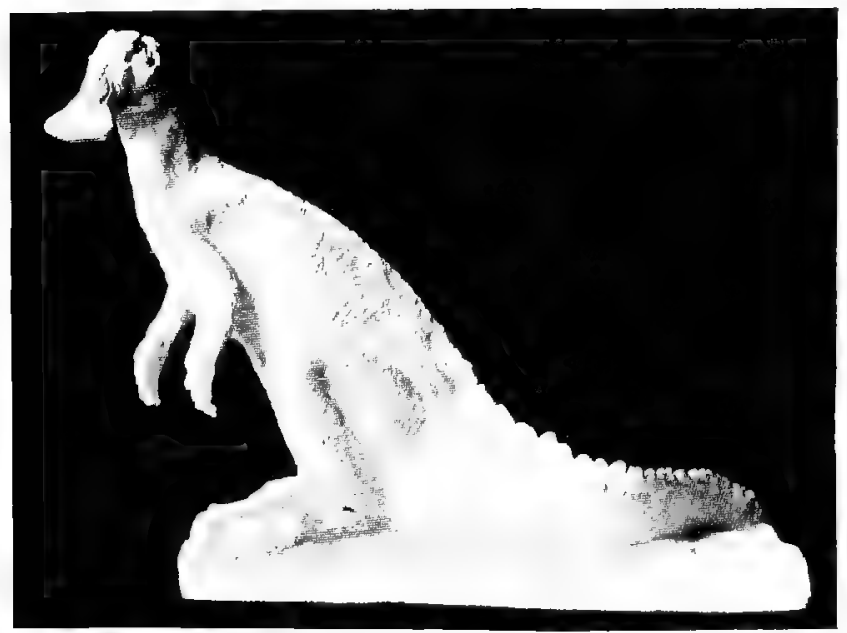

FIG. 339. - Hadrosaurus. From reconstruction model. Oshorn, "Rept. Amer. Mus. Nat. Hist."

former or fossil lizards were most characteristic of the middle life era or the Mesozoic age. They belong to three main groups; namely, swimming, walking or wading, ${ }^{1}$ and flying lizards. The swimming lizards were sometimes over 10 metres long, and had feet modified as paddles. The land lirards were elongated, three-toed, carnivorous reptiles, with hollow leg bones like birds. In the flying lizards a strong, compact body was provided with hollow, air-filled bones, and locomo- 
tion was effected by a huge membranous expanse stretched between the elongated posterior finger, the trunk, and the hind legs. The spread of the wing was about three feet.

The turtles, or Chelo'nia, ${ }^{1}$ form an order distinct from the lizards. They are characterized by a depressed form, a bony case, and toothless jaws. Like other reptiles, they are most abundant in tropical countries, since the high external tem-

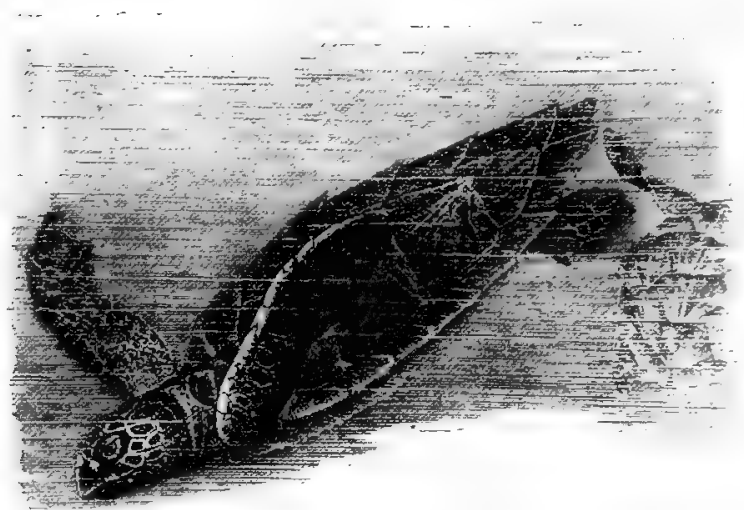

FIG. 340. - Hawkbill-turtle. Much reduced. From Brehm.

perature compensates in a way for the insufficiency of the mechanism for maintaining from the inside a high blood temperature. Turtles are abundant in Africa, and are much commoner in North America than in Europe. Three principal families of Chelonia may be distinguished. A short account of each follows.

The family of marine turtles includes certain turtles that live in all oceans, and may acquire a weight of as much as one thousand pounds. The green turtle, used in making soup,

${ }^{1}$ Chelōne, turtle. 
occurs on the Atlantic coast as far north as Long Island. From the hawkbill turtle (Fig. 340) comes the tortoise-shell used in certain ornaments. In the "leatherback" the shields are incompletely ossified.

The family of soft-shelled turtles includes certain turtles that live in rivers or ponds of the Mississippi Valley and the Gulf drainage basin (Fig. 341). They have a flat, rounded shell, the feet are broadly webbed, and the neck is long. Although the ancestors of turtles were without the hard shell, it seems probable from the whole structure of the upper and lower plates that the softshelled turtles are not ancestral, but of recent origin, and have recently lost the hard shell of their ancestors.

The family of fresh-water and land tortoises is known as Testudinidæ. ${ }^{1}$

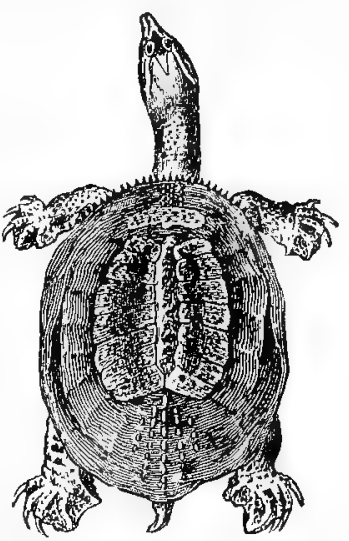
Our snapping-turtle is distributed Fig. 341. - Trionyx, threefrom Canada to equatorial South America. It feeds on fish, and lays clawed turtle of the Mississippi Valley. Reduced. From Leunis.

from forty to fifty eggs, which it buries at a depth of about a metre (Fig. 342). The alligator snapper of the Gulf States attains the length of a metre, and is regarded as the "most ferocious and, for its size, the strongest of reptiles." The box-tortoises occupy the northeastern and central parts of North America. They are well known by the fact that the body is short and high, the plastron is provided with a movable hinge, and the carapace is colored black and yellow. ${ }^{2}$
${ }_{1}^{1}$ From testa, a shell.
2 Fig. 343. 


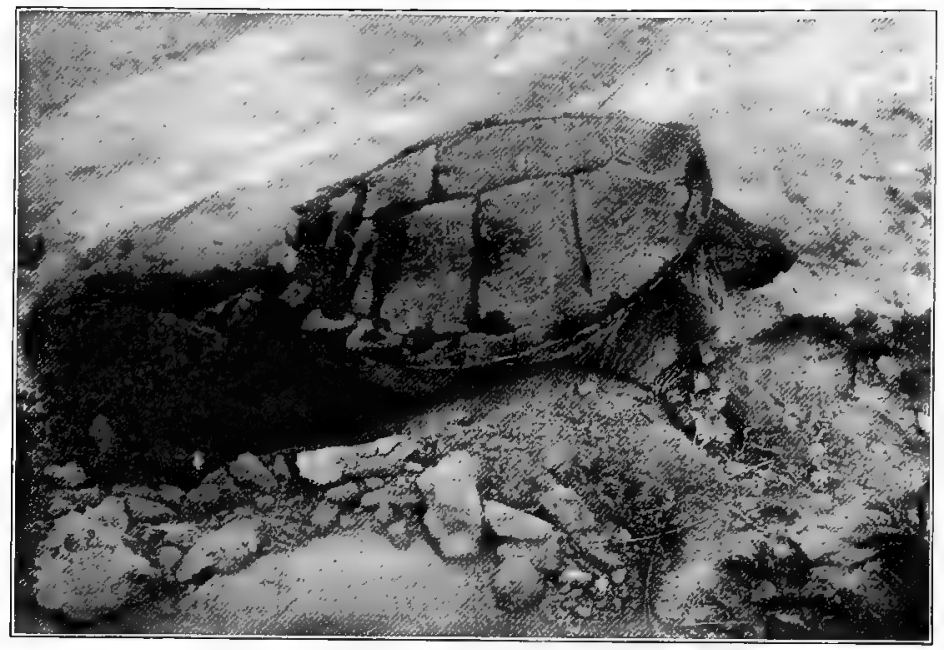

Fig. 342. - A snapping-turtle in the act of digging a nest.

Other common tortoises of the eastern United States are the muskturtle, told by a strong odor of musk; the painted turtle, of greenish black color and with marginal plates marked with bright red;

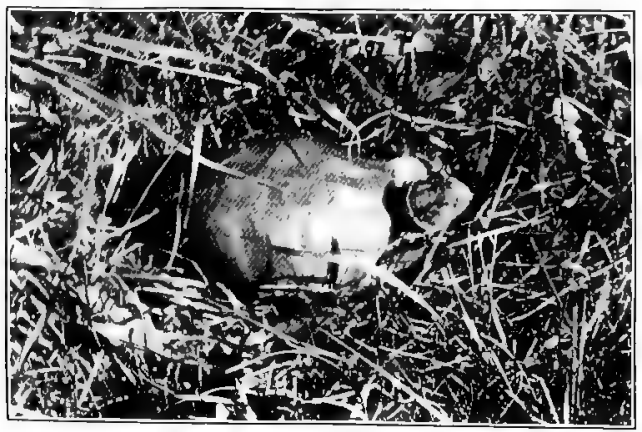

FIG. 343. - Terrapene carolina, the box-tortoise. Photo. of living animal by W. H. C. P. 
the speckled tortoise, black with round orange spots; and the wood tortoise, with keeled shell, and plates marked with concentric striæ.

The order of snakes, or Ophi'dia, ${ }^{1}$ is characterized by the elongated body without appendages, and by the absence of eyelids and sternum. Like other reptiles, the snakes are chiefly tropical, but inhabit also the temperate zones. They feed on living animals. Hidden in the muscles of certain kinds of

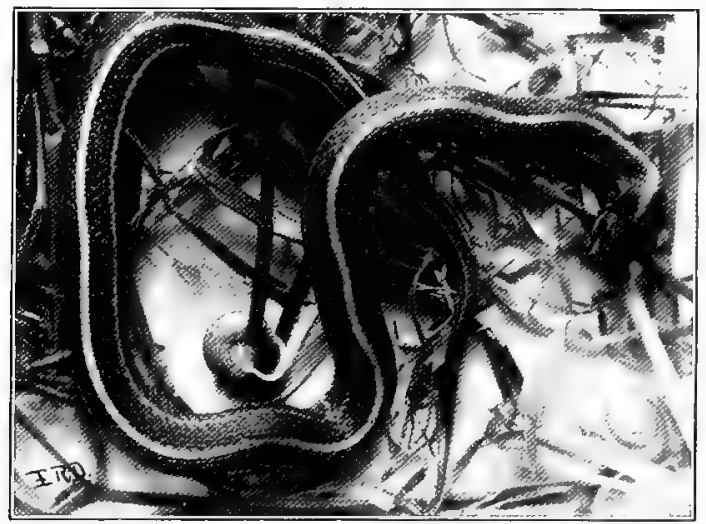

FIG. 344. - Eutænia, garter-snake, dorsal view. Photo. by E. R. D.

snakes, rudimentary appendages are found, so we may conclude that the ancestors of the snakes had legs. It is because snakes are without legs that they travel so well through thickly matted vegetation.

The family Colubridæ ${ }^{2}$ includes the great majority of our common non-venomous snakes, such as the garter-snake, ${ }^{3}$ water snake, black snake, milk snake, and spreading adder. Allied are the boas of South America and the pythons of India, which attain a length of six metres or more. Not being poison-

1 ophis, serpent.

${ }^{2}$ colubra, serpent.

${ }^{3}$ Fig. 344. 
ous, their bite is not dangerous, but they attack large birds and even medium-sized mammals, and crush them to death in the folds of their body.

The family Elapidæ includes the large, venomous serpents of the East, the cobra of the East Indies, and the asp of the

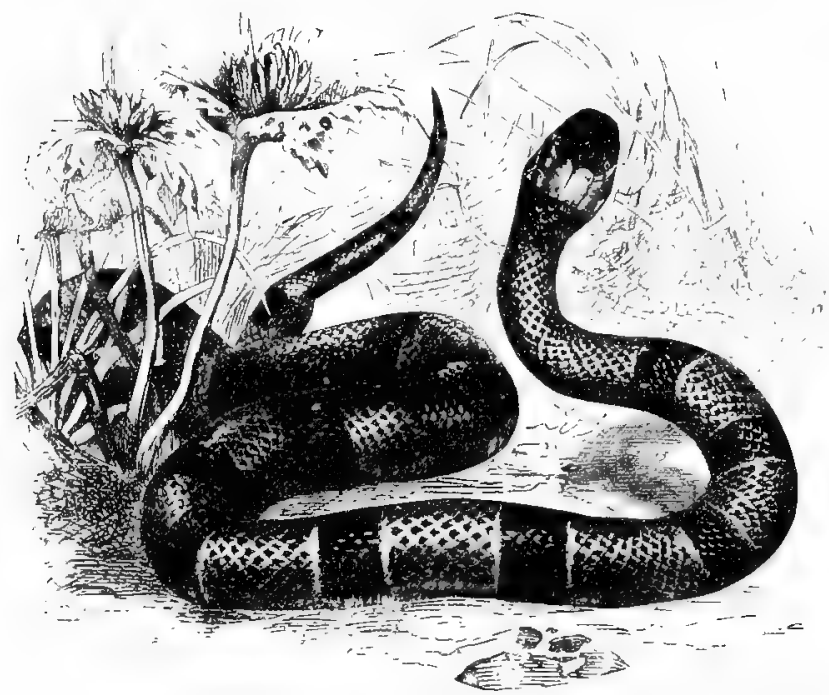

FIG. 345. - Elaps corallina, a harlequin snake of South America allied to the bead-snake of the South. From "Standard Natural History," after Brehm.

Egyptians. The bite of these serpents is quickly fatal to man. To this family belongs also the bead-snake of our Southern States, which is, however, harmless (Fig. 345).

The Crotalidæ ${ }^{1}$ include the rattlesnakes, characteristic of America. ${ }^{2}$ Of this family the most dangerous is the water moccasin, or black moceasin, which inhahits the Southern 


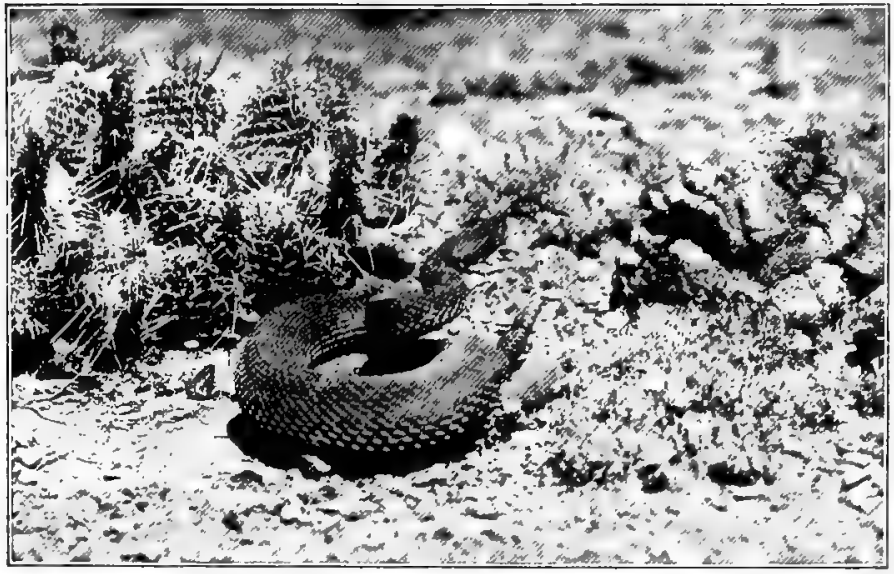

FIG. 346. - Crotalus, the rattlesnake. Photographed as the snake was about to strike. Taken in Wyoming and kindly lent by $H$. W. Menke.

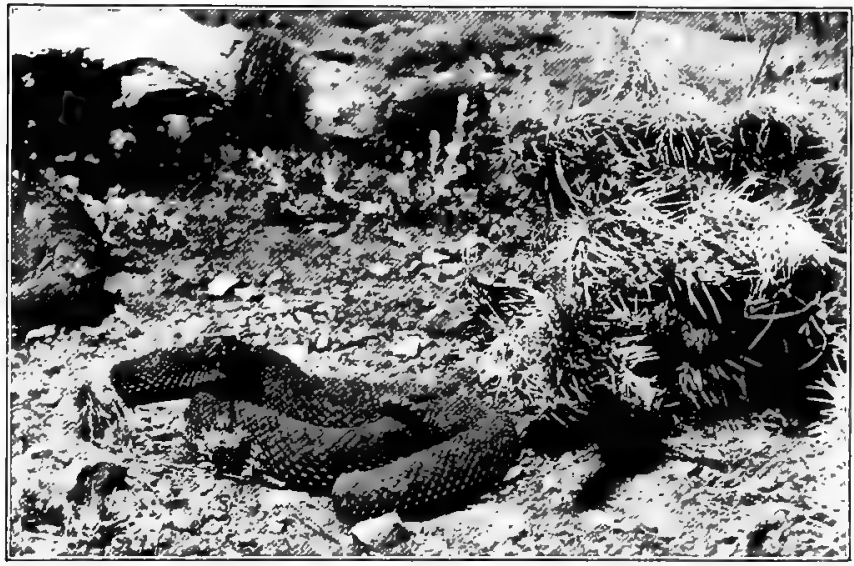

FrG. 347. - The rattlesnake. The recoil after striking. Photographed in Wyoming and kindly lent by $H$. W. Menke.

Note in both figures the elevated rattle, toward the right. 
States, and gives no warning noise as does the rattlesnake. The copperhead of the eastern half of the United States is also dangerous, but is mostly confined to wooded, mountainous regions. The rattlesnake was once common over the whole

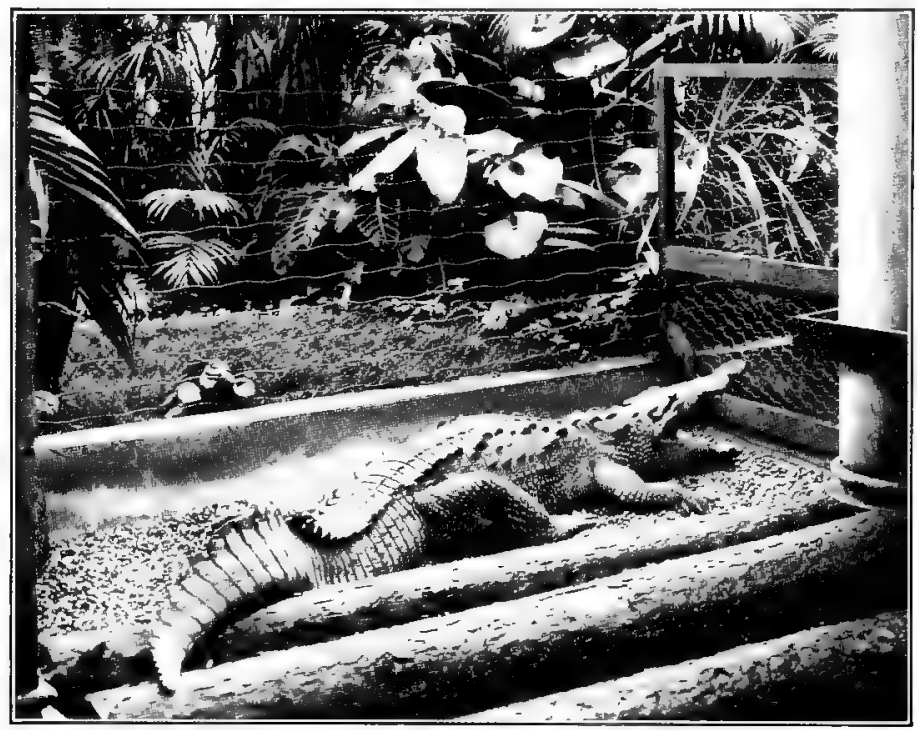

FIG. 348. - Florida crocodile. (Courtesy of the New York Zoological Park.)

of the Northern States as far west as the Rocky Mountains, but it is now nearly exterminated in well-settled districts. Related to these are the venomous vipers of Europe.

The order of crocodiles, or Crocodilina, contains only some twenty living species, distributed in three genera. The gavial is the crocodile of the Ganges River. It captures even large mammals and man. The crocodile in the strict sense is found in the Nile and other African rivers, in certain 
countries on the western border of the Pacific, and in northern South America, Central America, and the Antilles. Of the alligators, which have a different arrangement of the dentition from the crocodiles, there are seven slightly differing species, all of which are South American, excepting a Chinese species and the alligator of our Southern States. The latter feeds on fish, and attacks larger animals (Fig. 348). 


\section{CHAPTER XXV}

\section{THE ENGLISH SPARROW: A STUDY OF BIRDS AND MIGRATIONS}

Most animals, unlike most plants, are free to travel about in search of food and mates. Thus every morning in winter the crows can be seen flying from their rookery in the forest to distant fields where some grain still remains. At low tide along the seashore many of them come to pick up clams. At night they all fly hack again to their rookery. When a family has been raised, the young move away from their birthplace to seek feeding-grounds, mates, and homes of their own. Usually this dispersal is so gradual that it is not observed; but in certain mammals the young of a season may swarm from their native home and traverse the country like an army. This is the case with the widely known lemmings of Scandinavia. The importance of their march has been much exaggerated, for the migration has been noticed only a few times. The numbers involved in these migrations, however, were great. The lemmings travelled far; some did not stop even when they reached the sea, but plunged into it and were drowned. Their behavior well illustrates the blindness of the impulse that drives them from home.

Even man migrates when his native country becomes overcrowled and there are attractive prospects in other lands. History records the migrations in ancient times of men from central $A$ sia into Furope, and one may witness any day at the 
port of New York the incoming of hundreds of immigrants allured by the prospects of freedom from military service, excessive taxation, and oppression in various forms. To-day, with improved facilities for travelling across continents and oceans, the human tide moves back and forth more freely than ever before.

In temperate climates the change of seasons leads certain animals to migrate towards the equator during the winter and to return towards the poles in summer. It has been suggested that the animals were first driven southward by the glacier, a vast ice-cap that reached in North America from the pole southward to a line extending from New York City to southern Ohio, thence to near Chicago and on, southwestward, over the Great Plains to the Rocky Mountain region. When the glacier retreated northward again, the animals that had been forced south made their way back to the homes of their ancestors. But many of them returned to the south again on the approach of each winter's cold. For example, the Bison, which formerly lived in countless thousands on the Great Plains, migrated south with the sun, and thus kept in verdant pastures, and similarly to-day scores of species of birds migrate in the spring and autumn.

The Migration of Birds. - In respect to their migratory habits all birds are divided into four classes. The examples that follow are all taken from the latitude of New York City and Chicago.

1. Residents. These do not migrate, or migrate so short a distance that those individuals that nest in the northern part of the range do not move below the southern limit of the summer range of the species. Examples: the blue jay and song sparrow. 
2. Winter residents. This class includes those species that summer to the north and winter only less far north. Examples: white-throated sparrow and junco or snowhird.

3. Summer residents of any place comprise those species that nest at the place and winter southward. Examples: song-thrush, boholink.

4. Transients. These are species that pause at a place only while passing from their nesting-place in the North to their winter home in the South, or which tarry a few days on their northward journey. Examples: great blue heron, foxsparrow, black-poll warbler.

Migration Routes. - The nesting area of any of the migratory species has the form of a band extending east and west a certain clistance along the continent. From this zone during the fall migrating period the hirds move southward along the meridians, and as they do so the lines of migration gradually converge, corresponding to the narrowing of the continent. Consequently, there is a crowding along certain lines, such as the seashore and river-courses. Thus the birds that follow down the streams of the Middle West become concentrated into a narrow migration route when they all reach the lowlands of the Mississippi River. Some species pass south of the southern boundary of the United States, and a number even reach the mainland of South America. Thus the redstart, one of the commonest of our "wood-warblers," reaches Colombia, Venezuela, British Guiana, and Ecuador. In passing from southeastern United States to South America, hirds take various routes. Some go by the Antilles, and others fly across the Gulf of Mexico to Yucatan. The Antillan route has two main paths, one by the Bahamas and one by Cuba. 
To get a conerete iclea of the migration of a particular species let us consider in detail the movements of the redstart. This species breeds from the Gulf of St. Lawrence to British Columbia. Its northern limit in the summer is northern Canada, its southern is North Carolina. It winters in the Greater and Lesser Antilles and along the northern shore of South America. About March 20 the redstarts reach southern Florida, having come from Cuba. The van of the migrating hosts arrive, on the average, successively at Ralcigh, North Carolina, April 10; Washington, District of Columl ia, April 2:3; New York City, May 4; and Montreal, May 16. They move westward from Florida as well as north. They reach St. Louis, April 17; Chicago, May 8; Minitoba, May 14, and Athahasca, May 23. Kansas City is reached about May 5, and British Columbia early in June. By the middle of August the Canardian birds begin to migrate southward, the last being scen at Athahasea, August 14; Manitoba, September 20; Chicago, October 5; New Orleans, October 27, and southern Florida, November 4. Every year this broad red veil of bird life floats slowly northward, in April and May, and is drawn back to the tropies in September and October. Other species of birds move similarly, but with great variation in speed and distribution in their summer range.

The peculiar charm of the study of bird migration is due to the fact that the return of the birds after a long winter heralds the coming of spring. We hail with delight the return of the blackbird and robin. The successive weeks show a constantly increasing number of new arrivals. At the latitude of New York and Chicago the phœbe, field-sparrow, chipping-sparrow, barn-swallow, chimney-swift, cat-hird, wood-thrush, humming-bird, king-bird, orioles, and wood-warblers follow in quick succession. The height of the spring migration period is reached in the early part of May.

Of the species that do not migrate there is no better example 
than the English sparrow, which is common in all our large cities and in many farming districts. The term "English" sparrow is somewhat of a misnomer, for at the time it was introduced into our country this bird ranged over all Europe, where it is known as the house-sparrow. The history of the spread of this bird shows us in a vivid way what are the successful qualities among hirds. Originally this sparrow was confined to middle Europe, and prolably made its way into Germany at the time of the Romans. It has since swept all over Europe, including the British Isles, and has penetrated even into Siberia. It has crossed the Mediterranean and is found along the Senegal River, and, probahly through human ageney, has penetrated to the Cape of Crood Hope. It has been transplanted voluntarily by man to North America, Australia, and Java. It seems to occupy among birds the place taken among mammals by the rats. Crafty, pugnacious, obtrusive, thieving, dirty, it has become a nuisance wherever it has penetrated. But just these pushing qualitics, comhined with small size, great hardiness, a universal diet, and immense fecundity, have enabled it to make its way against all competitors. Its introduction into America can only be regarded as a deplorable blunder.

Spread of English Sparrows in America. - The first importations of the house-sparrow (Passer domcsticus) to Nurth America were made at Brooklyn, New York, in 1850 and 1852. The second importation surviverl and multiplied. S'ubsequent importations were made to Maine, Rhode Island, and Pennsylvania, so that by 1870 the sparrow was firmly estahlished in the eastern United States. From this time on the sparrow spread at a rate unparalleled hy any native bird. Br 1886 it had spread as far west as Kansas, and had established colo- 
nies at Salt Lake City, San Francisco, and other outlying regions; and throughout this territory it occurred in great abundance. Since then it has penetrated west to the Rocky Mountains, and south to Texas. This extraordinary spread has been due to several causes. As alrearly suggested, the bird can adapt itself to various climatic conditions and its fecundity is very great. Thus in our Southern cities there are from five to six broods a year, and from four to six young in each brood. Assuming that twenty-four young, half of them females, are produced by a pair each year, and that all the females breed when one year old, and successively for ten years, and that there are no deaths, then in the tenth year 136 billion individuals will have been produced from the original pair. To the realization of the possible maximum of reproduction there are, however, many checks, especially the destruction of birds by accidents, disease, and beasts and birds of prey.

Food of English Sparrow. - The house-sparrow was introduced for the purpose of destroying or holding in check the "canker-worm" and the various other caterpillars which destroy our fruit, forest, and shade trees. There is much doubt, however, whether the house-sparrow is at all efficient in the way of destroying insect pests, while it is quite certain that it fights with and drives away our native insect-eating birds. More important still, it destroys large quantities of grain in the field as well as many kinds of garden produce, so that, on the whole, the English sparrow must be reckoned destructive to agriculture. Of late years it has come into our Southern markets as a substitute for the rice-bird, and it is to be hoped that there will be a widespread demand for it in the market.

Increase of Exotic Species. - The extraordinary spread of the English sparrow after importation to this country is not 
wholly explained by its large fecundity ; for although equally reproductive in Europe it increases less rapidly there than here. Also it is not due to any peculiarity of our country, for the hird is a similar pest in Australia. Nimilar facts concerning the spread of other animals learl us to conclucle that it is the new country which permits the rapid spread and consequent destructiveness. Thus, when the cabbage-butterfly (Pieris rapa) was brought to this country, it spread with such rapiclity that, starting in 1860 at Quehee, it has now spread all over the United States as far as the Rocky Mountains. Again, the grapevine insect pest, Phylloxera, a native of this country, but not particularly destructive here, has heen accidentally transported to France, and there it has wrought great havoc in the vineyards. Another instance, this time of an aquatic animal, shows the same result: the periwinkle, Littorina littoria, ${ }^{1}$ now the commonest snail on the seashore north of $\mathrm{New}$ York, has nigrated down the shore from Halifax since 1868. This old species in the new country has almost clriven out the other shore mollusks, to such an extraordinary degree has it multiplied. Now why should animals in a new country develop with such unisual rapidity? It is because, coming into a new country, they have left behind them their natural enemies, and there has not yet been time for them to acquire new ones. Eventually new enemies are gained, or their old ones overtake them, and then the numbers of the exotic form become reduced; a new equilibrium becomes established.

As an example of the structure of a bird, and for comparison with the anatomy of the English sparrow, the common pigeon may be taken.

General Form of the Body. - If the smaller (or "contour") 1 See page 216. 


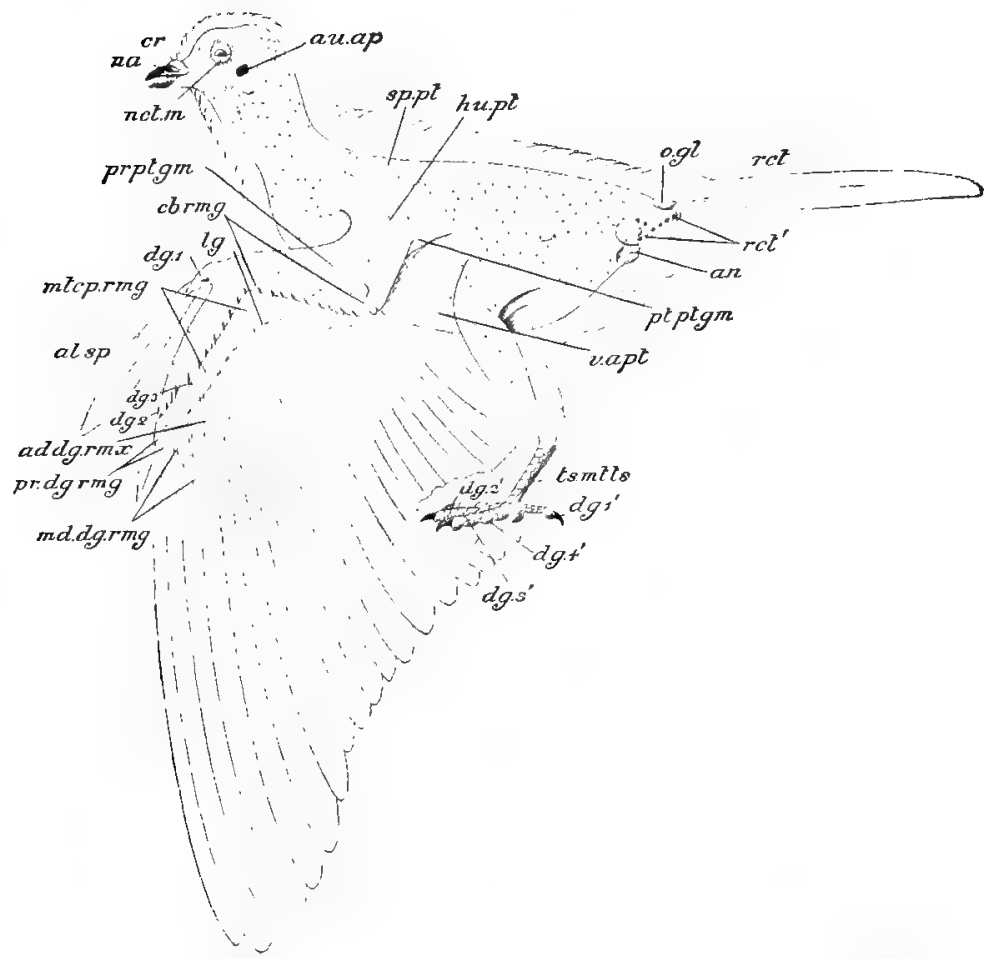

FIG. 349. - The pigeon viewed from the left side with most of the bodyfeathers removed. Feathers System : $a d . d g . r m x$, remex (flight) from the base of the fingers; al.sp, false wing; cb.rmg, remiges on the "cubit" or forearm; hu,pt, feather tract of the humerus; $l g$, ligament of the flights; md.dg.mmg, reniiges of the mid-digit; mtcp.rmg, remiges of the metacarpal region; pr.dg.rmg, reniges of the tip of the finger; pr.ptgm, wing web (patagium) in front of arm; pr.ptgm, patagium behind arm; ret, one of the tail feathers (rectrices) and the sics from which they have bcen removed $\left(r c t^{\prime}\right)$; sp.pt, feather tracts of the spine; v.apt, featherless space of the belly. Other references: an, anus; au.ap, ear opening; $c r$, cere; $d g, 1,2,3$, fingers; $d g, 1,2,3$, toes; na, nostril ; nct.m, nietitating membrane; o.gl, oil gland; ts.mtts, tarsus. From Parker and Haswell. 
feathers of the body he removed from one side of a pigeon (Fig. 349), it will be seen to consist of a head, trunk, and, behind the vent, a rudimentary tail. In front the trunk is drawn out

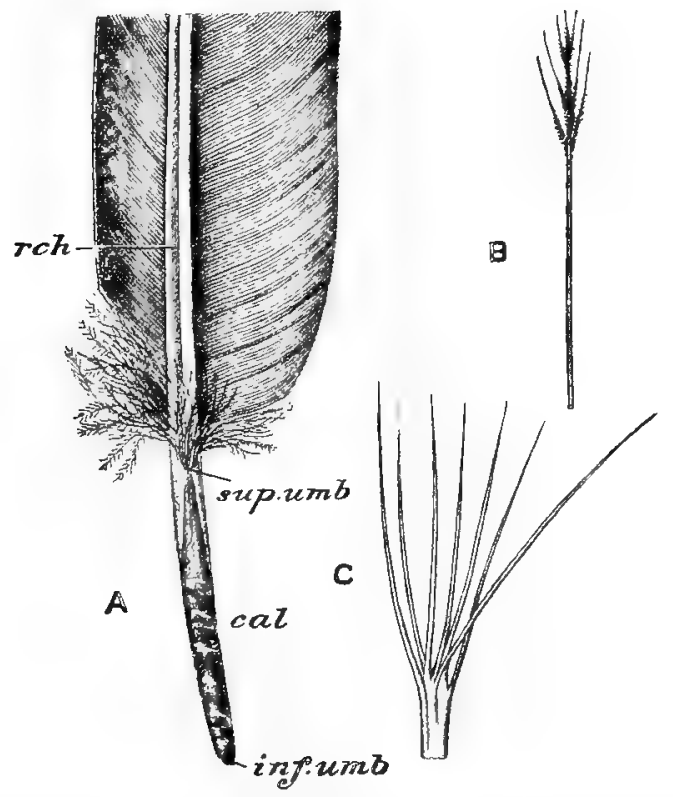

FIG. 350. - Feathers of the common pigeon. A, quill feather, basal portion ; $c a l$, the quill; inf.umb, lower depression; for admission of blood-ressel and nerve; supumb, upper depression; $r c h$, shaft. $B$. hair-like feathers, "filoplumes." $C$, nestling down. From Bronn's "Tiesreich."

into a long neck connecting with the head. The length of the neck gives great freedom of movement to the head, a movement useful not only in flight and in picking grain from the ground, but also in enabling the bird to reach every part of the plumage. There are two pairs of appendages, of which the anterior is greatly modified, being without fingers. 
and serving to carry the great flight feathers. The hinder appendages, used as legs, bear four toes, whose great spread serves to increase the base of support for the relatively large body.

Body Covering. - The feathers are of two general sorts, those which form a relatively close covering over the body of the bird and serve to maintain its high temperature, and the great quill feathers which are the main organs of flight. Those which are borne on the fore limbs serve to propel the bird through the air, whereas those which arise from the tail may, by their change in position, control the direction of flight. The earliest feathers of the young pigeon are called "down" feathers, and consist of a cylindrical base which breaks up into many branches above the skin (Fig. $350 \mathrm{C}$ ). Among the main body-feathers of the adult there are found hair-like feathers which break up into several branches at the tip (Fig. $350 \mathrm{~B}$ ). These feathers serve as connecting links to show the real relations between feathers and hair. The remaining feather's of the adult plumage are, however, much more complicated (Fig. $350 \mathrm{~A}$ ). They consist of a central shaft which passes into the quill below the level of the skin. Outsicle the skin, however, the shaft bears on each side a row of "barbs," which, taken all together, make up the "web" of the feather. The barbs cling together so that the web acts as a unit, and as the web is concave toward the downward stroke and convex toward the upward stroke, the air is held hetter in the down stroke, and this is therefore the more effective in lifting the bird than the upward stroke is in depressing it. When a single barb is removed from the web, it will be seen to bear two rows of microscopic organs which are the interlocking apparatus (Fig. 351). The organs on that side of the barb facing the tip 
are called distal barbules, and are provided with hooks, whereas the organs facing the base of the feather are called proximal barbules, and hear flanges. The hooks of the one barb interlock with the flanges of the next following barb, and thus all the barbs are held together in one firm web.

Skeleton. - The bones of birds are exceedingly light, many of them being hollowed out and filled with sacs connected with the lungs and containing heated air. This hot air greatly

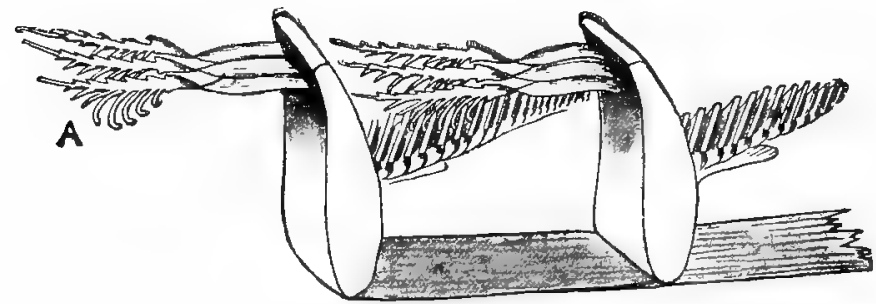

FIG. 351. - Structure of a feather. Two barbs are represented cut across. Each bears to the left three "distal harbules" armed with hooks which engage in the flanges of the "proximal barbules" lying to the right of the neighboring barb. After Pycraft.

increases the buoyancy of the bird in the air. The axial skeleton differs from that of most other vertebrates in the great length of the neck region, the compactness and rigidity of the trunk, and the shortness of the tail (Fig. 352). The latter ends in a square bone which consists of a lot of rudimentary vertebrx fused together. This piece corresponds to most of the long tails of reptiles, and in some fossil birds (Archeopterix, see also Fig. 388) the vertebre of the tip of the tail are still distinct. The skull is very compact and light, and the limits of the different bones of which it is composed are hard to make out except in young specimens (Fig. 353). The lower jaw is supported from the skull, as in the lower vertebrates, by a special 
hinge called the "quadrate" bone. Neither upper nor lower jaw bear teeth in living birds, but fossil birds are known which bear teeth. One of the most notable features of the skull of birds is the remarkable length of both the upper and lower

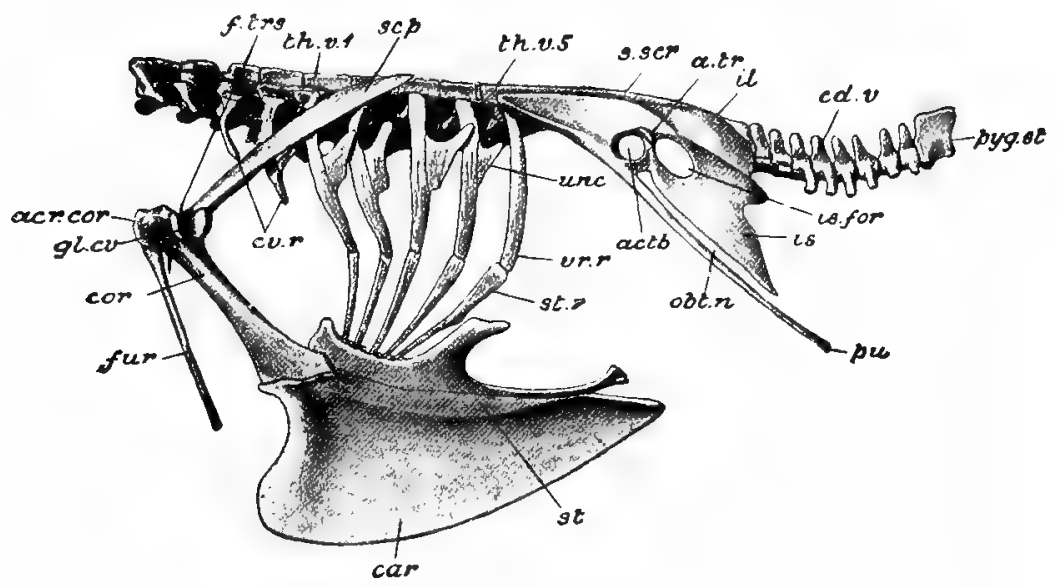

FIG. 352. - Bones of the trunk of the pigeon: th.v.1, first and th.v.5, last vertebra of the thorax; s.scr, sacrum; $c d . v$, caudal vertebræ, ending in the tail piece, pyg.st. The rios are short on the neck $(c v . r)$; on the thorax they consist of two parts, the vertebral (vr.r), and sternal (st.r) ribs, of which the former bears the uncinate process $(u n c)$; scp, scapula; cor, corocoid; fur, wishbone or furcula; acr.cor, process of the corocoid; gl.cv, plare of union of the humerus; st, sternum, and its keel, car. The pelvis includes: the ilium, $i l$, ischium, is, and pubis, puactb, acetabulum for reception of the head of the femur; a,tr, for attachment of the ligaments of the femur; is.for, foramen of ischium; obt.n, obturator notch. From Parker and Haswell.

jaws, which are drawn out to constitute the beak. Another feature is the enormous cavity reserved for the eye.

Surrounding the viscera are five pairs of ribs which connect below with the huge breastbone or sternum, a bone remarkable for its deep keel. This keel serves for the attachment of the breast muscles, by means of which the powerful downward 
stroke of the wing is performed. The skeleton of the wing is connected with that of the trunk by two bones, one of which

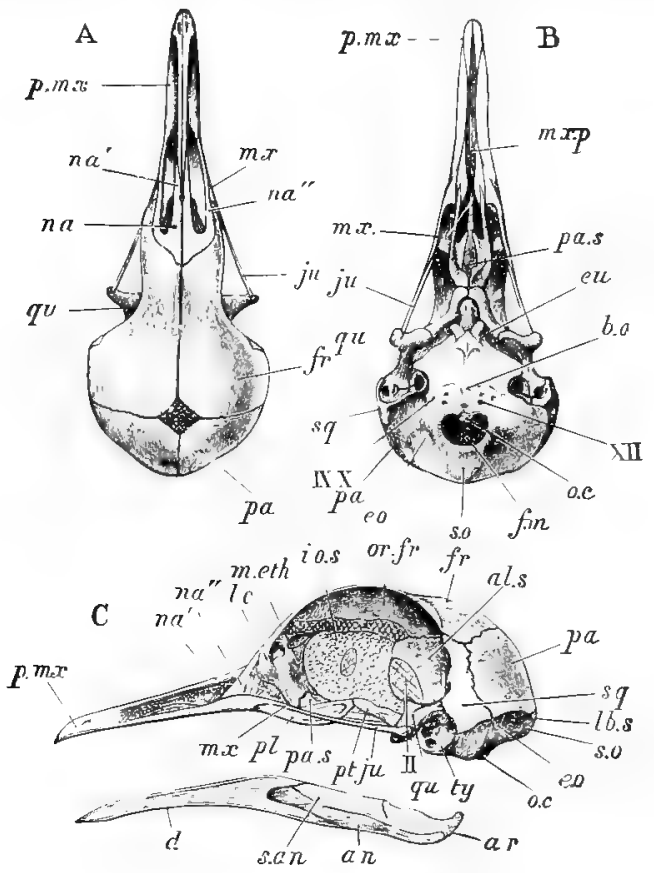

FIG. 353. - Skull of a young pigeon in three views: $A$, dorsal; $B$, ventral ; and $C$, lateral. With the aid of the skull of a young pigeon or chicken one can find the hones which bear the names indicated: al.s, alisphenoid; an, angular, and ar, articular of the lower jaw; bo, basioccipital; $d$, dentary (but bearing no teeth in modern hirds); eo, exoccipital; eu, opening of Eustachian tube; f.m, great foramen of skull; $f r$, frontal; i.o.s, interorbital septunı; $j u$, jugal; le, lachrymal; $l b . s$, lamboidal suture; m.eth, mesethmoid; $m x$, maxilla; rex.p, maxillopalatine process; $n a, n a^{\prime}, n a^{\prime \prime}$, nasal; o.c, occipital condyle; or. $f r$, orbital plate of frontal; $p a$, parietal; $p a, s$, parasphenoid; $p l$, palatine; $p . m x$, premaxilla: $p t$, pterygoid; $q u$, quadrate; s.an, supraangular; s.o, supraoccipital; sq, squamosat; $y$, tympanic cavity; $I I-X I I$, opening for cerebral nerves. From Purker's "Zootomy." 
runs up to the vertebræ and the other down to the breastbone. The two halves of the girdle thus formed are kept apart by a bone that serves as a spring, the so-called wishbone (Fig. 352, fur). While the shoulder girdle is thus characterized by a high degree of elasticity as befits its important work of supporting the strokes of the wing, the pelvic gircle, on the other hand, consists of a pair of bones rigidly fastened to the immovable sacral vertebræ.

The skeleton of the wing consists of a single bone in the upper arm, two bones in the forearm, and rudiments of three fingers in the hand. The skeleton of the leg consists of a single bone (femur) in the upper leg, two bones (tibia and fibula) in the lower leg, a kneepan (or patella) at the joint between the upper and lower leg, and a foot consisting of four digits which are grown together in what corresponds to the sole of the foot in man (the shank of the bird's Ieg), but are separate in the toes.

Organs of nutrition in the pigeon are much more complex than in the lower classes of vertebrates (Fig. 354). From the toothless mouth, with its long tongue, the long gullet leads through the neck to enlarge into a capacious crop lying just in front of the wishbone. Here the food, which consists chiefly of grain, is thoroughly soaked and softened. Thence it passes by a continuation of the gullet to the stomach, which, as in most birds, consists of two parts; the first, which is glandular; the second, or gizzard, which is muscular. In the first part the grain is further softened and treated by the secretions of the glands; in the second it is mechanically treated, being crushed and ground by aid of small stones that have been swallowed by the bird. From the gizzard leads the intestine. In its anterior part the digestive processes are active, and it 


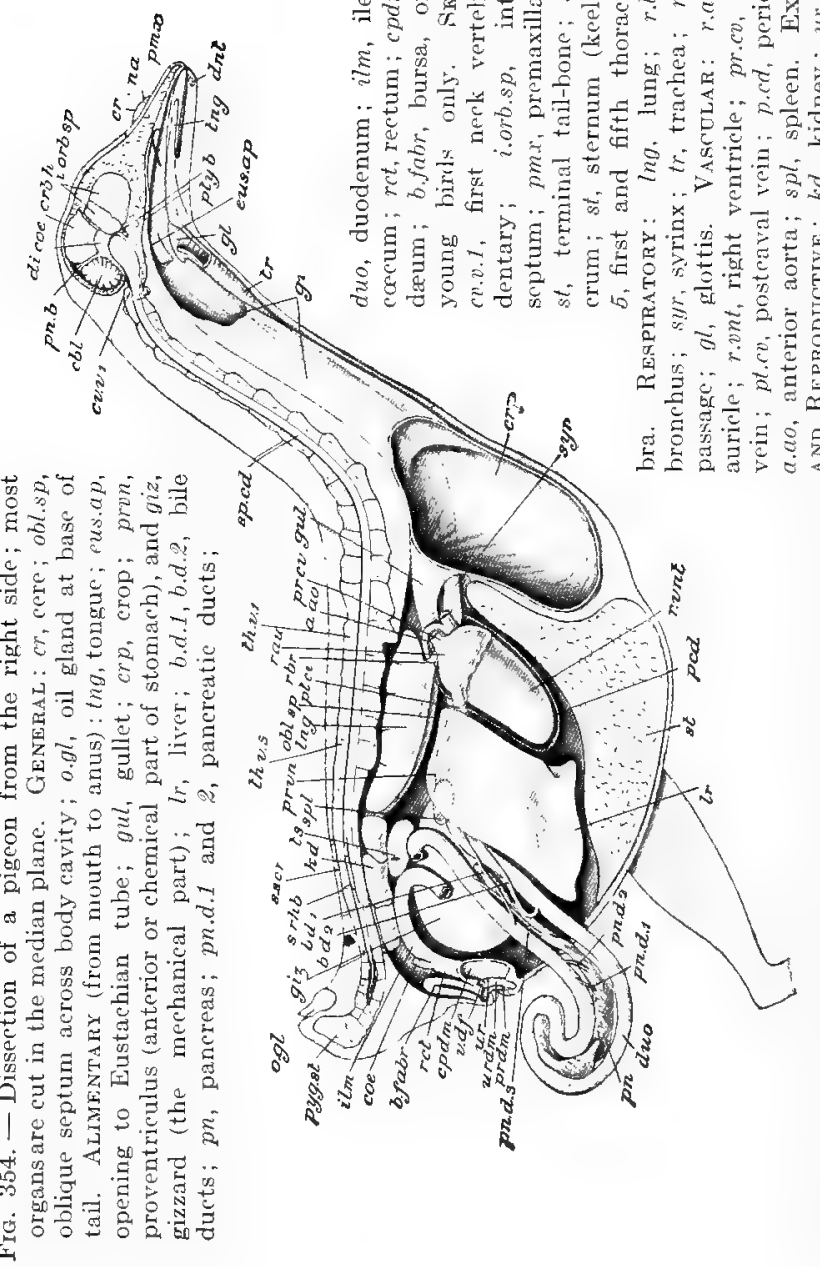

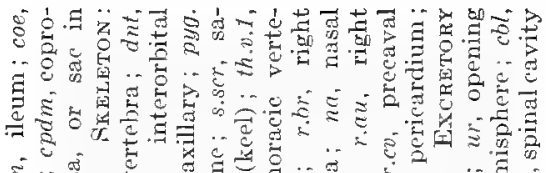

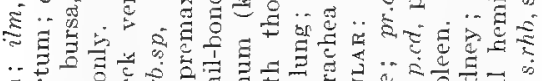
g

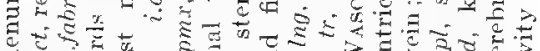

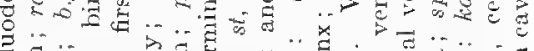

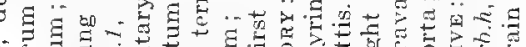
ध a. :

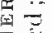
z

में

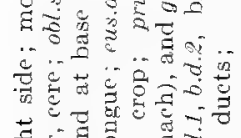

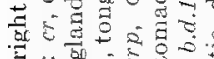
(1)

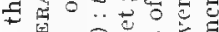

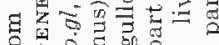
도용 글

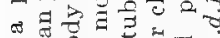

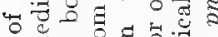

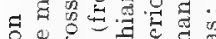

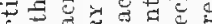
莎

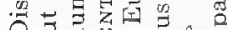

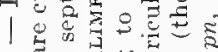
+0 व द

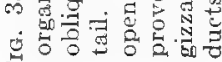

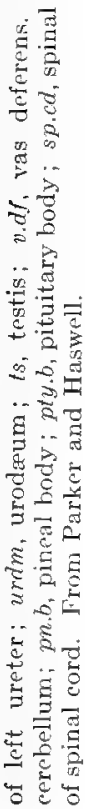


is into this region that the principal digestive fluids (those from the liver and pancreas) are poured. The great middle portion of the intestine, together with a pair of blind sacs (cæca) opening into it, serves for the absorption of the digested substances and, finally, the indigestible remnants are collected in the rectum, whence they pass, through a cloaca, to the external vent. The cloaca receives also the excretory products.

Organs of Respiration. - These also reach an extraordinary complication in birds. From the larynx, which, as in man, is supported by eartilages but is not, in birds, the vocal organ, a long windpipe passes to the two lungs. Where the windpipe begins to subdivide to form the bronchi of the lungs, there is found the vocal organ of birds - the syrinx (Fig. 355); nothing like it is found in any other class of vertebrates, and it gains a very complex structure in the singing-birds. As it would take a long time to describe the mechanism of the syrinx, this will not be attempted; suffice it to say that the sound is produced by the vibration of a membrane which is stretched part way across the windpipe.

The respiratory organs proper are of two kinds - the lungs and the air-sacs. The lungs (Fig. 355) are relatively small organs and are not mere bags, as in the lower orders of vertebrates, but spongy masses rich in blood-vessels. Through this sponge-work the pure inspired air rushes on its way to the airsacs which lie beyond. Consequently the blood of the lungs is bathed by a current of fresh air, and this insures that it shall receive a maximum of oxygen and this, in turn, results in the bird maintaining a high borly temperature, $103^{\circ} \mathrm{F} .\left(40^{\circ} \mathrm{C}\right.$.), instead of $98^{\circ} \mathrm{F} .\left(37^{\circ} \mathrm{C}\right.$.), as in mammals. The air-sacs of birds correspond, in a way, with the little terminal sacs of the bronchi in ourselves, but some of these have become immensely $2 \mathrm{c}$ 
enlarged and occupy great spaces of the body and even communicate with the cavities of the bones. These air-sacs serve not only to diminish the specifie gravity of the body, but also as reservoirs to receive the tidal air. From these reservoirs

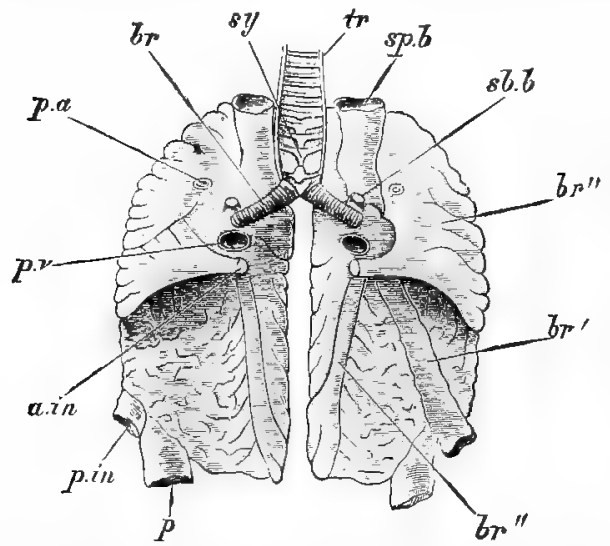

FiG. 355. - The lungs of the pigeon, together with the lower end of the trachea, viewed from the ventral side: $t r$, trachea with the syrinx (sy) at its lower and where the two bronchii (br) branch off, eventually dividing into branches, $b r^{\prime}, b r^{\prime \prime}$. The pulmonary artery enters at $p \cdot a$, and the rein leaves at $p . x$. With the lungs, various air saes are connected at a.in, the anterior thoracic; at p.in, the posterior thoracic; at $p$, the abdominal; at sh.h, the interclavicular, and at sp.b, the cervical. From Parker's "Zootomy." some of the air is no doubt ahsorbed by the blood and other fluids of the body; but the reservoirs are periodically emptied through the air-tube, as are the terminal sacs in our own lungs.

\section{Organs and Func-} tions of Circulation. - The heart is completely divided into a right and a left side, as in man. Each side has a receiving chamber or auricle, and a discharging chamber or ventricle. ${ }^{1}$ The impure blood from the tissues is received by the right auricle, passes to the right ventricle, and thence is pumped into a paired pulmonary artery, of which one branch goes to each lung, where it breaks up into capillaries. The recollected, oxygenated blood is returned to the left auricle, ${ }^{1}$ Fig. 354. 
enters the left ventricle, whence it is pumped to the tissues. The great artery that carries blood from the left ventricle is called the aorta. It quickly divides into a right and a left branch, from each of which an artery goes to the head with its brain and sense-organs, and to the wings and their great muscles. The right branch of the aorta passes up around the throat and reaches the vertebral column and runs under this (as the dorsal aorta) to the tail. It gives off blood-vessels to the food-canal and its glands, to the legs, to the kidneys, and other organs. The blood which is thus carried by the arteries to various organs of the body breaks up in each of them into capillaries and is finally collected into veins which eventually empty, as stated above, into the right auricle. While passing through the capillaries, the blood gives up its oxygen and receives from the organs carbon clioxide and other waste products of activity lying in these organs.

The organs of excretion consist of a pair of bodies of compact form like those of reptiles and mammals, and in striking contrast to the elongated, segmented kidneys of Amphibia. This kidney, indeed, represents only the hinder end of the kidney of Amphibia. It is richly supplied with blood that carries excretory products which, passing from the blood-vessels, enter little tubes. These tulsules eventually empty into a central basin which, in each kidney, connects by a larger tube with the cloaca and the exterior (Fig. 354).

The Organs and Functions of Reproduction. - In the female the ovary and oviduct of the right side has atrophied; only that of the left side persists. The eggs grow, in the oviduct, to an enormous extent by the addition of yellow food matter - the yolk. As a yolk passes down the oviduct a layer of albumin or "white" is poured around it; next a thin mem- 
brane, and lastly a hard, white shell. Two of these eggs are laid, one after the other, in successive days, and then incubated by the parents, who by sitting on them maintain them at the temperature of the body, so that the egg develops. After fourteen days the young pigeon hatches and is fed and brooded by the parents for a time longer until it is able to care for itself.

The muscular system is best developed in connection with the function of flight. Every one who has eaten a chicken or

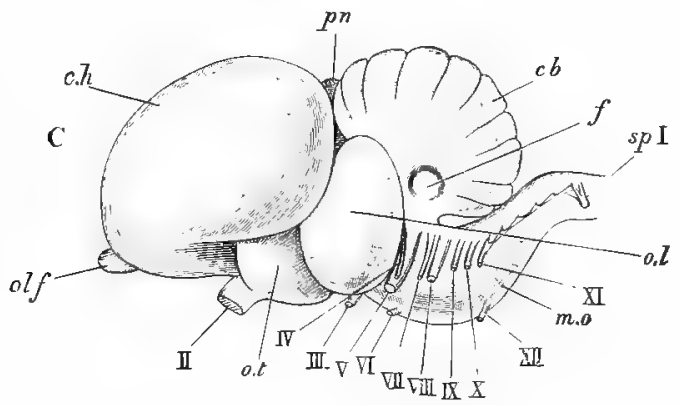

FIG. 356. - The brain of the pigeon, left side: olf, olfactory lobe; $c h$, cerebral hemispheres; $p n$, pineal body; $c b$, cerebellun with a side lobe at $f$; ot, optic tract; mo, medulla oblongata; $I$ - $Y I I$, cranial nerves; sp.I, spinal nerve. From Parker's "Zootomy."

turkey knows of the great "breast" muscles. These constitute "white" meat in the turkey because they are relatively bloodless, being little used for flying; but in pigeons, which fly readily, the breast muscles are full of blood and are dark. The great breast muscles depress the wing, the reaction to which keeps the bird in the air. The other muscles of the body are less important. Those of the neck and tail are well developed, corresponding to the mobility of these parts, but, owing to the compact, immobile nature of the trunk proper, the musculature of that region is very slight. 
The nervous system consists of the brain, spinal cord, and the sympathetic system. The brain shows a great advance , over reptiles, particularly in the development of the hind brain, or cerebellum - the centre of coördination (Fig. 356). Since flight demands extreme coördination, we can understand the large cerebellum of birds.

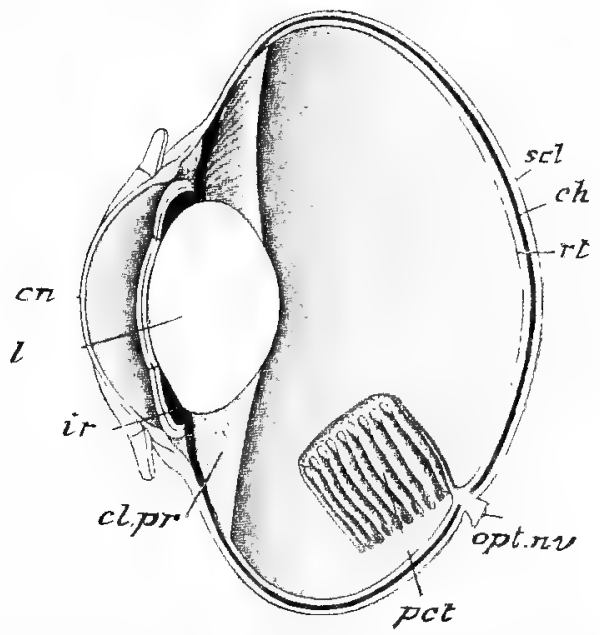

FIG. 357.-Median section through the eye of the pigeon: $c n$, cornea; $i r$, iris; $l$, lens; $c l . p r$, lens muscles; pct, pecten; opt.nr, optic nerve; $r t$, retina; ch, choroid coat; scl, sclerotic coat. After Vogt and Yung, from Parker and Haswell's "Zoology."

Sense-organs. - As befits such active animals, pigeons, like birds in general, have well-developed sense-organs. Organs of smell, lying at the base of the beak, and those of hearing, having much the same structure as in man, are present. But the most perfect organ is the eye which has relatively a large size. It differs from that of man in its lenticular (compressed) form, well adapted to the vision of distant objects. A peculiar organ 
lies in the aqueous humor in front of the entrance of the optic nerve - it has the form of a comb (whence called pecten) and is deeply pigmented, but its function is quite unknown (Fig. 357 ).

The class of Birds, or Aves, as they are technically called, is divided into eleven orders as follows:-

1. The running birds: Birds incapable of flight because their wings are rudimentary, e.g. Ostriches.

2. The swimming birds. These are the web-toed birds like the loons, gulls and terns, petrels, pelicans, ducks, geese, and swans.

3. The shore birds. These possess long, stilt-like shanks with slight web; such are the flamingoes, herons, storks, cranes, snipes, and plovers.

4. The ground birds, including the turkeys, grouse, fowl, and quail.

5. The pigeons, perchers on rocks, with all four toes on the same level.

6. The birds of prey, with hooked beak and claws (talons), including the vultures, hawks, and owls.

7. The talkers, with beak shorter than high, including the parrots, paroquets, etc.

8. The cuckoos and kingfishers.

9. The woodpeckers, with long beaks fitted for drilling into bark.

10. The long-uinged birds, or humming-hirds, swifts, and goat-suckers, of varied form, for the humming-hirds have slender bills, but the other groups have short bills and large mouths. The wings are generally long and pointed.

11. The perchers, including most of the common migratory birds. 
The order of runners (Cursores) includes the African ostrich, the American ostriches, or rheas, the cassowaries of the East Indies, and certain wingless birds of New Zealand (Apteryx ${ }^{1}$ ).

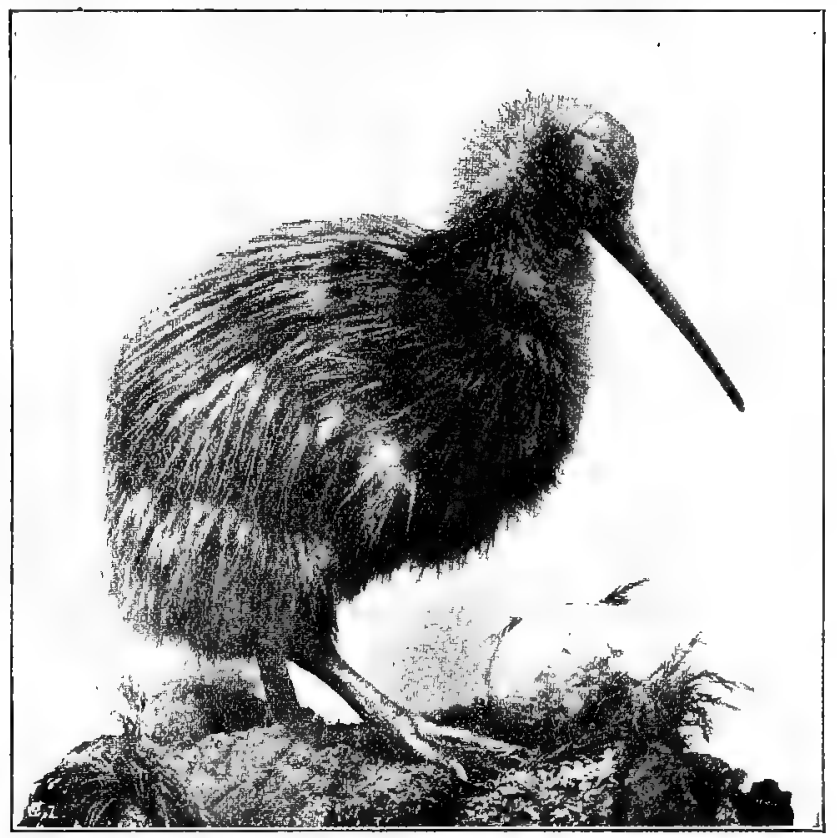

FIG. 358. - Apteryx australis, with egg. From a specimen in the Royal College of Surgeons, London. From Parker and Haswell, "Text-book of Zoology."

These are regarded as the most lowly developed of the birds; the vanes of their feathers are not united, but separate to form a sort of hair-like covering to the body. The African ostrich is the largest living hird. It wanders in families or flocks in the deserts of Africa, and feeds on grass, grain, and small 
animals. It also swallows undigestible matters, such as stones, which probahly aid it in triturating its food. The nest consists of a hollow scooped out of the earth, into which about thirty eggs are laid. Ostrich feathers are used for ornament, and so important is the commerce in these articles that ostriches are

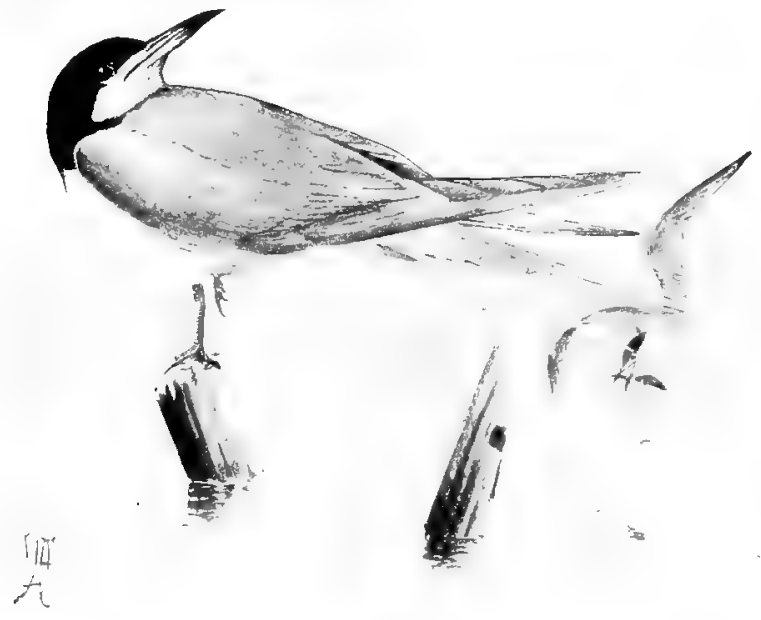

FIG. 359. - Common tern (Sterna hirundo).

extensively farmed in South Africa, southern California, and Arizona. The feathers are cut off and not pulled out, so that the operation of gathering the feathers is a painless one for the bird, but attended with some risk to the operator.

The swimmers, or Natatores, comprise the clucks and geese, the pelicans, the petrels, the gulls and terns, and the divers. Of the geese, the wild goose, or Canarla goose, is most commonly seen in its migrations. Of the native duclis we have many kinds, almost all rapidly disappearing before the "sportsman." The pelicans are large fish-eating birds, with a huge bag-like 
lower bill. In this country the white pelican is not uncommon. The large-winged petrels follow in the wake of coastal vessels. The terns, which are slender birds with a straight bill, ${ }^{1}$ were once abundant along our coast, but have been decimated to "ornament" bonnets. The gulls, which

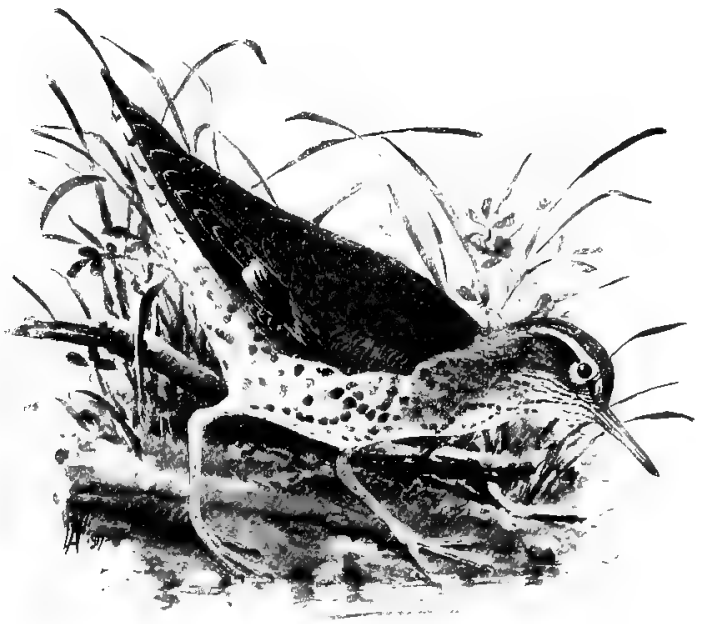

FIG. 360. - Spotted sandpiper (Actitis macularia).

are heavier than the terns, and have hooked bills, are still abundant along the seashore and Great Lakes. Finally, the loons are large birds, powerful fliers and swimmers, which are found in the lakes of the Northern Hemisphere. They are quick divers, and can swim under water for a considerable distance.

The waders (Grallatores) include a great number of shore birds known as plovers, sandpipers, snipes, rails, cranes, herons, and storks. The plovers walk and fly along shore, picking up

${ }^{1}$ Fig. 359. 
worms, mollusks, and amphibians; the golden plover is a wellknown game lird. The snipes are found in meadows or, lesi commonly, in woods. One of the most common is the spotted sandpiper, also called "tip-up" from its rocking morements (Fig. 360). It is seen walking around the margins of ponds and rivers. Wrodcock and large snipe are found in moist places. Among the herons, our great blue heron attains a length of

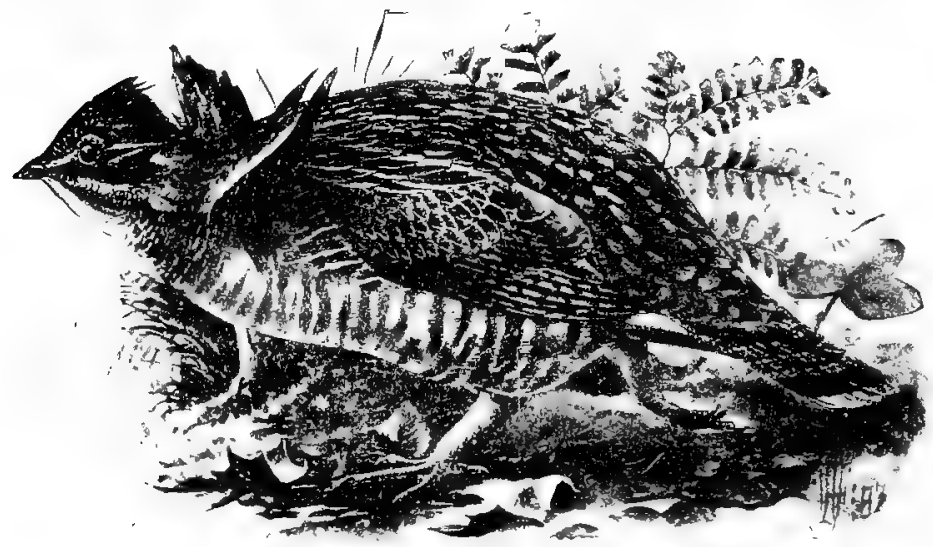

FIG. 361. - Ruffed grouse (Bonasa umbellus).

four feet, and is a notable resiclent of swampy regions, while the egrets have been practically exteminated to meet the demands of milliners.

The order of scratchers (Galline) includes a number of terrestial birds of large size, especially the grouse or partriclges, the pheasants and common fowl, the guinea-fowl, and the turkeys. On account of their large size and woll-flavored flesh, they are much used as human food. The grouse of America include the familiar "boh-white," or quail, which is being 
rapidly reduced in numbers in populous regions; the Canada grouse, which does not occur south of New York; the ruffed grouse of the Eastern States $;^{1}$ and the prairie chicken of the Great Plains, which has also become almost exterminated. In Europe the large "capercaillie" and the blackcock are favorite game birds. The pheasants are characteristic of southern Asia and China; they comprise some of the most brilliantly colored and greatly ornamented of birds, such as the peacock and the golden pheasant. Here also belong our barnyard fowl derived from a wild species, Gallus bankiva, inhabiting northern India, the East Indies, and the Philippines. The guineafowl is a native of Africa, where it goes in large flocks and is difficult of

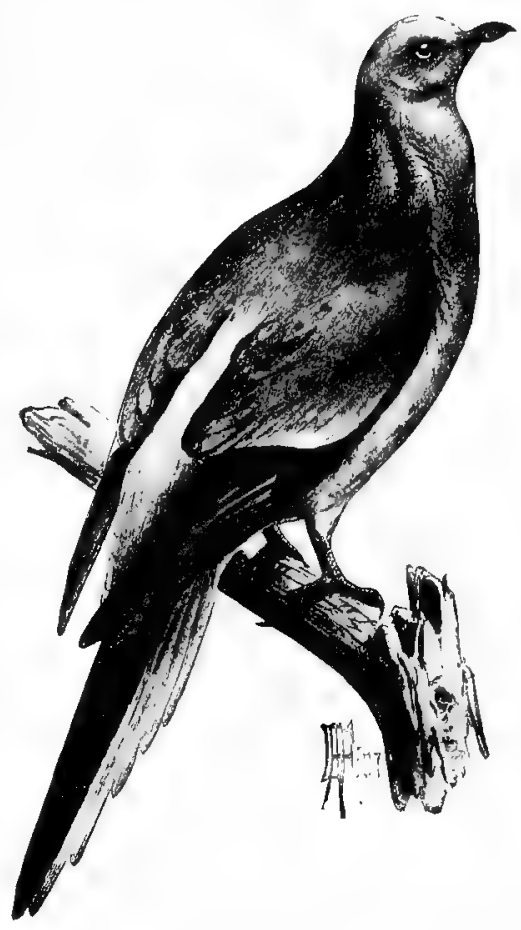
approach. The turkeys are North American birds. The wild turkey formerly occurred over all the United States and Mexico. It was first taken to Europe in 1524, was domesticated there, and now occupies much of its former habitat as

1 Fig. 361. 
a domesticated fowl. From this brief view we see that the family of Gallinacei is, for man at least, the most important family of food-birds.

The order Columbinæ includes the pigeons and allies, characteristic of the Eastern Hemisphere. The most interesting species of the group - the doclo and the solitaire, formerly inhabitants of the islands of Mauritius and Rodrigues, respectively - have become extinct within historic times through the settlement of these islands by white men. These birds had rudimentary wings and tail. Their nearest living ally seems to be the "manu-mea" 1 of the Samoan Islands. The pigeons proper are represented in North America by three wild species (Fig. 362). The domesticated pigeon, Columba livia, is a native of southern Europe or western Asia.

The birds of prey (Raptores) include eagles, hawks, and falcons; the vultures; condors; and owls. These birds feed chiefly on birds and mammals, which they capture alive in their claws or beaks; a few live on carrion. They occur in all parts of the globe. The bald eagle, used as a symbol of the republic, is the commonest of our eagles. Among our hawks, the sparrow-hawk, which is only about the size of the robin, is one of our most abundant; others are the sharp-shinned hawk, which kills birds almost exclusively and is especially destructive to poultry, and Cooper's hawk, which is also destructive to birds. These two hawks have practically no redeeming qualities, except the fact that they prey upon the English sparrow. The vultures are represented in our fauna by the turkey-buzzard which, like other menbers of the family, feeds on carrion. The condor is the largest of the American Raptores. It preys cven upon live sheep and calves. The 1 Redbird. 
owls, which live in dark holes and feed upon small mammals at night, are found over most of the globe. Our commonest species is the reddish gray screech owl. ${ }^{2}$ The great horned

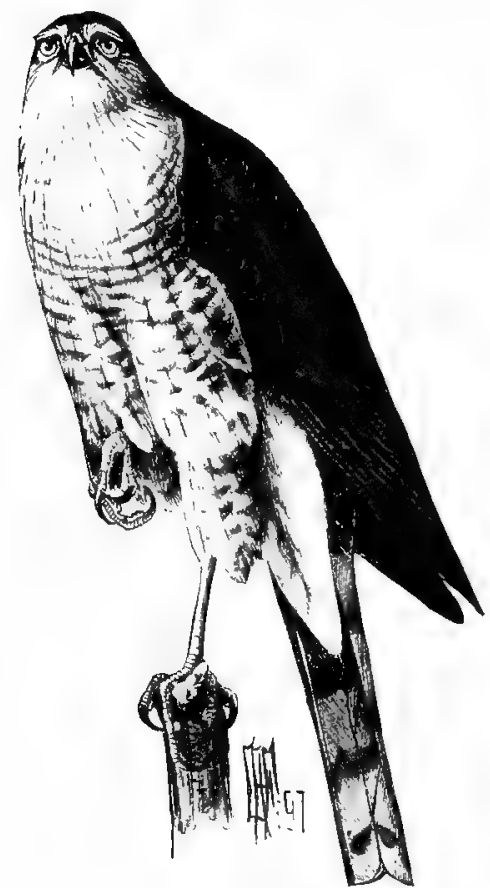

FIG. 363. - Sharp-shinned hawk (Accipiter velox).

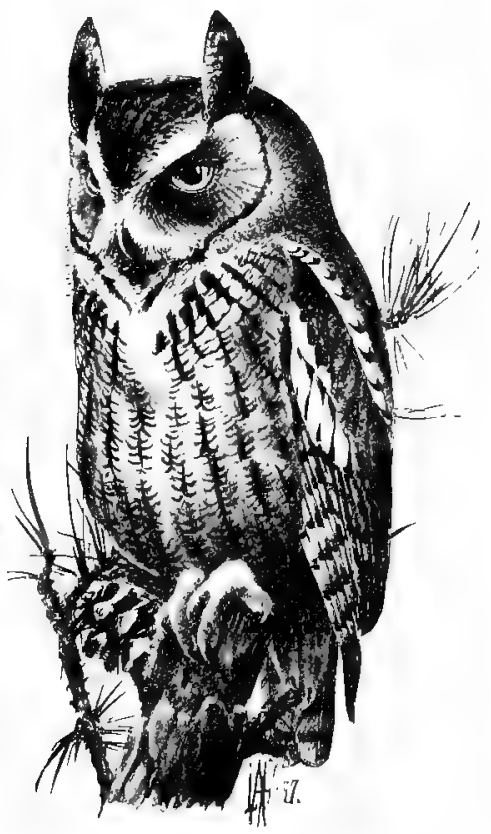

FIG. 364. - Screech owl (Megascops asio).

owl is an inhabitant of wooded tracts, and is destructive to poultry and small mammals. The snowy owl is one of the handsomest of all owls, and is frequently seen stuffed in houses in Europe as well as in North America.

The parrots and cockatoos (Psittaci) are sometimes called 2 Fig. 364. 
"climbers." In the cockatoos the feathers of the head are elevated to form a crest. In the parrots there is no such erest; in one subdivision the tail is long; in a second, very short. The representatives of this family are found almost exclusively in the tropics, in Brazil, the Moluceas, and in Australia. In gen-

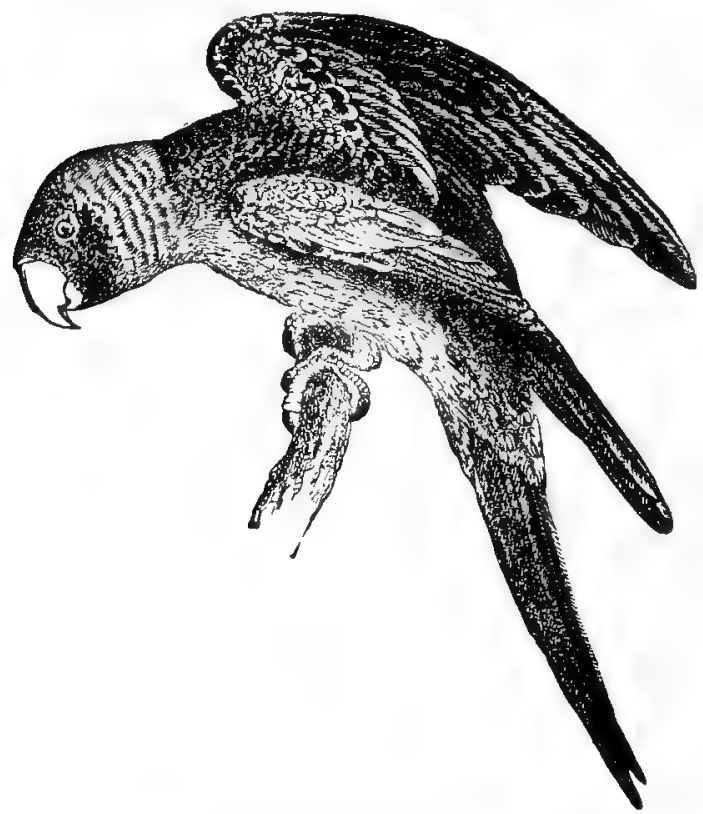

FIG. 365. - Conurus carolinensis, the Carolina paroquet. Une-fifth nat. size. After Wilson.

eral, these hirds have a loud voice, and certain species may be trained to articulate words and combine them into sentences. There is only one parrot native to the United States - the Carolina paroquet (Fig. 365). This formerly occurred north to the Ohio River, but it has been within recent years practically exterminated by plumage hunters. 
The toucans and cuckoos on the one hand and the kingfishers on the other are grouped into the order Coccyges. The toucans are characterized by an enormous bill, which in ext reme cases is as long as the rest of the bird. It would be extremely

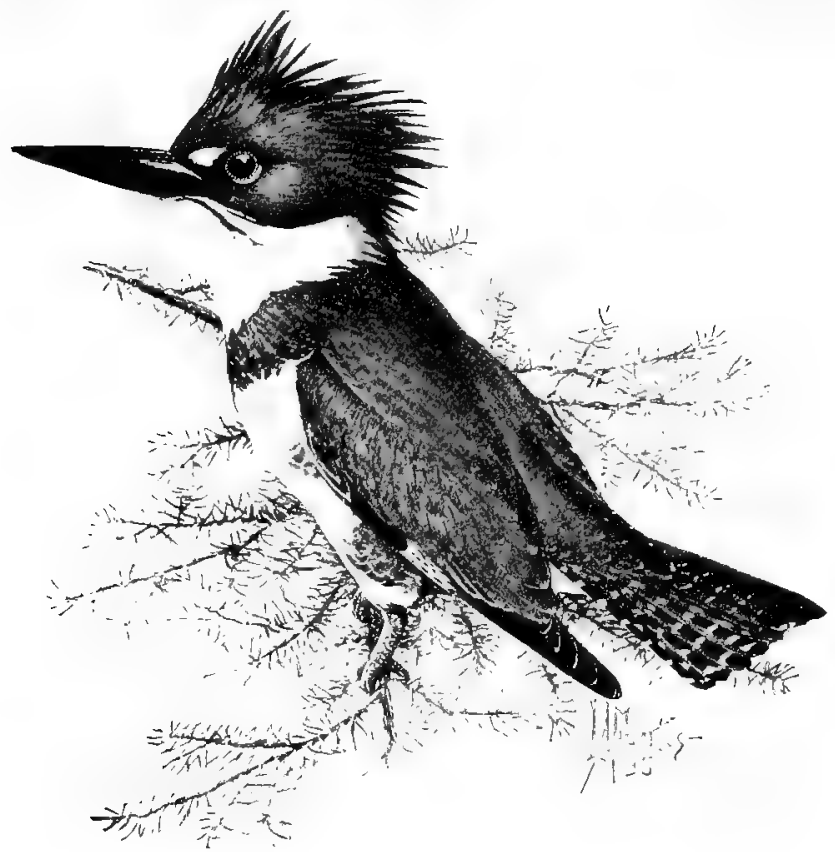

Frg. 366. - Belted kingfisher (Ceryle alcyon).

heavy were it not filled with air spaces of great extent. These birds inhabit Brazil. The great bills are of use in feeding on fruits. Filling the place in the Old World of the toucans of the New are the hornbills of Africa and $A$ sia, which are likewise frugivorous. The cuckoos are typically represented by the oldworld cuckoos. Like our own cow-bird, they have the peculiar 
habit of laying their egg in the nests of other birds, especially insectivorous hirch, where they are brooded and the young

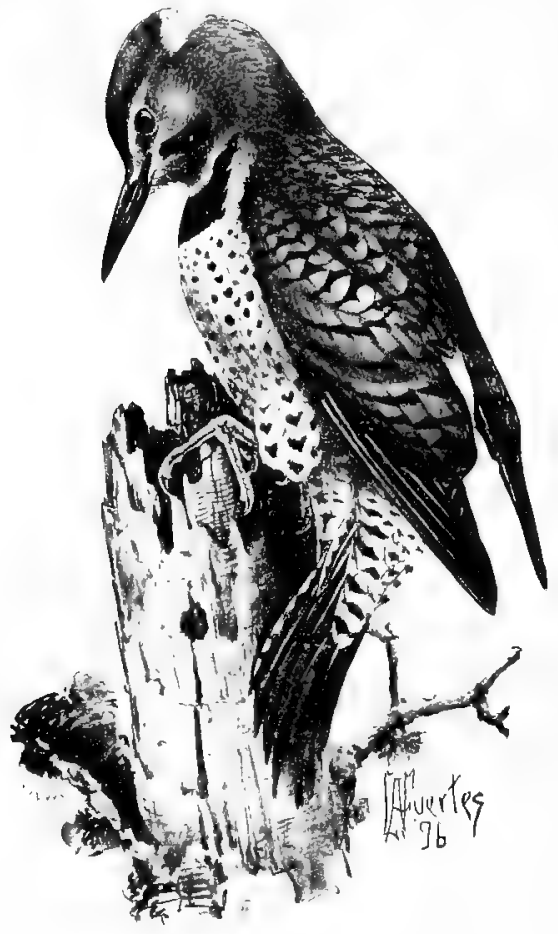

FIG. 367. - Flicker (Colaptes auratus). are fed by the fostermother. Our native cuckoo, however, broods its own eggs, and is a useful insectivorous bird. The kingfishers are also placed in this group. They are especially an Old-world family, but one genus (Ceryle) has found its way into the Americas. These birds feed chiefly on fish, and they have gained a compact, oily plumage to prevent them from getting wet when they plunge for their prey. Our species is known as the belted kingfisher (Fig. 366).

The woodpeckers, or Pici, include for the most part arboreal birds which feed chiefly on insects, and have lour, harsh cries. The common idea that they are sap-suckers and destructive to trees seems to be true only of one of our species - the yellow-bellied woodpecker. The heavy, long bill enables woodpeckers to peck holes in trees for wood-eating insects, and the long, 
barbed, protrusible tongue aids in removing the prey. Our commonest woodpeckers are the golden-winged woodpecker, or flicker, ${ }^{1}$ the red-headed woodpecker, the hairy woodpecker, and the downy woodpecker. An interesting question concerning the golden-winged woodpeckers of the East and southwest is whether they hybridize where their areas of distribution overlap.

The "long-wings" include the humming-birds, swifts, and goat-suckers. The humming-birds are mostly small species, limited to our hemisphere, and characteristic of the tropics. They fill the same place among the birds that hawk-moths do among insects, in so far as

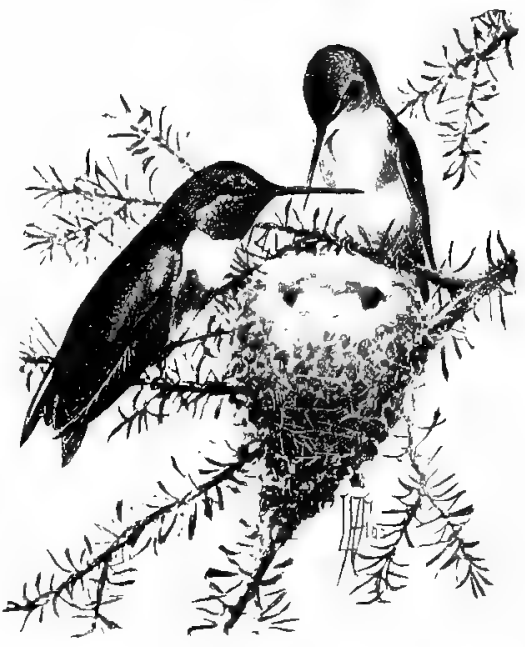
they are fitted to visit FIG. 368. - Ruby-throated humming-bird trumpet-shaped flowers. (Trochilus colubris).

They do not feed solely upon nectar, but devour insects also. They are usually brilliantly colored, and fly with great swiftness, nest in trees, and lay only two white eggs. One species, the ruby-throated humming-bird, reaches New England and Canada (Fig. 368).

The swifts have a broad gape, and no bristles at the base of the bill. They have habits much like swallows, and are found especially in the warm parts of the world. Most species of this ${ }^{1}$ Fig. 367. 
family have salivary glands, whose secretions aid in cementing the nest. Our common representative of this group is the chimney-swift, or chimney-strallow. ${ }^{1}$ Certain Chinese species make nests cntirely of the mucilaginous secretion of the salivary glands; these constitute the edible birds'-nests of the Chinese. The gout-suckers inclucle night-flying birds, with exceedingly broad gape and insectivorous habits. The night-

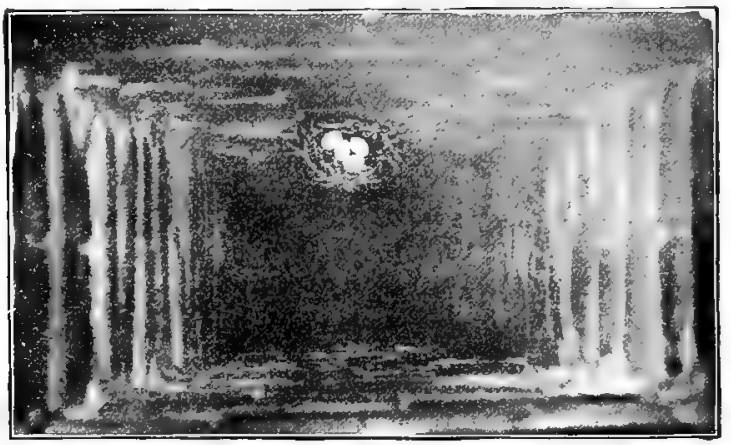

Fra. 369. - Nest of chimncy-swift. Photo. looking down chimney, by D. and $\mathrm{S}$.

hawk of North America, and the whippoorwill, named for its characteristic night cry, are familiar examples.

The order of perchers, or Passeres, is the most important for us because of the abundance of species and individuals included in it, and hecause of the intimacy that many of them have cultivated with man. The representatives of the order that live in the United states are arranged into about fifteen families, concerning each of which a brief account follows:

The flycatchers (or Tyranniclie) are an exclusively American family, feeding on insects. The best-known representatives are 
the courageous kingbird (Fig. 370), the worl pewee (Fig. 371), and the water-loving phobe.

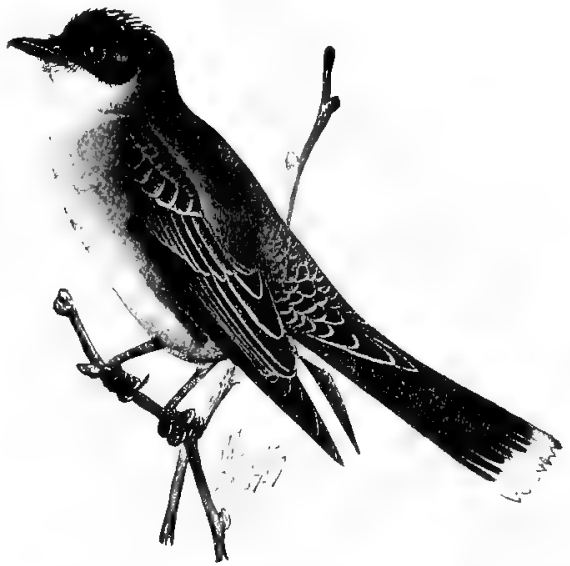

Fig. 370. - Kinglird (Tyramnus tyrannus).

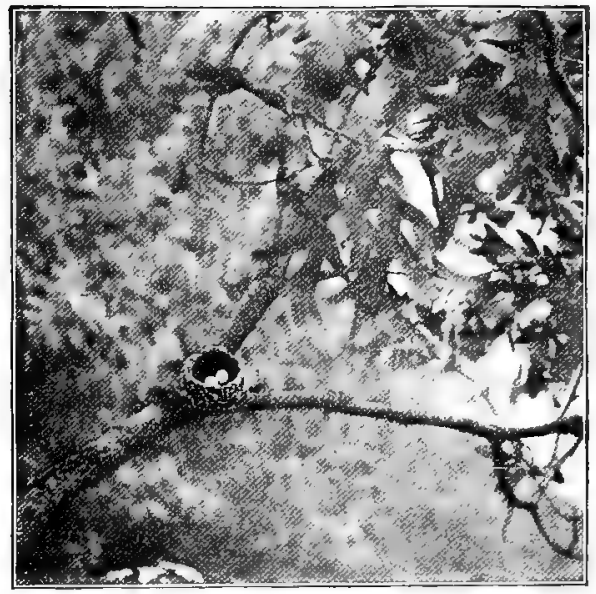

Fra. 371. - Nest of pewee. Photo. by D. and S. 
The larks are a family chiefly of Old-world birds of dull color, building a rough nest on the ground, and feeding on seeds and insects. The skylark of Europe is renowned as a songster.

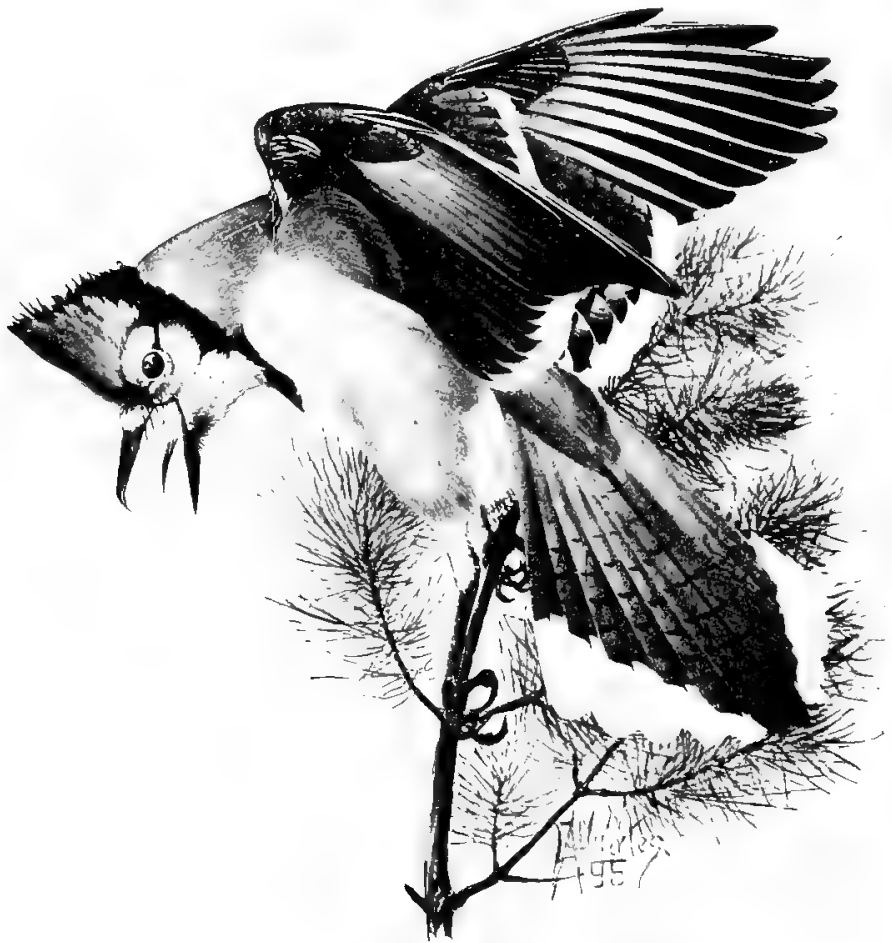

FIQ. 372, - Blue jay (Cyanocitta cristata).

In this country wo have one representative of the family, the horned lark, found also in Europe.

The crows (Corvicle) and their allies are all of them birds of large size and omnivorous, hut prefer animal food. The crow, the raven of the West and of Europe, and the blue jay 
(Fig. 372) are the commonest North American species of this family.

The blackbird family (Icteridæ) includes numerous species with different habits. These are also confined to America, and

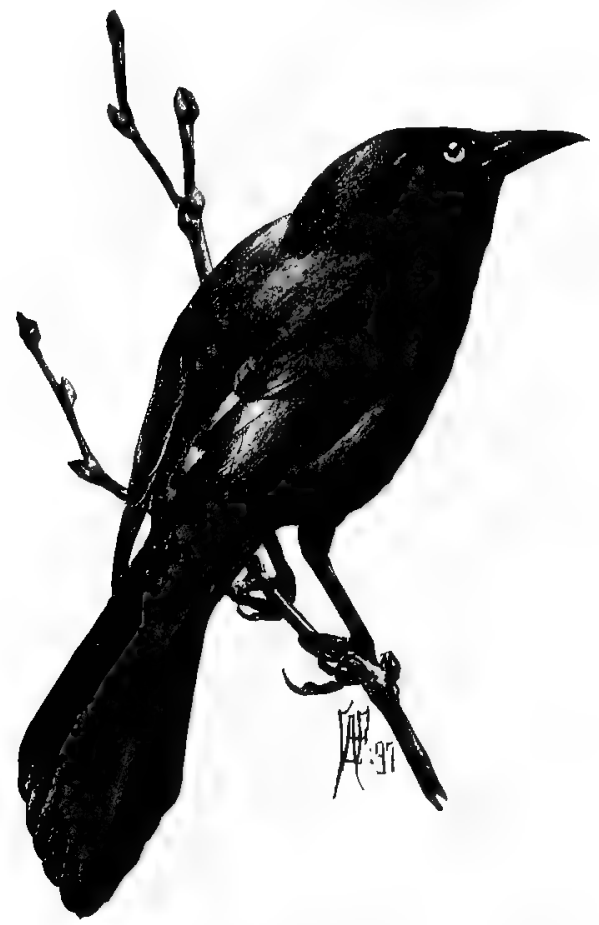

FIG. 373. - Purple grackle (Quiscalus quiscula).

are especially abundant in the tropics. They feed, for the most part, on seeds. The commonest representatives are the crow blackbird, ${ }^{1}$ of large size and iridescent plumage; the Baltimore oriole, which weaves a hanging nest; the orchard 1 Fig, 373. 
oriole, with less orange than the preceding; the large meadowlark, brownish ahove and yellow below; the red-winged blackbird; the cow-hird, which builds no nest, but lays its eggs in

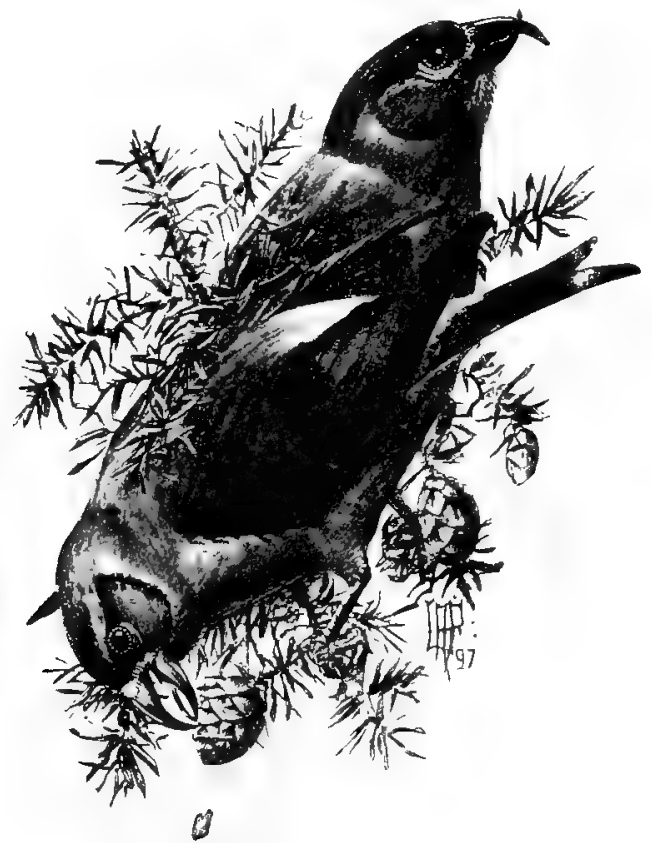

FIG. 374. - The American crossbill (Loxia curvirostra).

the nests of various small hirds; and the "boholink," as it is called in the North, whose song is the merriest of all birds. In the South, whither the hobolink migrates in the winter, it is a great pest in the rice-fields, and is known as the "rice-bird." It is slaughtered there as a game bird.

The sparrows (Fringillidie), to which family the English sparrow belongs, constitute a large group comprising over 
five hundred species, found in all parts of the world, excepting, until recently, Australia. In the United States it is the largest family of birds, comprising in most places about one-seventh of the species. Among common or striking native Fringillidæ may be mentioned the crosshills, ${ }^{1}$ yellowbird, vesper-sparrow, white-throated sparrow, tree-

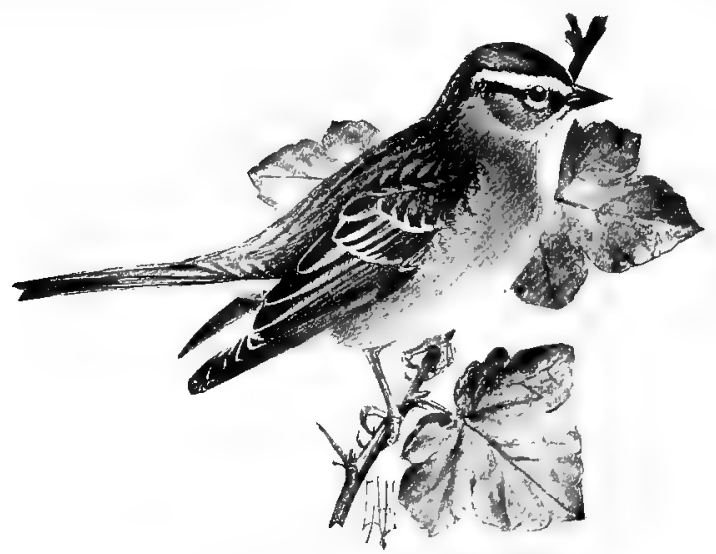

FIG. 375. - Chipping-sparrow (Spizella socialis).

sparrow, chipping-sparrow, ${ }^{2}$ snowbird, song-sparrow, foxsparrow, chewink, cardinal grosheak, rose-breasted grosbeak, and indigo-bird. Most of these birds are known to every country boy.

The tanagers are exclusively American and belong especially to the tropies. They live in the woorls, and feed on berries and fruits. The northernmost memher of the family is the scarlet tanager of the eastern United States (Fig. 376).

The swallows are found over the world. They are powerful fliers, and are insectivorous. Formerly all of them bred in ${ }^{2}$ Fig. 374 .

${ }^{2}$ Fig. 375 . 


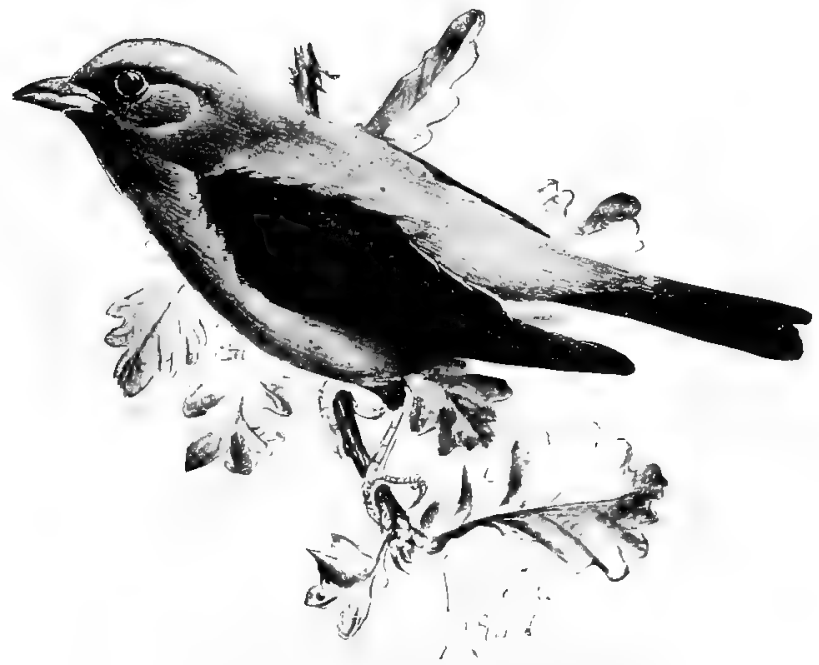

FIg. 376. - Srarlet tanager (Piranga trythomclas).

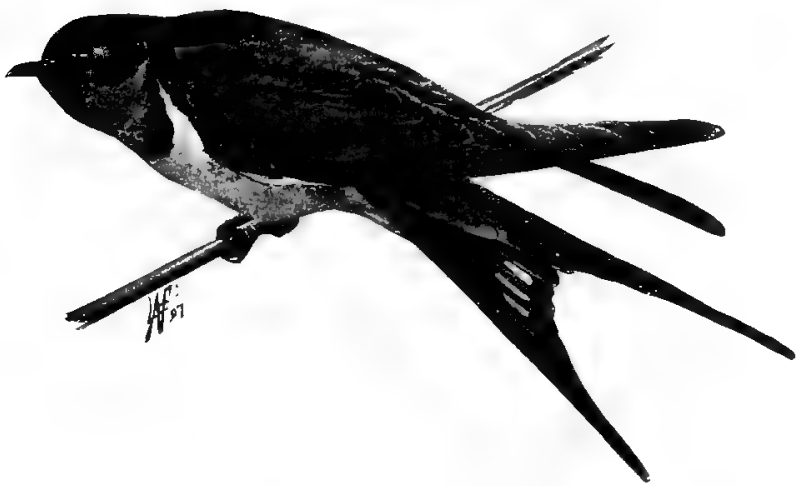

FiG. 377. - Barn-swallow (Chelidon erythrogaster). 
boughs, and hollow trees, cliffs, and some species still retain these habits. The best-known species are the bank-swallows, which, living in colonies, form numerous holes in railroad cuts and sand-banks in general; the white-bellied swallow, abundant about water; and the barn-swallow (Fig. 377), with a chestnut belly, which builds its nest in the rafters of our barns (Fig. 378.)

The waxwings are found over the Northern Hemisphere. They

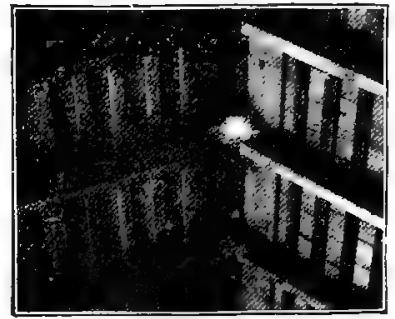

FIt: 378. - Nests of barn-swallow. Photo. by D. and $\mathrm{S}$. are migratory, go in flocks, feed on insects and fruits, and chatter rather than sing. Our commonest species is called "cedar-bird" (Fig. 379).

The shrikes are of world-wide distribution. They are vigorous, pugnacious birds, which have the habit of impaling grasshoppers and other small animals upon thorns, and leaving them there. In Germany there is a tradition that the shrike daily impales nine victims, and it is hence commonly called Neuntodter, or "ninekiller." The impaling seems to be done chiefly in the winter time, and apparently has for its purpose the storing of food against possible famine. Among birds frequently destroyed by them is the English sparrow, and it has been suggested that the shrikes should be encouraged to live in parks of cities infested by sparrow pests; but unfortunately the shrikes do not confine themselves to this intruder. We have two species of shrikes, a northern (Fig. 380) and a southern.

The vireos or greenlets are bright, handsome, and exclusively American birds. The commonest species are the red-eyed vireo (Fig. 381) and the yellow-throated vireo. 
The family of wood-warblers is the peculiar glory of America. It contains numerous small, mostly brilliantly colored birds, which migrate. Although a few of them - like the redstart, the Maryland yellowthroat (Fig. 382), the redpoll

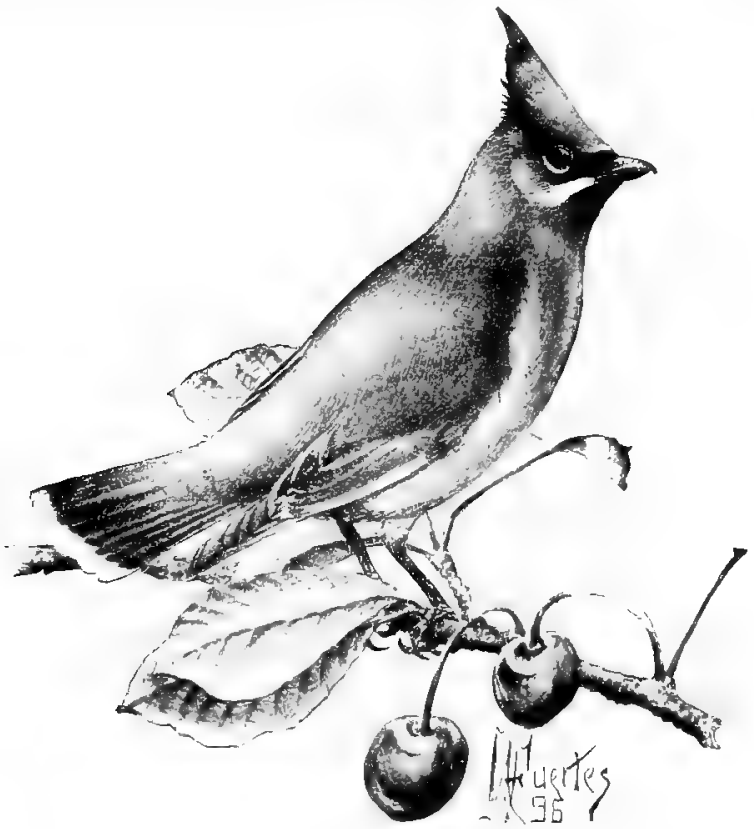

FIG. 379. - Cedar waxwing (Ampelis cedrorum).

warbler, the chestnut-sided warlbler, and the yellow warbler are abundant, few of the thirty-five or forty Eastern species can be saicl to be commonly known exeept to careful observers of birds; for cluring the migrations they hide in thickets, and are extremely shy.

The wrens are characteristic of South America, but some have 


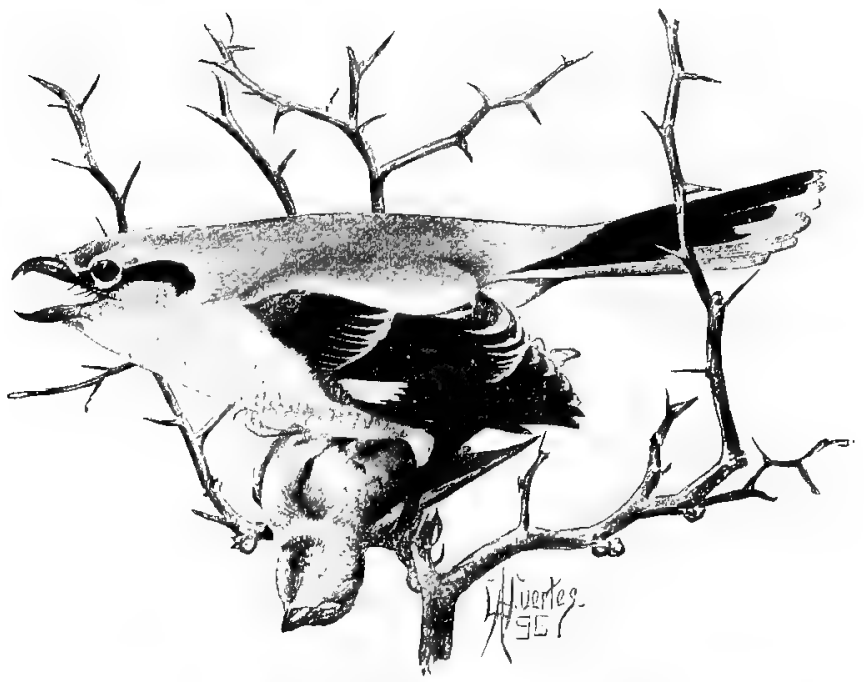

FIG. 3১0. - Great northern shrike (Lanius borealis).

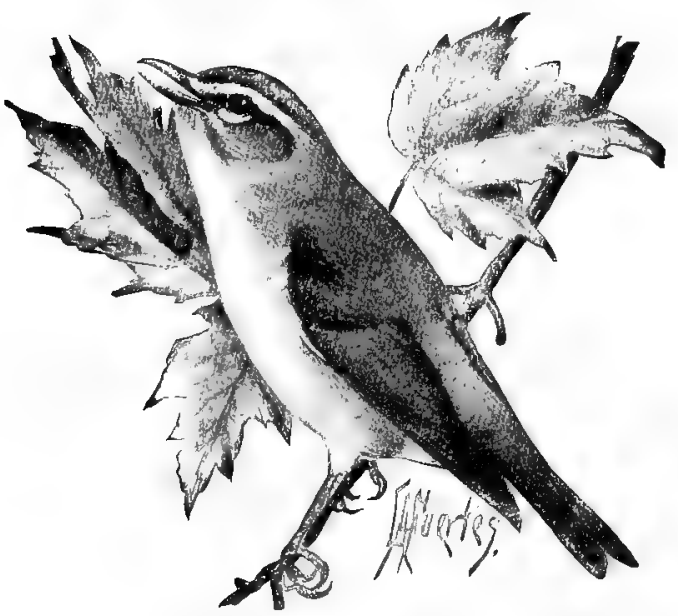

FIG. 381. - Red-cyed vireo (Vireo olivaceus). 
spread into North America and northern Europe. Our house wren, which is a near relative of the European house wren, is an active little brown bird, with a sharply bent-up tail. ${ }^{1}$ In this same family belong the mocking-birds, the centre of whose

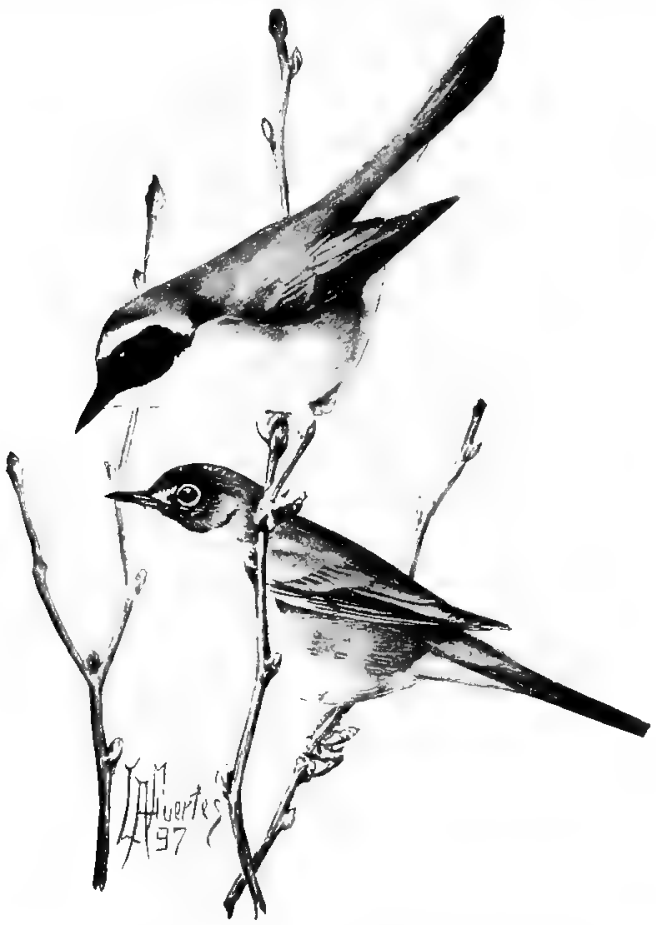

FIG. 382. - Maryland yellowthroat (Geothlypis trichas).

distribution is Central America, the West Indies, and the southern Lnited States. The large brown thrasher and the catbird are familiar over the country. The mocking-bird does not

I Fig. 383 , 
get far north into New England. It is regarded by many as superior to the nightingale as a singer.

The family of titmice includes also the nuthatches. The tits are chiefly Old-world birds, but we have a common representative in the blackcapped chickadee, well known from its cheerful whistle. In this family belong the nuthatches which run over treetrunks, head up or down, indiscriminately (Fig. $384)$.

The little brown creeper which travels over the bark of trees much as the nuthatches do and uses its tailfeathers as props against the tree-trunk (Fig. 385) belongs to an allied family.

The family of thrushes includes several common

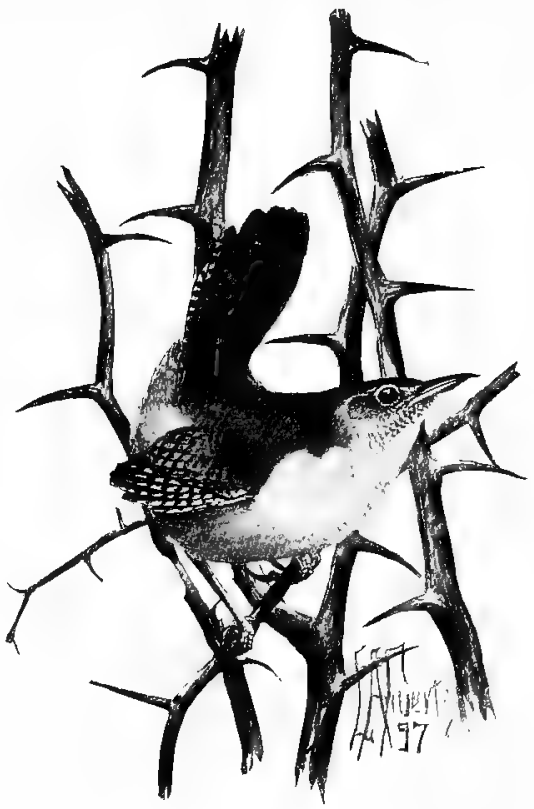

Fıа. 383. - House wren (Troglodytes aëdon). American birds, - the robin, abundant ahout houses during the summer, but for the most part migrating south from New England during the winter ; the wood or song thrush, ${ }^{1}$ one of our finest songsters; the bluebird, one of the earliest of our migrants, with "the sky on its back and the earth on its breast."

${ }^{1}$ Fig. 386, 
Bird flight. - The difficulties which must be overcome in order to fit hirds for flight are, first, that of sustaining the heary body in a medium of such low specific gravity as the air; and, secondly, that of progression in this medium. To diminish the difficulty of sustaining the body, the specific gravity is reduced

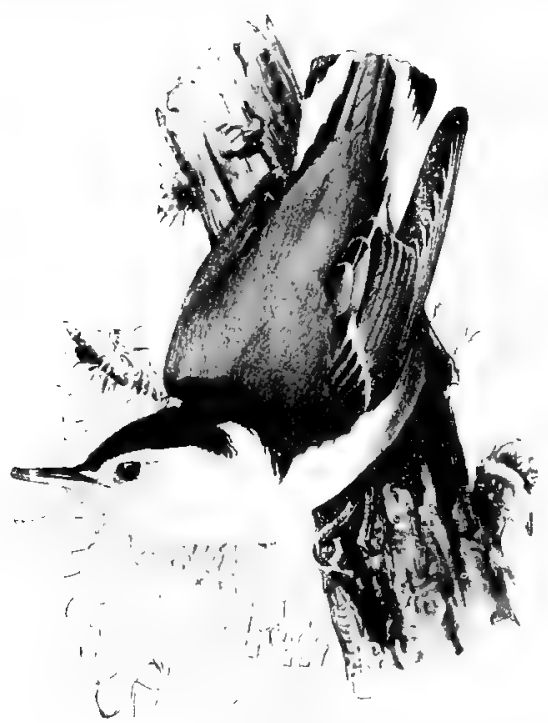

FIG. 384. - White-breasted nuthatch (Sitta carolinensis).

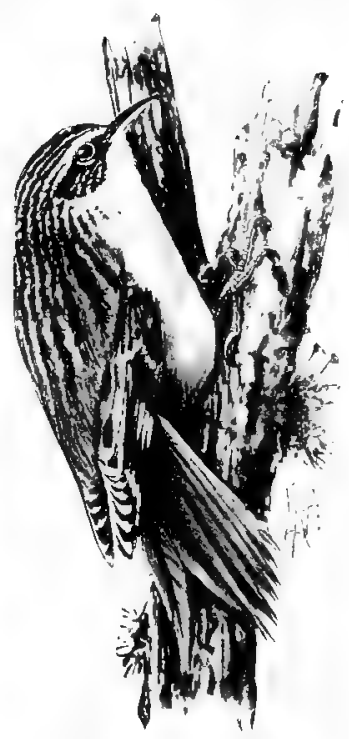

FIG. 385. - Brown creeper (Cerithia familiaris).

to a minimum by great air spaces in the body, which exist even in the hollow bones. The borly is kept from being overturned in the air by the position of the wings, which are placed high up on the trunk, while the digestive organs, breastbone, and breast muscles are placed low. To aid locomotion, the general form of the hody is marle conical, so as to offer little resistance to the air, while, by varying the position of the head, wings, and tail, 
the centre of gravity is quickly shifted. In starting to fly, the bird gains an initial velocity, if on the ground, hy springing into the air, or if on a tree, by combining the velocity due to gravity with a pushing from the limb; but aquatic birds strike the

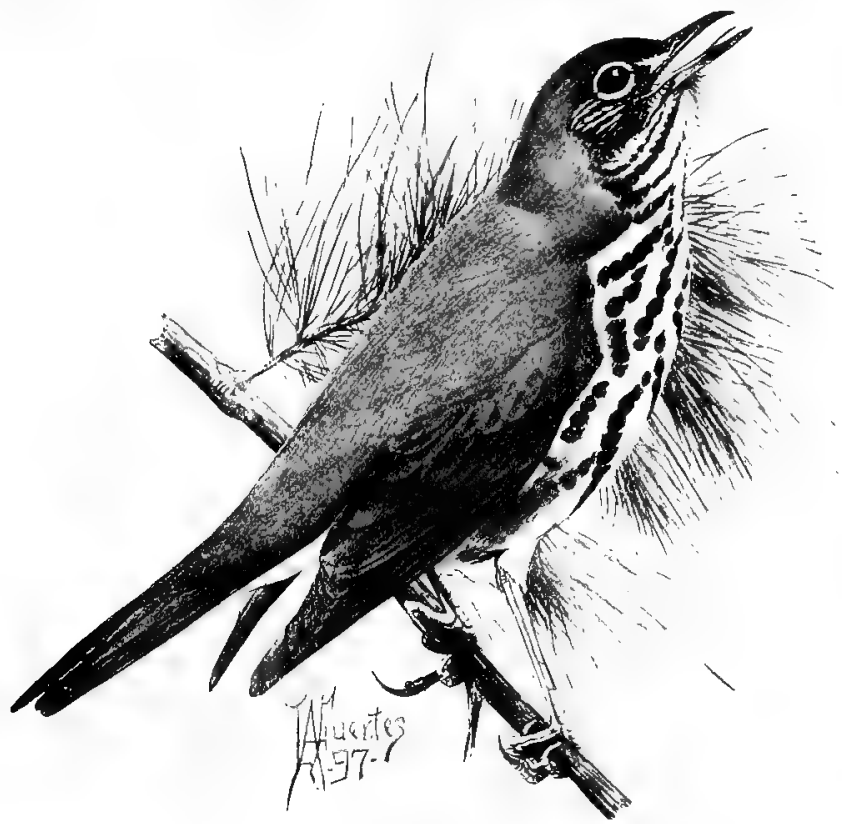

FIG. 386. - Wood-thrush (Turdus mustelinus).

surface of the water with their wings. The best fliers have relatively large, pointed wings. Three methods of flight are employed by birds when once in the air: $(a)$ stroking the air with the wing; (b) gliding or skimming; and (c) sailing or soaring. Some bircls can use all three methods, and all good fliers use the first two. In the stroke the wing moves downward and forward, backward and upward, so that the tip of the wing 
describes a $\infty$; and since the bones of the wing - its most rigid part - are at its front edge, the hinder edge tends to lag behind the front edge, so that the wing as a whole hits the air in a plane which is not perpendicular but oblique to the clirection of impact. Consequently on both the up and the down stroke one component pushes backward and tends to drive the bird forward (Fig. 387). In gliding, the wings are spread, but are not flapped; progression depends upon an
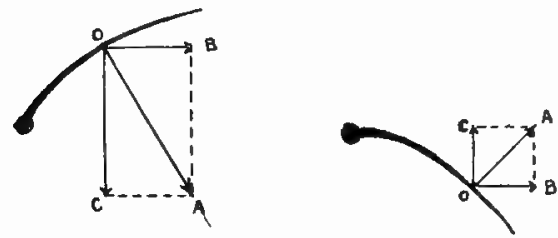

FIG. 387. - Diagram showing resolution of forres (A) on down and on up strokes of the wing; the component $B$, in both cases exerts a buckward pressure that drives the bird forward; whilc the component $C$ keeps the bird up. acquired velocity, as in aeroplanes, or upon the wind. In soaring, the wings remain motionless, and the bird does not lose its velocity nor tend to fall. The way in which the bird is supported and carried along is uncertain. It scems to depend upon certain favorable currents in the air.

Birch, like insects, have the closest economic relations with man. A few of them, chiefly belonging to the orders of swimmers and grouse, are very important as human food; but most of them concern man on account of their feeding habits, which are either favorable to man, as when noxious insects are destroyed, or injurious, as when grain-fields are ravaged or other hirds are preyed upon. Inquestionably the vast majority of hirds are commercially advantageous to man. The Raptores are only partially so, for they feed entirely upon animal food, chiefly birds and small (usually destructive) mammals. The bobolink and the American crow, to be sure, together annually destroy millions of dollars' worth of grain, 
yet during the breeding season they both feed much upon insects. Outside of the group Raptores, there are few, if any, completely noxious birds, and even many of the hawks are efficient destroyers of insects. Legislation directed toward the destruction of any kind of birds, excepting the English sparrow, the Cooper's and sharp-shinned hawks, and perhaps the crow, is quite as apt to do harm as good.

Bird Protection. - Travellers in certain parts of Europe, where the poverty and ignorance of the people have led them to prey upon birds, have remarked on the desolation of a birclless country. The natural enemies of insects being destroyed, there is no adequate check to the destruction of vegetation by insects, and the beauty of a forest landscape is missing. North America has been richly provided with a native bird fauna; but within the last few years it has become plain that most of our species are undergoing reduction, and many are near extermination. Careful inquiries recently made indicate that during the past fifteen years the number of our common song-birds has been reduced one-half, and the number of certain birds prized as food or ornament has been reduced to one-fourth. At the present rate, extermination of many species will occur during the lives of most of us. The causes of this destruction of birds are numerous. The most efficient cause is the shotgun in the hands of boys and thoughtless men and of those who gather bird skins to meet the demand for bonnet "ornaments." Very great destruction is also caused by egg-collectors, who annually gather scores of thousands of eggs, often of rare birds. The disastrous results of killing birds need only to be appreciated in order to put a stop to this destructiveness. No species, once exterminated, can ever be replaced, and the workl cannot afford to lose any of the objects of beauty and utility. 
Extinct Birds. - The destruction of species of birds goes on fast enough without the more efficient aid of man. We know of species which have become extinct within recent times through the introduction of new enemies among them. Such

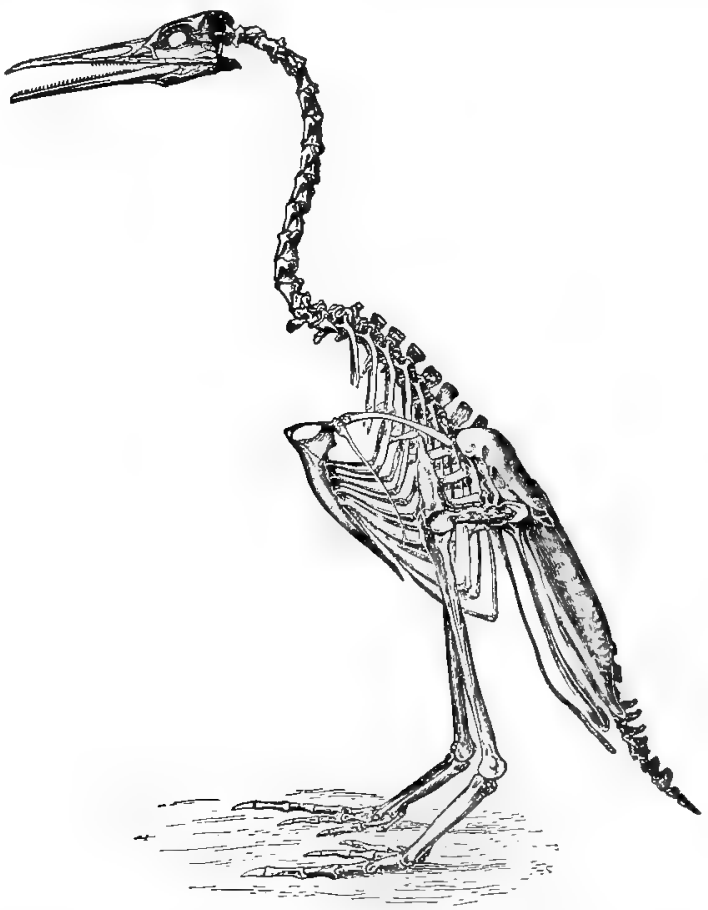

FIG. 388. - Hesperornis regalus. The restored skcleton. After Marsh. was the fate of the dodo and of the great auk of Labrador. The remains of species which lived in very remote periods have been preserved to us in the rocks. The oldest known fosil hird, Archæopteryx, of the Jurasicic age, has a long tail like a lizard; but feathers, which are only modified scales, 
were present even in this oldest known bird. In the Cretaceous rock deposits of the Great Plains there have been found fossil birds with teeth set in sockets or grooves, precisely as they are to-day in reptiles (Fig. 388). These remains show us in the clearest manner that birds have been derived from reptiles or both from a common source. Indeed, the two groups are closely related anatomically, and are often united under the name Sauropsida, or lizard-like animals. 


\section{CHAPTER XXVI}

\section{THE MOUSE: A STUDY OF THE EVOLUTION OF DOMESTIC ANIMALS}

Max loves company, not only of his own kind but also that of other animals, and many other animals similarly enjoy society. The dog is one of these. In the wild state it goes in packs and when alone gladly attaches itself to man. Such a mutual, social instinct was probably the earliest impulse to associations between man and other animals such as dogs and cats. Moreover, man found that certain other animals, which might not share his fireside, could nevertheless be trained to stay about his tent or hut, where they could be utilized for food, for clothing, or for burden-bearing. Thus man came to domesticate cattle, goats, sheep, and horses. A list of the more familiar domesticated animals is as follows:

Hairy animals (Mammalia): cat, dog, rabbits, guinea-pig, mouse and rats, pig, horse (including the ass), cattle, llama, camels, sheep, goats, and elephants.

Birds: canary bird and various finches, paraquets, poultry, pheasants, ducks and geese, guinea-fowl, turkey, and ostrich.

Fishes: goldfish. Insects: bee, silkworm.

Some of these domestic animals deserve a fuller description.

The cat is a solitary animal with a strong homing instinct. There are several domestic races, such as long-haired, shorthaired, and tailless (or Manx). In each of these races there are various color types, -- white, black, tortoise-shell, tiger, and 


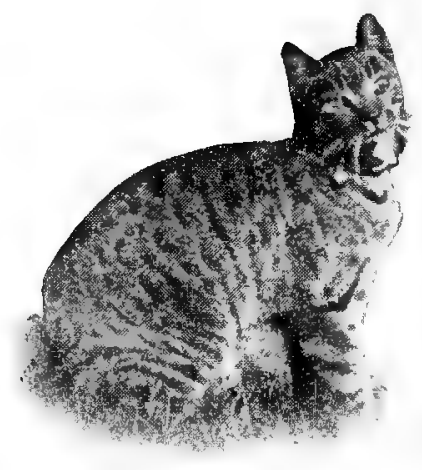

1. The Manx or tailless cat.

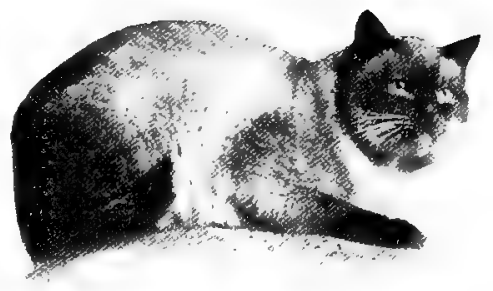

2. The Siamese cat.

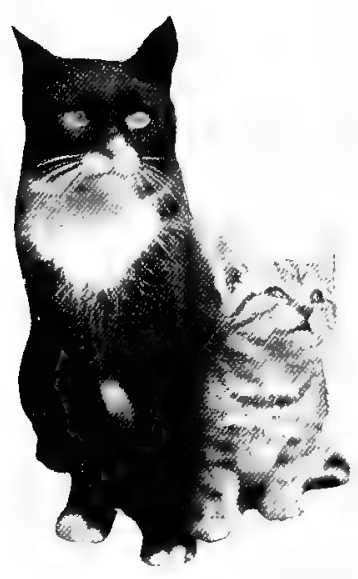

3. Short-haired cats. Black and white, and tiger marked.
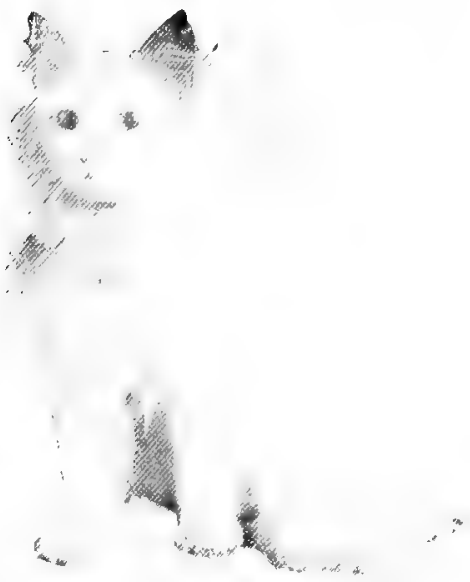

4. A white long-haired Angora cat.

FIG. 389. - A group of domestic cats, illustrating the results of domestication. 
maltese. Cats are carnivorous. Since they are sly, noiseless of tread, and quick of movement, they are the most efficient check upon the multiplication of house mice and rats (Fig. 389).

The dog belongs to a species that hunts in the wild state in bands or packs. It becomes attached to man, and readily removes with him to live in a new locality. Numerous races are recognized, varying in size and proportions of parts. The mastiffs and great Danes are breeds of large size, while the Japanese bulldogs and the toy spaniels are very small. The hair of dogs, like that of cats, is either long or short. It may be either straight, or curled as in the setters. In color it is white, black, red, and piebald, that is to say, a mixture of all three colors. Races of dogs differ in their mental as well as their physical attributes. Some dogs, like the collies, are gentle, while others, notably the bulldog, are very pugnacious. The dog was probably one of the first animals to be domesticated by man, although economically less useful to him than other races later acquired (Fig. 390).

Cattle are easily maintained in confinement, and furnish milk, meat, and hides. They originated from some unknown Asiatic species and have been domesticated for over 6000 years. The races differ in size and in the quality and quantity of milk. The large Holstein produces the greatest amount of milk, while the small Jersey produces milk which contains a large percentage of butter-making fat, and the Hereford and Angus breeds produce large animals for beef.

Horses were domesticated for purposes of transportation and general work. It is helieved that two species have been combined to make our common carriage horse. One is the small Siberian pony that was early brought into central and 

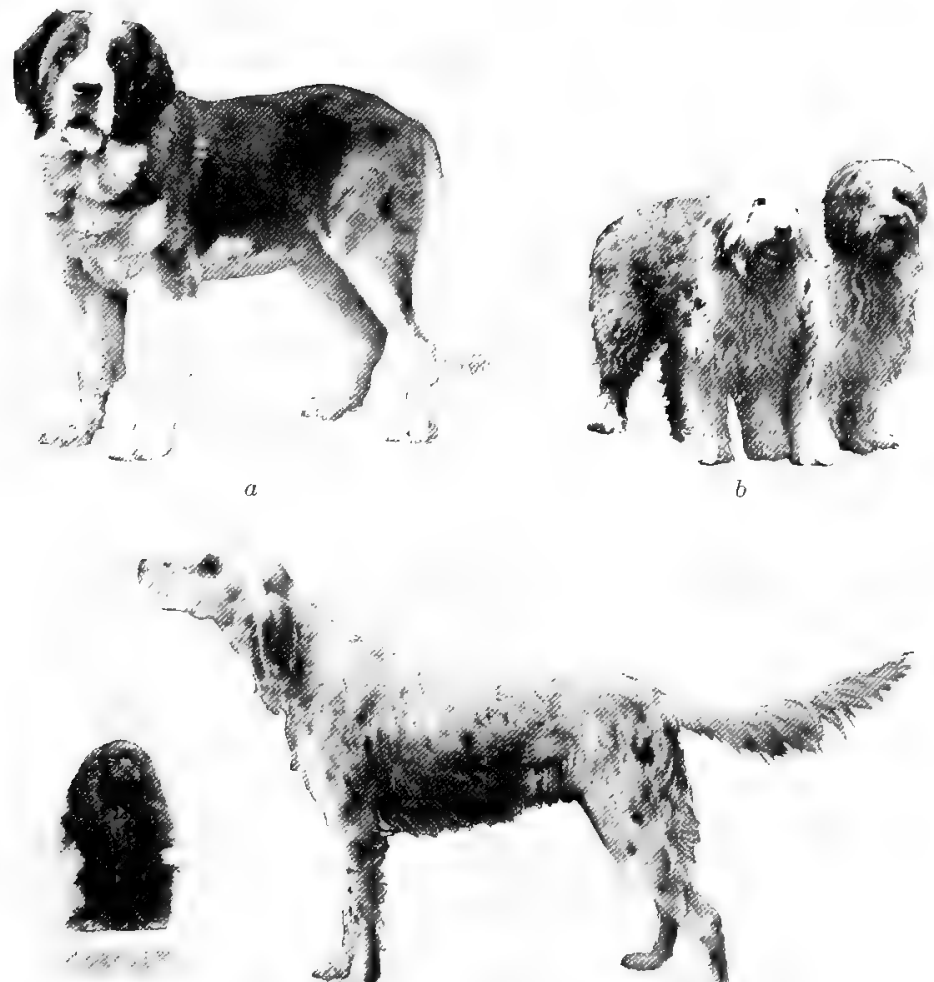

$c$
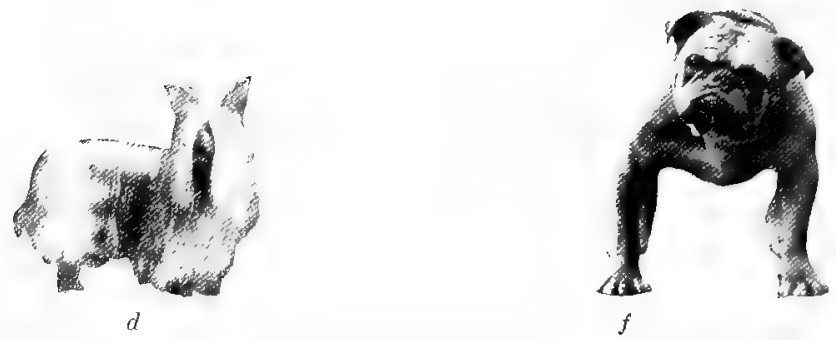

FIG. 390. - Types of races of domestic dogs : $a$, rough-coated St. Bernard ;

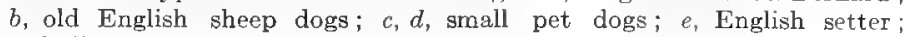
$f$, bull dog. 
western Europe; the other is the large, more gracefully molded Arabian horse. The horse of the ancient Gauls was so small that it was rarely used for horseback riding, but only for drawing chariots. Later it was much improved by crossing with the Roman horses, which had much Arabian blood. Horses range in size from great truck and draft horses of the Percheron type to the little Shetland pony. In color they are white, black, chestnut, and red, or bay, or the colors may be mottled and dappled. The gait of the horse also varies from running to pacing and trotting.

Sheep and goats have been domesticated both for their flesh and for their wool or hair. Goat's milk is especially prized in hospitals as an excellent food for young children and invalids, and from it cheese is made. The different races of sheep are characterized by various qualities. Thus, while most breeds are hornless, the Dorsets are horned. The merinos have very abundant wool, which is of good quality as well. The Southdowns have black faces and feet and are prized for the quality of their mutton. Of the goats, the two principal domesticated varieties are the short-haired and the long-haired, or Angora. The hair of the latter (mohair) is used in the manufacture of a cloth to cover furniture and buttons, and is employed for other purposes where great resistance to wear is essential.

Domestic rabbits depart little from the wild type although they have long heen kept in captivity and bred for food and for their hair which is used in the manufacture of felt. Both longand short-haired varieties are known. The ears of some varieties are short, while others have ears so long (lop-ears) that they drag upon the ground. Guinea-pigs occur in races that vary in color and length of ears. 
Of the domesticated birds the poultry are the most important. Under the term "poultry" are included the common fowl of the barnyard, ducks, geese, turkeys, guinea-fowl, and peacocks. The common fowl is one of the main sources of animal food in the United States. The annual value of eggs produced and poultry sold is estimated to amount to about half a billion dollars. A hen may lay eight times her weight in eggs in a single year at an average total valuation of $\$ 3$ for the year. The principal kinds of fowls are the game breeds, ${ }^{1}$ which are most like the wild fowl of the jungle; the Mediterranean breeds, ${ }^{2}$ which are prolific layers, but clo not, as a rule, incubate their eggs; and the Asiatic fowls, ${ }^{3}$ which are valuable for their great size and because they make excellent mothers. Combinations of these three groups have been made in profusion. Fowls have been kept under domestication in China for over 2000 years. They are not mentioned in the Old Testament, and hence probably reached Syria only shortly before our era began.

Pigeons have been derived from a blue, wild, rock pigeon having two black bars on the wings. From this ancestral form over a score of well-marked varieties have been produced by the fanciers. The pouters, fantails, and the tumblers are familiar examples. Not only are pigeons interesting to bird lovers, but they have considerable economic value, since the young birds, known as squahs, are highly esteemed as food because of their gamy flavor.

Of the fishes only the goldfish can be regarded as domesticated. It has been cultivated by the Chinese and Japanese in a great variety of colors and with extraordinary modifications of the fins.

${ }^{1}$ Fig. 391, c. ${ }^{2}$ Fig. 391, a. ${ }^{3}$ Fig. 391, d. 

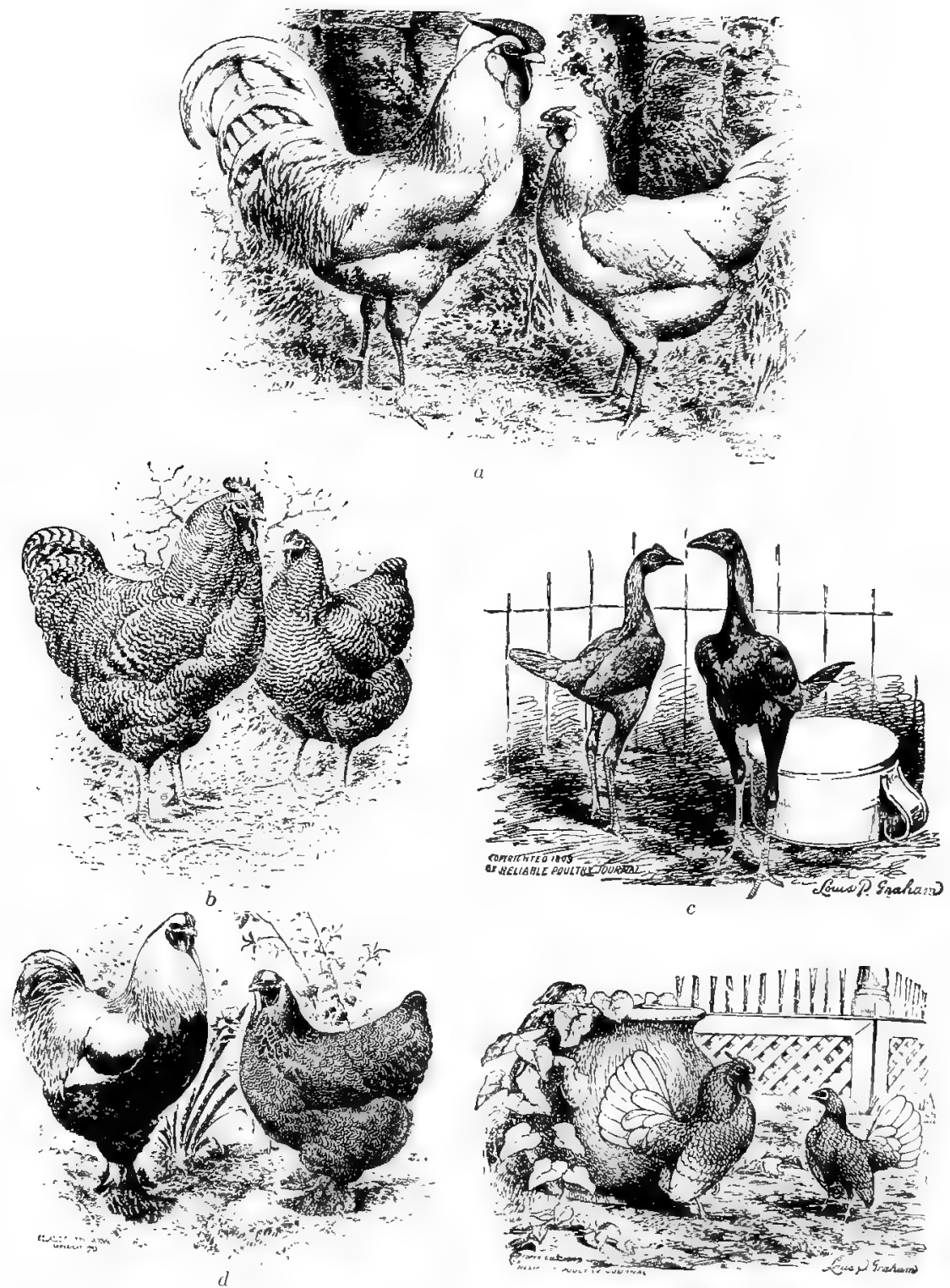

$c$

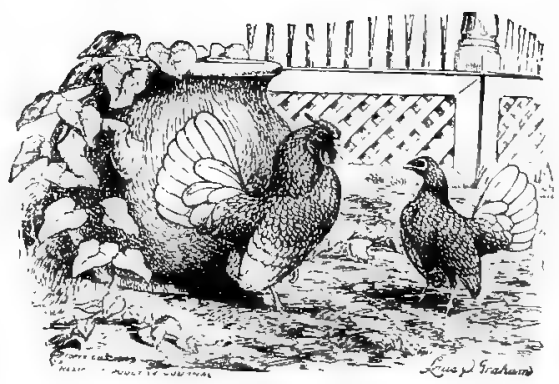

FIG. 391. - Types of domestic fowl: $a$, rose-comb white leghorn; $b$, barred Plymouth Rock; $c$, English game bantams; $d$, dark Brahmas, male and female; $e$, seabright 
Among insects bees have been domesticated from early times. The habits of the tame bees differ little from those in the wild state. In place of a hollow tree a box is provided which is so arranged that an excess of honey may be withdrawn without jeopardizing the life of the colony. The different races of domesticated bees differ much in color and in amiability. Perhaps of greater economic importance than bees are the silk moths, which manufacture silk threads in the construction of their cocoons. By proper treatment in hot water the threads are unwound from the cocoon. A number of these fine threads are spun together into stouter threads suitable for use in the manufacture of silk cloths.

This review of domestic animals shows that species that are under the care of man are much more variable than wild species. Why is this? Because man controls the breeding of domesticated animals. He carefully observes the young produced each year, and selects those that best conform to his icleal, or which possess some striking peculiarity which may be of economic importance. Any such peculiarity of an individual will be transmitted to its offspring. Thus a race may be improved or a new one founded. In the formation of perfected races, two processes are involved. First, an individual must appear with some new, some peculiar characteristic. Second, there must be a selection, a preservation, of the most perfect descendants of this individual. By such means the race is improved. Charles Darwin, ${ }^{1}$ to whom is due the present acceptance by naturalists of the theory of evolution, came to the conclusion that nature works with species in the same way that man does. Of the vast number of individuals produced in each generation in the wild state only a few survive, and these,

1 Fig. 392. 
in the long run, will be the most perfectly fitted to their environment. Darwin, however, dicl not sufficiently appreciate the process in nature that corresponds to the breeder's preservation of a new peculiarity. The Dutch naturalist De Vries has shown that in nature peculiarities, mutations, frequently suddenly occur and these may constitute the beginnings of new species. These two processes, the occurrence of variations and the inheritance of them, are sufficient to bring about those great changes in organisms which constitute evolution.

As a concrete illustration of the evolution of a domestic race, the fancy mice may be taken. Fancy mice have been derived from the house mouse. The house mouse is of an ashy gray Fig. 392. - Charles Darwin.

color. When its hairs are carefully examined, it will be found that they are black at the base and reddish yellow near the tip. Wild mice, like all other animals belonging to the class of mammals (including man), sometimes produce individuals without pigment in the skin, hair, and even the eyes. Such individuals are called albinos, and the peculiarity is designated as albinism. Albino or white mice with pink eyes have this peculiarity, that when bred together they prorluce only white mice. But when a white mouse is bred with a house mouse, none of the offspring are white. However, when the gray lescendants of white and house mice are bred together, one-fourth of their offspring will be white. This statement 
holds true not only for the inheritance of the color of mice but of most other animals. Indeed, many other characteristics of both plants and animals are inherited in these same proportions. The reason for this law is as follows: when the parents differ greatly in that one has and the other lacks a characteristic, the differences in the parents do not blend in the offspring, but all of the offspring show the characteristic. This presence of a characteristic is said to be "dominant" over its absence. The absence of the character - the recessive condition - is, however, not lost but exists in the reproductive cells of the offspring; half of the reproductive cells possess the characteristic and half lack it. Now if two individuals with an equal number of germ cells of the dominant and the recessive types are crossed, their germ cells meet in pairs, and it can be shown that, in the long run, the following four combinations of the two types are equally apt to occur. In the following formula the letter $d$ stands for the dominant condition, the letter $r$ for the recessive, the sign $\delta$ for the germ cells from the male parent, and the sign $\&$ for the germ cells from the female parent.

$$
\hat{\delta} d \& d, \hat{\delta} d \text { \& } r, \hat{\delta} r q d, \hat{\delta} r \& r \text {. }
$$

Whenever the combination contains the dominant character, the body of the fully grown offspring will show only the dominant character. It is easy to see that three-fourths of the offspring will be dominant, and one-fourth recessive. The foregoing law and its explanation were discovered forty years ago by a monk, Gregor Mendel, in his monastery garden in Austria. ${ }^{1}$ The law is important because it enables us to predict what proportion of the grandchildren will show the dominant character of their grandparents or its absence. Men- 
del's law thus affords a sort of explanation of why a child often resembles a grandparent rather than a parent. For a recessive condition that appears in only one grandparent on each sicle cannot appear in the following generation, but only in the grandchildren.

In addition to albinos breeders have obtained mice without the black pigment in the hair; the result is a golden yellow.

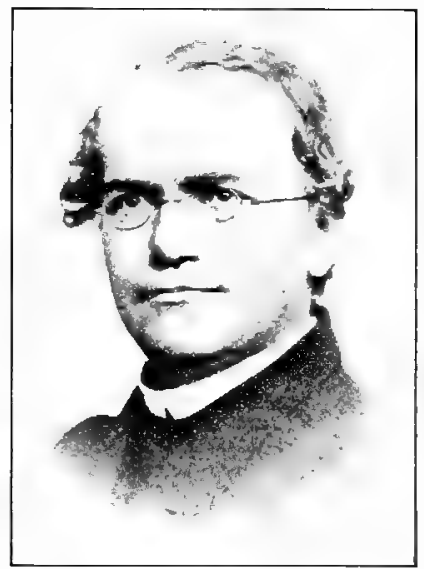

FIG. 393. - Gregor Johann Mendel. By reducing the yellow at the tips of the hair, the color becomes chocolate. When the red and yellow are both absent from the tips, a black race is produced. In addition, some mice move in circles, producing the race known as waltzing mice.

Mice are of interest not only on account of the evolution of the fancy races, but also on account of the rapidity with which they as well as their allies, the rats, have spread over the world. The house mouse was originally limited in its distribution to Asia. It made its way into Europe. By hiding in the cargoes of vessols, it has made its way over the whole world. America originally had not a single representative of the genus Mus to which rats and mice belong. Both rats and mice were imported to America by the carly explorers. Of the rats the roof rat seems to have been imported by the early Spanish discoverers to the Southern States, where it still persists. It originated in Egypt. The sccond was the black rat, believed to have 
been imported to America about 1544. It has existed from time immemorial in Europe; it has a mild disposition, and from it the white rats we keep as pets have been derived.

The brown, or Norway, rat has been the latest importation. The history of its migrations has been written. Probably originating in central Asia, it crossed the Volga in great troops in 1727, occupied Russia in 1730, France in 1750, and Denmark about 1810 . Before the advance of this powerful and aggressive foe, the black rat of Europe gave way and became wellnigh exterminated, although of late it is said to be reasserting itself in Germany. The brown rat was introduced into America in 1775, has spread over the whole country, reaching the Pacific coast ahout 1855 and, as in Europe, has nearly exterminated the black rat except in inland towns remote from railroads.

The habits of rats and mice are well known. They inhabit our buildings, gnaw our doors and furniture, destroy our provisions, kill poultry, and aid in spreading disease. They shun the light, living in holes during the day, run with great agility, and are capable of making long leaps. Owing to their instinct to go into holes, they are easily trapped by a funnel-shaped opening leading into a closed box. Despite the ease of trapping and their destruction by cats, they maintain themselves by virtue of a great fecundity, for, if no deaths occur, more than a hundred young may, in one year, descend from a single pair. The food of mice is very varied. They naturally thrive best on a vegetable diet; oats especially are recommended for tame mice, and hard-shelled nuts are useful because the mice keep their teeth sharp by gnawing the shells. If the teeth are not kept worn off, they soon become inconveniently long, owing to the fact that they grow continuously throughout 
life, and are not formed, once for all, like our teeth. In addition to plant materials, rats and mice eat a certain amount of animal food.

Rats and mice belong to the class . Iammalia ${ }^{1}$ characterized by having milk glands for the nourishment of the young. Most mammals have also hair, although in the case of porpoises and whales the hair is nearly or quite absent.

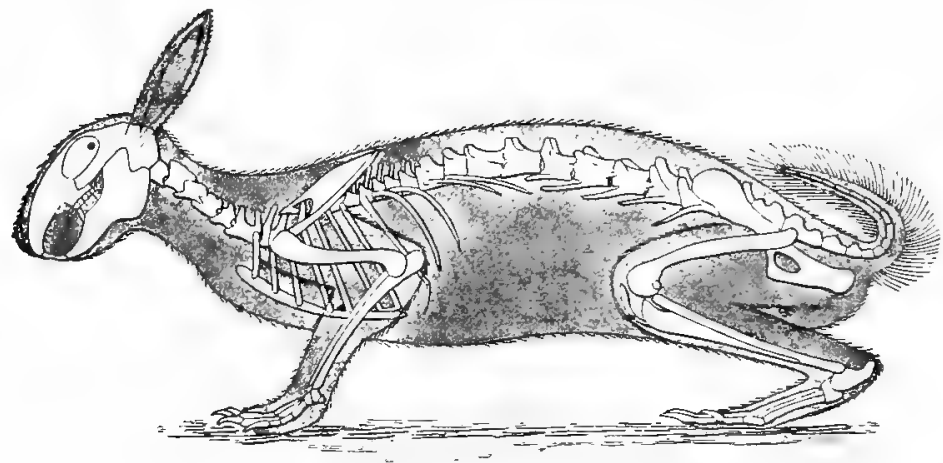

FIG. 394. - The rabhit. Lateral riew of skeleton enclosed in outline of body. From Parker and Haswell.

The structure of the mammalia may be illustrated by a study of the rabbit.

General Form of the Body. - The body consists of head, trunk, and tail, the latter in a rudimentary condition (Fig. 391). The head is connected to the trunk by a relatively narrow neck to insure mohility. Its large size results from the fact that it hears the strong teeth, brain, sense organs, and their supporting and protecting skull. Nearly the entire body is covered with hairs which develop in the skin. At the base of each hair is usually a gland that secretes an oily substance-sebaceous

${ }^{1}$ From mammals, belonging to the breast. 
gland. Along the under side of the body, best developed in the female, are two rows of milk glands. Each milk gland is an aggregation of sebaceous glands whose secretion is modified to furnish a nutritive fluid for the young mammal.

Two pairs of appendages are present, the hinder pair functioning the more vigorously in locomotion. The entire hand or foot does not lie flat on the ground as the sole of the human foot does, but the wrist and heel are slightly elevated, while in the horse the wrist and heel are elevated far from the ground, since it stands on the tip of a single finger. In the rabbit the hand has five digits, but the foot shows a reduction to four.

Skeleton. - The vertebral column of the rabbit, as of other mammals, is divisible into five regions: (1) The neck, or cervical vertebræ; (2) the chest, or thoracic vertebræ; (3) the waist, or lumbar vertebræ; (4) the pelvic, or sacral vertebræ; (5) the tail, or caudal vertebræ. Of the neck vertebræ there are seven, as in all other mammals whether the neck is short, as in the whale, or long, as in the giraffe; but the number of the other vertebræ is variable. Each vertebra bears a spine and processes for the attachment of muscles and ligaments. The thoracic vertebræ bear ribs. The anterior ribs abut ventrally upon a long rod, the breastbone, or sternum. The skull is heavier than that of the bird; the huge bone for the lower jaw - the quadrate - is a part of the brain case or cranium. A separate cheek-bone protects the eye cavity below.

The shoulder girdle consists on each side of two bones, forming a $V$, which embraces between its arms half of the thorax, and the skeleton of the appendages is fastened to the apex of the V. The dorsal arm of the $\mathrm{V}$ is the shoulder-blade (scapula); this is broad, and has a high ridge for the attachment of the muscles 
of the arm. The ventral arm of the $V$ runs down to the sternum, which affords it a firm support - this is the collar-bone. The skeleton of the fore limb consists of the same parts as that of man. They permit of a large amount of bending and rotation of the appendages. The pelvic girdle forms a complete ring surrounding the viscera of the posterior part of the abdomen. It consists on each sicle of three pieces, fused into one in the adult, which radiate from a centre as spokes from a hub, where the skeleton of the leg impinges. One of these pieces passes dorso-anteriorly and is fastened to the sacrum; it is called the ileum; the other two pass ventrally, each to unite with its fellow of the opposite side in the mid-ventral line. Indeed, all four bones are tied together here. The anterior pair of these bones is called the pubis, the posterior pair the ischium - being the bone which supports us when we sit. The rigidity and size of the pelvis is mecessary because it has to support the whole body when the animal sits up on its hind legs. The skeleton of the hind limbs of the rabbit differs little from that of man except in having only four toes instead of five.

Organs and Function of Digestion. - The teeth show an advance over those of reptiles in reduction of number, in specialization of form, and in being each lodged in a special socket. The number of dentitions has become reduced to two, the milk teeth and the permanent teeth, in contrast to the crocodiles, where the dentitions are changed throughout life. In the permanent dentition the front pair of teeth are called cutting teeth, or incisors. In rabbits the two middle incisors of the upper jaw continue to grow throughout life and, as the front edge only has a thick layer of hard enamel, the teeth keep a sharp, chisel-shaped edge very useful for cutting. The persistent growth of the teeth keeps them from wearing off com- 
pletely as a result of persistent use in gnawing hard vegetahle fibre. The rabbit has no canine teeth, as in man and carnivorous animals, where they are used for tearing flesh; and an

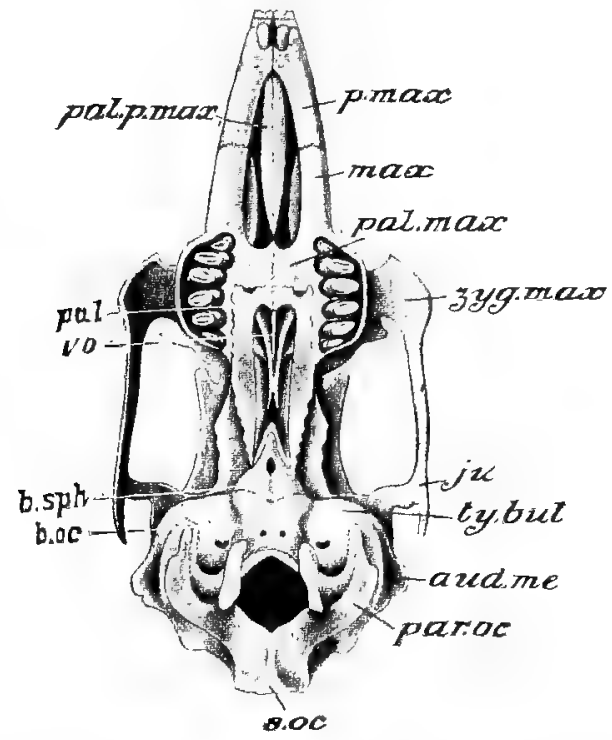

FIG. 395. - Ventral view of skull of rabhit. Bones named are as follows: p.max, premaxilla; pal.p.max, palatine process of premaxilla; max, maxilla; palmax, palatine plate of maxilla; pal, palatine bone; vo, vomer; $b . s p h$, basisphenoid; b.oc, basioccipital; $s . o c$, supraoccipital; zyg.max, zygotic process of maxilla; $j u$, jugular; ty.bul, tympanic bulla; aud.me, external ear opening; par.oc, paroccipital process. From Parker and Haswell.

empty space in the jaw is followed by a series of chewing teeth, or molars (Fig. 395).

The food passes first into the mouth cavity, where, by the help of the tongue, it is ground by the molars and at the same time moistened and acted on chemically by the secretions of the salivary glands. Then the food passes through a gullet to the 
stomach, where it is well churned and subjected to pepsin and hydrochloric acid. Thence the food goes to the first part of the small intestines (duodenum), where it is treated to the action of the bile and the pancreatic juice. The food, now digested, passes slowly down the long, small intestine, which is richly supplied with lymph and blood-vessels, into which the food passes to be carried away to the tissues. Further absorption takes place in the large intestine, and finally the unabsorbed remains collect in the rectum.

Organs of Circulation. - The circulation in general resembles that of birds. The heart is divided into two separate halves, each with its auricle and ventricle. The right auricle receives a pair of large veins from the fore limbs and head and a single vein coming from the posterior part of the body. The blood thus collected in the right auricle passes to the right ventricle, and thence is pumped to the right and left lungs. From the lungs it returns to the left auricle, to he pumped by the left ventricle into the aorta. The aorta gives off arteries to the fore limbs and head, and then passes on the left (instead of the right, as in birds) of the gullet to form the dorsal artery, which supplies the hinder part of the body and the viscera. While the blood from the tail, hind legs, germ glands, and kidneys goes directly back to the heart, the blood from the food-canal flows first to the liver to deliver its load of food there, and then passes on to the right auricle.

Organs of Respiration. - The air that enters through the nostrils crosses the back of the mouth and enters into the upper part of the windpipe or larynx, through a slit that is guarded from the entrance of food by a fold - the epiglottis. The wall of the larynx contains certain large cartilages which support and control the vocal cords; these are represented in 
man by the "Adam's apple." The wall of the windpipe (trachea) contains small rings of cartilage which serve to support it and prevent its collapse on exhalation of the breath. Below, the trachea divides into two tubes (bronchi), one of which goes to each lung. Here it divides repeatedly, and finally the smallest branches open into a thin-walled air vesicle called a lobule of the lung. The wall of the lobule is covered with a network of blood capillaries, and here oxygen passes from the air to the blood.

Organs of Excretion. - The kidneys are a pair of oval, beanshaped bodies lying close to the dorsal wall of the abdominal cavity. As in the pigeon, the kidney is a mass of tubules each associated with a capillary network where the waste products pass from the blood to the cavity of the tubules, whence they are collected in the central cavity of the kidney, and thence conducted by the ureters to a single urinary bladder, which is periodically emptied.

Organs of Reproduction. - The male and female germ glands - testes and ovary - are small organs lying in young animals in the dorsal part of the abdominal cavity. The products are carried by special tubes to the exterior - the sperm ducts and the oviducts. The eggs are of small size and not surrounded with albuminous and limy covering, as in birds, nor is there much food yolk. The reason for the difference is that, whereas the eggs of hirds, developing independently of the mother, must be supplied with a protective covering and a supply of food-stuff, the egg of the rabbit is not only fertilized in but develops in the oviduct, is protected by the maternal body, and is supplied with food from the maternal bloodvessels. Only after the embryonic rabbit has become well developed, has gained its coat of hair, and is almost ready to 
run about, is it expelled from the oviduct (horn) to live its separate existence.

Muscular System. - The muscles of mammals are developed in close relation with the skeleton. On the head, besides a thin sheet of skin muscles, the largest development is that of the jaws. On the trunk is a general skin musculature and a powerful dorsal musculature used in jumping. Then there is a rudimentary set of muscles uniting the rilss, and a muscular

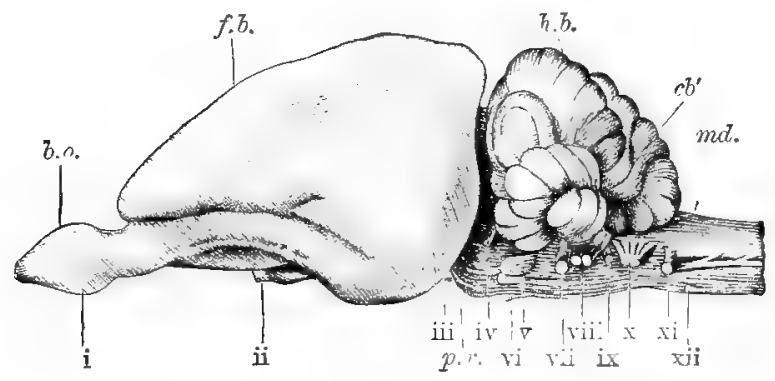

FIG. 396. - Brain of the rabhit seen from the right side: h.o, olfactory lobe; $f . h$, cerebrum; $h . h$, rerchellum and its median lobe, $c h^{\prime} ;$ md, medulla oblongata; p.e, the "pons" or hridge of transwerse fibres; $i-x i i$, cranial nerves. After Wicderwheim.

membrane (or cliaphragm) completely dividing the body carity into an anterior and a posterior portion. Both the rib muscles and diaphragm are used in breathing. The musculature of the appenlages is the most powerful, but so complex as to be beyond the limits of such a book as this.

Nervous System. -- The centril nerrous system consists, as in the pigeon, of a bruin and spinal cord. The chief advance in the brain is shown by the enlarged corebrum, showing traces of the follings of its surface which become more marked in the higher mammals and are dssociated with intelligence. 
Sense-organs. - In addition to certain diffuse senses, such as touch and heat and cold, the ralshit has complex organs of taste and smell, hearing and sight. The organs of taste and smell lie in the delicate lining of the mouth and nose - as small, diffuse sense cells. The ear is essentially like that of man, and differs from that of birds in the greater development of the cochlea, which, in the ralbbit, forms a close spiral of two and one-half turns. The eye lacks the pecten, and is more nearly

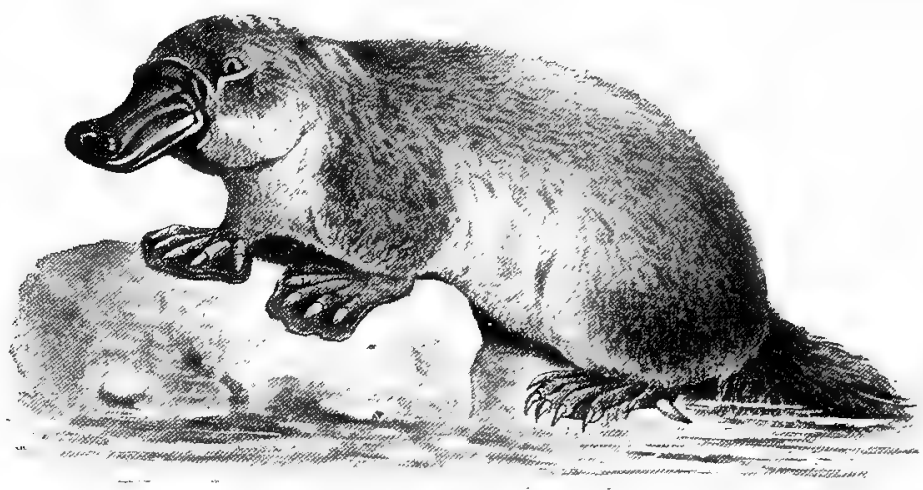

FIG. 397. - The duckbill, Ornithorhynchus anatinus. After Vogt and Specht.

spherical in shape. There are two eyelids; and the nictating membrane, so prominent in birds, is rudimentary.

Mammals are divided into three main groups. The division depends upon the condition in which the young are born. The lowest group is called monotremes. The milk glands are in a low state of development, and eggs are laid in the shell, as in reptiles and birds. There are two principal types, - the "Duckbill" (Fig. 397), with aquatic habits, and the "Spiny Ant-eaters" (Echidna, Fig. 398), inhabiting rocky places. Both types are confined to Australia and neighboring islands. 
In many ways this group seems to connect the mammalia with reptiles.

The second group is known as Marsupalia, because the mothers are provided with a marsupium, ${ }^{1}$ or pouch, in which the young are carried. The young are born very imperfectly developed. Immediately after birth they are placed in the

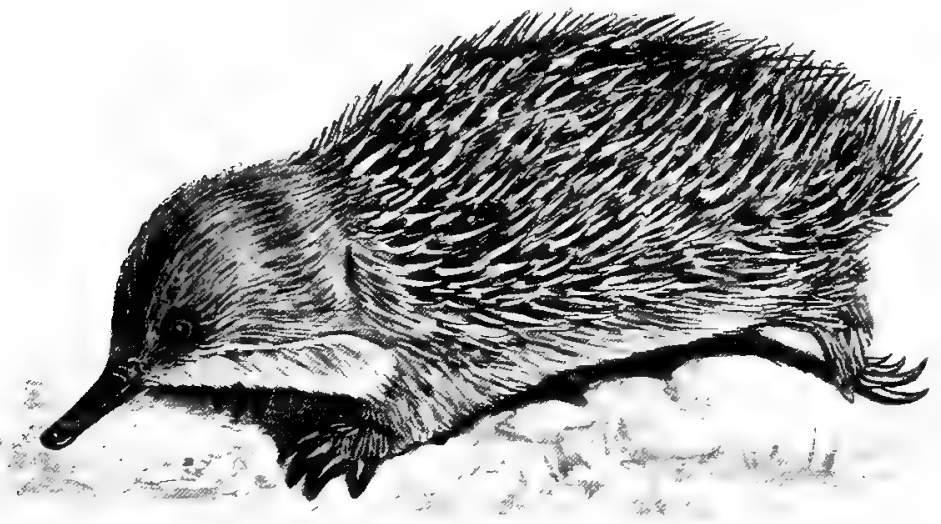

FIG. 398. - The spiny ant-eater, Echidna aculeata. After Vogt and Specht.

marsupium, where they become attached to the manmary glands which lie within the pouch. In this situation the young complete their development. All marsupials are confined to Australia and adjacent islands, excepting the family of opossums (Fig. 399), found only in the Americas. There is thus a great discontinuity in the distribution of marsupials. This is accounted for by the evidence that formerly the whole world contained marsupials, so that those liring to-day are the separated remnants of that once universal race. The opossums are

1 marsupium, a pouch. 
most numerous in the tropics, but the Virginian opossum ranges north to New York.

The third division of the Mammalia includes all of its remaining orders. These orders will be briefly considered in the following paragraphs.

The sloths and allies constitute a group that either have no teeth or imperfect ones. Here are associated with the

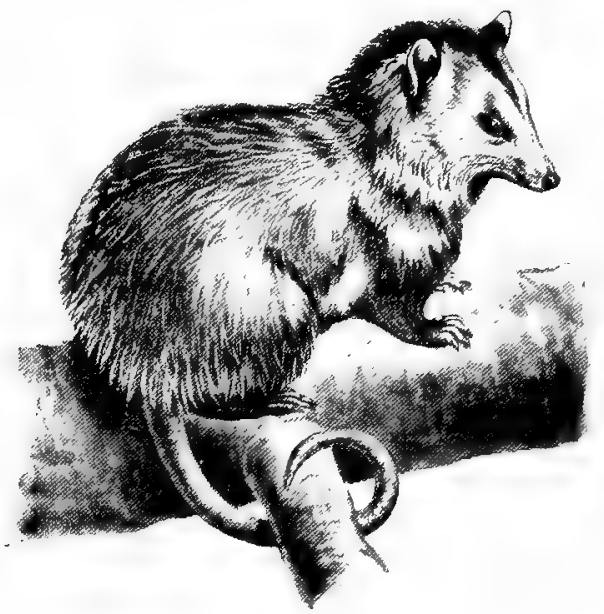

FIG. 399.- The opossum, Didelphys virginiana. After Vogt and Specht.

sloths the hairy ant-eaters, armadillos, scaly ant-eaters, and African ant-eaters. The three first-named families inhabit South America; the two latter, Asia and Africa. Here again, the discontinuity of the group indicates, what fossils prove, that the Edentata ${ }^{1}$ (as this group is named) have been killed off from the connecting continents. The sloths have cutting teeth, live in trees, and eat leaves (Fig. 400).

${ }^{1} e$, without; dens, dentis, tooth. 
The armadillos are protected by strong plates developed in the skin; they are chiefly nocturnal and omnivorous animals, and burrow rapilly. The other three families feed on ants and

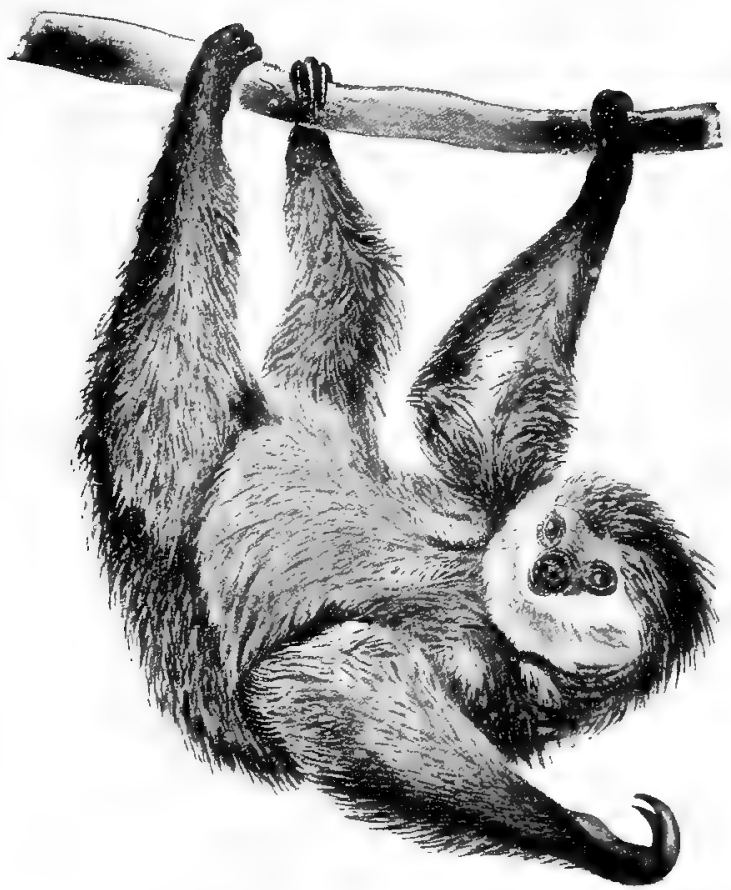

Fig. 40n. - Two-toed sloth, Choløpus. After Vogt and Specht.

termites, usually lack complete teeth, and either live in trees or burrow in the ground.

The whales and allies (Cetarew ${ }^{1}$ ) have taken to an aquatic life, for it is certain that their ancestors were land animals. The sea-cows (manatees ${ }^{2}$ ), found in rivers in various parts of 1 cetus, whale. ${ }^{2}$ From a native name. 
the world, seem ${ }^{1}$ to show a transition to the marine forms, such as the dolphins, the toothed whales (Fig. 401), and the toothless or whalehone whales. The largest of these whales the Greenland whale - reaches an extreme length of twentytwo to twenty-four metres, and a weight of over 100,000 kilogrammes. It is, indeed, the largest living animal. Although

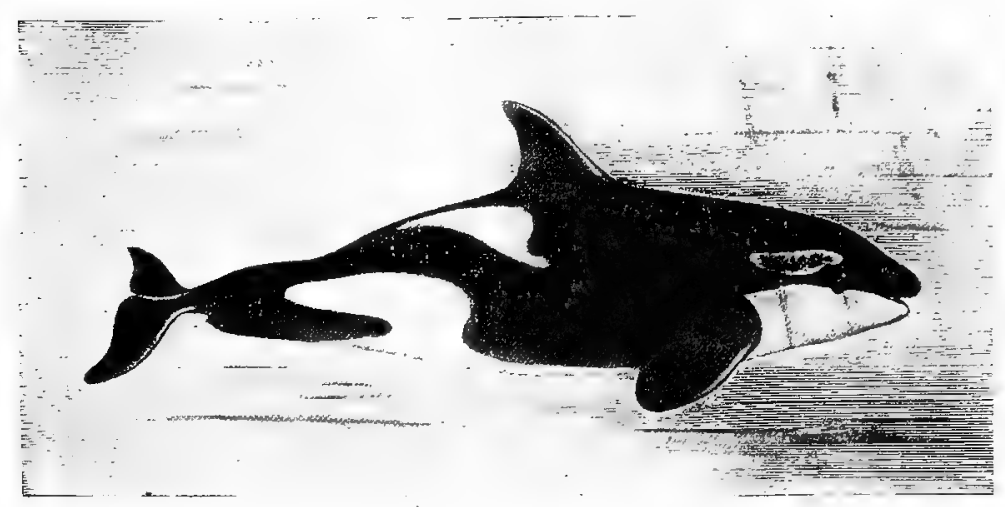

FIG. 401. - The killer whale, Orca. After True.

whales in general are partly adapted to an aquatic life, they still retain the essential mammalian qualities. They breathe air which passes to the lungs and is expelled again through the nostrils, which are placed high up on the hearl. The "blowing " of the whale is the forcible expiration of moisture-laden air, which becomes visible by condensation, just as our own breath does on a cold day. The young are necessarily born in the water, but the breeding habits are poorly known. The various Cetacea have diverse feeding habits. All are predaceous. The toothed whales feed on larger animals, the whalebone whales on floating fish, crustaceans, medusæ, and squids;

1 The relation to Cetacea is not close. 
their whalebone is, indeed, merely a strainer to let the water pass out of the mouth while the solid masses are retainerl.

The order of hoofed mammals includes a large number of animals, almost all of which are closely related and have never more than four functional toes, excepting in the allied groups of

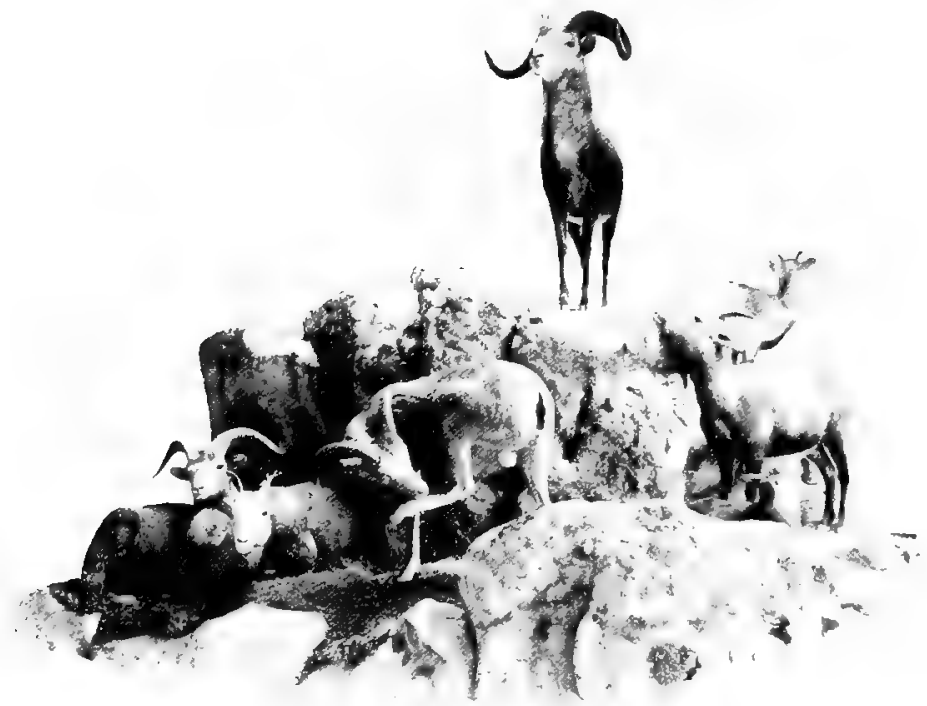

FIG. 402. - Stone's Alaskan black sheep. Photo. of a group in the Field Columbian Museum.

elephants and certain small animals allied to the "coney" of Scrirture, where there are typically five. Of the true hoofed mammals we distinguish the even-toed and the odd-toed, which we may consider further.

The even-toed hoofed mammals include the hippopotamus and other pigs and the peccaries, the camels and llamas, the deer, the giraffes, and the antelopes, sheep (Fig. 402), and oxen. 
Excepting the pigs, most of these feed exclusively on plants. The giraffes and antelopes are characteristic of Africa; but the "mountain goat" of our highest ranges may be placed with the antelopes, as may also the chamois of Europe. The prong-horn of our southwestern plains is remarkable in having hollow horns like the antelopes, which are, however, shed like those of the deer.

The odd-toed hoofed mammals include the horses, tapirs, and rhinoceroses. The horses are remarkable in that they stand upon the tocnail of the middle digit - all the other digits being rudimentary or absent. While fossil remains of horses are found in all continents, the living species have come from Asia and Africa. The African species are striped (zeloras). The tapirs are found living to-day only in South America and southeastern Asia. They frequent the depths of forests near watercourses, and feed on leaves and shoots of shrubbery. The rhinoceroses of Africa, of India, of Java, and of the Malay Archipelago, are quite clistinct. All are large, stupid, and ferocious when attacked, feed on herbage, and wallow in pools.

The elephants are distinguished by their long trunks, great incisors (tusks), and huge, complex grinding teeth. The Indian and African types are quite distinct. Elephants are intelligent, tractable, and capable of doing much work for man. Their diet is vegetable, consisting especially of the leaves and young branches of forest trees, which they gather with their proboscis.

The moles and shrews are small mammals and chiefly terrestrial. One of our common families includes the moles which burrow in the ground, have small eyes and broad, shovelshaped fore feet, used for digging their tunnels. They feed chiefly on earthworms. The other common family is that of 
the shrews, which are mouse-like, live chiefly on the surface and in the woods, and feed on insects and small crustaceans.

The flesh-eaters (Carnivora ${ }^{1}$ ) include both land and marine forms. To the first group (Fig. 403) belong the cats (including tigers, lions, leopards, lynx, etc.); the ciret-cats, mongoose, ete.; the hyenas; the dogs (including jackals, wolves, and foxes); the bears; the raccoons; and the great fur-bearers, -

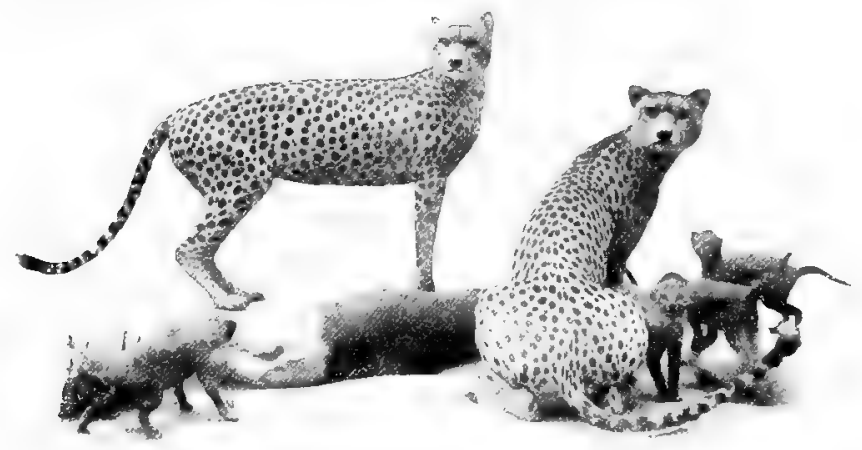

FIG. 403. - The cheetah, or hunting leopard, Felis jubata. Photo. of a group in the Field Columbian Museum.

martens, minks, weasels, hadgers and otters, and skunks. Marine Carnivora comprise the seals (Fig. 404), walruses, and sea-lions, the more valuable of which are disappearing as a result of man's lack of foresight. Altogether, the Carnivora comprise the most agile, the most intelligent, the most dreadful, and some of the commercially most important of fellow-animals.

The gnawing mammals include our types, the mouse and the rablit, and also the squirrels and marmots, heavers, jumping mice and gophers, and porcupines. The order contains no

${ }^{1}$ caro, carnis, flesh ; vorare, to devour. 
very large animals, as befits a group of burrowers - true contact lovers. The typical squirrels are, however, arboreal, and run over trees and from tree to tree; nevertheless, even they, by preference, make their nests in holes of trees. Our commonest squirrels are the gray, the little red, the striped or chipmunks, and the spermophiles of the Western States. On the whole, excepting perhaps the red squirrel, they are useful animals and deserve to be protected rather than slaughtered. It is shameful to see grown men shoot the harmless and com-

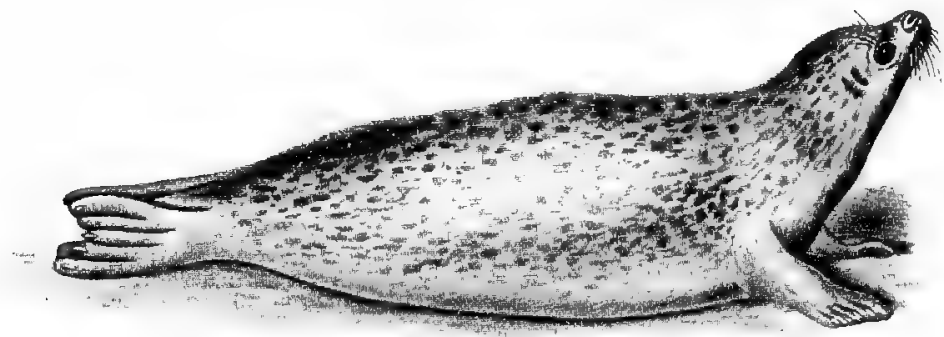

FIG. 404. - The harbor seal, Phoca vitulina. From Parker and Haswell, "Manual of Zoology."

panionable gray squirrel - one of the friendliest of the wild animals. Closely related to the squirrel are the prairie dogs and woodchucks, of which the former make extensive villages in the Great Plains regions, and the latter lives in solitary burrows throughout our northeastern States. The beavers are now almost exterminated. They were the leading engineers among animals, building dams across streams in order to make deep ponds for their protection. Near the middle of the pond a great house of mud and sticks was reared; the inner chamber lay above the level of the pond, but the entrance to it was under water. The pocket gophers (Fig. 405) are invet- 
erate tunnellers; their cheek pouches enable them to carry an extra supply of seeds and vegetables. The porcupine of our

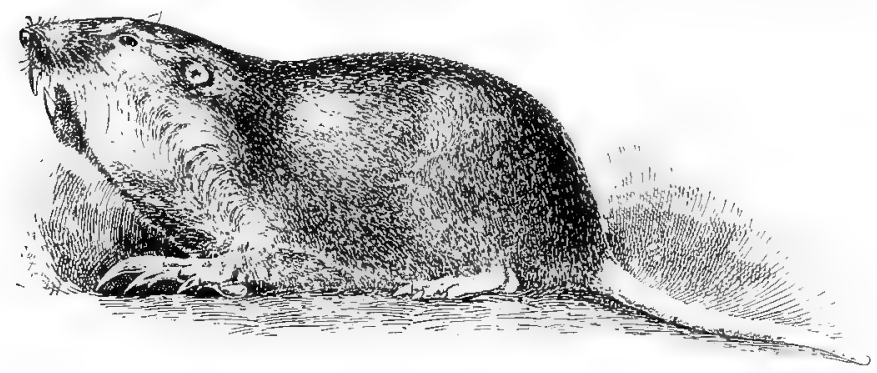

FIG. 405. - Geomys tuza, the Georgia gopher. One-half nat. size. After V. Bailey.

northern country is remarkable for its modified hairs, which form spines, many of which are hollow quills. These are formidable organs of defence. Finally, the hares and rabbits are characterized by their great ears, short tails, and swift flight;

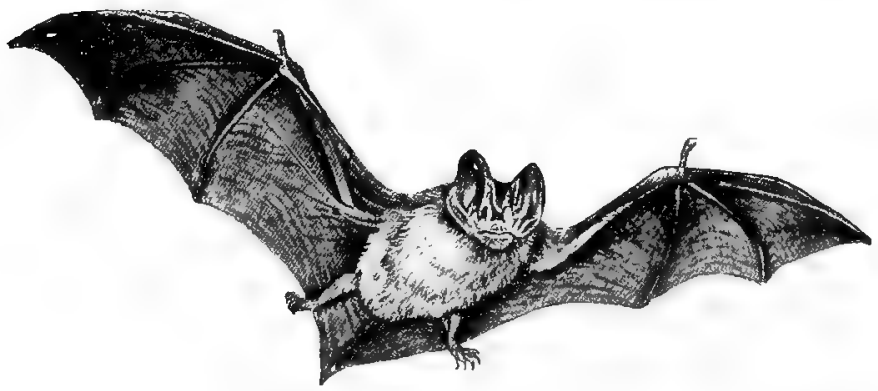

FIG. 406. - An insectivorous bat, Synotus. After Vogt and Specht. in these respects the hares have developed further than the rabbits.

The bats (Fig. 406) are extraordinarily modified mammals 
which, like the birds, seem to have penetrated into the air to prey on the flying insects. Not all bats are insectivorous, however, for certain Old-world bats feed on fruits. our commonest species are the little brown bats (with a nearly

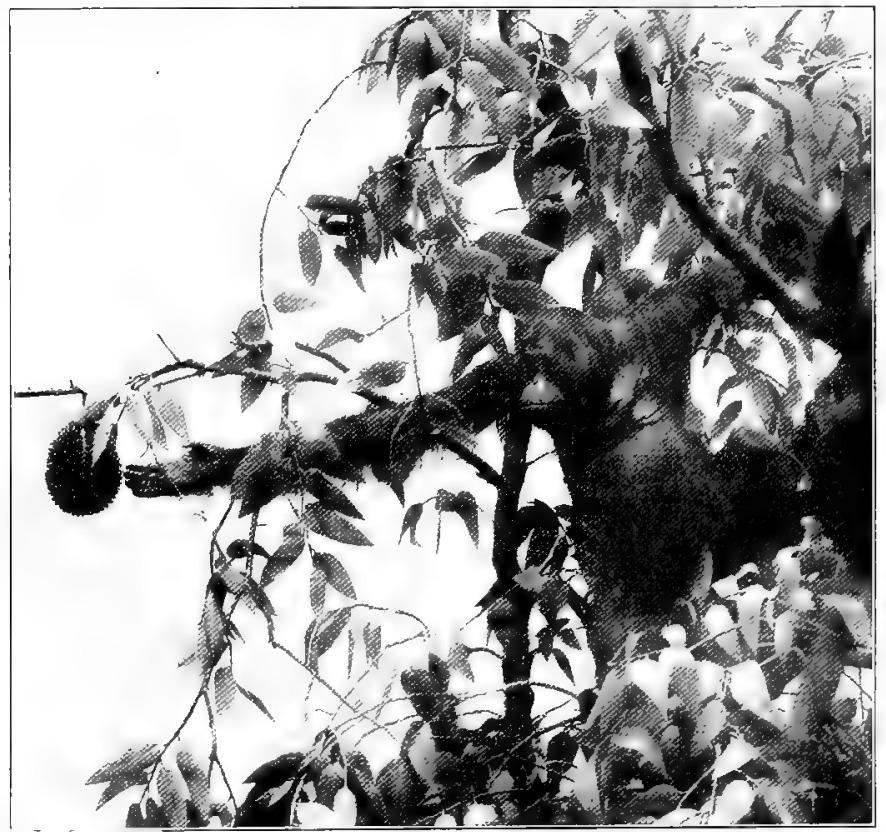

FIG. 407. - Simia satyrus, the orang-utan, in breadfruit trec. From a photograph of a group in the Field Columbian Museum.

furless wing), and the red bats (with patches of fur on the wing membrane).

The Primates ${ }^{1}$ are of interest because we ourselves are placed in this category, together with certain other animals that have attained a less lofty station. The lowest Primates 
are the lemurs, found chiefly in Madagasear. These have an arboreal habit, and feed on fruits, leaves, and small birds and insects. Next higher come the American marmosets, the howling monkeys, and the flat-nosed, prehensile-tailed American apes; still higher are the small-nosed, nonprehensiletailed apes, including the bahoons, mandrills, and macaques. Finally, come the tailless, manlike apes, found exclusively in the Old World - the gibhons, orangs (Fig. 407), chimpanzee, and the gorilla. The two latter are nearest to man, but one cannot say which is the nearer. For, while the chimpanzee approaches man more closely in facial appearance and in intelligence, the gorilla is more manlike in the size and complexity of the brain and in its habit of walking on the ground. There is no reason to doubt that man's species came off from the anthropoid apes; the discovery in Java of a fossil form (Pithecanthropus erectus) intermediate between man and the manlike apes is a strong additional piece of evidence. This differentiation of man's species probably began in late Tertiary times. 


\section{CHAPTER XXVII}

\section{THE DEVELOPMENT OF THE FROG'S EGG}

AlL living matter has the capacity of increasing itself under proper conditions to an almost unlimited extent, the food which animals devour being the material out of which the new living substance is made. This living substance exists in isolated particles, or masses, which we call individual animals or plants. The animal or plant has also at any stage a definite form which is not exactly alike in any two individuals, but is roughly alike within the "species." Now the number of individuals of any species ${ }^{1}$ tends constantly to diminish through death. It is actually maintained by reproduction, by a piece of the parent individual being cut off to form a new individual. This piece may be at first almost shapeless or approximately spherical. But as it grows larger it assumes more and more the form and complex structure of the adult. This process of growing into the adult form is development. In most of the more familiar cases development begins with an approximately spherical egg.

In the case of the frog, the egg is between one and two millimetres in diameter. The eggs, which are numerous, are laid in a common jelly, and during development float near the surface of the water in which they are laid. The first visible changes are furrows running across the surface of the egg, as a result of which the egg becomes divided into small areas which correspond to a division of the whole egg into " cells." This stage of development is called cleavage." Toward the end 
of the cleavage stage the white or yolk side of the egg becomes enveloped by the black dividing cells, excepting for a small white plug elged by a sharp groove. This is where cells have

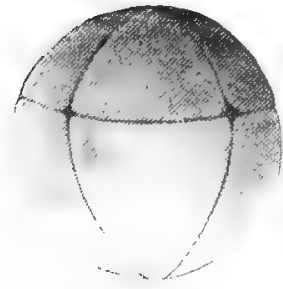

A

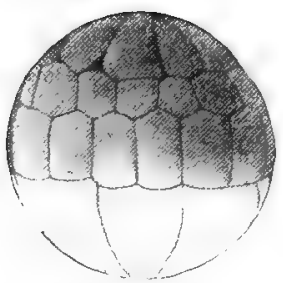

D

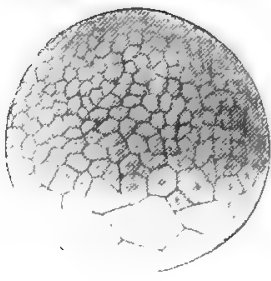

G

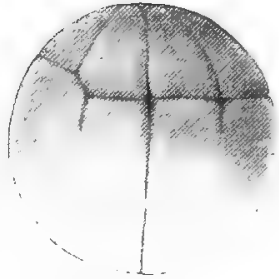

B

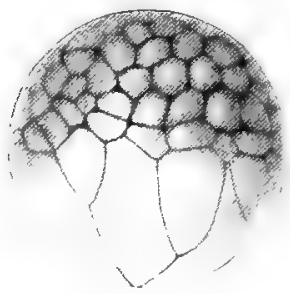

$E$

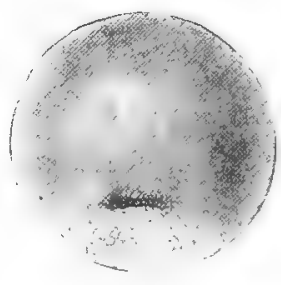

$\mathrm{H}$

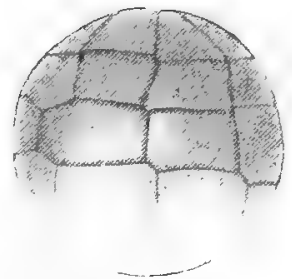

C

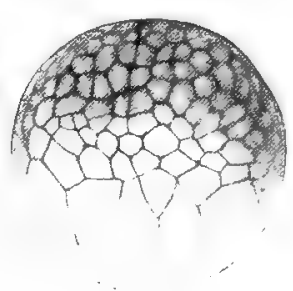

$\mathrm{F}$

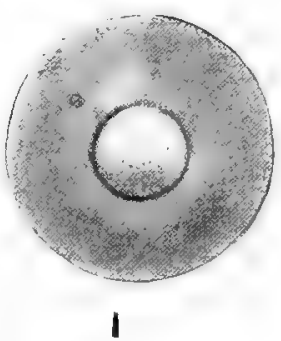

FIG. 408. - Cleavage of frog's egg, A-G; H, beginning of gastrulation;

I, the white plug. From Morgan, "Development of the Frog's Egg." 
rolled in to form the beginnings of the food canal (Fig. $407 \mathrm{H}$ ). Next, on the future dorsal side of the embryo, two ridges arise with a furrow between them; they are the beginnings of the brain and spinal cord (Fig. 409). When the furrow is closed by the ridges folding over it, the central nerve tube is formed and begins to sink into the body. Later the trunk elongates, nerves and muscles are formed, gills sprout out, and the taclpole is formed (Fig. 410).
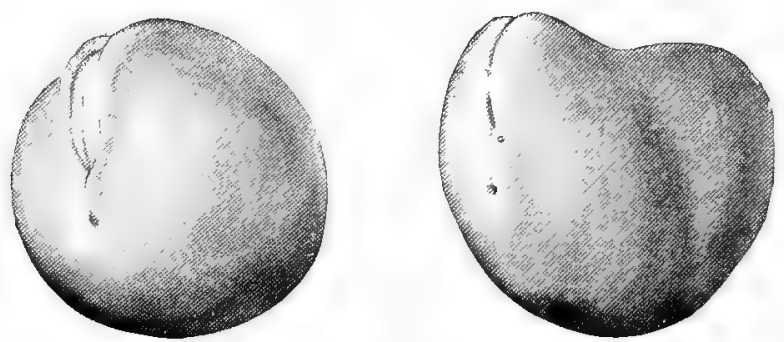

FIG. 409. - Two stages in the development of the frog while the brain and spinal cord are arising. From Morgan, "Developnent of the Frog's Egg."

Effect of Heat and Light on Development. - Eggs developing in normal environments in nature arrive at nearly the same end-result, even when the environments are not identical. We gain, in consequence, an impression that development proceeds unaffected by any changes in the outside world. But this is not true. For one thing, the rate at which the development of frogs' eggs proceeds depends closely upon the temperature of the water. They develop most rapidly at about $30-32^{\circ} \mathrm{C}$. If the temperature is elevated above this point, the rate of development is retarded, and finally ceases at about $40^{\circ} \mathrm{C}$. So, likewise, as the temperature is lowered, the development is retarded, until at the temperature of freezing water 
it ceases (Fig. 411). If the temperature is too high, development may be abnormal, so that a monstrosity is produced.

Light has a less striking effect on the development of the frog. If light is exclucled from the developing eggs, they will develop more slowly. The acceleration of development by rather high temperature and by daylight is probably due to a chemical effect of these agents. It indicates that development is a complex chemical process.

Healing and Regeneration. - If the egg of a frog be pricked slightly, there will be a loss of substance, and the resulting

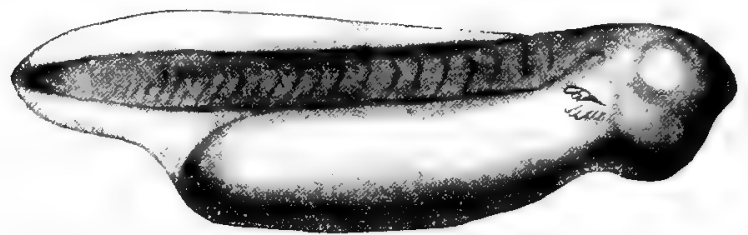

FrG. 410. - Young tadpole of the frog. From Morgan, "Development of the Frog's Egg."

embryo will be at first abnormal. Later, however, this abnormality will become smoothed over by appropriate development. So, also, if the tail of the developing larva is mutilated, the wound will heal and the missing parts will be re-formed. This capacity of the living organism to restore the normal form after mutilation is seen also in man. For if some of the skin be cut away, or even if parts of internal organs are removed the wounds will not merely heal, but the lost part will regenerate. The remarkable thing is that in regeneration almost exactly that is produced which was lost. Both regeneration and healing in the adult are a survival of the same capacity for development which we see in the egg. 
Postembryonic Development of the Frog. - After reaching a certain stage of development, the embryo frog, called tadpole,

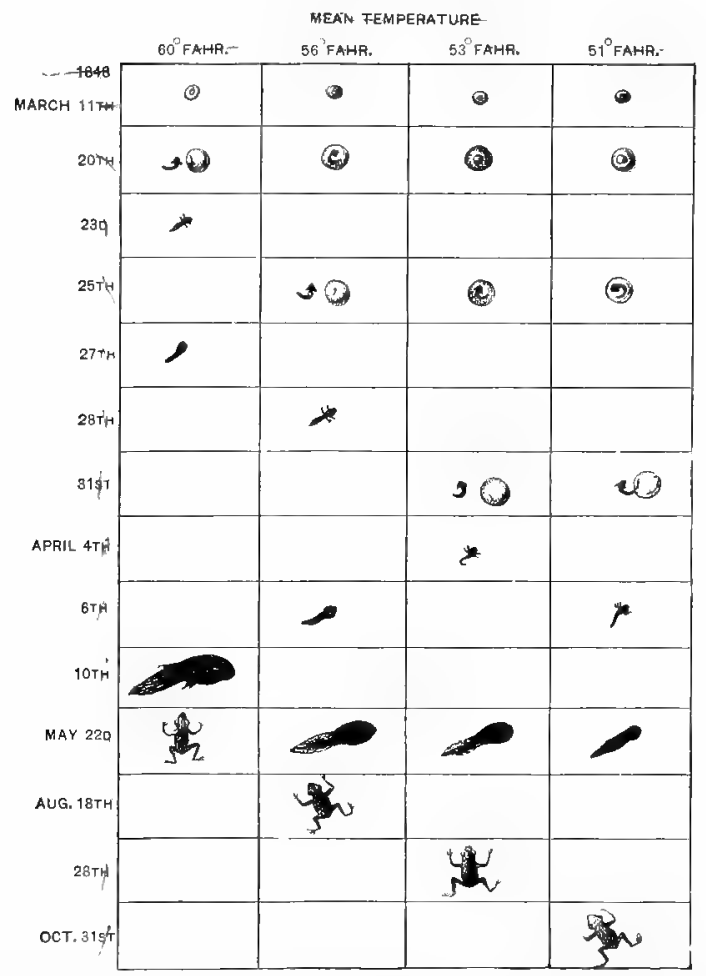

FIG. 411. - A chart showing the correlation between the stage of devclopment of the frog on successive days and the temperature at which it has developed. From Higgenbottom.

hegins to develop legs. The hind legs first appear, afterward the fore legs sprout out, and finally the tail begins to wither away, until the form of the four-legged tailless frog (anuran) is fully developed. In the leopard frog, as in the toad, this 
change of form (metamorphosis) is completed during the first summer, but in case of the bullfrog and green frog the tadpole passes through the winter in the immature state, and does not complete its metamorphosis until the second summer. Consequently, it is not uncommon to find quantities of large tadpoles in ponds at the time the ice breaks up in the spring.

Since Amblystoma and Necturus do not lose their tails, the metamorphosis which they undergo is less profound than that of the frog. In Amblystoma, as stated in Chapter XVII., the gills and the fin on the tail of the tadpole are lost in the metamorphosis. Necturus, on the contrary, retains gills and tail-fin, so that its acquisition of legs is almost the sole indication of metamorphosis.

General Laws of Development. - Development consists of an unfolding of potentialities wrapped up in the germ; an awakening in orderly succession of processes lying dormant there. But the causes which control development, the causes which determine when this process and that shall awaken, are still too obscure for us to attempt to picture them in detail. This much is certain, that the causes of clevelopment from the egg are the same as those of budding of leaves on a tree, the regeneration of the parts of a $\mathrm{Hy}$ ylra, or the healing of a cut in our skin. In the case of most of the higher plants and animals, the ripe egg will not develop until it is " fertilized," that is, until a germ from another inclividual has fused with the ripe egg. But the ripe egg of many of the lower plants and animals requires no fertilization for development, and the meaning of the fertilization process is quite obscure.

The developing eggs of all the higher animals pass through much the same sort of early stages. The egg " cleaves" into a number of cleavage spheres, each of which is destined to give 
rise to a particular part of the organism. By repeaterl division, a mass of small cells, constituting the morula stage, is formed. Usually a cavity arises in the middle of the morula, and into this some of the surface cells are pushed to form an internal sac the food canal. This is necessarily an early step, as all food is taken into the interior of the body. The process by which external cells are pushed in is known as gastrulation. Very early the body is seen to be composed mostly of layers, or membranes and cavities. It is by the folding and union and breaking through of these membranes that most of the organs of the adult arise. Development of the individual is, on the whole, accompanied by increase in complexity. The evolution of animals in the animal kingdom is likewise, on the whole, accompanied by increase in complexity of organization. Thus both the embryonic development of the individual and the evolution of the species proceed from simple to complex, and since they start from about the same point and reach the same goal, we are not surprised to find that the individual development of any species often goes through stages markedly like the stages in the evolution of the species. The parallelism of development and evolution was early noticed, and is often called "Von Baer's law," after a naturalist who lived in the middle of the nineteenth century and very clearly formulated this parallelism. 


\section{CHAPTER XXVIII}

\section{A BRIEF HISTORY OF THE SCIENCE OF ZOOLOGY}

A SCIENCE is the recorded body of facts and general ideas on some subject-matter, especially after they have been arranged under general laws. Zoology as a science, therefore, had its beginning when a man wrote out for public use some observations he had made on animals, while unwritten observations constitute personal knowledge or at best "folklore." The development of the science is traced by books, by special reports, and by the proceedings of scientific societies, which have appeared in ever increasing volume since the invention of printing.

Who first definitely recorded observations on animals it would be hard to say. Nascent man evolved in the company of other animals, and the dog was doubtless one of his earliest companions. Primitive language, in so far as it contains the names of animals, gives the first record of his observations, and these names show his appreciation of the fact that there are different kinds of animals. Later arise the oral traditions or folklore, with their animal stories, fables, superstitions connected with animals, and even a mass of fairly accurate observation. As time goes on, observation is sharpened, language is enriched with a constantly increasing number of names of animals and, cventually, as students and philosophers appear, critical studies are made on animals. Such studies, we find, were first made by the Greeks. While there were not lacking 
those who thought about and even dissected animals as early as the sixth century before Christ, yet so relatively vast were the observations and records make hy Aristotle (334-322 в.c.) that he is commonly accepted as the father of zoology. Living near the mild waters of the Mediterranean Sea, which swarm with living beings, he was led to make studlies on marine as well as terrestrial organisms. He made observations on snails, muscles, hermit crabs, sea-urchins, tunicates, and sea-anemones. His studies on nesting habits, care of young, and general economics of bees and wasps are extensive and valuable. While his observations lacked the thoroughness which is expected in modern zoological work, and his generalizations seem crude in view of established facts, yet we can only admire his ideal of making independent observations and his aim of finding a general law in nature, the law

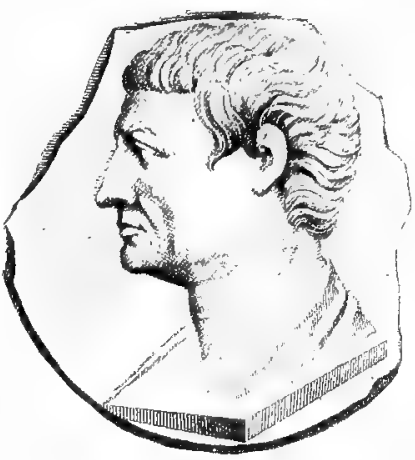

FIG. 412. - Aristotle. From Locy, "Biology and its Makers," New York, Henry Holt and Company. of fitness or " adaptation." He clearly saw also the principles of division of labor, and that the process of development in an organism is a progress from the simple and general to the complex and special. If Aristotle did not enter to any important extent into the speculations of the Greeks as to the origin and evolution of the universe, it is clear that he conceived a progressive development of the animal kingdom out of the simplest beings.

After Aristotle there was a decline in the intellectual life of Greece, and with the spread of Roman influence and ideas in 
which politics and the social organization dominated, science slumbered. The intellectual centre was transferred to Alexandria and here medicine, with its stimulus to careful studies in human anatony and physiology, flourished. The most famous of the anatomists who studied at Alexandria was Galen

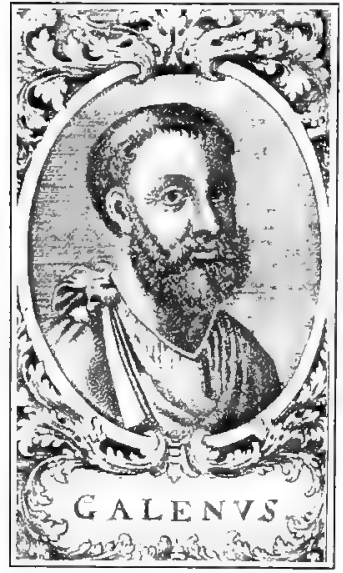

Fic. 413. - Galen. From Locy, "Biology and its Makers," New York, Henry Holt and Company. (second century of our era), who made numerous dissections on man, monkeys, ruminants, rats, and even many kinds of birds, snakes, and fish. His anatomy was for eleven or twelve centuries the most esteemed work on the subject, being by some apparently regarded as more reliable than nature itself. During the Middle Ages of Europe, the age of constant strife, central and northern Europe gradually acquired the culture of the south. At this time all science languished, but with the Renaissance, whose opening may be put at the discovery of America, we note the first stirrings of a return to nature. The epoch from 1500 to the present time may be divided into four periods, as follows: the Encyclopærlic period, 1500 to 1650 ; the Systematic period, 1650 to 1800 ; the Morphological period, 1800 to 1890; the Dynamic period, 1890 to the present.

The encyclopedic period is opened by Gesner (born in $\mathrm{Zu}-$ rich, 1516), who had the ain of collecting all facts concerning animals, of examining them critically, and of writing a compendium that would show the position of the science and obviate the necessity of consulting the older authors. His book was 
the great zoological text-book of the new era, as Pliny's was of the Roman era. Gesner's textbook appeared between 1551 and 1558 in four huge quarto volumes bound in parchment. He never completed this work, which is not strange, since he busied himself with many other great undertakings. He was the first to establish a museum and a botanical garden. Gesner's work was imitated and extended some

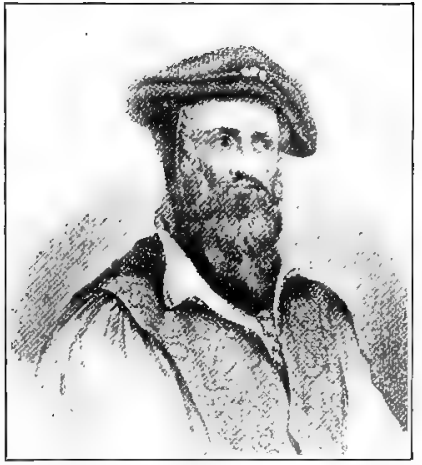

FIIx. 414. - Gesner. From Loey, "Biolegy and its Mikers," New York, Henry Holt and Compary. years later by Aldrovandi (b. 1522 in Bologna, d. 1605). Such works, which had many successors, characterized the

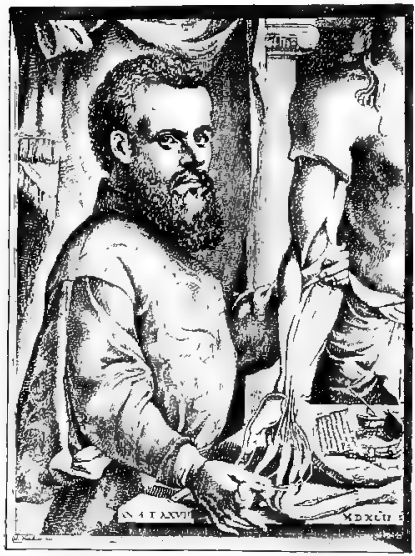

FIG. 415. - Andreas Vesalius. From Foster, "Lectures on the History of Physiology," by permission. encyclopædic period.

But the encyclopxedic period was one of original scientific investigation as well as of codification. The bonds of authority which held naturalists to the writings of Aristotle and Galen were at last broken by Vesalius (b. 1512, d. 1564). Born into a noted family of physicians, Vesalius early showed a strong taste for anatomy, and was well educated at different universities. He applied himself to careful personal dissections of the human body, and in 1543 published his 
memorable work, "Structure of the Human Body." This great work in anatomy created a revolution in the science, and scholars flocked to him at Bologna, Pisa, and Louvain. From anong these arose nearly all the prominent anatomists of the latter part of the sixteenth century, many of whom extended their anatomical studies to the lower animals. Indeed, the

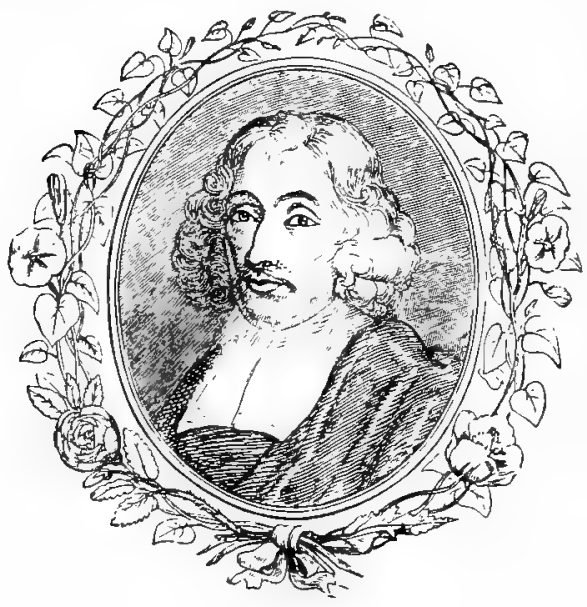

FIG. 416. - John Ray. From Ray Society Publications. scientific activity started by Vesalius has continued unbroken to the present time, and has resulted in the zoglogical sub-sciences of comparative anatomy and physiology.

In consequence of the construction of encyclopædic works on zoology, a search was made for new species in order to make the books as complete as possible. New countries were visited for the purpose of collecting new animals, the seashore and ponds were fished, and even the new world opened by the compound microscope at the beginning of the seventeenth century was utilized. The increase of species made necessary the invention of names for them. Gradually the necessity of recognizing subdivisions of the primitive groups of quadrupeds, birds, etc., became apparent, and this necessity led to the systematic period. This period is opened by the English natural- 
ist, John Ray. He saw the importance of recognizing in animals categories of successively diminishing rank in the various classes of the animal kingdom. But it was left to Linræus (b. in Sweden 1707, d. 1778) to perfect the system by (stablishing categories. The animal kingdom was divided by him into classes, the classes into orders, each order into genera, and each genus into species. He invented the binomial nomenclature that is still in use for both plants and animals. The first name is a sort of surname and indicates the genus; the second name gives the particular species. Thus, Felis catus is the particular name of the cat, Felis leo of the lion, Felis tigris of the tiger, and so on. Finally, Iinnæus introduced the method of brief de-

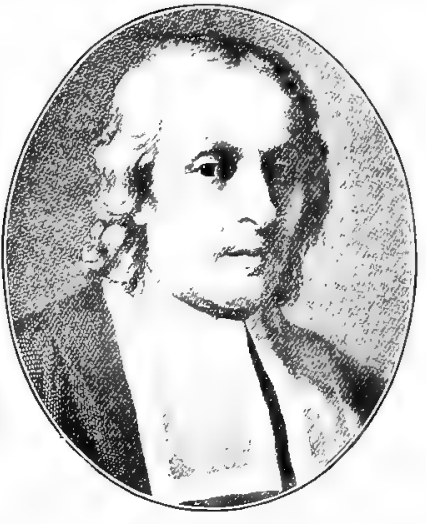
scription of the characteristic Fia. 417. - Marrellus Malpighi. points of each group in place of the wordy, ill-ordered descripFrom Locy, "IBiology and its Makers," New York, Henry Holt and Company.

tions of his predecessors. The brillianey of Linnæus's work attracted many investigators, and the interest in collecting and classifying species remains to this day. Such work, although often fascinating, is not the highest type of scientific work.

The foundations of modern morphological or anatomical zoology were laid in part by men whose original interest was medical and in part by a new school of naturalists who studied the structure and behavior of the lower animals. As early as the middle of the seventeenth century we find Malpighi, professor of medicine at Bologna, publishing his investigations 
upon the internal anatomy of the silk-moth, which afforded not only an extended but also the first insight into insect anatony. The Dutchman Swammerdam (b. 1637, d. 1680) marle even wider studies in the same field. His observations were published in a book entitled "Bible of Nature."

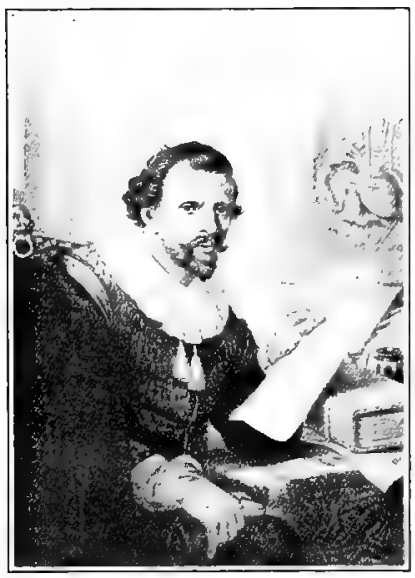

FIG. 417 a. - Sw a m merdam. From Lory, "Biologr and its Makers," New York, Henry Holt and Company.

The newly discovered and gradually much improved compound microscope lured many to a study of the structure and behavior of microscopic species and permitted the beginning of new sciences dealing with the tissues of organs (histology) and with the cell (cytology). The first to employ the compound microscope to serious work in zoology were the Italian Malpighi and the Dutchman Leeuwenhoek. The work of Malpighi upon insects has already been referred to. Not less important are his histological studies on higher animals. He first saw and described the circulation of the capillaries, observing it in the lung of the frog. He first gave a rirtailed account of the series of stages in the development of the chick, and was thus one of the founders of embryology. Hestuclied thoroughly the structure of various tissues of the higher animals, and may be said to be the founder of histology.

Unlike Malpighi, who used the microscope as an incidental aid to his rescarches, Leeuwenhoek used the microscope to study 
small things just because they were small. He first saw the red corpuscles, the cross striations of muscle fibres, the tubules in teeth, the dry cells of the outer skin. He first studied under the microscope numerous small animals, such as fleas, flies, various small beetles, and the compound eyes of insects. $\mathrm{He}$ discovered the parthenogenesis of the plant lice and the budding of Hydra. Also he discovered the rotifers and various Protozoa. It is rare that an opportunity arises to study, by the aid of a new invention, a wholly new world of organisms without leaving home, and Leeuwenhoek took full advantage of his unique opportunity.

The end of the seventeenth and the beginning of the eighteenth century was a period of immense seientific activity in many directions. Numerous learned societies or academies

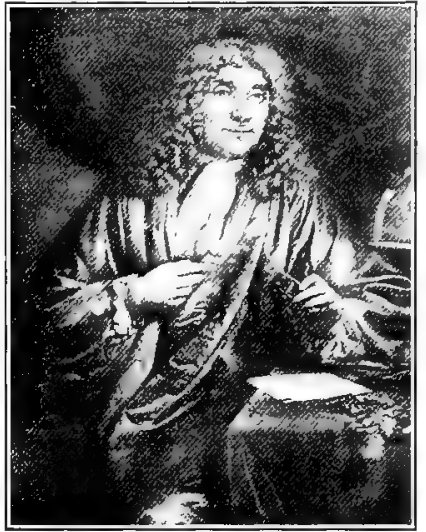

FIg. 418. - Leenwenhoek. From Locy, "Biology and its Mitkers," New York, Henry Holt and Company. were started in England, Germany, France, Italy, Austria, and Russia, and their publications served as repositories for the new discoveries. In consequence of the great collections of animals and plants that were being made, museums were founded, frequently by the academies, to care for them and to encourage further collecting. Zoological gardens were established to keep alive the new and strange animals that explorers brought back from newly discovered lands. All of these things must have stimulated the love of nature innate 
in normal young people, and were responsible for the creation of many zoological investigators.

As the eighteenth century drew to a close, a more philosophical tendency appeared in zoology - particularly in the French school. Buffon (1707-1788) began a great popular

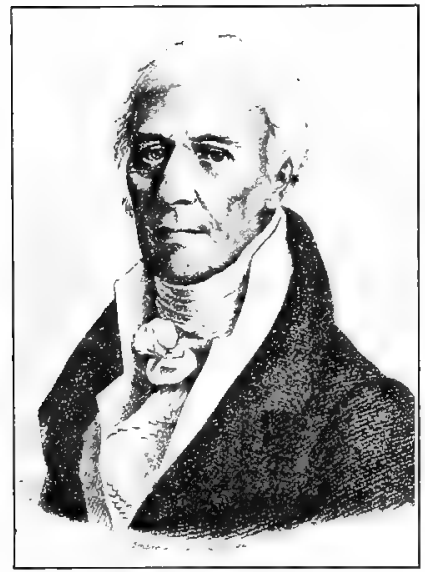

FI(t. 419. - Lamarck. From "Lanizck, his Life and his Work," by permission of the publishers, Messrs. Longmans, Green, and Company. encyclopædic work on the natural history of animals, but it was never completed by him. The work was finished by other hands. It is, however, on his theoretical opinions, particularly his recognition of the evolution of species, and his protest against Linnæus's view of immutability, that Buffon's greatest claim to recognition rests. But it is Lamarck (1744-1829) who has made most famous this French school of philosophical zoologists. He held that species are not immutable, but alter under changing environment, and that there has been an upward progression in the animal kingdom. He argued that changes in environment bring about changes in habits, and that new habits involve the use of new parts, resulting in modifying them. Such modifications are inherited, and thus are perpetuated as new specific characters. Rudimentary structures like the eyes of moles or cave animals result from this use. Webbed feet of birds, on the other hand, result from stretching the web by extending the toes to swim more effectively. The neck of 
the giraffe became elongated from the constant effort to reach the foliage higher up on the trees. Use and disuse, effort and habit, lie at the basis of Lamarck's theory of progressive evolution.

The French school contributed not only to general theory but also to the solid facts of zoology. Lamarck described hundreds of new species of invertebrates, and proposed a subdivision of invertebrates which was a marked advance over anything that had hitherto existed. In fact the division of animals into Vertebrata and Invertebrata was Lamarck's own suggestion. But the fame of Lamarck as a student and describer of animals was overshadowed by his colleague and opponent, Cuvier (1769-1832). As the greatest comparative anatomist of his age, he attracted to Paris many pupils. His anatomical studies em-

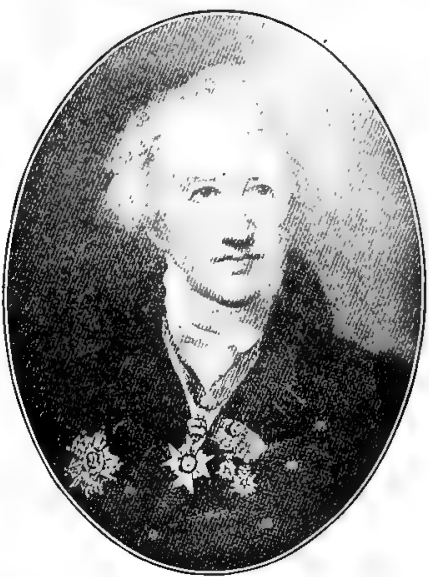

FIG. 420.- George Cuvier. From Locy, "Biology and its Makers," New York, Henry Holt and Company.

braced coelenterates, mollusks, arthropods, and vertebrates, and he recognized that fossil forms belong as truly to the dominion of zoology as do those that have not been so long dead. In his two great comprehensive works, "The Animal Kingdom classified on the Basis of Organization" and "Lessons in Comparative Anatomy," he introduced for the first time internal as well as external anatomy as the proper basis for classification. He also established the theory of distinet types of animal struc- 
ture which were independent and parallel and did not all fall intu one series leading from Protozoa to man. Cuvier opposed the theory of evolution, and so great was his influence in France that the ideas of Lamarck were neglected and almost forgotten in the supremacy of the view of the immutability of species.

The science of embryology had its heginnings in Aristotle's studies on the hen's egg, and in the revival of biological studies in the seventeenth century there were not wanting those who, like Malpighi, made some superficial studies on developing chicks; but it was not until the middle of the eighteenth century that serious embryological studies were marle. At this time there was raging a discussion as to the nature of development. On the one hand it was maintained that in the egg lay the embryo as we see it when the chick is hatched, only it is of very small size. Development consists in the growing of the different parts until they become visible. On the other hand, it was asserted that the sperm-cell contains the young creature and that it finds in the egg food for growth. One day a teacher in Germany remarked to a brilliant pupil, Caspar Friedrich Wolff, that many things of value would be got from a careful study of the development of the hen's egg. Wolff set to work and succeeded in proving that the egg is at first without the organs of the aclult, and that these are gradually formed in it. These conclusions, based on careful study, were combated by Haller, the eminent physiologist, and on account of his great authority he crushed, for a time, the truth; but at the heginning of the nineteenth century new studies were made by Carl Ernst von Baer, who confirmed Wolff's observations, and in 1832 established embryology as a separate science. During the remainder of the century embryology almost overshadowed the other sub-sciences of zoology. In England were Huxley and 
Balfour and their numerous pupils. In Germany, Russia, and France the workers were even more abundant, and America includes as its share the work of Agassiz and of men still active.

Cytology. - When thin sections of plant tissues were first looked at with a microscope, they were seen to be made up of spaces surrounded by thick walls, and these were called "cells." Similar cells were seen in animal tissues also. But it was not until 1838-1839 that the botanist Schleiden and the zoologist Schwann raised these isolated facts to a theory by declaring that the whole body of organisms is made up of such cells and their products. It was, however, left to Schultze to bring out the more fundamental idea that the body is made up of a living substance - protoplasm - which is divided for physiological purposes into more elementary parts called cells. Later it was discovered that the activity of each cell is controlled by a central body, or nucleus, and for the last three or four decades the behavior of the nucleus in cell division and in heredity has been the object of extensive investigation.

The Evolution Theory. - We have seen how the Greeks regarded the evolution of the organic world as a part of cosmic philosophy. Through a narrow interpretation of the Mosaic account of creation, the Christian church was led away from those broad views, and in this attitude it was supported by Linnæus and others. We have seen that a French school of evolution arose, but its explanation of the method of evolution was not acceptable, and the school was crushed by the authority of Cuvier. In England there were not wanting those who accepted or promulgated the theory with a very slight basis of fact. It was the great service of Charles Darwin to offer such a theory, accompanied by proofs so numerous and presented in a 
fashion so judicial as to win acceptance by all. Charles Darwin was born in Shrewsbury, England, in 1809; his uncle, Erasmus Darwin, had written a theory of evolution in metric form. After having studied in Edinburgh and Cambridge, Charles Darwin, at the age of 22, accompanied the ship

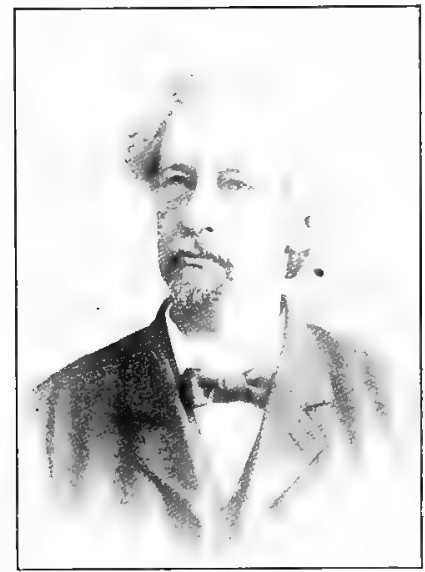

FIG. 421. - Hugo de Yries. Beagle on a five years' scientific expedition around the world. On this trip he made studies on the distribution of animals in space and time, and published a fascinating book on them. These studies led him, on his return, to collect facts which might bear on the origin of species. In 1859 Darwin published his book entitled "The Origin of Species through Natural Selection." Besides the general argument for evolution, he proposes the special hypothesis of selection to account for it. In every species many more individuals are produced in each generation than can survive. In this weeding-out process those individuals that in any way peculiarly fit the conditions of life will be more apt to survive than the less fit; thus the fact of aclaptation is accounted for, and, whenever the environment changes, a change in the species tends to occur. Darwin was inclined to helieve that the changes in successive generations would be always slight, hut the experiments and observations of the Dutchman De Vries ("The Mutation Theory" 19011903) make it seem probable that the progressive steps are 
usually new characters which breed true from their start. We find ourselves thus in the twentieth century with the theory of evolution generally accepted, but with the method of evolution incompletely worked out. There thus remains plenty of work on this theory to be done in the future.

Zoological expeditions. - We have seen that the work of the encyclopædists led men to add to the number of known species by exploring new countries. The great systematic works of Linnæus and the others had a similar effect. One of the greatest of the early expeditions was undertaken by Pallas (b. at Berlin 1741, d. 1811), who travelled through Siberia and as far south as the Caspian Sea. He also investigated the fauna of eastern and southern Russia in Europe, and published the results of his studies in extensive books.

During the early part of the nineteenth century a great interest was revived in the study of marine animals, and many expeditions were sent around the world. Of these the Challenger Expedition is the most noteworthy. Its results are published in fifty fine quarto volumes. In this country the expedition under Wilkes, which opened Japan to Western civilization, and those of Alexander Agassiz in the Blake and the Albatross are the most noteworthy. Despite all of this activity, much of the land and of the sea remains to be explored. 



\section{APPENDIX I}

\section{A LIST OF BOOKS DEALING CHIEFLY WITH ECOLOGICAL AND SYSTEMATIC ZOOLOGY OF AMERICAN ANIMALS}

\section{A. GENERAL SYNOPTIC WORKS}

Leunis, J. - Synopsis der Thierkunde. Dritte Auflage von H. Ludwig. 2 Bande. Hannover. 1883-86.

This is the nearest approach to a systematic manual, taking the place in Zoology which Gray's and Coulter's Manuals do in Botany. It deals chiefly with European species, and has not been translated.

Thomson, J. A. - Outlines of Zoology. 3d edition, with 332 illustrations. New York: D. Appleton \& Co. 1899. 819 pp.

An excellent condensed compendium; in which, however, the structural side predominates.

Riverside [formerly Standard] Natural History, edited by J. S. Kingsley. 6 vols., large 8vo. Boston and New York: Houghton, Mifflin \& Co. Price $\$ 30$.

The most important large compendium written by American authors, somewhat after the plan of Brehm's Thierleben.

Cambridge Natural History, edited by S. F. Harmer and A. E. Shipley. New York: The Macmillan Company. 1894-1908. An English work of surpassing merit.

Klassen und Ordnungen des Thierreiches, edited (originally) by Bronn. Leipzig u. Heidelberg: C. F. Winter.

An extensive and thorough work. Although the whole work is not yet completed, some of the volumes are out of date. The most recent and important are the volumes on Protozoa, Porifera, Ccelenterata, Vermes, Echinodermata, Crustacea, Mollusca, Reptilia, and Birds. 
Das Tierreich. Eine Zusammenstellung und Kennzeichnung der rezenten Tierformen. General redacteur: F. E. Schulze. Berlin; R. Friedländer und Sohn. 1896-

A systematic account of every known species, with keys for their determination. An ambitious enterprise which will hardly be finished during one generation.

\section{B. WORKS RELATING TO ANTMALS OF A PARTICULAR HABITAT}

Verrill, A. E. (and S. I. Smith). - Report upon the Invertehrate Animals of Vintyard Sound and the Adjacent Waters, in Report (of U.S. Fish Commission) on the Condition of the Sea Fisheries of the South Coast of New England in 1871 and 1872. (1873.) pp. $295-778$.

An indispensable accompaniment of the zoologist at the Eastern seashore; separate copies can he purchased of dealers in scientific books.

Emerton, J. H. - Life on the Seashore. [For sale by Bradlee Whidden, Boston.]

Mayer, A. G. - Seashore Life. New York Zoological Society.

\section{GENERAL WORKS ON HABITS, ECOLOGY, AND DISTRIBUTION}

Verworn, M. - General Physiology. An Outline of the Srience of Life. New York: The Macmillan Company. 1899. $615 \mathrm{pp}$. Price $\$ 4.00$.

Morgan, C. L. - Animal Life and Intelligence. New York: Edward Arnold. 1891. 503 pp.

Morgan, C. L. - Habit and Instinct. New York: Edward Arnold. 1896. $351 \mathrm{pp}$.

The two best books on the topir's considered.

Lubbock, J. On the Senses, Instinct, and Intelligence of Animals, with special reference to Insects. International Scientific Series, Vol. LXIV. New York: D. Appleton \& Co. 1888. 
Poulton, E. B. - The Colors of Animals. The International Scientifie Series, Vol. LXVII. New York: D. Appleton \& Co. 1890. Semper, K. - Animal Life as affected by the Natural Conditions of existence. International Scientific Series, XXX. New York: D. Appleton \& Co. 1881.

Even to-day the best hook on Animal Ecology.

Wallace, A. R. - Tropical Nature. London and New York: Macmillan \& Co. 1895.

Wallace, A. R. - Geographical Distribution of Animals. 2 vols. London: Maemillan \& Co. 1879.

Beddard, F. E. - Text-book of Zoogeography. Cambridge (Eng.) Scientific Series. 1895.

\section{WORKS DEALING CHIEFLY WITH ANATOMY AND EMBRYOLOGY}

Parker, T. J., and W. A. Haswell. - Text-book of Zoology. 2 vols. Many illustrations. New York: The Macmillan Co. 1897.

Parker, T. J., and W. A. Haswell. - Manual of Zoology. Adapted for use of American Schools and Colleges. 563 pp. 327 figs. New York: The Maemillan Co. 1900.

Rolleston, G., and W. H. Jackson. - Forms of Animal Life. 1888.

Lang, A. - Text-book of Comparative Anatomy. Translated by Bernard. 2 vols. New York: The Macmillan Co. 1896.

Brooks, W. K. - Handbook of Invertebrate Zoology. For laboratories and seaside work. Boston: S. E. Cassino. 1882. [May be purchased of Bradlee Whidden, Boston.]

Korschelt, E., and K. Heider. - Text-book of the Embryology of Invertebrates. 3 vols. New York: The Macmillan Co. 1899.

Balfour, F. M. - A Treatise on Comparative Embryology. In 2 vols. London: Macmillan \& Co. 1880-81.

Although decidedly out of date, yet gives the best general discussion in English of the subject.

Hertwig, O. - Text-book of the Embryology of Man and Mammals. Translated by E. L. Mark. New York: Macmillan, 1892. 
Wilson, E. B. - The Cell in Development and Inheritance. New York: The Macmillan Co. 1900.

\section{E. WORKS ON SPECIAL GROUPS}

\section{INSECTS IN GENERAL}

The Cambridge Natural History. Vols. V and VI. Macmillan. 1895 and 1899. [Especially ecological.]

Comstock, J. H. and A. B. - Manual for Study of Insects. Comstock Publishing Co. 1899. Price \$3.75. [Excellent systematic treatise.]

Comstock, J. H. - Insect Life. D. Appleton. 1897. Price $\$ 2.25$.

Folsom, J. W. - Entomology with Special Reference to its Biological and Economic Aspects. Blakiston. 1906. [Excellent in its field.]

Smith, J. B. - Economic Entomologyr. Lippincott. 1896. Price $\$ 2.50$.

Packard, A. S. - Fifth Report of United States Entomological Commission, U.S. Dept of Agriculture. Washington : Government Printing Office. 1890. [Extensive treatise.]

Miall, E. C. - Natural History of Aquatic Insects. Macmillan. 1895. Price \$1.75.

Needham, J. G., and C. Betten. - Aquatic Insects in the Adirondacks. University of State of New York, Albany. 1901. Price $\$ 0.45$.

Needham, J. G., and others. - Aquatic Insects of New York State. University of State of New York, Albany. 1903. Price $\$ 0.80$.

Needham, J. G., K. J. Morton, O. A. Johannsen. - Mayflies and Midges of New York. University of State of New York, Albany. 1905. Price $\$ 0.80$.

Needham, J. G. - Report of Entomologic Field Station conducted at Old Forge, N.Y. University of State of New York, Albany. 1908.

Lubbock, J. - Origin and Metamorphoses of Insects. Macmillan, 1895. 
Howard, L. O. - The Insect Book. Doubleday, Page \& Co. 1901. Smith, J. B. - Insects of New Jersey. (Franklin Dye, Secretary, Trenton, N.J.) [Excellent local list.]

Banks, N. - List of Works on North American Entomology. Washington : Government Printing Office. 1910.

Riley, C. V. - Directions for Collecting and Preserving Insects. Smithsonian Institution, Washington. 1892. Price $\$ 0.25$.

II. ORTHOPTERA, NEUROPTERA, HEMIPTERA, ETC.

Guthrie, J. E. - Collembola of Minnesota. Geological and Natural History Survey of Minnesota. 1903.

Scudder, S. H. - Guide to the Genera and Classification of the

North American Orthoptera found north of Mexico. Cambridge, Mass. 1897.

Lugger, O. - Orthoptera of Minnesota. State Experiment Station. 1898.

Morse, A. P. - Researches on North America Acridiidae. Carnegie Institute of Washington. 1904.

Miall, L. G., and A. Denny.- Structure and Life History of the Cockroach. London: Loweil, Reeves \& Co. 1886.

Calvert, P. P. Catalogue of the Odonata (Dragon Flies) of the vicinity of Philadelphia. Transactions Entomological Society, Philadelphia. Price $\$ 1.00$.

Williamson, E. B. - Dragonflies of Indiana. 24th Annual Report Department Geological and Natural Resources, Indiana. 1899.

Hagen, H. - Synopsis of Neuroptera of North America. Smithsonian Collections. 1861.

Banks, N. - Catalogue of Neuropteroid Insects of United States. Secretary, American Entomological Society, Philadelphia. 1907. Summers, H. E.- True Bugs, or Heteroptera, of Tennessee. Bulletin Tennessee Agricultural Experiment Station. 1891.

\section{LEPIDOPTERA AND HYMENOPTERA}

French, G. H. - Butterflies Eastern United States. Lippincott, Philadelphia, 1886. 
Scudder, S. H. - Butterfies of Eastern United States and Canada, 3 vols. Cambridge, Mass. Privately printed. 1889.

Scudder, S. H. - Brief Guide to Commoner Butterflies of Northern T'nited States and Canada. Holt. 1893. Price \$1.25.

Edwards, W. H. - Butterflies of North America. Houghton, Mifflin \& Co.

Holland, W. J. - Butterfly Book. Doubleday, Page \& Co. 1898. Holland, W. J. - Moth Book. Doubleday, Page \& Co. 1903.

Knobel, E. - Day Butterflies and Dusk Fliers of New England; how to find and know them (1895); also Night Moths of New England; how to determine them readily. Boston: Bradlee Whidden. 1895.

Wright, W. G. - Butterflies of West Coast of United States, San Franeisco. 1905.

Cresson. E. T. - Synopsis of Families and Genera of the Hymenoptera, North of Mexico. Secretary, American Entomological Society, Philadelphia. 1887. Price \$3.00.

Lubbock, J. - Ants, Bees, and Wasps. D. Appleton. 1882.

Wheeler, W. M. - Ants, their Structure, Development, and Behavior. Macmillan. 1910.

\section{COLEOPTERA}

Le Conte, J. L., and G. H. Horn. Classification of the Coleoptera of North America. Secretary, American Entomological Society. 1883. Price $\$ 2.50$.

Ulke, H. - List of Beetles of the District of Columbia, Proceedings United States Natural Museum, 25, pp. 57. Government Printing Office. 1902.

Knobel, E. - Beetles of New England; a guide to know them readily. Boston: Bradlee Whidden. 1895.

\section{DIPTERA}

Williston, S. W. - Manual of North American Diptera. 3d ed. New Haven. 1908.

Giles, G. M. - A Handbook of Gnats or Mosquitoes. London: John Bale Sons \& Danielsson. 1902. 
Howard, L. O.-- Mosquitoes. Doubleday, Page \& Co. 1901.

Knobel, E. - Beetles of New England. Boston : Bradlee Whidden. 1895.

\section{MYRIAPODA}

Bollman, C. H. - Myriapoda of North America, Bulletin 46, United States National Museum. Government Printing Office. 1893.

Wood, H. C., Jr. - Myriapoda of North America. Transactions American Philosophical Society, 13. 1865.

\section{ARACHNIDA}

Emerton, J. H. - Common Spiders of the United States. Ginn. 1902.

Comstock, J. H. - Classification of North American Spiders. Comstock Publishing Co. 1903.

McCook, H. C. - American Spiders and their Spinning Work. 3 vols., 4to. Secretary, Academy Natural Science, Philadelphia. 1889-93.

Peckham, G. W. and E. G. - North American Spiders of the Family Attidar. Transactions Wiseonsin Academy of Science, Vol. 7. 1888.

Kraepelin, K. - Scorpiones und Pedipalpi. Das Tierreich, S. Lieferung. Berlin: R. Friedländer. 1899.

Banks, N. - Synopsis of the Phalangida, American Naturalist, Vol. XXXV. 1901.

Banks, N. - A Treatise on the Acarina or Mites. Proceedings of United States National Museum, 28. United States Government Printing Office. 1904.

\section{CRUSTACEA}

Rathbun, R. - Natural History of Economic Crustaceans. Bulletin U. S. Fish Commission for 1889. Government Printing Office. 1893.

Huxley, G. H. - The Crayfish : an Introduction to the Study of Zoology. D. Appleton. 1880. 
Hay, W. P. - Synopsis of Astacidæ of North America. American Naturalist, Vol. XXXIII. 1899.

\section{MALACOSTRACA AND GEOGRAPHICAL DISTRIBUTION}

Stebbing, T. R. R. - A History of ('rustacea, Recent Malacostraca. D. Appleton. 1893.

Faxon, W. - Revision of the Astacidæ. Memoirs Museum Comp. Zool., Cambridge, Mass., Vol. X. 1885.

Herrick, F. H. - American Lobster, Bulletin U. S. Fish Commission, Vol. XV. 1896.

Kingsley, J. S. - Synopses of Caridea and Astacoid and Thalassinoid Crustacea. American Naturalist, Vol. XXXIII. 1899. Rathbun, M. J. - Synopses of Crabs, American Naturalist, Vol. XXXIV, 1900.

Wallace, A. R. - Geographical Distribution of Animals. 2 rols. Macmillan. 1876.

Heilprin, A. - Geographical and Geological Distribution of Animals. D. Appleton. 1887.

\section{ENTOMOSTRACA}

Richardson, H. - Monograph on the Isopods of North America. Government Printing Office. 1905.

Holmes, S. J. - Synopsis of Amphipoda. American Naturalist, Vol. XXXVII. 1903.

Wheeler, W. M. - Free-swimming Copepods of the Woods Hole region. Government Printing Office. 1900.

Marsh, C. D. - Revision of the New York Species of Cyclops. Transactions Wisconsin Academy. 1910.

Hay, W. P. - Ostracoda of North America, American Naturalist, Vol. XXXIII. 1899.

\section{WORMS}

Cambridge Natural History. Vol. II. Macmillan. 1896. Delage. Y., and E. Hérouard. - Les Vermidiens, in Traité de Zoologie concrète, Tome V. Schleicher frères. 1897. 


\section{OLIGOCHATA, LEECHES, BRYOZOA, AND BRACHIOPODA}

Michaelsen, W. - Oligochæta, in Das Tierreieh, 10 Lief. Berlin: R. Friedländer \& Sohn. 1900.

Darwin, C. - Formation of Vegetable Mold through the Action of Worms. D. Appleton. 1881.

Moore, J. P. - Hirudinea of Illinois, Bulletin Illinors State Laboratory of Natural History, Vol. V. 1901.

Davenport, C. B. - Fresh-water Bryozoa. American Naturalist, Vol. XXXIII. 1899.

\section{POLYCHETA AND LOWER WORMS}

Verrill, A. E. - New England Annelida. Transactions Connecticut Academy, Vol. IV. 1880.

Andrews, E. A. - Report on Annelida Polychæta of Beaufort. Proceedings U. S. National Museum, Vol. XIV. Government Printing Office. 1891.

Johnson, H. P. - Preliminary Account of Marine Annelids of Pacific Coast. Proceedings California Academy of Sciences, Vol. I. 1897.

Pratt, H. S. - Synopsis of the Trematodes. American Naturalist, Nos. 404, 432. 1900, 1902.

Coe, W. R. - Synopsis of the Nemerteans. American Naturalist, No. 463. 1905.

Montgomery, T. H. - Synopsis of the Gordiacea. American Naturalist, Vol. 33. 1899.

Ward, H. B. - Parasitic Worms of Man and the Domestic Animals, in Report for 1894 of Nebraska State Board of Agriculture. 1895 .

\section{MOLLUSCA}

Cooke, A. H. - Mollusca in Cambridge Natural History. Macmillan. 1896.

Tryon, Gen., Jr. - Structural and Systematic Conchology. S. R. Roberts. 1882, 1884. Price $\$ 6.00$. 
Gould, A. A. - Report on Invertebrata of Massachusetts. $2 \mathrm{~d}$ ed. Binney. 1870. [Mollusca and Tunicata.]

Apgar, A. C. - Molluses of the Atlantic Coast of the United States.

A. C. Apgar, 511 E. State St., Trenton. 1891. [Compact, excellent keys.]

Dall, W. H. - Shell-hearing Marine Molluses and Brachiopods of the Southeast Coast of United States. Government Printing Office. 1903. [Numerous figures.]

Baker, F. C. - Mollusea of Chicago Area. Chicago Academy of Science. 1898-1902.

Ingersoll, E., and J. A. Ryder. - Natural History of Economic Molluses of the United States, in Bull. U. S. Fish Commission for 1889. Government Printing Office. 1893.

\section{GASTROPODS AND CEPHALOPODS, AND ANIMAL BEHAVIOR}

Simpson, G. B. - Anatomy and Physiology of Polygyra albolabris and Limax maximus, etc. New York State Educational Department. 1901. Price $\$ 0.25$.

Verrill, A. E. - Report on the Cephalopods of the Northeastern Coast of America. Report of U. S. Fish Commission for 1879. Government Printing Office. 1882.

Thorndike, E. L. Animal Intelligence, in Psychological Review, No. 8. Macmillan. 1898.

Jennings, H. S. - Contributions to the Study of the Behavior of Lower Organisms. Carnegie Institution of Washington. 1904. Walter, H. E. - Behavior of the Pond Snail. Cold Spring Harbor Monographs, VI. 1906.

See also Section C.

\section{LAMELLIBRANCHS AND RIVER FAUNAS}

Drew, G. A. - Habits, Anatomy, and Embryology of the Protobranchia [Yoldia, Nurula]. Anatomischer Anzeiger. G. Fischer, Jena. 1899.

Drew, G. A. - Habits and Movements of the Razor Clam. Biological Bulletin, Vol. XII. 1907. 
Kellogg, J. L. - Observations on the Life History of the Common Clam, Mya arenaria. Bulletin of U. S. Fish Commission for 1899. Government Printing Office. 1900.

Simpson, G. B.--Anatomy and Physiology of Anodonta fluviatilus. 35th Annual Report N.Y. State Museum of Natural History. 1884.

C. A. Kofoid. - Plankton of the Illinois River, 1894-1899. Bulletin Illinois State Laboratory of Natural History, Vol. VI, 1903; Vol. VIII., 1908.

\section{XVII and XVIII. ECHINODERMS}

Agassiz, A. - North American Starfishes. Memoirs Museum Compar. Zoology, Vol. V. 1877.

Azassiz, A. - Revision of the Echini, Illustrated Catalogue of $\mathrm{Mu}$ seum Compar. Zoology, Vol. VII. 1872-73.

C.ark, H. L. - Synopsis of the Holothuroidea of North America, American Naturalist, Vol. XXXV. 1901.

Brooks, W. K. - Handbook of Invertebrate Zoology. Boston: Cassino. 1882. [Excellent chapter on the development of Echinoderms.]

\section{CELENTERATES}

Trembley, A. - Mémoires pour servir à l'histoire d'un genre de polypes d'eau douce à bras en forme de cornes. Leyden. 1744. [Remarkable first study of Hydra.]

Agassiz, L. - Acalephs, Ctenophoræ, Discophoræ, Hydroidæ, in Contributions to the Natural History of the United States. $1860,1862$.

Hargitt, C. W. - Synopsis of the Hydromedusæ of North America, American Naturalist, Vol. XXXV. 1901.

Parker, G. H. - Synopsis of the Actinaria of North America, American Naturalist, Vol. XXXIV. 1900.

Hyatt, A. - Guides for Science Teaching: III, Commercial and Other Sponges. Heath \& Co., Boston. 1893.

Potts, E. - Synopsis of American Fresh-water Sponges, Proceedings Academy of Natural Science of Philadelphia. 1887. 


\section{PROTOZOA}

Calkins, G. N. - Protozoa. Macmillan.

Brütschli, O. - Protozoa, in Bronn's Tierreich. 1889.

Leidy, J. - Fresh-water Rhizopods of North America. Government Printing Office. 1879.

Conn, H. W. - Protozoa of Fresh Water of Connecticut. Bulletin Geological and Natural History Survey of Connecticut. 1905.

\section{VERTEBRATES}

Jordan, D. S. - Manual of the Vertebrates of the Northern U. S. Chicago: MeClurg.

Kingsley, J. S. - Text-book of Vertebrate Zoology. Holt. 1899.

Parker, T. J., and W. A. Haswell. - Text-hook of Zoology, Vol. II. Macmillan. 1897.

\section{FISHES}

Jordan, D. S., and B. W. Evermann. - The Fishes of North and Middle America, Bulletin U. S. National Museum, No. 47. Government Printing Office. 1898. [Very valuable; with much hiological data and keys.]

Goode, G. B.--American Fishes. New York: Standard Book Co. 1888.

\section{AMPHIBIA}

Mivart, S. and G. - The Common Frog. Macmillan. 1881.

Dickerson, Mary E. - Frog Book. Douhleday, Page \& Co.

Sherwood, W. L. - Frogs and Toads in Vicinity of New York. Proc. Linn. Soc. of N. Y., No. 10. 1898.

Gage, S. H. - Life History of Newt. American Naturalist, December, 1891.

Ritter, W. E. - Life History of Habits of the Parific Coast Newt. Proceedings California Academy of Science, Vol. I. 1897.

Wilder, H. H. - Desmognathus fusea and Spelerpes bilineatus, American Naturalist, Vol. XXXIII. 1899.

Kirkland, A. H. - Hahits, Food and Eronomic Value of the American Toad. Hateh Experiment Bulletin No. 46. Amherst, Mass. 1897. 


\section{XXIV, REPTILIA}

Agassiz, L. - North American Testudinata and Embryology of the Turtle, in Contributions to the Natural History of the U. S. Little, Brown \& Co. 1857.

\section{BIRDS}

Newton, A., and Hans Gadow. - Dictionary of Birds. A. \& C. Black, Edinburgh. 1893-96.

Cowes, E. - Key to North American Birds. 1896.

Ridgeway, R. - Manual of North American Birds. Lippincott. 1896.

Chapman, F. M. - Bird Life. D. Appleton. 1897.

Parkhurst, H. E. - How to name the Birds. C. Seribner.

Wright, Mabel O., and E. Cones. Macmillan. 1898.

Walter, H. E. and A. H. - Wild Birds in City Parks.

Besides these there are dozens of good books on American birds and guides to their study; see any good book-store.

\section{MAMMALIA AND DOMESTIC ANIMALS}

Flower, W. H., and R. Lydekker. - Introduction to the Study of Mammals, Living and Extinct. A. \& C. Black. 1891.

Lydekker, R. - Geographical History of Mammals. Macmillan. 1886 .

Mivart, S. and G. - The Cat. Seribners. 1881.

Darwin, C. - The Variation of Animals and Plants under Domestication. 2d ed. D. Appleton. 1870.

Bateson, W. - Mendel's Principles of Heredity. Macmillan. 1909.

\section{DEVELOPMENT OF THE FROG'S EGG}

Morgan, T. H. - Development of the Frog's Egg. Macmillan. 1897.

\section{HISTORY OF ZOOLOGY}

Locy, W. A. - Biology and its Makers. Holt. 1908. 


\section{APPENDIX II}

\section{SYNOPSIS OF THE ANIMAL KINGDOM}

\section{GROUPS OF ANIMALS ARRANGED APPROXIMATELY}

IN AN ASCENDING SERIES; WITH REFERENCES TO ETERY FAMILY MENTIONED IN THE MAIN TEXT; AND WITH DEFINITIONS OF THE CLASSES AND ORDERS

Note. - Owing to the method employed in the text of proceeding from a type to the allied groups, the systematic relations of the organisms considered are often obscured. This synopsis is intended to make these relations clearer. It can also be used as a systematic index of the book. Moreover, the student can use it in reviewing his knowledge of the text, and as a key for the determination of the class in which a specimen falls. The teacher can employ it as a guide to collecting illustrative material; for every family mentioned should, as far as possible, be illustrated by specimens or good figures.

In the synopsis group-names printed in full-face are phyla; in LARGE CAPITALS, classes; in Shall CApitals, orders; in italics, families. Subphyla, subclasses, and suborders are indicated by bracketing. Thus [CILIATA] is a subclass. Numbers in parentheses refer to pages of the text.

\section{PROTOZOA}

Animals composed of a single cell; or, if of several cells, these are of one kind.

RHIZOPODA. Protozoa with retractile pseudopodia: Amœba (284).

SPOROZOA. Protozoa without appendages; internal parasites (285).

FLAGELLATA. Protozoa without ('ilia, but with one or more flagella (286). 
INFUSORIA. Protozoa with cilia or sucking tentacles (286).

[CILIATA]. Locomotor, with cilia: Holotricha (Paramecium, 287); Heterotricha (287); Peritricha: Vorticella (288). [SUCTORIA]. Sessile, with sucking tentacles (288).

\section{COELENTERATA}

Animals of radial strueture whose digestive eavity is lined by the body-wall (262).

\section{[SPONGIARIA]}

Colenterata whose body-wall is perforated by incurrent pores (262).

\section{[CNIDARIA]}

Cœlenterata whose body-wall is not perforated by incurrent pores, and which have nettling organs of some sort (264).

HYDROZOA. Cnidaria whose body is composed of more than two rays and contains a simple eavity. Hydromeduse, attached Hydrozoa in hydroid stage; medusa simple: Hydroida (265); Hydrocorallidae (267); Tubularidae (267); Campanularidce (267); Trachomedusce (Zygodactyla, 271). Siphonophora, a free swimming colony of Hydrozoa (271).

SCYPHOZOA. Cnidaria with many radii, and with radial partitions in cavity of body (273).

CTENOPHORA. Cnidaria with only two radii, and rows of cilia-plates (275).

\section{SCOLECIDA}

Animals of worm-like form, with bilateral, unsegmented body.

PLATYHELMINTHES. Bilaterally symmetrical, soft-bodied animals, without true segmentation of the body; flattened in a dorso-ventral direction, and having body-cavity filled with a loose meshwork of cells. Turbellaria, free-living flatworms whose body is covered by cilia; alimentary tract with only one opening to the exterior: Planaria (191). Trematoda, parasitie, without cilia in the adult; the mouth leads into a forked food-canal without anus: Distomum (193). Cestoda, elongated tape-like intestinal parasites, 
without mouth or food-canal : Trenia (195). Nemertini, body more or less flattened; food-canal with mouth and anus; a separate protrusible proboscis (190).

NEMATHELMINTHES. Bilateral, unsegmented, roundworms; usually with alimentary tract, mouth, and anus: Ascaris (191).

ROTIFERA. Small aquatic Scolerida, with eiliated band around mouth, and a special organ for attarchment, the foot; wheelanimalcules.

BRYOZOA. Scolecida in which the ciliated band is carried out on a series of tentacles surrounding the mouth; form colonies by budding. Endoprocta, Bryozoa with head and stalk, and crown of tentacles surrounding both mouth and anus (177). Ectoprocta, with anus outside tentacular corona (177).

BRACHIOPODA. Shelled, with long, tentaculiferous arms; lamp-shells $(180)$.

\section{MOLLUSCA ${ }^{1}$}

Animals with unsegmented body and without jointed appendages. Usually with a shell and with a muscular organ of locomotion, the foot.

LAMELLIBRANCHIATA. Mollusea with nearly symmetrical hody, leaf-like gills, and a shell composed of two valves. Ledider (236); Arride (234); Mytilide (234); Ariculide (235); Pectimider (236); Ostreide (236); L'nionide (228); Cycladide (230); Mactride (231); Veneridee (232); Myide (231); Solenide (231); Pholadida (230); Teredide (230).

GASTROPODA. Mollusca with head, feelers, and eyes, an unpaired foot, and a shell that is univalve when present. AmpHNEURA, with strict hilateral symmetry, no externally visible gills, and usually a shell composed of eight pieces: Chiton (220). ProsoBRANCHIATA, with gills in front, shelled and operculate: Acmaida (219); Patellide (219); Fissurellida (219); Naticidce (217); CaIyptraider (Crepidula, 218); Littorinide (216); Muricida (Urosalpinx, 218); Fasciolaride (Fulgur, 217). Opisthobranchiata,

${ }^{1}$ This elassification, unlike that of the text, follows Cooke in his "Mollusca." 
with gills behind heart; if shelled, without operculum; Eolidiidee (220). Pulmonata, breathing by means of lungs, no operculum: Auriculide (214); Limnoido (214); Limacide (211); Holicidee (213); Pupida (214).

CEPHALOPODA. Mollusca with large head, mouth surrounded by a circle of arms, and funnel-shaped foot. Argonautidce (221); Spirulida (221); Loliginida (221); Nautilida (221).

\section{ECHINODERMATA}

Animals of a prevailingly radial structure, with intestinal wall distinct from body-wall and with calcareous plates in the skin (192).

CRINOIDEA. Sessile Echinodermata, having a cup-shaped body (258).

ASTEROIDEA. Star-shaped Echinodermata, with a furrow along the under side of the arms (251).

OPHIUROIDEA. Star-shaped Echinodermata, with ungrooved arms (253).

ECHINOIDEA. With armless, globular, or cake-shaped body (254).

HOLOTHUROIDEA. Worm-like, with tentacles around mouth (256).

ANNELIDA

Bilateral, segmented worms without jointed legs.

POLYCHETA. Annelida possessing parapodia on one or more segments, and with many bristles on parapodia. ERrantia, freeswimming Polychæta: Autolytus (187), Lepidonotus (187), Nereis (185). Sedentaria, Polychæta which live in tubes composed of mud, sand, or lime: Amphitrite (189), Polycirrus (189), Cistenides (189), Clymenella (188), Serpula (189).

OLIGOCHATA. Annelida without parapodia and with few setæ; living in fresh water or in the ground. Limicol 2 , aquatic: Nais (173); Dero (172) ; Tubifex (172). TerRICoLe, earth-inhabiting: Allolobophora, Lumbricus (169).

GEPHYREA. Annelida having sessile habits and consequently without external segmentation in the adult, setæ sometimes present. Phascolosoma (176), Echiurus (177). 
HIRUDINEA. Annelida with short rings or none at all and with a ventral sucker; "bloodsuckers." Clepsine (175) ; Nephelis (175).

\section{ARTHROPODA}

Symmetrical, segmented animals, with jointed appendages.

CRUSTACEA. Typically, aquatic and gill-bearing Arthropoda. Two pairs of antennæ, except in Gigantostraca.

[ENTOMOSTRACA]. Crustacea with varied number of pairs of appendages; usually of small size. BranchIopoda, mandibles without palps, numerous legs (156). Trilobita, fossil (160). Cladocera, mandibles palpless, few legs (157). Ostracoda, palp on mandible, only two pairs of legs (157). COPEPODA, elongated Crustacea, with only one pair of maxillæ; females with external ovisacs (158). Cirripedia, attached Crustacea (barnacles, 158).

[MALACOSTRACA]. Crustacea with nineteen pairs of appendages. Amphipoda (146). Isopoda (145). Stomatopoda (144). Podophthalmata : [Macrura], large-tailed Podophthalmata : Caridide (138); Astacide (131); Thalassinide (138); Pagurida (138); Hippide (140). [BrachyurA], erabs: Oxyrhyncha (140); Cyclometopa (141); Catometopa (143).

[GIGANTOSTRACA]. Crustacea with five pairs of appendages on cephalo-thorax, abdomen without feet; body ends in a long telson, Limulus (146).

ARACHNOIDEA. Air-breathing Arthropoda without antennæ. Acarina, mites (117). Pycnogonida, sea-spiders (119). AreNEINA, spiders: Saltigradae (110); Citigradee (109); Laterigrada (109); Tubitelarice (105); Retitelarice (106); Orbitelarice (106); Territelarice (105). Phalangina, harvest-men (117). ArthroGASTRA, scorpions (116).

TRACHEATA. Air-breathing Arthropoda, with one pair of antennæ.

[PROTRACHEATA]. Tracheata with worm-like body. Each segment of the trunk hears a short, stout appendage. Peripatus (101).

[MYRIAPODA]. Tracheata with distinct head and abdomen, all the segments of the abdomen bearing appendages. CHI- 
LOPODA, centipedes: Scutigarida (98); Lithobiido (98); Scolopendridoe (99); Geophilidce (100). Diplopoda, millipedes: Julidœe (100); Polydésmidoe (100). Symphyla: Seolopendrella (101), Pauropus (101).

[HEXAPODA]. Tracheata with only three pairs of legs, confined to thorax. Orthoptera, Hexapoda with two pairs of wings, masticating mouth-parts, incomplete metamorphosis: Forficulida (17); Blattido (17); Mantidoe (17); Phasmida (18); Acridido (13); Locustida (19); Grillidee (20). Neuroptera, Hexapoda with two pairs of net-veined wings ; biting mouth-parts, metamorphosis complete or incomplete: Odonata (24); Ephemerida (24); Termitida (26); Sialida, Corydalis (28). Hemiptera, Hexapoda with two pairs of wings or none, sucking and piercing mouth-parts, incomplete metamorphosis. [HETEROPTERA], upper wings leathery: Reduvidace (23); Pentatomide (22). [HomopterA], wings alike: Cicada (23); [here, also, plant lice and animal lice]. Diptera: Hexapoda with (typically) one pair wings; piercing and sucking mouth-parts; complete metamorphosis. [APHANIPTERA], fleas (88). [Pupipara]: Hippoboscido. [Brachycera], true flies: Muscido (80); Estridoe (81); Syrphidce (82); Asilidoe (82); Tabanidae (82); Simuliide (83). [Nematocera], gnats: Cecidomyidee (83); Culicidee (84) ; Tipulidoe (87). Coleoptera, Hexapoda whose fore wings are modified into wing eovers; hind wings folded when not in use: Coccinellida (73); Chrysomelidce (72); Cerambycidce (72); Curculionida (71); Scolytidce (71); Lampyrida (70); Elaterida (70); Buprestidce (70); Lamellicornin (69); Lucanide (68); Dermestidce (68); Silphida (67); Staphylinida (66); Hydrophilida (65); Gyrinida (65); Dytiscidae (65); Carabidee (64); Cicindelida (63). Lepidoptera, Hexapoda with two pairs of scale-covered wings, sucking mouth-parts, complete metamorphosis : Tineida (47); Tortricida (47); Geometrides (47); Noctuida (45); Bombycida (42); Arctiidee (42); Xylotropida (42); Sphingida (47); Papilionida (40). Hymenoptera, Hexapoda with two pairs of membranous wings; biting and licking mouthparts; complete metamorphosis: [РнуторнAGA], plant-eating (59). [Entomophaga] insect parasites (58). [AcdLEAta] stinging: Formicida (52); Fossoria (52); Vespida (51); A pidoe (49). 


\section{CHORDATA}

Animals which possess, at some time of life, throat slits and a dorsal surporting rod or chorda.

\section{[HEMICHORDA]}

Animals of worm-like form, showing gill-slits like fishes. Balanoglossus (293).

\section{[TUNICATA]}

Usually sessile Chordata, often forming colonies (290).

\section{[VERTEBRATA-ACRANIA]}

Free-living fish-like Chordata, but without skull, paired fins, or heart, and with colorless blood. Amphioxus (294).

\section{[VERTEBRATA-CRANIATA]}

Free-living Chordata, with skull and complex brain, and red blood.

CYCLOSTOMII. Eel-like vertebrates without lower jaw, and living a parasitic life (322).

PISCES. Aquatic vertebrates with gills, without lungs, and with paired fins instead of legs. SELACHI, skeleton cartilaginous, no operculum, spiral valve (322). GANOIDEI, skeleton either cartilaginous or hony, spiral valve and operculum present : sturgeons (323); spoon-hill (324); garpilie (324); bowfin (324). Teleoster, sheleton bony, no spiral valve. [AcAnthopteri], dorsal, anal, and ventral fins with spines, pharyngeal hones distinet: perches (312); darters (311); sunfishes (313); toarfishes (313); sculpins (313); silversides (314); sticklehacks (315). [PHARYNGOGNATHI], fins with spines, pharyngeal bones united. [ANACANTHini], fins without spines, ventral fins far forward: codfishes (310); flatfishes (316). [Pнysostom], fins without spines, ventral fin placed far backward: smelts (309); trouts (310); whitefishes (316); catfishes (317); suckers (317); minnow (318); pikes (319); shads (319); eels 
(320). [Plectognathi], intermaxillaries and maxillaries united. [Lophobranchur], hody covered with bony plates: pipefishes (321). DipNor, lung-fishes (324).

AMPHIBIA (= Batrachia). Vertehrata having no lateral fins (but instead, legs); functional external gills during a part of their life. Urodera. Amphibia which retain the tail permanently: Sirenido (255); Proteide (339); Amphiumide (339); Cryptobranchide (339); Amblystomida (340); Plethodontida (342); Desmognathide (342). AnURA, Amphibia which lose the tail in the adult stage: Pipida (345); Hylide (345); Bufonide (347); Ranide (347). Gymnophions, Amphibia which have no limbs nor tails; body worm-like (329).

REPTILIA. Vertebrata which breathe exclusively by lungs and whose skin contains horny epidermal seales or bony plates. Chelonia, trunk enelosed in a bony case: Chelonide (362); Trionychidoe (363); Testudinido (363). SAuria, shoulder-girdle and sternum present, usually with eyelids: Chomaleonide (360); Igurenidce (357); Varanidce (358); Lacertidce (359); Helodermida (359); Anguido (360). Ophidia, footless scaled reptiles with no shouldergirdle, sternum, nor movable eyelids: Colubrida (365); Elapida (366); Crotalide (366). Crocodilina, large reptiles, with longitudinal vent (368).

AVES. Feathered Vertebrates. Cursores, Aves with keelless sternum (391). Natatores, swimming birds (392). GrallaTOREs, wading birds (393). Galline, large ground birds with strong, perching feet and flat nails (394). CoLumbın.e, short cloven feet and compressed nails (396). Coccyass, birds with powerful heak and feet adapted for climbing (399). PICI, woodpeckers (400). Macrochires, long-winged birds, without cere or seales on metatarsus (401). PAsseres, birds whose metatarsus is covered with laminæ or scales, usually with singing apparatus: Tyrannidee (402); Alaudida (404); Corvide (404); Icteride (405); Fringillido (406); Tanagride (407); Hirudinidee (408); Ampelida (409); Laniidee (409); Vireonida (409); Mniotilide (410); Troglodytida (410); Certhiide (413); Paridee (413); Turdidce (413). Raptones, hirds with cere, hooked bill, and strong, hooked claws (396). Psitraci, birds with cere, high, hooked beak, and fleshy tongue (parrots, 397). 
MAMMALIA. Vertebrates which nourish the young by means of milk, and are usually covered with hair. Monotremata, oviparous mammals (439). MARSUPALIA, provided with a marsupium (440). Edentata, teeth either ahsent, rudimentary, or without enamel (44). ('ETACEA, marine hairless mammals, hind limbs absent (412). UNGULATA, hoofed mammals: even-toed ungulates (444); odd-toed ungulates (445); elephants (445). Rodentia, canines absent, incisors grow continuously through life (446.) CARNivora, canines large (446). INSECTIVORA, small, terrestrial, carnivorous mammals, with small canines (445). Cherroptera, mammals with flying membrane between elongated digits (448). Primates, with hands (449). 


\section{INDEX}

A

Abdomen, 3, 120 .

Abnormalities in Crustacea, 151.

Aboral, 238.

Academies established, 465 .

Acarina, 117.

Acartia, 158.

Acmæa, 219.

Admiral, 40.

Agassiz, Alexander, 471.

Agassiz, Louis, 469.

Agricultural ant of Texas. 55.

Air-bladder, 305.

Albino mice, 430.

Aldrovandi, 461.

Alternation of generation, 269.

Alligator Snapper, 363.

Alligators, 351, 369.

Amblyopsis. 94 .

Amblystoma, 343,456 .

Amblystomidæ, 340 .

Aneiurus catus, 317.

Amia, 323, 324.

Ammonites, 222.

Amceba, 284.

Amphibia, 328 ; metamorphosis of, 343.

Amphioxus 294.

Amphipoda, 145.

Amphitrite, 188.

Amphiumidæ. 339.

Anatomical Zoology, 463.

Anatomy, 2; of Anphibia, 329; of Annelids, 161; of birds, 376 ; of Crustacea, 120; Echinoderms, 238; insects, 1; mammals, 432; Mollusca, 199; turtle, 352.

Ancestry of Vertebrates, 289, 296.

Angle-wings, 40.

Animal architecture, 102.

Animal behavior, A study of, 208 .

Animalcula, 282.

Annelids, 161, 172; anatomy of, 161; circulatory system of, 164 ; excretory organs of, 166; general form of body, 161 ; musculature of,
167; organs of nutrition, 163; physiology of, 161 ; respiration in, 164 ; reproductive organs of, 160 ; sense-organs of, 167.

Anodonta, 228.

Anolis, 357.

Anopheles, 86.

Anrophthalnuts, 95.

Ant-eater, 441.

Antelopes, 444, 445.

Antennse, 4, 13, 31 .

Anterior, 2.

Ant-lions, 28.

Ants, 52; armies, 55; colonies, 53, 55; language, 54; leaf-cutting, 56 .

Anura, 329, 344.

Apes, 450.

Aphids, 24.

Aphrodite, 186.

Apidre, 49.

Aplysia, 212.

Appendages, 3; of Amphibia, 331 ; of Annelids, 163; of birds, 382; of Crustacea, 120; insects, 3; mammals, 434.

Apteryx, 391.

Aquatic pulmonates, 214.

Arabian horse, 424.

Arachnida, 114.

Araneina, 104.

Arbacia, 256.

Arca pexata, 234.

Archreopteryx, 418.

Arcidæe, 230, 234.

Arctiidæ, 42.

Argiope, 107.

Argonauta, 221.

Arion, 212.

Aristotle, 459.

Arks, 234.

Armadillo, 441.

Army-worm, 45.

Arthrobranch, 123.

Arthropods, 114.

Ascaris, 191.

Asiphonata, 227.

Assassin-bug, 22. 
Astacus, 130; food, 133; geographical ' Blindworm, 360 .

distribution, 130; organs of, 123.

Asterias, 251, 252.'

Atoll, $27 \%$.

Attached animals, a study of, 260 .

Atticle, 110.

Auriculide, '2'14.

Autolytus, 187.

Ariculida, $230,235$.

\section{B}

Baboon, 450 .

Bacteria, 76.

Budger, 446.

Balanoglossus, 293.

Balfour, 469 .

Baltimore oriole, 405 .

Bark-borers, 71.

Barnacles, 158.

Barrier reesf: 277 .

Basket fikh, 251, 255.

Bat, 92, 448.

Beaker animals, '271.

Bears, 446 .

Beaver, 446.

Bedbug, 23.

Bees, 49 ; domestication of, 427 ; honey, 50; social, 49; swarming, 50.

Beetles, 60 ; development of, 62 ; economic importance of, 74, 75: food of, 61 ; geographical range of, 62 ; habitats of, 61 ; larval habits of, 62 .

Behavior, animal, 208.

Bell-animaleule, 288.

Bell-hydroids, 267.

Bilateral symmetry, 290.

Binonial nonenclature, 463 .

Birds, 420: classes of, 390: domesticated, 425: extinction of, 41s; flight of, 414; migration of, 371 ; migration routes of 372 ; muscular system of, 388; nerrous svstem of, 389; organs of, 383-387; of prey, 396; protection of, 417: sense-organs of 389 ; study of, 370 ; teeth of, 419 .

Bivalve Entomostraca, 157.

Rivalves, 227.

Blackbirds, 405.

Black-flies, 83.

Black rat, 430 .

Black snake, 365.

Black Swallow-tail, 40.

Blattidae, 17.

Blind crayfish, 92, 97.

Blister beetle. 75 .

Blood-ressels, 2. (See also Circulation.)

Bluebird, 413 .

Blue crab, 142 ; economic importance of, 146.

Blue jay, 404.

Boa, 365.

Bobolink, 406.

Boll-worm, 45.

Bombus, 49.

Bombycidix, 39, 42.

Bombyx, 42.

Bony fishes, 322.

Boring Mollusca, 230.

Bot-fly, $\rightarrow 1$.

Botryllus, 29.3.

Bougtiinvillia, 269.

Bowfin, 324.

Box-tortoise, 36.3.

Brachiopoda, 1so.

Brachycera, 80.

Brachyura, 140.

Brain coral, 275.

Brain, divisions of, 304 .

Branchiopod, 156, 160.

Brittle-star, 253.

Brook suckers, 317.

Brown ereeper, 413.

Brown rat, 431.

Brown-tail moth, 47.

Bruchidxe, 62.

Bryozoa, 177; of estuaries, 225.

Buck beetle, 72 .

Budding in corals, 277.

Buffalo-bug, 61, 6s.

Buffalo-gnat, sir.

Buffon. 466.

Bufonidse, 347 .

Bugula, 17s.

Bullfrog, 348.

Bullhead, 317.

Bumblebees, 49.

Bupestide, 70.

Burrowing habits, 168.

Buthus, 116.

Butteriy, 29; broods of, 34 ; development of, hahits and food of, 32: nimicry, 35; polymorphism, 34; protective resemblance, 35 ; types of, 40 ; wings of, 33 .

Byssus, 22:9.

Cabbage butterflies, 34, 40 .

Callinectes, 142.

Calosoma, 64.

Cambarus, 132, 143. 
Cameis, 444.

Campanularidæe, 267.

Camponotus, 53.

Canada grouse, 395.

Cancer, 142.

Canker-worm, 47.

Capillaries, circulation in, 464.

Carabidæ, 64, 95.

Carapace, 363; of lobster, 123.

Carboniferous age, 12.

Carchesium, 287.

Cardinal Grosheak, 407.

Carnivora, 446.

Carnivorous, 17.

Carolina paroquet, 398.

Carpenter ant, 53.

Carrion beetles, 67.

Case-bearers, 48 .

Cassowary, 391.

Cat, $420,446$.

Caterpillar, 30, 31.

Catfish, 317.

Catocala, 35, 45.

Cattle, 422 .

Caudina, 258, 259.

Cave beetles, 95 .

Cave crickets, 95.

Cave fish, 93.

Cecropia moth, 44.

Cedar waxwing, 410.

Cells, 469.

Centipedes, 97.

Cephalopoda, 198, 220.

Cephalothorax, 104.

Cerambycidx, 62, 72 .

Ceryle, 400.

Cetacea, 442.

Ceuthophilus, 95.

Chætæ, 163.

Chretopod, 163.

Chameleon, 357, 360 .

Cheetah, 446.

Cheliceræ, 105.

Chelonia, 351, 362.

Chestnut-sided warbler, 410 .

Chewink, 407.

Chickadee, 413.

Chigger, 119.

Chilopoda, 97.

Chimney swift, 402.

Chimpanzee, 450 .

Chinch-bugs, 22.

Chipping-sparrow, 407.

Chitin, 201.

Chiton, 220.

Cholera, 281.

Choloepus, 442.

Chorda, 289, 294.
Chordates, 289; relationship to invertebrates, 290.

Chrysomelide, 72.

Chrysops, 83.

Ciczda, 23.

Cicindolidæe, 63.

Cilia, $276,286$.

Ciona, 29:3.

Circulation, organs of, in Annelids, 164 ; in birds, 356 ; inserts, 7 ; in fish, 307 ; in frog, 333; in lobster, 124 ; in mamnals, 436 ; in turtles, 353.

Cirri, 189.

Cistenides, 189.

Citheronia, 44.

Civet-cats, 446 .

Cladocera, 157.

Clams, fresh-water, 227 ; marine, 231.

Cleavage, 456 ; of frog's egg, 451.

Clepsine, 175.

Click-beetles, 70 .

Clisiorampa, 45.

Clothes-nioth, 32, 48.

Clymenella, 188.

Cnidaria, 275.

Cobra, 366 .

Cobweh spiders, 106.

Coccinellidæ, 73 .

Coccrges, 399.

Cockatoos, 397.

Cockroaches, 17.

Cocoon, 31; of spider, 109.

Codfish, 316.

Codling-moth, 47 .

Coelenterata, 262.

Colaptes, 400.

Coleoptera, 60.

Colonies, in ants, 53 ; in hees, 49 ; in cnidaria, 277; wasp. 51.

Colorado potato-beetle, 73 .

Colubridæ, 365.

Columbinæ, 396.

Condor, 396.

Congo snake, 339 .

Contact lovers, 447.

Contour feathers, 376 .

Conurus, 398.

Cooper's hawk, 396.

Copepoda, 158.

Copperhead, 368.

Coppers, 41.

Copris, 69.

Coral, brain, 275; formation of colonies of, 277 ; organ-pipe, 267 ; reefs, 276.

Cordylophora, 265.

Coregonus, 311 . 
Corvidre, 404.

Cotton-worm, 45.

Cow-bird, 406.

Crab, burrowing, 142; spider, 109; swimning, 142 .

Crab-spiders, 109.

Crane, 393.

Crane-flies, 87.

Crayfish, 128 ; distribution, 130.

Creeper, 413.

Crepidula, 218.

Cribella, 252.

Cricket, 1, 20; cave, 20; external structure, 3; general form, 2; mole, 21.

Cricket-grasshopper, 20.

Crinoids, 238, 258.

Crocodiles, 351, 368.

Crop, of birds, 383 ; of cricket, 6; of Mollusea, 202.

Crossbill, 406.

Crotalidæe, 366.

Croton bug, 17.

Crow, 404.

Crow hlackhird, 405.

Crustacea, 134, 281; abnormalities in, 151 ; anatomy of, 120 ; physiology of, 120 ; regeneration of lost parts of, 149 .

Cryptobranchidæ, 339.

Ctenophora, 275.

Cuckoos, 399.

Cucumaria, 258.

Culicidze, 84.

Curculionidse, 71.

Currant-worm, 59.

Cursores, 391.

Cuticula, 3, 4, 30.

Cuttlefish, 220.

Cut-worm, 46.

Curier, 467, 469.

Cyclas, 230 .

Cyclops, 158 ; rate of reproduction. 158.

Cyclostomi, 322.

Cynthia noth, 43.

Cytology, 469 .

\section{D}

Daddy-long-legs, 117.

Danaidæe, 37.

Daphnia, 134, 153, 157.

Darters, 312.

Darwin, Charles, 469, 470.

Darwin, Erasmus, 470.

Darwinism, 37,470 .

Decapods, economic importance of, 145.

Deer, 444.

Dermestidæ, 68 .

Dero, 172.

Desmognathidæ, 342 .

Desmognathus, $326,342$.

Development, beetle, 62 ; crayfish, 148; effect of heat on, 453; of light on, 453; frog's egg, 451; $\mathrm{fly}, 78$; general laws of, 456 ; grasshopper, 15; Lepidoptera, 29 ; lobster, 146; mammals, 437 ; postembryonic, of frog, 455 ; star fishes, 247 ; Urodela, 343.

Devonian age, 12.

De Tries, 428,470 .

Diapheromera, 19.

Didelphys, 441.

Digestion (see Nutrition).

Digger wasps, 52.

Dimorphism, sexual, 113.

Diplopoda, 100.

Dipnoi, 303, 324.

Diptera, 76-89.

Discontinuous genera, 132.

Disease-producing animals, 76 .

Distomum, 196.

Diver-heetle, 65.

Dirision of labor, physiological, in Cnidaria, 278; in Crustacea, 151.

Dodo, 396, 418.

Dog, 422, 146 .

Dolphins, 443 .

Donestic animals, evolution of, 420 .

Dominant characters, 429.

Dorsal, 2.

Downy woodpecker, 401.

Dragon-flies, 25.

Dryness-lovers, 349.

Duckbill, 439.

Duckłill catfish, 324 .

Dytiscidæ, 61, 65 .

\section{$\mathrm{E}$}

Eagle, 396.

Earthworm, 168; economies of, 171; food of, 170 ; regeneration in, 170 ; source of diseases, 172 .

Earwig, 17.

Echidna, 439.

Echinoderms, 238; anatomy of, 238 ; musculature of, 244; nerrous system of, 245 ; organs of circulation, 24.3; excretion, 244 ; reproduction, 244: respiration, 242 ; physiology of, 238; sense-organs of, 245 ; water-vascular system $\mathrm{cf}$, 240. 
Echinoids, 254.

Echiurus, 177.

Ecology, beetles, 60 ; birds, 416 ; butterflies, 32 ; grasshopper, 13.

Economies of, beetles, 61 ; birds, 416 ; earthworms, 171 ; fishes, 298 ; grasshopper, 13; Lepidoptera, 34; oysters, 236; parasitic worms, 195 ; smelts, 309 ; slugs, 211 ; spider webs, 112.

Ectoderm, 262.

Ectoprocta, 179.

Edentata, 441.

Edible crab, 141.

Eel, 320 ; lamprey, 322.

Effect of heat and light on the development of the egg, 45:3.

Egg, fertilization of, 247, 307, 335, 437.

Egrets, extermination of, 394 .

Elapidæ, 366.

Elateridæ, 70.

Elephants, 445.

Elytra, 60, 66.

Embryology, definition of, 247 ; history of, $46 x$; study of, 246.

Encyclopædic zoology, 462.

Endoprocta, 177.

Enemies of the lobster, 136.

English sparrow, 370 ; body covering, 379; food of, 375 ; form of borly, 376; spread of, in America, 374.

Engraver beetle, 71.

Ensis, 231.

Entodern, 262.

Entomostraca, 134, 153, 281 ; bivalve, 157 ; distribution of, 155 ; volume of, 153 .

Eolis, 2:20.

Ephemeridx, 24.

Euglena, 286.

Eupagurus, 139.

Even-toed hoofed mammals, 444.

Evolution, of domestic animals, 420 ; of species, 466 ; theory of, 469.

Excretion (see Excretory organs).

Excretory ducts, 2.

Excretory organs, annelids, 166 ; birds, 387 ; pricket, 7 ; fish, 307 ; frog, 334; lizards, 354; lobster, 125; mammals, 437.

Exhalent opening, 291.

Exotic species, increase of, 375 .

Extinct birds, 418.

Eyespot, 295.

\section{F}

Fairy shrimp, 156.

Falcon, 396.
Fertilization, 9.

Fenur, 5.

Fiddler-crabs, 143.

Filaria, 86.

Fireflics, 61,70 .

Fish, 420; armored, 303; bony, 302; cartilaginous, 302; rlassificatiun of, 302; culture of, 301; donesticated, 425; general form of body, 303; musculature of, 30s; nervous system of, 308; organs of circulation, 307; excretion, 307; nutrition, 305; reproduction, 307 ; respiration in, 307 ; study of the food of, 15.3; senserergans of, 30s. use of, by man, 3(3\%).

Fisheries, value of, 299.

Fissurella, 219

Flagellata, $2 \infty 6$.

Flatfish, 316.

Flatworm, 191.

Flea, 88 .

Flesh-eaters, 446.

Flight of birds, 414 .

F lower-flies, 82 .

Fly, 76 ; degenerate, 87; development, 78; econonic importance of, 88,89 ; food, 78 ; miniery in, 82 ; parasitic, 8789 .

Flycatchers, 402.

Food-canal, 294.

Food of beetles, 61 ; butterflies, 32: earthworm, 170 ; fishes, 153 ; flics, 78 ; fresh-water mussels, 228; hydra, 265; lobster, 122; nercis, 1๖6; mice, 431; sparrow, 375 ; whale, 443.

Food supply, a study of, 298 .

Forficulide, 17.

Form of body, frog, 329; mamnalia, 432 : turtle, 352 .

Formicida, 52.

Fossil brachiopods, 180; hirds, 418; cephalopods, 222; lizards, 361; man, 450 .

Fowl, domestic, 4:5, 426 .

Fox, 446.

Fox-sparrow, 407.

Fresh-water hydroids, 265; mussels, 228; sponges, origin of, 225 ; turtles, 363 .

Fringillidæ, 406 .

Fringing reefs, 277.

Fritillaries, 40 .

Frog, 325, 347; genernl form of body, 329 ; muscular system of, 335 : nervous system of, 336 ; organs of circulation, 333; excretion, 334; 
nutrition, 331 ; reproduction, 334; Grapta, 40.

respiration, 333 ; sensu-orgins of, 338 ; skeleton of, 329.

Frog's egg, development of, 451.

Fulgur, 217.

Fundulus, 319.

\section{G}

Gadus, 316.

Galen, the anatomist, 460 .

Galley-worm, 100.

Gall-grats, 83.

Gall-wasp, 58 .

Galline, 394.

Galls, 84.

Gallus, 395.

Ganglia, 9.

Ganoidei, 323.

Ganoids, 303.

Garpikes, 324 .

Garter-snalic, 365.

Gisteropoda, 210.

Cilsteropods, 198; forn of body, 198; organs of respiration, 202 .

Gisterosteus, 315.

Gastrolith, 137.

Giastrulation, 457 .

Gecse, 425.

Grosimus, 143 .

Genera, discontinuous, 133.

Generations, alternation of, 269 .

Geographical distribution of rrayfish, 128.

Geometridie, 47.

Geomys, 44 is.

Geophilus, 100.

Gephyrea, 176.

Germ-cell, $8,246$.

Germ theory of disense, 283.

Gesner, 460.

Gibbon, 450 .

Gila monster, 359.

Gills, 24; of Jobster, 123.

(ill-slits, 294, 295, 250.

Cirstfe, 444, 445 .

(ildss-snako, 360.

(ilorhidium, 2299.

(Hossina, 81 .

Glow-worm, 71 .

(inat, 8.3.

Cinawing maumals, 446.

Gioats, 424 .

Goat-suckers, 401.

(in)lalish, 319 .

(iopher, 446.

(inrilla, 450 .

Grillatores, 399.

Grasshopper, 11; allies of, 16; cricket, 20; long-horned, 19.

Gray-veined White Butterfly, 34.

Crreat auk, 418.

Great northern shrike, 411.

Green frog, 348.

Green turtle, 362.

Gregarious, 13.

Ground-heetles, 64 .

Grouse, 395.

Cryllida, 20.

Gryllotalpa, 21.

Guinea-fowl, 395.

Guinea-pigs, domesticated, 424.

Gull, 392.

Gyminophiona, 329.

Gypsy moth, 46.

Gyrinidæe, 65.

\section{$\mathrm{H}$}

Habitat: aerial, 12,371 ; cave, 92-97; darkness, 90,91 ; desert, 349 ; fresh-water, 223: land, 325 ; river, 223 ; seashore, 182 ; sessile, 260; sub-terrestrial, 16\%'

Hiemal, 297.

Mair-streaks, 41.

Hairy ant-eater, 441.

Hairy antelope, 401.

Hard-shelled clans, 232.

Hare, 448.

Harvester ant, 55 .

Harvestmen, 117.

Hawk, 396.

Hawk-hill turtle, 363 .

Hawk-moths, 41.

Head, 3.

Healing, 454.

Heart (see Circulation).

Heat, effect on development of egr, 453.

Helix, 213; variability of, 214 .

Holltender, 341 .

Holodernidie, 359.

Hcmiptera, 2:2.

Henocyanin, 204.

Hen clams, 231.

Hormaphrodite, 160 .

Hermit-crabs, 138.

Heron, 393 .

Hesperornis, 418 .

Hessian-fly, 83.

Heteroptera, 2'2

Heterotrichia, 267.

Hexapoda, 12.

IIippidx, 140. 
Hiplonot:anus, 444.

Histry of sirience of Zoology, 458.

Holothurians, 240, 241, 256.

Holotrichia, $2, \overline{7}$.

Homarus, distribution of, 134 .

Honoptera, 22, 23.

Honey bees, 50.

Hoofed manmals, 144.

Horn-fly, 88.

Horn-pout, 317.

Horned Corydalis, 28.

Horned toad, 357 .

Hornet, 51.

Horse-flies, 82.

Horses, 4:2, 445.

House-flies, do.

House wren, 412.

Hunming-birds, 401 .

Huxley, 465.

Hydra, 260, 262, 264,275 ; discovery of budding in, 465; -like animals of estuaries, 225 ; regeneration in, 279 .

Hydrachnids, 117.

Hydractinia, 260.

Hydranth, 267, 271, 278.

Hydrocorallida, 267.

Hydroids, brll, 267 ; fresh-water, 265 ; tubularian, 267.

Hydromeduse, 271.

Hydrophilidxe, 65.

Hydrozoa, 271.

Hyenas, $4 \pm 6$.

Hylidæ, 345.

Hymenoptexa, 48; boring, 48 ; planteating, 59 ; stinging, 48.

\section{I}

Ichneumon, 58 .

Icteridæ, 40.5 .

Iguanids, 357.

Imago, 24, 32, 33; of Diptera, 78.

Increase of exotic species, 375.

Indigo bird, 407.

Infusoria, 282,286 .

Inhalent openings, 291.

Insects, disseminator's of disease, 28:; domesticated, 427.

Intelligence of ants, 53.

Intestine of cricket, 6.

Isabella caterpillar, 42 .

Isopoda, 145.

Isoptera, 26.

Jackals, 446.

Jay, 404.
Jellyfish, 270; of fresh water, 266; life-history of, 26t.

Jigger, 119.

Joint-snake, 360 .

Julus, 100.

Jumping spiders, 110 ; mice, 446.

June-lugs, 69.

\section{II}

Kallima, 36.

Katydids, 19.

Kirlney tubules, 295.

Killer whale, 443.

Killifish, 318.

Kinghird, 403.

Kingfishers, 400 .

Kitchen-middens, 237 .

\section{$\mathrm{L}$}

Lalbium, 4.

Lacertida, 359.

Lachnosterna, 63.

Ladybird beetle, 73.

Lady-crab, 142.

Lamarck, 466, 467.

Lanellibranclis, 198.

Lamellicorn bectles, 68.

Lamprey eels, 302, 32*2.

Limp-shells, 180.

Lampyridie, 70 .

Land life, origin of, 325.

Land-locked fishes, 309.

Land tortoises, 36:3.

Language of ants, 54 .

Lantern of Aristotle, 242.

Larks, 404.

Limvacea, 291 .

Larvæ, of amphibia, 342; of Coleoptera, 62 ; of Diptera, 78 ; of Lepidoptera, 32 ; of lobster, 14ל.

Larval stage, 30.

Lash animalcules, 286.

Laws of development, 456 .

Leaf-cutting ants, 56 .

Leaf-eating bectles, 72 ; lamellicorns, 69.

Lcaf-hopper, 24.

Leaf-insects, 18.

Leaf-miner. 47.

Leaf-roller, 47.

Learned societies, establishment of, 465.

Ledida, 230, 236.

Leeches, 174.

Lecuwenhoek, 464.

Lenuur, 450. 
Leopard, 446.

Leopard frog, 348.

Lepidonotus, 186.

Lepidoptera, 29; economics of, 39; general development, 29.

Lepidosteus, 323.

Libinia, $1+1$.

Licer, $2: 3$.

Lirla, 236.

Life on the scashore, 182.

Light-shunners, 90 .

Liniax, 211, 212.

Linnitis, 37.

Limnæu, 214.

Limpet, 219.

Limulus, 146.

Line-weavers, 106.

Linnzeus, $463,466$.

Liobunum, 118.

Lions, 446.

Lithobius, 90, 97, 98.

Littorina, 216; littoria, spread of, 217,379 ; palliata, 217 ; rudis, 217 .

Liver of frog, 331 ; lobster, 122; vigenn, 355 ; smelt, 305.

Liver-fluke, 19\%3.

Lizards, 349, 356, 357; common, 359; as dryness lovers, 349; fossil, 361 .

Llamas, 444.

Lobster, 120; circulation in, 124: development of, 146 ; distribution of, 134; economic importance of, 145; enemies of, 136 ; excretion in, 125 ; molting of, 136 ; musculature of, 125 ; nervous system of, 126 ; nutrition in, 122: protection of, 135: reproductive organs, 125 ; respiration in, 122; sense-organs of, 126.

Locomotion, of bird, 415 ; of snail, 200.

Locust borer, 74.

Locustidæ, 19.

Locusts, 15, 23.

Loligo, 221.

Long-horned beetles, 72; flies, 82; grasshoppers, 19.

Long-winged birds, 401.

Louse-flies, 87.

Luranide, 68.

Lung surs, 105.

Lung-snails, 213.

Lycenas, 41.

Lycosidx, 109.

Lynx, 446.

Macaques, 450 .

Macrura, 140.
Mactra, 232.

Mactridæ, 230, 231.

Madreporite, 240.

Maggots, $>0$.

Malacostraca, 134, 144.

Malaria, 281, 285; causes of, 85 .

Malpighi, 463, 464, 46 s.

Nammalia, 420, 432, 441.

Mammals, even-toed, hoofed, 444 ; form of body of, 432 ; function of digestion, 434; gnawing, 446; hoofed, 441; muscular systen of, 438 ; nervous system of, $43 b$; odd-toed, hoofed, 445; organs of circulation, 436; digestion, 434; excretion, 437 ; reproduction, 437 ; respiration, 436 ; sense organs of, 439; skeleton of, 433 ; structure of, 432 .

Manatees, 44:.

Mandrills, 450 .

Mantidæ, 17.

Mantis shrimp, 144.

Mantle of Moliusca, 198, 199, 210.

Manx cat, $4 \geq 0$.

Marmoset, 450.

Marnot, 446.

Marsupialia, 410.

Martens, 446.

Maryland yellow-throat, 410 .

Maxillæ, 4 .

May flies, 24, 26.

Meadow grasshopper, 20.

Meadow-lark, 406.

Meal-beetles, 61 .

Mealy bugs, 24.

Measuring worms, $35,47$.

Medusxe, 259.

Melanupus, 214.

Membranes, 1.

Mendel, 429.

Mendel's law, 429.

Metallic wood-borers, 70 .

Metanorphosis, 13; Anpphibia, 343, 456: Coleoptera, 62; Diptera, so; Echinodermata, 249; Lepidoptera, 31: Tunicata, 292.

Metridiun, $273,274,275$.

Mice, domestication of, 428; food of, 431 ; habits of, 431 ; rapid distribution of, 430 .

Microhydra, 266.

Migration routes, of birds, 372; of redstart, 373 ; study of, 370.

Milk-snake, 365 .

Millipedes, 97, 100.

Mimicry, $35,37,82$.

Minks, 446. 
Minnows, 318.

Mites, 117.

Moccasin snake, 366.

Mocking-bird, 412.

Mole, 445 .

Mole-crabs, 140 .

Mole-cricket, 21.

Mollusea, 210 ; anatomy of, 198 ; musculature of, 206 ; nervous system of, 206 ; organs of circulation, 203; excretion, 204; nutrition, 200; reproduction, 204; physiology of, 198 ; sense-organs of, 206.

Molt, 16; of lolssters, 136.

Monarch, 37, 40.

Mongoose, 446.

Monkeys, 450.

Monotremes, 439.

Morone, 311.

Morphological Zoology, 463.

Morula, 457.

Mosquitoes, 84 .

Moth, 29.

Mother-of-pearl, 236.

Mourning-cloak, 40.

Mouse, 420, 446.

Mud-eel, 338 .

Mud-puppy, 339.

Mud-snail, 218.

Mud-wasps, 52.

Mus, 430.

Muscidæe, 80.

Muscles, 2.

Musculature, of annelids, 167 ; birds, 388 ; cricket, 9 ; erhinoderms, 244 ; fish, 308; frog, 335; gasteropods, 206 ; lobster, 125 ; mammals, 43s; turtles, 355 .

Muskallunge, 319.

Musk-turtle, 364 .

Mussels, 234; pearl, 235.

Mutation theory, 470.

Mutations, $42 r$.

Mya arenaria, 231

Myidæ, 230, 231.

Myriapoda, 92, 97.

Mytilidæ, 230, 234.

\section{$\mathrm{N}$}

Nais, 173.

Nassa, 218.

Natatores, 392.

Natica, 217.

Natural selection, 37.

Nautilus, pearly, 221.

Necturus, $339,456$.

Nematocera, 82.
1 Nemertini, 190.

Nephelis, 175 .

Nereis, 162, 164, 182; food of, 186

Nerve, 2; chord, 289.

Nervous system, of birds, 389 : cricket, 9 ; echinoderms, 245; fish, 308 ; frog, 336 ; lolsster, 126 ; mammals, 439; mollusca, 206; lizard, 355.

Nest, of barn swallow, 409 ; of chimney swift, 402; of pewee, 403.

Nettle animals, 264.

Neuroptera, 27.

Newt, 326, 342; transformation, 326.

Nighthawk, 402 .

Noctuidx, 45.

Norway rat, migrations of, $43 \mathrm{I}$.

Nucleus, 28d, 469.

Nuthatch, 413.

Nutrition, functions and organs of, 5 ; in echinoderms, 241; fish, 305; frog, 331; lobster, 122; lizard, 352 ; mammals, 434.

Nymphs, 40.

Obelia, 267, 278.

Odd-toed, hoofed mammals, 445.

Odonata, 25.

Oligochætæ, 172; terrestrial, 174.

Omnivorous, 17.

Oniscus, 145.

Operculum, annelids, 190 ; fishes, 304.

Ophidia, 351, 365.

Ophiuoridea, 253.

Opisthobranchs, 212,220 .

Opossum, 441.

Oral, 238.

Orang-utan, 449, 450.

Orb-weavers, 106.

Orb-web, structure, 107.

Orbitelariæ, 106.

Orca, 443.

Orchard oriole, 405.

Origin of land life, 325.

Organ-pipe coral, 267.

Organs, of circulation, in echinoderms, 243 ; fish, 307 ; frog, 333 ; Mollusca, 203; lizard, 353 ; excretion, in birds, 387; echinodermos, 244; fish, 307; Mollusea, 204 ; lizard, 354; lobster, 122 ; nutrition, in birds, 383; echinoderms, 241 ; fish, 305; Mollusca, 200; lizard, 352 ; respiration, in birds, 385 ; echinoderms, 242; gasteropods, 
202 ; lizard, 354; reproduction, in / Petrel, 393.

lirds, 387; fish, 307 ; Mollusea, Petromyzon, 322. 204 ; lizard, 354 .

Ornithorhynohus, 439 .

Orthoptera, 13.

Osnerus, 309.

Ostracuda, 157.

Ostrea. 237.

Ostreida, 230, 236 .

Ostrich, 391

Otueyst of lobster, 127.

()tter, 446.

Oripositor, $9,57$.

Owlet moths, 45.

Owls, 396.

Oxen, 444.

Oyster-crab, 143.

Oyster-drill, 218.

Oysters, 236.

Pewee, 403.

Phalangidea, 117.

Pharynx, 295.

Phascolosona, 176.

Phasmidæ, 18.

Pheasants, 394.

Phora, 447.

Phabe, $40: 3$

Pholadide, 230.

Photuris, 71.

Phry nosona, 357.

Phylum, 289.

Physa, 215.

Physalia, 271, 272.

Physiological division of lahor in Crustacea, 151.

Physiology of annelids, 161 ; Crustacea, 120; Insecta, 1; Mollusca, 198.

Pici, 400.

Paddle-fish, 3:4.

Paguridæe, 138.

Painted turtle, 364.

Pickerel, 319.

Pieris, 40.

Palamonetes, 138.

Pallene, 119.

Palm-crah, 140.

Pairdorus, 41.

Panopeus, 142.

Papilio, 40 ; ajax, 34; asterias, 40; turnus, 40.

Paramarcium, 280, 283, 284, 2\$6.

Parapodia, 186.

Pigeons, domesticated, 425.

Pigs, 444, 445.

Pike, 319.

Pine-horer, 71.

Pincal gland, 356 .

Pipe-fish, 321.

Pividae, 345.

Pithecanthropus, 450.

Planaria, 191, 194.

Planorlis, 215.

Parasitic Hynenoptera, 57 ; protista, 281 vertebrates, 322; worms, econonic insportance of, 195.

Parrot, 397.

Parthenogenetic, 158.

Partridges, 394.

Passenger yigeon, 395.

Passeres, 402 .

Patella, 219.

Pauropus, 101.

Pearl-fishing, 235.

Pearl nusseds, 235.

Pearl ovisters, 235.

Peurly nautilus, 2.)1.

Perecaries, 444.

Peeten, 236.

Pestinide, 230, 236.

Pedicellina, 177.

Plant-eating Hynenoptera, 59.

Plant-lice, 24.

Plastron, 363.

Plethodon, 34:.

Plethodontidæ. 342.

Pleurobranch, 123.

Pleuron, 123.

Plovers, 393.

Plumatellit, 17s.

Pudoloranch, 123.

Pogononyrmex, 55.

Poisonous spiders, 113.

Polistes, 51.

Polychata, circulatory systent in, 164; respiration in, 164 ; sedentary, 1st.

Polycirrus, Is?.

Prdipalps, 105.

Polydesnius, 100 .

Polymorphism, 34 .

Pelican, 393.

Pelopreus, 52.

Perch, 312.

Perchers, 402.

Peripatus, 101.

Polyp, 273, 275.

Polyphenus moth, 43.

Pond snail, 214.

Porcupine, 446,44 s.

Portuguese max-of-war, 271. 
Postemlaryonic development of the frog, 455 .

Posterior, 2.

Potato beetle, 61 .

Potato "worm," 41.

Poultry, domesticated, 425.

Prairie dog, 447.

Prawns, 138.

Praying mantises, 17.

Primates, 449.

Proboscis, 32, 293.

Prong-horn, 445.

Promethia moth, 43.

Protection of hirds, 417 ; lobster, 135.

Protective resemblance, $35,37,38$.

Protista, 280 ; cause of discases, 281 ; parasitic, 281.

Protophyta, 280.

Protoplasm, 1, 469.

Protozoa, 250; discovery of, 282, 465 ; origin of, $2 ৯ 2$; reproduction in, 282 .

Psittaci, 397.

Pulmonata, 210, 213; aruatie, 214.

Pumpkin-seed sunfish, 313.

Pupa, 31, 32, 214.

Purple grackle, 405.

Quadrate, 304.

\section{Q}

Quail, 395.

Quedius, 95.

Queen bec, 50.

\section{$\mathrm{R}$}

Ralubits, 424, 446, 448.

Raccoons, 446.

Radii of echinoderms, 239.

Radula, 201.

Rail, 393.

Ranidæe, 347.

Raptores, 396.

Rat, distribution of, 430 ; habits of, 431 ; systematic position of, 432 .

Rattlesnakes, 366, 367.

Ray, John, 462 .

Rays, 322.

Razor-clams, 231.

Recessive, 429.

Red-eyed vireo, 409.

Red-headed woodpecker, 401.

Redstart, 410 ; migration of, 373 .

Red-winged blackbird, 406.

Reefs, barrier, 277; coral, 277; fringing, 277.

Regeneration, 454 ; earthworms, 170 ; Schultze, 469. flatworms, 191; hydra, 279; lost parts in Crustacea, 149; nenerteans, 190.

Reproduction by transverse division, 173 ; in the cricket, $b$; in mammals, 387; in Protozoa, $2 x 3$.

Reproductive ducts, 2.

Reproductive organs, of annelids, 166; of hirds, 387; of echinoderms, 244; of fish, 307; of frog, 334; of lobster, 125; of mammals, 437; of lizard, 354.

Reptiles, 350.

Respiration, in annelids, 164 ; cricket, 6 ; fish, 305; lotster, 122; organs of, in frog, 332; manmmals, 436; lizard, 354 .

Rhea, 391.

Rhinoceros, 445.

Rhizopods, 284.

Rice-bird, 406 .

River faunas, origin of, 225 ; study of, 223.

River nollusks, 225.

Robber-flies, 8\%.

Rolin, 413.

Rock eel, 314.

Rodentia, 447.

Roof rat, 430.

Rose-breasted grosheak, 407.

Rose-bug, 70.

Rotifers, discovery of, 465 .

Round worms, 191.

Ruby-throated humming-bird, 401 .

Running beetles, 62 .

Running birds, 391.

Running spiders, 109.

\section{$\mathrm{S}$}

Salanınder, 93, 340.

Salmon, 304, 310 .

Salmonidx, 309.

Sand-dollars, 256.

Sandpipers, 393.

Sandworm, 185.

Sauria, 351, 356.

Sawflies, 59 .

Scale, 29.

Scale-bugs, 24.

Scaled-worms, 187.

Scitlop, 235.

Sraly ant-cater, 441.

Scarabidæ, 69.

Scarlet tanager, 408.

Sichleiden, 469 . 
Sichwann, 469.

Scolopendra, 99.

Scolopendrella, 101 .

Scolytida, 71 .

Scorpions, 116.

Siratchers, 394.

Screech owl, 397.

Sculpin, 313.

S'sutigera, 98.

Scyphozoa, 273, 275 .

Sea-anemones, 273.

Sea-cows, 44:.

Sea-cucumber, 258.

Sea-lilies, 258.

Sealion, 446.

Sea-mouse, $186,187$.

Sea-spiders, 119.

Sea-urehins, 238, 254.

Sea walnuts, 275 .

Seal, 446 .

Searcher, 64.

Segruentation, of body of annelids, 162.

Segmented animals, 290.

Selachians, 322.

Sense-organs of annelids, 167 ; birds, 389 ; crickets, 10; echinoderms, 245 ; fish, 308 ; frog, 338 ; lizard, 355 ; lobster, 126; mammals, 439; Mollusca, 206.

Serpent. 351.

Serpent-stars, 253.

Serpula, 189.

Sertularia, 268, 278.

Sexton beetles, 67.

Sexual dimorphism, 113.

Shad, 319 ; fishing, value of, 320 .

Sharks, 322.

Sharp-shinned hawk, 397.

Shell, rudimentary, in cephalopods, 221.

Sheep, 424, 444 .

Sheep-tick, 88 .

Short-horned Diptera, 80.

Short-horned grasshoppers, 13.

Short-winged beetles, 66.

Shrews, 445.

Shrikes, 409.

Shrimps, 138; burrowing, 138.

Nilkworms, 39,42 ; culture of, 43 .

Silphida, 67.

Silyersides, 314.

Simia, 449.

Siphonata, 227.

Siphonophore, 271.

Siren, 338.

Skeleton, 1; birds, 380 ; frog, 329 ; lizard, 352 ; mammals, 433 .
Skunk, 446.

Skylark, 404.

Sloth, 441.

Slow-worms, 360.

Slug, 208, 210; apparent absence of shell of, 211; economical importance of, 211 ; food of, 211 ; habitat of, 211.

Snuallest organisms, a study of, 280.

Smelt, 298, 309; economic importance of, 309 .

Snail, 198; form of body, 198; musculature of, 206.

Snake, 365.

Snapping-turtle, 364.

Snipe, 394.

Snowbird, 407.

Snowy owl, 397.

Social bees, 49 .

Social life of ants, 55 .

Soft-shelled clams, 231, 232.

Soft-shelled turtle, 363 .

Solenida, $230,231$.

Sonites, 3,4 .

Song-sparrow, 407.

Song thrush, 413.

Sow-bugs, 145.

Spanish $f y, 75$.

Sparrow, 406; English, 370.

Sparrow-hawk, 396.

Spelerpes, $93,344$.

Sphingidæ, 41 .

Spider, $10^{2}, 104$; cave, 96 ; position of in zoological system, 114; webs, economic importance of, 112 .

Spider-crabs, 140.

Spinnerets, 104.

Spinning instinct, uses of, 110; methods of, in spiders, 112.

Spiny ant-eater, 439.

Spiracles, 3 ; of cricket, 6 .

Sponges, 262.

Spontaneous generation, theory of, 282.

Spoonbill, 324.

Spore animalcules, 285.

sporozoa, 285; ('ause of malaria. 285.

Spotted sandpiper, 393.

Spreading adder, 365.

Spread of English sparrow in America, 374 .

Spring azures, $34,41$.

Spring-tails, 92, 96.

Squash-bugs, 22.

Squids, 220.

Squirrel, 446, 447.

Stag-beetles, 68. 
Staggers of sheep, 82 .

Staphylinidæ, 66.

Starfish, 246; abnormalities of, 251; devclopment, 247; distribution, 251 ; habitat, 251 ; serpent-stars, 253 ; study of embryology, 246; systematic position of, 251 .

Stegomyia, 86.

Stentor, 287.

Sterna, 392.

Stickleback, 315.

Sting of scorpions, 116.

Stink-bugs, 22.

Stolons, 279.

Stomach of crickets, 6 .

Stomapoda, 144.

Storks, 393.

Strongylocentrotus, 256.

Sturgeons, 323.

Stylactis, 266.

Subterrestrial organisms, 168.

Suckers, 317.

Suctoria, 288.

Sunfish, 313.

Swallow, 407.

Swallow-tails, 40 .

Swanmerdam, 464.

Swarming of bees, 50 .

Swifts, 401 .

Swimming birds, 392.

Sycon, 263.

Synapta, 259.

Syrphidæ, 82.

\section{$\mathrm{T}$}

Tahanus, 83.

Tænia, 197.

Talorchestia, 146.

Tanagers, 407.

Tapeworm, 195, 197.

Tapirs, 445.

Tarantula, 113.

Tarsus, 5.

Teeth, anuphibia, 331; birds, 419; echinoderms, 242; fish, 304, 305; mammals, 435 .

Tentacles, 271 .

Tent-caterpillar, 44-46.

Teredida, 230.

Termites, 26, 52.

Tern, 392.

Testudinidæ, 363.

Thalassinidæ, 138.

Theclas, 41.

Theory of evolution, 469 .

Thomisus, 112.

Thorax, 3.

Thrushes, 413.
Tibia, 5.

Ticks, 117.

Tiger, 446.

Tiger-beetles, 61,63 .

Tiger-moths, 42 .

Tiger swallow-tails, 40.

Tineids, 47.

Tipulidæe, 87.

Titmice, 413.

Toad, 347.

Toadfish, 313 .

Tomato worm, 35, 41.

Tortricids, 47.

Toucans, 399.

Trachea, 13, 80 ; of cricket, 6 .

Trec-hopper, 24.

Tree-spariow, 407.

Tree-toad, 345.

Trichina, 191.

Trilobite, 160 .

Trionyx, 363.

Trochilus, 401.

Troglodytes, 413 .

Trout, 310 .

True bugs, 22.

Trunk, 3.

Tsetse-fly, 80.

Tube-weavers, 105 .

Tubifex, 172 .

Tubularian hydroids, 267.

Tubularidæ, 267.

Tumble-lougs, 69.

Tunicates, 290.

Tunnel-weavers, 105.

Turdus, 415.

Turkey, 395.

Turkey-buzzard, 396.

Turtles, 351, 362; general form of body, 352; marine, 362 ; muscular system of, 355 ; nervous system of, 355 ; organs of circulation, 353 ; excretion, 354 ; nutrition, 352 ; reproduction, 354 ; respiration, 354 ; sense-organs, 355 ; skeleton, 352 .

Tussock moth, 46 .

Twin-spotted sphinx, 41.

Tyrannidæe, 402.

Unionidæ, 228.

Unios, 228; development of, 229; economic value of, 229 ; spawning season, 229.

Urodela, 328, 338; early development of, 343 .

Urosalpinx, 218.

Uses of spinning instinct, 110. 


\section{V}

Viranide, 358

Tarialsility of Holix, 214.

Voneridx, 2:30, 23:2.

Ventral, 2.

Venus, 23:2.

Vertebrates, 302; ancestry of, 289. 206.

Vesalius, 461.

Tespa, 51.

Vesper-sparrow, 407.

Tispidee, 51 .

Viceroy, 37, 40.

Vinegar eel, 191.

Vireos, 409.

Tolvox, 286.

Ion Baer's liaw, 457.

Vurticella, 2ass.

Vultures, 396.

\section{W}

Waders, 393.

Walhing-stick, 18.

Walrus, \pm \pm 6 .

Wrampum, 2:34.

Wandering spiders, 109.

Warbler, 410.

Wasps, 51.

Water-boatnan, 22.

Water-flea, 157.

Water-lizard, 358 .

Water seavenger-beetle, 65 .

Water-scorpion, '2:.

Water snahe, 305.

Water-striders. 22,

Water-vascular systen in echinoderms, 240.

Waste produets, 7.

Waxwings, 409.

Wrasels, 146 .

Weevils, 62, 71 .

Whales, 442, 443.

Whippoorwill, 40:?

Whirligig beetles, 65 .
White ant, 26 .

Whitefish, 310 .

White-throated sparrow, 407.

Wigglers, 85.

Wing, butterfly, 33.

Wing-cells, 5.

Wiug-treins, 5.

Wingless birds, 391; cockroaches, 17.

Wireworms, T0.

IIolf, 446.

Tiolff, $46 \mathrm{~s}$.

TIolf spiders, 109.

Troodcock, 394.

Wrood-feeders, 42.

II ood-lice, $1 \pm 5$.

Woudpeckers, 400.

Wood-warbler, 410.

Woul-buetle, 68.

Worker bee, 50.

Worm, earth. 169 17:; parasitic, 190-195; ringed, 161; stind, 185; scaled, 187; stomach, 191; tape, 195.

Wren, 410.

$$
\text { I }
$$

Xylotropids, 42.

\section{Y}

Yellow fever, 281.

Yellow warbler, 410.

Yoldia, 2.35.

\section{Z}

Zebra, 445 .

Zehra swallow-tail, 34.

Lovids, $271,279,2901$.

Zoological expeditions, 471 ; gardens, 465.

Zoology, 45s: foundation of, anatomical, 463; morphological, 463: history of science of, 458 ; yhilosophical, 466.

Zygodactyla, 271. 




\title{
HIGH SCHOOL COURSE IN LATIN COMPOSITION
}

BY

\author{
CHARLES McCOY BAKER
}

Horace Mann High School. Teachers College

AND

\section{ALEXANDER JAMES INGLIS \\ Horace Mann High School, Teachers College \\ Cloth I2mo xiii +464 pages $\$$ L.oo net}

The "High School Course in Latin Composition" is planned to furnish material for practice in writing Latin during the last three years of the course. The exercises are divided into three parts which correspond to the years in which Casar, Cicero, and Vergil are read.

Part I treats the syntax of nouns and the following subjects in the syntax of verbs: indirect questions, tense sequence, simple sentences in indirect discourse, purpose and result clauses, infinitives, gerunds and gerundives, cum clauses, participles, the ablative absolute, the passive periphrastic conjugation, and complex sentences in indirect discourse.

Part II develops the syntax of the verb and supplements the noun syntax of Part I.

The first twenty-four lessons of Part III review and supplement the syntax of Parts I and II; the rest are exercises in writing connected prose.

The exercises have been so based on the texts of Cæsar and Cicero usually read in our schools, as to summarize the content of those texts and to have sequence of thought from sentence to sentence. However, the text has not been so closely followed as to lead students to look for aid from that source.

A general English-Latin vocabulary is given at the end of the book. In addition a set of special vocabularies, consisting of twenty words, is given for each lesson, at the ends of Parts I, II, and III. Great care has been taken to make these vocabularies as serviceable as possible, and not only the individual words are given, but the idioms associated with those words and the references to the principles of syntax with them.

\section{THE MACMILLAN COMPANY}

\section{4-66 Fifth Avenue, New York}




\section{FIRST BOOK IN LATIN}

By Alexander James Inglis, Instructor in Latin, Horace Mann High School, Teachers College, and Virgil Pretryann, Principal Horace Mann High School, Teachers College. Revised Edition. Izmo. Cluth. 30 I pages, 90 cents net.

A series of sixty-five lessons affording an adequate preparation for the reading of Cxsar. The lessons are carefully graded; the rules, clear and concise.

Without assuming much knowledge of English grammar on the part of the student, the general principles of inflection and syntax are gradually developed.

The selection of words for the vocabulary is based on the latest and most systematic analysis of the vocabulary of the authors usually read in our schools. Words have been chosen with particular attention to their comparative frequency of occurrence, and with especial reference to the vocabulary of Casar, so that few words have been admitted which are not of very common occurrence in that author.

The exercises consist of three parts: detached Latin sentences; a passage of connected Latin; and sentences for translation from English into Latin. The detached Latin sentences are intended for practice in the paradigms and syntax of the lesson, while the passages of connected Latin afforcl practice in reading narrative Latin and review work in vocabulary and syntax.

A simple system of reference and cross reference is employed so that any page, paragraph, or footnote may be quickly found. The paradigms presenting the inflections of the various parts of speech are found in Appendix I. A summary of rules is given in Ap. pendix II.

\section{THE MACMILLAN COMPANY \\ Publishers 64-66 Fifth Avenue New York}




\section{PLANE AND SOLID GEOMETRY}

By Arthur Schultze and F. L. Sevenoak. izmo. Half leather, xii + 370 pages. \$I.Io net.

\section{PLANE GEOMETRY}

Separate. I2mo. Cloth. xii +233 pages, 80 cents net.

This Geometry introduces the student systematically to the solution of geometrical exercises. It provides a course which stımulates him to do original work and, at the same time, guides him in putting forth his efforts to the best advantage.

The schultze and Sevenoak Geometry is in use in a large number of the leading schools of the country. Attention is invited to the following important features: 1. Preliminury Propositions are presented in a simple manner; 2. The numerous and well-graded Exercises - more than 1200 in number in the complete book. These are introduced from the beginning; 3. Statements from which General Principles may be obtained are inserted in the Exercises, under the heading "Remarks"; 4. Proofs that are special cases of general principles obtained from the Exercises are not given in detail. Hints as to the manner of completing the work are inserted; 5. The Order of Propositions has a clistinct pedagogical value. Propositions easily understood are given first and more difficult ones follow; 6. The Analysis of Problems and of Theorems is more concrete and practical than in any other text-book in Geometry; 7. Many proofs are presenterl in a simfler and more direct manner than in most text-books in Geometry; 8. Difficult Propositions are made somewhat easier by applying simple Notation; 9. The Algebraic Solution of Geonetrical Exercises is treated in the Appendix to the Plane Geometry; ro. Pains have been taken to give Excellent Figures throughout the book.

\section{KEY TO THE EXERCISES}

In Schultze and Sevenoak's Plane and Solid Geometry. By ARTHUR Schultze, Ph.D. I2mo. Cloth. 200 pages. \$I.ro net.

This key will be helpful to teachers who cannot give sufficient time to the solution of the exercises in the text-book. Must solutions are merely outlines, and no attempt has been made to present these solutions in such form that they can be used as models for class-room work. 


\section{ELEMENTARY ALGEBRA}

By Arthur Schultze, Assistant Professor of Mathematics, New York Univer* sity, Head of the Mathematical Department, High School of Commerce, New York City. I2mo. Half leather. $x i+373$ pages, 落. Io net.

The treatment of elementary algebra here is simple and practical, without the sacrifice of scientific accuracy and thoroughness. Particular care has been bestowed upon those chapters which in the custumary cuurses offer the greatest difficulties to the beginner, especially Problems and Factoring. The introduction into Problem Wurk is very much simpler and more natural than the methods given heretofure. In Factoring, comparatively few methods are given, but these few are treated so thoroughly and are illustrated by so many varied examples that the student will be much better prepared for further work, than by the superficial study of a great many cases. The Exercises are very numerous and well graded; there is a sufficient number of easy examples of each kind to enable the weakest students to do some work. A great many examples are taken from geometry, physics, and commercial life, but none of the introduced illustrations is so complex as to require the expenditure of time for the teaching of physics or geometry. To meet the requirements of the College Entrance Examination Board, proportions and graphical methods are introduced into the first year's course, but the work in the latter subject has been so arranged that teachers who wish a shorter course may omit it.

\section{ADVANCED ALGEBRA}

By Arthur Schultze, Ph.D. I2mo. Half leather. xiv $+5^{62}$ pages. $\$$ T.25 net.

The Advanced Algebra is an amplification of the Elementary. All subjects not now required for admission by the College Entrance Examination Board have been omitted from the present volume, save Inequalities, which has been retained to serve as a basis for higher work. The more important subjects which have been omitted from the body of the work - Indeterminate Equations, Logarithms, etc. - have been relegated to the Appendix, so that the book is a thoroughly practical and comprehensive text-book. The author has emphasized Graphical Methods more than is usual in text-books of this grade, and the Summation of Species is here presented in a novel form. 







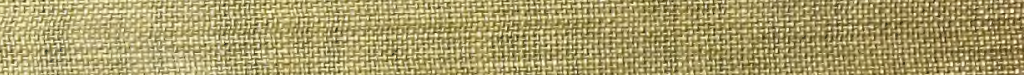

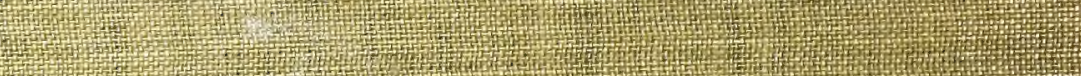

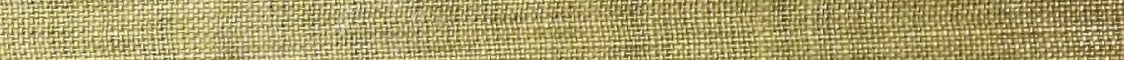
HF

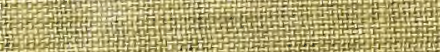

HF

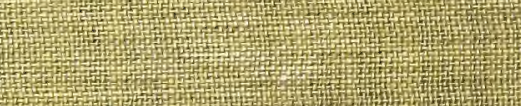

$\mathrm{H}^{\mathrm{H}} \mathrm{T}$

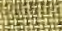

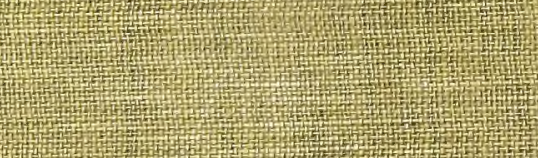

